Universidade de São Paulo

Instituto de Biociências

Departamento de Zoologia

\title{
Análise filogenética de Cryptobranchia (Mollusca: Nudibranchia) com base em anatomia comparada
}

Aluna: Patricia Oristanio Vaz de Lima

Orientador: Luiz Ricardo Lopes de Simone

Outubro, 2016

São Paulo 


\section{Análise filogenética de Cryptobranchia (Mollusca: Nudibranchia) com base em anatomia comparada}

Phylogenetic analysis of Cryptobranchia (Mollusca: Nudibranchia) based on comparative anatomy

Tese apresentada ao Instituto de Biociências da Universidade de São Paulo para obtenção do Título de Doutor em Zoologia, na Área de Malacologia.

Orientador: Prof. Dr. Luiz Ricardo Lopes de Simone. 
Lima, Patricia Oristanio Vaz de

Análise filogenética de Cryptobranchia (Mollusca: Nudibranchia) com base em anatomia comparada.

Tese (Doutorado) - Instituto de Biociências da Universidade de São Paulo. Departamento de Zoologia.

1. Análise filogenética. 2. Cryptobranchia 3. Anatomia comparada. I. Universidade de São Paulo a. Instituto de Biociências. Departamento de Zoologia.

Comissão julgadora

Prof. Dr. Instituição

Julgamento: Assinatura:

Prof. Dr. Instituição

Julgamento: Assinatura:

Prof. Dr. Instituição

Julgamento: Assinatura:

Prof. Dr. Instituição

Julgamento: Assinatura:

Prof. Dr. Luiz Ricardo L. Simone Orientador 
Agradecimentos

Ao Prof. Dr. Luiz Ricardo Lopes de Simone, por acreditar na continuidade do meu trabalho e me manter como sua aluna, agora de doutorado. Obrigada por mais essa oportunidade que completa mais uma parte do meu ciclo profissional.

A agência de fomento, CNPq e ao Departamento da Pós-Graduação de Zoologia, do Instituto de Biociências/USP, por financiarem essa pesquisa e ao Museu de Zoologia da USP, instituição que me propiciou um espaço físico para desenvolver meu trabalho.

Aos meus familiares, minha mãe, Regina, que mesmo longe fisicamente, sempre me apoiou e se preocupou em saber como estava o meu trabalho. Aos meus irmãos, Rodrigo e Bárbara, que sempre se orgulharam da irmã mais velha estudar tanto. Principalmente aos meus avós, Giuseppe e Rosa, que estiveram, física e emocionalmente, ao meu lado, me apoiando em todas as decisões que eu tomei para seguir na carreira de bióloga.

Ao meu amigo, colega de laboratório e marido, Daniel Abbate, pelo suporte emocional para passarmos por tantas coisas nesses quatro anos. Desde o início, sem nem uma semana de férias entre o mestrado e o doutorado, até o abalo emocional por conta do falecimento do meu pai (Jair). Obrigada pela paciência, te amo muito!!!

Ás contribuições profissionais dos meus colegas de profissão, em especial ao Dr. Carlo Magenta, Dr. Vinícius Padula, Dra. Juliana Alvim e Ms. Hilton Galvão.

Ás instituições que cederam material de empréstimo para que se fizesse possível a análise de todas as espécies escolhidas para esta análise: Prof. Dr. Terrece Gosliner (por meio de Elizabeth Kools - California Academy of Science), Prof. Dr. Martin Vinther Sørensen (por meio de Tom Schiøtte - Natural History Museum of Denmark), 
especialmente pelo empréstimo de alguns holótipos; Dr. Mandy Reid, do Australian Museum Research Institute.

Ao laboratório de Microscopia Eletrônica de Varredura, Lara (MZSP) pela realização das imagen de estruturas fundamentais para a comparação entre as espécies estudadas. 
Sumário

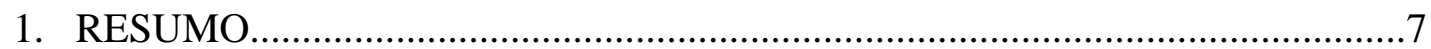

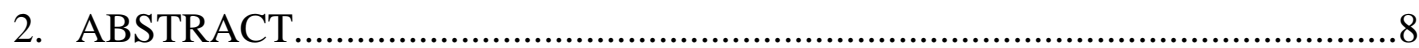

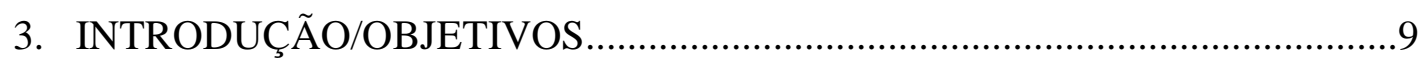

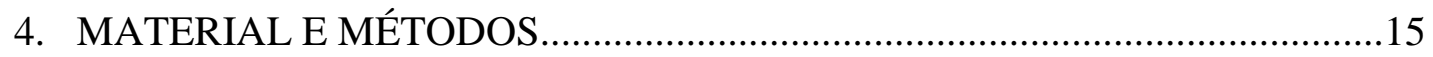

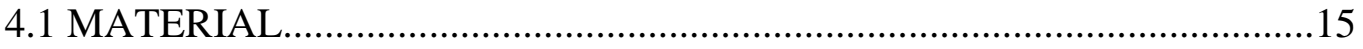

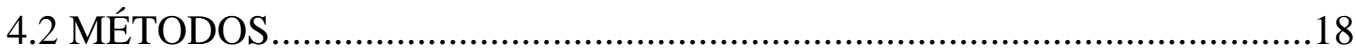

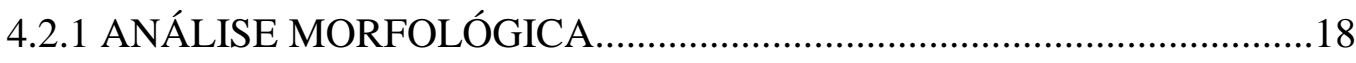

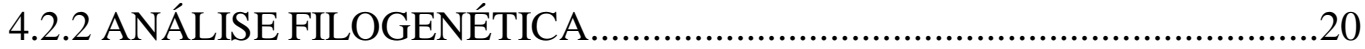

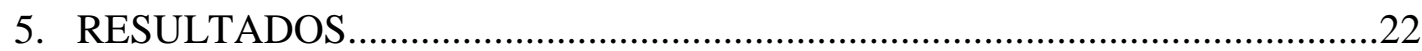

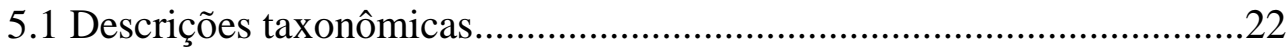

5.2 Apresentação e discussão dos caracteres.............................................252

5.2.1 Caracteres excluídos da análise..................................268

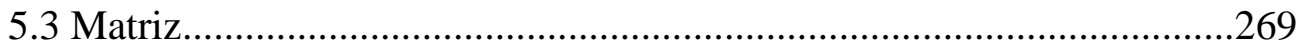

5.4 Análise do Cladograma....................................................................270

5.5 Análise taxonômica resultande da filogenia obtida............................277

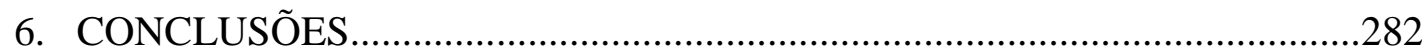

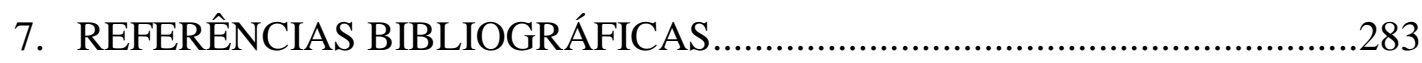

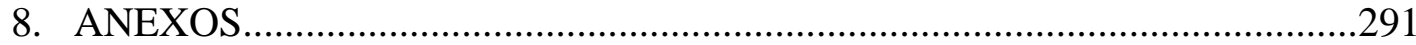




\section{RESUMO}

Cryptobranchia é considerado o clado com maior número de representantes entre os Nudibranchia, com aproximadamente 1500 espécies e são reconhecidos por apresentarem uma cavidade para retração da brânquia quando perturbados. É considerado um táxon monofilético e apresenta as seguintes sinapomorfias: presença de um lábio; brânquia dorsal retrátil; cavidade ao redor do ânus; redução dos músculos do tubo oral e odontóforo; e próstata diferenciada. De acordo com a última sugestão filogenética, baseada em dados morfológicos, Cryptobranchia está dividido em dois táxons, também monofiléticos: Porostomata e Labiostomata. Este trabalho apresenta um estudo morfológico detalhado de alguns representantes-chave de Cryptobranchia e outros Nudibranchia visando testar a monofilia deste clado, bem como elucidar o posicionamento filogenético dos gêneros de cada família do clado. Todas as famílias pertencentes à Cryptobranchia estão representadas, no entanto não todos os gêneros. Os gêneros estão representados, em sua maioria, pela espécie-tipo, totalizam um grupo interno de 30 espécies. O grupo externo inclui outros nudibrânquios e um Cephalaspidea (Haminoea elegans), utilizado para o enraizamento, totalizando 9 espécies. Uma análise cladística foi realizada, com buscas heurísticas e uma pesagem diferencial, específica determinada pela constante $(\mathrm{K})$. Dentre várias conclusões, o resultado da análise confirmou a monofilia de Cryptobranchia, entretanto não confirmou a monofilia do táxon Labiostomata. Tambja brasiliensis (Polyceroidea) resultou como grupo-irmão de Cryptobranchia. Alguns sistemas foram analisados com mais precisão e mostraram-se potencialmente informativos, principalmente para táxons mais específicos.

Palavras-chave: Cryptobranchia, sistemática, morfologia 


\section{ABSTRACT}

Cryptobranchia is considered have the largest number of representatives amongst Nudibranchia, with about 1500 known species, recognized in having a branchial sheath to retract the gills when disturbed. It is a monophyletic taxon with supported by following synapomorphies: labium present, dorsal gill retractable (when present), cavity around the anus, reduced number of oral tube bulb muscles, and differentiated prostate. According to the last phylogenetic suggestion, Cryptobranchia is divided in two monophyletic taxa: Porostomata and Labiostomata. This study presents a detailed morphological study of some key representatives of Cryptobranchia and other Nudibranchia taxa, aiming to test the monophyly and elucidate the phylogenetic position of the genera of each family. All families belonging to Cryptobranchia are represented, although not all genera. The genera are represented, in most cases, by the type species, totaling an internal group of 30 species. The outgroup is represented by other nudibranchs and a cepalaspidean (Haminoea elegans), for rooting, totalizing 9 species. A cladistic analysis is performed in a heuristic basis and a differential weighing, determined by specific constant $(\mathrm{K})$. The result of the analysis confirmed the monophyly of Cryptobranchia, although the monophyly of the Labiostomata is not confirmed. Tambja brasiliensis (Polyceroidea) appears as Cryptobranchia sister group. Some systems were analyzed more accurately and show to be informative, especially for more specific taxa.

Key words: Cryptobranchia, systematic, morphology 


\section{INTRODUÇÃO}

A ordem Nudibranchia é a maior e mais diversa dentro de Heterobranchia. É um grupo de gastrópodes exclusivamente marinhos, encontrados em todos os oceanos e constitui um grupo com mais de 3000 espécies conhecidas, com maior representação nos mares tropicais. Variam de $4 \mathrm{~mm}$ de comprimento até $600 \mathrm{~mm}$ quando adultos, sendo a maioria das espécies em torno de $30 \mathrm{~mm}$ (Willan \& Coleman, 1984; Willian, 1998; Rudman, 1998; Wägele \& Willan, 2000; Schrödl et al., 2010).

De acordo com classificações mais recentes, Nudibranchia tem como grupoirmão a ordem Pleurobranchomorpha, reunidos num clado denominado Nudipleura, apresentando como principais sinapomorfias: um sistema reprodutor androdiáulico, ausência de osfrádio e a presença de uma glândula de sangue (Wägele \& Willan, 2000). Além disso, dados moleculares também comprovam a monofilia deste táxon (Wollscheid-Lengeling et al., 2001).

Algumas das características mais comuns dos nudibrânquios são: ausência de concha e opérculo, presença de papilas no notum, cabeça distinta do pé, rinóforos, cerata, sistema reprodutor hermafrodita com maturação simultânea dos gametas, fertilização cruzada envolvendo cópula e uma enorme variedade morfológica e uma atrativa coloração (Thompson, 1976; Willian, 1998).

Uma das estruturas corporais muito característica são os rinóforos, estruturas quimiossensoriais (sentido de olfato e gustação) localizadas normalmente na região anterior dorsal, conectadas ao sistema nervoso, utilizados para a percepção de presas, predadores e parceiros para reprodução (Debelius \& Kuiter, 2007; Coleman, 2008).

Os órgãos respiratórios estão, em sua maioria, na superfície dorsal do corpo e consistem em um círculo de brânquias perianal ou apêndices dorsais especializados: cerata (conjunto de ceras) (Rudman, 1998; Willan, 1998; Schrödl et al., 2010).

As cerata são estruturas multifuncionais, dispostas dorso-lateralmente no corpo, que podem conter ramificações da glândula digestiva com sacos especiais (cnidosacos) no seu ápice (Rudman, 1999; Debelius \& Kuiter, 2007). Apesar de ser uma estrutura tipicamente encontrada em nudibrânquios, outros opistobrânquios também a possuem, como todas as espécies pertencentes à superfamília Limapontioidea da ordem Sacoglossa (Jensen, 1996).

Sem a proteção física proporcionada pela concha, os nudibrânquios apresentam outras estratégias de defesa, tanto morfológicas (espículas, nematocistos e 
camuflagem), quanto químicas (utilização direta de toxinas das presas e síntese de toxinas como fluídos repugnantes) e comportamentais (autotomia) (Wägele \& Willan, 2000). A adaptação a diversas formas de alimentação (poríferos, cnidários, briozoários e tunicatos) tem grande papel nessas defesas, já que algumas espécies desenvolvem a capacidade de incorporar e utilizar o sistema de defesa de suas presas, como produtos químicos tóxicos de esponjas ou cnidócitos de cnidários (Willian, 1998; Wägele \& Willan, 2000).

Em sua maioria, os nudibrânquios, são animais bentônicos, no entanto há algumas exceções que tem hábito pelágicos, por exemplo: Scyllaea pelagica Linnaeus, 1758 que se agarra em algas flutuantes, principalmente Sargassum, alimentando-se de hidróides ligados à referida alga (Thompson \& Brown, 1981; Marcus, 1961) e Glaucus atlanticus Forster, 1777, que flutua na superfície do mar e é transportada pelas correntes e ventos, juntamente com seu alimento, a caravelaportuguesa (Physalia) (Thompson \& Bennett, 1970; Kamalakannan et al., 2010).

\subsection{Histórico taxonômico de Nudibranchia}

O nome Nudibranchia foi introduzido por Cuvier (1817) e desde então o táxon passou a ser classificado de várias maneiras, como demonstrado na compilação feita por Wägele \& Willan (2000) em uma análise filogenética baseado em dados morfológicos (Fig. 1). 


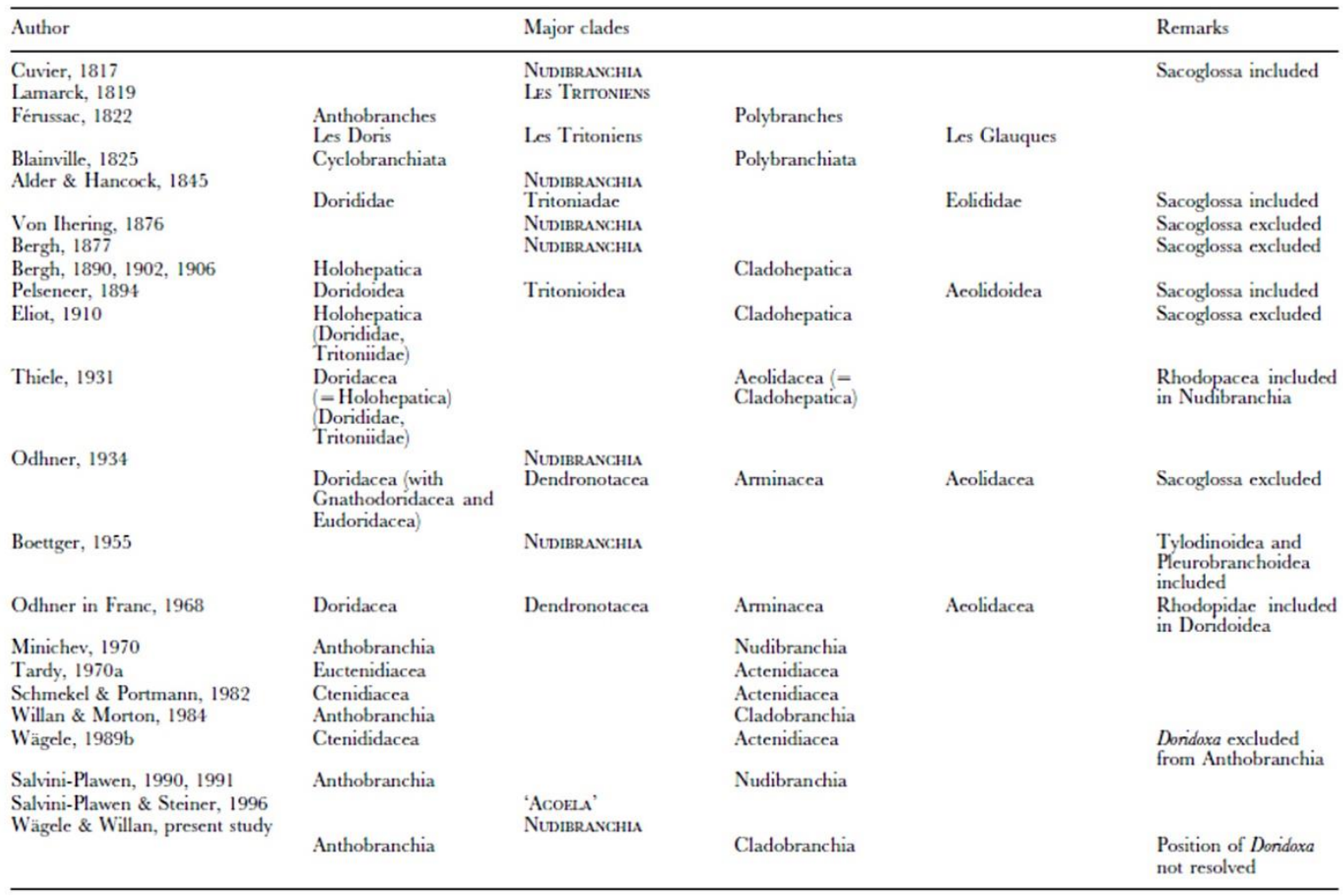

Figura 1: Sumário do histórico das divisões taxonômicas de Nudibranchia representando os clados maiores. Retirado de Wägele \& Willan (2000).

A taxonomia mais recente, baseada em uma ampla pesquisa bibliográfica, e ultimamente bastante utilizada para Nudibranchia foi realizada por Bouchet \& Rocroi (2005), e considera a ordem dividida em dois clados Euctenideacea e Dexiarchia, remetendo às classificações de Tardy (1970) e Wägele (1989b) (Fig. 1).

Os trabalhos recentes de filogenia de englobando representantes Nudibranchia (Wägele \& Willan, 2000; Valdés, 2002a; Alejandrino \& Valdés, 2005; Dayrat, 2010), baseados em dados morfológicos, consideram a classificação de Willan \& Morton (1984) (Fig. 1), com a divisão em dois táxons monofiléticos: Cladobranchia [contendo Dendronotoidea, Arminoidea (parafilético) e Aeolidoidea], com representante que não possuem um ctenídio verdadeiro e com o ânus e o poro excretor estão localidados na lateral direita do corpo, e Anthobranchia (com Bathydoridoidea e Doridoidea), com representantes que apresentam um ctenídio (=brânquia) verdadeiro e o ânus e o poro excretor estão na posição mediana dorsal (Wollscheid-Lengeling et al., 2001; Ardila, et al., 2007).

Cladobranchia é um táxon bastante controverso, embora não apresente caracteres exclusivos existem algumas características morfológicas que podem apoiar uma hipótese de monofilia do táxon, por exemplo: ausência (através da perda) de 
brânquias primárias, mandíbula aliforme; ausência (através da perda) da bursa copulatrix, ausência (através da perda) da glândula de sangue, posição do ânus no lado direito e a presença de um epitélio vacuolizado no sistema digestivo (Schmekel, 1985; Wägele \& Willan, 2000).

Também para as três superfamílias normalmente aceitas de Cladobranchia, mantém-se o status confuso sobre suas características exclusivas. A superfamília Dendronotoidea é considerada monofilética e apresenta como principal sinapomorfia a presença de uma bainha rinoforal (Odhner, 1934). Além disso, seus representantes apresentam uma extensão tentacular no véu oral e uma cutícula que reveste o estômago (Wägele \& Willan, 2000). Ainda possuem um ou dois pares de cerata, no entanto não apresentam a glândula digestiva ramificada nas cerata e ainda possuem a chamada "ceratal gills", que são tufos branquiais isolados (Thompson \& Brown, 1981).

A superfamília Aeolidoidea parece ser a mais consistente de Cladobranchia, apresentando as seguintes sinapomorfias: presença de um cnidosaco e a presença do véu oral derivado em tentáculos orais (Wägele \& Willan, 2000). Os membros desse táxon são facilmente reconhecidos por seus corpos alongados e afilados e pela presença das cerata (Carmona, et al., 2013).

Diversas famílias de nudibrânquios foram unidas na superfamília Arminoidea por muitas espécies apresentarem um véu oral ou tentáculos derivados desse véu oral (Odhner, 1934), característica essa que também aparece nas outras superfamílias. Outas características morfológicas são encontras em Arminoidea, como a presença do ânus lateral e noto espesso com margens estendidas, sulcos longitudinais no dorso, brânquias na lateral direita do corpo embaixo do noto (Coleman, 2008; CAS, 2015). No entanto, ainda nenhuma sinapomorfia foi definida para o táxon, mantendo-se parafilético (Wägele \& Willan, 2000).

Já a monofilia de Anthobranchia, segundo clado de Nudibranchia, apresenta maior consenso. Entretanto, alguns caracteres que têm sido utilizados para suportar essa hipótese não são rigorosamente válidos dentro de um contexto filogenético (Wagële \& Willan, 2000). Por exemplo, a ausência de mandíbula, a presença da glândula de sangue (considerada sinapomorfia de Nudipleura) e um epitélio vacuolizado no rinóforo (Schmekel, 1985). A presença de um ceco digestivo, para Wagële (1989b), pode ser considerada uma sinapomorfia, se esse ceco for revestido somente por um epitélio ciliado e não um epitélio glandular. 
Até o momento, são reconhecidas três sinapomorfias de Antobranchia: noto cobrindo a cabeça e circundando o rinóforo durante a ontogenia; ânus, nefróstoma e círculo braquial situados na região médio/posterior; presença de um ceco revestido por epitélio ciliado (Wägele \& Willan, 2000).

Considerando a classificação mais recente, entre as superfamílias de Anthobranchia, Bathydoridoidea é composta apenas por uma única família, Bathydorididae, contendo um gênero, Bathydoris, que reune as espécies encontradas em grandes profundidades e nos oceanos Antártico e Ártico (Valdés, 2002b). É considerado o táxon mais basal e grupo irmão de Doridoidea (Wägele, 1989).

A superfamília Doridoidea, apresenta o maior número de espécies entre os Nudibranchia, cerca de 2.000 descritas, com grande diversidade morfológica e um histórico taxonômico muito complexo e controverso. Apresenta uma divisão em dois clados amplamente aceita por diversos autores, Phanerobranchia, com aproximadamente 500 espécies e Cryptobranchia, com cerca de 1500 espécies (Valdés \& Gosliner, 1999; Valdés, 2002a; Valdés, 2004; Fahey \& Gosliner, 2004; Pola et al., 2007; Pola \& Gosliner, 2010).

A característica primária normalmente presente nos representantes de Phanerobranchia é a presença de uma brânquia dorsal não retrátil, considerada uma característica plesiomórfica. Como resultado da ausência de uma cavidade para proteção das brânquias, esses animais desenvolveram apêndices protetores para os filamentos branquiais (Valdés, 2002a; Fahey \& Gosliner, 2004). Entretanto, até o momento é considerado um clado parafilético, pois não apresenta uma característica única encontrata em todos os representantes. Exibe uma variabilidade em forma e coloração, algumas espécies são bem parecidas com os doridídeos criptobrânquios [e.g., Gymnodoris rubropapillosa (Bergh, 1905)], outras apresentam o dorso coberto por numerosas papilas alongadas (e.g., Okenia kendi Gosliner, 2004). São animais predadores de briozoários, ascídias, esponjas, poliquetas e outros opistobrânquios (Rudman, 1998; Vallès et al., 2000; CAS, 2015).

Cryptobranchia é considerado o táxon com o maior número de espécies conhecidas entre os nudibrânquios, com representes que apresentam uma cavidade para retrair a brânquia quando perturbados. É um táxon monofilético com as seguintes sinapomorfias: presença de um sulco transversal na região anterior do pé (borda anterior do pé bilabiada), que em alguns casos pode ser fendido longitudinalmente; 
brânquia dorsal retrátil; cavidade ao redor do ânus; redução dos músculos do tubo oral e odontóforo; e próstata diferenciada (Valdés, 2002a).

Houveram diversas tentativas históricas para classificar os "criptobrânquios doridídeos". Na tentativa de englobar todos os trabalhos que trataram da taxonomia do grupo, Valdés (2002a) fez uma síntese deste histórico, que mostrou uma variedade de classificações (Fischer, 1887; Bergh, 1891; Pelsener, 1906; Thiele, 1929-35; Odhner, 1939; Odhner in Franc, 1968; Thompson, 1976; Schmekel \& Portmann, 1982; Rudman, 1984).

Os primeiros trabalhos que começaram a utilizar a filogenia como base para classificação, baseadas normalmente em dados morfológicos, surgem na década de 80 (Schemekel, 1985; Brunckhorst, 1993; Baranetz \& Minichev, 1993; Gosliner \& Johnson, 1999; Wägele \& Willan, 2000; Valdés, 2002a). O uso de outros dados como moleculares e de defesa química para novas propostas filogenéticas, surgem no fim dos anos 90, início dos anos 2000 (Cimino \& Ghiselin, 1999; Thollesson, 1999; Valdés 2003).

O estudo úlimo estudo filogenético, baseado em morfologia comparada, sugere a divisão de Cryptobranchia em dois clados: Labiostomata e Porostomata, baseado na presença ou ausência de rádula, respectivamente (Valdés, 2002a).

Porostomata, introduzido por Bergh (1878), é um dos grupos mais tradicionais dos nudibrânquis doridídeos, e está representado por indivíduos que não possuem rádula e por isso desenvolveram uma série de transformações anatômicas no sistema digestivo anterior (região do tubo oral), todas elas adaptadas para a alimentação através de sucção (Young, 1969). Duas famílias são reconhecidas como válidas: Dendrodorididae e Phyllidiidae (Valdés \& Gosliner, 1999). Esta última foi considerada pela mais recente classificação dos Gastropoda (Bouchet \& Rocroi, 2005), em uma superfamília, Phyllidioidea.

O táxon mais recente da classificação de Cryptobranchia, Labiostomata, foi definido para agrupar os indivíduos que apresentam os seguintes caracteres sinapomórficos: presença de rádula e armadura labial (mandíbula); área da boca bem desenvolvida; tentáculos orais pequenos; e glândula de sangue situada dorsal ao sistema nervoso central (Valdés, 2002a). 
Considerando que Cryptobranchia abrange a maior representatividade entre os nudibrânquios e uma ampla diversidade morfológica, muita confusão ainda se faz na taxonomia deste clado.

Assim sendo, a proposta desta tese tem como objetivos:

(1) ampliar o conhecimento sobre a anatomia e taxonomia de alguns representantes-chave de Cryptobranchia, através da comparação de caracteres morfológicos,

(2) agrupar o máximo de caracteres de diversos sistemas (circulatório, digestório, nervoso, reprodutor, etc), normalmente não utilizados para os Nudibranchia,

(3) estabelecer hipóteses sobre as relações filogenéticas entre as espécies analisadas de Cryptobranchia, através de uma análise filogenética e

(4) testar a monofilia de Cryptobranchia. 


\section{MATERIAL E MÉTODOS}

\subsection{MATERIAL}

O material analisado neste estudo tem procedência principal da Coleção Malacológica do Museu de Zoologia da USP (MZSP). Adicionalmente foram obtidos empréstimos de exemplares da coleção do Australian Museum (AMS), Natural History Museum of Denmark (ZMUC), do California Academy of Science (CAS), Museu Nacional do Rio de Janeiro (MNRJ) e Coleção Malacológica Professor Henry Ramos Matthews (CMPHRM), da Universidade do Ceará. Foram examinados um total de 119 lotes e 362 espécimes. A lista completa do material examinado está arranjada depois da descrição de cada espécie.

Foram estudadas 39 espécies, sendo 30 pertencentes ao grupo interno (Cryptobranchia) e 9 espécies para o grupo externo (Tabela I). As espécies foram escolhidas de forma a representar os gêneros e espécies tipo de cada principal vertente morfológica do grupo.

Para o grupo externo foi utilizado um representante dentro dos "Opisthobranchia" basais, um Cephalaspidea [Haminoea elegans (Gray, 1825)], para o enraizamento, um representante do grupo-irmão de Nudibranchia, Pleurobrancomorpha [Berthella agassizii (MacFarland, 1909)], um representante de cada subordem do táxon Cladobranchia, sendo um Arminoidea [Armina muelleri (Ihering, 1886)], um Aeolidoidea [Noumeaella kristenseni (Ev. Marcus \& Er. Marcus, 1963)] e um Tritonioidea [Bornella calcarata Mörch, 1863)]. Das outras superfamílias de doridáceos, um Phyllidioidea [Phyllidiella pustulosa (Cuvier, 1804)], dois representantes de Onchidoridoidea [Knoutsodonta brasiliensis (Alvim, Padula \& Pimenta, 2011)] e [Goniodoris mimula Er. Marcus, 1955], e por fim um representante de Polyceroidea [Tambja brasiliensis Pola, Padula, Gosliner \& Cervera, 2014].

Tabela I - Lista das espécies analisadas. (*) Espécie-tipo do gênero.

\begin{tabular}{|l|c|c|}
\hline \multicolumn{1}{|c|}{ Táxon } & Instituição & Número de lotes \\
& Detentora & \\
\hline GRUPO EXTERNO & MZSP & 2 \\
\hline Haminoea elegans (Gray, 1825) & & \\
\hline
\end{tabular}




\begin{tabular}{|c|c|c|}
\hline Berthella agassizii (MacFarland, 1909) & - & - \\
\hline Armina muelleri (Ihering, 1886) & MZSP & 1 \\
\hline $\begin{array}{l}\text { Noumeaella kristenseni (Ev. Marcus \& Er. Marcus, } \\
\text { 1963) }\end{array}$ & MZSP & 1 \\
\hline Bornella calcarata Mörch, 1863 & MZSP & 2 \\
\hline (*) Phyllidiella pustulosa Cuvier, 1804 & & 2 \\
\hline $\begin{array}{l}\text { Knoutsodonta brasiliensis (Alvim, Padula \& Pimenta, } \\
\text { 2011) }\end{array}$ & MZSP & 2 \\
\hline Goniodoris mimula Er. Marcus, 1955 & MZSP & 5 \\
\hline $\begin{array}{l}\text { Tambja stegosauriformis Pola, Cervera \& Gosliner, } \\
2005\end{array}$ & MZSP & 2 \\
\hline \multicolumn{3}{|l|}{ GRUPO INTERNO } \\
\hline \multicolumn{3}{|l|}{ Porostomata Bergh, 1891} \\
\hline (*) Dendrodoris limbata (Cuvier, 1804) & CAS & 1 \\
\hline (*) Doriopsilla areolata (Bergh, 1880) & MZSP/CAS & 3 \\
\hline (*) Mandelia mirocornata Valdés \& Gosliner, 1999 & CAS-IZ & 1 \\
\hline \multicolumn{3}{|l|}{ Labiostomata Valdés, 2002} \\
\hline \multicolumn{3}{|l|}{ Família Actinocycidae } \\
\hline Hallaxa apafae Er. Marcus, 1957 & MZSP & 1 \\
\hline Actinocyclus verrucosus (Bergh, 1878) & CAS & 2 \\
\hline \multicolumn{3}{|l|}{ Família Dorididae } \\
\hline (*) Doris verrucosa Linné, 1758 & MZSP/MN & 2 \\
\hline Doris januarii (Bergh, 1878) & MZSP & 13 \\
\hline Doris ilo (Er. Marcus, 1955) & MZSP & 4 \\
\hline Doris bovena Er. Marcus, 1955 & MZSP & 5 \\
\hline Doris kyolis (Ev. Marcus \& Er. Marcus, 1967) & MZSP & 7 \\
\hline Doris ananas Lima, Tibiriçá \& Simone, 2016 & MZSP & 5 \\
\hline Família Chromodorididae & & \\
\hline
\end{tabular}




\begin{tabular}{|c|c|c|}
\hline (*) Hypselodoris obscura Stimpson, 1855 & CAS & 4 \\
\hline Felimare lajensis Troncoso, Garcia \& Urgorri, 1998 & MZSP & 3 \\
\hline Mexichromis kempfi (Ev. Marcus, 1971) & MZSP & 3 \\
\hline (*) Chromodoris magnífica (Quoy \&Gaimard, 1832) & CAS & 5 \\
\hline Felimida neona (Er. Marcus, 1955) & MZSP & 2 \\
\hline Cadlina rumia Er. Marcus, 1955 & MZSP/CAS & 3 \\
\hline Doriprismatica atromarginata (Cuvier, 1804) & & 1 \\
\hline Tyrinna evelinae (Er. Marcus, 1958) & MZSP/CAS & 3 \\
\hline \multicolumn{3}{|l|}{ Família Discodorididae } \\
\hline Jorunna spazzola (Er. Marcus, 1955) & MZSP/CAS & 4 \\
\hline (*) Discodoris boholiensis Bergh, 1877 & CAS-IZ & 5 \\
\hline Discodoris branneri (Er. Marcus, 1955) & MZSP & 2 \\
\hline Platydoris angustipes (Mörch, 1863) & MZSP/CAS & 4 \\
\hline Platydoris sp. & MZSP & 1 \\
\hline (*) Diaulula sandiegensis (Cooper, 1862) & USNM/CAS & 1 \\
\hline Montereina greeleyi (MacFarland, 1909) & $\mathrm{MZSP} / \mathrm{CAS}$ & 8 \\
\hline Discodoris pusae (Er. Marcus, 1955) & MZSP & 5 \\
\hline Thordisa ladislavii (Ihering, 1886) & MZSP & 1 \\
\hline (*) Sclerodoris tuberculata Eliot, 1903 & MZSP/CAS & 2 \\
\hline Sclerodoris sp. BR & MZSP & 1 \\
\hline
\end{tabular}




\subsection{MÉTODOS}

\subsubsection{ANÁLISE MORFOLÓGICA}

Todas as espécies foram dissecadas e os dados foram extraídos desse estudo, exceto Bethella agassizii, a qual utilizamos dados da recente revisão feita para o gênero (Alvim \& Pimenta, 2015). Para Thordisa ladislavii, Hallaxa apefae e Knoutsodonta brasiliensis alguns dados foram retirados da literatura (Marcus, 1958; Gosliner \& Johnson, 1994; Alvim et al., 2011), pois não foi possível analisar algumas estruturas nos espécimes disponíveis. As espécies da família Dorididae foram analisadas durante o meu mestrado (2010-2012), sendo que duas delas, Doris verrucosa e Doris januarii já estão com anatomia publicadas em artigo anexado (Anexo I). A espécie Doris ananas também está em anexo, como publicação (Anexo II).

As dissecções foram realizadas sob lupa estereoscópica, modelo Zeis Stemi SV 06 e SV 11, com objetivas de 0.4, 0.63 e 1.0 de acordo com o tamanho de cada exemplar e estruturas. Para as dissecções foram utilizados materiais cirúrgicos oftalmológicos (pinças e tesouras), com o espécime imerso em uma cuba com álcool $70 \%$ e fixado por alfinetes entomológicos. Cada exemplar foi dissecado a partir de um corte longitudinal dorsal no meio do dorso e circundando o círculo branquial, o que possibilitou expor toda massa visceral mostrando de modo geral a topografia da anatomia interna e como estão dispostos todos os sistemas: circulatório, excretor, digestivo, reprodutor e nervoso, descritos nessa sequência para cada espécie. Cada sistema foi isolado para uma análise individual.

As rádulas foram examinadas no Laboratório de Microscopia Eletrônica de Varredura do MZSP. A preparação das rádulas se deu através da retirada das mesmas do odontóforo, em seguida cada rádula foi colocada em uma solução composta de 3/4 de água e 1/4 de Hipoclorito de Sódio, com a finalidade de retirar qualquer resíduo tecidual dos dentes radulares. Cada rádula permaneceu nessa solução por um período variável entre 5 e 20 minutos, dependendo do tamanho da rádula, lembrando que foi necessário acompanhar o processo, verificando o tempo de cada rádula para não corroer os dentes radulares caso fiquem mais tempo do que o necessário. Em seguida, a rádula foi colocada em uma solução de $1 / 2$ de água filtrada e $1 / 2$ de limpador de uso geral, Veja Multiuso, e chacoalhada por alguns segundos, logo em seguida foi realizado o enxágue da rádula com água filtrada. Depois do processo de limpeza a 
rádula foi fixada em um Stub, com fita dupla face, e encaminhada para metalização e à microscopia eletrônica.

A terminologia das estruturas foi baseada em algumas revisões, como Hancock \& Embleton (1852), Hancock (1864), Marcus (1955), García \& García-Gómez (1990), Valdés (2002), Simone (2004), Dayrat (2010).

Os desenhos dos espécimes dissecados foram realizados com a ajuda de uma câmara clara acoplada à lupa estereoscópica, posteriormente foram passados à limpo em papel vegetal com caneta nanquim e digitalizados.

Abreviatura das Instituições: AMS - Australian Museum; CAS - California Academy of Science; ZMUC - Natural History Museum of Denmark; MZSP - Museu de Zoologia da Universidade de São Paulo; MNRJ - Museu Nacional do Rio de Janeiro; CMPHRM - Coleção Malacológica Professor Henry Ramos Matthews, da Universidade do Ceará.

As abreviações nas figuras estão listadas a seguir, em inglês (para facilitar as publicações): aa: anterior aorta; ab: afferent branchial vein; ag: acessory gland; an: anus; am: ampulla; ap: posterior aorta; ar: afferent branchial ring; au: auricle; at: aortic trunk; av: auricle vein; bc: Bursa copulatrix; bg: blood gland; bs: buccal sphincter; bt: branchial tubercle; ca: caryophyllidia; cb: buccal commissure; cc: cerebral commissure; ce: cerebral ganglia; cg: connective buccal ganglia; co: cnidocito; cp: pedal commissure; cr: cerata; cs: cephalic shield; ct: ctenidium; cu: caecum; cv: ctenidial vein; dd: duct of digestive gland; dg: digestive gland; ds: salivar duct; dt: dorsal tubercle; ef: oesophageal folds; er: efferent branchial ring; es: oesophagus; ev: efferent branchial vein; ey: eye; fg: female gland; ft: foot; gb: buccal ganglia; gc: gill circle; ge: gonopore; gf: gill filament; gg: gastro-oesophageal ganglia; go: gonad; gp: pedal ganglia; gr: genital groove; hd: hermaphrodite duct; ho: Hancock organs; hy: hyponotal; il: inner lip; in: intestine; ja: jaw; kd: kidney; le: lateral extension; ma: mantle; mc: mantle cavity; md: dorsal septated mucle; mg: mucous gland; mo: mouth; m2 - m10: odontophore muscles; mp: penis's muscle; ms: medial sinus; mt: oral tube muscle; ne: nephrostome; oc: odontophore cartilage; ol: outer lip; on: optical nerve; ot: oral tube; ov: oviduct; pa: papilla; pb: proboscid; pc: pericardium; pe: penis; pg: gizzard plates; pl: pleural ganglia; pp: penial papillae; pr: prostate; ra: radula; rc: renal chamber; rg: rhinophoral ganglia; ri: rhinophore; 
rm: retractor muscle gill; rn: rhinophoral nerve; rp: reproductive system; rs: radular; sac; rt: rhinophoral tubercle; rv: renal vesicle; sa: supraesophageal ganglia; sg: salivar gland; st: stomach; sn: nervous system; sp: spine; sr: seminal receptacle; su: subesophageal ganglia; to: oral tentacle; ud: uterine duct; va: vagina; vb: buccal vein; vd: vas deferent; ve: ventricle; vg: visceral ganglia; vo: oral veil; vp: reproductive system vein; vn: nervous system vein: vs: radular sac vein; vv: auricoventricular valve.

\subsubsection{ANÁLISE FILOGENÉTICA}

A análise filogenética foi conduzida com base nos princípios da Cladística de acordo com os conceitos de Hennig (1966) e as propostas subsequentes de Farris (1983) e Nixon \& Carpenter (1993).

A definição dos caracteres que foram utilizados na análise foi feita com base no estudo anatômico comparativo dos espécimes, levando-se em consideração a variação existentes nos caracteres tradicionalmente utilizados nas filogenias de nudibrânquios. A formulação dos caracteres foi feita de acordo com a proposta de Sereno (2007), que reconhece dois tipos fundamentais de caracteres morfológicos, os neomórficos (binários) e os transformacionais (multiestado).

A busca pela árvore mais parcimoniosa foi realizada a partir do enraizamento em Haminoea elegans (Gray, 1825), um Cephalaspidea. A polarização dos caracteres foi feita à posteriori, onde o estado plesiomórfico de cada caráter é decidido no enraizamento do diagrama pela análise de parcimônia de todos os táxons terminais (grupos externos e internos, simultaneamente) (Nixon \& Carpenter, 1993). A seleção dos grupos externos foi baseada nas filogenias de Valdés (2002a) e Wägele \& Willan (2000). Para o teste da monofila de Cryptobranchia foram selecionados táxons das outras superfamílias Onchidoridoidea, Polyceroidea e Phyllidioidea, além de representantes de Cladobranchia: Tritonioidea, Arminoidea e Aeolidoidea, e um representante do grupo irmão de Nudibranchia, Pleurobranchomorpha.

A matriz de táxons e caracteres foi montada com o software Mesquite version 3.04. Para um determinado caráter e/ou estado não aplicável ao táxon foi utilizado o símbolo “_“ para a codificação, e quando o caractere e/ou estado não foi visualizado em algum táxon o símbolo adotado para a codificação foi “?”. 
A fim de obter a árvore filogenética mais parcimoniosa, os dados foram analizados utilizando o recurso da busca heurística no software TNT (Goloboff et al., 2008) com os seguintes parâmetros: Maximum trees to keep $=10000$ e Numbers of replications $=100$. Foi utilizado o algoritmo de pesagem implícita para os caracteres e busca do valor de K (constante de concavidade), Setk.run. O valor de "K"encontrado e utilizado foi de $\mathrm{k}=6.484375$. Esta análise resultou em uma única árvore (Fig.147).

A árvore obtida foi salva e carregada, juntamente com a matriz, no software Winclada 1.00.08 (Nixon, 1999). Neste programa, foram calculados os índices de consistência (Kluge \& Farris, 1969) e de retenção (Farris, 1989), assim como as otimizações ACCTRAN (Accelerate Transformation), onde as homoplasias são consideradas como um único surgimento e posterior reversão para o estado plesiomórfico; e DELTRAN (Delayed Transformation) que considera as homoplasias como eventos convergentes. Seguindo o conceito de de Pinna (1991), na maioria das otimizações necessárias optou-se por ACCTRAN, que é a forma de otimização que melhor preserva as hipóteses de homologia primária. No entanto, em alguns casos específicos optou-se pela otimização DELTRAN, quando as aquisições independentes pareceram ser eventos mais prováveis.

Para a discussão dos caracteres foi usada a topologia da árvore de pesagem. Por fim, foi gerado um arquivo de imagem, com a árvore resultante, com todos os caracteres e seus estados plotados, esta foi finalizada em um programa de edição de imagens. 


\section{RESULTADOS}

\subsection{Descrições taxonômicas}

As descrições serão apresentadas do grupo externo para o interno, assim como apresentadas na filogenia, para facilitar a localização de cada espécie, seguindo a partir da espécie utilizada no enraizamento.

\section{SYSTEMATICS}

Order Cephalaspidea P. Fischer, 1883

Superfamily Haminoeoidea Pilsbry, 1895

Family Haminoeidae Pilsbry, 1895

\section{Genus Haminoea Turton \& Kingston [in Carrington], 1830}

Type species: Bulla hydatis Linnaeus, 1758, type by monotypy

Haminoea elegans (Gray, 1825)

(Figures 2-7)

Haminoea elegans (Gray, 1825): Pilsbry, 1893: 355; Morretes, 1949: 113; Marcus, Er., 1957: 395; 1958b: 35; Warmke \& Abbott, 1961: 141. Ev. Marcus \& Er. Marcus, 1963: 6; 1967: 24, fig. 13; Rudman, 1971: 545; Marcus, Ev., 1972: 75; Redfern, 2001: 156, fig. 651, pl. 69, fig. 651D, pl. 114; Valdés et al., 2006: 24; Rios, 2009: 403, fig. 1091; Camacho-García et al., 2014: 112.

Bulla elegans Gray, 1825: 408.

Bulla diaphana Gould, 1852: 222, 1860, pl. 15, figs. 265-265d.

Bulla guildingii Swainson, 1840: 360, fig. 46.

Haminoea taylorae Petuch, 1987: 31, pl. 4, fig. 12-13.

Type locality: British Sea and the Mediterranean

\section{Redescription}

Visceral mass: (Figure 2A-E): Size $\sim 17 \mathrm{~mm}$ length, $\sim 10 \mathrm{~mm}$ width without shell. Cephalic shield trapezoidal, developed posteriorly into a small cephalic lobe, covering anterior part of shell. Body rounded. Hancock's organ with 23 leaves (Fig. 2A, E). Parapodial lobes extended dorsally. Gill internal to mantle cavity. Mouth opening in anterior ventral region, between anterior region of cephalic shield and foot (metapodium). 
Digitiform tentacles absent. Lateral extensions of integument barrel-shape, about half of size of mouth (Fig. 2D). Anterior border of foot not bilabiate (Fig. 2D).

Haemocoel organs (Figure 2B, C): general form as involute spiral, fulfilling shell spire. Pericardium occupying $15 \%$ of haemocoel volume. Buccal mass and anterior digestive, occupying $20 \%$ of haemocoel volume. Nervous system dorsal to buccal mass occupying $5 \%$ of haemocoel volume. Reproductive system occupying $20 \%$ of haemocoel volume, divided in male and female parts. Stomach, intestine, digestive gland occupying $40 \%$ of haemocoel volume.

Circulatory and excretory systems (Figure 3A): Reno-pericardial region dorsolateral situated, covering digestive gland. Pericardium occupying $\sim 1 / 4$ of renopericardial region, anterior to gill; situated on left anterior margin of visceral mass. Auricle membranous, posterior to ventricle, with three connections: anterior to ventricle; divided in two posteriorly, one on right side that divided in two connections, on the fourth filament and other between fifth and sixth filament; and one on left side with kidney. Kidney glandular-shape occupying $\sim 1 / 2$ of reno-pericardial region.

Digestive system (Figures 3B-G; 4A-D; 7A-D): Oral tube composed of outer lip, with transverse fold; inner lip with two broad lengthwise fold, eache one whit a jaw (Fig. $3 \mathrm{E})$; mt, absent. Odontophore internal to oral tube, oval, connected to oral tube by very thin and short lateral muscles (m10) (Fig.3D). Odontophore muscles (Fig. 4A-D): m2, buccal retractors absent; $\mathbf{m 4}$, pair of dorsal tensor muscles, strong and broad, occupying $\sim 2 / 5$ of odontophore volume, twice as long as wide, covering $1 / 3$ of cartilage, inserted on ventral portion of subradular membrane; m5, pair of dorsal auxiliary tensor muscles, occupying $~ 2 / 5$ of odontophore volume, twice as long as wide, originating on most anterior region of odontophore cartilages, passing dorsally to $\mathrm{m} 4$, inserting on ventral side of subradular membrane, around radular sac; m6, unpaired horizontal muscle, with transverse fibers connecting to median surface of left and right odontophore cartilages and anterior portion of $\mathrm{m} 4$, about same length and half as wide as $\mathrm{m} 4$, triangle-shape; $\mathbf{m} 7$, unpared muscles, originating on posterior region of m6. Pair of odontophore cartilages elliptical, located more posteriorly. Radular sac $\sim 1 / 6$ of odontophore volume. Radular teeth (Fig. 7A, B): rachidian teeth absent; formula $28 \times 22.1 .22$ (in $17 \mathrm{~mm}$ long specimen). Each lateral tooth with broad base, tapering toward apex, hook-shaped, with single terminal cusp; outermost teeth thinner, inner base width about half of lateral teeth width, apex also hook-shaped, cusp simple and smooth. Jaws symmetrical (Fig. 3E). Gizzard with three plates, each with $8 / 9$ ridges (Figs. 3G; 7C-D). Pair of salivary glands long, 
tubular; duct inserting in anterior region of esophagus, extending posteriorly to anterior region of gizzard (Fig. 3B, C). Esophagus simple, originating dorsally to odontophore, inserting directly in anterior region of gizzard plates area, two lateral internal longitudinal folds along entire length (Fig. 3D, F). Stomach like broad sphincter, 1/3 of midgut, close to anterior region of intestine. Intestine, about three times longer than esophagus and about half esophagus diameter, immersed on digestive gland (Fig. 2B, C). Caecum absent. Digestive gland dark beige, being largest organ of visceral mass and occupying, rounded, inner face of digestive gland sponge-like. Anus opening on posterior left side (Fig. 2A, B).

Genital system (Figure 2B, C; 4E; 5A-C): Genital opening on right side, anterior third of length of animal from head, located between foot and notum. Gonad immersed in digestive gland, easy to distinguish it, clusters of small white dots (Fig. 2B, C). Hermaphrodite not distinguished from ampulla. Ampulla located posteriorly on female gland, elongated and tubular. Female gland well-developed, rounded, occupying 15\% of reproductive system volume (considering male and female parts), divided into mucus gland ( $2 / 3$ of female gland, color beige), and albumen gland $(\sim 1 / 3$ of anteriormost region, dilated, irregularly shaped, color dark brown). Oviduct occupying $\sim 1 / 2$ of female gland volume. Uterine duct and seminal receptacle absent. Bursa copulatrix rounded, length $\sim 1 / 2$ of female gland, connected to mucous gland, next to oviduct. Male genital system (Fig. 4E; 5A, B) located next to foregut on left side, inserting on integument by short, strong and wide penis's muscle. Prostate formed from two distinct, contiguous lobes with granulouse surfaces. Distal lobe more slender than proximal, 2/3 of prostate length. Vas deferens about same length as penis, connected to penis' muscle. Penis three times wider than vas deferens, with apex tip spatulate; posterior portion with an external papilla (Fig. 5A, B). Penial opening on anterior left side, anterior to Hancock's organ.

Nervous system (Figure 6A-C): Pair of cerebral ganglia connected by broad and simple commissure. Pleural ganglia fused with each cerebral ganglion, but not fused among themselves. Pedal ganglia fused with cerebral ganglia ventrally. Pedal commissure simple and broad same as cerebral commissure, surrounding esophagus and salivary glands (Fig. 6B). Buccal ganglia short, connected to cerebral ganglia through long and slender connective tissue, united with short, but easy to see, buccal commissure (Fig. 6C). Subesophageal ganglia and visceral ganglia seem to be fused, with about same length of cerebral ganglia, connected to pedal ganglia by long and slender connective (Fig. 6A). Supraesophageal ganglia located at right side, $\sim 1 / 2$ of length of cerebral ganglia, algo 
connected to pedal ganglia by long and slender connective (Fig. 6A). Eyes connected to cerebral ganglia by long optical nerve, locate on anterior region of buccal bulb, visible externally (Fig. 6A).

Distribution: Florida to Brazil (São Paulo); West Africa

Habitat: Estuarine species, muddy bottonms (Rios, 2009).

Material examined: BRAZIL, Estuário do Rio Ceará, Caucaia, Ceará, CMPHRM 3077B, 100 specimens (H. Galvão Filho et al., 12/xii/2009); North face of Pencel Bridge, in mud of mangrove, São Vicente, São Paulo, MZSP 35597, 100 specimens (L.R.L. Simone coll., 1985) 

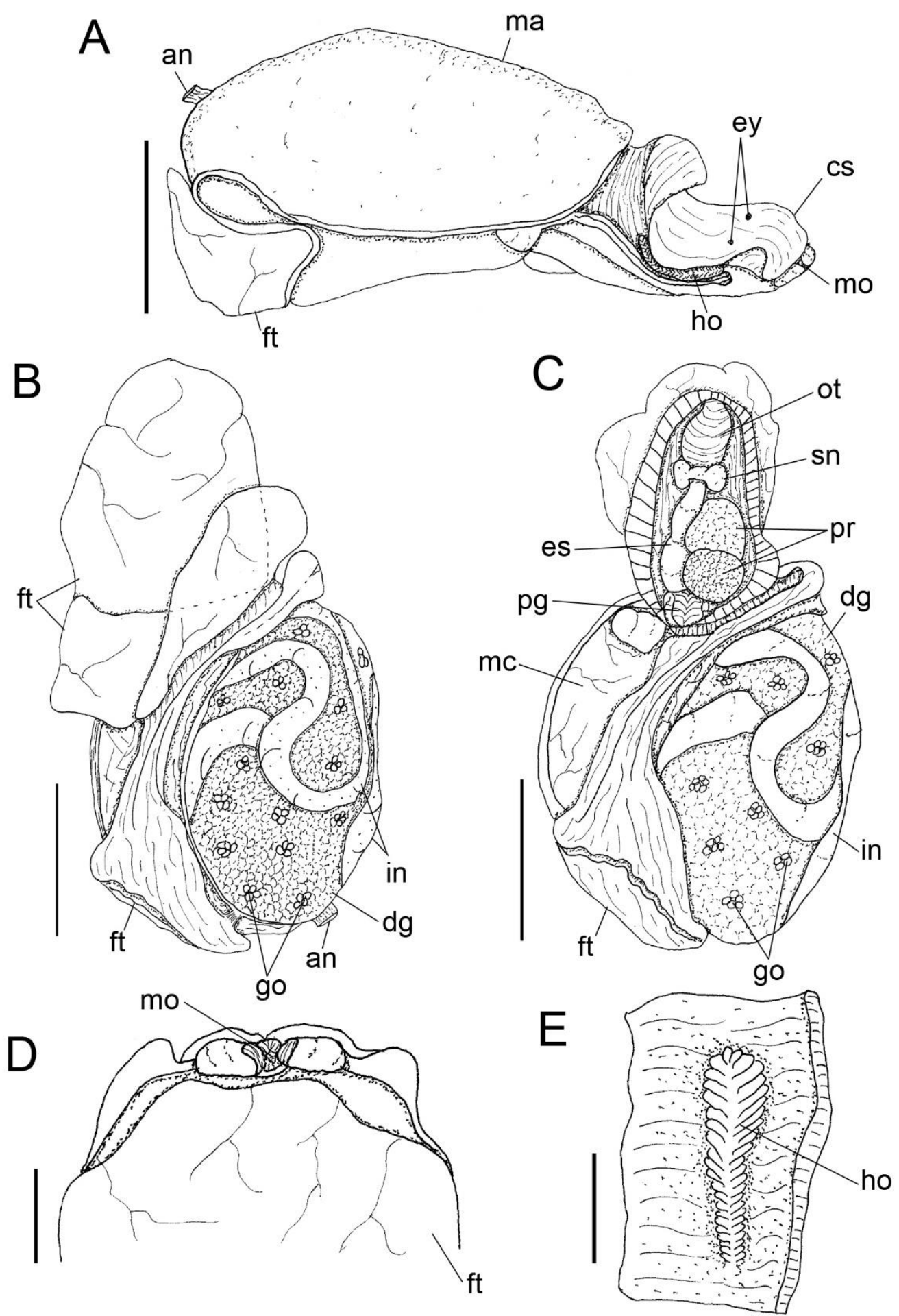

Figure 2: Visceral mass of Haminoea elegans, fixed animal. A. Rigth lateral view. B. Ventral view. C. Ventral view, with removed foot. Scales: $5 \mathrm{~mm}$. D. Detail of anterior region, mouth and flattened oral tentacles. Scale: $2 \mathrm{~mm}$. E. Detail of Hancock' organ in the integument. Scales: $1 \mathrm{~mm}$. 

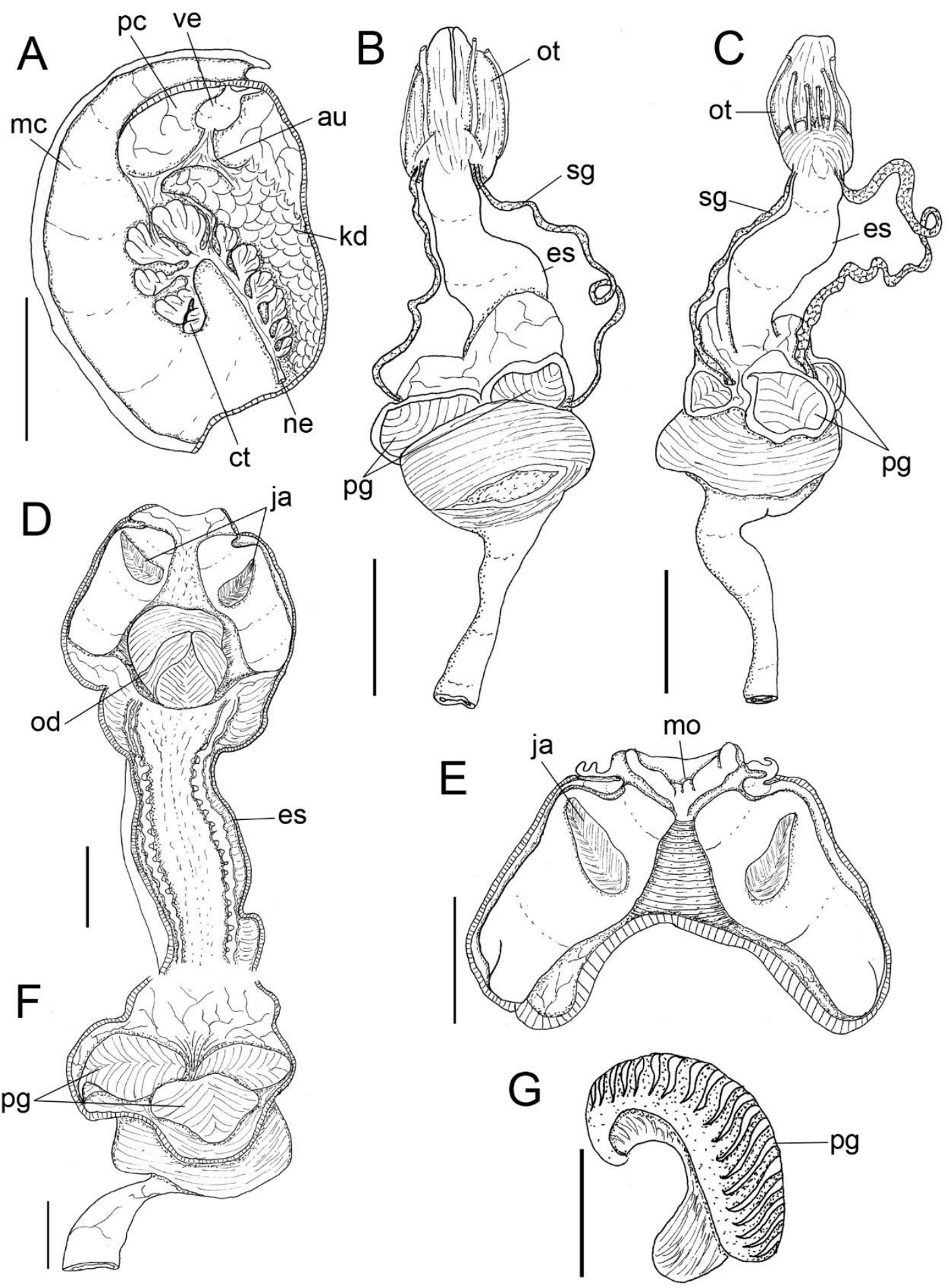

Figure 3: Haminoea elegans. A. Palial cavity, organs involved by pericardium, ventral view. Scale: $5 \mathrm{~mm}$. Anterior digestive system. B. Dorsal view. C. Ventral view. D. Longitudinally sectioned, ventral view. Scale: $2 \mathrm{~mm}$. E. Oral tube with jaws, ventral view. Scale: $1 \mathrm{~mm}$. F. Longitudinally sectioned of gizzard plates, ventral view. Scale: $2 \mathrm{~mm}$. G. Gizzard plate, lateral view. Scales: $1 \mathrm{~mm}$. 

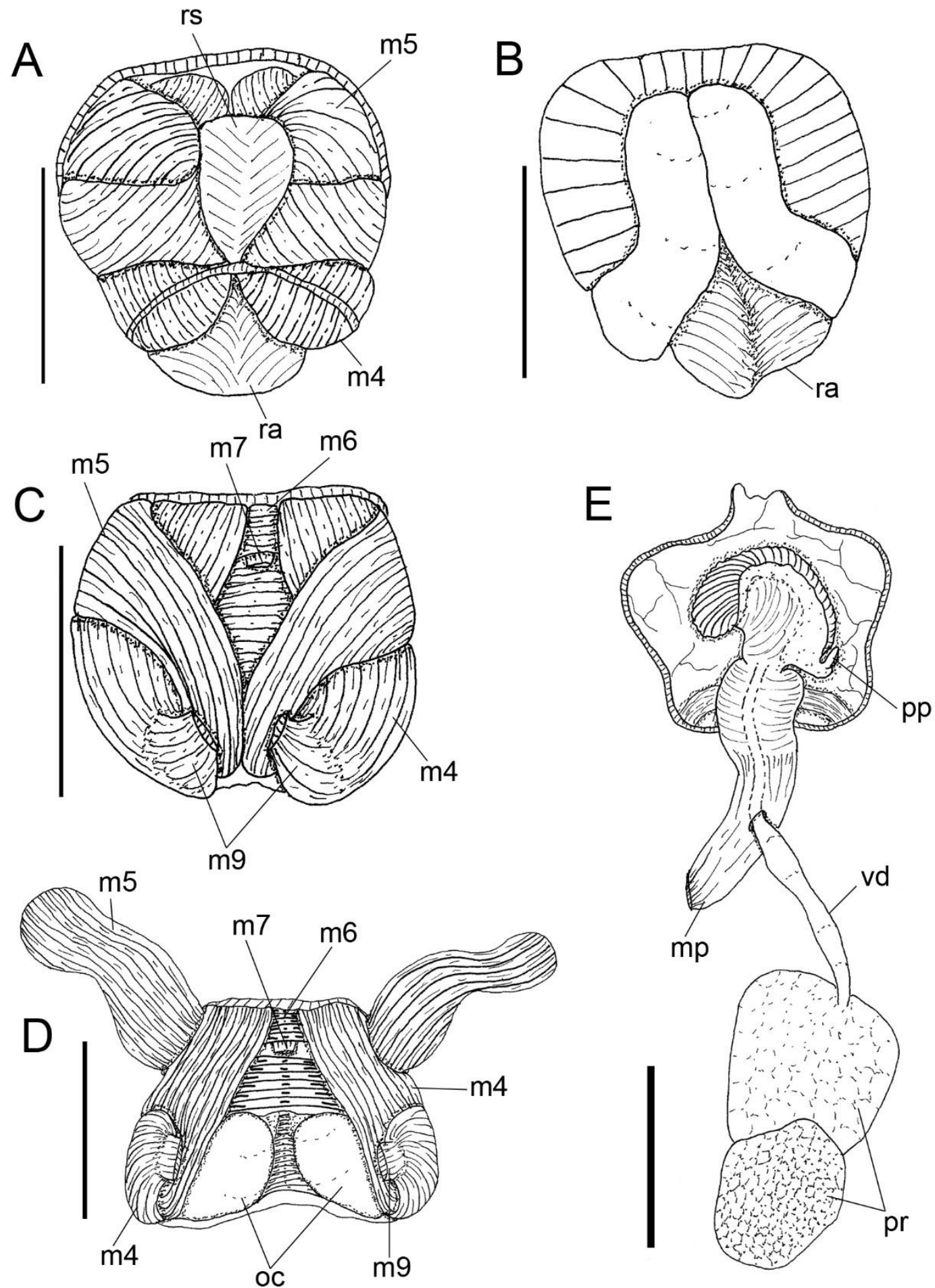

Figure 4: Haminoea elegans. Odontophore A. Dorsal view. B. Ventral view, C. Dorsal view with radula removed. D, Ventral view, $\mathrm{m} 4$ and $\mathrm{m} 5$ folded down to expose odontophore cartilage. Scales: $1 \mathrm{~mm}$. E. Male reproductive system, dorsal view. Scale: $2 \mathrm{~mm}$. 
A

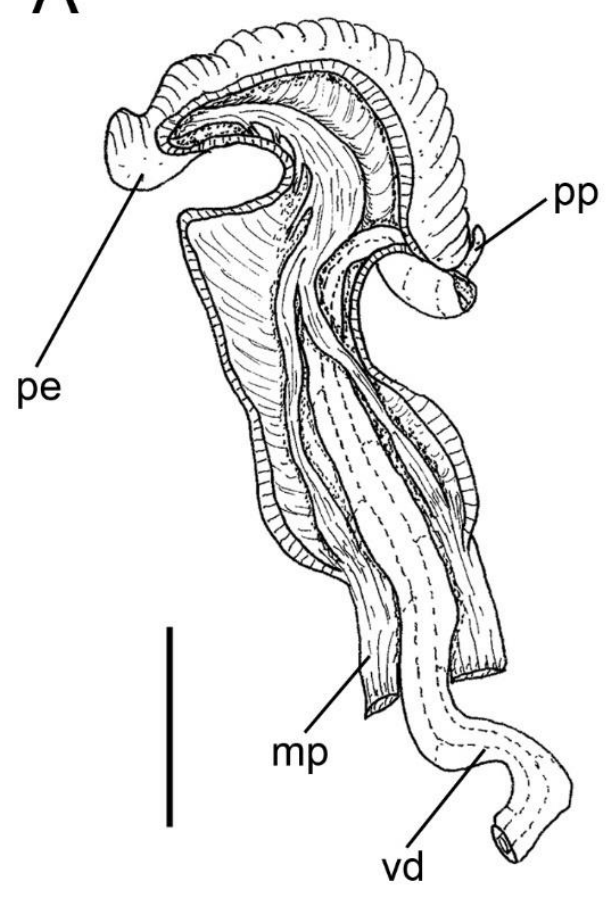

B

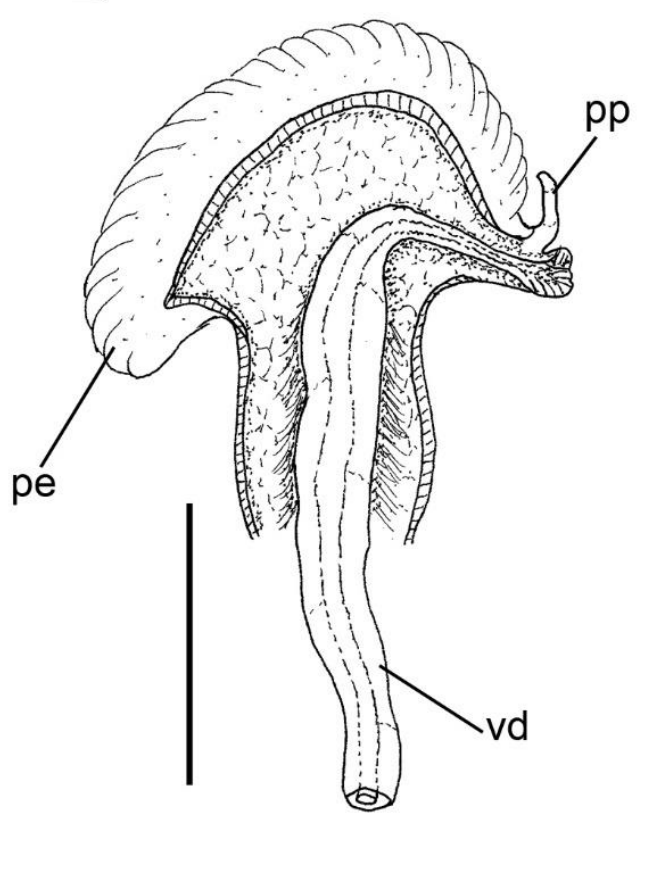

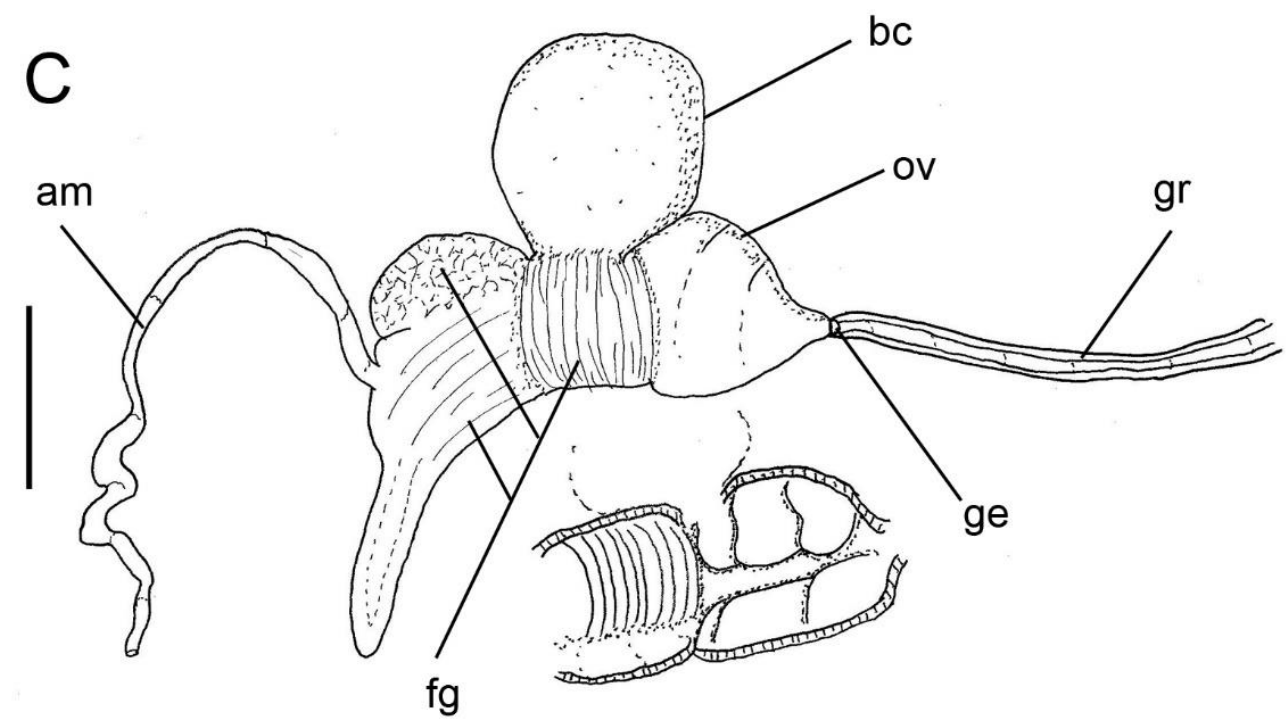

Figure 5: Haminoea elegans. Reproductive system. A. Detail of penis with penis's muscle, dorsal view. B. Same, without penis's muscle, dorsal view. C. Female, dorsal view, with internal detail of female gland. Scales: $1 \mathrm{~mm}$. 
A

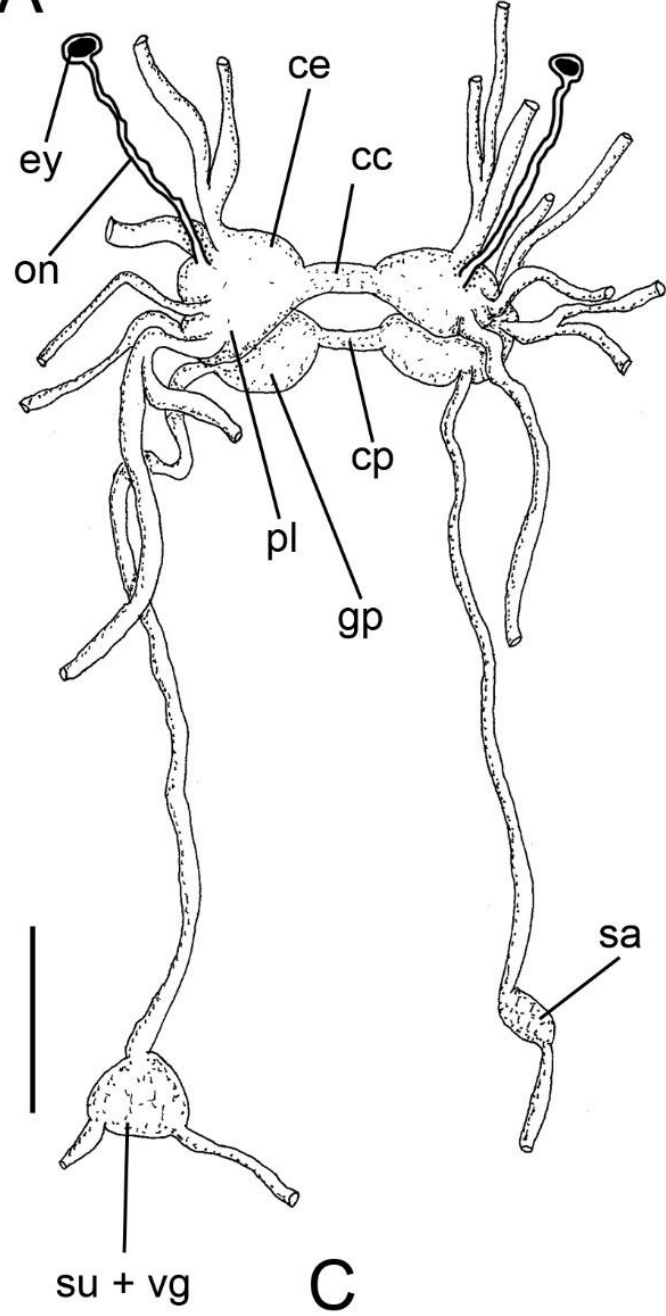

B

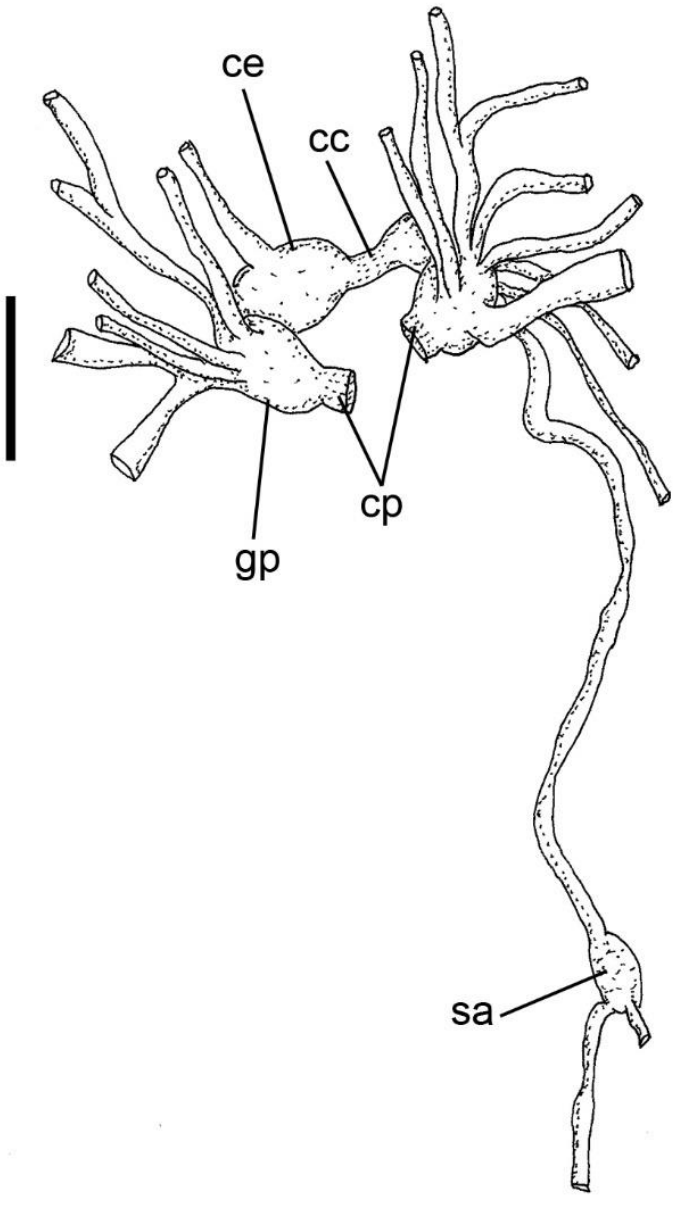

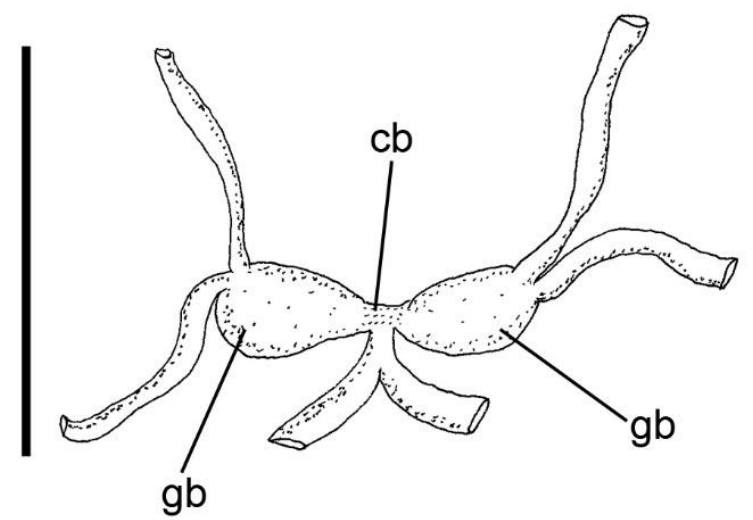

Figure 6: Haminoea elegans. Nervous system. A. Dorsal view. B. Same, ventral view. F. Detail of buccal ganglia, ventral view. Scales: $1 \mathrm{~mm}$. 


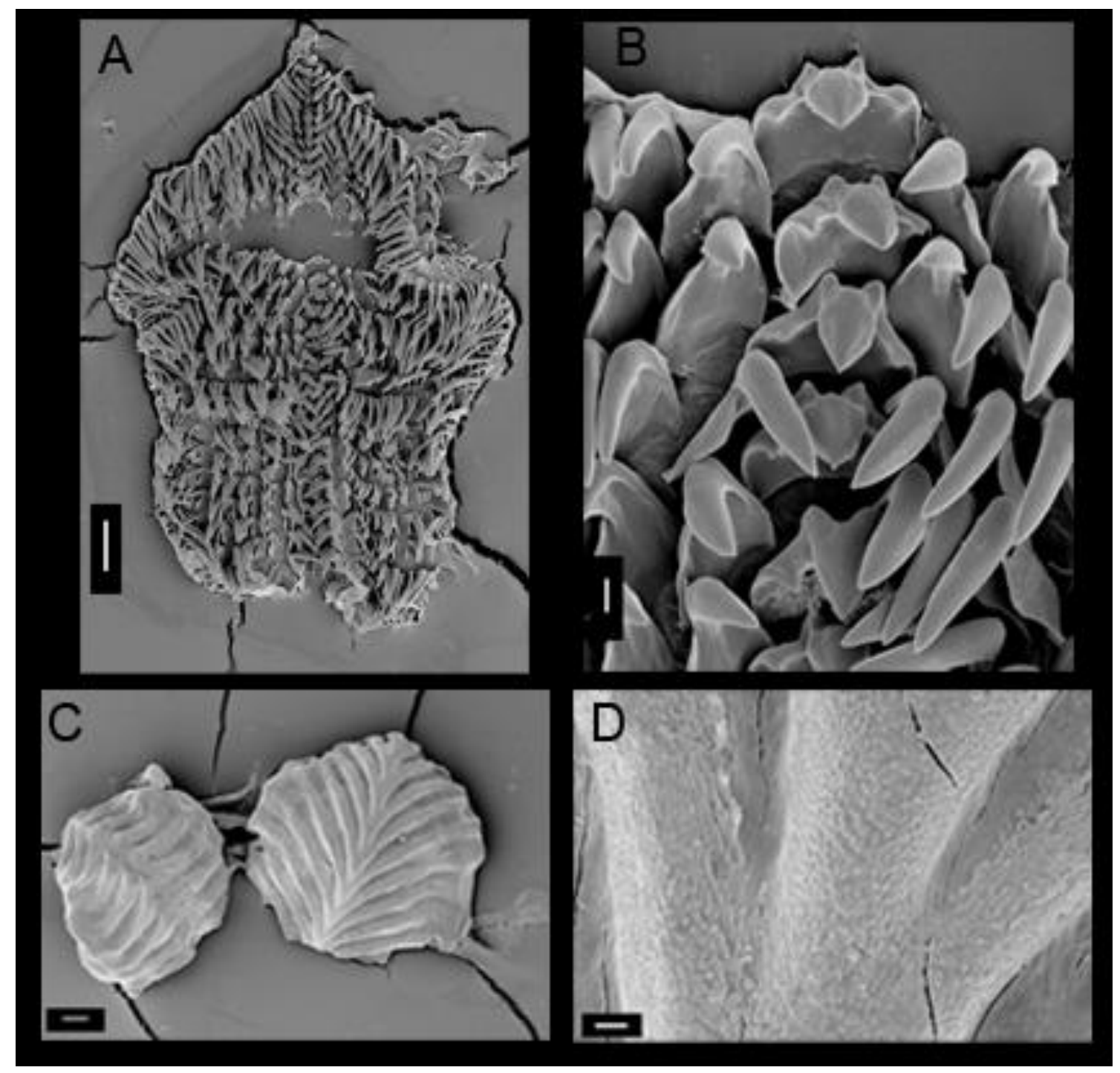

Figure 7: Haminoea elegans. SEM of radula and gizzard plates. A. Panoramic view of radula. Scale:

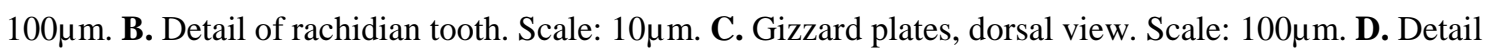
of gizzard plate. Scale: $10 \mu \mathrm{m}$.

Order Pleurobranchomorpha Pelseneer, 1906

Superfamily Pleurobranchoidea Gray, 1827

Family Pleurobranchidae Gray, 1827

Genus Berthella Blainville, 1824

Berthella agassizii (MacFarland, 1909)

See Alvim \& Pimenta (2015) 
Order Nudibranchia Cuvier, 1817

Superfamily Arminoidea Iredale \& O’Donoghue, 1923 (1841)

Family Arminidae Iredale \& O’Donoghue, 1923 (1841)

Genus Armina Rafinesque, 1814

Type species: Armina tigrina Rafinesque, 1814, type by subsequent designation

Armina muelleri (Ihering, 1886)

(Figures 8-12)

Pleurophyllidia muelleri Ihering, 1886: 223, pl. 9, fig.1.

Armina muelleri: Morretes: 1949: 117; Marcus \& Marcus, 1960: 170, figs. 61-67; 1966: 192; 1967: 108; Ardila \& Diaz, 2002: 28; Ardila \& Valdés, 2004: 133; Valdés et al., 2006: 208; Rios, 2009: 432; Báez et al., 2011: 1108, figs. 1-2.

Type locality: Armação, Desterro, in Province of Santa Catarina, Brazil.

\section{Redescription}

External morphology (Figures 8A-D; 9A-C): Size 26mm length, 12mm widh. Body rounded with posterior end pointed. Rhinophores anterior with longitudinal lamellae, black color (Fig. 8D); rhinophoral sheaths absent. Twenty-eitgh branchial lamellae on the left side of body, seventeen on right (Fig. 8B, C). Fifteen hyponotal lamellae on each side of body (Fig. 9A). Gill lateral on both side, arranged in transversal lamellae. Mouth opening in anterior ventral region, between anterior region of notum and foot (Fig. 8B). Digitiform tentacles absent. Oral veil present. Anterior border of foot not bilabiate (Fig. 8B, C).

Haemocoel organs (Figure 9D, E): pericardium occupying 5\% of haemocoel. Buccal mass located anteriorly, occupying $20 \%$ of haemocoel volume. Nervous system dorsal and posterior to buccal mass, occupying $5 \%$ of haemocoel volume. Reproductive system on right ventral side of animal, occupying 30\% of haemocoel volume. Stomach, intestine and digestive gland occupying $40 \%$ of haemocoel volume.

Circulatory and excretory systems (Figure 9D, F): pericardial cavity dorsal, median and transversal to gonad. Gill retractor muscle absent. Auricle funnel-like, tapering anteriorly in connection with ventricle, with thin walls. Ventricle sligthly taller than wide, with thick muscular walls. Aortic trunk branched into anterior artery irrigating 
buccal mass, odontophore and nervous system; posterior artery irrigating stomach and digestive gland and a third short artery irrigating only reproductive system (Fig. 9F). Renal vesicle absent.

Digestive system (Figures 10A-E; 12A-E): Oral tube composed of outer lip, with pleats lengthwise; inner lip with transverse fold; mt, four pairs of retractor muscles of buccal mass, originating on oral tube, running dorsally and ventrally to oral tube, inserting on body side, about same wide and twice longer as m10. Odontophore oval, connected to oral tube by pair of ventral protractor muscles (m10) (Fig. 10C); broad longitudinal, dorsal and ventrolateral protractors of oral sphincter, originating in anterior region of odontophore and inserted in posterior region of integument close to oral tube. Oral sphincter very muscular, circular, surrounding chitinous part of oral tube. Odontophore muscles (Fig. 10D, E) reduced: $\mathbf{m} \mathbf{2}, \mathbf{m 6}$ and $\mathbf{m 7}$ absent; $\mathbf{m 4}$ and $\mathbf{m 5}$, fused originating very strong muscle surrounding odontophore cartilages. Pair of odontophore cartilages elliptical, occupying $~ 2 / 6$ of odontophore volume. Subradular membrane thin, strong, translucent. Radular sac $\sim 1 / 6$ of odontophore volume. Radular teeth (Figure 12A-E): rachidian tooth present, with one very prominent median cusp with 12 thin lateral cusps on each side of median cusps; First lateral tooth knife-shape with median line of small cusps. The remaining lateral teeth elongate and also bear denticles on both side of each tooth. Radular formula $\sim 15$ x 40.1.1.1.40 (in $26 \mathrm{~mm}$ long specimen). Pair of salivary glands rounded with long duct inserting in anterior region of esophagus (Fig. 10B). Esophagus simple, originating dorsally to odontophore, inserting directly in anterior region of stomach, internal longitudinal folds with same diameter along entire length. Stomach oval, located on left/median of visceral mass, connected straight with digestive gland (Fig. 10A). Intestine originating on thirth posterior region of stomach, following dorsal and lateral to digestive gland. Caecum absent. Digestive gland dark beige, coneshaped; anterior portion about three times wider than posterior portion, inner face of gland sponge-like, bearing multiple branches that connect to lateral/ventral gill fillaments (Fig. 10A). Anus opening into anal papilla located slightly behind midpoint, posterior to gonopore (Fig. 10A).

Genital system (Figures 8C; 10F; 11A, B)): Genital opening on midle of right side, located between foot and notum (Fig. 8C). Gonad enterily distinct to digestive gland (Fig. 10F). Hermaphrodite duct thin, long. Ampulla located on female gland, very wide and convoluted. Prostate tubular, glandular, length third length of ampulla. Vas deferens not distinguished from penis. Penis' muscle absent. Penis muscular, cylindrical and 
elongated, about same length and width of vagina, with protruding papilla (Fig.11B). Female gland well-developed, rounded, surrounding ampulla and prostate, occupying $\sim 15 \%$ of reproductive system volume, divided into mucus gland $(\sim 2 / 3$ of female gland, color beige), and albumen gland ( 1/3 of anteriormost region, dilated, irregularly shaped, color dark brown). Oviduct occupying 1/9 of female gland volume. Uterine duct absent. Seminal receptacle rounded, same length of vagina, and twice wide of ampulla, connected to vagina on posterior end (Fig. 11A). Bursa copulatrix absent. Vagina cylindrical, elongated, approximately as long and same wide as penis, located parallel to penis in genital opening (Fig. 11B).

Nervous system (Figure 11C-E): Pair of cerebral and pleural ganglia fused with each other dorsally and ventrally. Pedal ganglia fused with cerebral and pleural ventrally, but not fused among themselves. Pedal commissure simple and long, surrounding esophagus and salivary glands (Fig. 11D). Buccal ganglia short with a long commissure connecting both ganglia, located ventrally to odontophore, between radular sac and anterior portion of esophagus, connected to cerebral ganglia through long and slender connective tissue, united to gastro-esophageal ganglia by short connective tissue; radular nerve originating from buccal commissure (Fig. 11E). Gastro-esophageal ganglia length about 1/4 of buccal ganglia length, circular (Fig. 11E). Rhinophoral (olfactory) ganglia absent, rhinophoral nerve connected directly with cerebral ganglia. Dorsal eyes located on cerebral ganglia (Fig. 11C).

Distribution: Lesser Antilles on the coast of Dominica to Brazil.

Habitat: Found on hard substrate and sand bottoms, on intertidal rocks (Rios, 2009; Baéz et al., 2011).

Material examined: BRAZIL, São Sebastião, São Paulo, MZSP 34861, 1 specimen (Biota-FAPESP, 17/v/2001; 45m deep, unconsolidated infralitoral). 

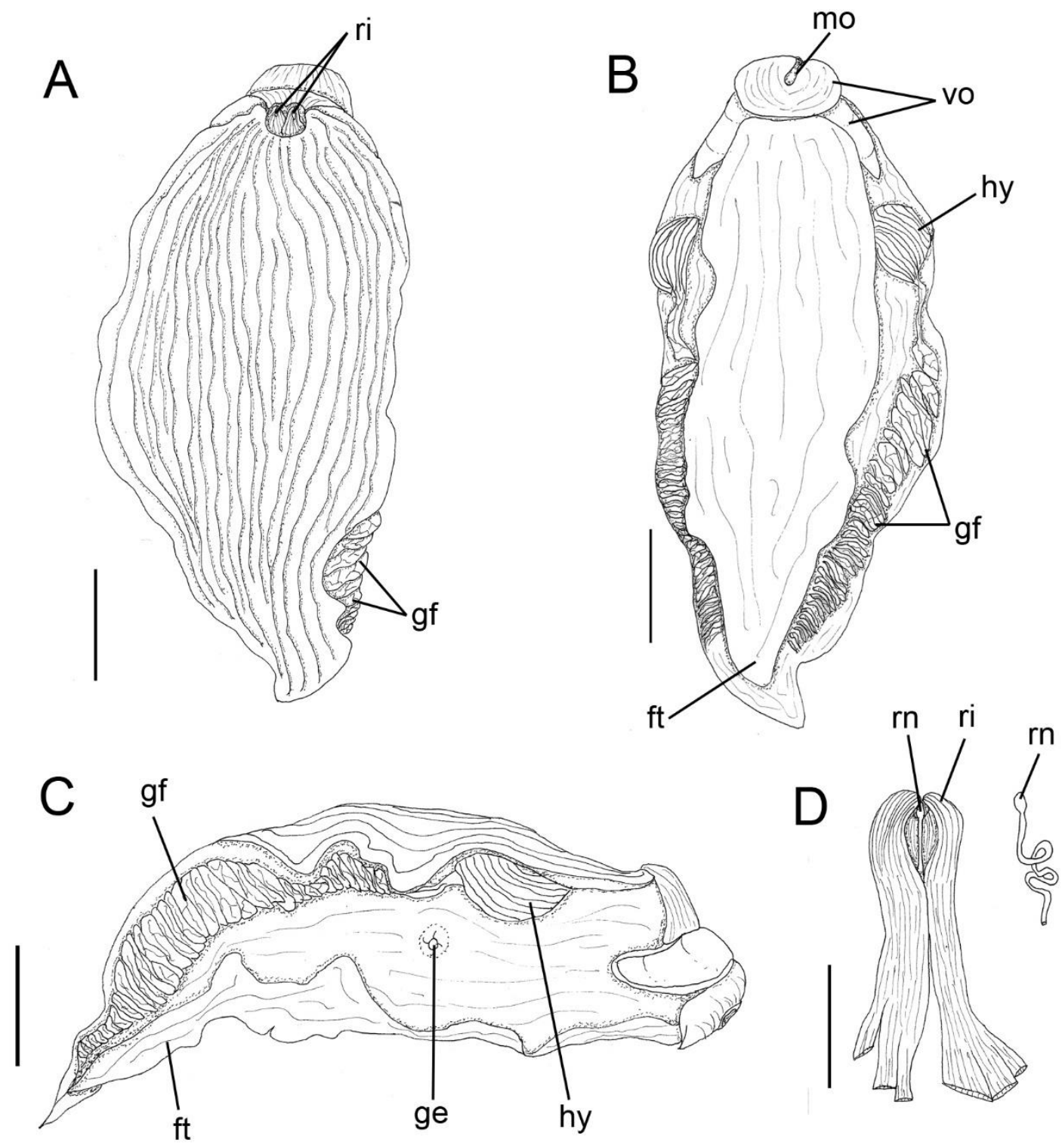

Figure 8: Armina muelleri fixed animal. A. Dorsal view. B. Ventral view. C. Rigth lateral view. Scales: $5 \mathrm{~mm}$. D. Detail of rhinophore and rhinophoral nerve. Scales: $2 \mathrm{~mm}$. 


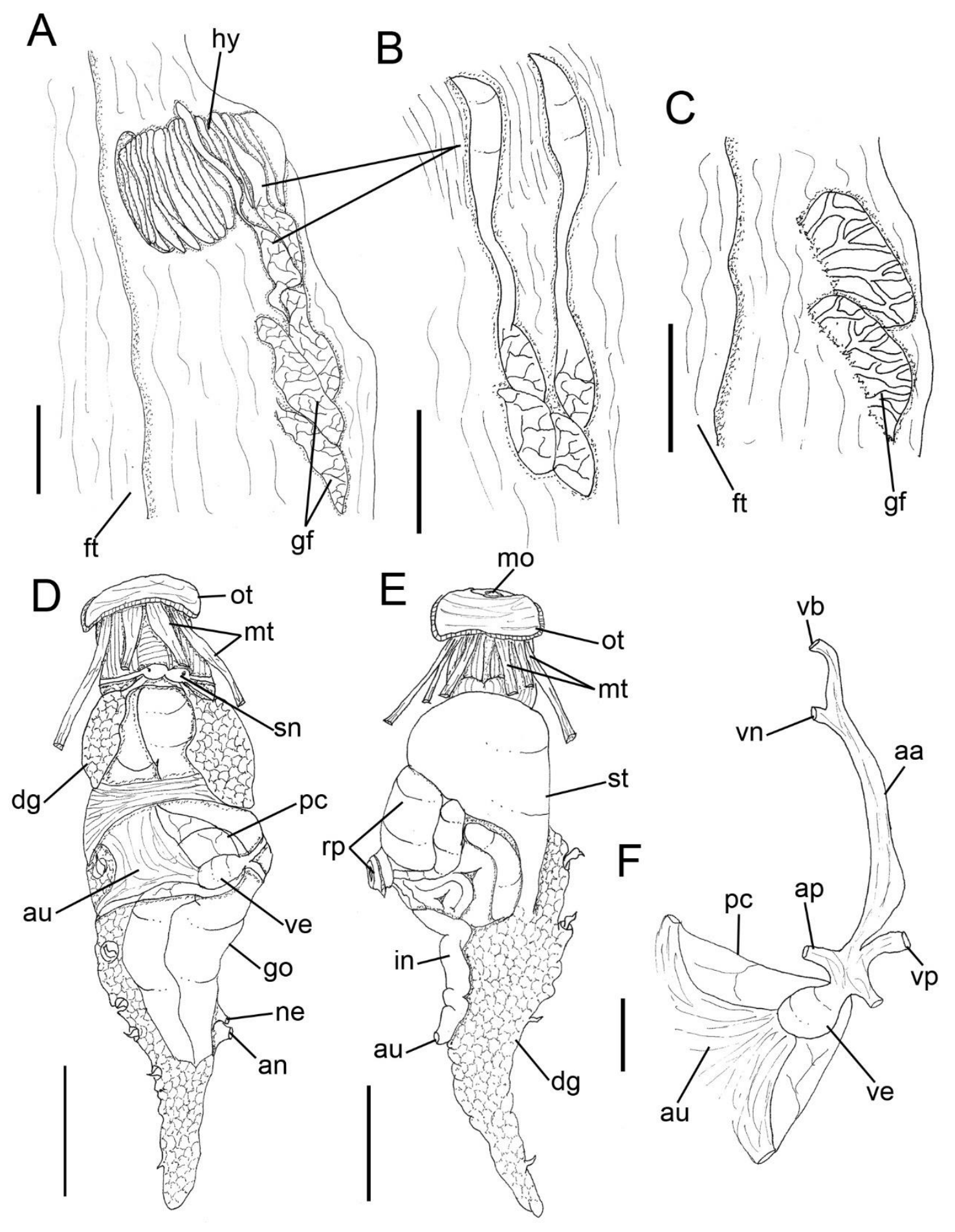

Figure 9: Armina muelleri. A-C. Detail of hyponotal and branchial lamellae, ventral view. Scales: $2 \mathrm{~mm}$. Visceral mass D. Dorsal view. E. Same, ventral view. Scales: $5 \mathrm{~mm}$. F. Circulatory system, dorsal view. Scale: $2 \mathrm{~mm}$. 

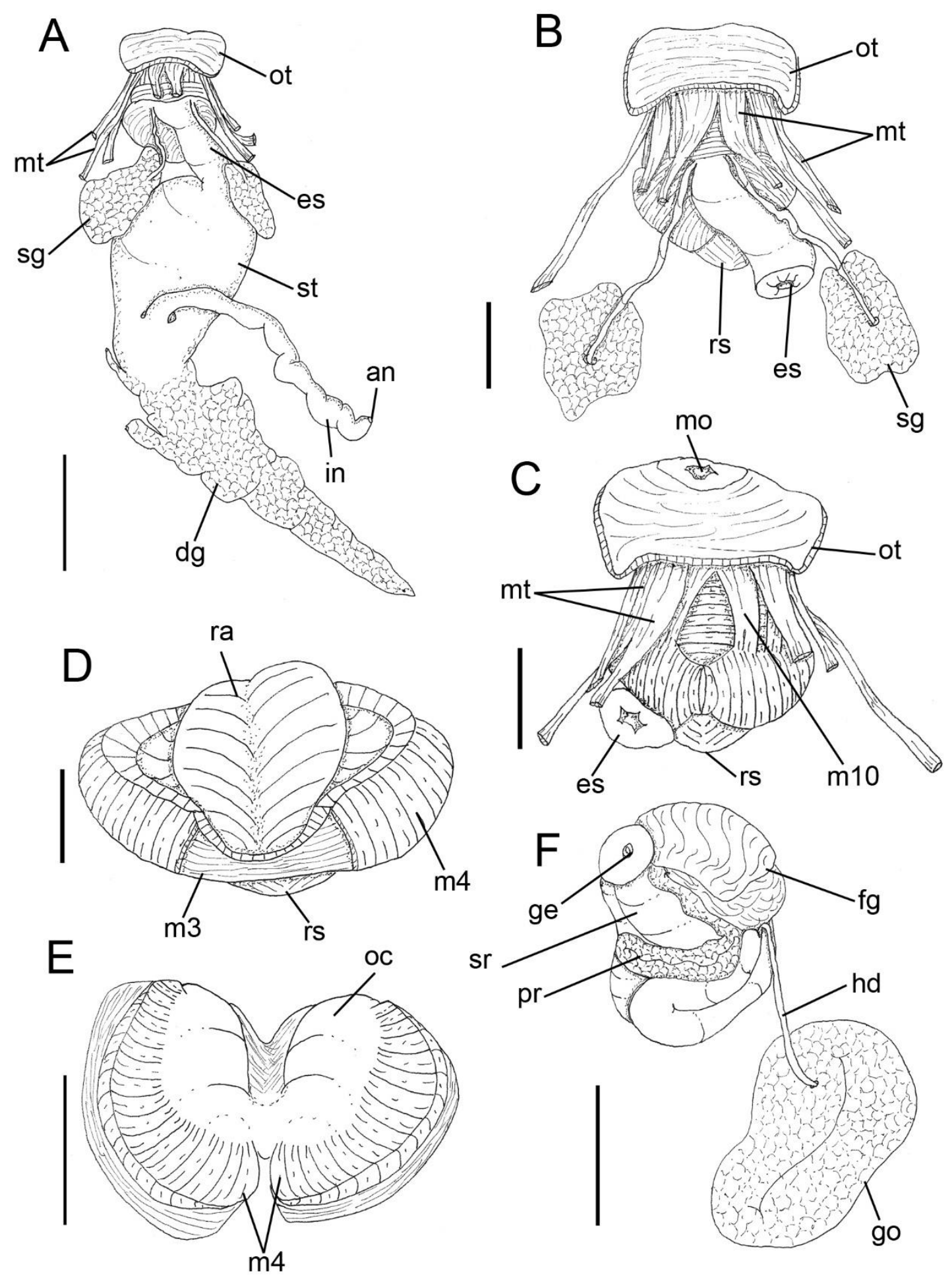

Figure 10: Armina muelleri. A. Digestive system, dorsal view. Scale: 5mm. B. Anterior digestive system, dorsal view. C. Same, ventral view. Scale: $2 \mathrm{~mm}$. Odontophore. D. Dorsal view with radula. Scale: $1 \mathrm{~mm}$. E. Same, dorsal view with radula removed. Scale: $2 \mathrm{~mm}$. F. Reproductive system, dorsal view. Scale: $5 \mathrm{~mm}$. 

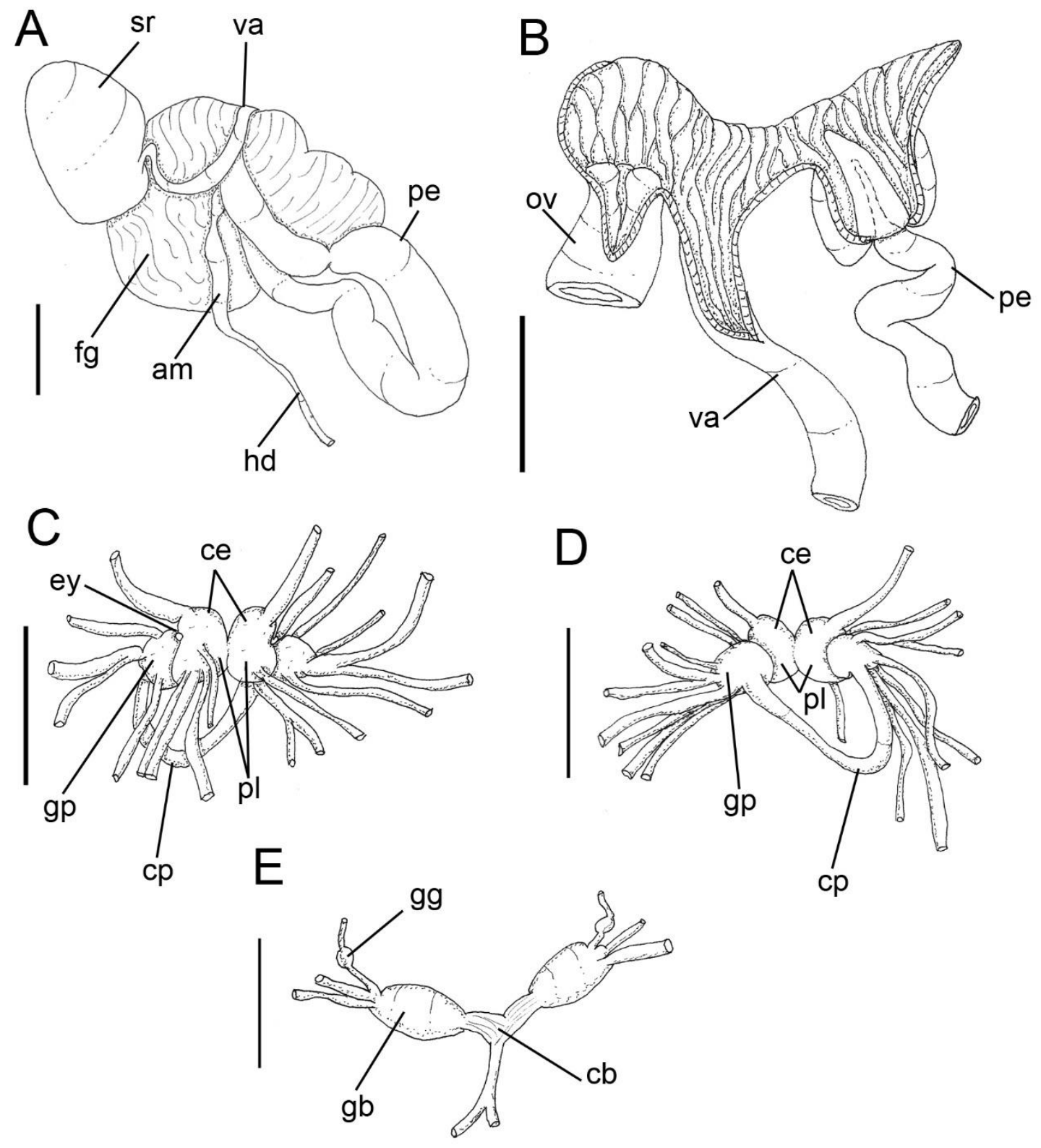

Figure 11: Armina muelleri. A. Detail of reproductive system. Scale: $2 \mathrm{~mm}$. B. Detail of gonopore, with three aperture, oviduct, vagina and penis (with papilla). Scale: $1 \mathrm{~mm}$. Nervous system. C. Dorsal view. D. Same, ventral view. Scales: $2 \mathrm{~mm}$. E. Detail of buccal ganglia, dorsal view. Scale: $1 \mathrm{~mm}$. 


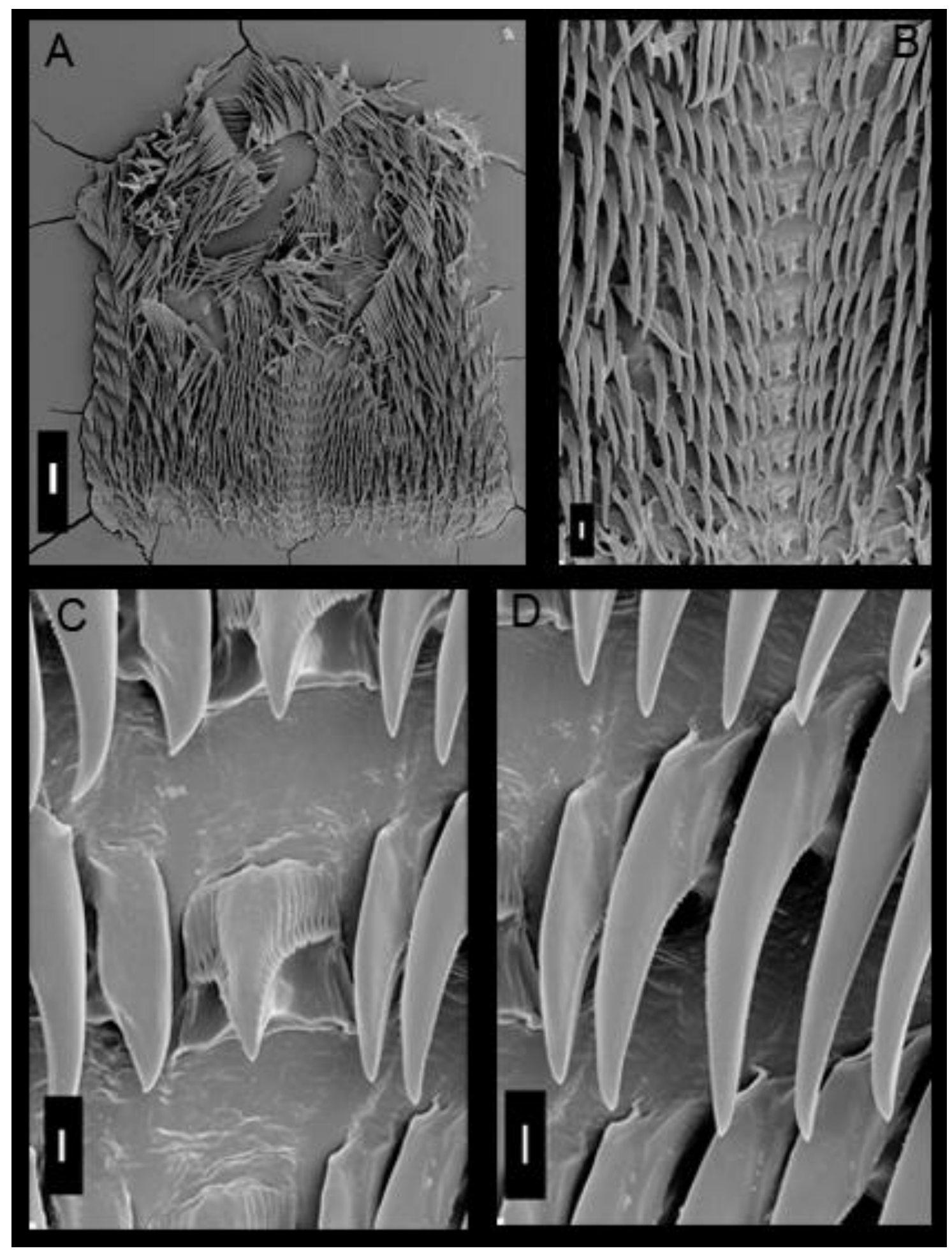

Figure 12: SEM of radula of Armina muelleri. A. Panoramic view. Scale: $200 \mu \mathrm{m}$. B. Central view of innermost lateral teeth. Scale: $30 \mu \mathrm{m}$. C. Detail of rachidina tooth. Scale: $10 \mu \mathrm{m}$. D. First lateral teeth. Scale: $10 \mu \mathrm{m}$. 


\section{Superfamily Aeolidoidea Gray, 1827}

Family Facelinidae Bergh, 1889

Genus Noumeaella Risbec, 1937

Type species: Noumeaella curiosa Risbec, 1937, type by original designation

\section{Noumeaella kristenseni (Ev. Marcus \& Er. Marcus, 1963)}

(Figures 13-17)

Moridilla kristenseni Ev. Marcus \& Er. Marcus, 1963: 44, figs. 57-60; Er. Marcus \& Ev. Marcus, 1970: 80, figs. 142-143; Redfern, 2001: 182, fig. 749A, B, pl. 121.

Noumeaella kristenseni (Ev. Marcus \& Er. Marcus, 1963) Valdés et al., 2006: 250.

Palisa kristenseni (Ev. Marcus \& Er. Marcus, 1963) Edmunds \& Just, 1983: 197

Type locality: Pier of the Carmabi, Piscadera Baai, Curaçao

\section{Redescription}

External morphology (Figures 13A-F; 14A-C): Size 9mm length, 3mm width. Body elongate, limaciform (Fig. 13A-C). Rhinophores with united base, lamellae papillae-shape (Fig. 13D, E). Rhinophoral sheaths absent. Cerata arranged in $\sim 6$ groups on each side (Fig. 13F). Several cerata (6-9) originating from a common peduncle (Fig. 14C). Cerata with variable length. Mouth opening in anterior ventral region, between anterior region of notum and foot (Fig. 14C). Oral veil derived in labial tentacles, longer than cerata around mouth. Anterior border of foot tentacular, blent posteriorly, with deep groove on ventral side (Fig. 14C).

Haemocoel organs (Figure 14D-E): pericardium on anterior region occupying $10 \%$ of haemocoel volume. Buccal mass located anteriorly, occupying $15 \%$ of haemocoel volume. Nervous system dorsal to buccal mass, occupying 5\% of haemocoel volume. Reproductive system posterior to buccal mass, occupying $20 \%$ of haemocoel volume. Stomach, intestine and digestive gland/gonad, occupying 50\% of haemocoel volume.

Circulatory and excretory systems: pericardial cavity dorsal and anterior to digestive gland. Branches located along digestive gland, following for each pedunculated cerata. Gill retractor muscle absent. Renal vesicle absent.

Digestive system (Figures 13C; 14A, D-F; 15A-E; 17A-C): Oral tube composed by cartilaginous part on both side; mt absent. Odontophore oval, connected to oral tube 
by pair of ventral protractor muscles (m10); thin longitudinal, reduced, ventrolateral protractors of oral sphincter, originating in anterior region of odontophore and inserted in posterior region of integument close to oral tube. Oral sphincter surrounding chitinous part of oral tube. Odontophore muscles (Fig. 15A-E): mj, unpaired muscle originating in middle of $\mathrm{m} 4$, lateral to odontophore cartilages; $\mathbf{m} \mathbf{2}$, pair of thin retractor muscles of buccal mass, twice as long as wide, origin on anterior dorsal odontophore, ventrally to $\mathrm{m} 4$ and inserted ventrally on dorsal portion of oral tube; $\mathbf{m} \mathbf{4}$, pair of dorsal tensor muscles, strong and broad, occupying 4/9 of odontophore volume, 1/3 as long as wide, covering $2 / 3$ of cartilage, inserted on ventral portion of subradular membrane; $\mathbf{m 5}$, seems to be fused with m4; m6 and $\mathbf{m} 7$, absent. Pair of odontophore cartilages elongate and thin. Radular sac very short, $\sim 1 / 15$ of odontophore volume. Radula not analyzed. Jaw paired, triangle-shaped with some short cusps anteriorly (Fig. 17A-C). Pair of salivary glands with irregular surface, duct inserting in median region of esophagus, extending parallel to it (Fig. 14F). Esophagus simple, originating dorsally to odontophore, proceed continuous to stomach, intestine and anus, all of them following bottleneck of esophagus with bend in middle, changing intestinal path to anterior median region. Caecum absent. Digestive gland dark beige, being largest organ of visceral mass, elongate, anterior portion pointed, bearing various branches that following to cerata (Fig. 14A, D, E). Anus opening into anal papilla at right lateral, subsequent to gonopore (Fig. 13C).

Genital system (Figure 16A-C): Genital opening on right side, anterior fourth of length of animal from head, located between foot and notum. Gonad immersed in digestive gland, difficult to distinguish it. Hermaphrodite duct thin, long. Ampulla located on female gland, very wide and convoluted, inserting on female gland. Prostate glandular, originating on female galnd, $1 / 2$ length of ampulla (Fig. 16A). Female gland welldeveloped, rounded, occupying $\sim 30 \%$ of reproductive system volume, divided into mucus gland ( $\sim 2 / 3$ of female gland, color beige), and albumen gland ( 1/3 of anteriormost region, dilated, irregularly shaped, color dark brown). Seminal receptacle pyriform, as large and wide as bursa copulatrix, both connected with vagina by short stalk. Bursa copulatrix rounded, connected with base of vagina, united with seminal receptacle (Fig. 16B). Vagina cylindrical, elongated, approximately twice as long as ampulla with accessory sac at genital opening (Fig. 16B, C).

Nervous system (Figure 16D-F): Pair of cerebral and pleural ganglia fused with each other dorsally and ventrally. Pedal ganglia fused with cerebral and pleural ventrally, but not fused among themselves. Pedal commissure inconspicuos surrounding esophagus 
and salivary glands (Fig. 16E). Buccal ganglia short, with inconspicuous commissure, located ventrally to odontophore (Fig. 16F). Gastro-esophageal ganglia not visualized. Rhinophoral (olfactory) ganglia inconspicuos. Dorsal eyes located on cerebral ganglia (Fig. 16D).

Distribution: Caribbean Se ato Brazil.

Material examined: BRAZIL, Ilha dos Porcos, Ubatuba, São Paulo, MZSP 122461, 1 specimen (Biota-FAPESP, 08/vi/2001). 


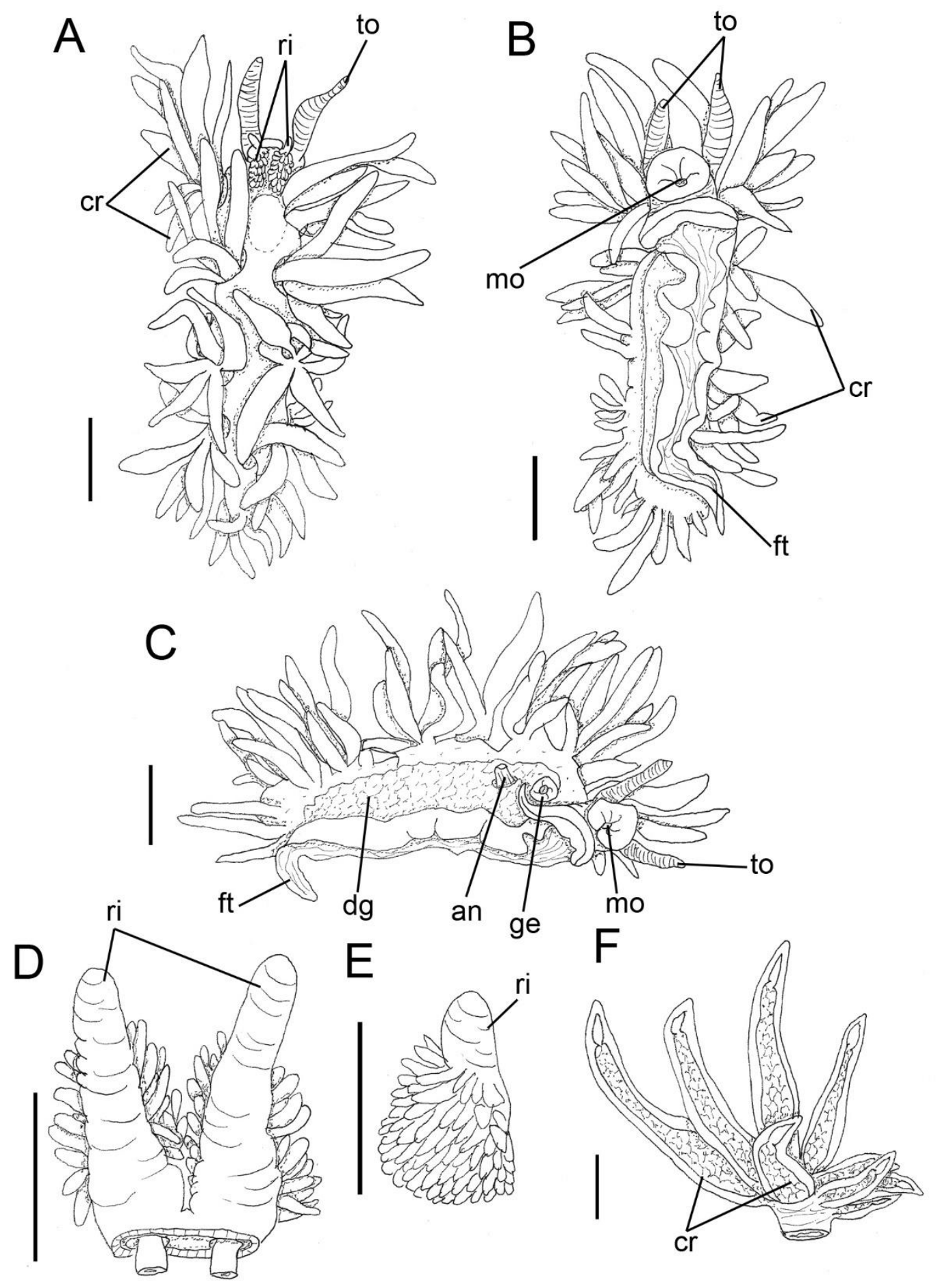

Figure 13: Noumeaella kristenseni, fixed animal. A. Dorsal view. B. Ventral view. C. Rigth lateral view. Scales: $2 \mathrm{~mm}$. D. Detail of rhinophore, anterior view. E. Same, posterior/dorsal view. F. Detail of cerata. Scales: $1 \mathrm{~mm}$. 

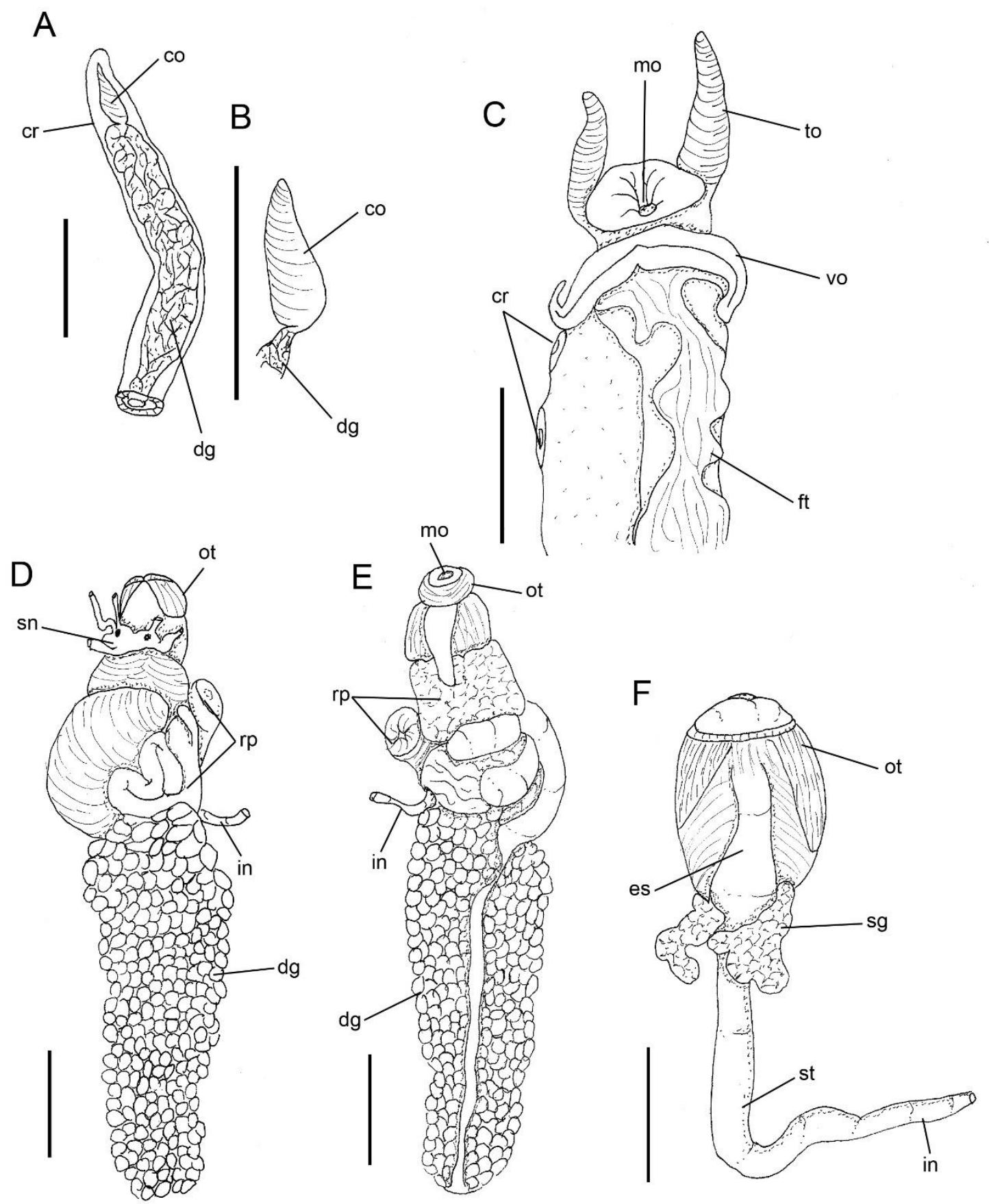

Figure 14: Noumeaella kristenseni. A. Detail of digestive gland ramified in a cera. B. Detail of cnidocit. Scales: $1 \mathrm{~mm}$ C. Detail of anterior border of foot. Visceral mass. D. Dorsal view. E. Ventral view. Scale: $2 \mathrm{~mm}$. F. Anterior digestive system, dorsal view. Scale: $1 \mathrm{~mm}$. 

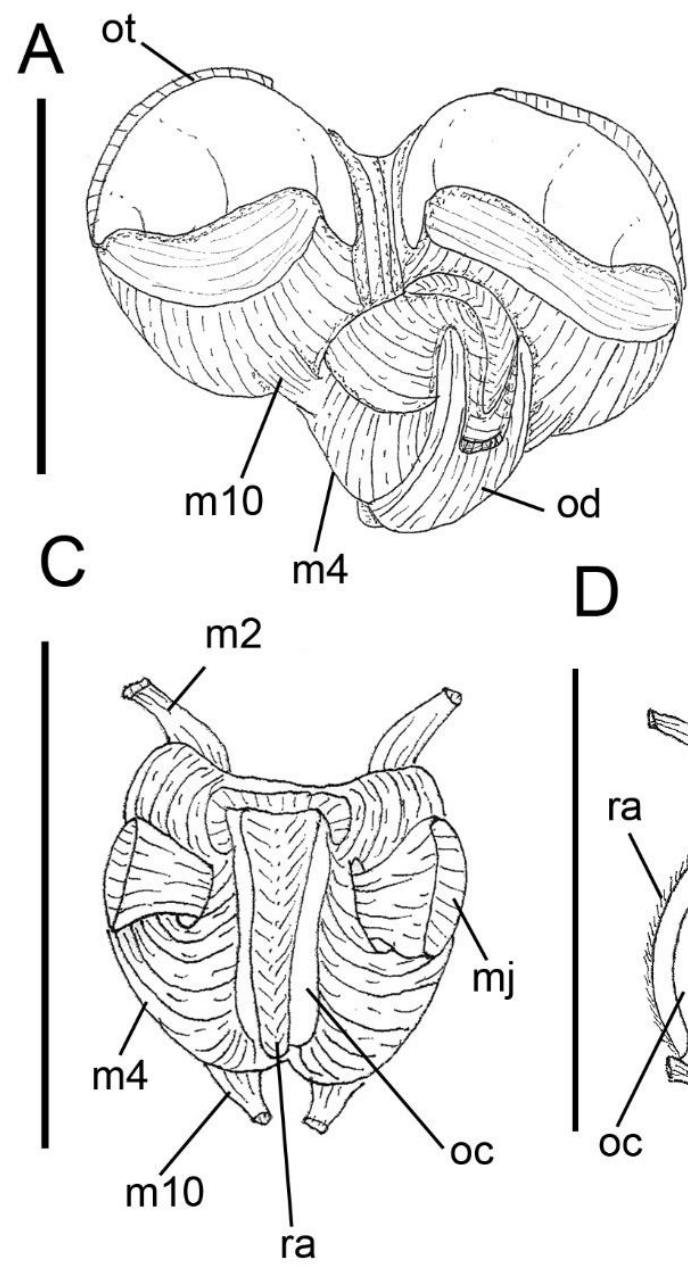
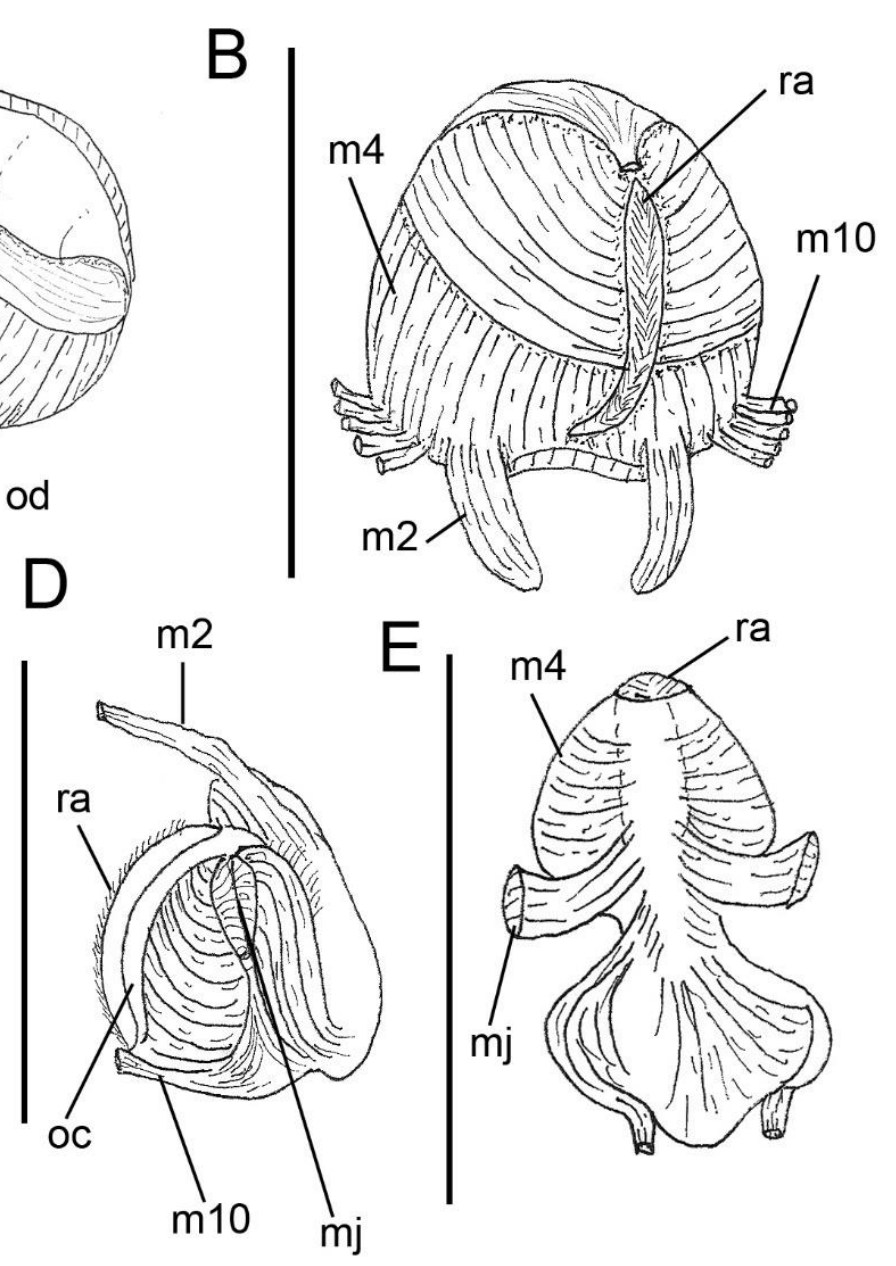

Figure 15: Noumeaella kristenseni. Odontofore. A. Dorsal view, still connected with oral tube. B. Same view removed from oral tube. C. Dorsal view with detail of radula. D. Lateral view. E. Dorsal view with removed radula and folded down muscles. Scales: $1 \mathrm{~mm}$. 

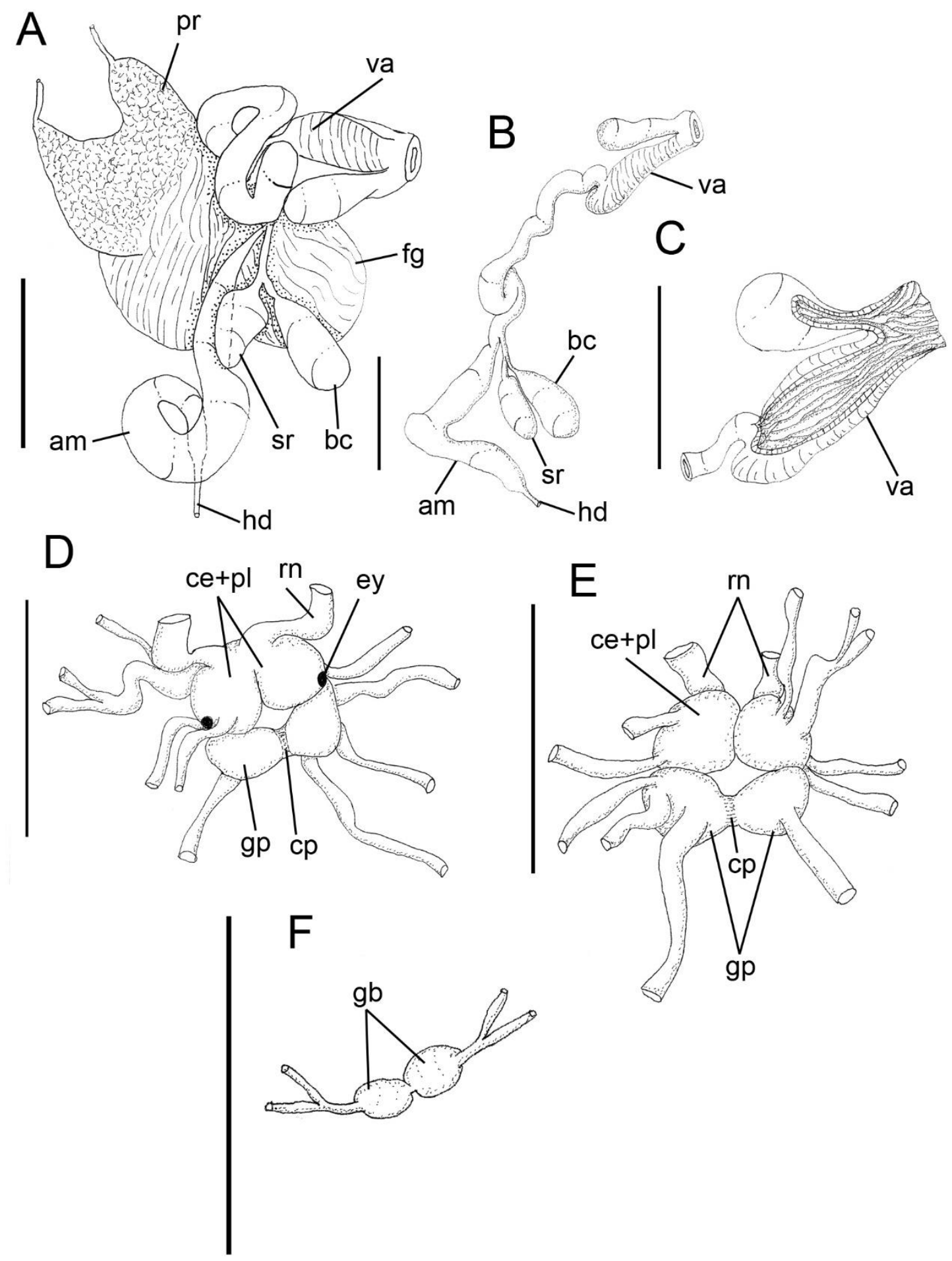

Figure 16: Noumeaella kristenseni Reproductive system. A. Dorsal view. B. Detail without female gland and prostate. C. Detail of aperture. Nervous system. D. Dorsal view. E. Same, ventral view. F. Detail of buccal ganglia. Scales: $1 \mathrm{~mm}$. 


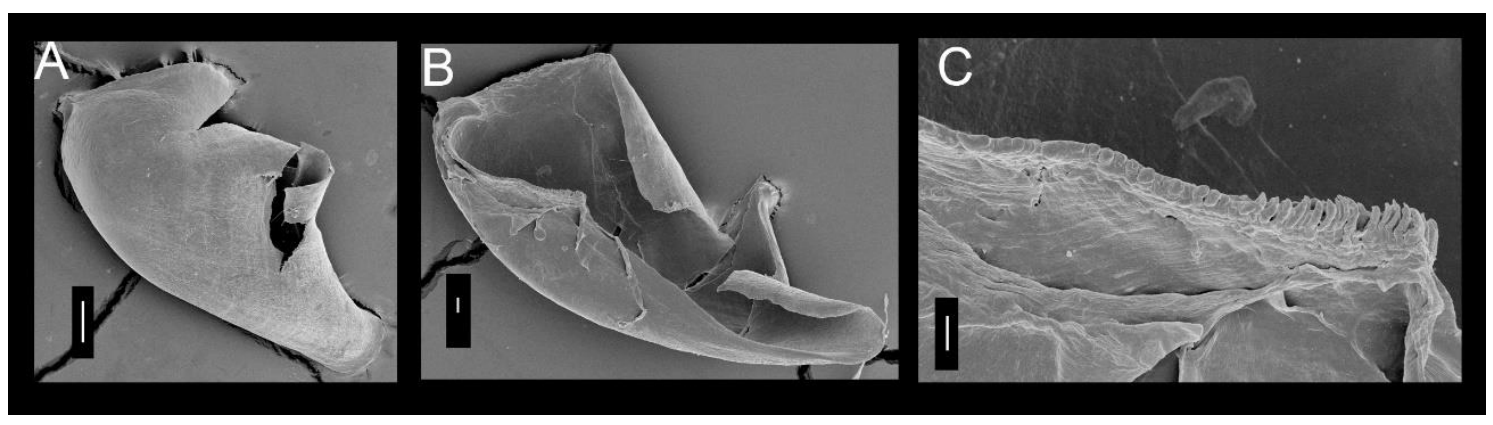

Figure 17: SEM of jaw of Noumeaella kristenseni. A. Panoramic, dorsal view. Scale: 100 $\mu$ m. B. Same, ventral view. Scale: $30 \mu \mathrm{m}$. C. Detail of anterior border, ventral view. Scale: $10 \mu \mathrm{m}$.

\section{Superfamily Tritonioidea Lamarck, 1809}

Family Bornellidae Bergh, 1874

Genus Bornella Gray, 1850

Type species: Bornella adamsii Gray, 1850, type by monotypy

\section{Bornella calcarata Mörch, 1863}

(Figures 18-22)

See Pola, et al., 2009

Complement: Camacho-García et al., 2014: 123

Type locality: Virgin Islands (Danish Antilles), Caribbean

\section{Redescription}

External morphology (Figure 18A-F): Size 30mm length, 10mm width. Body elongate and limaciform with posterior end long and tapering (Fig. 18A, B). Rhinophores with about 27 transverse lamellae, color similar to body (Fig. 18D); rhinophoral sheaths with tall stalk, with about three elongate and bluntly tipped papillae arranged around upper edge (Fig. 18C). Taller posterior crest inserted just below upper edge of stalk, posterior crest with central papillae and four secondary papillae. Four pair of welldeveloped dorsolateral process, followed by one smaller unpaired process in end pointed (Fig. 18E). Four bipinate secondary gill, associated with each dorsolateral process (Fig. $18 \mathrm{~F})$. Mouth opening in anterior ventral region, with each sid of mouth with oral tentacle 
modified into lobe, with about 10 papillae (Fig.18B). Anterior border of foot not bilabiate (Fig. 18B).

Haemocoel organs (Figure 19A, B): pericardium on median lateral dorsal surface, occupying $10 \%$ of haemocoel volume. Buccal mass located anteriorly, occupying $20 \%$ of haemocoel volume. Nervous system dorsal, more posteriorly, to buccal mass, occupying $5 \%$ of haemocoel volume. Reproductive system posterior to buccal mass, occupying $15 \%$ of haemocoel volume. Stomach, intestine and digestive gland occupying $50 \%$ of haemocoel volume.

Circulatory and excretory systems (Figure 19A): pericardial cavity dorsal to digestive gland, median and lateral, with longitudinal orientation. Auricle funnel-like (wider anteriorly) with thin walls. Ventricle as taller as wide, with thick muscular walls. There are four major vessels: 1) aortic trunk, located anteriorly to pericardium, connected to anterior ventricular region; 2) auricular vessels connecting lateral cavities of integument to auricle; 3) branchio-cardiac vessel located at posterior end of pericardium, running to nephrostome; Aortic trunk branched into anterior artery irrigating reproductive system, buccal mass, odontophore and nervous system and posterior artery irrigating stomach and digestive gland. Renal vesicle absent. Nephrostome opening anaterior to anus, on right lateral of visceral mass.

Digestive system (Figures 19C-E; 20A-G; 22A-B): Oral tube composed of outer lip, with transversal broad pleat; inner lip with thin transverse folds (Fig. 20C); mt, three pairs of retractor muscles of buccal mass, originating on oral tube, running dorsally and ventrally to oral tube, inserting on body side, about five times as wide and twice as long as m10 (Fig. 20D). Odontophore oval, connected to oral tube by pair of ventral protractor muscles (m10), thin longitudinal, dorsal and ventrolateral protractors of oral sphincter, originating in posterior region of odontophore and inserted in posterior region of integument close to oral tube. Oral sphincter surrounding chitinous part of oral tube. Odontophore muscles: m2, absent; $\mathbf{m 4}$, pair of dorsal tensor muscles, strong and broad, occupying 4/9 of odontophore volume, 1/3 as long as wide, covering 2/3 of cartilage, inserted on ventral portion of subradular membrane (Fig. 20G); m5, pair of dorsal auxiliary tensor muscles, $1 / 3$ of $\mathrm{m} 4$ width, originating on most posterior region of odontophore cartilages, covering $\sim 1 / 3$ of posterior cavity of odontophore, inserting on dorsal sid of odontophore cartilages (Fig. 20G); m6 and m7, absent. Pair of odontophore cartilages elliptical, occupying $\sim 20$ of odontophore volume (Fig. 20F). Subradular membrane thin, strong, translucent. Radular sac $\sim 1 / 3$ as large as odontophore. Radular 
teeth (Fig. 22A-B): rachidian teeth robust, slightly winder than higher, lack welldeveloped secondary cusps on central cusp, but with number of irregular faint ridges at posterior base of central cusp; formula 23 x 10.1 .10 (in $30 \mathrm{~mm}$ long specimen). Lateral teeth pointed, increase in size from innermost to ninth then slightly decrease until end. Jaw present. Pair of salivary glands short, bag-shaped; duct inserting in anterior ventral region of esophagus (Fig. 20A). Esophagus short, simple, originating posteriorly to odontophore, inserting directly in anterior region of stomach, internal longitudinal folds with same diameter along entire length. Three digestive ducts well distincts in anterior region of stomach (Fig. 19C, D). Digestive gland dark beige, being divided in three lobes, two anterior with one ramification on each lobe; and one bigger that following to posterior end of visceral mass. Caecum absent. Stomach divided in two parts, 1: with 12 longitudinal rows of chitinous brown spines; 2 : same length of st 1 , with longitudinal folds with same diameter along entire length, with bottleneck in anterior region of intestine (Fig. 19D, E). Intestine with same length and width of stomach, with just one transversal fold in anterior region, tapering to anus (Fig. 19E).

Genital system (Figures 19B; 21A-B): Genital opening on right side, anterior third of length of animal from head, located lateral between foot and notum (Fig. 19B). Gonad well distinct from digestive gland, with five rounded follicle lying in middle third of visceral mass above posterior digestive gland, connected by hermafrodict duct. Hermaphrodite duct thin, long, connected with posterior region of ampulla. Ampulla located on female gland, elongated and tubular. Prostate tubular, five times longer than ampulla. Vas deferens not distinguished from prostate and penis. Penis' muscle absent. Penis strong, muscular, cylindrical and elongated, about 2/3 of length of prostate, with well developed folds and glandular regions interiorly (Fig. 21B). Female gland not welldeveloped, rounded, occupying $\sim 10 \%$ of reproductive system volume, divided into mucus gland ( $\sim 2 / 3$ of female gland, color beige), and albumen gland ( 1/3 of anteriormost region, dilated, irregularly shaped, color dark brown). Oviduct occupying $\sim 1 / 4$ of female gland volume. Uterine duct absent. Seminal receptacle pyriform connected to vagina on posterior region. Bursa copulatrix absent. Vagina cylindrical, short, approximately $1 / 5$ of length and $1 / 3 \mathrm{f}$ widht of penis, followed ventrally by prostate and located parallel to penis in genital opening (Fig. 21A).

Nervous system (Figure 21C-F): Pair of cerebral and pleural ganglia fused with each other dorsally. Pair of cerebral ganglia with short commissure and two connectives with pedal ganglia; posterior connective surrounding statocysts. Pedal ganglia fused with 
cerebral and pleural ventrally, but not fused among themselves. Pedal commissure short and simple, surrounding esophagus and salivary glands (Fig. 21D). Buccal ganglia short, located ventrally to odontophore, between radular sac and anterior portion of esophagus, connected to cerebral ganglia through long and slender connective tissue, united to gastroesophageal ganglia by short connective tissue (Fig. 21F). Buccal commissure short, almost inconscpicuous. Gastro-esophageal ganglia length about 1/6 of buccal ganglia length, circular (Fig. 21F). Rhinophoral (olfactory) fused with each cerebral ganglion. Dorsal eyes located connected to cerebral ganglia by long connective (optical nerve) (Fig. 21E).

Distribution: Caribbean Se ato Brazil.

Habitat: On coral and other hard substrates.

Material examined: BRAZIL, Barra Grande de Camamu, Maraú, Bahia, MZSP 84448, 1 specimen (Claudio Sampaio coll.; 12/xi/2006; Recifes de Itaipu de fora, 0,5m deep); Ilha Escalvada, Guarapari, Espirito Santo, MZSP 106869, 1 specimen. 

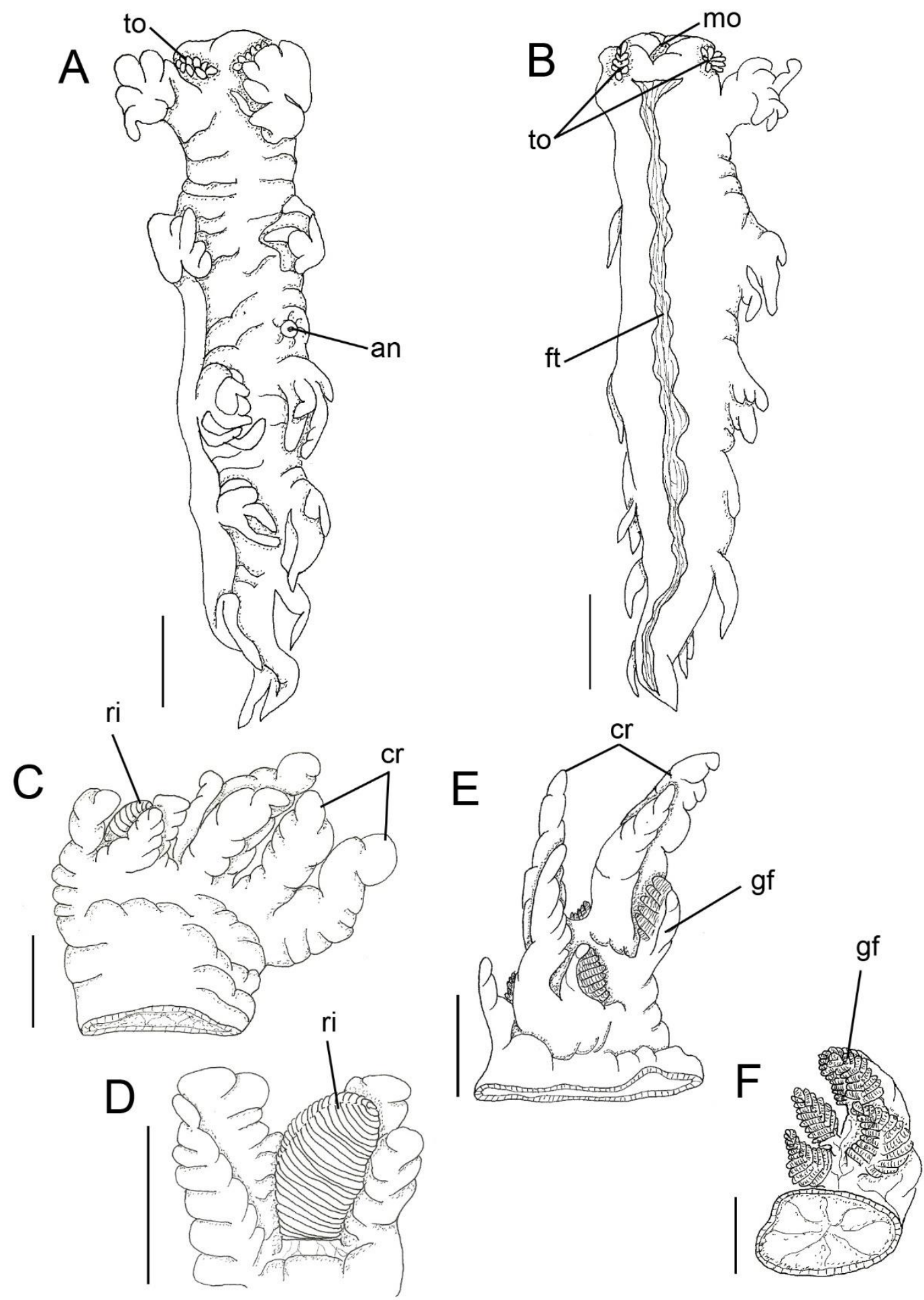

Figure 18: Bornella calcarata, fixed animal. A. Dorsal view. B. Ventral view. Scale: $5 \mathrm{~mm}$. C. Detail of rhinophoral sheaths. D. Detail of rhinophore. E. Detail of branchial cerata. Scale: $2 \mathrm{~mm}$. F. Detail of gill filament. Scale: $1 \mathrm{~mm}$. 


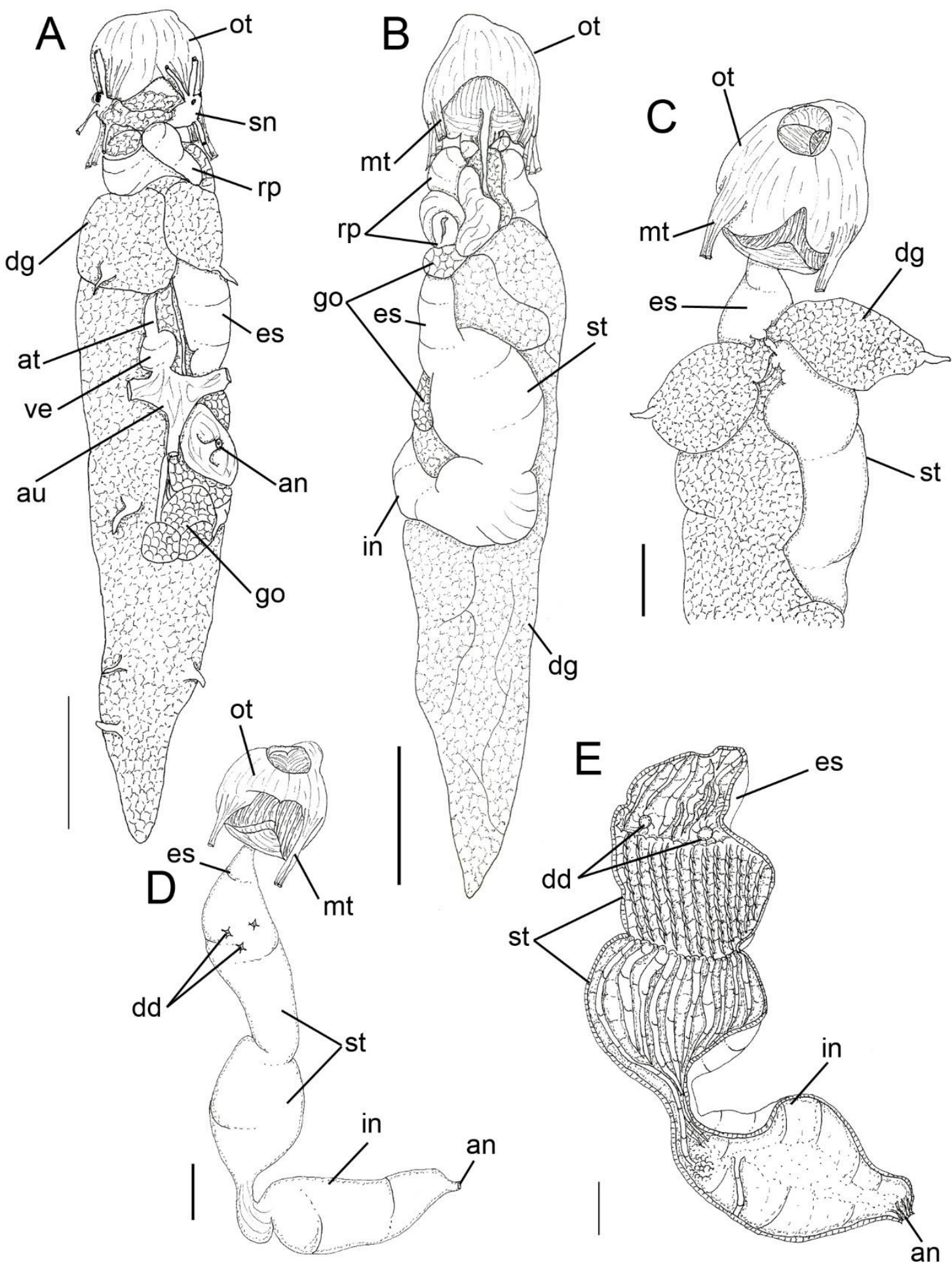

Figure 19: Bornella calcarata. Visceral mass. A. Dorsal view. B. Same, ventral view. Scales: $5 \mathrm{~mm}$. C. Detail of anterior digestive system. E. Digestive system, dorsal view. E. Digestive system longitudinally sectioned, internal view. Scales: $2 \mathrm{~mm}$. 

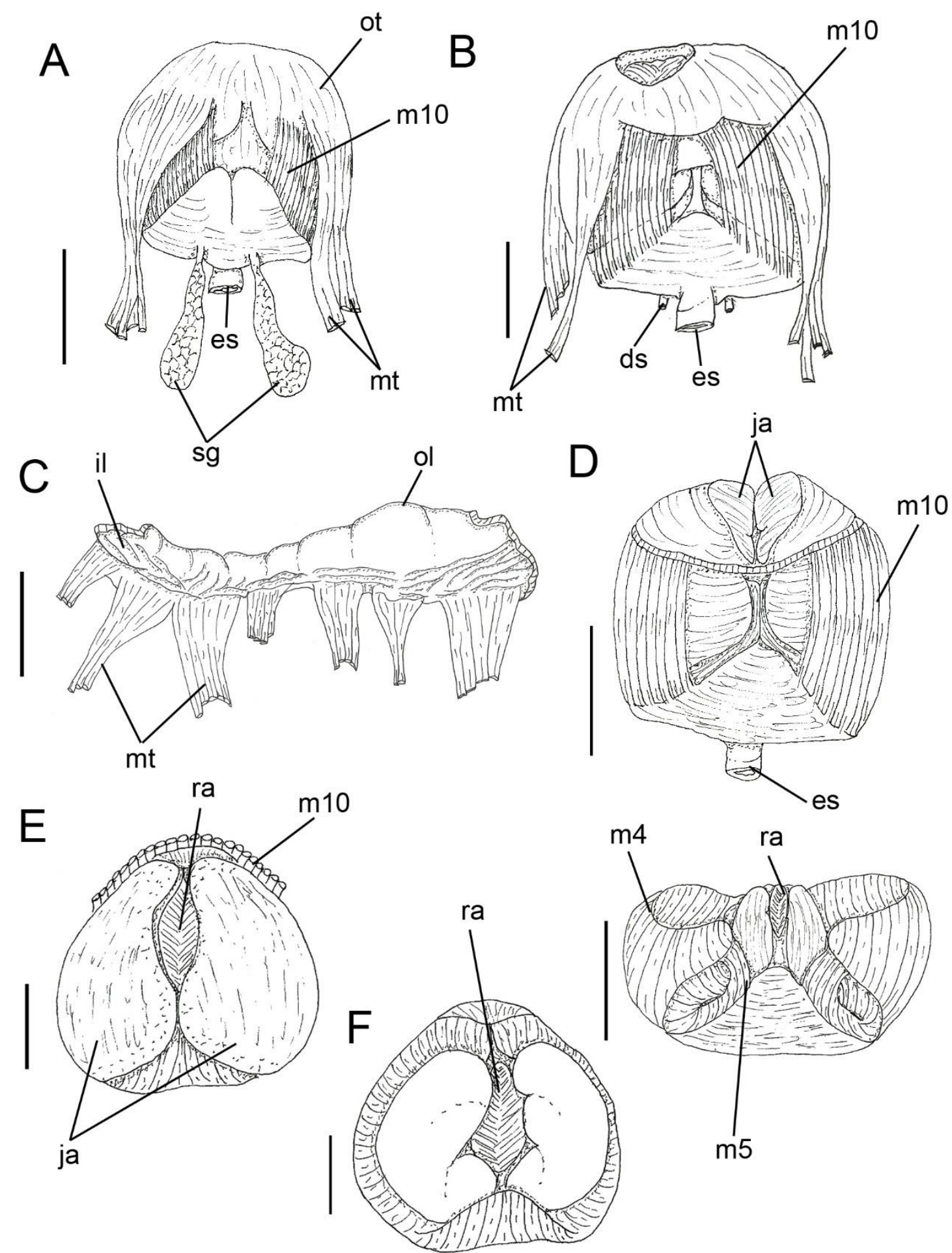

Figure 20: Bornella calcarata. Anterior digestive system. A. Dorsal view. B. Ventral view. C. Oral tube, longitudinally sectioned. Scales: $2 \mathrm{~mm}$. Odontophore. D. Wiht buccal sfincter and jaws. Scale: $2 \mathrm{~mm}$. E. Dorsal view with jaws. F. Jaws removed, radula exposed. G. Without buccal sfincter, muscles exposed. Scales: $1 \mathrm{~mm}$. 


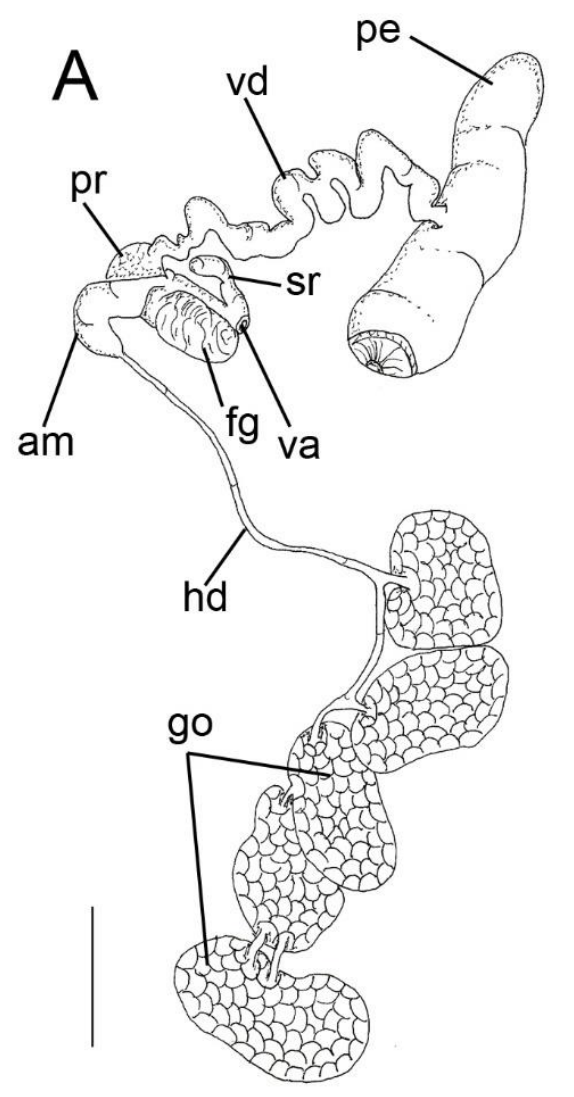

$\mathrm{D}$
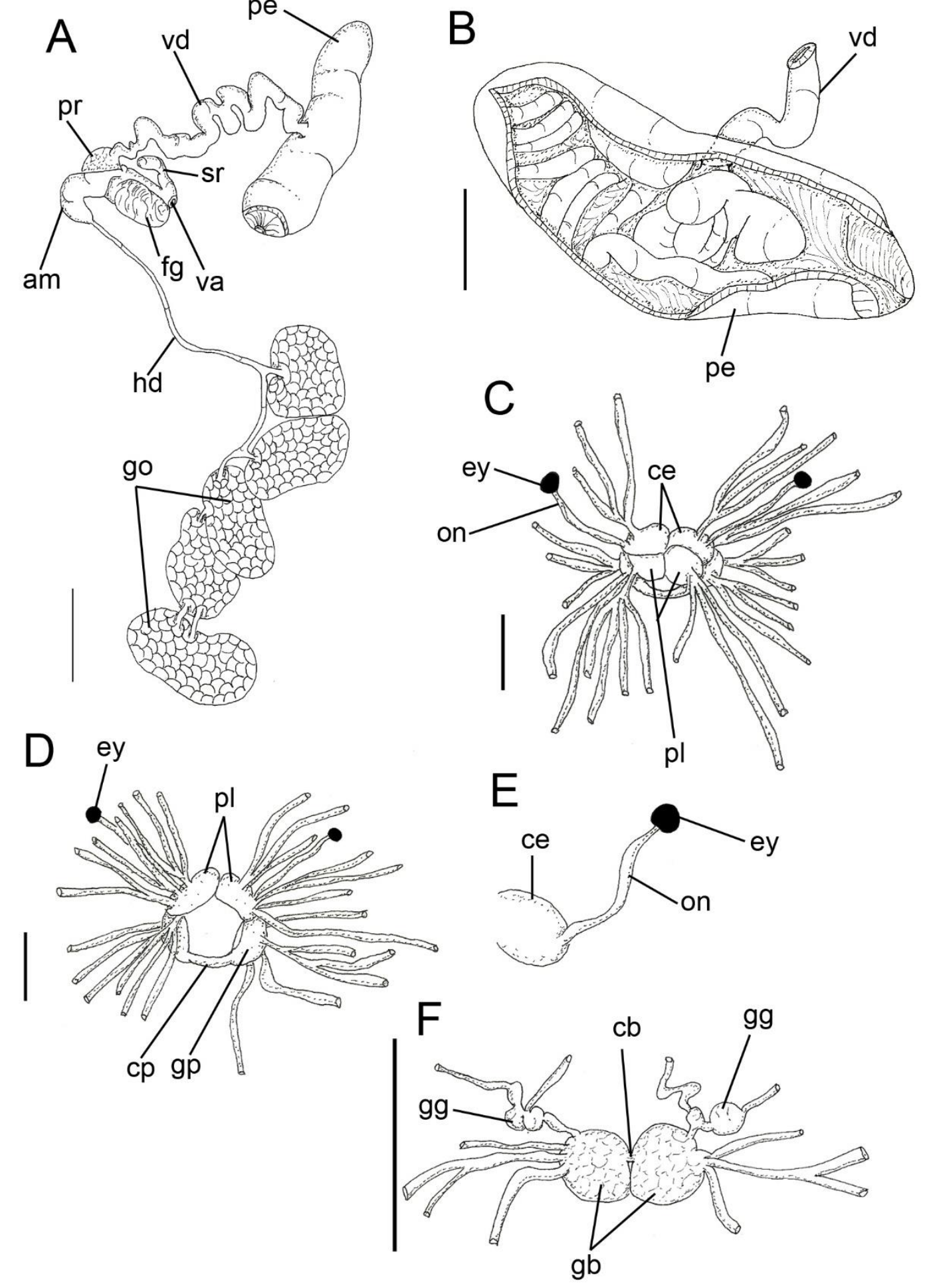

Figure 21: Bornella calcarata. Reproductive system. A. Dorsal view. Scale: $2 \mathrm{~mm}$. B. Detail of penis. Nervous system. C. Dorsal view. D. Same, ventral view. E. Detail of optical nerve connected with cerebral ganglia. F. Detail of buccal and gastroesophageal ganglia. Scales: $1 \mathrm{~mm}$. 


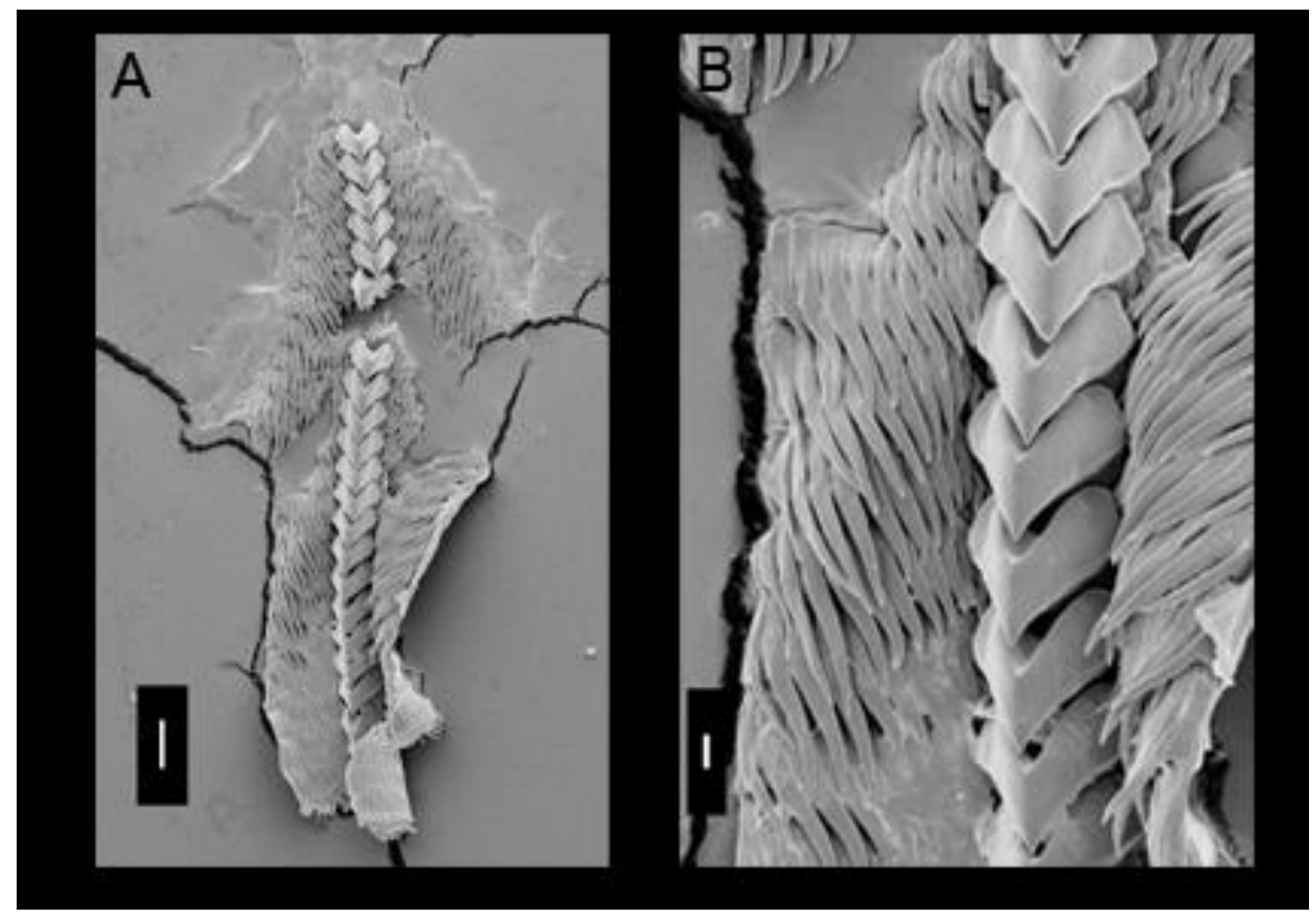

Figure 22: SEM of radula of Bornella calcarata. A. Panoramic view. Scale: $100 \mu \mathrm{m}$. B. Detail of rachidian tooth. Scale: $20 \mu \mathrm{m}$.

Superfamily Phyllidioidea Rafinesque, 1814

Family Phillidiidae Rafinesque, 1814

Genus Phyllidiella Bergh, 1869

Type species: Phyllidiella pustulosa (Cuvier, 1804)

Phyllidiella pustulosa (Cuvier, 1804)

(Figures 23-25)

See Dominguez et al., 2007.

Type locality: Western Pacific Ocean

\section{Redescription}

External morphology (Figure 23A-E): Size 33mm length, 13mm width. Color black with white tubercles organized in cluster. Body elongate (Fig. 23A-C). Rhinophores with about 25 transverse lamellae, color similar to body (Fig. 23D); rhinophoral sheaths 
with tubercles. Gill, color similar to body, arranged ventral between notum and foot (Fig. 23B, E); branchial sheaths absent. Mouth opening in anterior ventral region, between anterior region of notum and foot (Fig. 23B). Oral tentacle barrel-shaped with united base, anterior to mouth, not lateral. Anterior border of foot not bilabiate.

Haemocoel organs (Figure 24B, C): pericardium occupying 10\% of dorsal visceral mass. Buccal mass located anteriorly, occupying $30 \%$ of haemocoel volume. Nervous system posterior to buccal mass, covered by blood gland, occupying 5\% of haemocoel. Reproductive system on right side of animal, occupying $25 \%$ of haemocoel volume. Stomach internal to digestive gland, intestine with small curve at anterior portion, occupying $30 \%$ of haemocoel.

Circulatory and excretory systems (Figure 24A): pericardial cavity dorsal and posterior to digestive gland, anterior to anus. Gill retractor muscle absent. Auricle lozengal with thin walls. Ventricle sligthly taller than wide, with thick muscular walls. Aortic trunk branched into anterior artery irrigating stomach and digestive gland; posterior artery irrigating reproductive system, buccal mass and nervous system. Renal vesicle located on right dorsal side of pericardium, near base of auricle, connected to inner surface of pericardium, 1/3 of the size of ventricle. Renal chamber connected to renal vesicle, extending posteriorly parallel to intestine and opening in nephrostome, next to base of anal papilla. Gill ventral around foot and notum, lamellae insert into integument.

Digestive system (Figure 24D-F): Oral tube composed of six sections of pleats, all pleats with longitudinal folds (Fig. 24E); mt, a pair of retractor muscle of buccal mass, originating on oral tube, running dorsally to integument, inserting on body side (Fig. 24E). Odontophore absent. Salivary glands around oral tube; duct inserting in anterior region of esophagus (Fig. 24D). Esophagus divided into two parts, originating dorsally to odontophore, inserting directly in anterior region of stomach, 1/3 anterior with three internal broad and longitudinal folds with same diameter along entire length, 2/3 posterior with small longitudinal folds (Fig. 24F). Stomach widespread in digestive gland (Fig. 24F). Caecum absent. Intestine with longitudinal folds along its entire length, diameter about half esophagus diameter, but more uniform (Fig. 24D). Digestive gland dark beige, cone-shaped, anterior portion about twice as wide as posterior portion, inner face of gland sponge-like. Anus opening into anal papilla.

Genital system (Figure 24C; 25A-B): located between buccal mass and digestive gland, mainly on right side and dorsally and ventrally. Genital opening on right side, anterior fifth of length of animal from head, located between foot and notum (Fig. 24C). 
Gonad reticulated up to digestive gland. Hermaphrodite duct thin, long. Ampulla located on female gland, elongated and tubular. Prostate glandular, length same as ampulla. Vas deferens about same diameter as penis. Penis' muscle absent. Penis cylindrical and elongated, about twice of length of prostate. Female gland well-developed, rounded, occupying $\sim 50 \%$ of reproductive system volume, divided into mucus gland ( $2 / 3$ of female gland), and albumen gland ( 1/3 of anteriormost region, dilated, irregularly shaped, color dark brown). Oviduct occupying $\sim 1 / 3$ of female gland volume. Uterine duct thin, length $1 / 2$ of vagina length, located at base seminal receptacle, inserted in female gland near oviduct. Seminal receptacle pyriform, as large as bursa copulatrix, length $1 / 2$ of vagina length, connected to bursa copulatrix through short stalk. Bursa copulatrix rounded, length $1 / 2$ of vagina length, connected directly to vagina. Vagina cylindrical, elongated, approximately as long and wide as penis, followed ventrally by prostate and located parallel to penis in genital opening.

Nervous system (Figure 25C-D): located posteriorly to oral tube, mostly covered by blood gland. Pair of cerebral and pleural ganglia fused with each other dorsally and ventrally. Pedal ganglia fused with cerebral and pleural ganglia ventrally, but not fused among themselves. Pedal commissure simple and short, surrounding anterior portion of esophagus (Fig. 25D). Buccal ganglia and gastro-esophageal ganglia not visualized. Rhinophoral (olfactory) ganglia bulb-shaped, connected to anterior portion of cerebral ganglia (Fig. 25C). Dorsal eyes connected with cerebral ganglia by medium connective/optical nerve (Fig. 25C).

Distribution: Tropical Indo-West Pacific (Brunckhorst, 1993)

Material examined: THAILAND, Phi Phi Island, AUS - C162690, 1 specimen (D.J. Brunckhorst coll., 25-27/vii/1989, 4-15m depth); PHILIPPINES, Balicasag Island, Black forest $\left(9.00^{\circ} 31.10^{\prime}\right.$ ' 'N 123.0041.30' ' ' E), CAS 175862, 1 specimen (T. Gosliner, Y. Camacho-Garcia, J. Templado, M. Malaquias, M. Poddubetskaia, coll., 04/vi/2004, edge of reef plataforma and slope, 6-22m depth). 

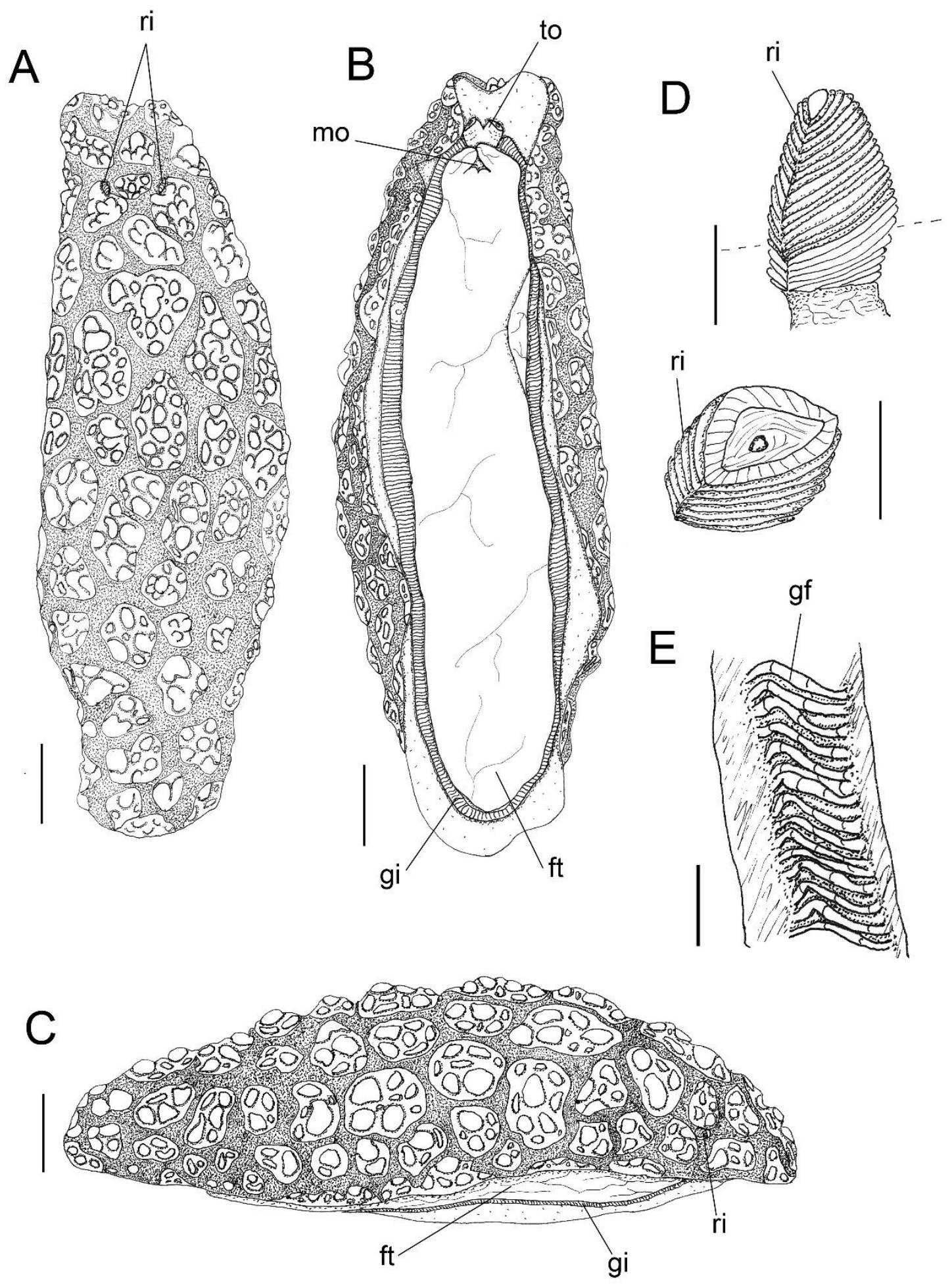

Figure 23: Phyllidiella pustulosa, fixed animal. A. Dorsal view. B. Same, ventral view. C. Same, right lateral view. Scales: $5 \mathrm{~mm}$. C. Detail of rhinophore. Scale: $1 \mathrm{~mm}$. E. Detail of gill filaments. Scale: $2 \mathrm{~mm}$. 


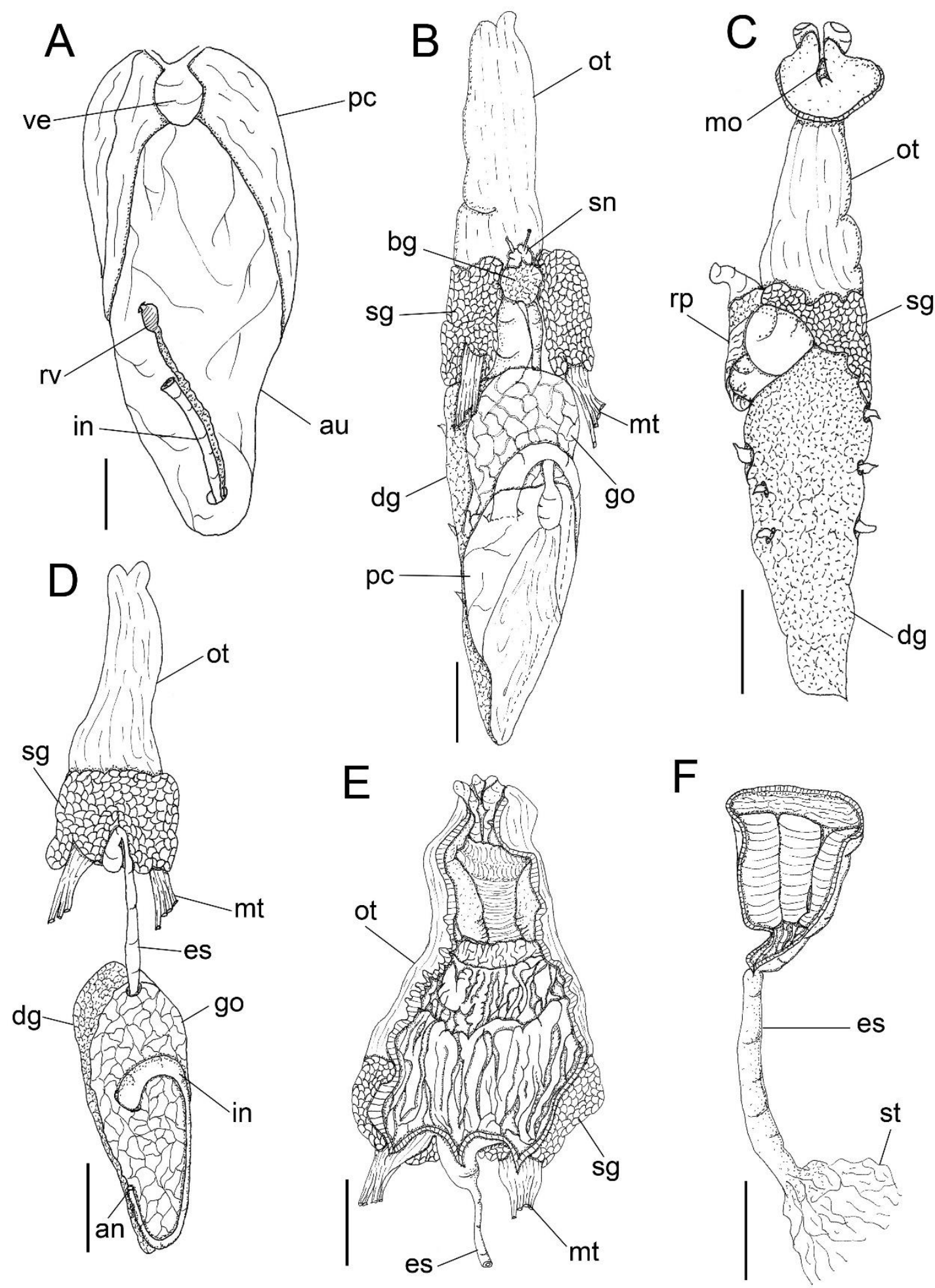

Figure 24: Phyllidiella pustulosa. A. Circulatory and excretory system, ventral view. Scale: $2 \mathrm{~mm}$. Visceral mass. B. Dorsal view. C. Same, ventral view. Digestive system. D. Dorsal view. E. Anterior digestive system, longitudinally sectioned. Scales: $5 \mathrm{~mm}$. F. Detail of esophagus, dorsal view. Scales: $2 \mathrm{~mm}$. 

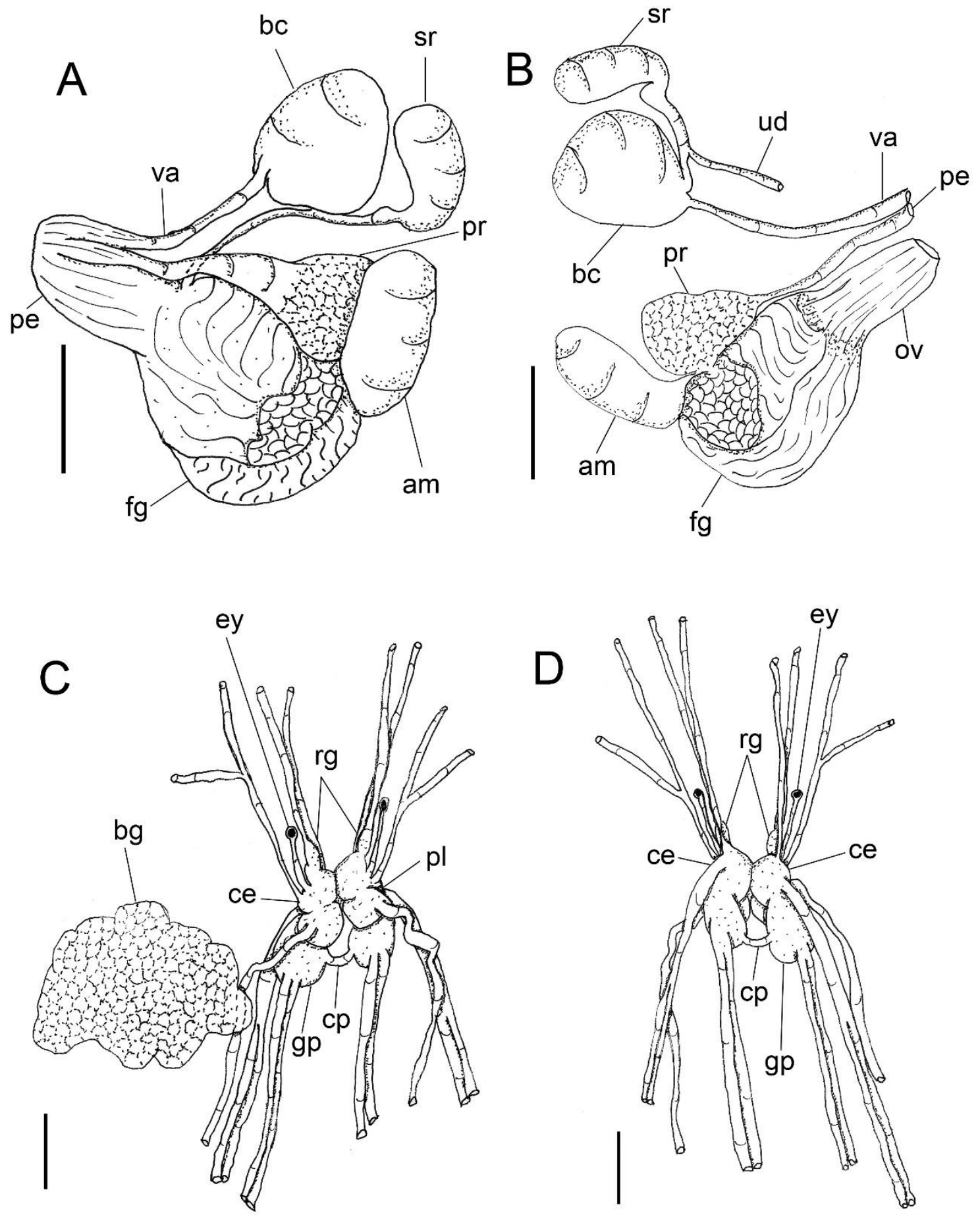

Figure 25: Phyllidiella pustulosa. Reproductive system. A. Ventral view. B. Same, dorsal view, with uterine duct disconnected. Scales: $2 \mathrm{~mm}$. Nervous system. C. Dorsal view, with blood gland. D. Same, ventral view. Scales: $1 \mathrm{~mm}$. 


\section{Superfamily Onchidoridoidea Gray, 1827}

\section{Family Onchidorididae Gray, 1827}

\section{Genus Knoutsodonta Hallas \& Gosliner, 2015}

Type species: Adalaria jannae Millen, 1987, by original designation

\section{Knoutsodonta brasiliensis (Alvim, Padula \& Pimenta, 2011)}

(Figures 26-28)

Onchidoris brasiliensis Alvim, Padula \& Pimenta, 2011: 506, fig. 1-3.

Knoutsodonta brasiliensis (Alvim, Padula \& Pimenta,2011): Hallas \& Gosliner, 2015: 25.

Type locality: Praia do Forno, Arraial do Cabo, Rio de Janeiro, southern eastern- coast of Brazil

\section{Redescription}

External morphology (Figure 26A-F): Size 5mm length, 4mm width. Body rounded with elongate tubercles; network of spicules well developed. Rhinophores with about 8 ringed lamellae, color similar to body; rhinophoral sheaths smooth. Gill composed of 14 unipinate branchial leaves non retractile, color similar to body, arranged in circular fashion surrounding anus; branchial sheaths absent. Mouth opening in anterior ventral region, in middle of oral veil. Digitiform tentacles absent. Anterior border of foot not bilabiate.

Haemocoel organs (Figure 27A): pericardium posterior half of visceral mass, occupying $15 \%$ of haemocoel volume. Buccal mass located anteriorly, occupying $5 \%$ of haemocoel volume. Nervous system dorsal to buccal mass, with a thin posterior blood gland, occupying $10 \%$ of haemocoel volume. Reproductive system on right side of animal, occupying $30 \%$ of haemocoel volume. Stomach, intestine and digestive gland occupying $40 \%$ of haemocoel volume.

Circulatory and excretory systems (Figure): not analized.

Digestive system (Figure 27A-G): Oral tube very short followed by dorsal septate muscle; mt, one pairs of retractor muscles of buccal mass, originating on oral tube, running dorsally and ventrally to oral tube, inserting on body side (Fig. 27B, C). Odontophore internal to septate muscle, oval, very small, insert to oral tube by short circular muscle (md) (Fig.27C). Oral sphincter absent. Radular teeth not analized. Pair of salivary glands short, bag-shaped, duct inserting in anterior region of esophagus, extending posteriorly to anterior region of digestive gland (Fig. 27B). Esophagus simple, 
originating dorsally to odontophore, inserting directly in anterior region of stomach, internal longitudinal folds with same diameter along entire length. Stomach immersed on digestive gland. Intestine with longitudinal folds along its entire length, same diameter of esophagus diameter. Caecum absent. Digestive gland dark beige, rounded (Fig. 27A). Anus opening at center of gill circle. Anal papilla absent.

Genital system (Figure 27A): visualized just the position on visceral mass, not well preserved. Genital opening on right side, anterior third of length of animal from head, located between foot and notum. Gonad around digestive gland with white color.

Nervous system (Figure 28A-B): Pair of cerebral, pleural and pedal ganglia fused with each other dorsally. Pleural ganglia with short commissure. Pedal ganglia fused with cerebral and pleural ventrally, but not fused among themselves. Pedal commissure simple and short, surrounding esophagus and salivary glands. Buccal and gastroesophageal ganglia not analized. Rhinophoral (olfactory) ganglia bulb-shaped, connected to anterior portion of cerebral ganglia. Dorsal eyes located on cerebral ganglia. Statocysts small and iridescent, located ventrally between cerebral and pedal ganglia.

Distribution: Brazil (Rio de Janeiro to São Paulo).

Habitat: Intertidal zone down to $8 \mathrm{~m}$ depth.

Material examined: Brazil, Parcel da Pedra Lisa, Ilha de Búzios, Ilha Bela, São Paulo, MZSP 103228, 1 specimen (V. Padula, coll., 18/i/2012, 8m depth, on bryozoans with same appearence that mollusk); MZSP103266, 2 specimens (V. Padula, coll., 20/i/2012, 4m depth, on incrusting bryozoans). 

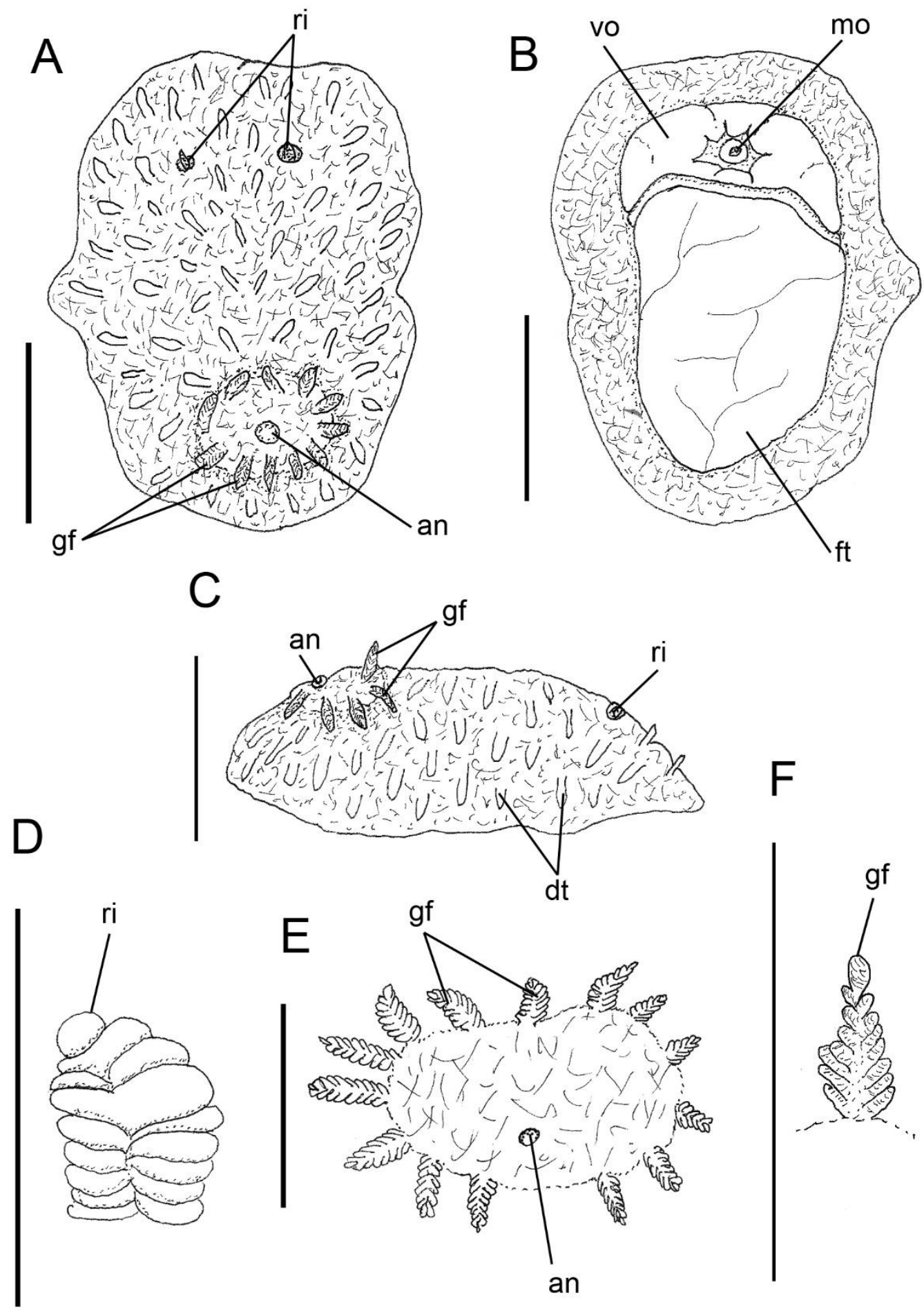

Figure 26: Knoutsodonta brasiliensis, fixed animal. A. Dorsal view. B. Same, ventral view. C. Same, rigth lateral view. Scales: $2 \mathrm{~mm}$. D. Detail of rhinophore. E. Topology of branchial filaments, dorsal view. F. Detail of gill filament. Scales: $1 \mathrm{~mm}$. 


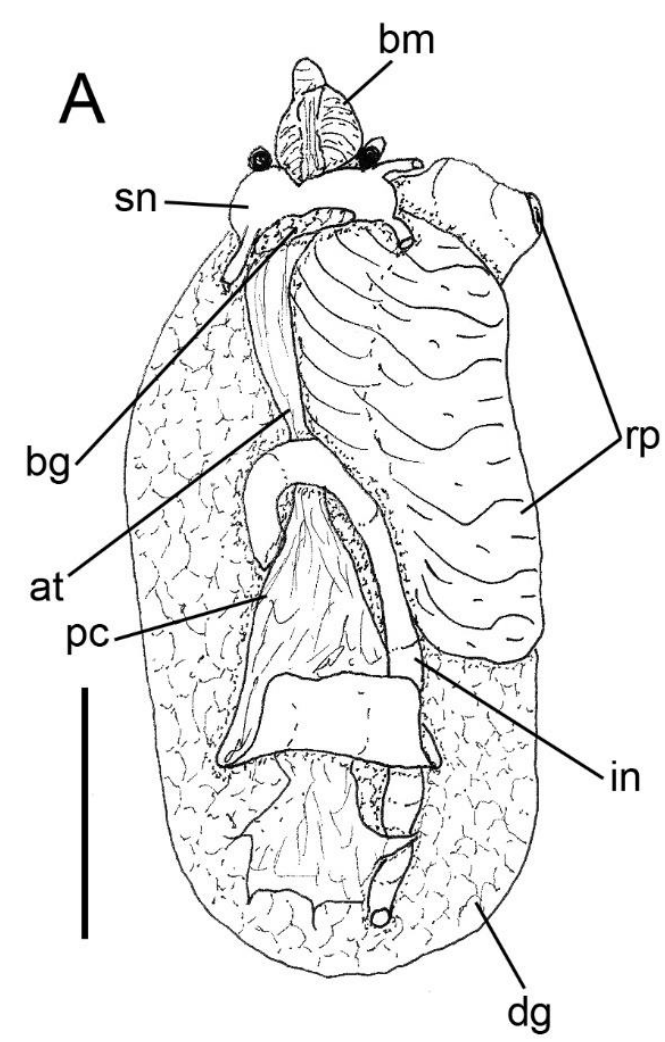

D

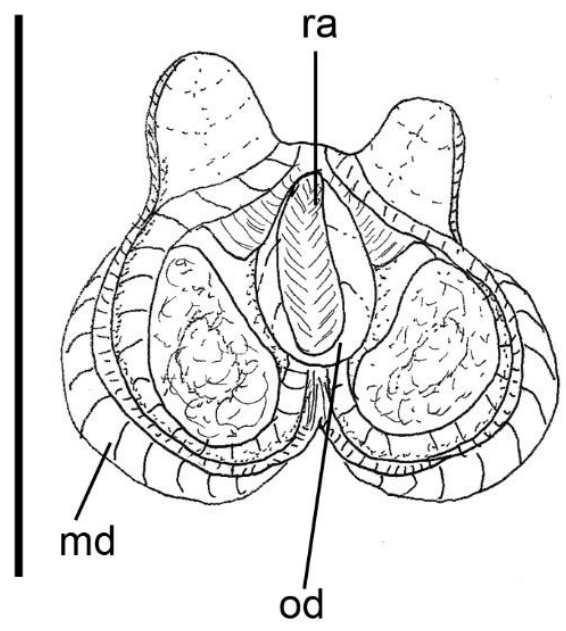

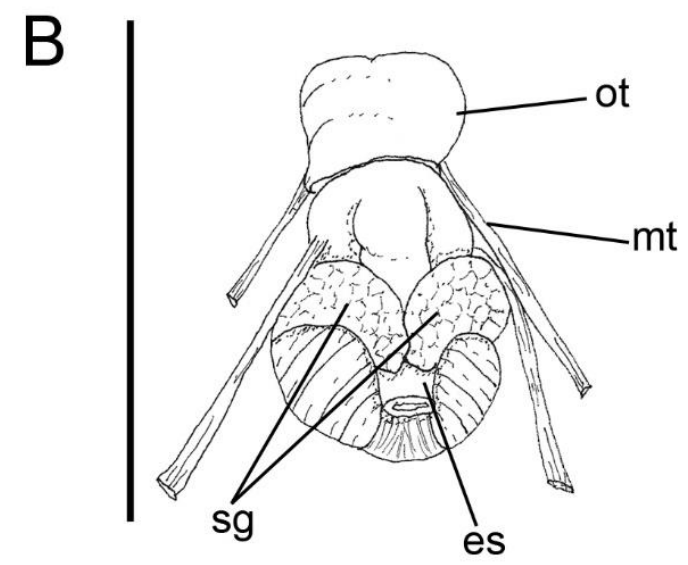

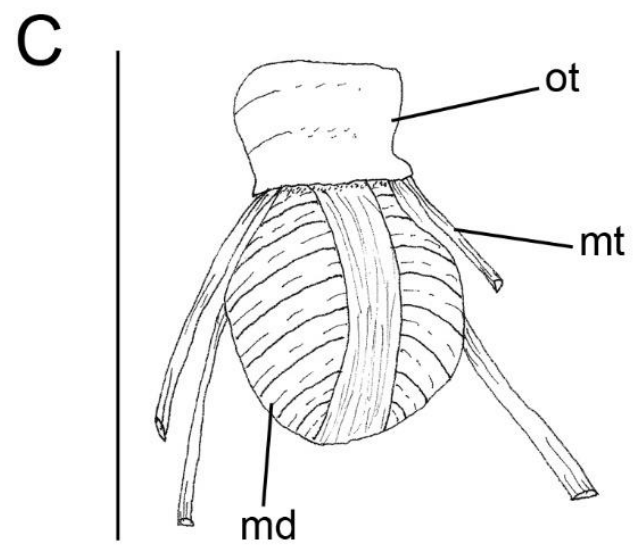

$\mathrm{F}$

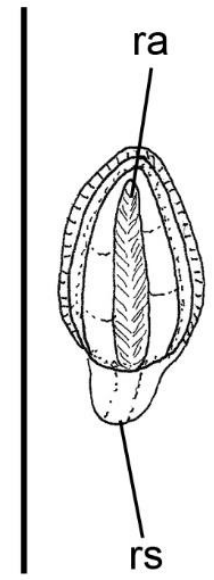

Figure 27: Knoutsodonta brasiliensis. A. Visceral mass, dorsal view. Anterior digestive system. B. Dorsal view. C. Same, ventral view. D. Buccal mass londitudinally sectioned. Odontophore. F. Dorsal view. G. Same, ventral view. Scales: $1 \mathrm{~mm}$. 


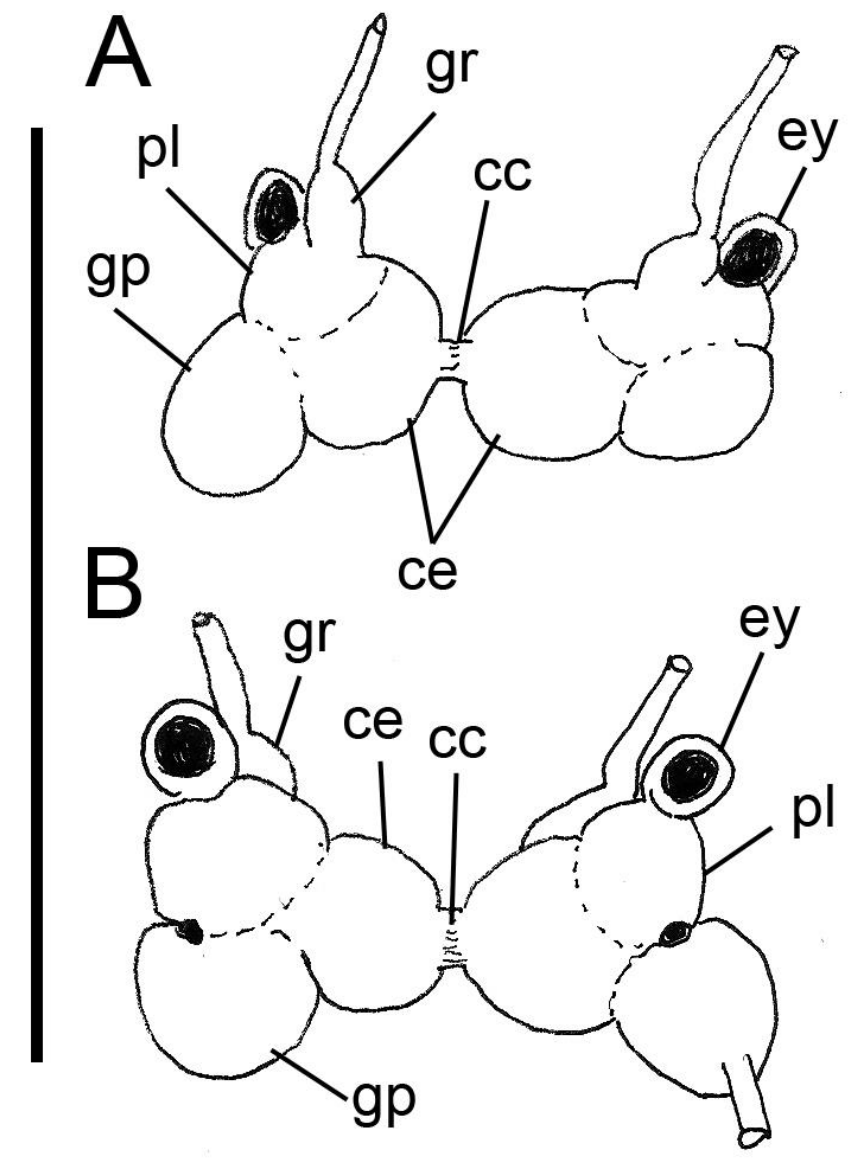

Figure 28: Knoutsodonta brasiliensis. Nervous system. A. Dorsal view. B. Same, ventral view. 


\section{Family Goniodorididae H. Adams \& A. Adams, 1854 \\ Genus Goniodoris Forbes \& Goodsir, 1839 \\ Goniodoris mimula Er. Marcus, 1955}

(Figures 29-31)

Goniodoris mimula Er. Marcus, 1955: 161, fig. 203-208; Valdés et al., 2006: 124; Rios, 2009: 422.

Type locality: São Paulo, Brazil.

\section{Redescription}

External morphology (Figure 29A-D): Size 4mm length, 2mm width. Color brown with various white dots. Body rounded with pointed end of foot (Fig. 29B). Small tubercles covering notum susface. Rhinophores with about 6 ringed lamellae, color similar to body (Fig. 29D); rhinophoral sheaths absent. Gill composed of 7 unipinate branchial leaves non retractile, color similar to body, arranged in circular fashion surrounding anus (Fig. 29A); branchial sheaths absent. Mouth opening in anterior ventral region, in middle of oral veil. Oral veil with lateral tentacular extentions. Digitiform tentacles absent. Anterior border of foot not bilabiate (Fig. 29B).

Haemocoel organs (Figure 30A, B): pericardium 1/4 anteriorly of visceral mass, occupying $5 \%$ of haemocoel volume. Buccal mass located anteriorly, occupying $10 \%$ of haemocoel volume. Nervous system dorsal to buccal mass, occupying $5 \%$ of haemocoel volume. Reproductive system on right side of animal; occupying $30 \%$ of ventral haemocoel volume. Stomach, intestine and digestive gland occupying 50\% of haemocoel volume.

Circulatory and excretory systems (Figure 30A): very poorly preserved, not analized; pericardial cavity dorsal and $1 / 4$ more anteriorly; anterior to gill circle. Blood gland not visualized.

Digestive system (Figure 30A, C-G): Oral tube very short followed by rounded septate muscle; mt, absent. Odontophore internal to septate dorsal muscle (Fig. 30D, E), oval, very small, insert to oral tube by short circular muscle. Oral sphincter absent. Radular teeth not analized. Radular sac $\sim 1 / 2$ as large as odontophore (Fig. 30G). Pair of salivary glands very short and shapeless (Fig. 30D). Esophagus simple, originating dorsally to odontophore, inserting directly in anterior region of stomach, internal 
longitudinal folds with same diameter along entire length. Stomach oval, located on left side of visceral mass, close to anterior region of intestine (Fig. 30C). Common opening for esophagus and stomach located on digestive gland. Intestine with longitudinal folds along its entire length, about half esophagus diameter (Fig. 30C). Caecum absent. Digestive gland dark beige, being largest organ of visceral mass, rounded. Anus opening at center of gill circle (Fig. 30A). Anal papilla absent.

Genital system (Figure 31A-D): Genital opening on right side, anterior fourth of length of animal from head, located between foot and notum. Gonad immersed in digestive gland, but easily distinguished from it. Hermaphrodite duct thin, long. Ampulla located on female gland, elongated and tubular (Fig. 31D). Prostate tubular, glandular, two times longer than ampulla and half of width. Vas deferens four times longer than penis, distinguished from prostate (Fig. 31C). Penis' muscle absent. Penis muscular, cylindrical and elongated, about same length and $1 / 2$ width of vagina. Female gland welldeveloped, rounded, occupying $\sim 40 \%$ of reproductive system volume, divided into mucus gland ( 2/3 of female gland, color beige), and albumen gland ( 1/3 of anteriormost region, dilated, irregularly shaped, color dark brown) (Fig. 31A). Oviduct occupying 1/4 of female gland volume. Uterine duct inconspicuos, located in common open with vagina, seminal receptacle and bursa copulatrix, inserted in female gland near oviduct (Fig. 31B). Seminal receptacle pyriform, as large as bursa copulatrix. Bursa copulatrix rounded, connected to vagina after seminal receptacle (Fig. 31B). Vagina cylindrical, elongated, approximately as long as and half as wide as penis, followed ventrally by prostate and located parallel to penis in genital opening.

Nervous system (Figure 31E-G): Pair of cerebral and pleural ganglia fused with each other dorsally and ventrally. Cerebral commissure present (Fig. 31E). Pedal ganglia fused with cerebral and pleural ventrally, but not fused among themselves. Pedal commissure doubles, surrounding esophagus and salivary glands. Buccal and gastroesophageal ganglia not visualized (Fig. 31G). Rhinophoral (olfactory) ganglia bulbshaped, connected to anterior portion of cerebral ganglia (Fig. 31F). Dorsal eyes located on cerebral ganglia.

Distribution: Mexico to Brazil (São Paulo) (Rosenberg, 1993)

Habitat: Intertidal zone do $10 \mathrm{~m}$ depth.

Material examined: BRAZIL, Praia do Segredo, Pedra da Baleia, São Sebastião, São Paulo. MZSP 103298, 1 specimen (J. Bahia col., 21/i/2012, under purple colonial ascidians); MZSP 103299, 1 specimen (J. Bahia col., 21/i/2012, under purple colonial 
ascidians); MZSP 103300, 1 specimen (J. Bahia col., 21/i/2012, under purple colonial ascidians); MZSP 103301, 1 specimen (J. Bahia col., 21/i/2012, under purple colonial ascidians); MZSP 76255, 1 specimen (Col. Marcus Randal 1974).
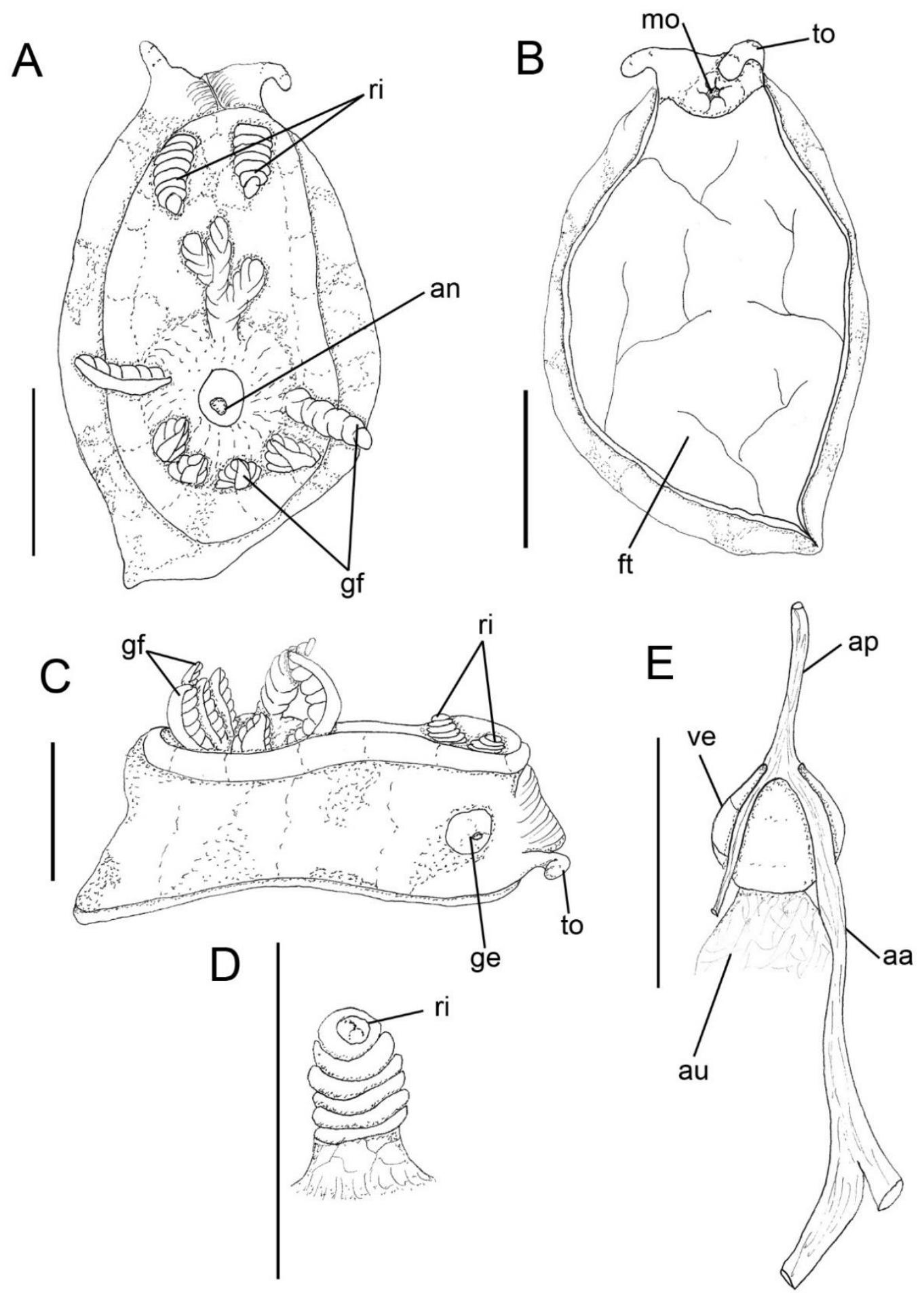

Figure 29: Goniodoris mimula, fixed animal. A. Dorsal view. B. Same, ventral view. C. Same, right lateral view. D. Detail of rhinophore. E. Circulatory system, ventral view. Scale: $1 \mathrm{~mm}$. 

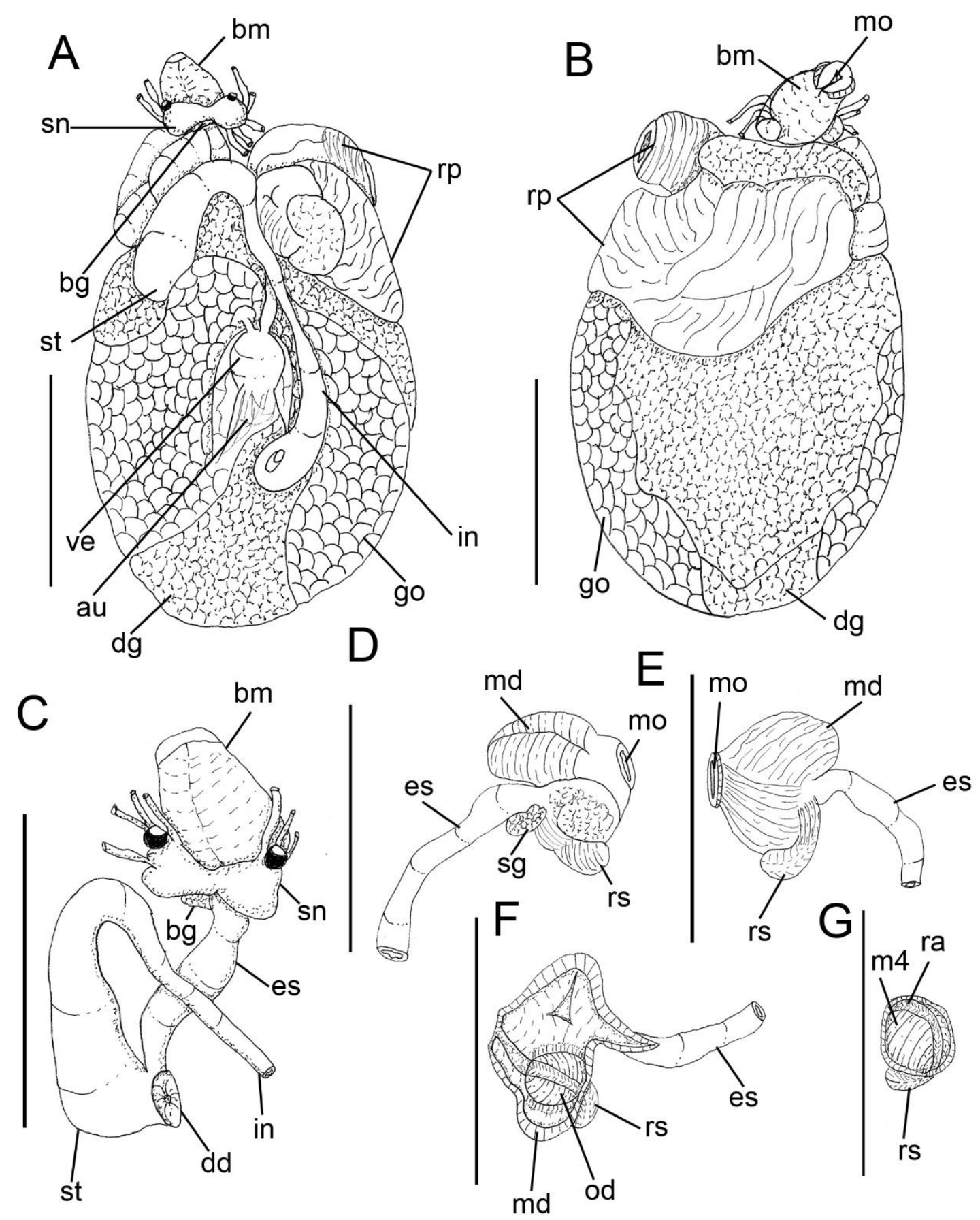

Figure 30: Goniodoris mimula. Visceral mass. A. Dorsal view. B. Same, ventral view. C. Digestive system, dorsal view. Anterior digestive system, buccal mass. D. Rigth lateral view. E. Same, left view, whitout salivary gland. F. Same, longitudinally sectionaded, dorsal view. G. Odontophore, dorsal view. Scales: $1 \mathrm{~mm}$. 

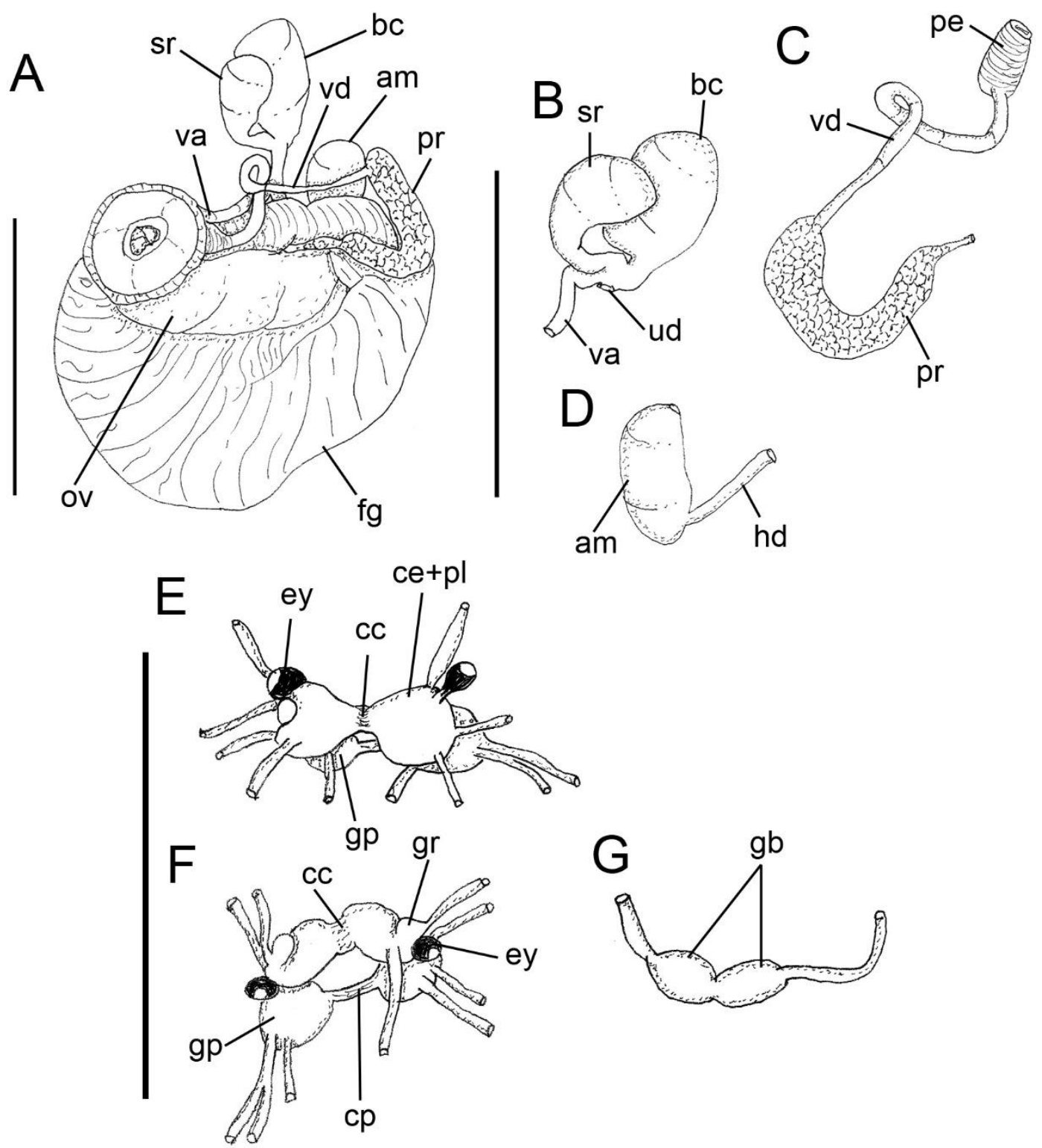

Figure 31: Goniodoris mimula. Reproductive system. A. Vental view. B. Detail of bursa copulatrix, seminal receptacle and vagina. C. Detail of prostate, vas deferent and penis. D. Detail of ampulla and hermafrodict duct. Nervous system. E. Dorsal view. F. Same, ventral view. G. Detail of buccal ganglia. Scales: $1 \mathrm{~mm}$. 


\section{Superfamily Polyceroidea Alder \& Hancock, 1845}

Family Polyceridae Alder \& Hancock, 1845

Genus Tambja Burn, 1962

Type species: Nembrotha verconis Basedow \& Hedley, 1905, by original designation

\section{Tambja brasiliensis Pola, Padula, Gosliner \& Cervera, 2014}

(Figures 32-37)

Tambja brasiliensis Pola, Padula, Gosliner \& Cervera, 2014: 616, figs. 3c, 5a-d, 6

Type locality: Ilha do Papagaio, Cabo Frio, Rio de Janeiro, Brazil.

\section{Redescription}

External morphology (Figure 32A-E): Size $12 \mathrm{~mm}$ length, 5mm width. Color yellow-green. Body elongate and limaciform with long and pointed end of foot (Fig. 32A, B). Rhinophores with about 20 transverse lamellae, bule-green color; rhinophoral sheaths tall and smooth (Fig. 32D). Gill composed of 5 bipinate branchial leaves, also blue-green color, arranged in circular fashion surrounding anus (Fig. 32E); branchial sheaths absent. Mouth opening in anterior ventral region, between anterior region of notum and foot (Fig. 32B). Oral tentacles flattned, triangular, about half of size of mouth, each one with ventral furrow up to half of extensions. Anterior border of foot bilabiate (Fig. 32B).

Haemocoel organs (Figure 33A, B): pericardium and gill circle located $\sim 1 / 4$ more anterior of visceral mass, occupying $15 \%$ of haemocoel volume. Buccal mass located anteriorly, occupying $20 \%$ of haemocoel volume. Nervous system dorsal more posterior to buccal mass, covered by blood gland, occupying 5\% of haemocoel volume. Reproductive system on right side of animal, occupying $20 \%$ of haemocoel volume. Stomach, intestine and digestive gland occupying $40 \%$ of haemocoel volume.

Circulatory and excretory systems (Figure 32E; 33A, F): Afferent and efferent branches located inside each gill filament, flowing from and to afferent and efferent branchial veins. Gill retractor muscle absent. Auricle funnel-like (wider anteriorly) with thin walls. Ventricle as taller as wide, with thick muscular walls. There are three major vessels: 1) aortic trunk, located anteriorly to pericardium, connected to anterior ventricular region; 2) auricular vessels connecting lateral cavities of integument to auricle; 3) branchio-cardiac vessel located at posterior end of pericardium, connecting 
branchial efferent ring to auricle. Aortic trunk branched into anterior artery irrigating reproductive system, buccal mass, odontophore and nervous system; posterior artery irrigating stomach and digestive gland (Fig. 33F). Renal vesicle located on right dorsal side of pericardium, near base of auricle, connected to inner surface of pericardium, 1/4 of size of ventricle. Renal chamber extending from dorsal to medial sinus, previously connected to renal vesicle, extending posteriorly to center of gill circle and opening in nephrostome, easy to visualized near anal papilla (Fig. 32E).

Digestive system (Figures 33C, E; 34A-F; 35A-C; 37A-C): Oral tube composed of outer lip, with pleats lengthwise; inner lip with transverse fold (Fig. 34D); mt, three pairs of retractor muscles of buccal mass, originating on oral tube, running dorsally and ventrally to oral tube, inserting on body side, about nine times as wide and twice as long as m10 (Fig. 34A, B, D). Odontophore oval, connected to oral tube by pair of ventral protractor muscles (m10); thin longitudinal, dorsal and ventrolateral protractors of oral sphincter, originating in anterior region of odontophore and inserted in posterior region of integument close to oral tube. Oral sphincter surrounding chitinous part of oral tube (Fig. 34E, F). Odontophore muscles (Fig. 35A-C): m2, absent; m4, pair of dorsal tensor muscles, strong and broad, covering 3/4 of cartilage, inserted on ventral portion of subradular membrane; m5, pair of dorsal auxiliary tensor muscles, twice as long as wide, originating on most posterior region of odontophore cartilages, covering $\sim 1 / 4$ of posterior cavity of odontophore, as long as, but with $\sim 1 / 3$ of $\mathrm{m} 4$ width, inserting on ventral side of subradular membrane, around radular sac; m6, unpaired horizontal muscle, with transverse fibers connecting to median surface of left and right odontophore cartilages, about same length and half as wide as $\mathrm{m} 4$, same width to anterior and posterior portion; $\mathbf{m 7}$, pair of thin muscles, originating from center of odontophore cartilages, passing beteewn $\mathrm{m} 4$ and $\mathrm{m} 5$ and insertiong on lateral of radular sac. Pair of odontophore cartilages elliptical (Fig. 35C). Subradular membrane thin, strong, translucent. Radular sac $\sim 1 / 3$ as large as odontophore. Radular teeth (Fig. 37A-C): rachidian teeth present (Fig. 37B); formula 32 x 4.1.1.1.4 (in $12 \mathrm{~mm}$ long specimen). All teeth same as original description (Pola et. al, 2014). Pair of salivary large and wide, inserting in anterior dorsal region of esophagus (Fig. 34A). Esophagus simple, originating dorsally to odontophore, inserting directly in anterior region of stomach, internal longitudinal folds with same diameter along entire length. Stomach two times more broad than esophagus, with folds at entire inner surface (Fig.34C). Common opening for esophagus and stomach located on digestive gland. Intestine with longitudinal folds along its entire length, diameter about 
same esophagus diameter. Caecum absent. Digestive gland dark beige, rounded, inner face of gland sponge-like, bearing distinct main duct (Fig. 33E). Anus opening into anal papilla at center of gill circle, $\sim 1 / 6$ of gill filament length.

Genital system (Figures, 32B; 33D; 35D, E): Genital opening on right side, in middle of length of animal from head, located between foot and notum (Fig. 32B). Gonad around digestive gland, seens like carpet with small circular sphere and some bigger yellow sphere (Fig. 33D). Hermaphrodite duct thin, long. Ampulla located on female gland, elongated and tubular. Prostate glandular, length same as ampulla. Vas deferens about five times longer than penis (Fig. 35D). Penis' muscle absent. Female gland welldeveloped, rounded, occupying $\sim 30 \%$ of reproductive system volume, divided into mucus gland ( $\sim 2 / 3$ of female gland, color beige), and albumen gland ( 1/3 of anteriormost region, dilated, irregularly shaped, color dark brown). Uterine duct very short, length $\sim 1 / 16$ of vagina length, located at base of vagina, inserted in female gland near oviduct (Fig. 35E). Seminal receptacle pyriform, as large as bursa copulatrix, connected to vagina near uterine duct through short stalk. Bursa copulatrix rounded, length $\sim 1 / 2$ of vagina length, connected to vagina after seminal receptacle, also through short stalk. Vagina cylindrical, elongated, approximately half length and width as penis, followed ventrally by prostate and located parallel to penis in genital opening. Two rounded pouches in middle of vagina, unarmed (Fig. 35E).

Nervous system (Figure 36A-C): Pair of cerebral and pleural ganglia fused with each other dorsally and ventrally. Pedal ganglia fused with cerebral and pleural ventrally, but not fused among themselves. Pedal commissure double, surrounding esophagus (Fig. 36B). Buccal ganglia short, located ventrally to odontophore, between radular sac and anterior portion of esophagus, connected to cerebral ganglia through long and slender connective tissue (Fig. 36C). Gastro-esophageal ganglia not visualized. Rhinophoral (olfactory) ganglia bulb-shaped, connected to anterior portion of cerebral ganglia. Dorsal eyes located on cerebral ganglia (Fig. 36A).

Distribution: South-eastern and Southern Brazil, from Rio de Janeiro to Santa Catarina States (Pola et. al, 2014).

Habitat: Vertical walls covered with Bugula spp. Between 5-30m depth (Pola et al., 2014).

Material examined: BRAZIL, Cabo Frio, Rio de Janeiro, MZSP 92892, 3 specimens (V. Padula, coll.); Ilha da Serraria, São Sebastião, São Paulo, MZSP 103248, 
9 specimens (V. Padula, Y. Tibirica, P. Oristanio \& J. C. Garcia, coll. 19/i/2012, 3-10m depth, in vertical wall covered by Bugulidae).
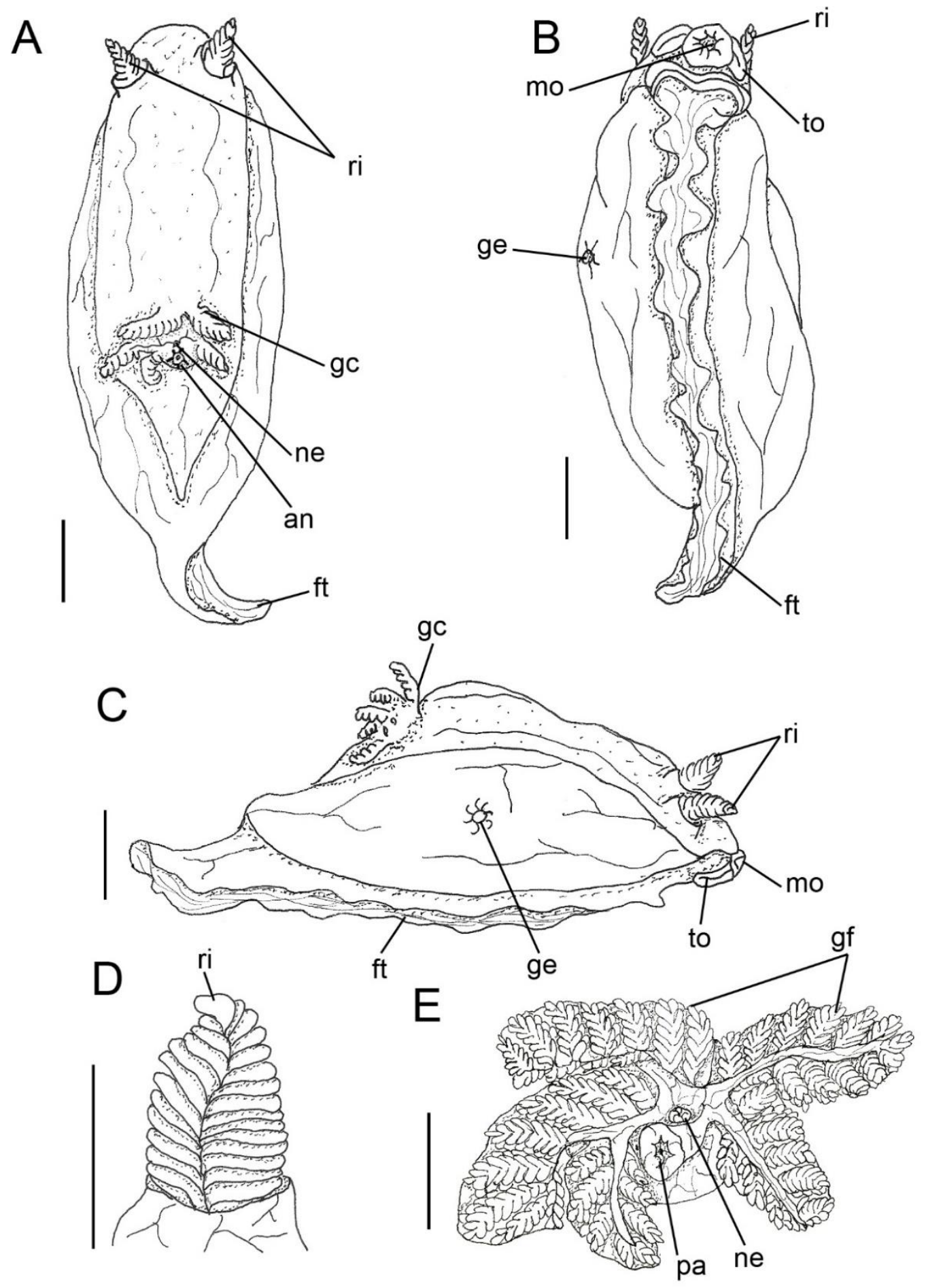

Figure 32: Tambja brasiliensis, fixed animal. A. Dorsal view. B. Same, ventral view. C. Rigth lateral view. Scales: $2 \mathrm{~mm}$. D. Detail of rhinophore. E. Gill circle, dorsal view. Scales: $1 \mathrm{~mm}$. 

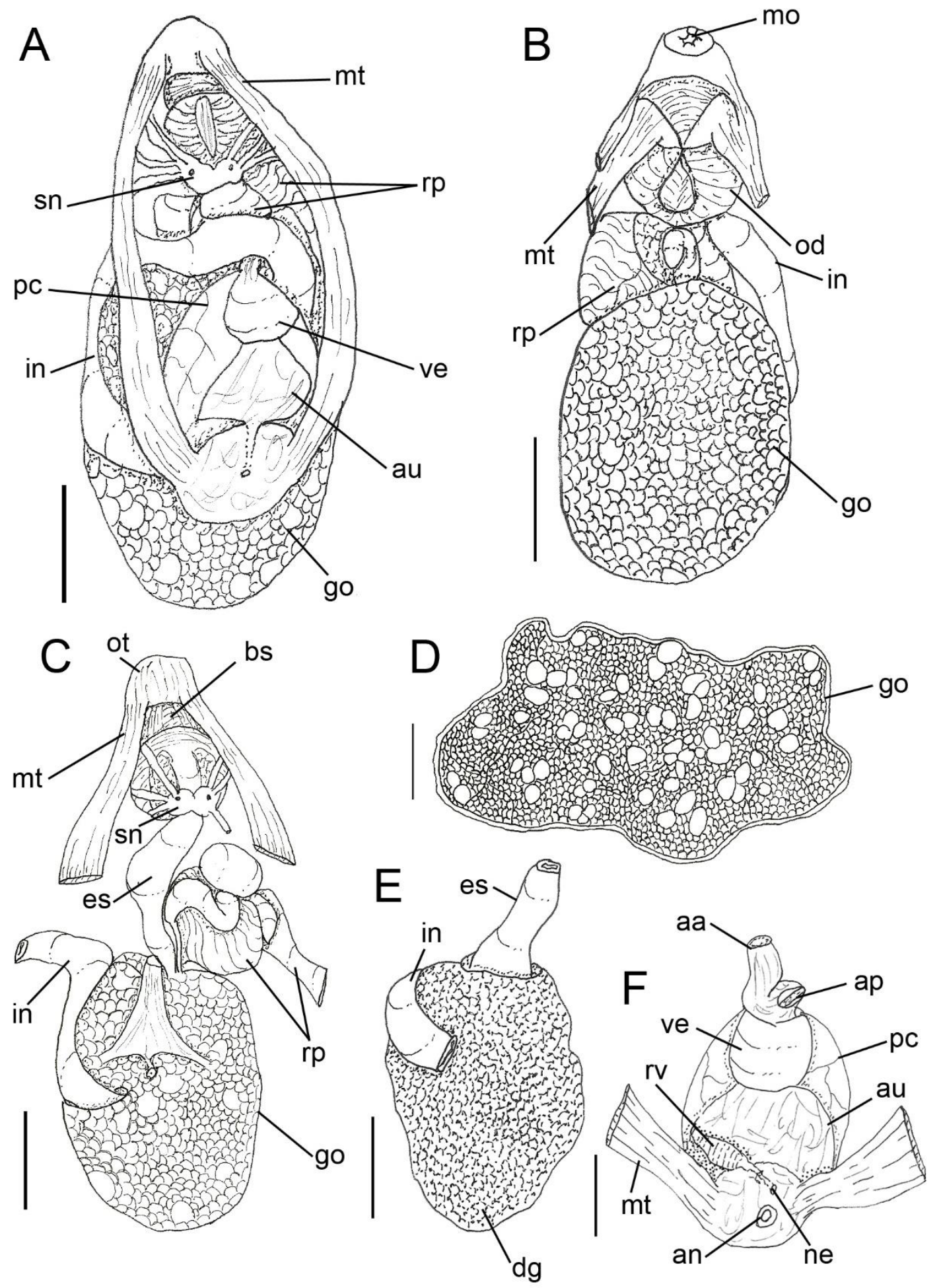

Figure 33: Tambja brasiliensis. Visceral mass. A. Dorsal view. B. Same, ventral view. C. Same, dorsal view, whit removed pericardium. D. Detail of gonada, removed from digestive gland. E. Medium digestive system, dorsal view. Scales: $2 \mathrm{~mm}$. F. Circularory and excretory system, vental view. Scale: $1 \mathrm{~mm}$. 

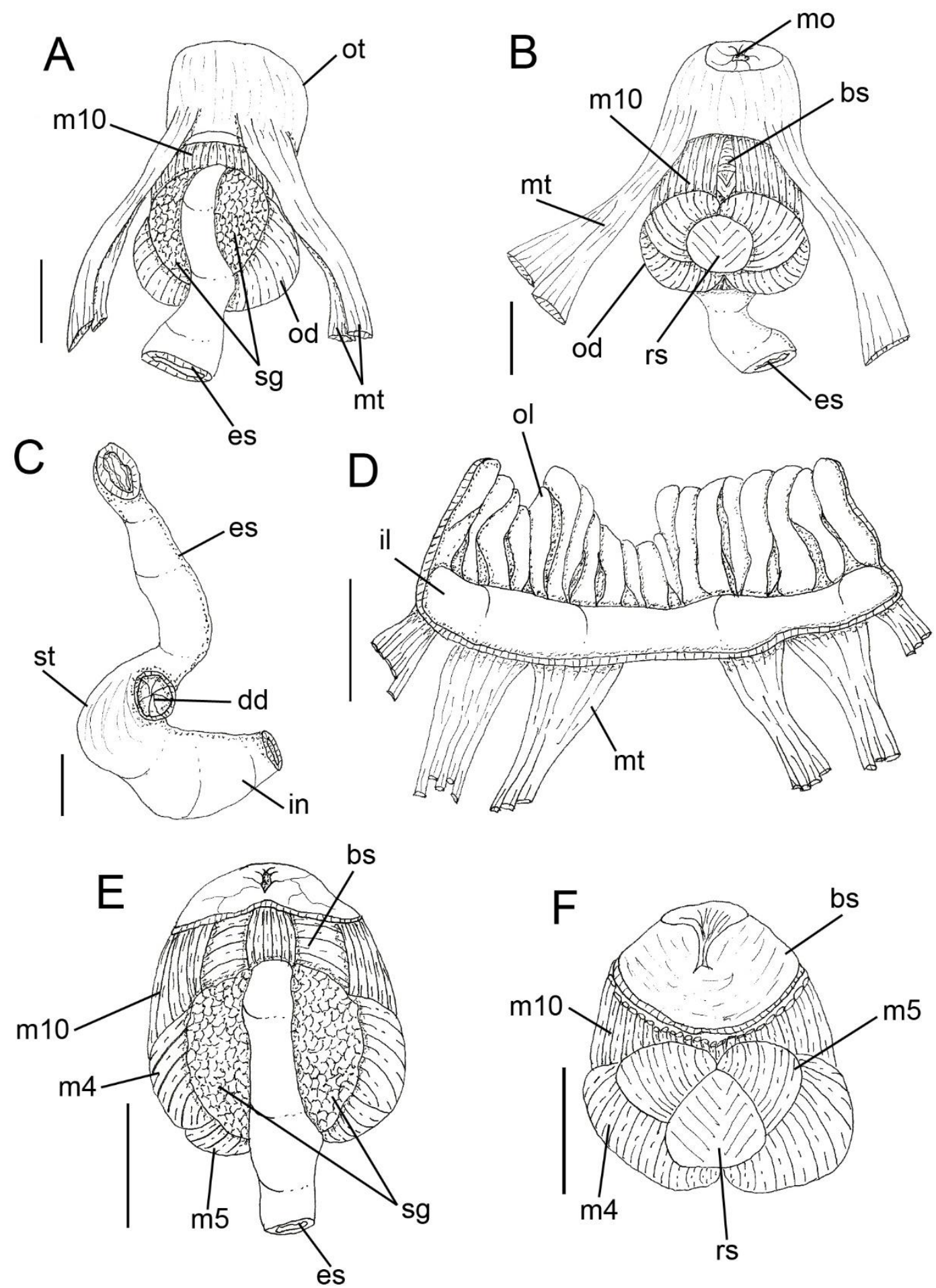

Figure 34: Tambja brasiliensis. Anterior digestive system. A. Dorsal view. B. Same, ventral view. C. Medium digestive system, with removed digestive gland. D. Oral tube, longitudinally sectioned. Odontophore with buccal sphincter. E. Dorsal view. F. Same, ventral view. Scales: $1 \mathrm{~mm}$. 


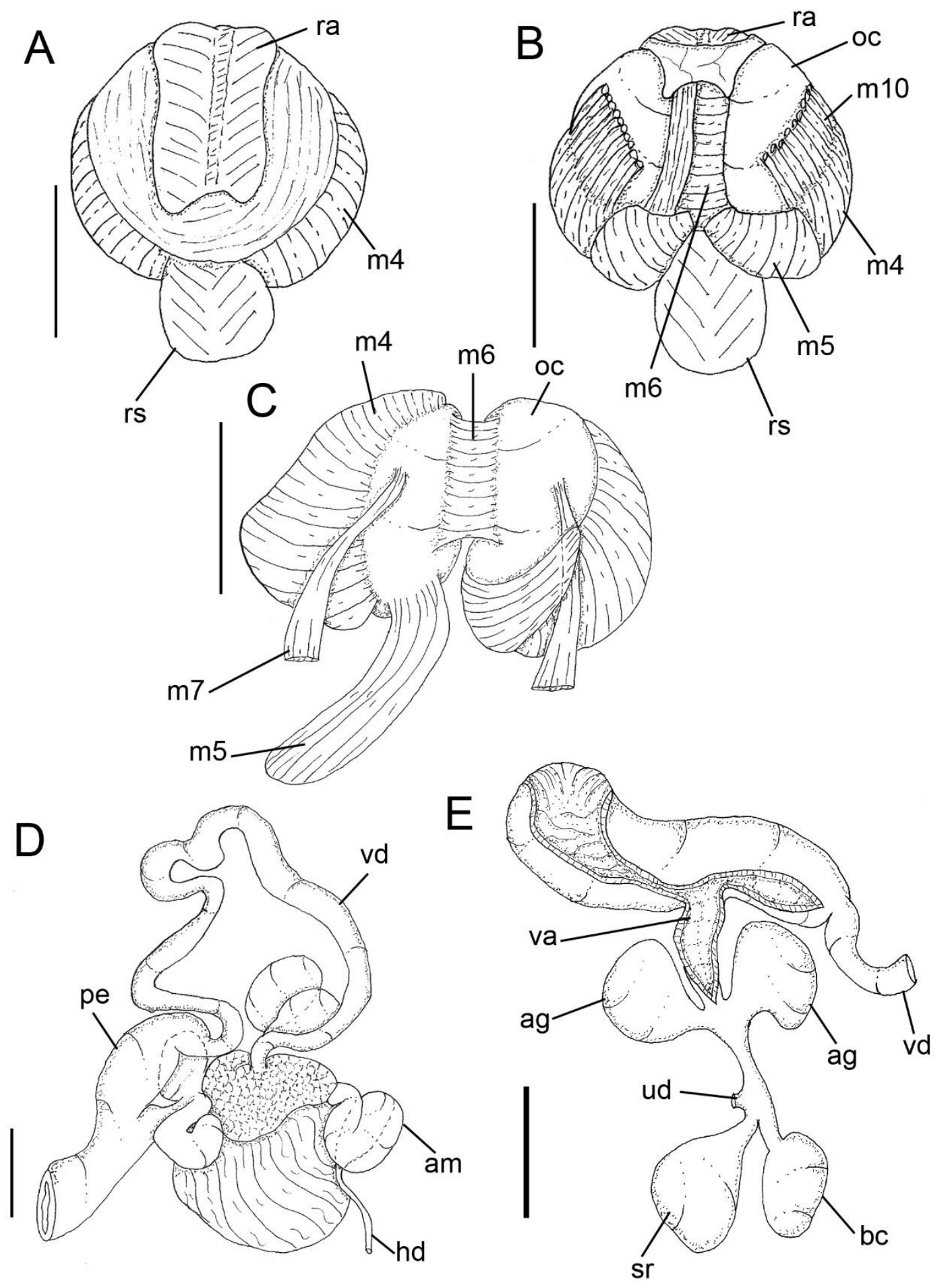

Figure 35: Tambja brasiliensis. Odontophore. A. Dorsal view with radula. B. Same, ventral view. C. Same, dorsal view with removed radula and folded down muscles. Reproductive system. D. Ventral view. E. Detail of aperture of penis and vagina. Scales: $1 \mathrm{~mm}$. 

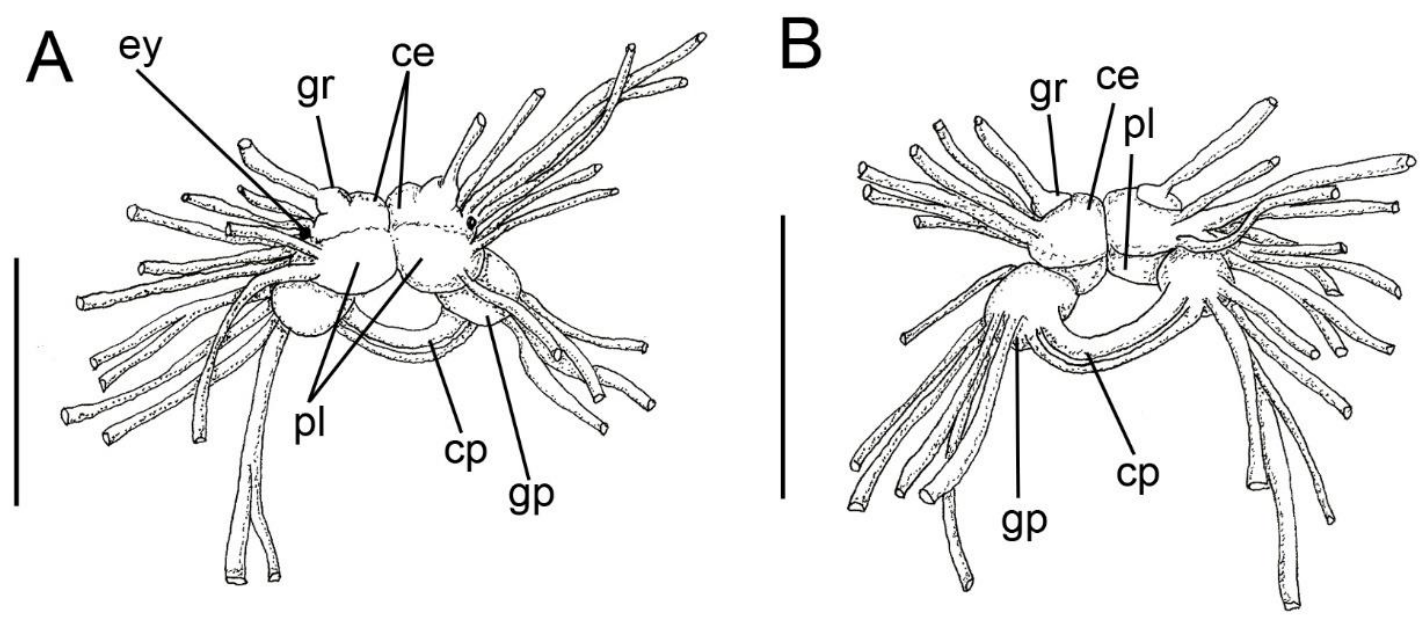

C

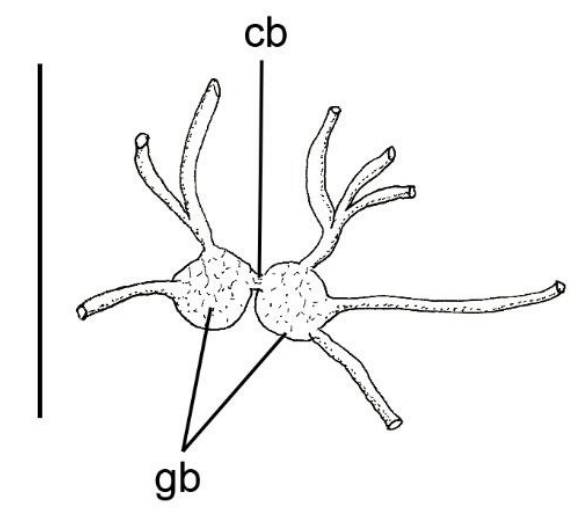

Figure 36: Tambja brasiliensis. Nervous system. A. Dorsal view. B. Same, ventral view. C. Detail of buccal ganglia. Scales: $1 \mathrm{~mm}$. 


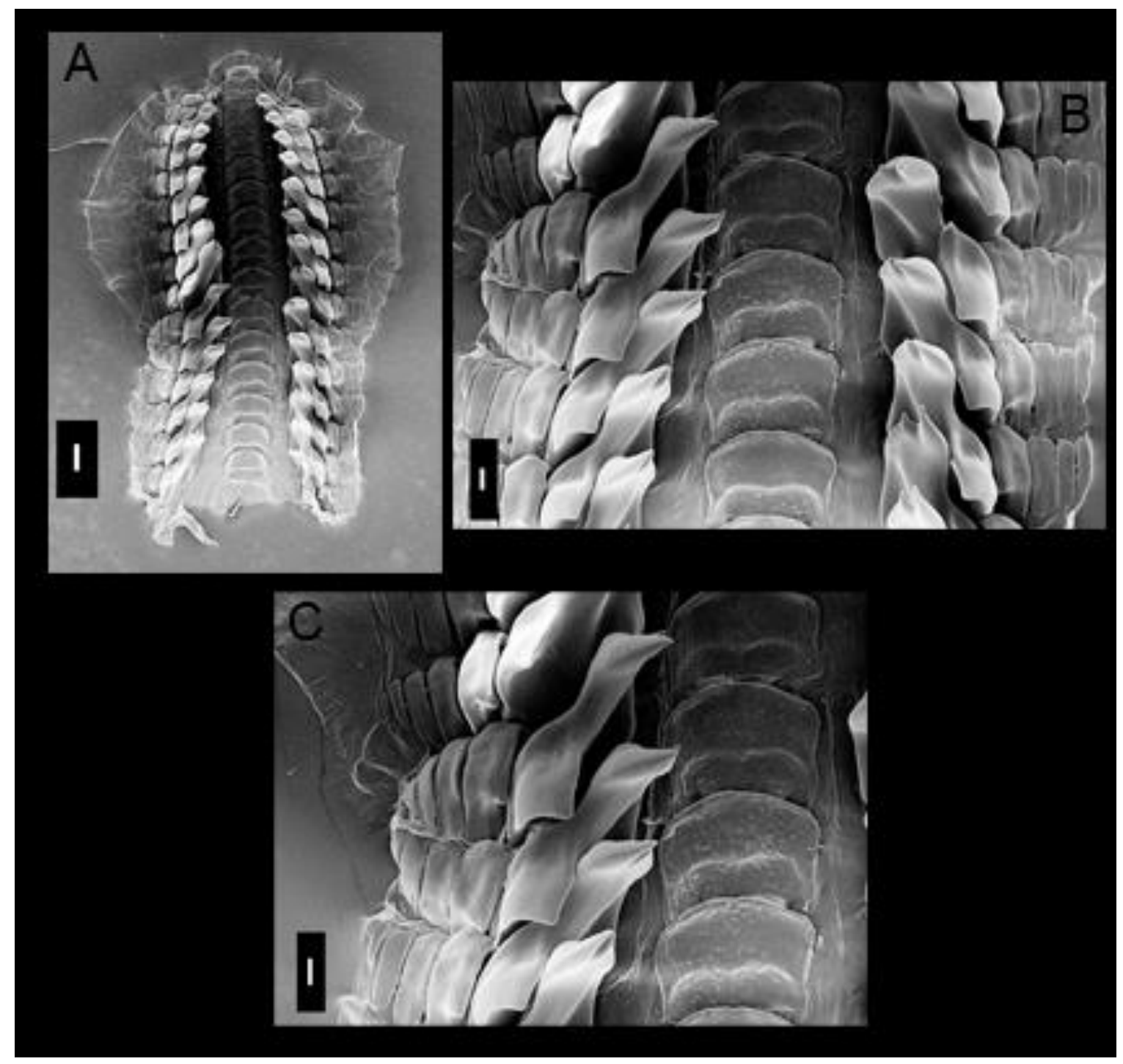

Figure 37: SEM of radula of Tambja brasiliensis. A. Panoramic view. Scale: $100 \mu \mathrm{m}$. B. Rachidian tooth. Scale: $30 \mu \mathrm{m}$. C. Innermost lateral tooth. Scale: $30 \mu \mathrm{m}$. 


\section{Superfamily Doridoidea Rafinesque, 1815}

\section{Family Chromodorididae Bergh, 1891}

Genus Hallaxa Eliot, 1909

Type species: Hallaxa decorate (Bergh, 1877) by original designation. (see Gosliner \& Johnson, 1994)

\section{Hallaxa apefae Er. Marcus, 1957}

(Figures 38-41)

Hallaxa apefae Er. Marcus, 1957: 421, figs. 73-80; Gosliner \& Johnson, 1994: 157, figs. 2-3; Ortea et al., 1997: 86; Rios, 2009: 425.

Type locality: Ubatuba, Sao Paulo, Brazil

\section{Redescription}

External morphology (Figures 38A-E; 39A, B): Size 5mm length, 2mm width, $1 \mathrm{~mm}$ width foot/notum. Body elongated, three time longer than wide (Fig. 38A-C). Rhinophores with about 9 transverse lamellae (Fig. 38E); rhinophoral sheaths smooth. Gill circle composed of 7 unipinnate branchial leaves, arranged in circular fashion surrounding anus; branchial sheaths smooth (Fig. 39A, B). Mouth opening in anterior ventral region, between anterior region of notum and foot (Fig. 38D). Digitiform tentacles present, flattened (Fig. 38D). Anterior border of foot bilabiate transversely (Fig.). Foot exceed the notum, like in Chromodorididae (Fig. 38B).

Haemocoel organs (Figs.): pericardium and posterior half of visceral mass volume occupying $10 \%$ of haemocoel. Buccal mass located anteriorly, occupying $15 \%$ of haemocoel volume. Nervous system dorsal to buccal mass, covered by blood gland, occupying $5 \%$ of haemocoel volume. Reproductive system on right side of animal; occupying $30 \%$ of haemocoel volume. Stomach, digestive gland, intestine occupying $40 \%$ of haemocoel volume.

Circulatory and excretory systems (Figure 39A-C, E): pericardial cavity dorsal and posterior to digestive gland, anterior to gill circle. Afferent and efferent vein located inside each gill filament (Fig. 39B). Retractor muscle gill divided in two fibers originating from base of gill circle, running longitudinally up to half of foot level, inserting into dorsal surface of foot (Fig. 39A). Auricle funnel-like (wider anteriorly) with thin walls. Ventricle 
sligthly taller than wide, with thick muscular walls (Fig. 39E). Aortic trunk anterior to pericardium, connected to anterior ventricular region, branched into anterior artery irrigating stomach and digestive gland; posterior artery irrigating reproductive system, buccal mass, odontophore and nervous system inserting on blood gland. Blood gland undivided and located more posteriorly to fused ganglia (Fig. 39C). Auricular vessels connecting lateral cavities of integument to auricle. Renal vesicle located on right dorsal side of pericardium, near base of auricle, connected to inner surface of pericardium, elliptical, 1/3 of size of ventricle (Fig. 39E). Renal chamber extending from dorsal to medial sinus, previously connected to renal vesicle, extending posteriorly to center of gill circle and opening in nephrostome, probably next to anus pore. Nephrostome difficult to see.

Digestive system (Figures 39A, D; 40A-E): Oral tube composed of outer lip, with pleats lengthwise; inner lip with transverse fold; mt, two pairs of retractor muscles of buccal mass, originating on oral tube, running dorsally and ventrally to oral tube, inserting on body side, about half as wide and twice as long as m10 (Fig. 40A, B). Odontophore oval, connected to oral tube by several fine ventral protractor muscles $(\mathbf{m} 10)$; thin longitudinal, ventrolateral protractors of oral sphincter, originating in anterior region of odontophore and inserted in posterior region of integument close to oral tube (Fig. 40A). Buccal sphincter surrounding chitinous part of oral tube. Odontophore muscles: $\mathbf{m} \mathbf{2}$, pair of strong retractor muscles of buccal mass, six time longer than wide, origin on anterior dorsal odontophore, running laterally to $\mathrm{m} 4$ and inserted ventrally on dorsal portion of foot (Fig. 40B); m4, pair of dorsal tensor muscles, strong and broad, 1/2 winder than long, covering 2/3 of cartilage, inserted on ventral portion of subradular membrane (Fig. 40D, E); m5, pair of dorsal auxiliary tensor muscles, twice as long as wide, originating on most posterior region of odontophore cartilages, covering $\sim 1 / 3$ of posterior cavity of odontophore, as long as, but with $\sim 1 / 3$ of $\mathrm{m} 4$ width, inserting on ventral side of subradular membrane, around radular sac (Fig. 40D, E); m6 and $\mathbf{m 7}$, not visualized. Pair of odontophore cartilages slender elliptical (Fig. 40E). Subradular membrane thin, strong, translucent. Radular sac $\sim 1 / 5$ of odontophore. Radula not analyzed by SEM. Pair of salivary glands tubular, 1/3 of esophagus length, duct inserting in anterior region of esophagus, extending posteriorly to anterior region of digestive gland (Fig. 40A). Esophagus simple, originating dorsally to odontophore, inserting directly in anterior region of stomach, internal longitudinal folds with same diameter along entire length. Stomach oval, with folds at the center of entire inner surface. Common opening for 
esophagus, stomach and intestine located on digestive gland (Fig. 40C). Intestine originating to anterior region of stomach, with longitudinal folds along its entire length, twice of esophagus diameter (Fig. 40C). Caecum absent. Digestive gland dark brown, elongated; inner face of gland sponge-like, bearing one main duct (Fig. 39D). Anus opening into pore at center of gill circle (Fig.). Anal papillae absent (Fig. 39A).

Genital system (Figure 38D; 39D; 41A): Gonopore on right side, anterior fourth of length of animal from head, located between foot and notum (Fig. 38D). Gonad immersed on digestive gland, easy to distinguished it (Fig. 39D). Hermaphrodite duct thin, long located at bases of ampulla. Ampulla located on female gland, elongated and tubular. Prostate glandular connected with female gland with a commun duct with ampulla (Fig. 41A). Vas deferens distinguished from penis and $\sim 1 / 2$ of length of it. Penis muscular, cylindrical and elongated. Female gland well-developed, rounded, occupying $\sim 40 \%$ of reproductive system volume, divided into mucus gland and albumen gland $(\sim 1 / 3$ of anteriormost region, dilated, irregularly shaped, color dark brown). Oviduct occupying $\sim 1 / 9$ of female gland volume (Fig. 41A). Uterine duct, seminal receptacle, bursa copulatrix and vagina not visualized in examinaded specimen.

Nervous system (Figure 41B-D): located dorsally to odontophore, posteriorly covered by blood gland. Pair of cerebral and pleural ganglia fused with each other dorsally and ventrally. Pedal ganglia fused with cerebral and pleural ventrally, but not fused among themselves, connected by short and thin pedal commissure. Pedal commissure simple, $1 / 2$ of length of pleural ganglia, surrounding esophagus and salivary glands (Fig. 41C). Buccal ganglia short, located ventrally to odontophore, between radular sac and anterior portion of esophagus, connected to cerebral ganglia through long and slender connective tissue, united to gastro-esophageal ganglia by very short connective tissue (Fig. 41D). Buccal commissure inconspicuous. Gastro-esophageal ganglia length about 1/3 of buccal ganglia length, circular (Fig. 41D). Rhinophoral ganglia bulb-shaped, well developed, connected to anterior portion of cerebral ganglia (Fig. 41B). Dorsal eyes located on cerebral ganglia (Fig. 41B)

Distribution: only know for the type locality, Ubatuba, Sao Paulo, Brazil (Gosliner \& Johnson, 1994).

Habitat: under intertidal stones

Material examined: MZSP 76208, 1 specimen (Col. Marcus C039) 


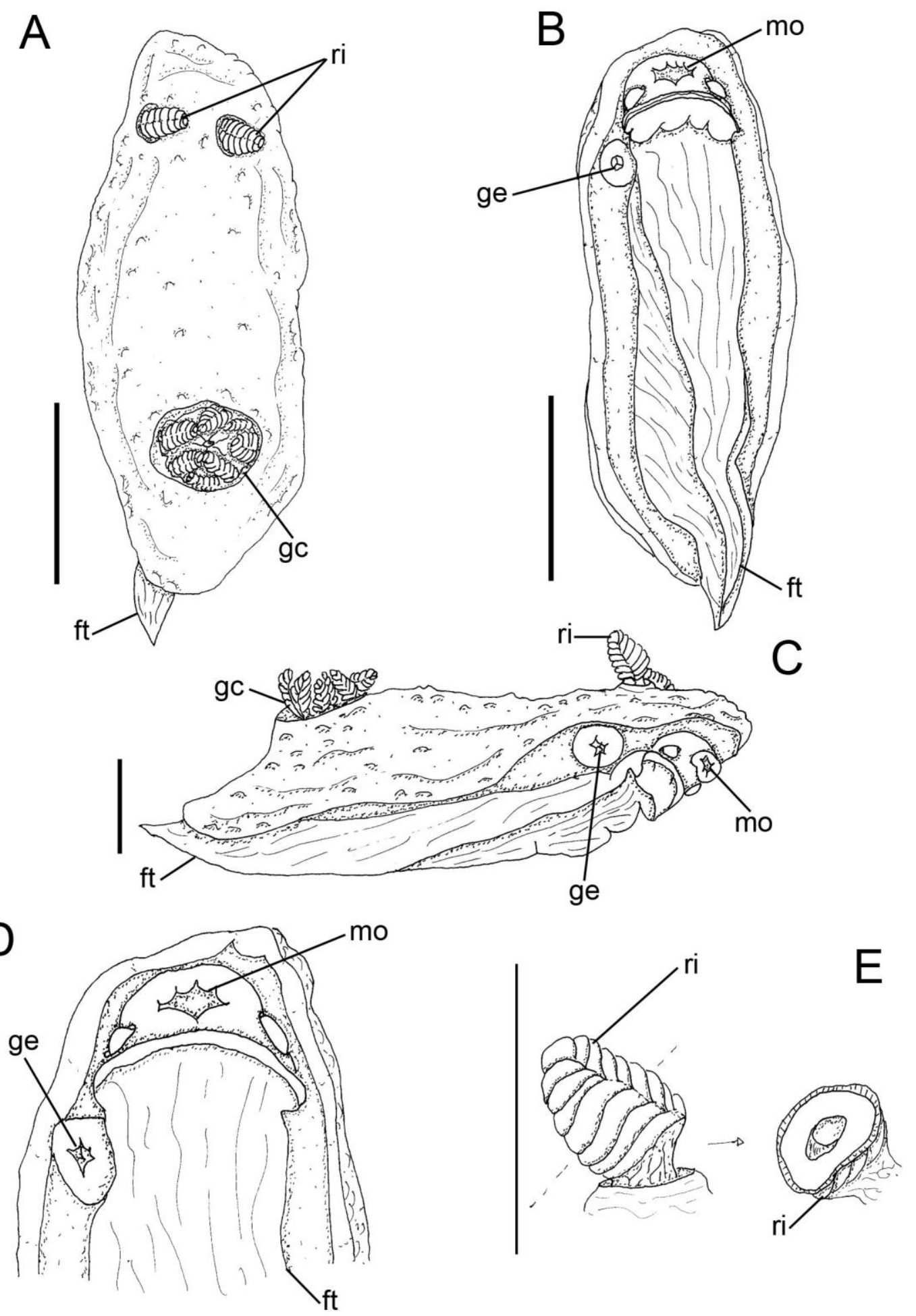

Figure 38: Hallaxa apefae, fixed animal. A. Dorsal view. B. Same, ventral view. Scales: $2 \mathrm{~mm}$. C. Same, right lateral view. D. Detail of anterior border of foot. E. Detail of rhinophore, with transversal sectioned. Scales: $1 \mathrm{~mm}$. 

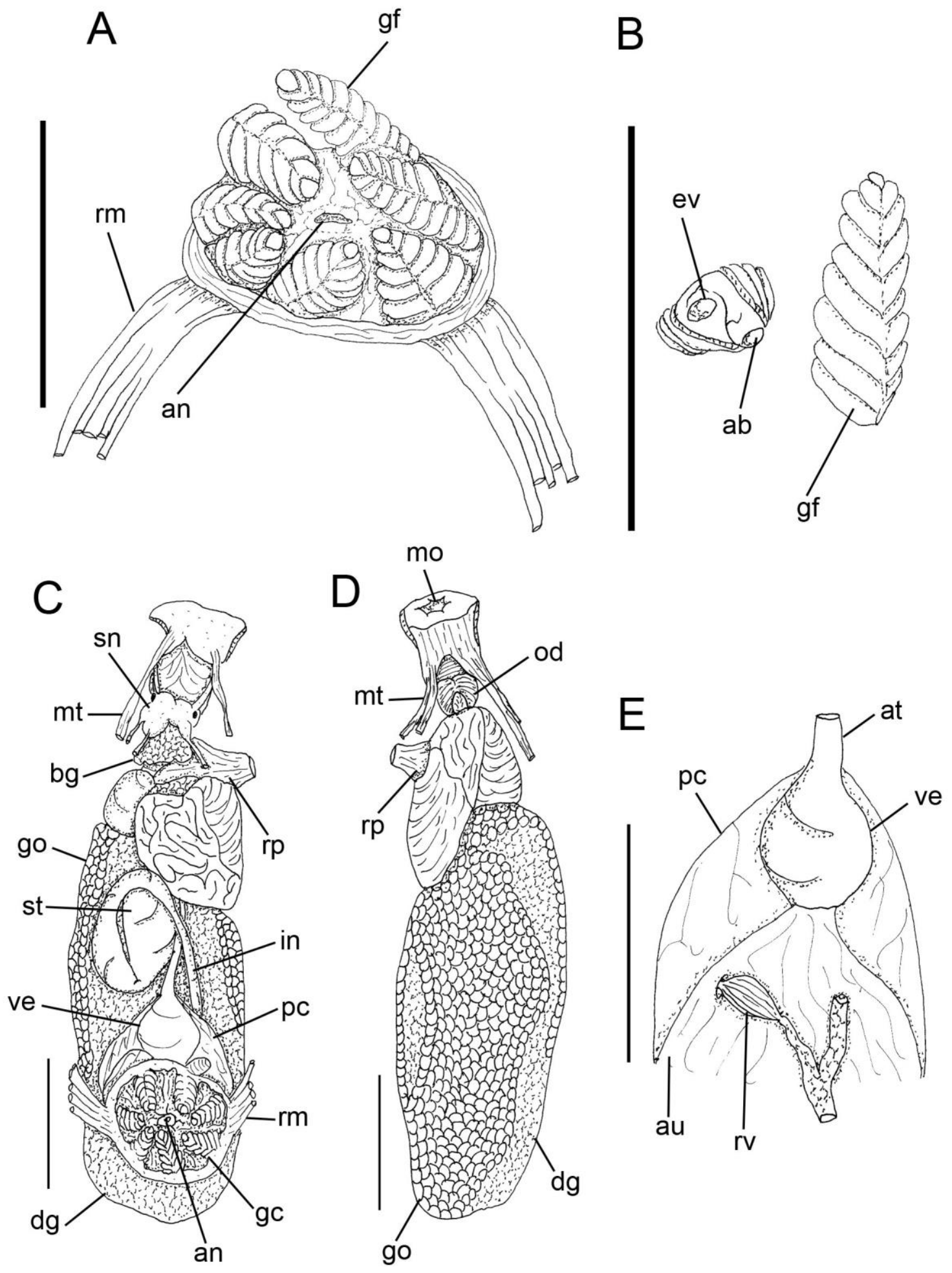

Figure 39: Hallaxa apefae. A. Gill circle, dorsal view. B. Detail of gill filament, with transverse sectioned, showing afferent and efferent branchial ring. Visceral mass. C. Dorsal view. D. Same, ventral view. E. Circulatory and excretory system, ventral view. Scales: $1 \mathrm{~mm}$. 
A

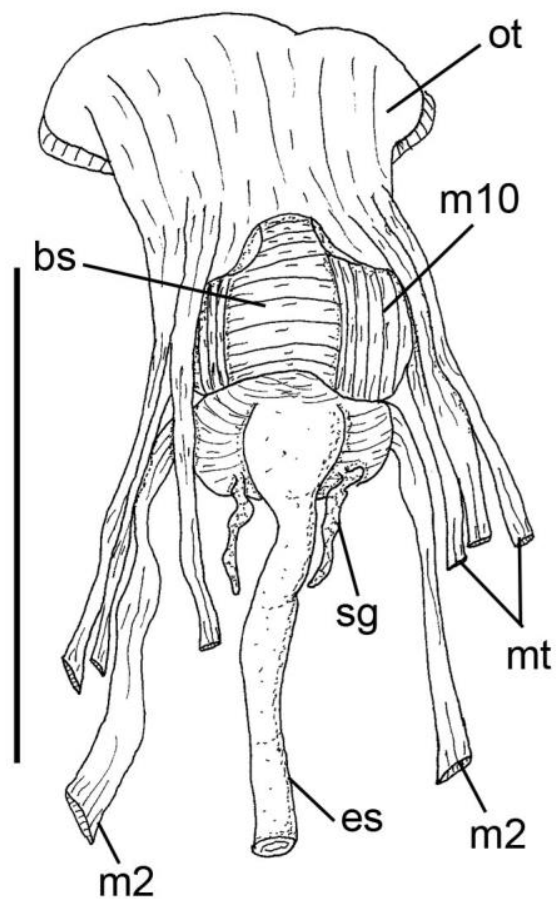

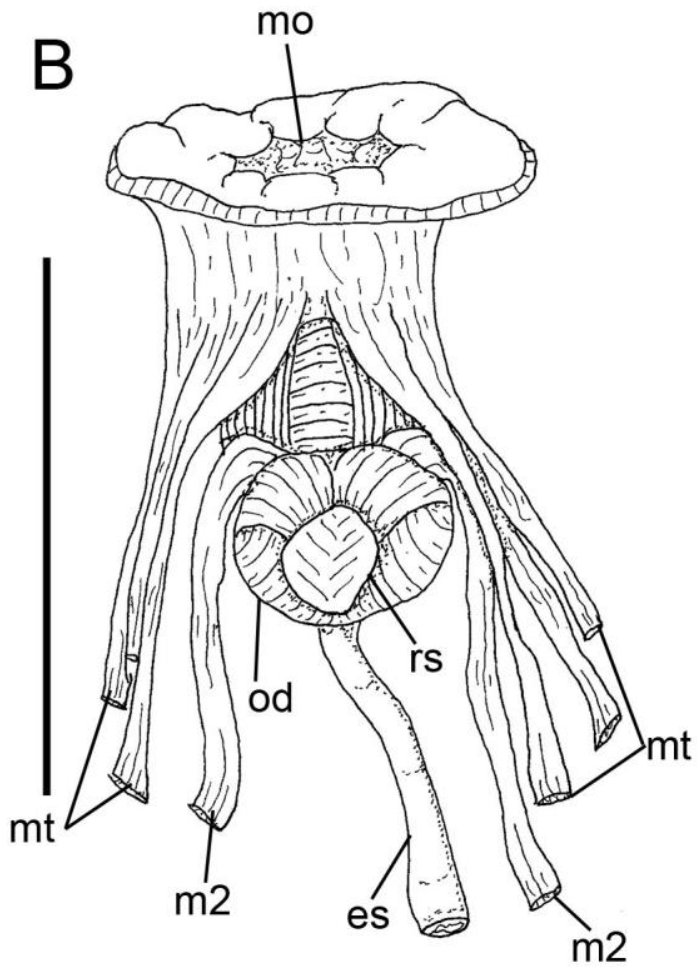

C

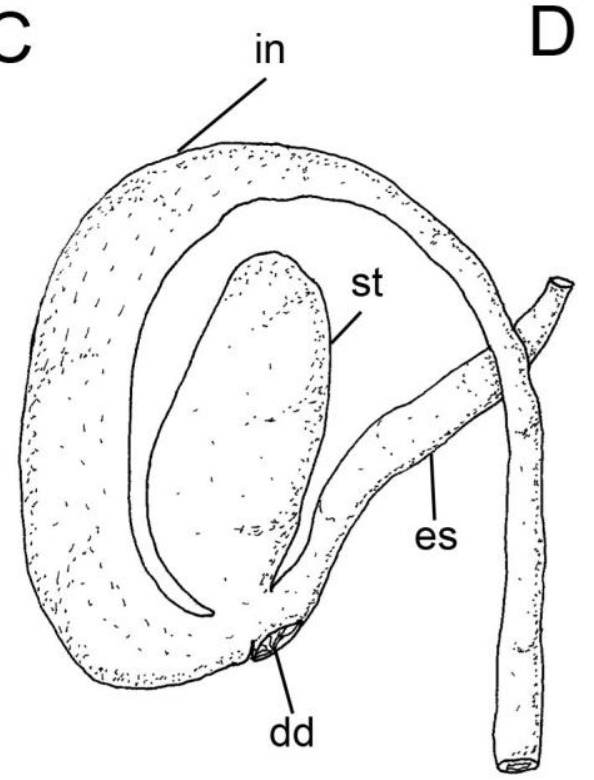

$\mathrm{D}$

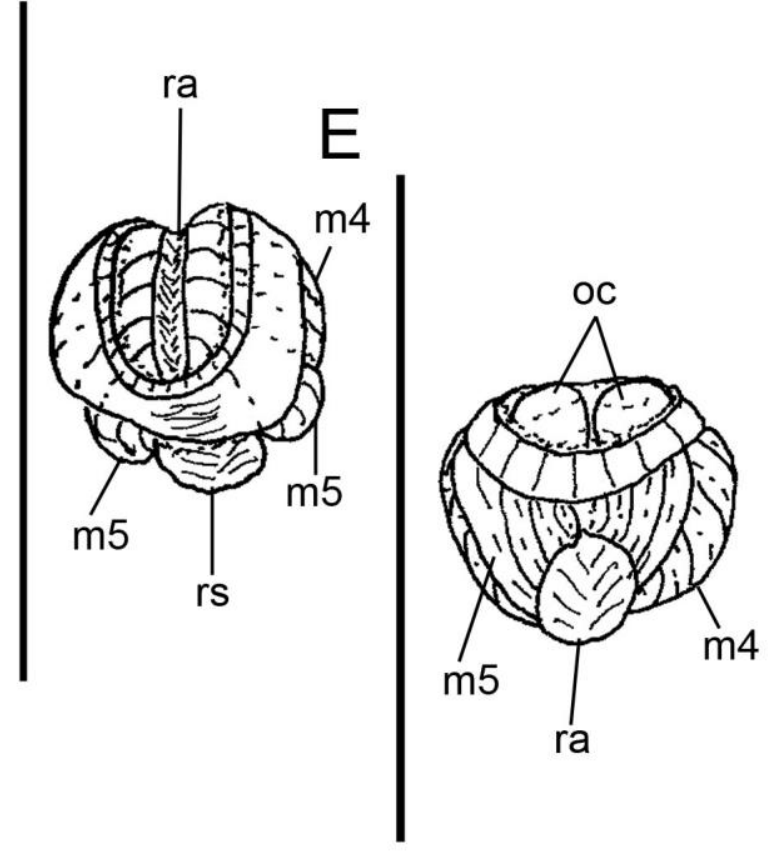

Figure 40: Hallaxa apefae. Anterior digestive system. A. Dorsal view. B. Same, ventral view. C. Median digestive system. Odontophore. D. Dorsal view. E. Same, ventral view. Scales: $1 \mathrm{~mm}$. 


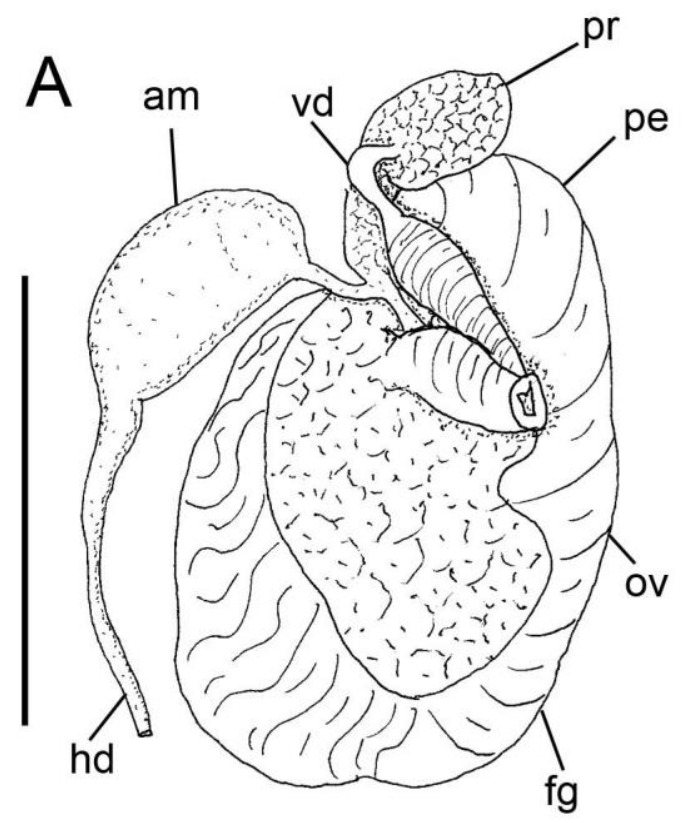

B
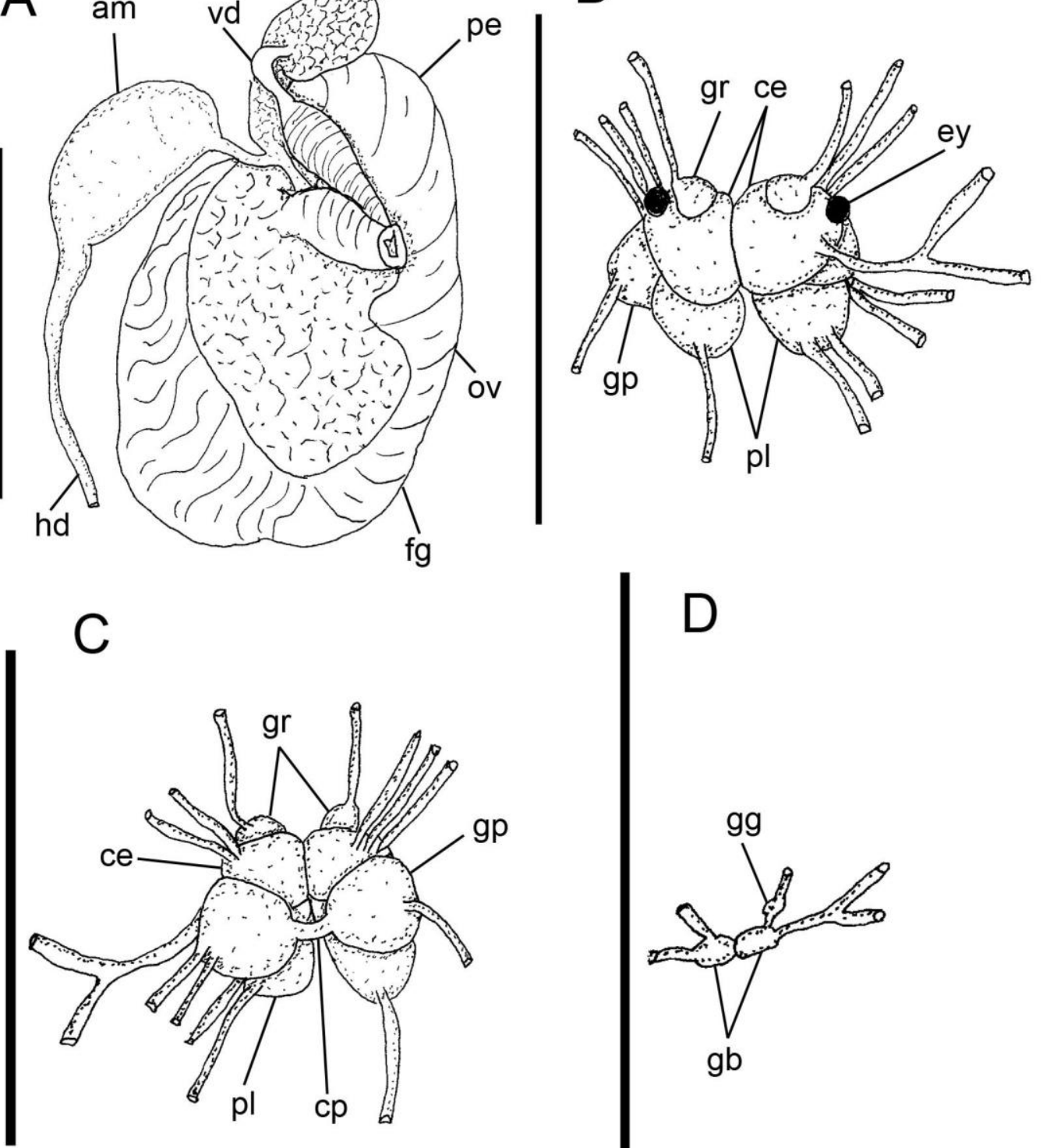

D

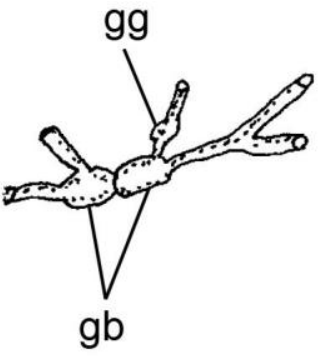

Figure 41: Hallaxa apefae. Reproductive system. A. Dorsal view. Nervous system. B. Dorsal view. C. Same, ventral view. D. Detail of buccal and gastroesophageal ganglia. Scales: $1 \mathrm{~mm}$. 


\section{Genus Chromodoris Alder \& Hancock, 1855}

Type species: Doris magnifica Quoy \& Gaimard, 1832

\section{Chromodoris magnifica (Quoy \& Gaimard, 1832)}

(Figures 42-46)

Doris magnifica Quoy \& Gaimard, 1832: 270-272, pl. 20, figs 1-4.

Chromodoris magnifica (Quoy \& Gaimard): Alder \& Hancock, 1855: Appendix p. 17; Rudman, 1977: 380-382, figs 15-1 7.

Glossodoris quadricolor (Ruppell \& Leuckart); Pruvot-Fol, 1934: 71-72, fig. 26.

Type locality: New Guinea

\section{Redescription}

External morphology (Figure 42A-F): Size 42mm length, 12mm width. Color five longitudinal lines black (3) and with (2), white line surrounding edge, then other orange line, twice as white one, and other fine white line at edge (Fig. 42A). Body elongate with pointed end of foot. Rhinophores very elongate with narrow apex and about 28 transverse lamellae, orange color; rhinophoral sheaths smooth (Fig. 42C, D). Gill composed of 13-15 unipinate branchial leaves, orange color like rhinophore, arranged in circular fashion surrounding anus; branchial sheaths smooth, color similar to body (Fig. 42E, F). Mouth opening in anterior ventral region, between anterior region of notum and foot. Digitiform tentacles present, not grooved, triangular shape. Anterior border of foot bilabiate (Fig. 42B).

Haemocoel organs (Figure 43A, C): pericardium and posterior half of visceral mass volume occupying $15 \%$ of haemocoel volume. Buccal mass located anteriorly, occupying $20 \%$ of haemocoel volume. Nervous system dorsal to buccal mass, covered by blood gland, occupyning 5\% of haemocoel volume. Reproductive system on right side of animal, occupying $20 \%$ of haemocoel volume. Stomach, intestine and digestive gland occupying $40 \%$ of haemocoel volume.

Circulatory and excretory systems (Figure 42E, F; 43A, C): pericardial cavity dorsal and posterior to digestive gland, anterior to gill circle. Afferent and efferent branches located inside each gill filament, flowing from and to afferent and efferent branchial veins (Fig. 42F). Gill retractor muscle divided originating from base of gill circle, running longitudinally up to half of foot level, inserting into dorsal surface of foot (Fig. 42E). Auricle funnel-like (wider anteriorly) with thin walls. Ventricle sligthly taller 
than wide, with thick muscular walls (Fig. 43C). There are three major vessels: 1) aortic trunk, located anteriorly to pericardium, connected to anterior ventricular region; 2) auricular vessels connecting lateral cavities of integument to auricle; 3) branchio-cardiac vessel located at posterior end of pericardium, connecting branchial efferent ring to auricle. Aortic trunk branched into posterior artery irrigating stomach and digestive gland; anterior artery irrigating reproductive system, buccal mass, odontophore and nervous system. Medial sinus connected to afferent branchial ring, irrigating entire digestive gland. Renal vesicle located on right dorsal side of pericardium, near base of auricle, connected to inner surface of pericardium, same the size and half width of ventricle (Fig. 43C). Renal chamber extending from dorsal to medial sinus, previously connected to renal vesicle, extending posteriorly to center of gill circle and opening in nephrostome, in a pore, next to base of anal papilla (Fig.42E). Blood gland divided, posterior portion twice as anterior (Fig. 43A).

Digestive system (Figures 42E; 43B, D-E; 44A-D; 46A-D): Oral tube composed of outer lip, with pleats lengthwise; inner lip with transverse fold; mt, three pairs of retractor muscles of buccal mass, originating on oral tube, running dorsally and ventrally to oral tube, inserting on body side, about three times as wide and three times as long as m10 (Fig. 43B). Odontophore oval, connected to oral tube by pair of ventral protractor muscles (m10); thin longitudinal, dorsal and ventrolateral protractors of oral sphincter, originating in anterior region of odontophore and inserted in posterior region of integument close to oral tube (Fig. 44B). Oral sphincter surrounding chitinous part of oral tube (Fig. 44A). Odontophore muscles: $\mathbf{m} 2$, pair of strong retractor muscles of buccal mass, as wide as long, origin on anterior dorsal odontophore, running laterally to $\mathrm{m} 4$ and inserted ventrally on dorsal portion of foot (Fig. 44B, C); m2a, pair of retractor muscle that running anteriorly to oral tube (Fig. 44C); m4, pair of dorsal tensor muscles, strong and broad, 1/3 as long as wide, covering $2 / 3$ of cartilage, inserted on ventral portion of subradular membrane (Fig. 44C, D); m5, pair of dorsal auxiliary tensor muscles, three times longer than wide, originating on most posterior region of odontophore cartilages, covering $\sim 1 / 3$ of posterior cavity of odontophore, as long as, but with $\sim 1 / 4$ of m4 width, inserting on ventral side of subradular membrane, around radular sac (Fig. 44C, D); m6, unpaired horizontal muscle, with transverse fibers connecting to median surface of left and right odontophore cartilages, about same length and half as wide as $\mathrm{m} 4$, anterior and posterior portion with same width; $\mathbf{m} 7$, pair of thin muscles originating on odontophore cartilages and inserting on radular sac (Fig. 44D); m9, unpaired and horizontal muscle, 
originating on posterior portion of $\mathrm{m} 4$, connecting pair of $\mathrm{m} 4$ (Fig. 44D). Pair of odontophore cartilages elliptical, occupying $20 \%$ of odontophore volume. Subradular membrane thin, strong, translucent (Fig. 44D). Radular sac $\sim 1 / 3$ as large as odontophore (Fig. 44B). Radular teeth (Fig. 46A-D): rachidian teeth absent; formula $\sim 70$ x 65.0 .65 (in $40 \mathrm{~mm}$ long specimen). Innermost lateral tooth on each side with large central cusp and four secondary cusps on each lateral side of tooth, tapering toward apex, hook-shaped, with single terminal cusp; outermost teeth thinner, inner base width about half of lateral teeth width, apex also hook-shaped, cusp simple and smooth. Pair of salivary glands long, tubular; duct inserting in anterior region of esophagus, extending posteriorly to anterior region of digestive gland (Fig. 43B; 44A). Esophagus simple, originating dorsally to odontophore, inserting directly in anterior region of stomach, internal longitudinal folds with same diameter along entire length. Stomach with same length/width of esophagus, internal to digestive gland, with one big fold at anterior region at height of opening of digestive gland ducts, close to anterior region of intestine (Fig.43D, E). Intestine with longitudinal thin folds along its entire length, diameter about same esophagus and stomach diameter (Fig.43D). Caecum absent. Digestive gland dark beige, being largest organ of visceral mass, cone-shaped, anterior portion about twice as wide as posterior portion, inner face of gland sponge-like, two well defined ducts (Fig. 43B; 43E). Anus opening into broad anal papilla at center of gill circle, $\sim 1 / 2$ of gill filament length (Fig. 42E).

Genital system (Figure 42B; 43B; 44E, F)): located between buccal mass and digestive gland, mainly on right side and dorsally. Genital opening on right side, anterior third of length of animal from head, located between foot and notum (Fig. 42B). Gonad immersed in digestive gland, but easily distinguishable (Fig. 43B). Hermaphrodite duct thin, long. Ampulla located on female gland, very elongated and tubular (Fig. 44E). Prostate tubular, glandular, three times longer than ampulla. Vas deferens about twice as penis, Penis' muscle absent. Penis muscular, cylindrical and elongated, about 1/8 of length of prostate (Fig. 44F). Female gland well-developed, rounded, occupying 10\% of reproductive system volume, divided into mucus gland $(\sim 2 / 3$ of female gland, color beige), and albumen gland ( $1 / 3$ of anteriormost region, dilated, irregularly shaped, color dark brown) (Fig. 44E). Oviduct occupying $~ 1 / 2$ of female gland volume (Fig. 44E). Uterine duct thin, same length and $1 / 2$ width of vagina, located at base of vagina, inserted in female gland near oviduct. Seminal receptacle pyriform, 2/3 length and $1 / 2$ width of bursa copulatrix, connected to vagina near uterine duct through short stalk (Fig. 44F). 
Bursa copulatrix rounded, length twice of vagina length, connected to vagina after seminal receptacle, also through short stalk. Vagina cylindrical, elongated, approximately as long and half as wide as penis, followed ventrally by prostate and located parallel to penis in genital opening (Fig. 44F).

Nervous system (Figure 45A-C): located dorsally to odontophore, mostly covered by blood gland. Pair of cerebral and pleural ganglia fused with each other dorsally and ventrally. Pedal ganglia fused with cerebral and pleural ventrally, but not fused among themselves. Pedal commissure double, surrounding esophagus and salivary glands (Fig.45B). Buccal ganglia short, located ventrally to odontophore, between radular sac and anterior portion of esophagus, connected to cerebral ganglia through long and slender connective tissue, united to gastro-esophageal ganglia by short connective tissue (Fig. 45C). Buccal commissure shorth. Gastro-esophageal ganglia length about 1/5 of buccal ganglia length, circular. Rhinophoral (olfactory) ganglia bulb-shaped, connected to anterior portion of cerebral ganglia (Fig. 45A). Dorsal eyes connected with cerebral ganglia by medium connective/optical nerve.

Distribution: Indonesia, Papua New Guinea and Eastern Australia, also Philippines (Seaslugforum)

Material examined: Philippines, Linapacan Island, CAS 71296, 1 specimen (R. Van Syoc, coll., 07/vi/1988, rock and reef at east of South Bay, 20-40ft [RVS-156]); Papua New Guinea, AUS-C156426.001, 1 specimen (D.J. Brunckhorst, 17/vi/1988, submerged patch of reef of Lion Is. 15kmm SE of Port Moresby, $10 \mathrm{~m}$ depth); AUSC156425.001, 1 specimen (D.J. Brunckhorst, 16/vi/1988,10m depth); Australia, Queensland, Hazaed Bay, Orpheus Is., Palm Ids. (18³8.000’S, $\left.146^{\circ} 29.500^{\prime} E\right)$, AUSC379387, 1 specimen (N. Wilson, 05/xi/1998, crawling size, 4-6m depth); GBR, Day Reef, S end, AUS-C144545.001, 1 specimen (I. Loch, coll., 12/xii/1984, 17m depth). 

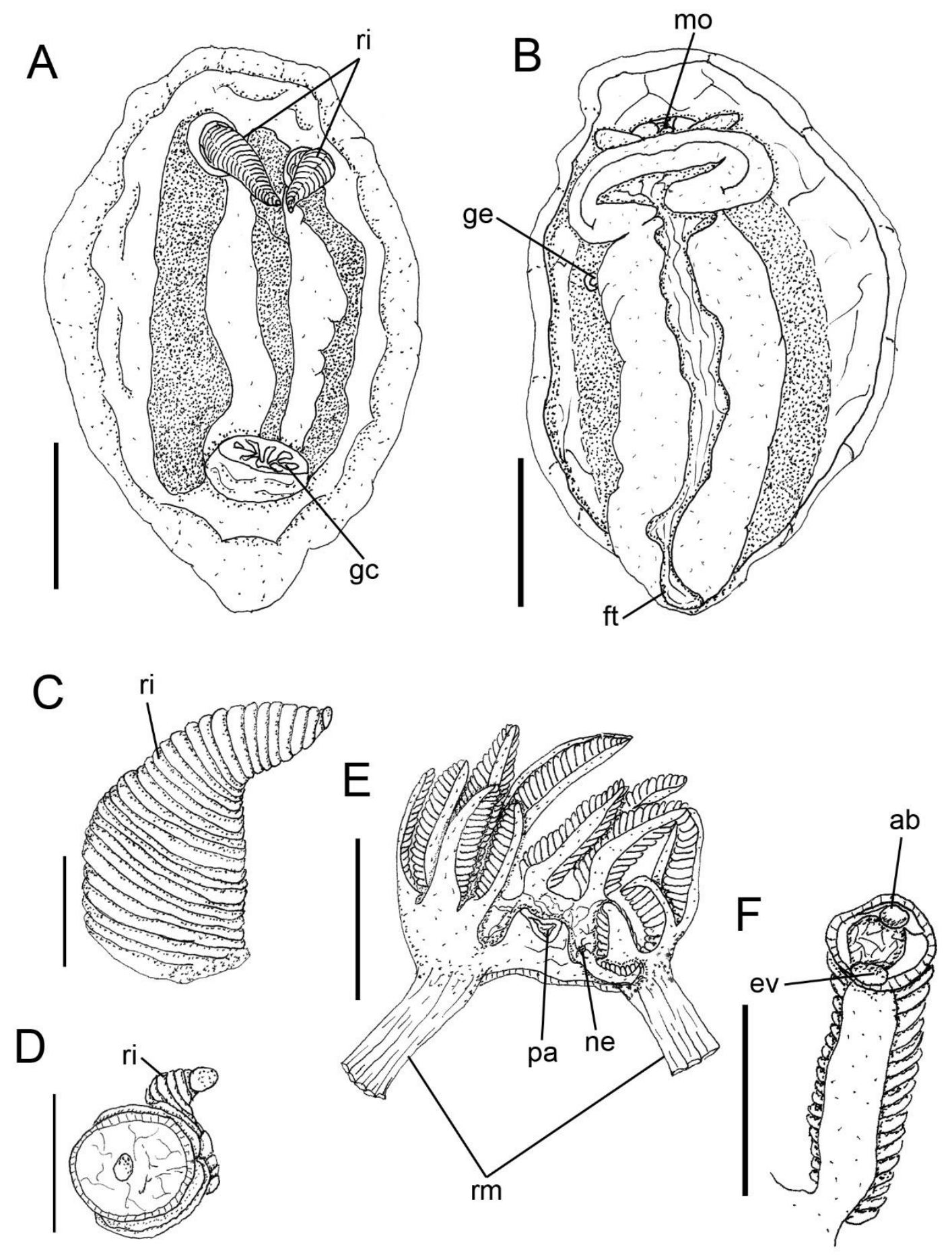

Figure 42: Chromodoris magnifica, fixed animal. A. Dorsal view. B. Ventral view. Scales: $5 \mathrm{~mm}$. C. Rhinophore. D. Transversal section of rhinophore. Scales: $1 \mathrm{~mm}$. E. Gill circle, dorsal view. Scale: $2 \mathrm{~mm}$. F. Detail of gill filament, with afferent and efferent branchial ring. Scale: $1 \mathrm{~mm}$. 

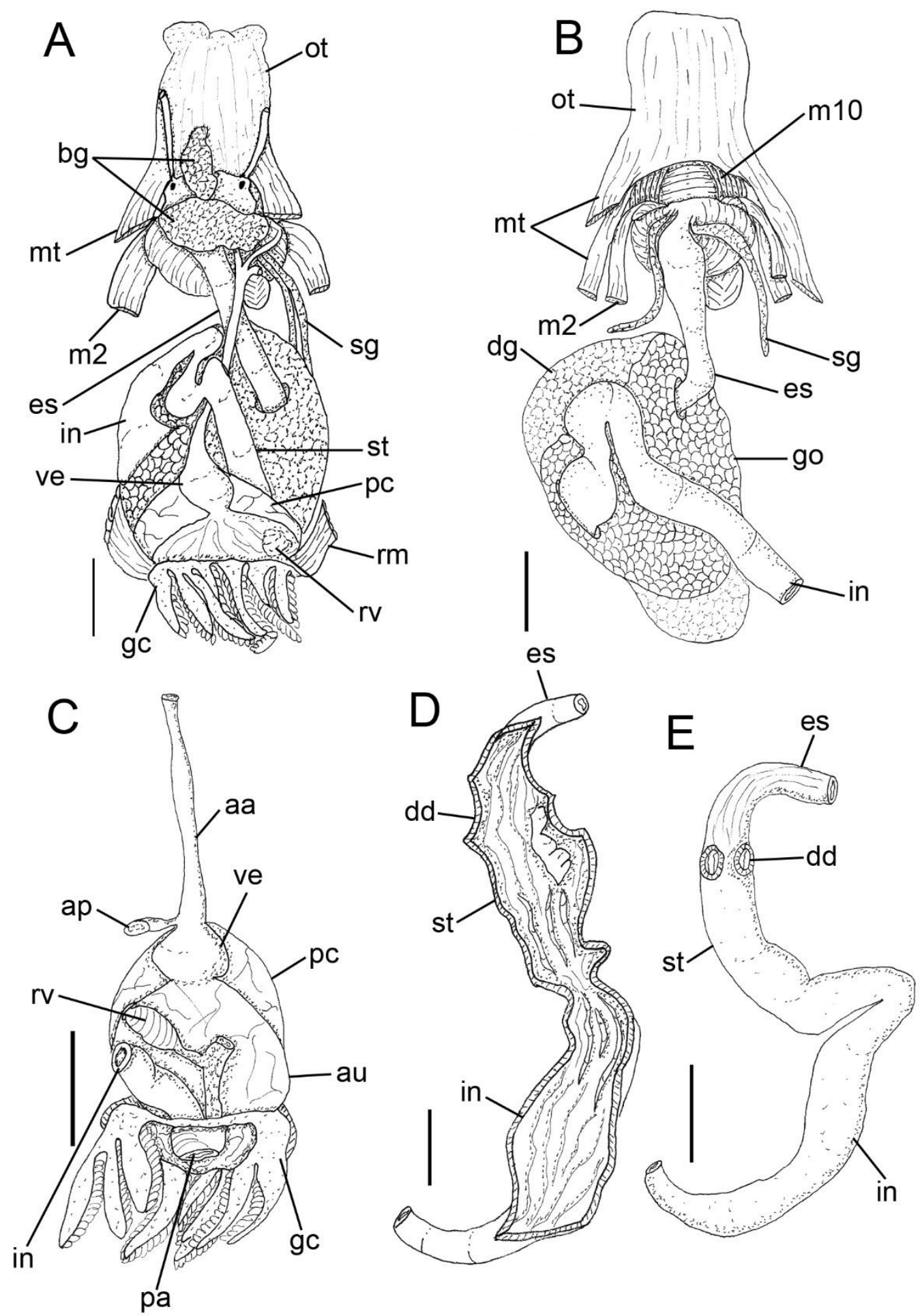

Figure 43: Chromodoris magnifica. Visceral mass. A. Dorsal view. B. Same, ventral view. C. Circulatory and excretory system, ventral view. Median digestive system. D. Longitudinally sectioned. E. Detail of ducts of digestive gland. Scales: $2 \mathrm{~mm}$. 


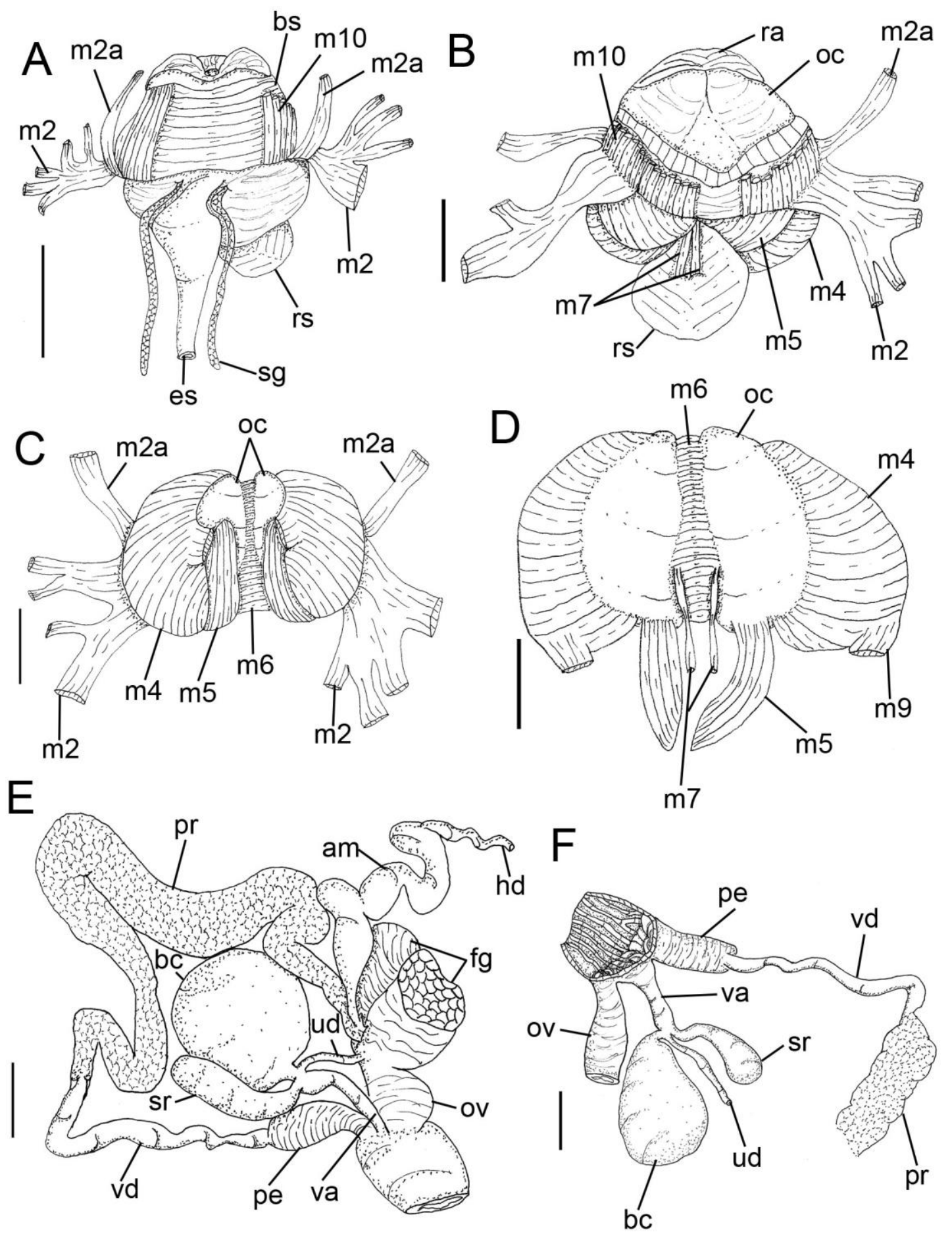

Figure 44: Chromodoris magnifica. A. Anterior digestive, with oral tube removed, dorsal view. Scale: 2mm. Odontophore. B. Ventral view. C. Dorsal view, with removed radula. D. Folded down muscles. Reproductive system. E. Dorsal view. F. Detail of aperture. Scales: $1 \mathrm{~mm}$. 

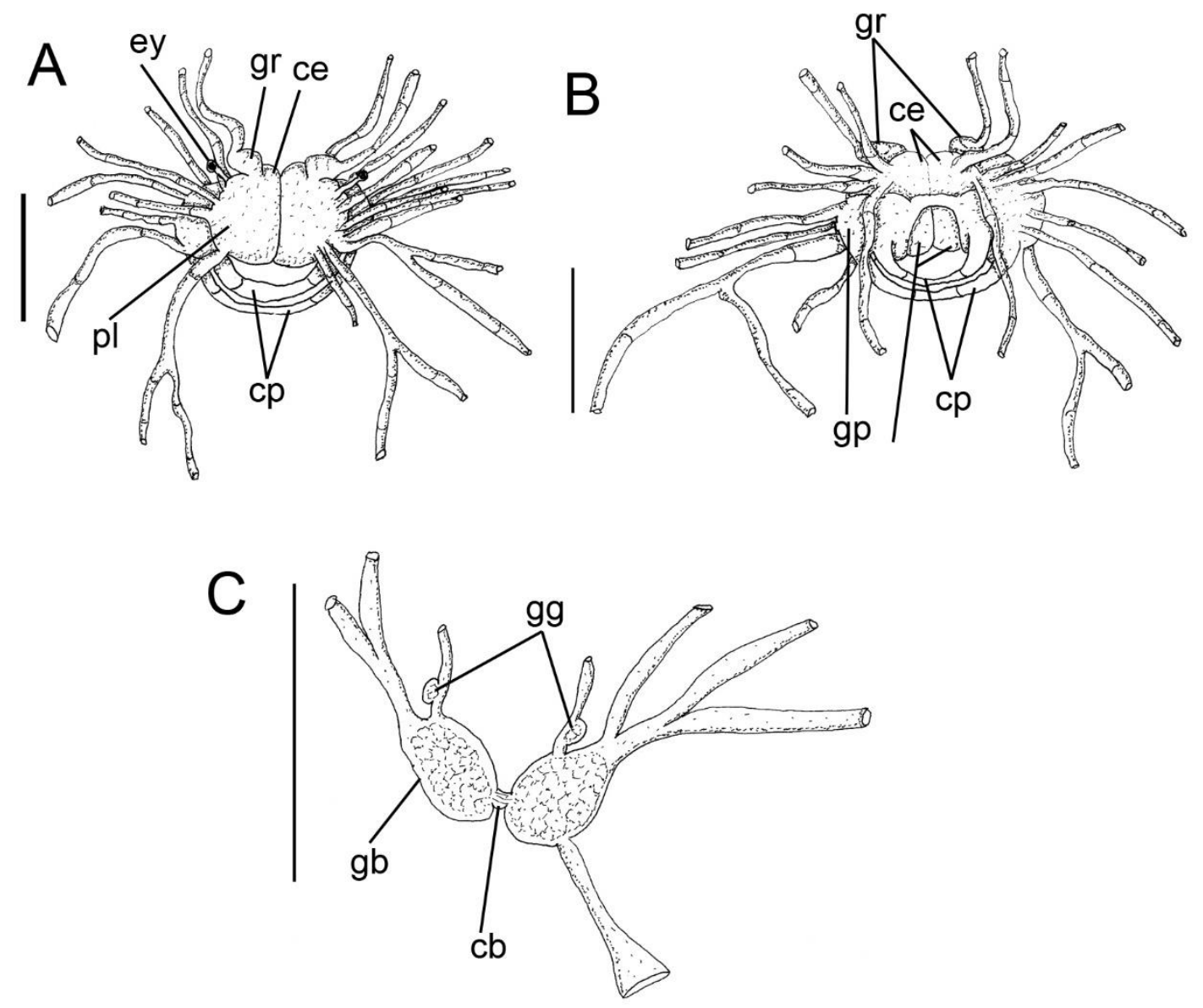

Figure 45: Chromodoris magnifica. Nervous system. A. Dorsal view. B. Same, ventral view. C. Detail of buccal and gastroesophageal ganglia. Scales: $1 \mathrm{~mm}$. 


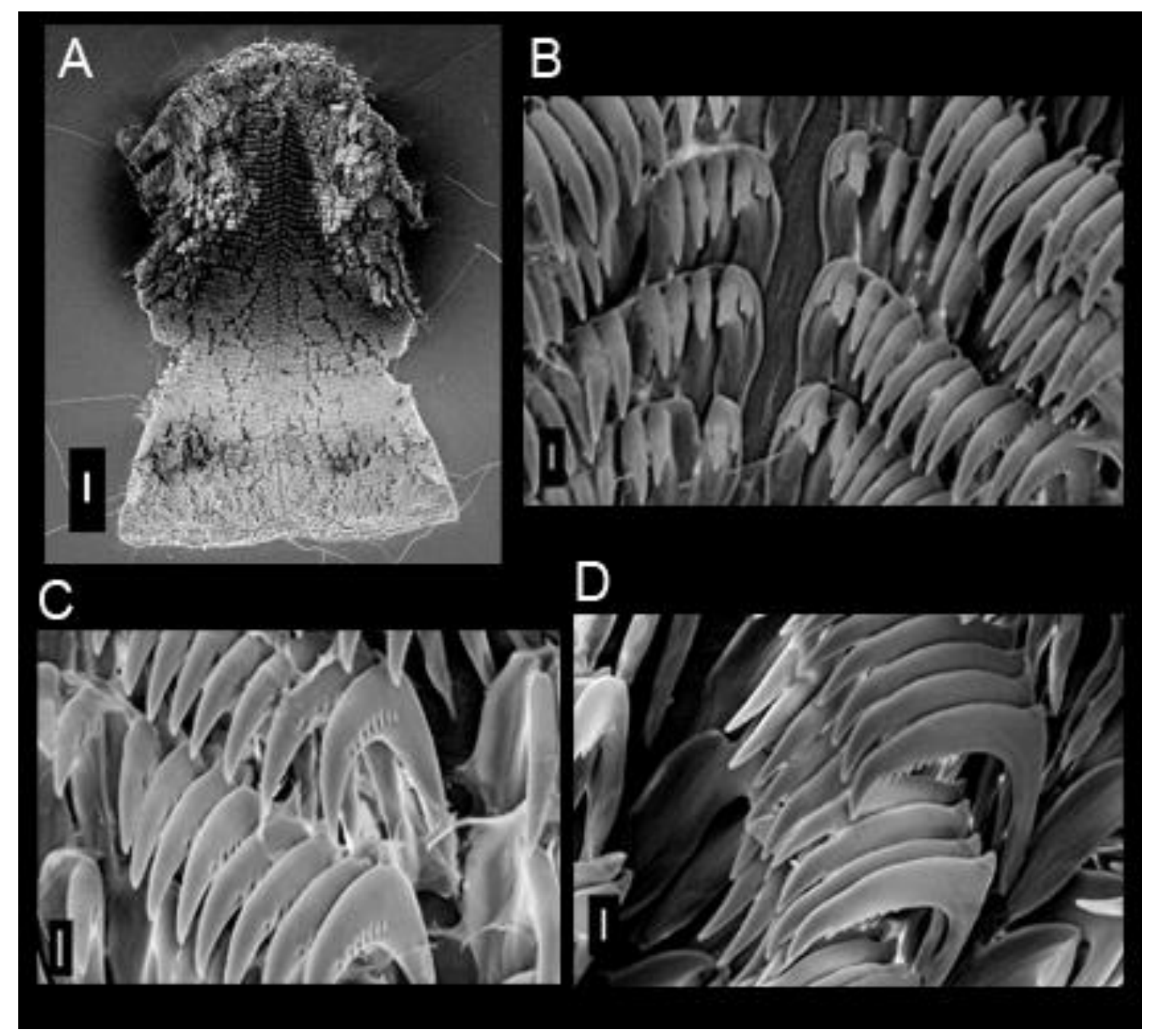

Figure 46: SEM of radula of Chromodoris magnifica. A. Panoramic view. Scale: $200 \mu \mathrm{m}$. B. Detail of middle, rachidian toot absent. Scale: $10 \mu \mathrm{m}$. C. Innermost lateral teeth. Scale: $10 \mu \mathrm{m}$. D. Outermost lateral teeth. Scale: $10 \mu \mathrm{m}$. 


\section{Genus Doriprismatica d'Orbigny, 1839}

Type species: Doris atromarginata Cuvier, 1804

\section{Doriprismatica atromarginata (Cuvier, 1804)}

(Figures 47-50)

Doris atromarginata Cuvier, 1804

Casella atromarginata see McDonald, 2006: 76.

Casella atromarginata var. pallida Bergh, 1905: 163, pl. 4; fig.12.

Glossodoris atromarginata Rudman, 1986: 103, figs. 1-3, 46, 47; Yonow, 1989: 298, pl. 14;

Yonow \& Hayward, 1991: 13, fig.3F; Yonow, 2001: 27, pl.3, fig. 8.

Doris maccarthyi Kelaart, 1859: 292; Kelaart, 1883: 85; Eliot, 1906: 1001.

Goniodoris atromarginata (Cuvier, 1804) Burn, 1965: 87

Type locality: Indo Pacific

\section{Redescription}

External morphology (Figures 47A-E; 48D): Size 17mm length, 6mm width. Color lemon yellow with black-edged. Body elongated with posterior end pointed (Fig. A). Rhinophores with about 20 transverse lamellae, black color; rhinophoral sheaths smooth (Fig. 47E). Gill composed of 15 unipinate branchial leaves, two of them more internal to gill circle; black color like rhinophores, arranged in circular fashion surrounding anus; branchial sheaths smooth, color similar to body (Fig. 48D). Mouth opening in anterior ventral region, between anterior region of notum and foot (Fig. 47D). Structures around mouth absents. Anterior border of foot bilabiate (Fig. 47D).

Haemocoel organs (Figure 48A, B): pericardium more anterior to visceral mass, occupying $15 \%$ of haemocoel volume. Buccal mass located anteriorly, occupying $20 \%$ of haemocoel volume. Nervous system dorsal to buccal mass, occupying $5 \%$ of haemocoel volume. Reproductive system on right side of animal, occupying $20 \%$ of haemocoel volume. Stomach, intestine and digestive gland occupying $40 \%$ of haemocoel volume.

Circulatory and excretory systems (Figure 48A-E): pericardial cavity dorsal 1/4 more anterior to digestive gland, anterior to gill circle (Fig. 48A). Afferent and efferent branches located inside each gill filament, flowing from and to afferent and efferent branchial veins (Fig. 48E). Gill retractor muscle divided originating from base of gill circle, running longitudinally up to half of foot level, inserting into dorsal surface of foot (Fig. 48B). Auricle funnel-like (wider anteriorly) with thin walls. Ventricle sligthly taller 
than wide, with thick muscular walls (Fig. 48C). There are three major vessels: 1) aortic trunk, located anteriorly to pericardium, connected to anterior ventricular region; 2) auricular vessels connecting lateral cavities of integument to auricle; 3) branchio-cardiac vessel located at posterior end of pericardium, connecting branchial efferent ring to auricle. Aortic trunk branched into posterior artery irrigating stomach, caecum and digestive gland; anterior artery irrigating reproductive system, buccal mass, odontophore and nervous system (Fig. 48C). Renal vesicle located on right dorsal side of pericardium, near base of auricle, connected to inner surface of pericardium, half size of ventricle (Fig. 48C). Renal chamber extending from dorsal to medial sinus, previously connected to renal vesicle, extending posteriorly to center of gill circle and opening in nephrostome, in a papilla, next to base of anal papilla (Fig. 48D). Blood gland undivided (Fig. 48A)

Digestive system (Figures 48H-J; 49A, B; 50): Oral tube composed of outer lip, with pleats lengthwise; inner lip with two transverse fold (Fig. 48H); mt, four pairs of retractor muscles of buccal mass, originating on oral tube, running dorsally and ventrally to oral tube, inserting on body side, about four times as wide and three time as long as m10 (Fig. 48H, F). Odontophore oval, connected to oral tube by pair of ventral protractor muscles (m10); thin longitudinal, ventrolateral protractors of oral sphincter, originating in anterior region of odontophore and inserted in posterior region of integument close to oral tube. Oral sphincter surrounding chitinous part of oral tube. Odontophore muscles: $\mathbf{m} 2$, pair of strong retractor muscles of buccal mass, as wide as long, origin on anterior dorsal odontophore, running laterally to $\mathrm{m} 4$, divided on posterior region, inserted ventrally on dorsal portion of foot (Fig. 48I); m4, pair of dorsal tensor muscles, strong and broad, as long as wide, covering $2 / 3$ of cartilage, inserted on ventral portion of subradular membrane (Fig. 49A); m5, pair of dorsal auxiliary tensor muscles, twice as long as wide, originating on most posterior region of odontophore cartilages, covering $\sim 1 / 3$ of posterior cavity of odontophore, as long as, but with $\sim 1 / 2$ of $\mathrm{m} 4$ width, inserting on ventral side of subradular membrane, around radular sac; m6, unpaired horizontal muscle, very narrow, with transverse fibers connecting to median surface of left and right odontophore cartilages, about same length and $1 / 4$ as wide as $m 4$, posterior portion same length in full extention (Fig. 49A); m7, pair of thin muscles, originating from center of odontophore cartilages, passing ventral to radular sac (Fig. 49A); m9, unpaired and horizontal muscle, originating on posterior portion of $\mathrm{m} 4$, connecting pair of $\mathrm{m} 4$. Pair of odontophore cartilages elliptical, occupying 2/4 of odontophore volume (Fig.49A, B). Subradular membrane thin, strong, translucent. Radular sac $\sim 1 / 7$ as large as odontophore 
(Fig. 48J). Radular teeth (Fig. 50): rachidian teeth absent. Each lateral tooth with hookshaped, with four lateral cusps. Pair of salivary glands long, tubular; duct inserting in anterior region of esophagus, extending posteriorly to anterior region of digestive gland (Fig. 48F, G). Esophagus simple, originating dorsally to odontophore, inserting directly in anterior region of stomach, internal longitudinal folds with same diameter along entire length (Fig. 48F). Stomach elliptical, with folds at the center of entire inner surface (Fig. 48G). Common opening for esophagus, stomach and caecum located on digestive gland. Intestine with longitudinal folds along its entire length, about same esophagus diameter. Caecum as rounded sac, located ventrally to stomach, opening on anterior portion of stomach, close to esophageal insertion, $\sim 1 / 3$ length and $\sim 1 / 2$ of width of stomach (Fig. $48 \mathrm{G})$. Digestive gland dark beige, being largest organ of visceral mass cone-shaped; anterior portion about twice as wide as posterior portion, inner face of gland sponge-like, bearing distinct main duct (Figs.48B; 48G). Anus opening into anal papilla at center of gill circle, $\sim 1 / 2$ of gill filament length (Fig. 48D).

Genital system (Figures 48B; 49C, D): located between buccal mass and digestive gland, mainly on right side and dorsally (Fig. 48B). Genital opening on right side, anterior third of length of animal from head, located between foot and notum. Gonad immersed in digestive gland, difficult to distinguish from it. Hermaphrodite duct thin, long. Ampulla located on female gland, elongated and tubular. Prostate tubular, glandular, length same as ampulla (Fig. 49C). Vas deferens about half penis's length. Penis' muscle absent. Penis muscular, cylindrical and elongated, about $1 / 2$ of length of vas deferens. Female gland not well-developed, rounded, occupying $\sim 10 \%$ of reproductive system volume, divided into mucus gland ( $2 / 3$ of female gland, color beige), and albumen gland ( $\sim 1 / 3$ of anteriormost region, dilated, irregularly shaped, color dark brown) (Fig. 49C). Oviduct occupying $\sim 1 / 3$ of female gland volume. Uterine duct thin, relatively short, length $\sim 1 / 3$ of vagina length, located at base of vagina, inserted in female gland near oviduct. Seminal receptacle pyriform, $1 / 2$ length of bursa copulatrix, connected to vagina near uterine duct through short stalk (Fig. 49D). Bursa copulatrix rounded, length $\sim 1 / 3$ of vagina length, connected to vagina after seminal receptacle, also through short stalk (Fig. 49D). Vagina cylindrical, elongated, approximately half length and half width of penis, with $1 / 2$ posterior portion more winder; followed ventrally by prostate and located parallel to penis in genital opening.

Nervous system (Figure 49E-G): mostly covered by blood gland. Pair of cerebral and pleural ganglia fused with each other dorsally and ventrally. Pedal ganglia fused with 
cerebral and pleural ventrally, but not fused among themselves. Pedal commissure short and simple, surrounding esophagus and salivary glands. Buccal ganglia short, located ventrally to odontophore, between radular sac and anterior portion of esophagus, connected to cerebral ganglia through long and slender connective tissue, united to gastroesophageal ganglia by short connective tissue. Buccal commissure short. Gastroesophageal ganglia length about $1 / 6$ of buccal ganglia length, circular. Rhinophoral (olfactory) ganglia bulb-shaped, connected to anterior portion of cerebral ganglia. Dorsal eyes located on cerebral ganglia.

Distribution: from the Red Sea and East African coast to eastern Australia and Japan (Yonow, 2001).

Material examined: THAILAND, Chantaburi, Kung Kraben Bay, MZSP 55336, 2 specimens (L.R.L. Simone, 27/vii/2005; 12³2,862`N - 101 ${ }^{\circ} 57,713^{`}$ E). 

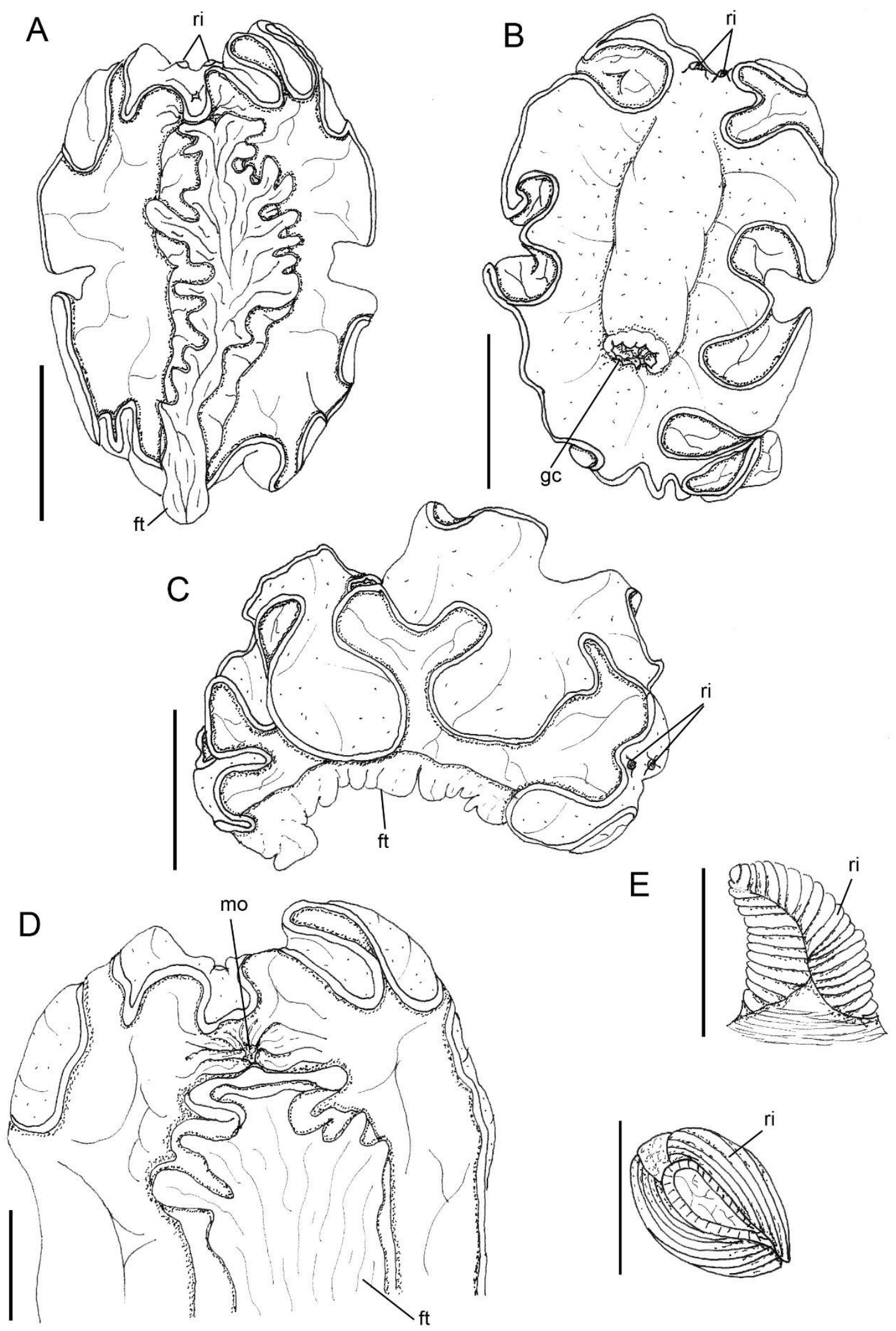

Figure 47: Doridigitata atromarginata, fixed animal. A. Dorsal view. B. Same, ventral view. C. Same, right lateral view. Scales: $5 \mathrm{~mm}$. D. Detail of anterior border of foot. Scale: $2 \mathrm{~mm}$. E. Detail of rhinophore, with transversal section. Scale: $1 \mathrm{~mm}$. 


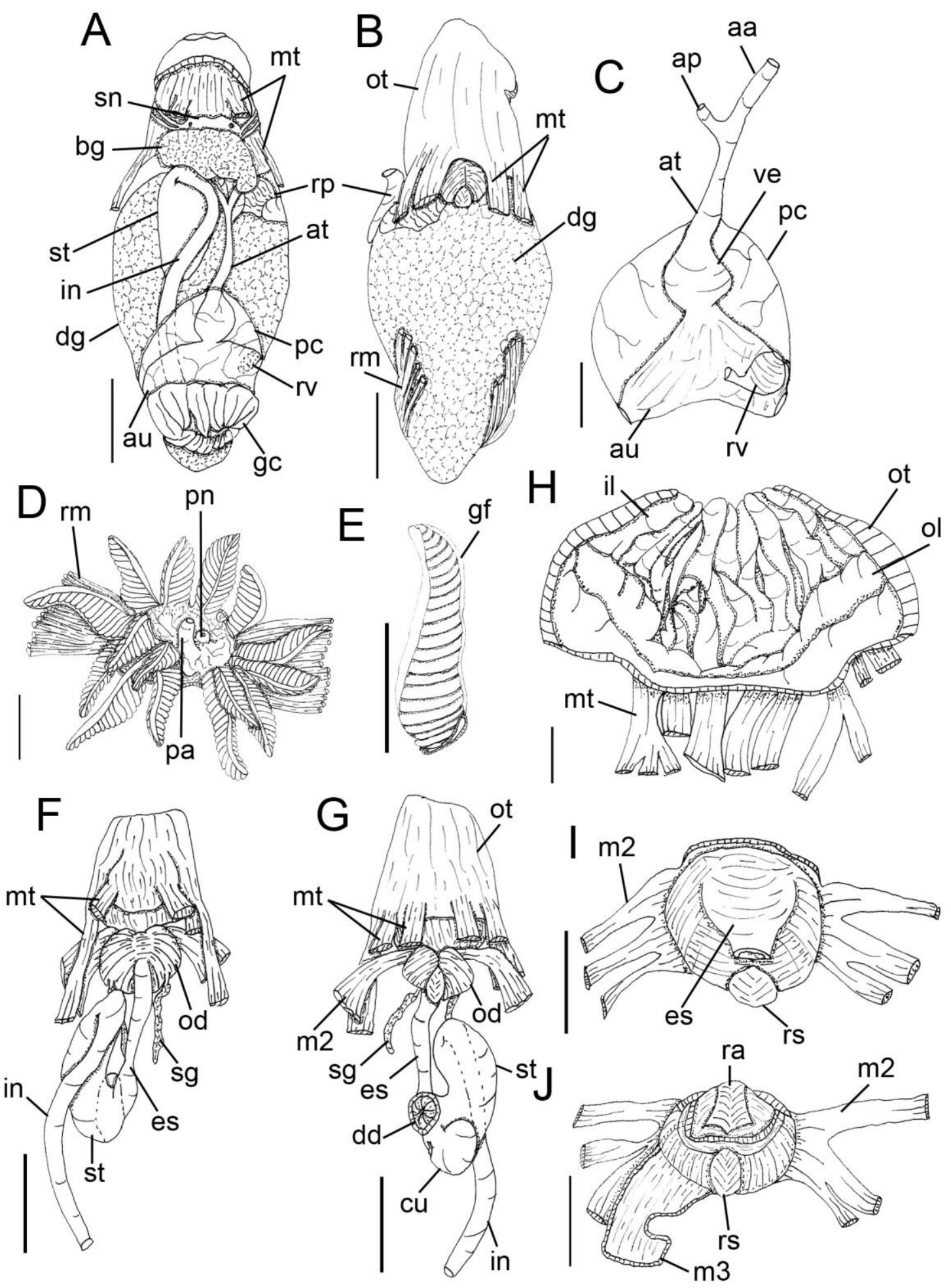

Figure 48: Chromodoris magnifica. Visceral mass. A. Dorsal view. B. Same, ventral view. Circulatory and excretory system. C. Pericardium, ventral view. Scales: $2 \mathrm{~mm}$. D. Gill circle, dorsal view. E. Gill filament. Scales: $1 \mathrm{~mm}$. Anterior digestive system. F. Dorsal view. G. Same, ventral view. Scales: $2 \mathrm{~mm}$. H. Oral tube, longitudinally sectioned. Odontophore. I. Dorsal view. J. Dorsal view with removed esophagus. Scales: $1 \mathrm{~mm}$. 

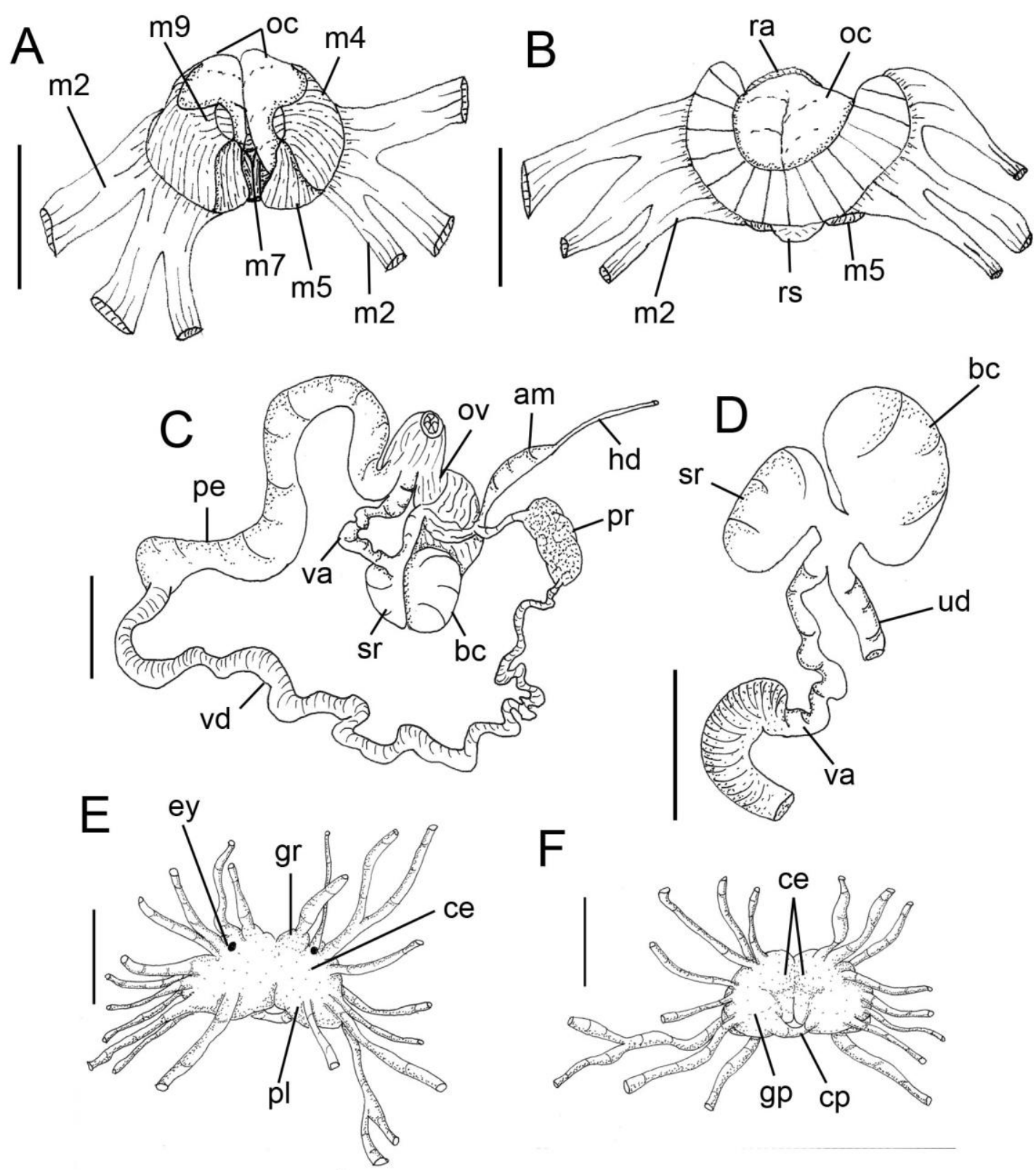

$\mathrm{F}$

G

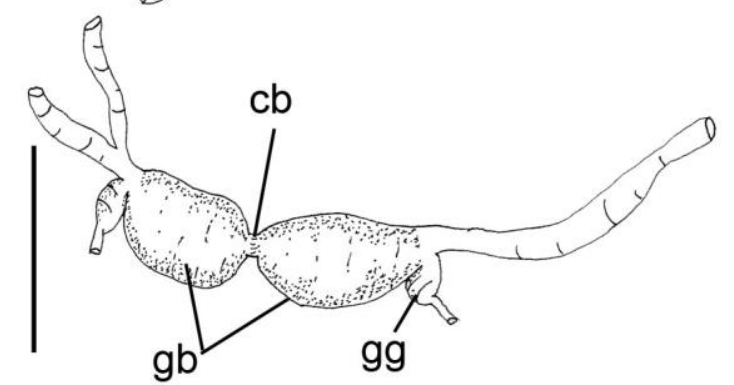

Figure 49: Chromodoris magnifica. Odontophore. A. Dorsal view, with removed radula. B. Same, ventral view. Reproductive system. C. General view. D. Detail of bursa copulatrix, seminal receptacle and vagina. Nervous system. E. Dorsal view. F. Same, ventral view. G. Buccal and gastroesophageal ganglia. Scales: $1 \mathrm{~mm}$ 


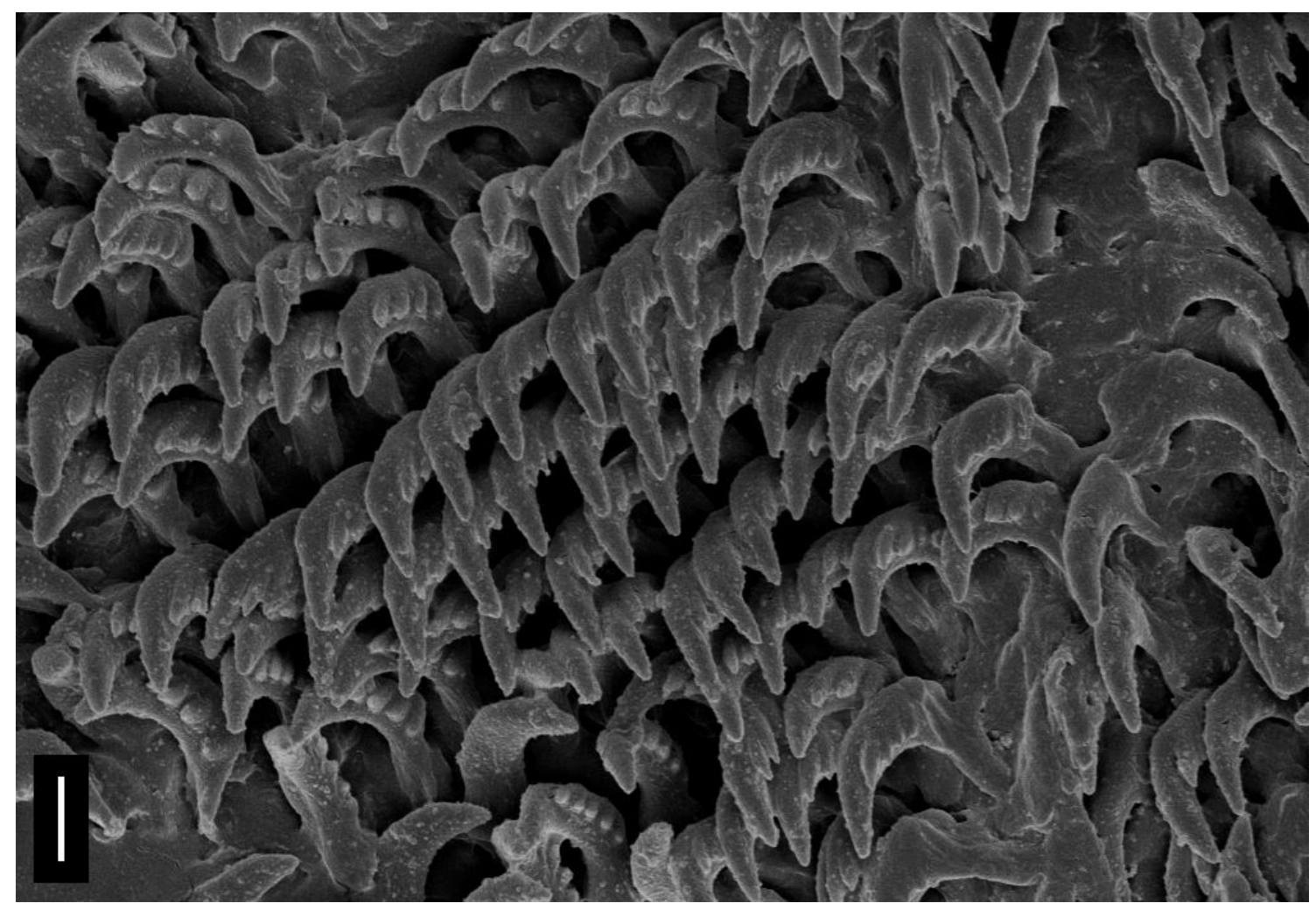

Figure 50: SEM of radula of Doriprismatica atromarginata, innermost lateral teeth. Scale: $10 \mu \mathrm{m}$.

\section{Genus Mexichromis Bertsch, 1977}

Type species: Chromodoris antonii Bertsch, 1976, type by original designation

Mexichromis kempfi (Ev. Marcus, 1970)

(Figures 51-53)

Chromodoris kempfi Ev. Marcus, 1970: 940; figs. 34-38; Ev. Marcus, 1972: 78; Rios, 2009: 424. Mexichromis kempfi (Ev. Marcus, 1971): 940, figs. 24-38; Valdés et al., 2006: 167.

Felimare kempfi (Ev. Marcus, 1971): Jonhson \& Gosliner, 2012: 10; Camacho-García et al., 2014: 120.

Type locality: off Maranhão, Brazil

\section{Redescription}

External morphology (Figures 52A-E): Size 2-4mm. Color blue with orange/yellow mantle border, white mantle midline, between orange and blue a band of seven/nine blue intercalated with white spots on both sides. Body elongated, dorsum smooth (Fig. 52A, C); Rhinophores with about 10 transverse/diagonal lamellae, color 
blue; rhinophoral sheaths smooth (Fig. 52D). Gill composed of 9 unipinnate branchial leaves, color blue, gill circle not entirely closed, but surrounding anal and nephortome papila; branchial sheaths smooth (Fig. 52A). Mouth opening in anterior ventral region, between anterior region of notum and foot. Digitiform tentacles present. Anterior border of foot bilabiated (Fig. 53E).

Haemocoel organs (Figure 52A): pericardium and posterior half of visceral mass volume occupying $15 \%$ of haemocoel volume. Buccal mass located anteriorly, occupying $10 \%$ of haemocoel volume. Nervous system dorsal to buccal mass, anterior covered by blood gland, occupying 5\% of haemocoel volume. Reproductive system on right side of animal; occupying $30 \%$ of haemocoel volume. Stomach, intestine and digestive gland, occupying $40 \%$ of haemocoel volume.

Circulatory and excretory systems (Figure 52A, B): pericardial cavity dorsal and posterior to digestive gland, anterior to gill circle. Afferent and efferent branches located inside each gill filament, flowing from and to afferent and efferent branchial veins. Gill retractor muscle originating from base of gill circle, running longitudinally up to half of foot level, inserting into dorsal surface of foot. Auricle funnel-like (wider anteriorly) with thin walls. Ventricle sligthly taller than wide, with thick muscular walls; auricle-ventricular valve clear, with two protruding tabs projected from auricle towards ventricle. There are three major vessels: 1) aortic trunk, located anteriorly to pericardium, connected to anterior ventricular region; 2) auricular vessels connecting lateral cavities of integument to auricle; 3) branchio-cardiac vessel located at posterior end of pericardium, connecting branchial efferent ring to auricle. Aortic trunk branched into posterior artery irrigating stomach and digestive gland; anterior artery irrigating reproductive system, buccal mass, odontophore and nervous system. Renal vesicle not visualized. Blood gland undivided (Fig. 52A)

Digestive system (Figures 52C-F; 53A): Oral tube composed of outer lip, with pleats lengthwise; inner lip with transverse fold; mt, two pairs of retractor muscles of buccal mass, originating on oral tube, running dorsally and ventrally to oral tube, inserting on body side, about six times as wide and three times as long as m10 (Fig. 52E). Odontophore oval, connected to oral tube by pair of ventral protractor muscles (m10); thin longitudinal, dorsal and ventrolateral protractors of oral sphincter, originating in anterior region of odontophore and inserted in posterior region of integument close to oral tube. Oral sphincter surrounding chitinous part of oral tube (Fig. 52E). Odontophore muscles: m2, pair of strong retractor muscles of buccal mass, three times longer than 
wide, origin on anterior dorsal odontophore, running laterally to $\mathrm{m} 4$ and inserted ventrally on dorsal portion of foot (Fig. 52D, F); m4, pair of dorsal tensor muscles, strong and broad, twice as long as wide, covering $2 / 3$ of cartilage, inserted on ventral portion of subradular membrane (Fig. 53A); m5, pair of dorsal auxiliary tensor muscles, twice as long as wide, originating on most posterior region of odontophore cartilages, covering $\sim 1 / 3$ of posterior cavity of odontophore, as long as, but with $\sim 1 / 2$ of $\mathrm{m} 4$ width, inserting on ventral side of subradular membrane, around radular sac (Fig. 53A); m6, unpaired horizontal muscle, with transverse fibers connecting anterior surface of left and right odontophore cartilages, about $1 / 3$ length and half as wide as $\mathrm{m} 4$, anterior and posterior portion with same length (Fig. 53A); m7, pair of thin muscles, originating from center of odontophore cartilages, passing ventral to radular sac (Fig. 53A). Pair of odontophore cartilages elliptical, occupying $\sim 1 / 3$ of odontophore volume. Subradular membrane thin, strong, translucent. Radular sac $\sim 1 / 4$ as large as odontophore (Fig. 52D). Radular teeth not analized. Pair of salivary glands long, tubular; duct inserting in anterior region of esophagus, extending posteriorly to anterior region of digestive gland (Fig. 52C). Esophagus simple, originating dorsally to odontophore, inserting directly in anterior region of stomach, internal longitudinal folds with same diameter along entire length. Stomach internal to digestive gland. Intestine with small curve in anterior region, longitudinal folds along its entire length, diameter about half esophagus diameter, but more uniform. Caecum absent. Digestive gland dark beige, being largest organ of visceral mass, cone-shaped; anterior portion about twice as wide as posterior portion, inner face of gland sponge-like (Fig. 52A). Anus opening into anal papilla at center of gill circle.

Genital system (Figure 52A; 53B, C): located between buccal mass and digestive gland, mainly on right side and dorsally (Fig. 52A). Genital opening on right side, anterior fourth of length of animal from head, located between foot and notum. Hermaphrodite duct thin, long. Ampulla located on female gland, elongated and tubular. Prostate tubular, about twice length as ampulla (Fig. 53B). Vas deferens about half length of penis. Penis' muscle absent. Penis muscular, cylindrical and elongated, about same length of prostate (Fig. 53B). Gonad immersed in digestive gland, easy to distinguish it (Fig. 52A). Female gland well-developed, rounded, occupying $\sim 15 \%$ of reproductive system volume, divided into mucus gland ( $\sim 2 / 3$ of female gland, color beige), and albumen gland ( 1/3 of anteriormost region, dilated, irregularly shaped, color dark brown). Oviduct occupying $\sim 1 / 6$ of female gland volume (Fig. 53B). Uterine duct thin, length $1 / 2$ of vagina length, located at base of vagina, inserted in female gland near oviduct (Fig. 53C). Seminal 
receptacle pyriform, half length of bursa copulatrix, connected to vagina near uterine duct through short stalk. Bursa copulatrix rounded, length $\sim 1 / 2$ of vagina length, connected to vagina after seminal receptacle, also through short stalk (Fig. 3C). Vagina cylindrical, elongated, approximately as long as and half as wide as penis, followed ventrally by prostate and located parallel to penis in genital opening.

Nervous system (Figure 52A; 53D-F): wolly covered by blood gland (Fig. 52A). Pair of cerebral and pleural ganglia fused with each other dorsally and ventrally (Fig. 53D). Pedal ganglia fused with cerebral and pleural ventrally, but not fused among themselves. Pedal commissure short and simple, surrounding esophagus and salivary glands (Fig. 53E). Buccal ganglia short, located ventrally to odontophore, between radular sac and anterior portion of esophagus, connected to cerebral ganglia through long and slender connective tissue (Fig. 53F). Gastro-esophageal ganglia not visualized. Rhinophoral (olfactory) ganglia bulb-shaped, connected to anterior portion of cerebral ganglia. Dorsal eyes located on cerebral ganglia (Fig. 53D).

Distribution: off Maranhão, Rio de Janeiro and São Paulo.

Habitat: rocky subtidal region, found from 5-37m depth.

Material examined: BRAZIL, Ilha do Papagaio, Enseada 3, Cabo Frio, Rio de Janeiro, MZSP 92264, 2 specimens (A.P. Dornellas coll., 14/ix/2009); Enseada 2, MZSP 97347, 2 specimens (P. Oristanio, coll. 24/x/2010); Arquipélago de Alcatrazes, São Sebastião, São Paulo, MZSP 109379, 1 specimen (P. Oristanio coll., 04/xii/2012, ponto 2). 

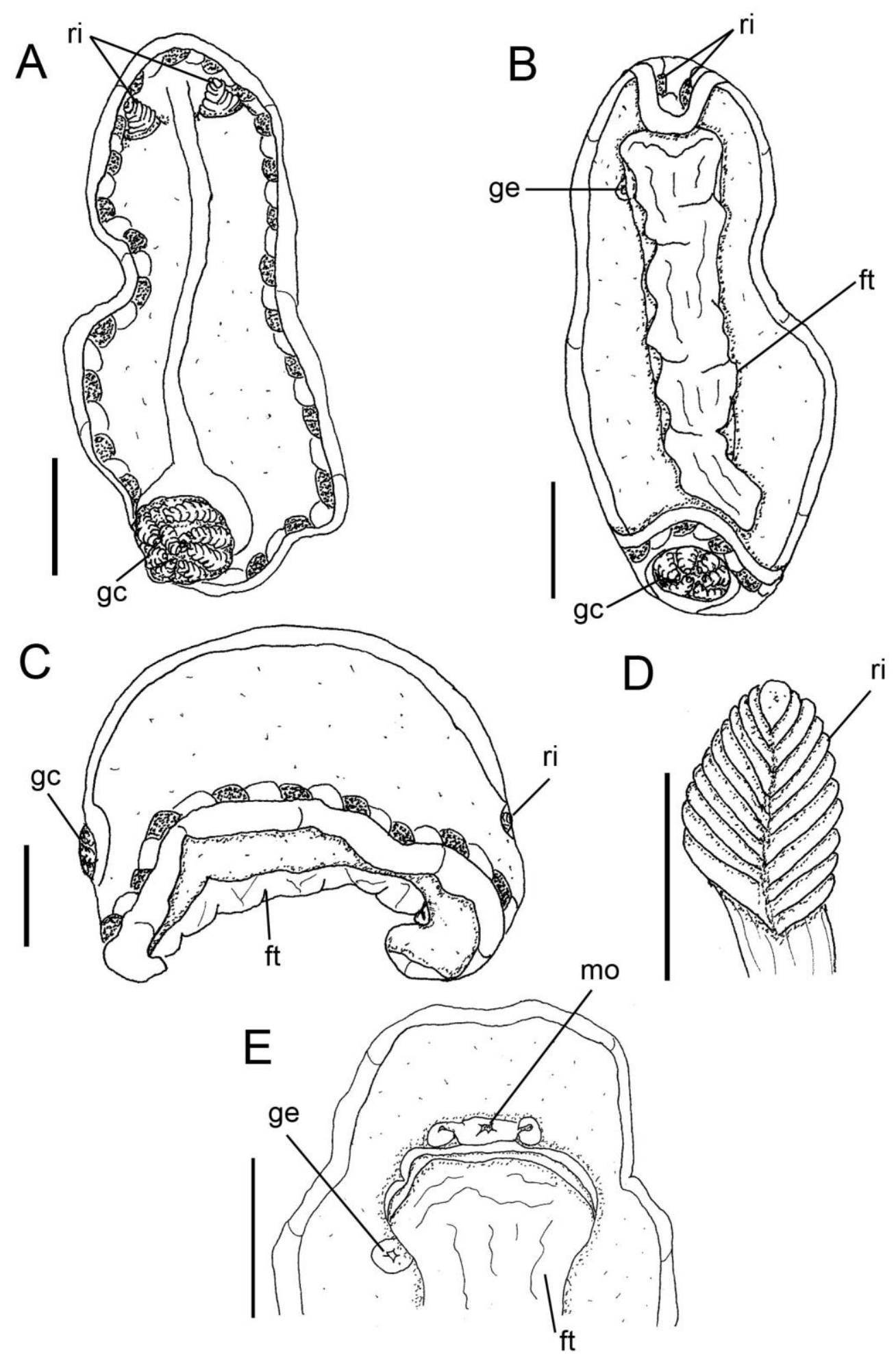

Figure 51: Mexichromis kempfi, fixed animal. A. Dorsal view. B. Same, ventral view. C. Same, right lateral view. Scales: $1 \mathrm{~mm}$. D. Rhinophore. Scale: $0,5 \mathrm{~mm}$ E. Anterior region border of toot. Scale: $1 \mathrm{~mm}$. 


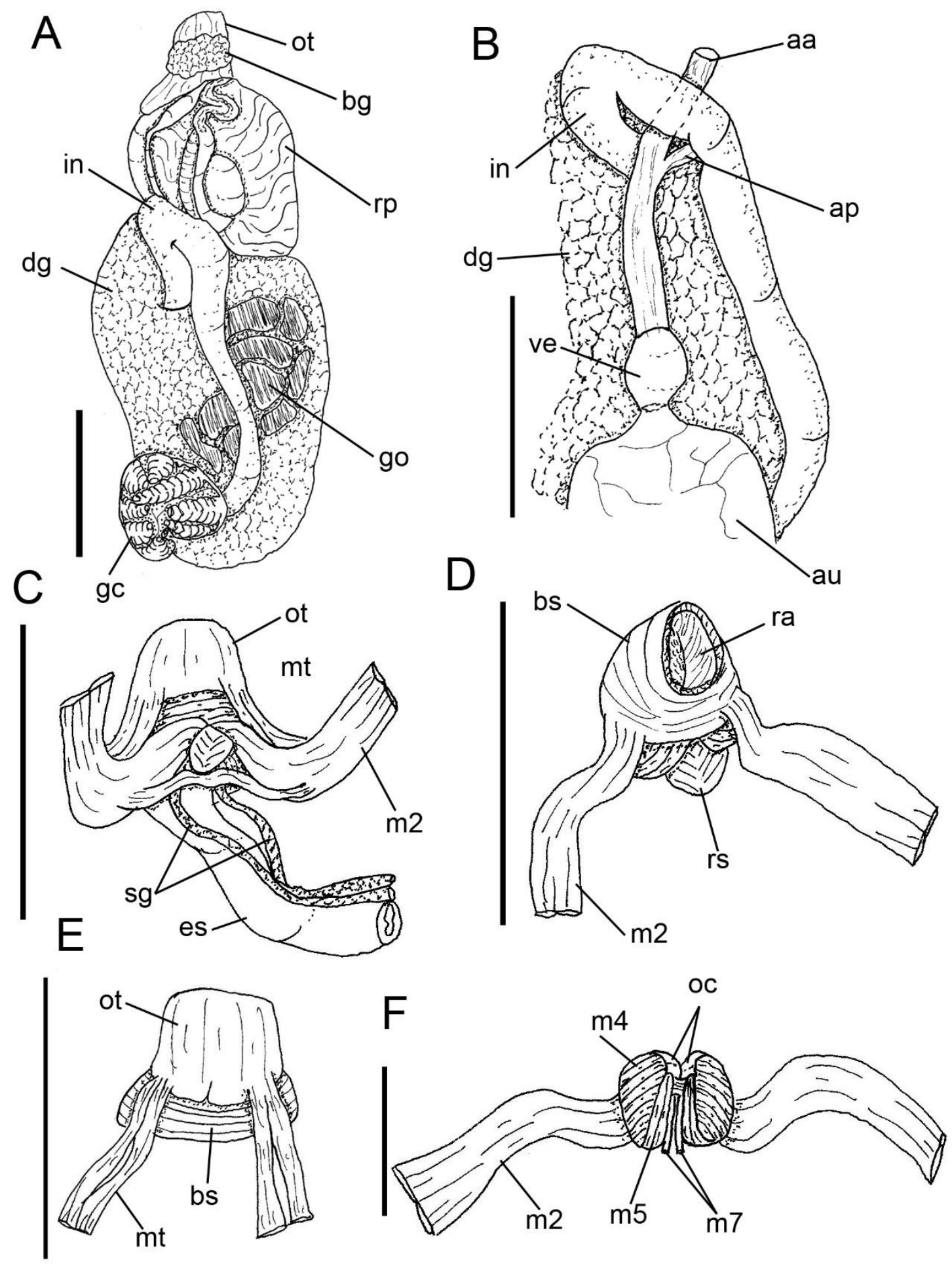

Figure 52: Mexichromis kempfi. Visceral mass. A. Dorsal view. Circulatory system. B. Dorsal view. Anterior digestive system. C. Ventral view. D. Oral tube removed. E. Dorsal view of oral tube and buccal sphincter, detail of mt. Odontophore. Scales: $1 \mathrm{~mm}$. F. Dorsal view with removed radula. Scale: $0,5 \mathrm{~mm}$. 

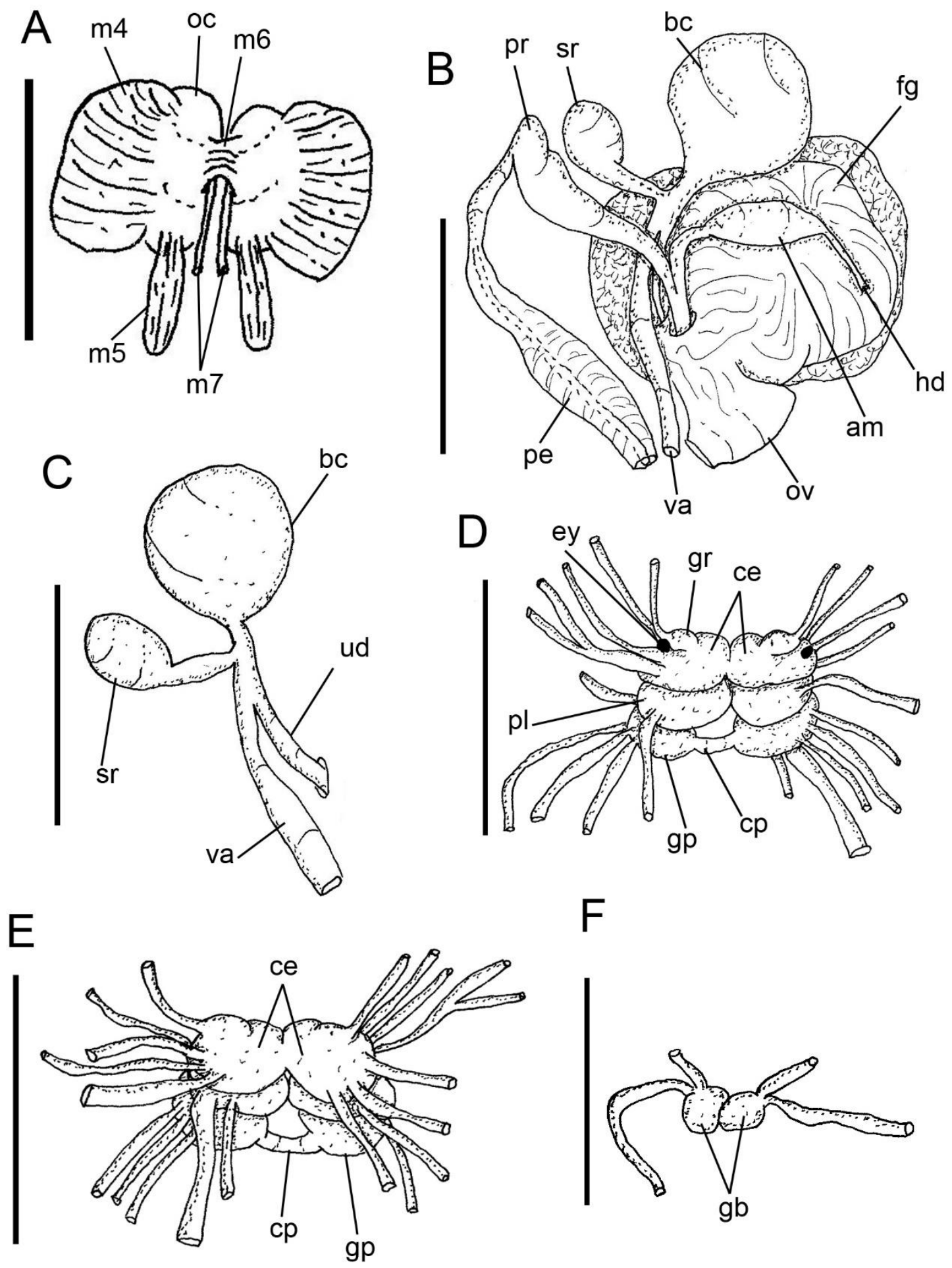

F

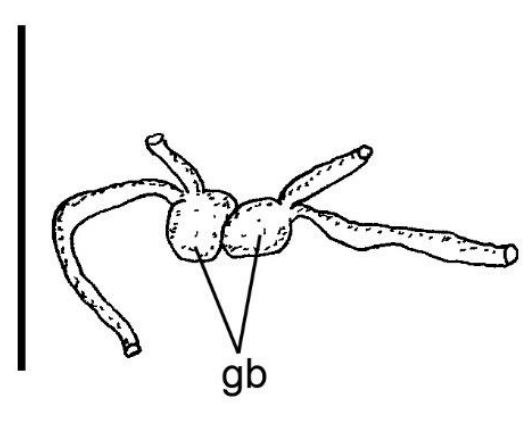

Figure 53: Mexichromis kempfi. Odontophore A. Dorsal view with folded down muscles. Scale: 0,5mm. Reproductive system. B. Ventral view. C. Detail of bursa copulatrix, seminal receptacle, uterine duct and vagina. Scales: $1 \mathrm{~mm}$. Nervous system. D. Dorsal view. E. Same, ventral view. Scales: $1 \mathrm{~mm}$. F. Buccal ganglia. Scale: $0,5 \mathrm{~mm}$. 


\section{Genus Felimare Ev. Marcus \& Er. Marcus, 1967}

Type species: Felimare bayeri Ev. Marcus \& Er. Marcus, 1967 (type by original designation)

\section{Felimare lajensis (Troncoso, García \& Urgorri, 1998)}

(Figures 54-58)

Hypselodoris picta lajensis Troncoso, García \& Urgorri, 1998: 133, fig. 1-5; Domínguez, García \& Troncoso, 2006: 633, fig. 1K; Debelius \& Kuiter, 2007: 111; García et al., 2008: 126; Rios, 2009: 425; DaCosta et al., 2010: 19, figs. 5-7.

Type locality: Laje de Santos, off shore from Santos Bay, Sao Paulo, Brazil

\section{Redescription}

External morphology (Figure 54A-F): Size 19mm length, 5mm width. Color blue with longitudinal yellow lines and white-edged. Body elongate with poited end (Fig. 54A-C). Rhinophores with about 20 transverse lamellae, blue color similar to body; rhinophoral sheaths smooth (Fig. 54D). Gill composed of 12 unipinate branchial leaves, blue color similar to body, arranged in circular fashion surrounding anus; branchial sheaths smooth, color similar to body (Fig. 54E, F). Mouth opening in anterior ventral region, between anterior region of notum and foot (Fig. 54B). Digitiform tentacles present. Anterior border of foot bilabiate.

Haemocoel organs (Figure 55A-B): pericardium more anterior of visceral mass volume occupying $15 \%$ of haemocoel volume. Buccal mass located anteriorly, occupying $10 \%$ of haemocoel volume. Nervous system dorsal to buccal mass, covered by blood gland, occupying $5 \%$ of haemocoel volume. Reproductive system on right side of animal; occupying $30 \%$ of haemocoel volume. Stomach, ceacum, intestineand digestive gland occupying $40 \%$ of haemocoel volume.

Circulatory and excretory systems (Figure 54E; 55A, C): pericardial cavity dorsal and $1 / 4$ more anterior to digestive gland, anterior to gill circle (Fig. 55A). Afferent and efferent branches located inside each gill filament, flowing from and to afferent and efferent branchial veins. Gill retractor muscle divided, originating from base of gill circle, running longitudinally up to half of foot level, inserting into dorsal surface of foot (Fig. 55A, C). Auricle funnel-like (wider anteriorly) with thin walls. Ventricle as taller as wide, with thick muscular walls (Fig. 55C). Same patter of anterior species described vessels. 
Aortic trunk branched into posterior artery irrigating stomach, caecum and digestive gland; anterior artery irrigating reproductive system, buccal mass, odontophore and nervous system (Fig. 55C). Medial sinus connected to afferent branchial ring, irrigating entire digestive gland. Renal vesicle located on right dorsal side of pericardium, near base of auricle, connected to inner surface of pericardium; renal chamber elliptical, 1/3 the size of ventricle (Fig. 55C). Renal chamber extending from dorsal to medial sinus, previously connected to renal vesicle, extending posteriorly to center of gill circle and opening in nephrostome, in a pore, next to base of anal papilla (Fig. 54E). Blood gland undivided, very broad, covering all nervous system (Fig. 55A).

Digestive system (Figures 54E; 55A-B, D-F; 56A-E; 58A-D): Oral tube composed of outer lip, with pleats transverse; inner lip with transverse fold (Fig. 56A); mt, three pairs of retractor muscles of buccal mass, originating on oral tube, running dorsally and ventrally to oral tube, inserting on body side, about three times as wide and twice as long as m10 (Fig. 55D, E; 56A). Odontophore oval, connected to oral tube by pair of ventral protractor muscles (m10); thin longitudinal, dorsal and ventrolateral protractors of oral sphincter, originating in anterior region of odontophore and inserted in posterior region of integument close to oral tube (Fig. 56B). Oral sphincter surrounding chitinous part of oral tube. Odontophore muscles: $\mathbf{m} \mathbf{2}$, three pairs of strong retractor muscles of buccal mass, three times longer than wide, origin on anterior dorsal odontophore, running laterally to $\mathrm{m} 4$ and inserted ventrally on dorsal portion of foot (Fig. 56B); m2a, pair of retractor muscles, same length of $\mathrm{m} 2$, originating on anterior dorsal odontophore, but running anteriorly to oral tube (Fig. 56B); m3, transversely thin muscle, covering dorsally $\mathrm{m} 9$ (connected with $\mathrm{m} 4$ ), ventral to esophagus (Fig. 56D); m4, pair of dorsal tensor muscles, very strong and broad, divided in three portions, covering 2/4 of cartilage, inserted on ventral portion of subradular membrane (Fig. 56E); m5, pair of dorsal auxiliary tensor muscles, twice as long as wide, originating on most posterior region of odontophore cartilages, covering $\sim 1 / 4$ of posterior cavity of odontophore, as long as, but with $\sim 1 / 4$ of $\mathrm{m} 4$ width, inserting on ventral side of subradular membrane, around radular sac (Fig.56C, E); m5a, originating on posterior region of $\mathrm{m} 4$ and inserting on posterior region of m5 (Fig. 56E); m6, unpaired horizontal muscle, with transverse fibers connecting to median surface of left and right odontophore cartilages, about same length and half as wide as $\mathrm{m} 4$, same length in all posterior and anterior portion (Fig. 56E); $\mathbf{m 7}$, pair of thin and narrow muscle, originating in middle of $\mathrm{m} 6$ running posterior to inserting on radular sac (Fig. 56E); m9, unpaired and horizontal muscle, originating on 
posterior portion of $\mathrm{m} 4$, connecting pair of $\mathrm{m} 4$. Pair of odontophore cartilages elliptical, occupying $\sim 1 / 3$ of odontophore volume (Fig. 56E). Subradular membrane thin, strong, translucent. Radular sac $\sim 1 / 4$ as large as odontophore (Fig. 56C, D). Radular teeth (Fig. 58A-D): rachidian teeth absent; formula 56 x 65.0 .65 (in $15 \mathrm{~mm}$ long specimen). Same as in original description (DaCosta et al., 2010). Pair of salivary glands very long, tubular; duct inserting in anterior region of esophagus, extending posteriorly to anterior region of digestive gland (Fig. 55D, E). Esophagus simple, originating dorsally to odontophore, inserting directly in anterior region of stomach, internal longitudinal folds with same diameter along entire length (Fig. 55F). Stomach oval, internal to digestive gland, with folds at the center of entire inner surface (Fig. 55F). Common opening for esophagus, stomach and digestive gland. Intestine with longitudinal folds along its entire length, diameter about half esophagus diameter, but more uniform (Fig. 55F). Caecum as a bulging between posterior portion of stomach and anterior region of intestine (Fig. 55F). Digestive gland dark beige, being largest organ of visceral mass, cone-shaped; anterior portion about twice as wide as posterior portion, inner face of gland sponge-like, bearing distinct main duct (Fig. 55A, B, F). Anus opening into anal pore at center of gill circle (Fig. 54E).

Genital system (Figure 54C; 55B; 57A-C): located between buccal mass and digestive gland, mainly on right side and dorsally (Fig. 55B). Genital opening on right side, anterior fouth of length of animal from head, located between foot and notum (Fig. 54C). Gonad immersed in digestive gland, easy to distinguish it (Fig. 55B). Hermaphrodite duct thin, long. Ampulla located on female gland, elongated and tubular. Prostate tubular, glandular, very long, six times longer than ampulla. Vas deferens about twice length as penis (Fig. 57B). Penis' muscle absent. Penis muscular, cylindrical and elongated, about 1/5 of length of prostate. Female gland well-developed, rounded, occupying $\sim 30 \%$ of reproductive system volume, divided into mucus gland ( $2 / 3$ of female gland, color beige), and albumen gland ( $\sim 1 / 3$ of anteriormost region, dilated, irregularly shaped, color dark brown) (Fig. 57A). Oviduct occupying 1/6 of female gland volume. Uterine duct thin, length $\sim 1 / 4$ of vagina length and 1/3 of width, located at base of vagina, inserted in female gland near oviduct. Seminal receptacle pyriform, 1/2 of bursa copulatrix length and width, connected to vagina near uterine duct through short stalk. Bursa copulatrix rounded, same of vagina length, connected to base of vagina after seminal receptacle (Fig. 57C). Vagina cylindrical, elongated, approximately half length 
and same width as penis, followed ventrally by prostate and located parallel to penis in genital opening (Fig. 57C).

Nervous system (Figure 57D-F): located dorsally to odontophore, mostly covered by blood gland. Pair of cerebral and pleural ganglia fused with each other dorsally and ventrally. Pedal ganglia fused with cerebral and pleural ventrally, but not fused among themselves. Pedal commissure simple and long, surrounding esophagus and salivary glands (Fig. 57E). Buccal ganglia short, located ventrally to odontophore, between radular sac and anterior portion of esophagus, connected to cerebral ganglia through long and slender connective tissue, united to gastro-esophageal ganglia by short connective tissue. Buccal commissure short. Gastro-esophageal ganglia length about 1/4 of buccal ganglia length, circular (Fig. 57F). Rhinophoral (olfactory) ganglia bulb-shaped, connected to anterior portion of cerebral ganglia. Dorsal eyes located on cerebral ganglia (Fig. 57D).

Distribution: Brazil: Rio de Janeiro, São Paulo.

Material examined: BRAZIL, Laje de Santos, Santos, São Paulo, MZSP 32417, 1 specimen (C.L. Francini coll., 16/iv/2000, 18m deep, under rocks); Ilha do Papagaio, Cabo Frio, Rio de Janeiro, MZSP 92317, 3 specimens (A.P. Dornellas coll., 14/ix/2009; 8m deep); Enseada 3, MZSP97467, 3 specimens (V. Padula coll., 13/xii/2008). 


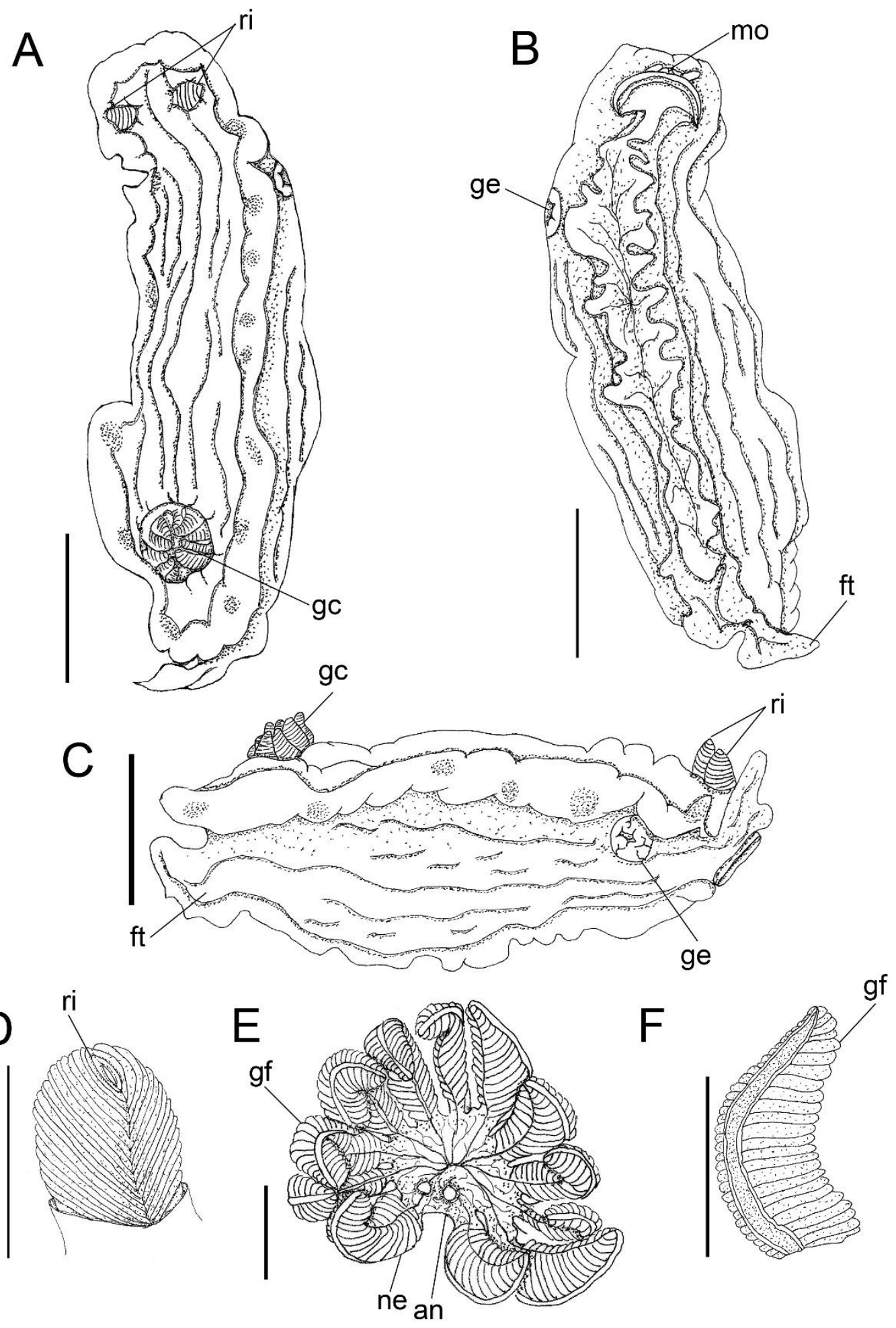

Figure 54: Felimare lajensis, fixed animal. A. Dorsal view. B. Same, ventral view. C. Same, right lateral view. Scales: 5mm. D. Rhinophore. E. Gill circle, dorsal view. F. Gill filament. Scales: $1 \mathrm{~mm}$. 

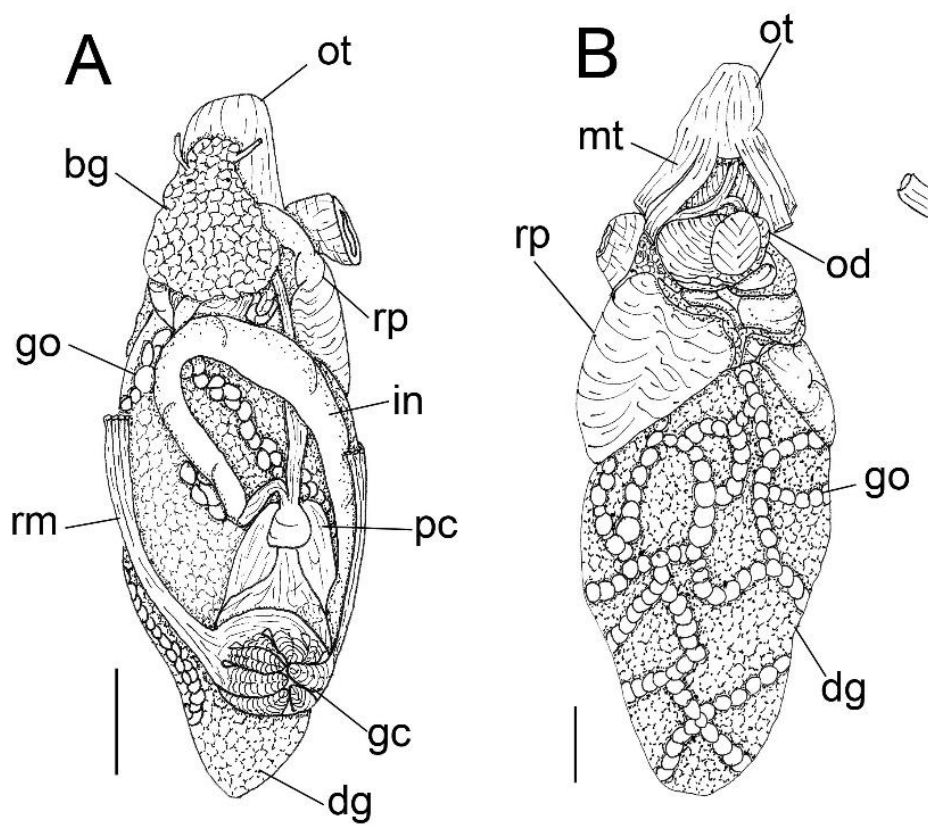

C
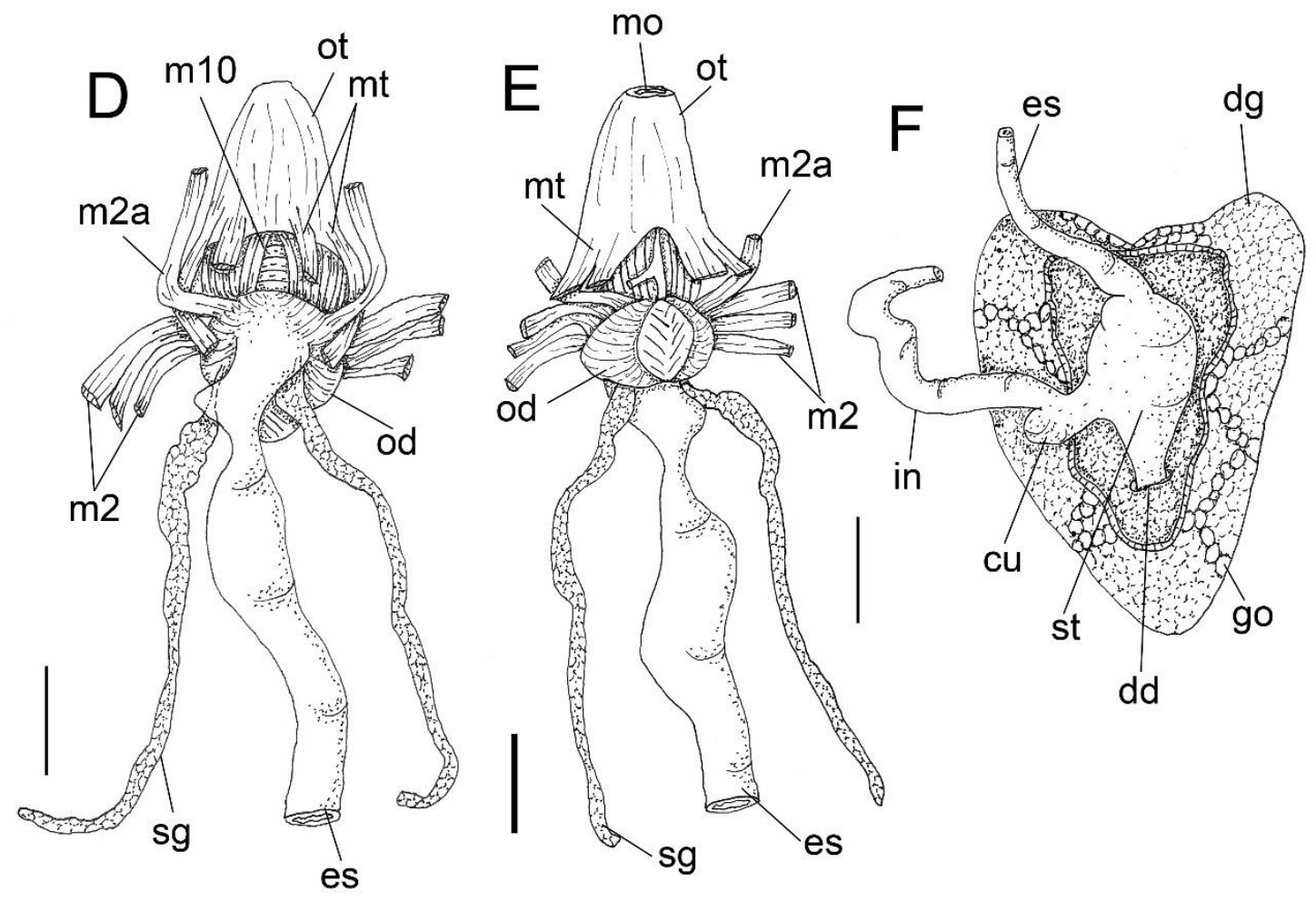

Figure 55: Felimare lajensis. Visceral mass. A. Dorsal view. B. Same, ventral view. C. Circulatory and excretory system, lateral view. Anterior digestive system. D. Dorsal view. E. Same, ventral view. F. Median digestive system. Scales: $2 \mathrm{~mm}$. 

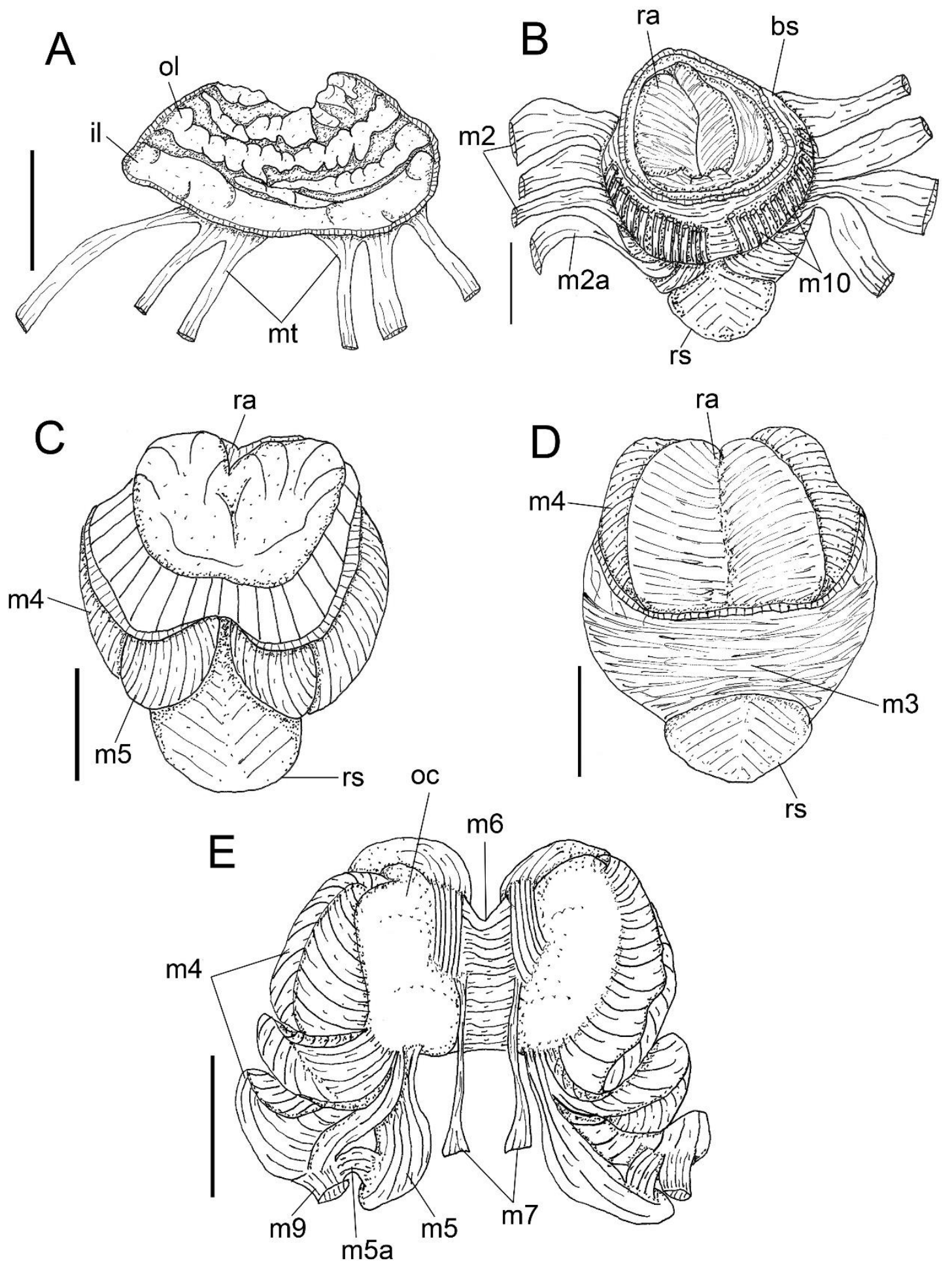

Figure 56: Felimare lajensis. A. Oral tube, longitudinally sectioned. Scale: $2 \mathrm{~mm}$. B. Anterior view of buccal sphincter and odontophore. Odontophore. C. Ventral view. D. Dorsal view with radula. E. Same, dorsal view with folded down muscles. Scales: $1 \mathrm{~mm}$. 

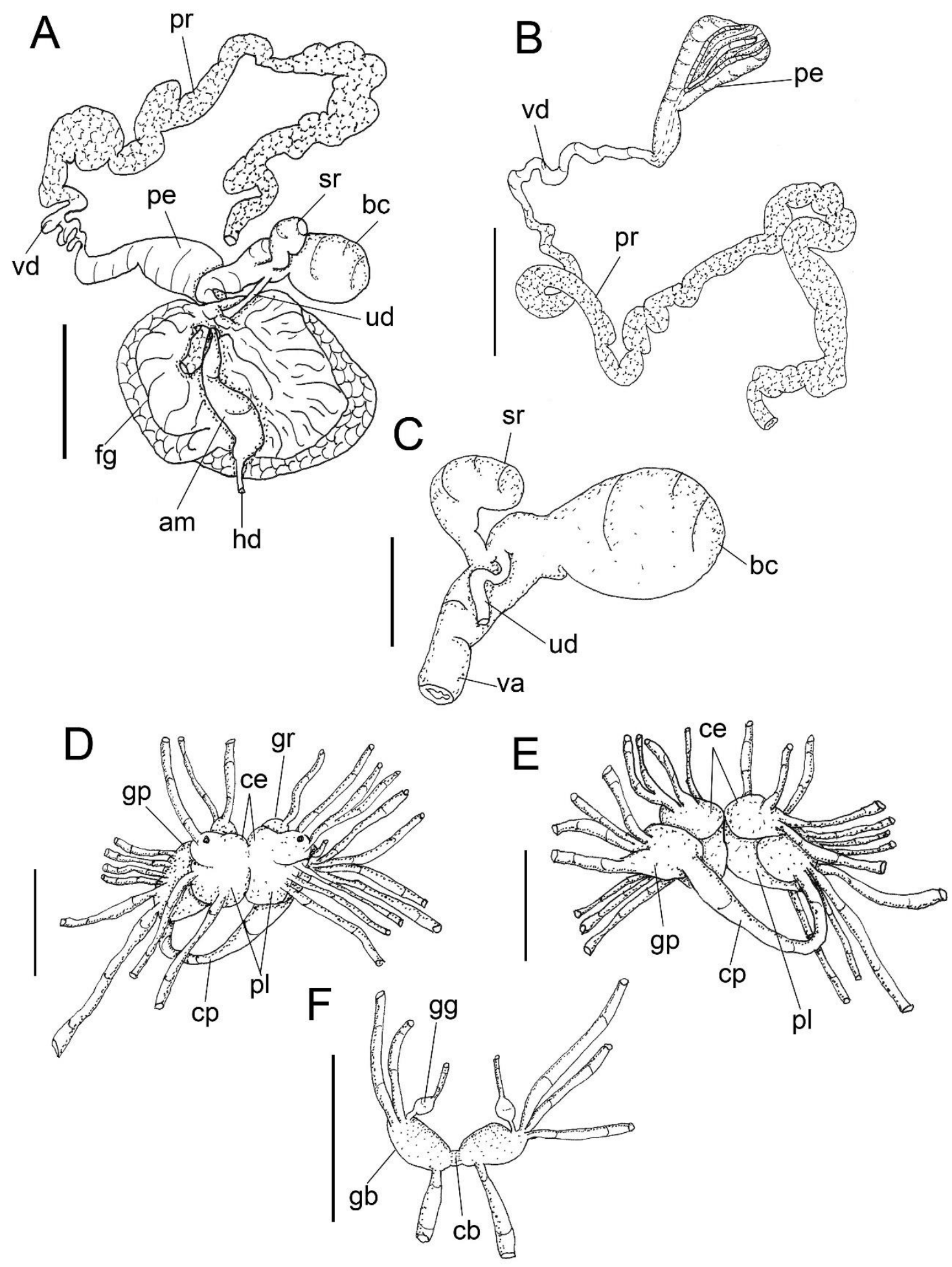

Figure 57: Felimare lajensis. Reproductive system. A. General view. B. Detail of prostate, vas deferens and penis. Scales: $2 \mathrm{~mm}$. C. Detail of bursa copulatrix, seminal receptacle and vagina. Nervous system. D. Dorsal view. E. Same, ventral view. F. Buccal and gastroesophagel ganglia. Scales: $1 \mathrm{~mm}$. 


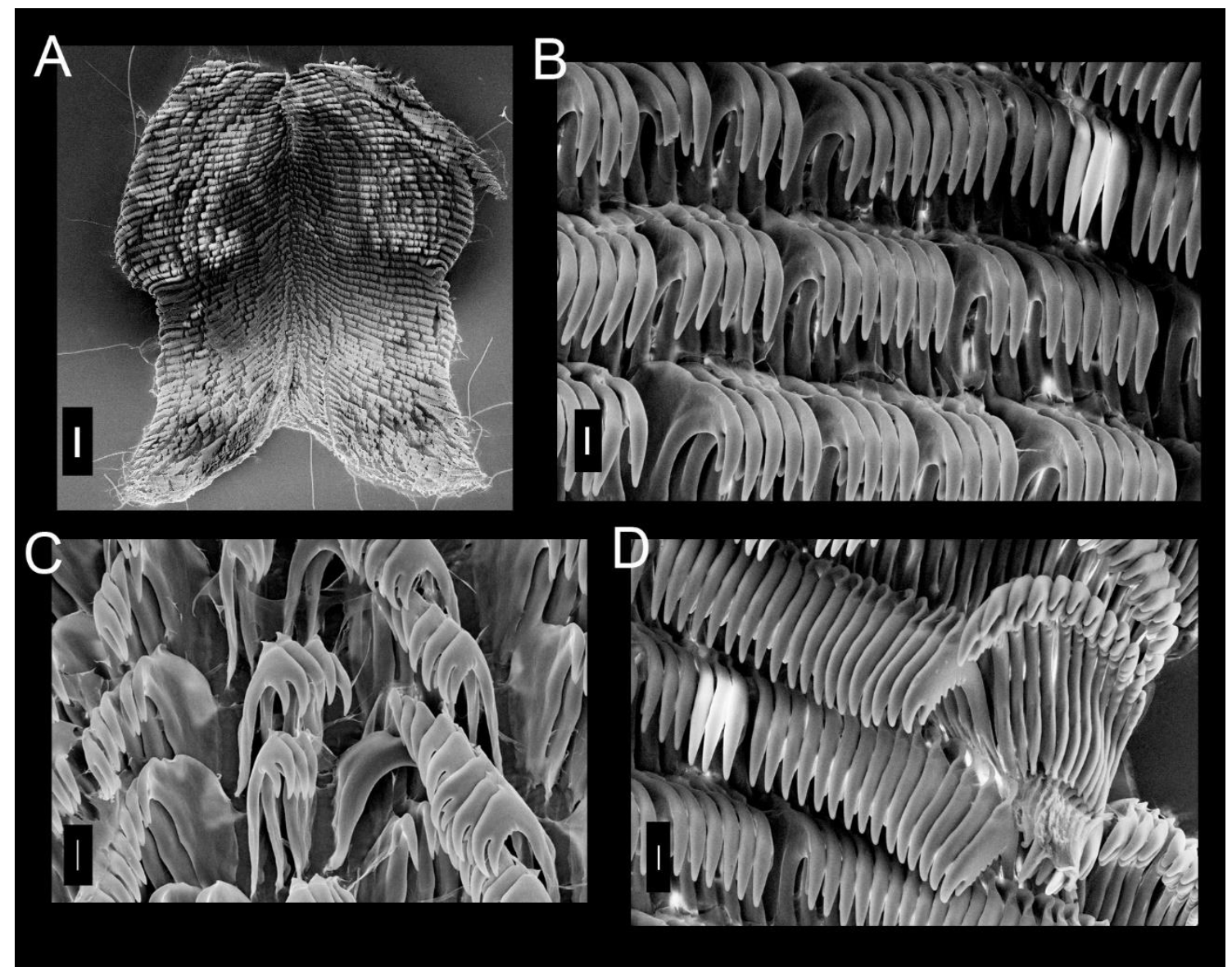

Figure 58: SEM of radula of Felimare lajensis. A. Panoramic view. Scale: $200 \mu \mathrm{m}$. B. Lateral teeth. Scale: $10 \mu \mathrm{m}$. C. Detail of middle of radula, rachidian tooth absent. Scale: $10 \mu \mathrm{m}$. D. Outermost lateral teeth. Scale: $10 \mu \mathrm{m}$.

\section{Genus Felimida Ev. Marcus, 1971}

Type species: Felimida sphoni Ev. Marcus, 1971 (type by original designation)

\section{Felimida neona (Er. Marcus, 1955)}

(Figures 59-62)

Glossodoris neona Er. Marcus, 1955: 124, figs. 90-101; Abbott, 1974: 354, fig. 4241.

Chromodoris neona (Er. Marcus, 1955): Ev. Marcus \& Er. Marcus, 1967: 51, p. 1. Figs. 4-9; $57-$ 58; Valdés et al., 2006: 151; Domínguez et al., 2006: 627, fig. 1G, 5.

Felimida neona Rios, 2009: 424.

Type locality: São Sebastião, São Paulo, Brazil

\section{Redescription}


External morphology (Figure 59A-F)): Size 4mm length, 2mm width. Body elongate with pointed end of foot (Fig. A-C). Rhinophores with about 11 transverse lamellae, purple and white color; rhinophoral sheaths smooth (Fig. 59D). Gill composed of 9 unipinate branchial leaves, purple and white color, arranged in circular fashion surrounding anus; branchial sheaths smooth (Fig. 59F). Mouth opening in anterior ventral region, between anterior region of notum and foot. Digitiform tentacles present, with lateral groove. Anterior border of foot bilabiate (Fig. 59E).

Haemocoel organs (Figure 60A-B): pericardium and posterior half of visceral mass volume occupying $15 \%$ of haemocoel volume. Buccal mass located anteriorly, occupying $20 \%$ of haemocoel volume. Nervous system dorsal to buccal mass with blood gland divided, occupying $5 \%$ of haemocoel volume. Reproductive system on right side of animal, occupying $20 \%$ of haemocoel volume. Stomach, intestine and digestive gland occupying $35 \%$ of haemocoel volume.

Circulatory and excretory systems (Figure 60A, B): pericardial cavity dorsal and posterior to digestive gland, anterior to gill circle (Fig. 60A). Afferent and efferent branches located inside each gill filament, flowing from and to afferent and efferent branchial veins. Gill retractor muscle single originating from base of gill circle, running longitudinally up to half of foot level, inserting into dorsal surface of foot (Fig. 60B). Auricle funnel-like (wider anteriorly) with thin walls. Ventricle sligthly taller than wide, with thick muscular walls. Same pattern of anterior species vessels. Aortic trunk branched into posterior artery irrigating stomach, caecum and digestive gland; anterior artery irrigating reproductive system, buccal mass, odontophore and nervous system. Renal vesicle not visualized. Blood gland divides in anterior and posterior portion, same length for both (Fig. 60A).

Digestive system (Figures 59F; 60A, C-H; 62A-D): Oral tube composed of outer lip, with broad pleats lengthwise; inner lip with transverse fold; mt, three pairs of retractor muscles of buccal mass, originating on oral tube, running dorsally and ventrally to oral tube, inserting on body side, about five times as wide and twice as long as m10 (Fig. C, D). Odontophore oval, connected to oral tube by pair of ventral protractor muscles (m10); thin longitudinal and lateral protractors of oral sphincter, originating in anterior region of odontophore and inserted in posterior region of integument close to oral tube. Oral sphincter surrounding chitinous part of oral tube (Fig. 60C). Odontophore muscles: m2, pair of strong retractor muscles of buccal mass, three times longer than wide, origin on anterior dorsal odontophore, running laterally to $\mathrm{m} 4$ and inserted ventrally on dorsal 
portion of foot; $\mathbf{m 4}$, pair of dorsal tensor muscles, strong and broad, 1/3 as long as wide, covering $2 / 3$ of cartilage, inserted on ventral portion of subradular membrane (Fig. 60G, $\mathrm{H})$; m5, pair of dorsal auxiliary tensor muscles, twice as long as wide, originating on most posterior region of odontophore cartilages, covering $\sim 1 / 3$ of posterior cavity of odontophore, as long as, but with $\sim 1 / 3$ of $\mathrm{m} 4$ width, inserting on ventral side of subradular membrane, around radular sac (Fig. G, H); m6, unpaired horizontal muscle, with transverse fibers connecting to median surface of left and right odontophore cartilages, about same length and half as wide as $\mathrm{m} 4$, posterior portion twice as wide as anterior portion (Fig. $60 \mathrm{H}$ ); m7, not visualized; m9, unpaired and horizontal muscle, originating on posterior portion of $\mathrm{m} 4$, connecting pair of $\mathrm{m} 4$ (Fig. 60G). Pair of odontophore cartilages elliptical (Fig. 60 E, H). Subradular membrane thin, strong, translucent. Radular sac $\sim 1 / 3$ as large as odontophore (Fig. 60E, F). Radular teeth (Fig. 62A-D): rachidian teeth present, low triangle with small and smooth cusp; formula 39 x 31.1.31 (in $4 \mathrm{~mm}$ long specimen). Each lateral tooth with broad base, with single terminal cusp, with four to five small cusps on each side of main cusp; following lateral tooth with gradually increasing hook-shaped with about 7 to 9 cusps on outer side; 3 outermost teeth with apex rounded and with cusps. Pair of salivary glands short and sac-like; duct inserting in anterior region of esophagus (Fig. 60D). Esophagus simple, originating dorsally to odontophore, inserting directly in anterior region of stomach, aboute five well difined internal longitudinal folds with same diameter along entire length (Fig. 60C). Stomach internal to digestive gland. Caecum absent. Intestine with longitudinal folds along its entire length, diameter about twice esophagus diameter (Fig. 60A). Digestive gland dark beige, being largest organ of visceral mass, cone-shaped; anterior portion about twice as wide as posterior portion, inner face of gland sponge-like (Fig. 60A). Anus opening into anal papilla at center of gill circle, $\sim 1 / 2$ of gill filament length (Fig. 59F).

Genital system (Figure 61A): located between buccal mass and digestive gland, mainly on right side and dorsally. Genital opening on right side, anterior third of length of animal from head, located between foot and notum. Gonad immersed and distinct of digestive gland, purple color. Hermaphrodite duct thin, long. Ampulla located on female gland, elongated and tubular. Prostate tubular, glandular, four time longer than ampulla, $1 / 2$ width. Vas deferens about same length as penis. Penis' muscle absent. Penis muscular, cylindrical and elongated, about 1/2 of length of prostate, same width. Female gland welldeveloped, rounded, occupying $\sim 30 \%$ of reproductive system volume, divided into mucus gland ( 4/5 of female gland, color beige), and albumen gland ( 1/5 of anteriormost 
region, dilated, irregularly shaped, color dark brown). Oviduct occupying $\sim 1 / 7$ of female gland volume. Uterine duct thin, $\sim 1 / 2$ of vagina length, located at base of vagina, inserted in female gland near oviduct. Seminal receptacle pyriform, as large as bursa copulatrix, $\sim 1 / 2$ of vagina width, connected to vagina near uterine duct through short stalk. Bursa copulatrix rounded, length $\sim$ same vagina length, connected to vagina after seminal receptacle, also through short stalk. Vagina cylindrical, elongated, approximately $1 / 2$ of length and $1 / 2$ of wide of penis, followed ventrally by prostate and located parallel to penis in genital opening.

Nervous system (Figure 60A; 61B-C): Blood gland divided anterior and posterior to ganglia fused. Pair of cerebral and pleural ganglia fused with each other dorsally and ventrally. Pedal ganglia fused with cerebral and pleural ventrally, but not fused among themselves. Pedal commissure simple and short, surrounding esophagus and salivary glands (Fig. 61C). Buccal ganglia short, located ventrally to odontophore, between radular sac and anterior portion of esophagus, connected to cerebral ganglia through long and slender connective tissue, united to gastro-esophageal ganglia by short connective tissue. Gastro-esophageal ganglia length about 1/6 of buccal ganglia length, circular. Rhinophoral (olfactory) ganglia bulb-shaped, connected to anterior portion of cerebral ganglia. Dorsal eyes located on cerebral ganglia (Fig.61B).

Distribution: Brazil: Rio de Janeiro, São Paulo.

Habitat: on intertidal rocks

Material examined: Brazil, São Sebastião, São Paulo, MZSP 112226, 2 specimens (A. Morandini donor; 12/x/2011); Ilha da Serraria, MZSP 103241, 1 specimen. (Y. Tibiriçá, col. 19/i/2012, 6m deep, in a vertical wall). 


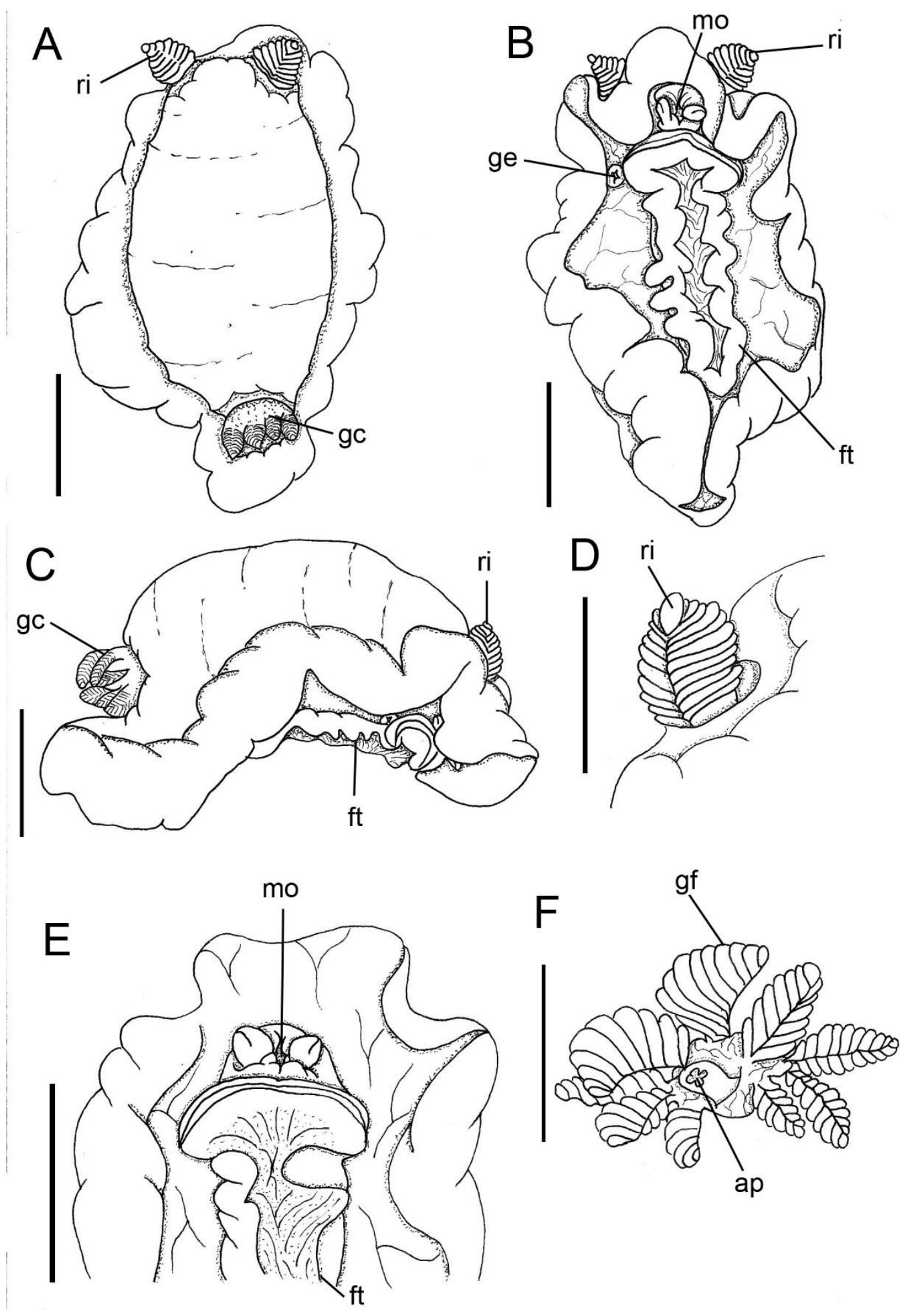

Figure 59: Felimida neona, fixed animal. A. Dorsal view. B. Same, ventral view. C. Same, right lateral view. D. Rhinophore in th rhinophoral cavity. E. Detail of anterior border of foot. F. Gill circle, dorsal view. Scales: $1 \mathrm{~mm}$. 

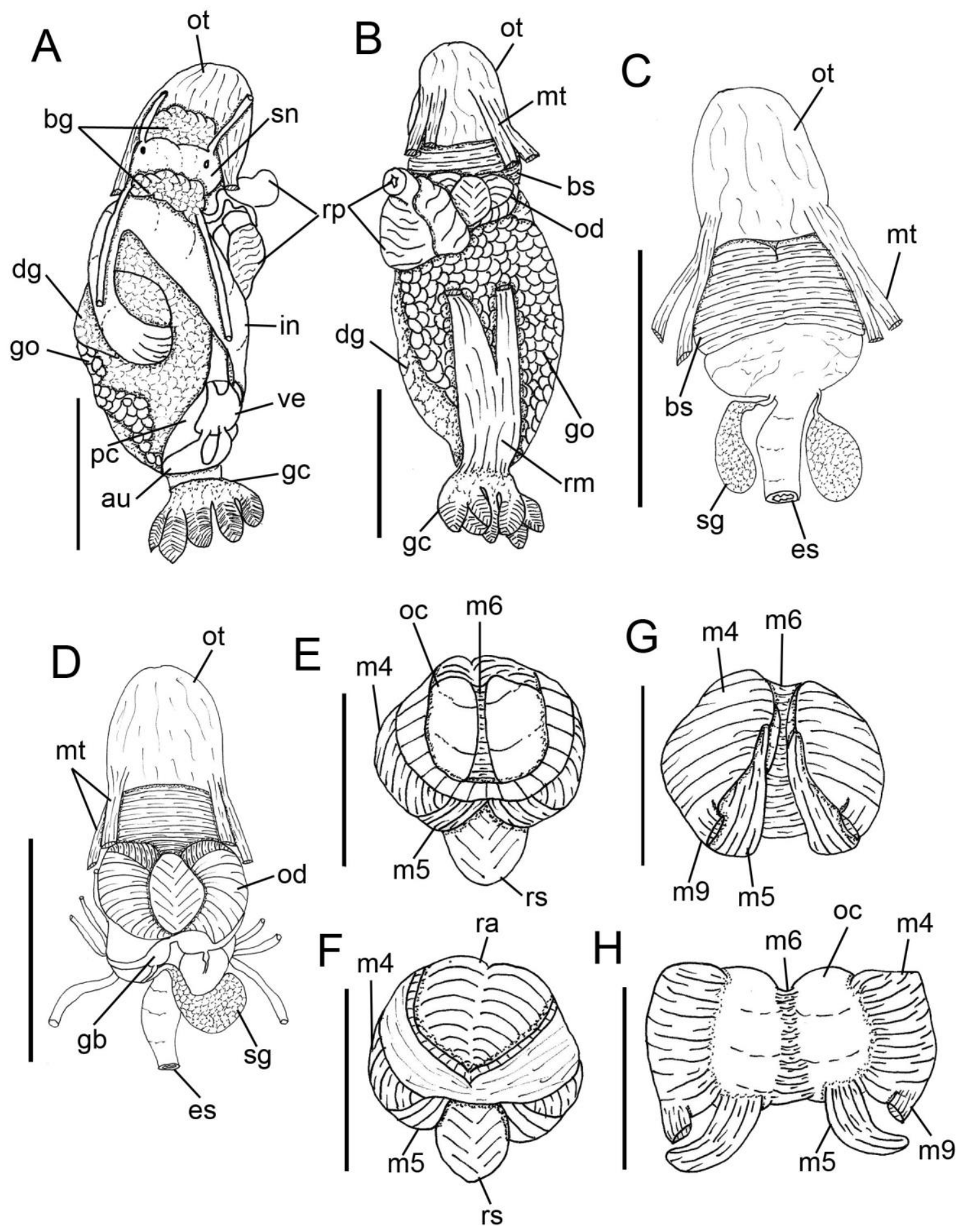

Figure 60: Felimida neona. Visceral mass. A. Dorsal view. B. Same, ventral view. Anterior digestive system. C. Dorsal view. D. Same, ventral view. Scales: 1mm. Odontophore. E. Ventral view. F. Same, dorsal view. G. Same, dorsal view with radula removed. H. Same, dorsal view with folded down muscles. Scales: $0,5 \mathrm{~mm}$. 


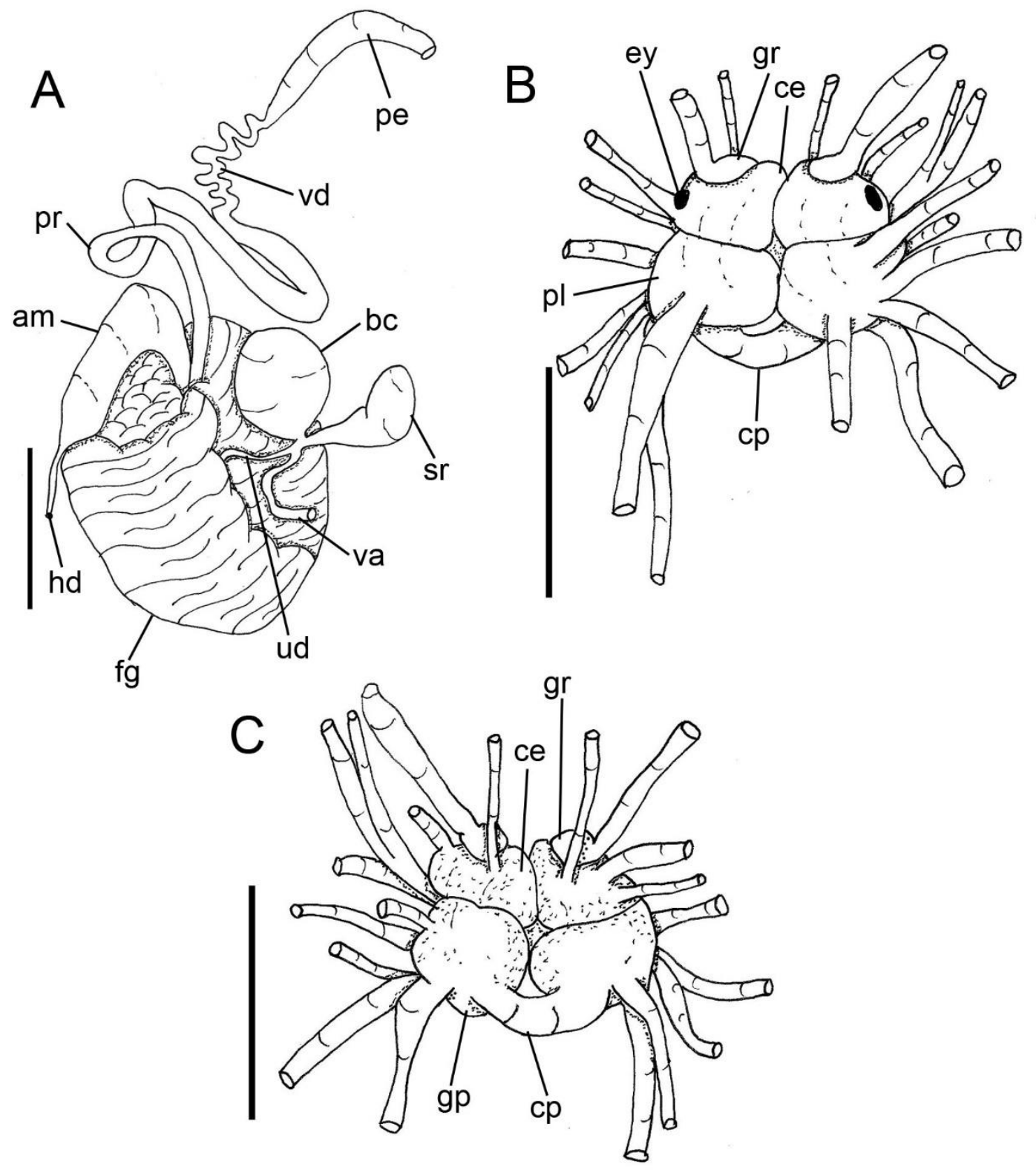

Figure 61: Felimida neona. Reproductive system. A. Dorsal view. Scales: $1 \mathrm{~mm}$. Nervous system. B. Dorsal view. C. Same, ventral view. Scales: 0,5mm. 


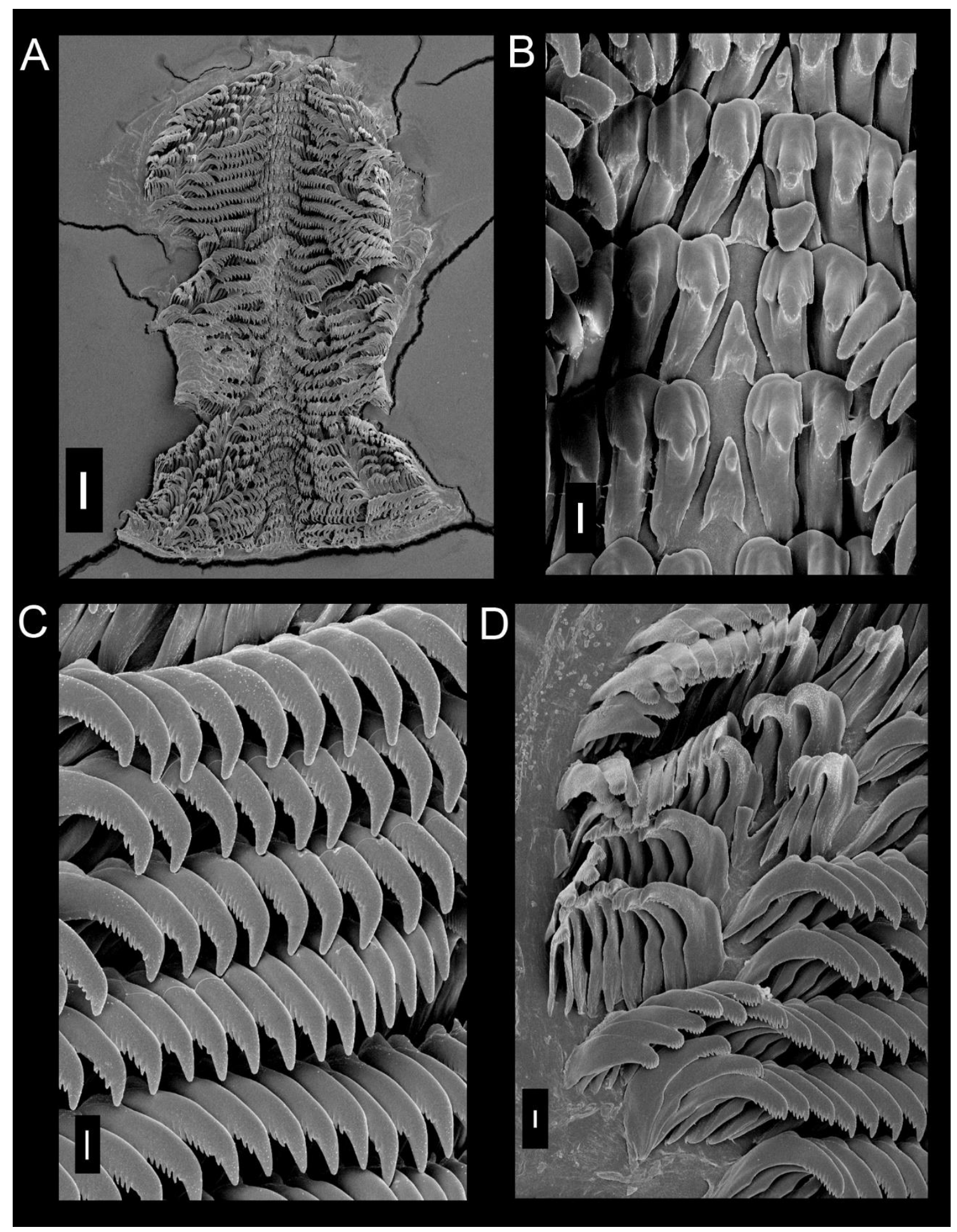

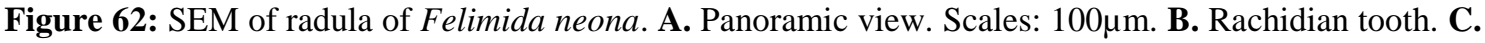
Innermost lateral teeth. D. Marginal teeth. Scales: $10 \mu \mathrm{m}$. 


\section{Genus Hypselodoris Stimpson, 1855}

Type species: Hypselodoris obscura (Stimpson, 1855)

\section{Hypselodoris obscura (Stimpson, 1855)}

(Figures 63-67)

See Johnson \& Valdés, 2001

Type locality: Southeastern Australia

\section{Redescription}

External morphology (Figure 63A-E): Size $17 \mathrm{~mm}$ length, $7 \mathrm{~mm}$ width. Color blue with small dark blue and white dots and larger yellow dots. Body elongate with pointed end (Fig. 63A, B). Rhinophores with about $\sim 17$ transverse lamellae, red and white color; rhinophoral sheaths smooth (Fig. 63C). Gill composed of 12 unipinate branchial leaves, same as rhinophores, arranged in circular fashion surrounding anus; branchial sheaths smooth, color similar to body (Fig. 63D). Mouth opening in anterior ventral region, between anterior region of notum and foot. Digitiform tentacles present. Anterior border of foot bilabiate (Fig. 63B).

Haemocoel organs (Figure 64A-B): pericardium and posterior half of visceral mass volume occupying $20 \%$ of haemocoel volume. Buccal mass located anteriorly, occupying $10 \%$ of haemocoel volume. Nervous system dorsal to buccal mass, covered by blood gland, occupying $5 \%$ of haemocoel volume. Reproductive system on right side of animal; occupying $15 \%$ of haemocoel volume. Stomach, intestine and digestive gland occupying $50 \%$ of haemocoel volume.

Circulatory and excretory systems (Figure 63D, E; 64A, C): pericardial cavity dorsal and posterior to digestive gland, anterior to gill circle (Fig. 64A). Afferent and efferent branches located inside each gill filament, flowing from and to afferent and efferent branchial veins (Fig. 63E). Gill retractor muscle divided originating from base of gill circle, running longitudinally up to half of foot level, inserting into dorsal surface of foot (Fig. 63D; 64A). Auricle funnel-like (wider anteriorly) with thin walls. Ventricle sligthly taller than wide, with thick muscular walls. Same pattern of anterior escpecies vessels. Aortic trunk branched into posterior artery irrigating stomach, caecum and digestive gland; anterior artery irrigating reproductive system, buccal mass, odontophore and nervous system (Fig.64C). Renal vesicle located on right dorsal side of pericardium, 
near base of auricle, connected to inner surface of pericardium, 1/10 the size of ventricle (Fig. 64C). Renal chamber extending from dorsal to medial sinus, previously connected to renal vesicle, extending posteriorly to center of gill circle and opening in nephrostome, in a pore, next to base of anal papilla (Fig. 63D). Blood gland divided in tow partes, anterior twice longer than posterior (Fig. 64A).

Digestive system (Figures 63D; 64A, D; 65A-F): Oral tube composed of outer lip, with pleats lengthwise; inner lip with transverse fold; mt, three pairs of retractor muscles of buccal mass, originating on oral tube, running dorsally and ventrally to oral tube, inserting on body side, about six times as wide and twice as long as m10 (Fig. 65A, B). Odontophore oval, connected to oral tube by pair of ventral protractor muscles (m10); thin longitudinal, ventrolateral protractors of oral sphincter, originating in anterior region of odontophore and inserted in posterior region of integument close to oral tube (Fig. 65A). Oral sphincter surrounding chitinous part of oral tube (Fig. 65A). Odontophore muscles: m2, pair of strong retractor muscles of buccal mass, four times longer than wide, origin on anterior dorsal odontophore, running laterally to $\mathrm{m} 4$ and inserted ventrally on dorsal portion of foot (Fig. 65C, D); m2a, pair of retractor muscles, same as $\mathrm{m} 2$, but running anteriorly, well distinct from $\mathrm{m} 2$ (Fig. 65C, D); m4, pair of dorsal tensor muscles, strong and broad, $1 / 2$ as long as wide, covering $2 / 3$ of cartilage, inserted on ventral portion of subradular membrane (Fig. 65E, F); m5, pair of dorsal auxiliary tensor muscles, twice as long as wide, originating on most posterior region of odontophore cartilages, covering $\sim 1 / 3$ of posterior cavity of odontophore, as long as, but with $\sim 1 / 4$ of $\mathrm{m} 4$ width, inserting on ventral side of subradular membrane, around radular sac (Fig. 65E, F); m6, unpaired horizontal muscle, with transverse fibers connecting to median surface of left and right, about same length and $\sim 1 / 3$ as wide as $\mathrm{m} 4$, anterior and posterior portionsame width (Fig. $65 \mathrm{~F}) ; \mathbf{m} 7$, pair of thin and narrow muscle, originating in middle of $\mathrm{m} 6$ running posterior to inserting on radular sac (Fig. 65F); m9, unpaired and horizontal muscle, originating on posterior portion of $\mathrm{m} 4$, connecting pair of $\mathrm{m} 4$ (Fig. 65E). Pair of odontophore cartilages elliptical, occupying 30\% of odontophore volume (Fig. 65F). Subradular membrane thin, strong, translucent. Radular sac $\sim 1 / 3$ as large as odontophore (Fig. 65C). Radular teeth (Fig. 67A-D): rachidian teeth absent; formula 57 x 20.0.20 (in $17 \mathrm{~mm}$ long specimen). Each lateral tooth with broad base, tapering toward apex with three cusps; in middle of row there are a single tooth with inner cusp with six cusps aroud the central cusp (Fig. 67D); outermost teeth thinner, inner base width about half of lateral teeth width, apex also hook-shaped, cusp double and smooth. Pair of salivary glands long, tubular; duct inserting 
in anterior region of esophagus, extending posteriorly to anterior region of digestive gland (Fig. 65A). Esophagus simple, originating dorsally to odontophore, inserting directly in anterior region of stomach, internal longitudinal folds with same diameter along entire length. Stomach internal to digestive gland. Intestine with longitudinal folds along its entire length, about twice esophagus diameter, but more uniform. Caecum absent. Digestive gland dark beige, being largest organ of visceral mass and occupying $40 \%$ of its volume, cone-shaped; anterior portion about twice as wide as posterior portion, inner face of gland sponge-like (Fig. 64A). Anus opening into anal papilla at center of gill circle, $\sim 1 / 2$ of gill filament length (Fig. 63D).

Genital system (Figure 64A, D; 66A, B): located between buccal mass and digestive gland, mainly on right side and dorsally (Fig. 64A). Genital opening on right side, anterior third of length of animal from head, located between foot and notum. Gonad immersed in digestive gland, but easy to distinguish it (Fig. 64D). Hermaphrodite duct thin, long. Ampulla located on female gland, elongated and tubular. Prostate tubular, glandular, about six times longer than ampulla. Vas deferens about half length as prostate. Penis' muscleabsent. Penis muscular, cylindrical and elongated, about 1/11 of length of prostate (Fig. 66B). Female gland well-developed, rounded, occupying $\sim 15 \%$ of reproductive system volume, divided into mucus gland ( $2 / 3$ of female gland, color beige), and albumen gland ( $1 / 3$ of anteriormost region, dilated, irregularly shaped, color dark brown). Uterine duct thin, relatively long, length same of vagina length, located at base of vagina, inserted in female gland (Fig. 66A). Seminal receptacle pyriform, very short, 1/20 of bursa copulatrix length, connected to bursa copulatrix base (Fig. 66A). Bursa copulatrix rounded, $\sim$ same length of vagina, connected to vagina through short stalk. Vagina cylindrical, elongated and broad, approximately as long as and twice as wide as penis, followed ventrally by prostate and located parallel to penis in genital opening (Fig. 66A).

Nervous system (Figure 64D; 66C-E): mostly covered by blood gland. Pair of cerebral and pleural ganglia fused with each other dorsally and ventrally (Fig. 64D). Pedal ganglia fused with cerebral and pleural ventrally, but not fused among themselves. Pedal commissure simple, surrounding esophagus and salivary glands (Fig. 66D). Buccal ganglia short, located ventrally to odontophore, between radular sac and anterior portion of esophagus, connected to cerebral ganglia through long and slender connective tissue, united to gastro-esophageal ganglia by short connective tissue (Fig. 66E). Buccal commissure inconspicuous. Gastro-esophageal ganglia length about 1/4 of buccal ganglia 
length, circular (Fig. 66E). Rhinophoral (olfactory) ganglia bulb-shaped, connected to anterior portion of cerebral ganglia. Dorsal eyes located on cerebral ganglia (Fig. 66C).

Distribution: Southeastern Australia from Southern Queensland to Southern New South Wales (Rudman, 1998)

Material examined: Australia, Queensland, Mooloolaba, SE Queensland, CAS 146017, 1 specimen (S. Fahey, coll., 12/xi/2000); Australia, Queensland, Amity Pier, Amity Point, North Stradbroke Island (27²4.000'S, 153²6.000'E), AUS-C379393, 1 specimen (W.B. Rudman, coll., 2000, 7,5m depth, crawling size); Shoalwater Bay, off Canoe Passage between Townshend and Marquis Islands (22 $\left.18.235^{\prime} \mathrm{S}, 150^{\circ} 27.543^{\prime} \mathrm{E}\right)$, AUS-C415150, 4 specimens (I. Loch, D.L. Beechey \& A.C. Miller, 09-10/ix/2002, rock shoal with coarse muddy sand); New South Wales, Towfold Bay, W end Fisheries Beach (376.700'S, $\left.149^{\circ} 55.200^{\prime} E\right)$, AUS-C408095, 1 specimen (W.B. Rudman, A.C. Miller \& H. Barlow, 28/ii/2002, narrow rock plataorm running out into bay). 
A
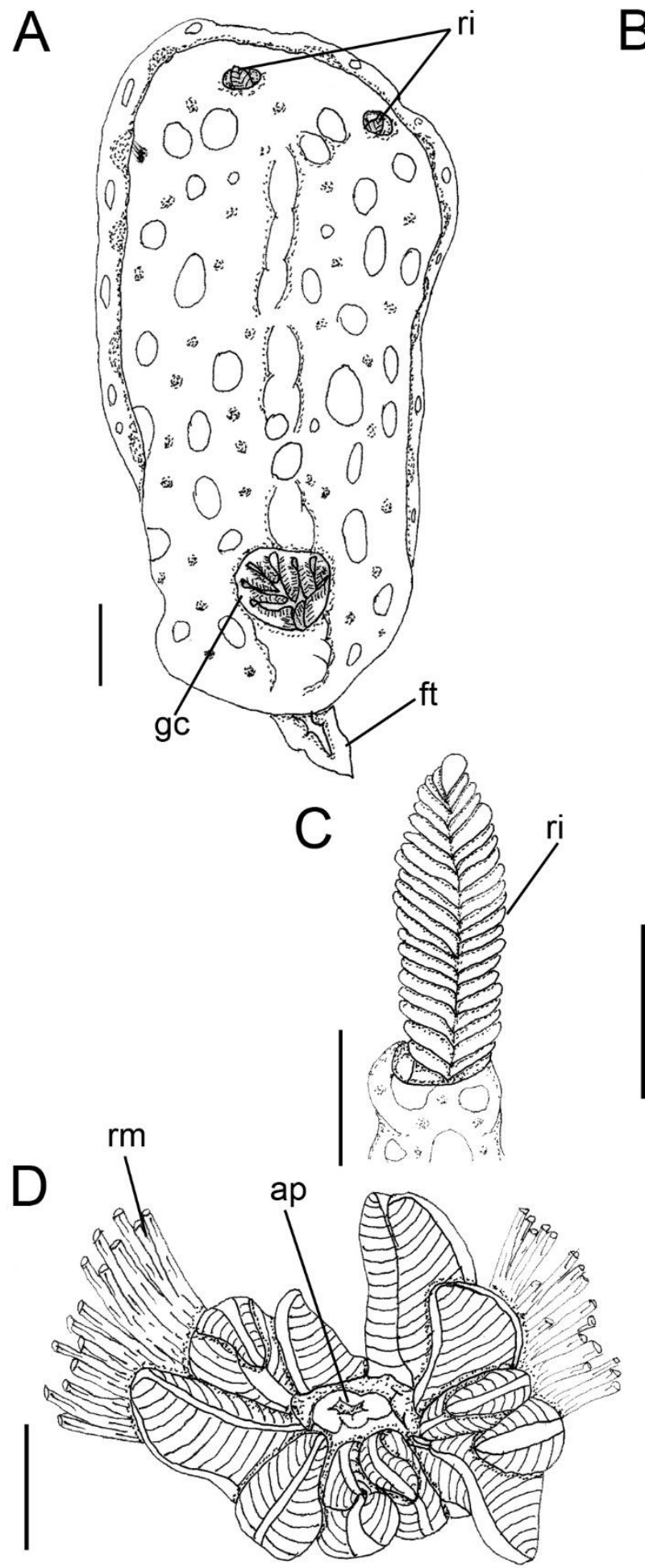

B
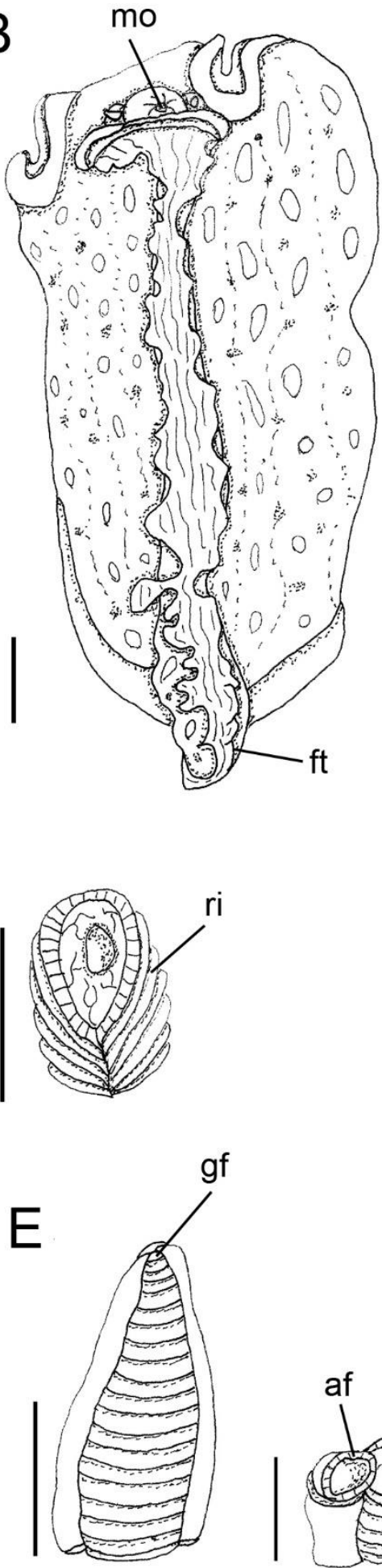

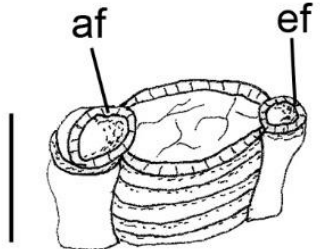

Figure 63: Hypselodoris obscura, fixed animal. A. Dorsal view. B. Same, ventral view. Scales: $2 \mathrm{~mm}$. C. Rhinophoral sheath and transversal section. D. Gill circle, dorsal view. F. Gill filament and tranversal section with afferent and effetend branchial ring. Scales: $1 \mathrm{~mm}$. 

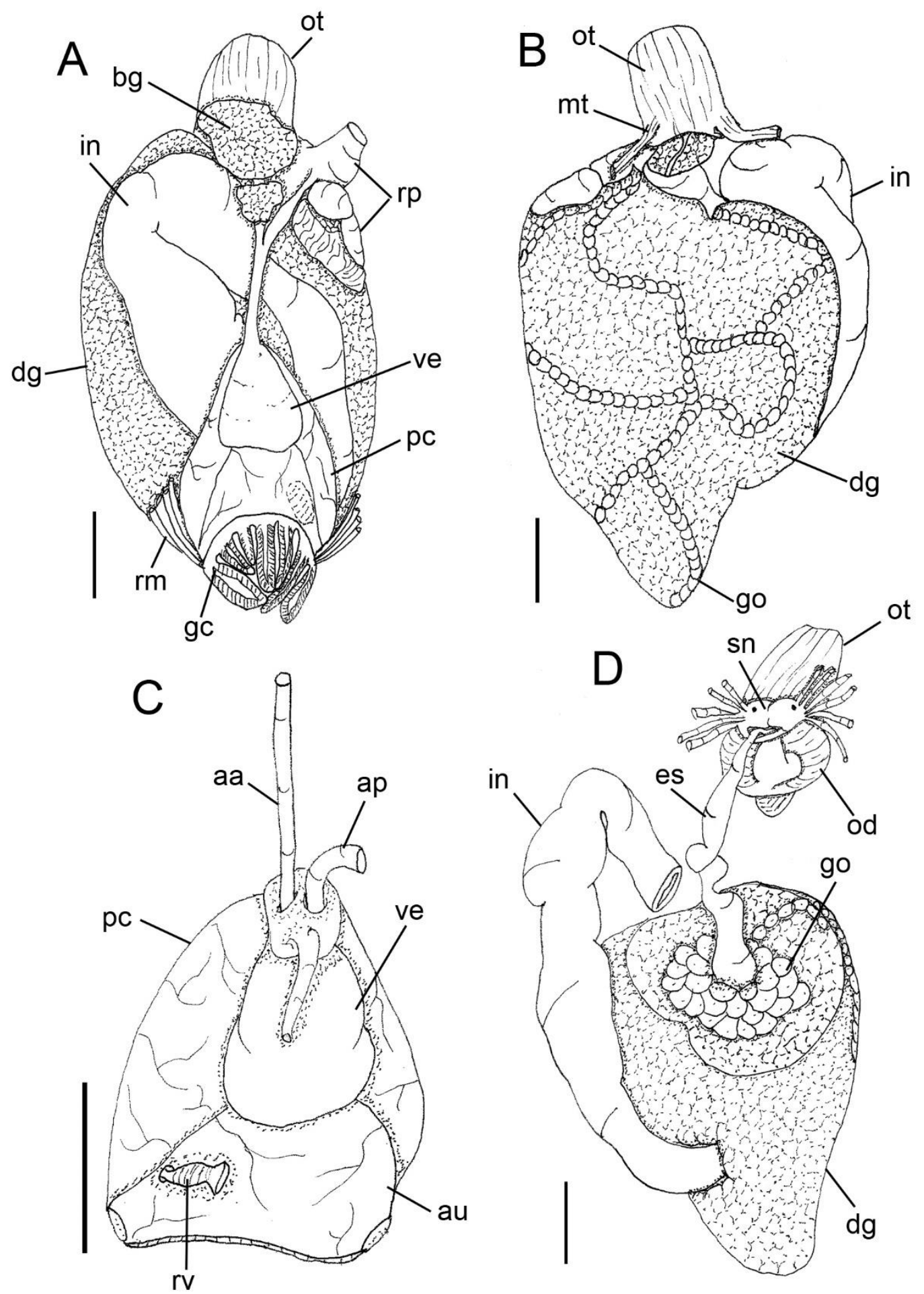

Figure 64: Hypselodoris obscura. Visceral mass. A. Dorsal view. B. Same, ventral view. C. Circulatory and excretory system. D. Digestive system, dorsal view. 

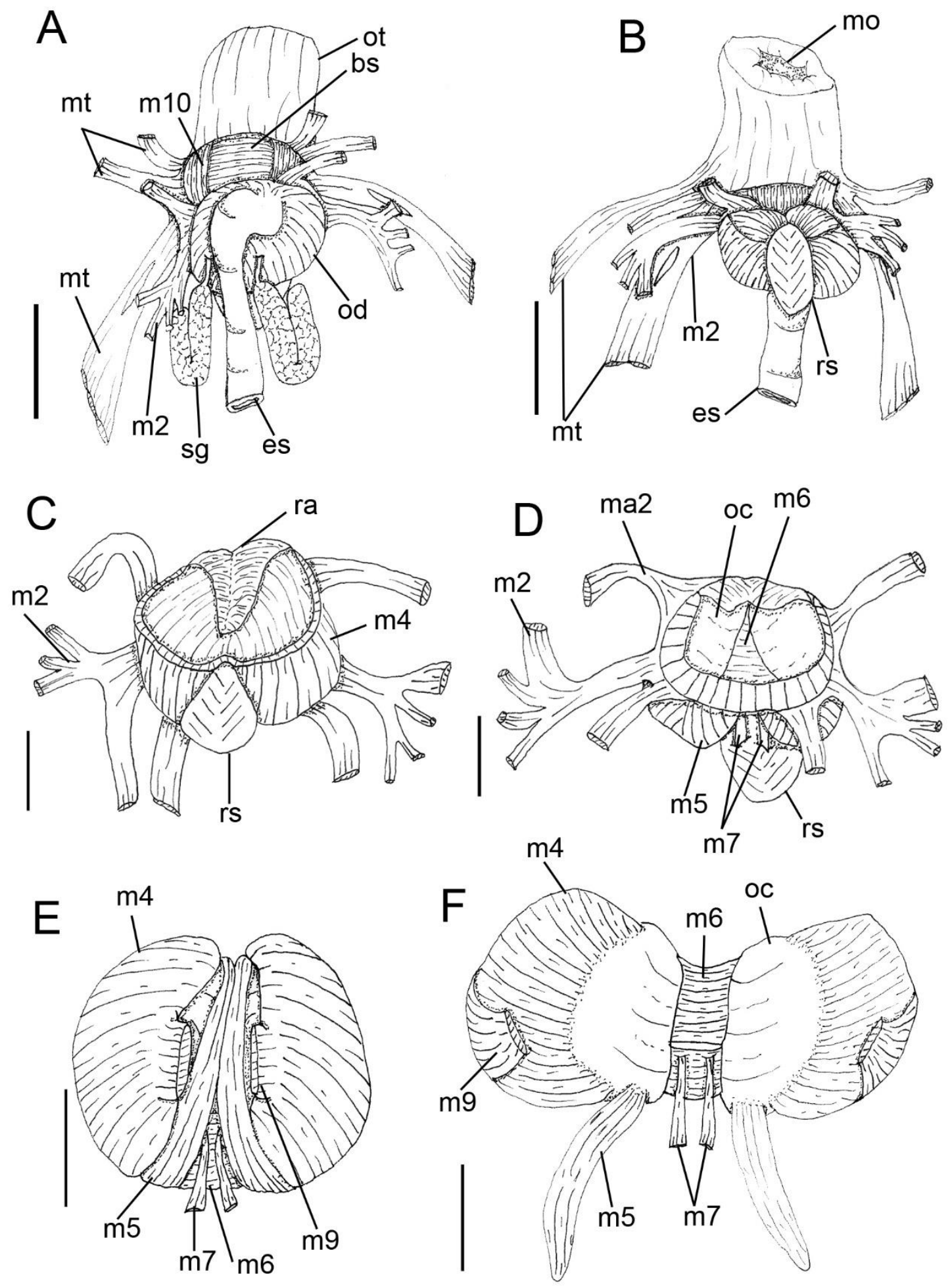

Figure 65: Hypselodoris obscura. Anterior digestive system. A. Dorsal view. B. Same, ventral view. Scales: $2 \mathrm{~mm}$. Odonrophore. C. Dorsal view with radula. D. Same, ventral view. E. Same, dorsal view with radula removed. F. Same, dorsal view with folded down muscles. Scales: $1 \mathrm{~mm}$. 

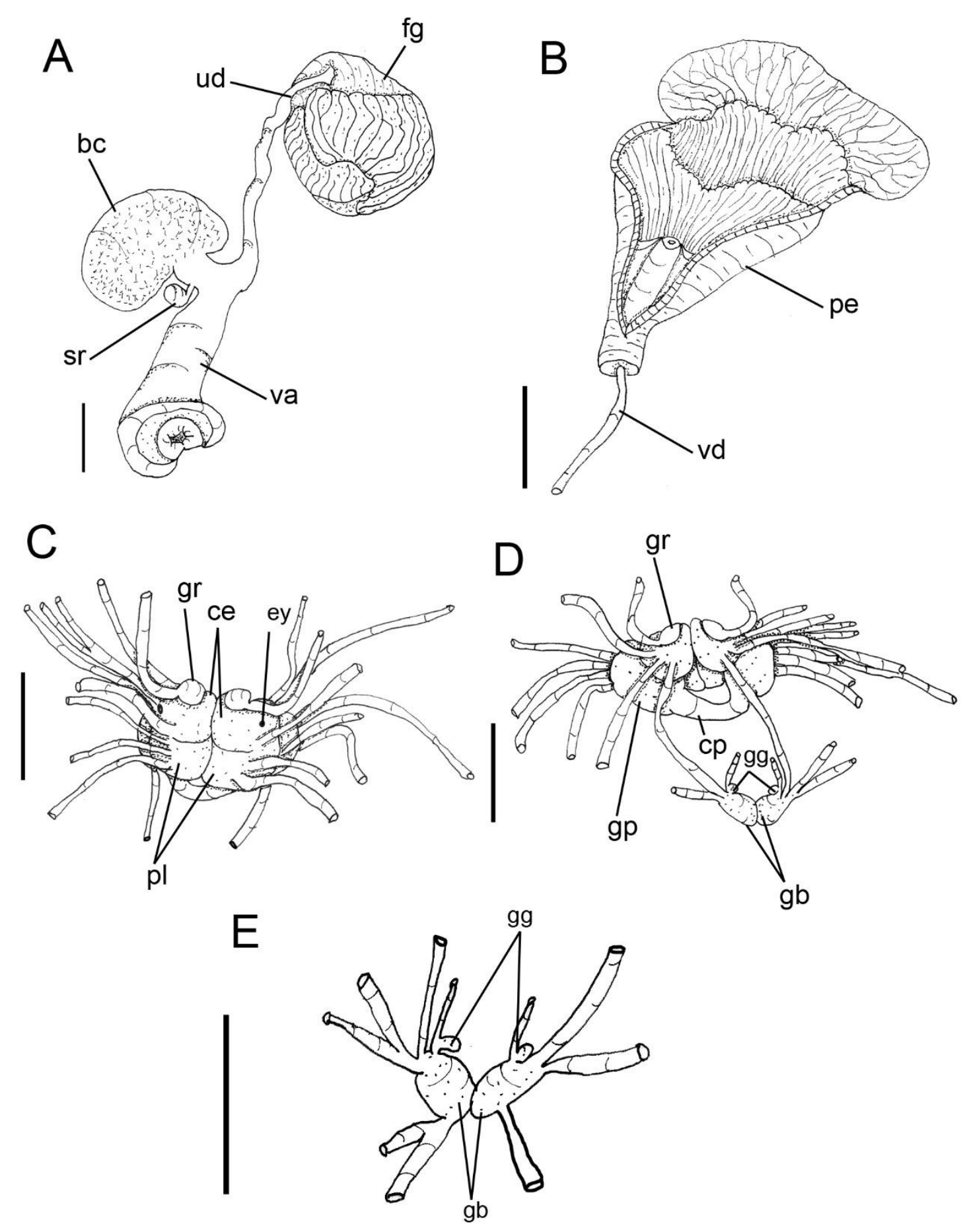

Figure 66: Hypselodoris obscura. Reproductive system. A. General view. B. Detail of penis. Nervous system. C. Dorsal view. D. Same, ventral view. E. Buccal and gastroesophageal ganglia. Scales: $1 \mathrm{~mm}$. 


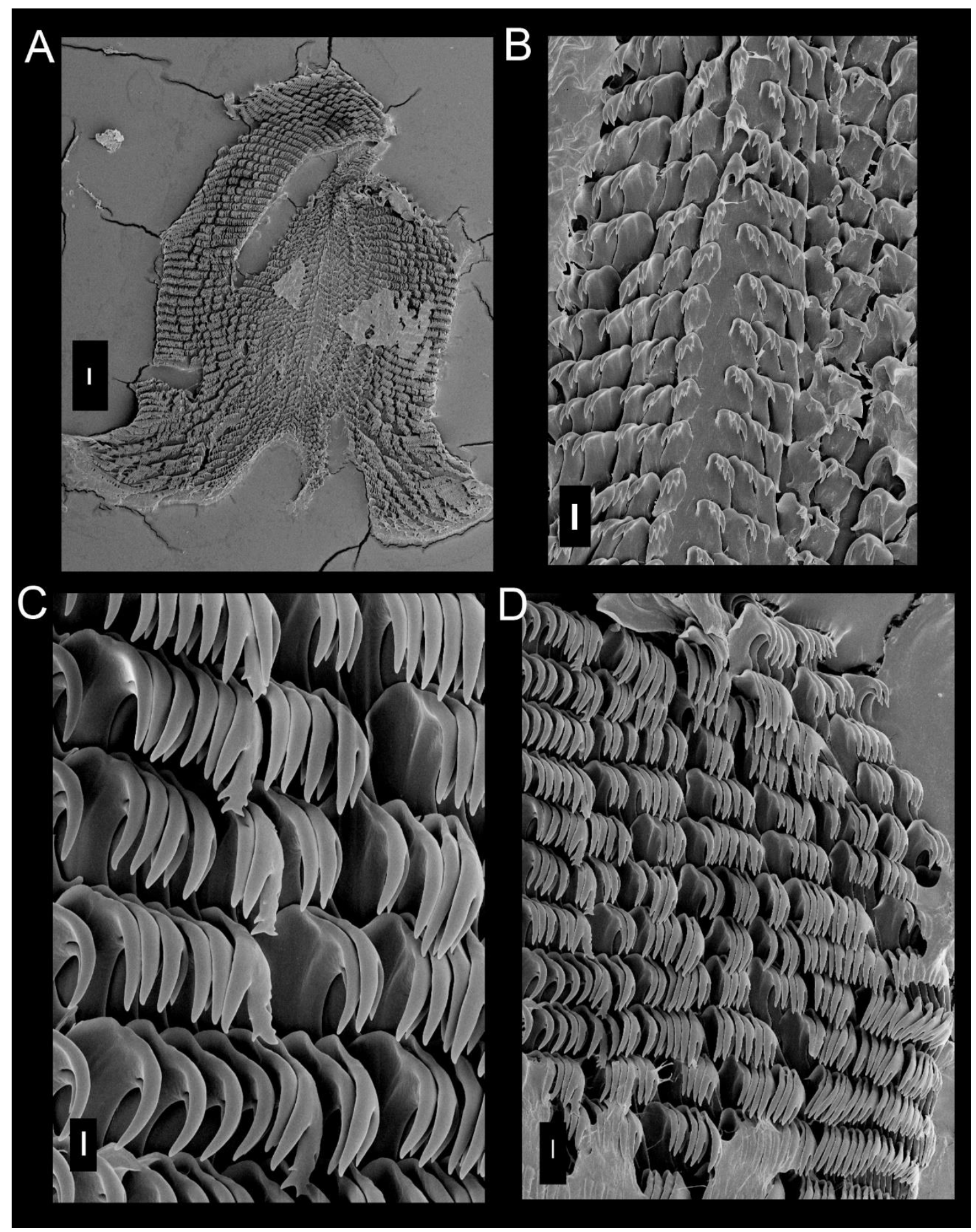

Figure 67: SEM of radua of Hypselodoris obscura. A. Panoramic view. Scale: $100 \mu \mathrm{m}$. B. Detail of middle, rachidian tooth absent. Scale: $20 \mu \mathrm{m}$. C. Lateral teeth. D. Detail of one distinct tooth in the middle of lateral teeth. Scale: $10 \mu \mathrm{m}$. 


\section{Genus Tyrinna Bergh, 1898}

Type species: Tyrinna nobilis Bergh, 1898

\section{Tyrinna evelinae (Marcus, 1958)}

(Figures 68-72)

Cadlina evelinae Marcus, 1958: 18, figs. 28-33; Collier \& Farmer, 1964: 380; Marcus \& Marcus, 1967: 168; Thompson, 1980: 76; Farmer, 1980: 82; Abbott, 1974: 357, fig. 4267; Edmunds, 1981: 176; 1982: 517.

Tyrinna evelinae: Rudman 1984: 244; Muniaín et al., 1996: 265; Domínguez et al., 2006: 624, fig.1C; Valdés et al., 2006: 144; Rios, 2009: 424; Schrödl \& Millen, 2001: 1160, fig. 7-11. Cadlina burnayi Ortea, 1988: 2, fig. 1-2, pl. 1A.

Type locality: alto litoral de Ilha Bela e Guarujá, perto de Santos, São Paulo, Brazil

\section{Redescription}

External morphology (Figures 68A-F): Size 9mm length and 6mm width. Color white with orange dots covering all dorsum. Body smooth, elongate, with pointed end (Fig. A-C). Rhinophores with about 15 transverse lamellae, white color; rhinophoral sheaths smooth (Fig. 68E). Gill composed of 6 bipinnate branchial leaves, white color, arranged in circular fashion surrounding anus; branchial sheaths smooth color similar to body (Fig. 68F). Mouth opening in anterior ventral region, between anterior region of notum and foot (Fig. 68D). Oral tentacles peg-shaped with external furrow (Fig. 68D). Anterior border of foot bilabiate (Fig. 68B).

Haemocoel organs (Figure 69A, B): pericardium and posterior half of visceral mass volume occupying $15 \%$ of haemocoel volume. Buccal mass located anteriorly, occupying $10 \%$ of haemocoel volume. Nervous system dorsal to buccal mass, covered by blood gland, occupying 5\% of haemocoel volume. Reproductive system on right side of animal; occupying $30 \%$ of haemocoel volume. Stomach, intestine and digestive gland occupying $40 \%$ of haemocoel volume.

Circulatory and excretory systems (Figure 69A-C): pericardial cavity dorsal and posterior to digestive gland, anterior to gill circle (Fig. 69A). Afferent and efferent branches located inside each gill filament, flowing from and to afferent and efferent branchial veins. Gill retractor muscle divided originating from base of gill circle, running longitudinally up to half of foot level, inserting into dorsal surface of foot (Fig. 69B). Auricle funnel-like (wider anteriorly) with thin walls. Ventricle sligthly taller than wide, 
with thick muscular walls (Fig. 69A, C). Same pattern of anterior especies. Aortic trunk branched into posterior artery irrigating stomach, caecum and digestive gland; anterior artery irrigating reproductive system, buccal mass, odontophore and nervous system. Medial sinus connected to afferent branchial ring, irrigating entire digestive gland (Fig. 69C). Renal vesicle located on right dorsal side of pericardium, near base of auricle, connected to inner surface of pericardium, 2/3 of size of ventricle (Fig. 69C). Renal chamber extending from dorsal to medial sinus, previously connected to renal vesicle, extending posteriorly to center of gill circle and opening in nephrostome, in a pore, next to base of anal papilla, but very difficult to see. Blood gland undivided covering all nervous system (Fig. 69A).

Digestive system (Figures 68F; 69C-F; 70A-D; 72A-D): Oral tube composed of outer lip, with pleats lengthwise; inner lip with transverse fold; $\mathbf{m t}$, three pairs of retractor muscles of buccal mass, originating on oral tube, running dorsally and ventrally to oral tube, inserting on body side, about four times as wide and twice as long as m10 (Fig, 69E, F). Odontophore oval, connected to oral tube by pair of ventral protractor muscles (m10); thin longitudinal, ventrolateral protractors of oral sphincter, originating in anterior region of odontophore and inserted in posterior region of integument close to oral tube (Fig. 69F). Oral sphincter surrounding chitinous part of oral tube (Fig. 69E). Odontophore muscles: m2, pair of strong retractor muscles of buccal mass, as wide as long, origin on anterior dorsal odontophore, running laterally to $\mathrm{m} 4$ and inserted ventrally on dorsal portion of foot (Fig. 70A, B); m4, pair of dorsal tensor muscles, strong and broad, 1/3 as long as wide, covering 3/4 of cartilage, inserted on ventral portion of subradular membrane (Fig. 70C, D); m5, pair of dorsal auxiliary tensor muscles, three times longer than wide, originating on most posterior region of odontophore cartilages, covering $\sim 1 / 4$ of posterior cavity of odontophore, as long as, but with $\sim 1 / 4$ of $\mathrm{m} 4$ width, inserting on ventral side of subradular membrane, around radular sac (Fig. 70C, D); m6, unpaired horizontal muscle, with transverse fibers connecting to median surface of left and right odontophore cartilages, about $1 / 2$ length and $1 / 3$ as wide as $\mathrm{m} 4$, posterior portion $\sim$ twice as wide as anterior portion(Fig. 70D); $\mathbf{m} 7$, pair of thin and narrow muscle, originating in middle of m6 running posterior to inserting on radular sac (Fig. 70D); m9, unpaired and horizontal muscle, originating on posterior portion of $\mathrm{m} 4$, connecting pair of $\mathrm{m} 4$. Pair of odontophore cartilages elliptical (Fig. 70D). Subradular membrane thin, strong, translucent. Radular sac $\sim 1 / 6$ as large as odontophore (Fig. 70A). Radular teeth (Fig. 72AD): rachidian teeth present, bears four cusps; formula $65 \times 52.1 .52$ (in $6 \mathrm{~mm}$ long 
specimen). All teeth are same as original description (Marcus, 1958, fig. 32) (Fig.). Pair of salivary glands long, tubular, anterior portion wider; duct inserting in anterior region of esophagus, extending posteriorly to anterior region of digestive gland (Fig. 69E). Esophagus simple, originating dorsally to odontophore, inserting directly in anterior region of stomach, longitudinal folds in anterior region; internal longitudinal folds with same diameter along entire length. Stomach oval, with several digestive ducts. Intestine with longitudinal folds along its entire length, diameter about half esophagus diameter, but more uniform (Fig. 69D). Caecum as rounded sac, located ventrally between stomach and anterior portion of intestine, $\sim 1 / 7$ length and $\sim 1 / 3$ of width of stomach (Fig. 69D). Digestive gland dark beige, being largest organ of visceral mass and occupying $40 \%$ of its volume, rounded, inner face of gland sponge-like, bearing various ducts (Fig. 69C). Anus opening into anal papilla at center of gill circle, $\sim 1 / 2$ of gill filament length (Fig. $68 \mathrm{~F})$.

Genital system (Figure 69B; 70E, F): located between buccal mass and digestive gland, mainly on right side and dorsally (Fig. 69B). Genital opening on right side, anterior third of length of animal from head, located between foot and notum. Gonad immersed in digestive gland, difficult to distinguish it. Hermaphrodite duct thin, long. Ampulla located on female gland, elongated and tubular. Prostate tubular, glandular, twice length as ampulla. Vas deferens about twice length as penis (Fig. 70E). Penis' muscle absent. Penis muscular, cylindrical and elongated, about 1/3 of length of prostate. Female gland well-developed, rounded, occupying $~ 30 \%$ of reproductive system volume, divided into mucus gland ( $2 / 3$ of female gland, color beige), and albumen gland ( $\sim 1 / 3$ of anteriormost region, dilated, irregularly shaped, color dark brown). Oviduct occupying $\sim 1 / 7$ of female gland volume. Uterine duct thin, $\sim 1 / 3$ of vagina length, located at base of vagina, inserted in female gland near oviduct (Fig. (70F). Seminal receptacle pyriform, $\sim 1 / 2$ as bursa copulatrix length and with, connected to vagina near uterine duct through short stalk. Bursa copulatrix rounded, about same of vagina length, connected to vagina after seminal receptacle, also through short stalk. Vagina cylindrical, elongated, approximately as long and half as wide as penis, followed ventrally by prostate and located parallel to penis in genital opening (Fig. 70F).

Nervous system (Figure 71A-B): mostly covered by blood gland. Pair of cerebral and pleural ganglia fused with each other dorsally and ventrally. Pedal ganglia fused with cerebral and pleural ventrally, but not fused among themselves. Pedal commissure simple, surrounding esophagus and salivary glands (Fig. 71B). Buccal ganglia short, located 
ventrally to odontophore, between radular sac and anterior portion of esophagus, connected to cerebral ganglia through long and slender connective tissue, united to gastroesophageal ganglia by short connective tissue (Fig. 71A). Buccal commissure short. Gastro-esophageal ganglia length about $1 / 5$ of buccal ganglia length, circular. Rhinophoral (olfactory) ganglia bulb-shaped, connected to anterior portion of cerebral ganglia. Dorsal eyes located on cerebral ganglia (Fig. 71A).

Distribution: Costa Rica to Brazil.

Habitat: Intertidal zone to $5 \mathrm{~m}$ depth, on rocks.

Material examined: BRAZIL, Reef of Rock Sac, Maceió, Alagoas, MZSP 103351, 1 specimen (J. Bahia, coll., 26/i/2012, 1m depth, under rocks); Praia das Conchas, Cabo Frio, Rio de Janeiro, MZSP 97600, 2 specimens (V. Padula, coll., 25/vi/2005); Ilha de Búzios, Baia das Estatuas, São Sebastião, São Paulo, MZSP 117128, 3 specimens (G. Pastorino et al. coll., 26/viii/2014, IV Workshop of Neogastropoda). 

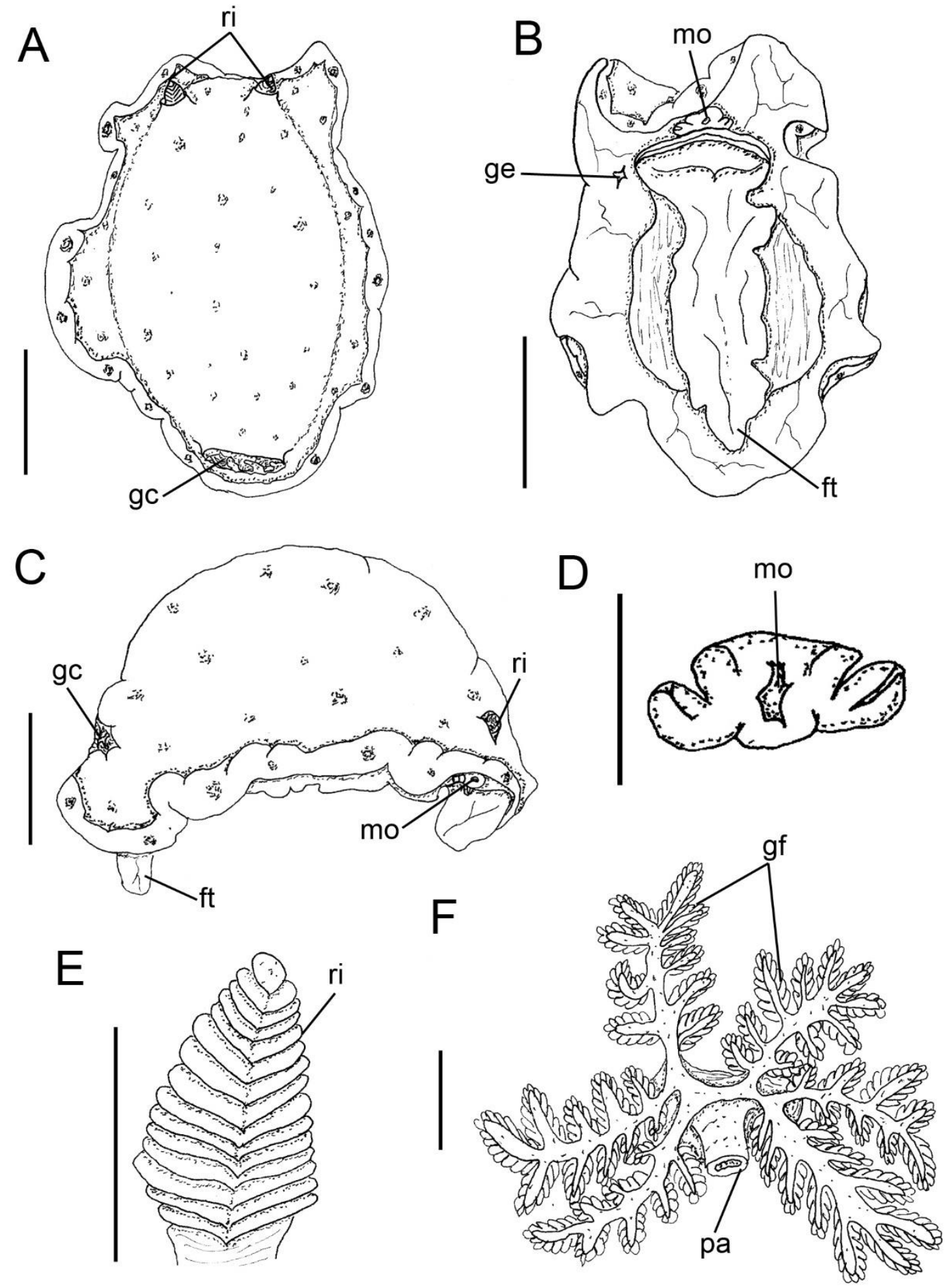

Figure 68: Tyrinna evelinae, fixed animal. A. Dorsal view. B. Same, ventral view. Scales: $2 \mathrm{~mm}$. C. Same, right lateral view. Scales: $2 \mathrm{~mm}$. D. Detail of mouth and digitiform tentacles. E. Rhinophoral sheath and transversal section. F. Gill circle, dorsal view. Scales: $1 \mathrm{~mm}$. 

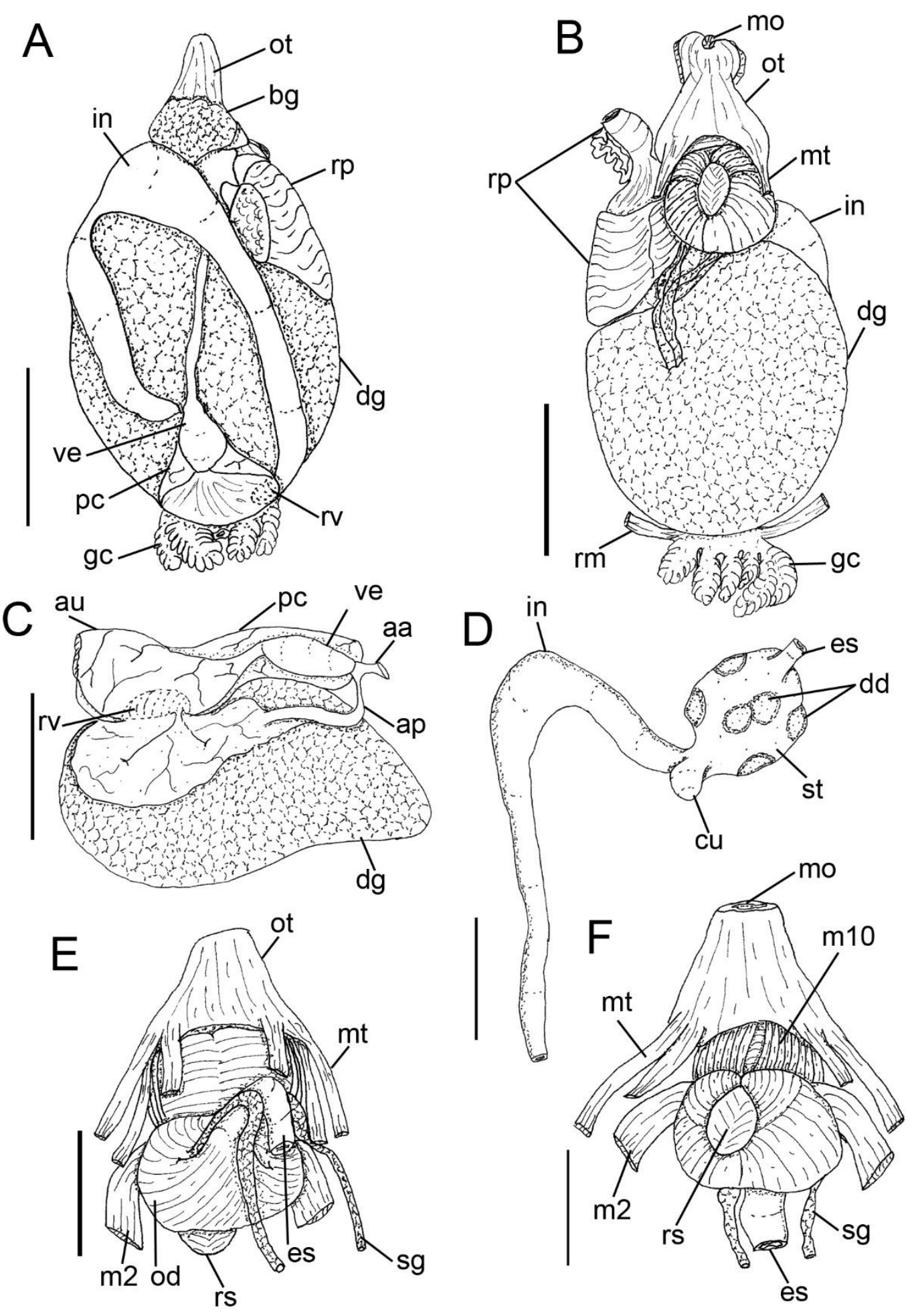

Figure 69: Tyrinna evelinae. Visceral mass. A. Dorsal view. B. Same, ventral view. C. Circulatory and excretory system in situ. D. Median digestive system, detail of ducts of digestive gland. Scales: $2 \mathrm{~mm}$. Anterior digestive system. E. Dorsal view. F. Same, ventral view. Scales: $1 \mathrm{~mm}$. 

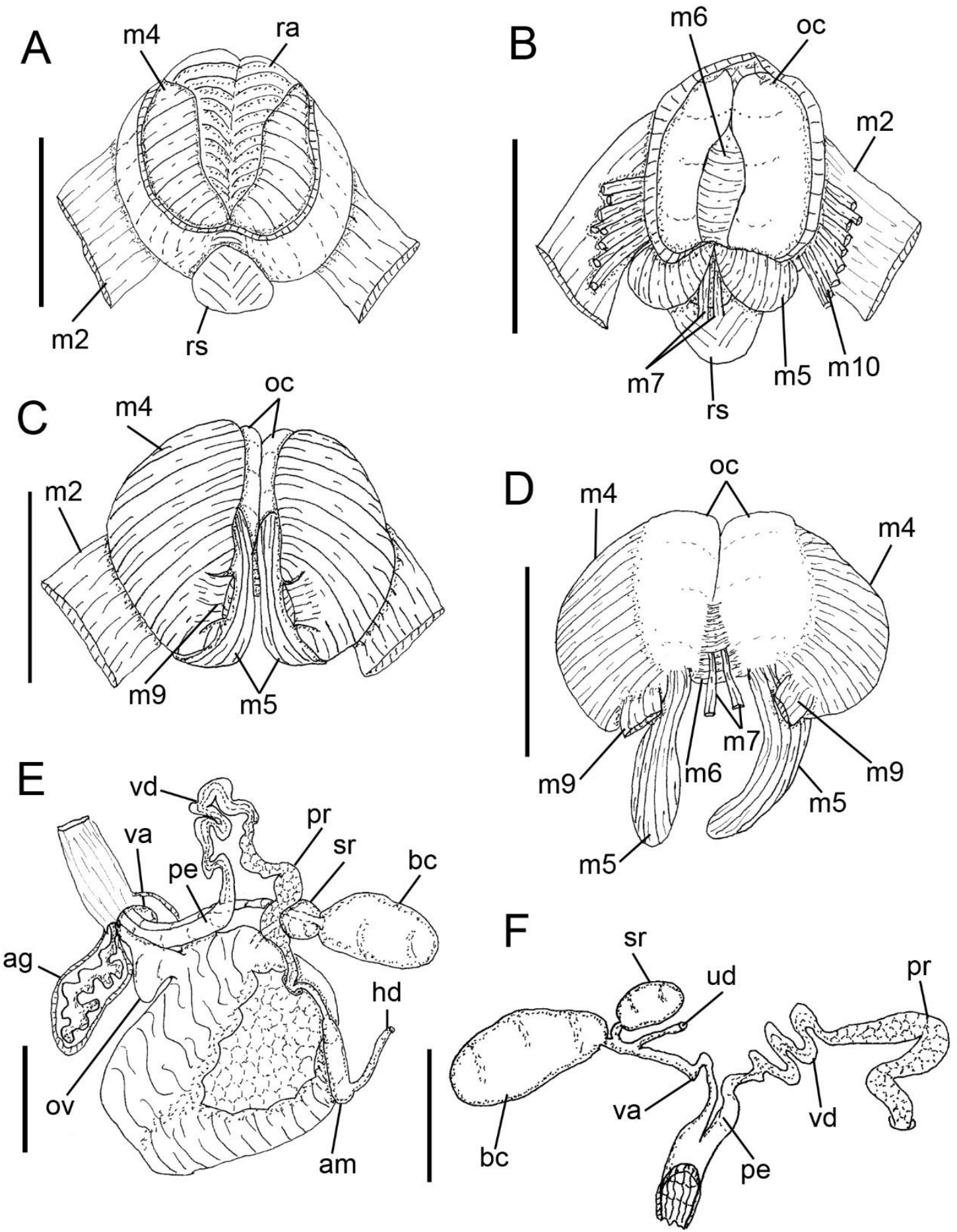

Figure 70: Tyrinna evelinae. Odontophore. A. Dorsal view with radula. B. Same, ventral view. C. Same, dorsal view with radula removed. D. Same, dorsal view with folded down muscles. Reproductive system. E. General view. F. Detail of aperture, vagina and penis. Scales: $1 \mathrm{~mm}$. 

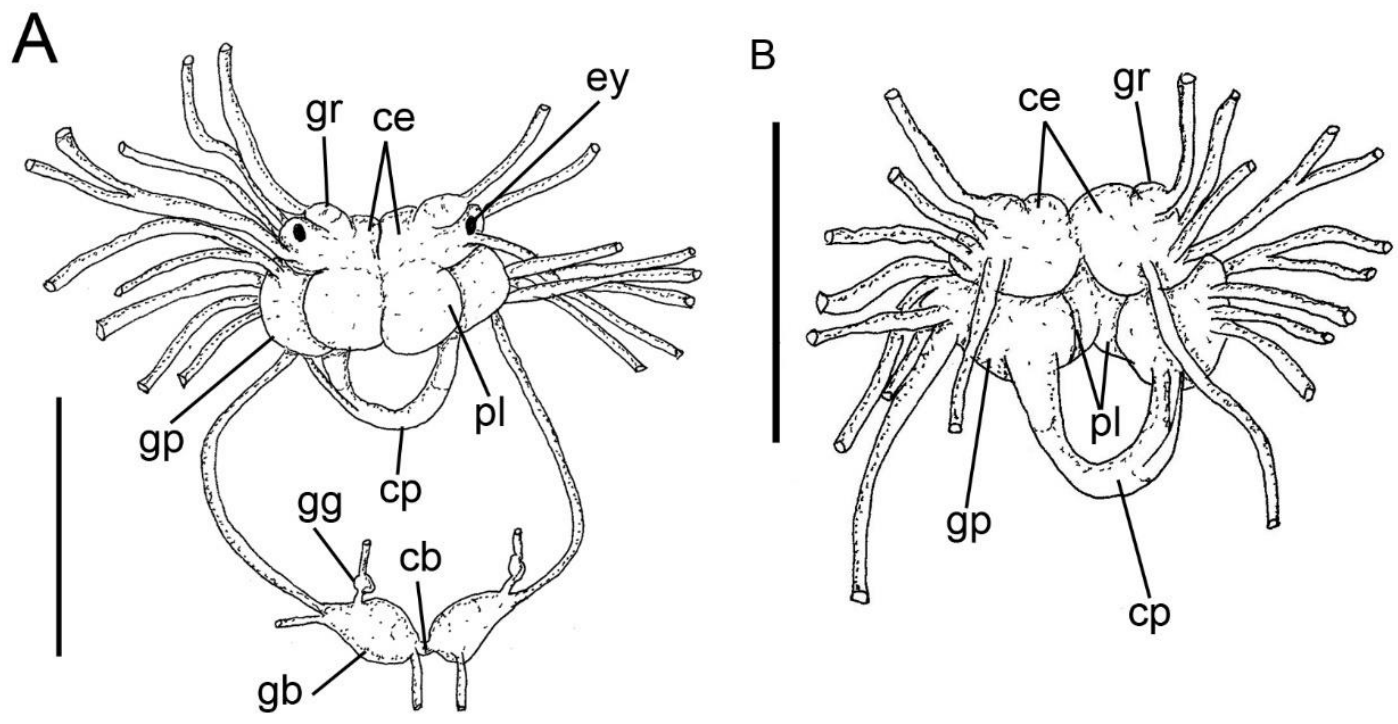

Figure 71: Tyrinna evelinae, Nervous system. A. Dorsal view, with buccal and gastroesophageal ganglia. B. Same, ventral view. Scales: $1 \mathrm{~mm}$.

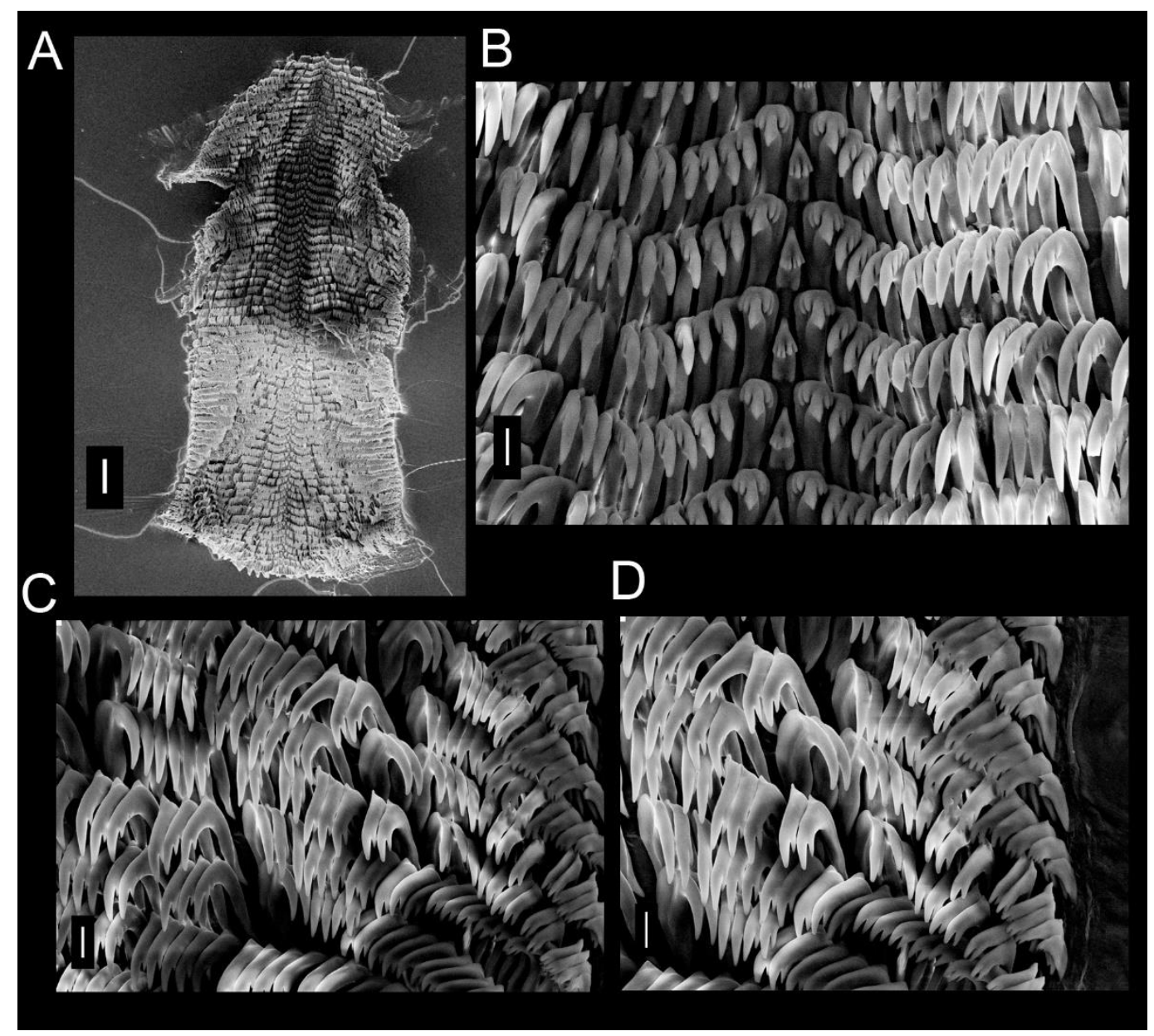

Figure 72: SEM of radula of Tyrinna evelinae. A. Panoramic view. Scale: $100 \mu \mathrm{m}$. B. Rachidian tooth. C. Inner lateral teeth. D. Outermost lateral teeth. Scales: $10 \mu \mathrm{m}$. 


\section{Family Cadlinidae Bergh, 1891}

\section{Genus Cadlina Bergh, 1879}

Type species: Cadlina leavis (Linnaeus, 1767)

\section{Cadlina rumia Er. Marcus, 1955}

(Figures 73-76)

Cadlina rumia Er. Marcus, 1955: see Rosenberg (2009); Rios, 2009: 424; Padula el al., 2012: 3; Sales et al., 2013: 689; Belmmonte et al., 2015: 193, fig. 8.

Type locality: São Sebastião, São Paulo, Brazil

\section{Redescription}

External morphology (Figures 73A-D): Size 10mm length, 5mm width. Color with with yellow spots. Body rounded (Fig. A, B). Rhinophores with about 8 transverse lamellae, color similar to body with brown apex; rhinophoral sheaths smooth (Fig. 73D). Gill composed of eigth unippinate branchial leaves, color similar to body, arranged in circular fashion surrounding anus; branchial sheaths smooth, color similar to body (Fig. 73C). Mouth opening in anterior ventral region, between anterior region of notum and foot. Lateral extensions of integument flattened, each one with lateral furrow up to their extensions. Anterior border of foot bilabiate (Fig. 73B).

Haemocoel organs (Figure 74A, B): pericardium and posterior half of visceral mass volume occupying $10 \%$ of haemocoel volume. Buccal mass located anteriorly, occupying $20 \%$ of haemocoel volume. Nervous system dorsal to buccal mass, covered by blood gland, occupying 5\% of haemocoel volume. Reproductive system on right side of animal; occupying $25 \%$ of haemocoel volume. Stomach, intestine and digestive gland occupying $40 \%$ of haemocoel volume.

Circulatory and excretory systems (Figure 74A, B): pericardial cavity dorsal and posterior to digestive gland. Blood gland undivided, dorsal to nervous system (Fig. 74A). Gill retractor muscle divided, originating from base of gill circle, running longitudinally up to half of foot level, inserting into dorsal surface of foot (Fig. 74B). Same pattern of anterior species vessels. Auricle funnel-like (wider anteriorly) with thin walls. Ventricle sligthly taller than wide, with thick muscular walls. Nephrostome difficult to see. 
Digestive system (Figures 73C; 74A, C-G; 75A; 76A-D): Oral tube composed of outer lip, with pleats lengthwise; inner lip with transverse fold (Fig. 74E); mt, two pairs of retractor muscles of buccal mass, originating on oral tube, running dorsally and ventrally to oral tube, inserting on body side, about six times as wide and twice as long as m10 (Fig.74E). Odontophore oval, connected to oral tube by pair of ventral protractor muscles (m10); thin longitudinal, ventrolateral protractors of oral sphincter, originating in anterior region of odontophore and inserted in posterior region of integument close to oral tube. Oral sphincter surrounding chitinous part of oral tube. Odontophore muscles: $\mathbf{m} 2$, pair of strong retractor muscles of buccal mass, occupying 2/9 of odontophore, four times longer than wide, divides in origin, running laterally to $\mathrm{m} 4$ and inserted ventrally on dorsal portion of foot (Fig. 74F, G); m4, pair of dorsal tensor muscles, strong and broad, $1 / 3$ as long as wide, covering $2 / 3$ of cartilage, inserted on ventral portion of subradular membrane (Fig. 75A); m5, pair of dorsal auxiliary tensor muscles, twice as long as wide, originating on most posterior region of odontophore cartilages, covering $\sim 1 / 3$ of posterior cavity of odontophore, as long as, but with $\sim 1 / 2$ of $\mathrm{m} 4$ width, inserting on ventral side of subradular membrane, around radular sac (Fig. 75A); m6, unpaired horizontal muscle, with transverse fibers connecting to median surface of left and right odontophore cartilages, about same length and half as wide as $\mathrm{m} 4$, posterior portion $\sim$ twice as wide as anterior portion; m7, not visualized. Pair of odontophore cartilages elliptical. Subradular membrane thin, strong, translucent. Radular sac $\sim 1 / 5$ as large as odontophore (Fig. 74G). Radular teeth (Fig. 76A-D): formula 64 x 20.1.1.1.20 (in $8 \mathrm{~mm}$ long specimen). Rachidian teeth with 6-7 parallel teeth, two central more longer than rest. First lateral tooth with two inner cusps followed by big one cusp and five outer. Following lateral teeth only with big tooth and seven to six cusps. Pair of salivary glands long, tubular and thin; duct inserting in anterior region of esophagus, extending posteriorly to anterior region of digestive gland (Fig. 74C, D). Esophagus simple, originating dorsally to odontophore, inserting directly in anterior region of stomach, internal longitudinal folds with same diameter along entire length (Fig. 74D). Stomach shorth and central to digestive gland (Fig. 74A). Common opening for esophagus and stomach located on digestive gland. Intestine with longitudinal folds along its entire length, diameter about half esophagus diameter. Caecum not visualized. Digestive gland dark beige, rounded, inner face of gland sponge-like (Fig. 74A). Anus opening into anal papilla at center of gill circle, $\sim 1 / 2$ of gill filament length (Fig. 73C). 
Genital system (Figure 75B): located between buccal mass and digestive gland, mainly on right side and dorsally. Genital opening on right side, anterior third of length of animal from head, located between foot and notum. Gonad immersed in digestive gland, but easy to distinguish it. Hermaphrodite duct thin, long. Ampulla located on female gland, elongated and tubular. Prostate tubular, glandular, ten times longer than ampulla. Vas deferens about same length and half width as prostate. Penis' muscle absent. Penis muscular, cylindrical and elongated, about 1/10 of length and twice as wide of prostate. Female gland well-developed, rounded, occupying $20 \%$ of reproductive system volume, divided into mucus gland ( $2 / 3$ of female gland, color beige), and albumen gland ( $\sim 1 / 3$ of anteriormost region, dilated, irregularly shaped, color dark brown). Oviduct occupying $\sim 1 / 7$ of female gland volume. Uterine duct thin, relatively short, length $\sim 1 / 6$ of vagina length, located at base of seminal receptacle, inserted in female gland near oviduct. Seminal receptacle pyriform, as large and wide as bursa copulatrix, connected to vagina through long stalk. Bursa copulatrix rounded, length $\sim 1 / 5$ of vagina length, connected to vagina before seminal receptacle, also through short stalk. Vagina cylindrical, elongated, approximately as long and wide as penis, followed ventrally by prostate and located parallel to penis in genital opening.

Nervous system (Figure 75C-E): located dorsally to odontophore, mostly covered by blood gland. Pair of cerebral and pleural ganglia fused with each other dorsally and ventrally. Pedal ganglia fused with cerebral and pleural ventrally, but not fused among themselves. Pedal commissure triple and short, surrounding esophagus and salivary glands (Fig. 75D). Buccal ganglia short, located ventrally to odontophore, between radular sac and anterior portion of esophagus, connected to cerebral ganglia through long and slender connective tissue, united to gastro-esophageal ganglia by short connective tissue. Gastro-esophageal ganglia length about 1/4 of buccal ganglia length, circular (Fig. 75E). Rhinophoral (olfactory) ganglia bulb-shaped, connected to anterior portion of cerebral ganglia. Dorsal eyes located on cerebral ganglia (Fig. 75C).

Distribution: Flórida (USA) to São Paulo (Brazil)

Habitat: On intertidal rocks.

Material examined: Brazil, Ilha Itaçucê, Ilha Bela, São Paulo, MZSP 103272, 10 specimens (C.M. Cunha, P. Oristanio \& J.C. Garcia, 20/i/2012, 1-7m depth, under rocks); Ilha das Cabras, MZSP 103318, 1 specimen (Y. Tibiriçá, coll., 22/i/2012, intertidal, under rocks); Praia do Segredo, Pedra da Baleia, São Sebastião, São Paulo, MZSP 103303, 1 specimen (L.S. Tocino, coll., 21/i/2012, intertidal). 

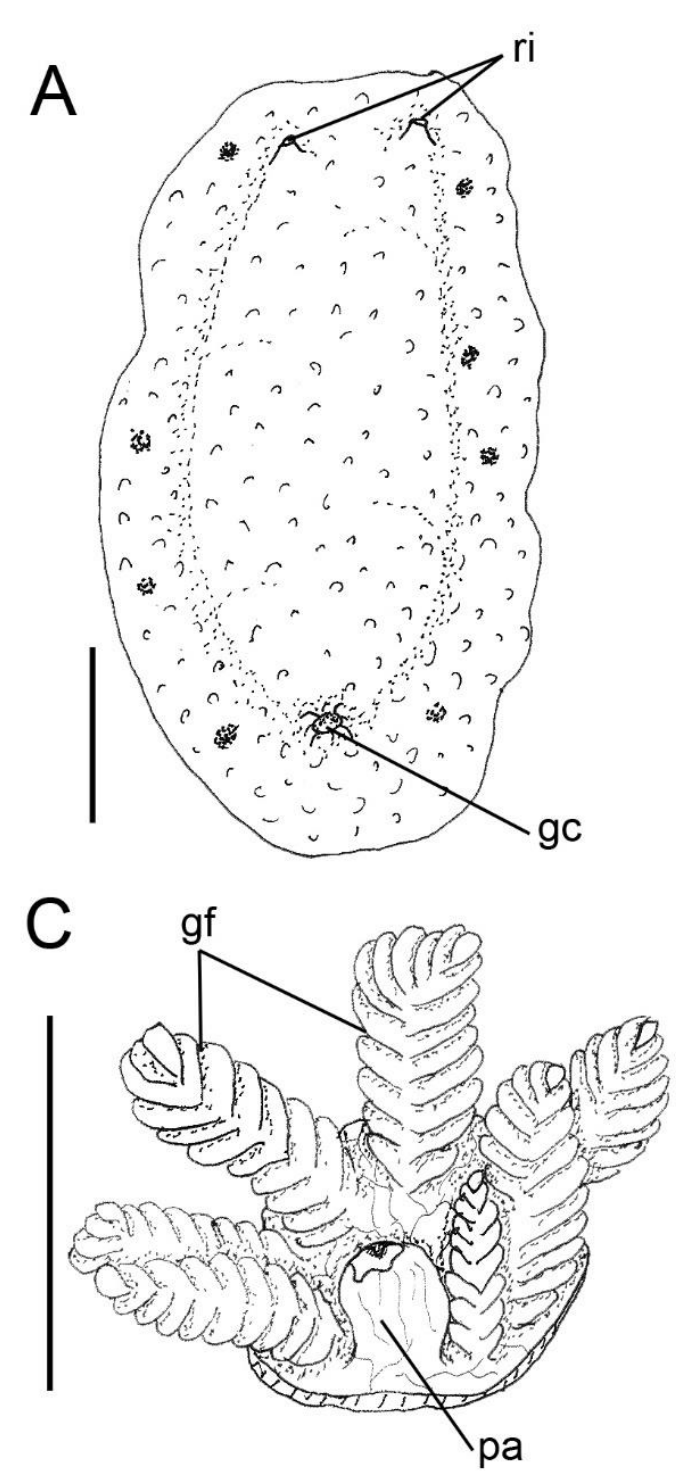
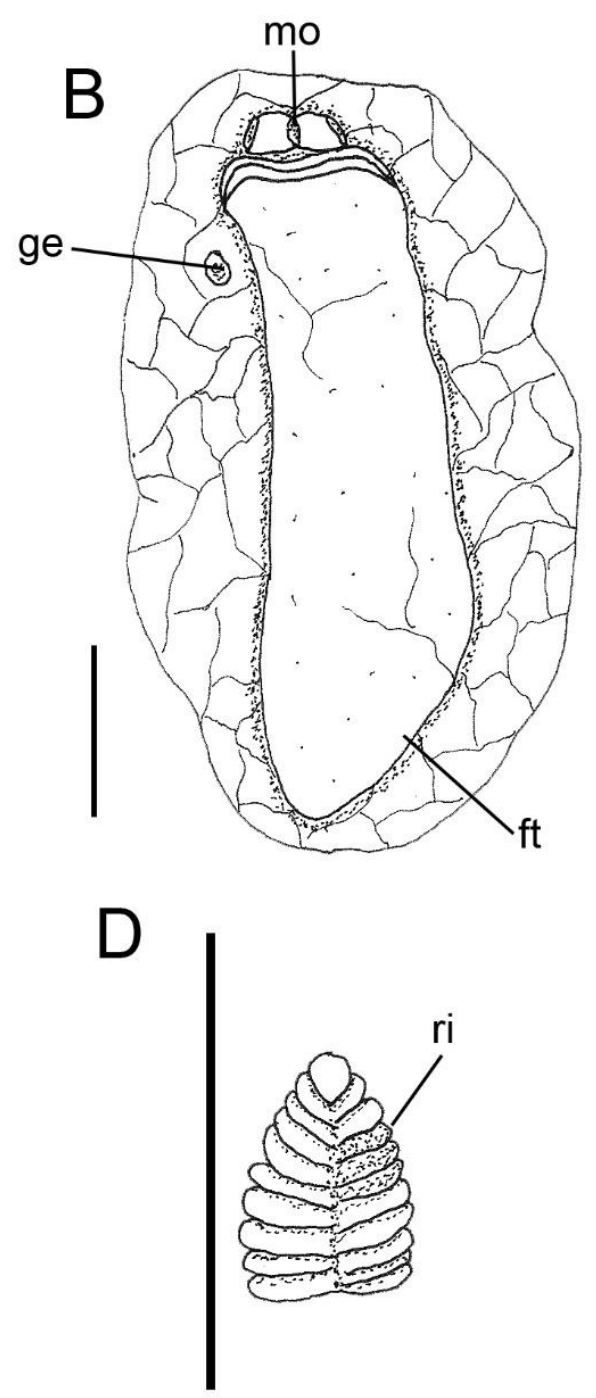

Figure 73: Cadlina rumia, fixed animal. A. Dorsal view. B. Same, ventral view. Scales: $2 \mathrm{~mm}$. C. Gill circle. D. Rhinophore. Scales: $1 \mathrm{~mm}$. 

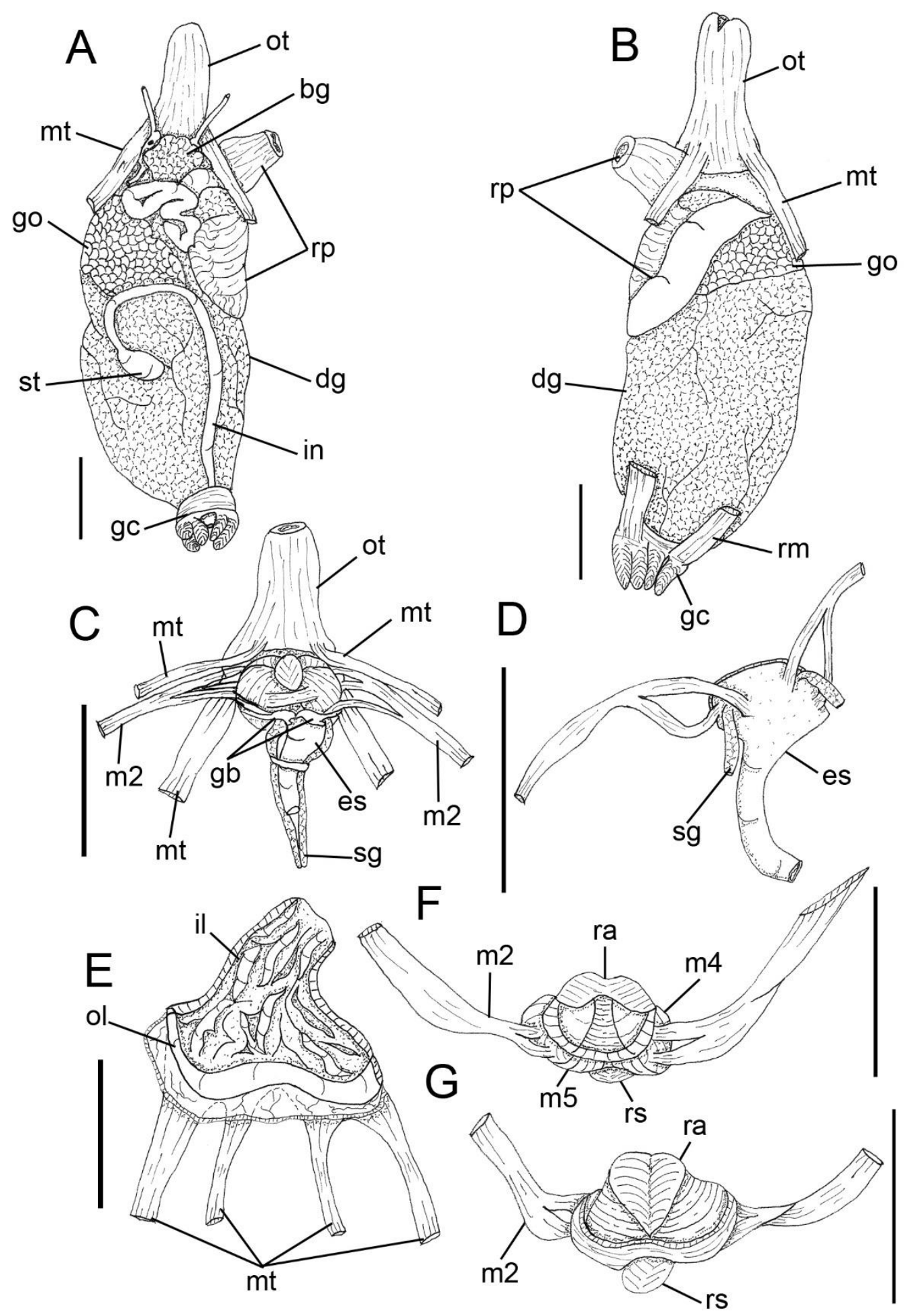

Figure 74: Cadlina rumia. Visceral mass. A. Dorsal view. B. Same, ventral view. Anterior digestive system. C. Ventra view. D. Detail of origin of salivary glands. E. Oral tube, longitudinally sectioned. Odontophore. F. Ventral view. G. Same, dorsal view, with radula. 


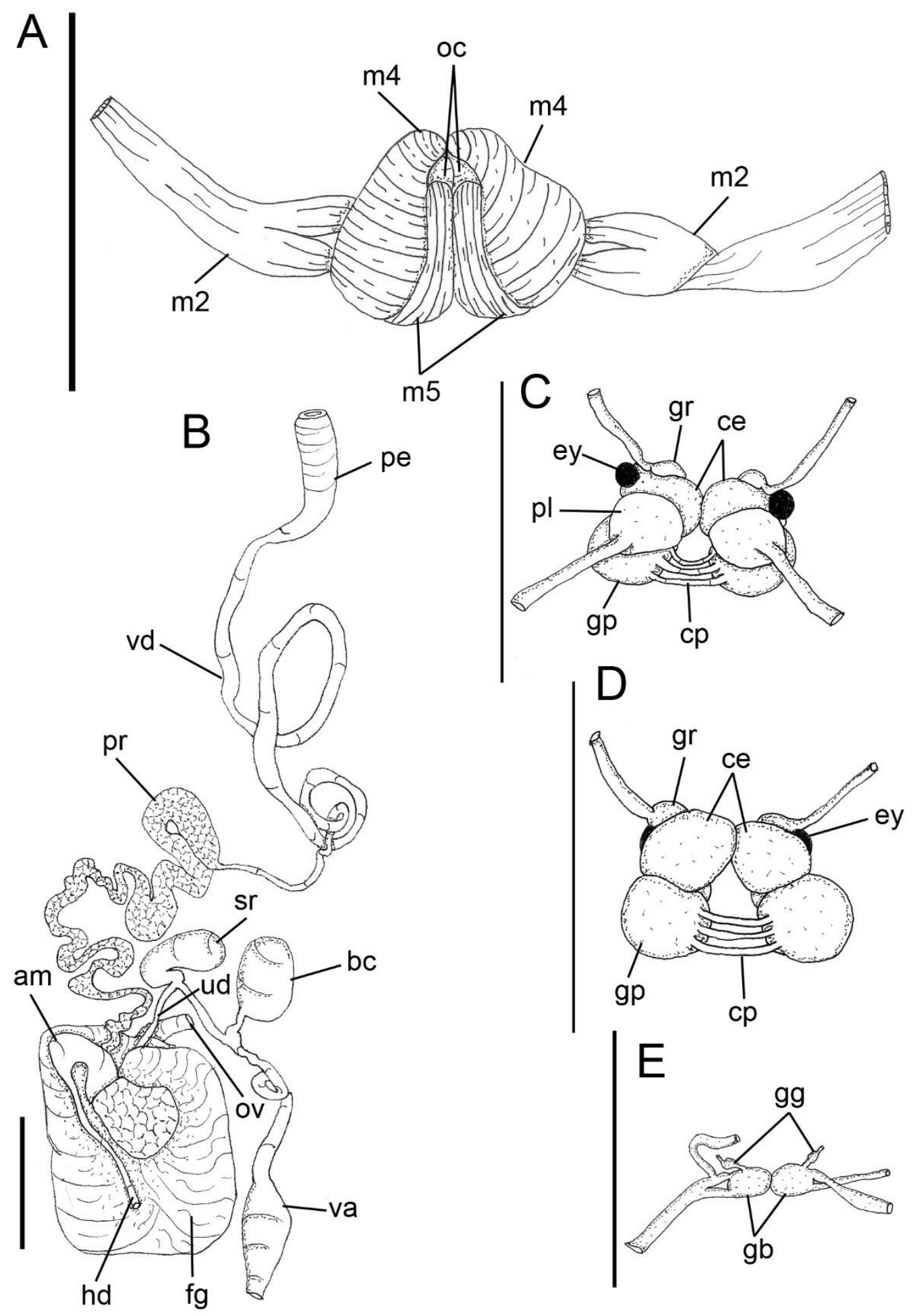

Figure 75: Cadlina rumia. A. Dorsal view of odontophore with radula removed. B. Reproductive system, dorsal view. Nervous system. C. Dorsal view. D. Same, ventral view. E. Buccal and gastroesophageal ganglia. 


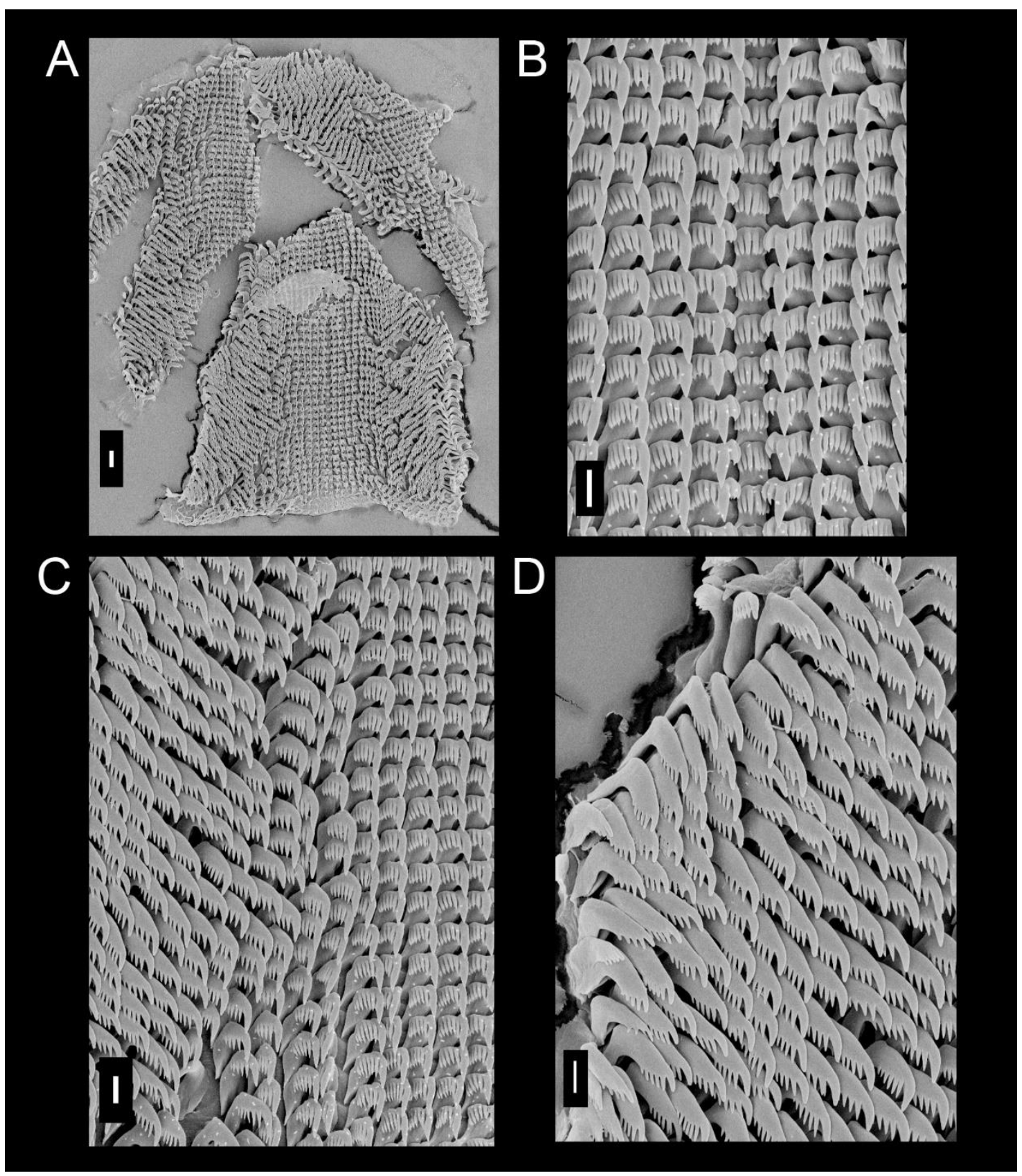

Figure 76: SEM of radula of Cadlina rumia. A. Panoramic view. Scale: $30 \mu \mathrm{m}$. B. Rachidian tooth. C. Lateral teeth. D. Marginal teeth. Scales: $10 \mu \mathrm{m}$.

Family Actinocyclidae O’Donoghue, 1929

\section{Genus Actinocyclus Ehrenberg, 1831}

Type species: Actinocyclus verrucosus Ehrenberg, 1831, by subsequent designation of J.

E. Gray (1847) 


\section{Actiocyclus verrucosus Ehrenberg, 1831}

(Figures 77-81)

Actinocyclus verrucosus Ehrenberg, 1831: 28.

Spaherodoris punctata Bergh, 1877a: 66; Bergh, 1878: 587, pl. 65, figs. 1-5.

Spaherodoris laevis Bergh, 1890: 925, pl. 88, figs. 3-12.

Spaherodoris japonica Eliot, 1913: 23.

Aldisa nhatrangensis Risbec, 1956: 14, pl. 20, fig. 109, pl. 22, upper right figure.

Type locality: Virgin Islands (Danish Antilles)

\section{Redescription}

External morphology (Figures 77A-D; 78A-E): Size 20mm length, 14mm width, $3 \mathrm{~mm}$ width foot/notum. Color grayish with some black dots. Body rounded, oval almost as long as wide (Figs. 77A, B). Rhinophores with about 17 transverse lamellae (Figs.); rhinophoral sheaths smooth (Fig. A-C). Gill circle composed of 16-19 unipinnate branchial leaves, arranged in circular fashion surrounding anus; branchial sheaths smooth (Fig. 78D, E). Mouth opening in anterior ventral region, between anterior region of notum and foot (Fig. 77D). Digitiform tentacles present (Fig. 77D). Anterior border of foot concave shape not grooved or notched (Fig. 77D). Foot does not exceed the notum (Fig. 77B).

Haemocoel organs (Figure 78G, H.): pericardium and posterior half of visceral mass volume occupying $40 \%$ of haemocoel. Buccal mass located anteriorly, occupying $20 \%$ of haemocoel volume. Nervous system dorsal to buccal mass, covered by blood gland, occupying $10 \%$ of haemocoel volume. Reproductive system on right side of animal; occupying $20 \%$ of haemocoel volume. Stomach internal to digestive gland, intestine with small curve at anterior portion, both occupying $10 \%$ of haemocoel volume.

Circulatory and excretory systems (Figure 78D-G): pericardial cavity dorsal and posterior to digestive gland, anterior to gill circle (Fig. 78G). Afferent and efferent vein located inside each gill filament (Fig. 78E). Retractor muscle gill divided in two fibers originating from base of gill circle, running longitudinally up to half of foot level, inserting into dorsal surface of foot (Fig.78D). Auricle funnel-like (wider anteriorly) with thin walls. Ventricle sligthly taller than wide, with thick muscular walls (Fig. 78F). Aortic trunk anterior to pericardium, connected to anterior ventricular region, branched into anterior artery irrigating stomach, caecum and digestive gland; posterior artery irrigating reproductive system, buccal mass, odontophore and nervous system inserting on blood 
gland. Auricular vessels connecting lateral cavities of integument to auricle. Medial sinus connected to afferent branchial ring, irrigating entire digestive gland. Renal vesicle located on right dorsal side of pericardium, near base of auricle, connected to inner surface of pericardium; renal chamber elliptical, with longitudinal folds, 1/4 of size of ventricle (Fig. 78F). Renal chamber extending from dorsal to medial sinus, previously connected to renal vesicle, extending posteriorly to center of gill circle and opening in nephrostome, next to anus pore (Fig. 78D). Blood gland undivided (Fig. 78G).

Digestive system (Figure 78D; 79A-J; 81A-D): Oral tube composed of outer lip with pleats lengthwise and inner lip with transverse fold (Fig. 79C); mt, two pairs of retractor muscles of buccal mass, originating on oral tube, running dorsally and ventrally to oral tube, inserting on body side, about three times as wide and twice as long as $\mathrm{m} 10$ (Fig. 79A, B). Odontophore oval, connected to oral tube by several fine ventral protractor muscles (m10); thin longitudinal, dorsal and ventrolateral protractors of oral sphincter, originating in anterior region of odontophore and inserted in posterior region of integument close to oral tube. Buccal sphincter surrounding chitinous part of oral tube. Odontophore muscles: $\mathbf{m} \mathbf{2}$, pair of strong retractor muscles of buccal mass, six time longer than wide, origin on anterior dorsal odontophore, running laterally to $\mathrm{m} 4$ and inserted ventrally on dorsal portion of foot (Fig. 79C, E, F); m3, transversal fibers between esophagus and odontophore (Fig. 79C, D); m4, pair of dorsal tensor muscles, strong and broad, 1/2 winder than long, covering $2 / 3$ of cartilage, inserted on ventral portion of subradular membrane (Fig. 79E, G, H); m5, pair of dorsal auxiliary tensor muscles, twice as long as wide, originating on most posterior region of odontophore cartilages, covering $\sim 1 / 3$ of posterior cavity of odontophore, as long as, but with $\sim 1 / 3$ of m4 width, inserting on ventral side of subradular membrane, around radular sac (Fig. 79E, $\mathrm{G}, \mathrm{H}$ ); m6, unpaired horizontal muscle, with transverse fibers connecting to anterior surface of left and right odontophore cartilages, as long as wide, about same length and half as wide as m4 (Fig. 79H); m7, pair of thin muscles originating each into an odontophore cartilages and inserting on $\mathrm{m} 7$ a passing ventrally by $\mathrm{m} 5$, and on radular sac (Fig. 79G, H); m7a, originating on posterior region of odontophore cartilage and inserting on radular sac (Fig. 79H). Pair of odontophore cartilages slender elliptical (Fig. 79G). Subradular membrane thin, strong, translucent. Radular sac $\sim 1 / 6$ of odontophore. Radular teeth (Figs. 81A-D): rachidian teeth absent; formula $50 \times 17.0 .17$ (in $20 \mathrm{~mm}$ long specimen). Innermost lateral teeth broad and thick, with large and rounded apex and about eigth cusps along inner edge. Mid-lateral teeth narrow basally and elongated, with apical 
cusp larger than other eighteen lateral cusps. Outermost teeth shorter than middles laterals. Pair of salivary glands long, tubular; duct inserting in anterior region of esophagus, extending posteriorly to anterior region of digestive gland (Fig. 79B). Esophagus simple, originating dorsally to odontophore, inserting directly in anterior region of stomach, internal longitudinal folds with same diameter along entire length (Fig. 79A-D). Stomach oval, with folds at the center of entire inner surface; longitudinal pleats thicker posteriorly, close to anterior region of intestine (Fig. 79I, J). Common opening for esophagus, stomach and caecum located on digestive gland (Fig. 79I). Intestine with longitudinal folds along its entire length, diameter same esophagus diameter. Caecum as an elongated sac, located ventrally to stomach, opening on anterior portion of stomach, close to esophageal insertion, $\sim 1 / 2$ length and $\sim 1 / 2$ of width of stomach (Fig. 79I, J). Digestive gland dark brown, internal to gonad, cone-shaped; inner face of gland spongelike, bearing three ducts (Fig. 79I). Anus opening into pore at center of gill circle (Fig. 78D).

Genital system (Figures 77B; 78G, H; 79I; 80A-C): located between buccal mass and digestive gland, mainly on right side and dorsally (Fig. 78G, H). Gonopore on right side, anterior fifth of length of animal from head, located between foot and notum (Fig. 77B). Gonad around digestive gland, dark beige color (Fig.79I). Hermaphrodite duct thin, long located at bases of ampulla (Fig. 80B). Ampulla located on female gland, elongated and tubular. Prostate glandular connected with female gland. Vas deferens and penis muscular, cylindrical and elongated (Fig. 80B). Female gland well-developed, rounded, occupying $\sim 40 \%$ of reproductive system volume, divided into mucus gland and albumen gland ( $\sim 1 / 3$ of anteriormost region, dilated, irregularly shaped, color dark brown) (Fig. 80A, B). Oviduct occupying 1/3 of female gland volume (Fig.80B). Uterine duct located at base of vagina, inserted in female gland near oviduct, relatively short, length $\sim 1 / 10$ of vagina length and same diameter of vagina (Fig. 80C). Seminal receptacle pyriform, as large as bursa copulatrix, connected to vagina near uterine duct through short stalk. Bursa copulatrix rounded, connected to vagina after seminal receptacle, length $\sim 1 / 6$ of vagina length, also through stalk three times longer than uterine duct. Vagina cylindrical, elongated, same width and four times longer than penis, followed ventrally by prostate and located parallel to penis on gonopore (Fig.90C).

Nervous system (Figure 80D-F): located dorsally to odontophore, mostly covered by blood gland. Pair of cerebral and pleural ganglia fused with each other dorsally and ventrally. Pedal ganglia fused with cerebral and pleural ventrally, but not fused among 
themselves, connected by long and thin pleural commissure (Fig. 80D). Pedal commissure simple, $1 / 2$ of length of pleural commissure, both surrounding esophagus and salivary glands (Fig. 80E). Buccal ganglia short, located ventrally to odontophore, between radular sac and anterior portion of esophagus, connected to cerebral ganglia through long and slender connective tissue, united to gastro-esophageal ganglia by short connective tissue. Gastro-esophageal ganglia length about 1/4 of buccal ganglia length, circular (Fig. 80F). Rhinophoral ganglia bulb-shaped, connected to anterior portion of cerebral ganglia. Dorsal eyes located on cerebral ganglia with short optical nerve (Fig. 80D).

Distribution: Indo Pacific (Ehrenberg, 1831 (Red Sea); Bergh, 1878 (Philippines), 1890 (Indonesia); Eliot, 1904 (East Africa and Malaysia), 1913 (Japan); Ribesc, 1956 (Vietnam); Kay \& Young, 1969 (Hawaii); Willan \& Coleman, 1984 (Queensland); Wells \& Bryce, 1993 (Western Australia); Valdés, 2002 (Madagascar and Marshall Island).

Material examined: AUSTRALIA, Coral Sea, North East Herald Cay, AUS 333868.001, 2 specimens (M. Preker, coll., 24/vi/1997, beachrock, SE side of cay, LT at dusk); Vanuatu, Espiritu Santo Island, Palikulo Peninsula (15.00 28.90' 'S $167.00^{\circ}$ 15.50' ' E), CAS 179791, 1 specimen (M. Pola-Perez, Y. Camacho-Garcia et al. Coll., 15/ix/2006, intertidal, soft bottom). 


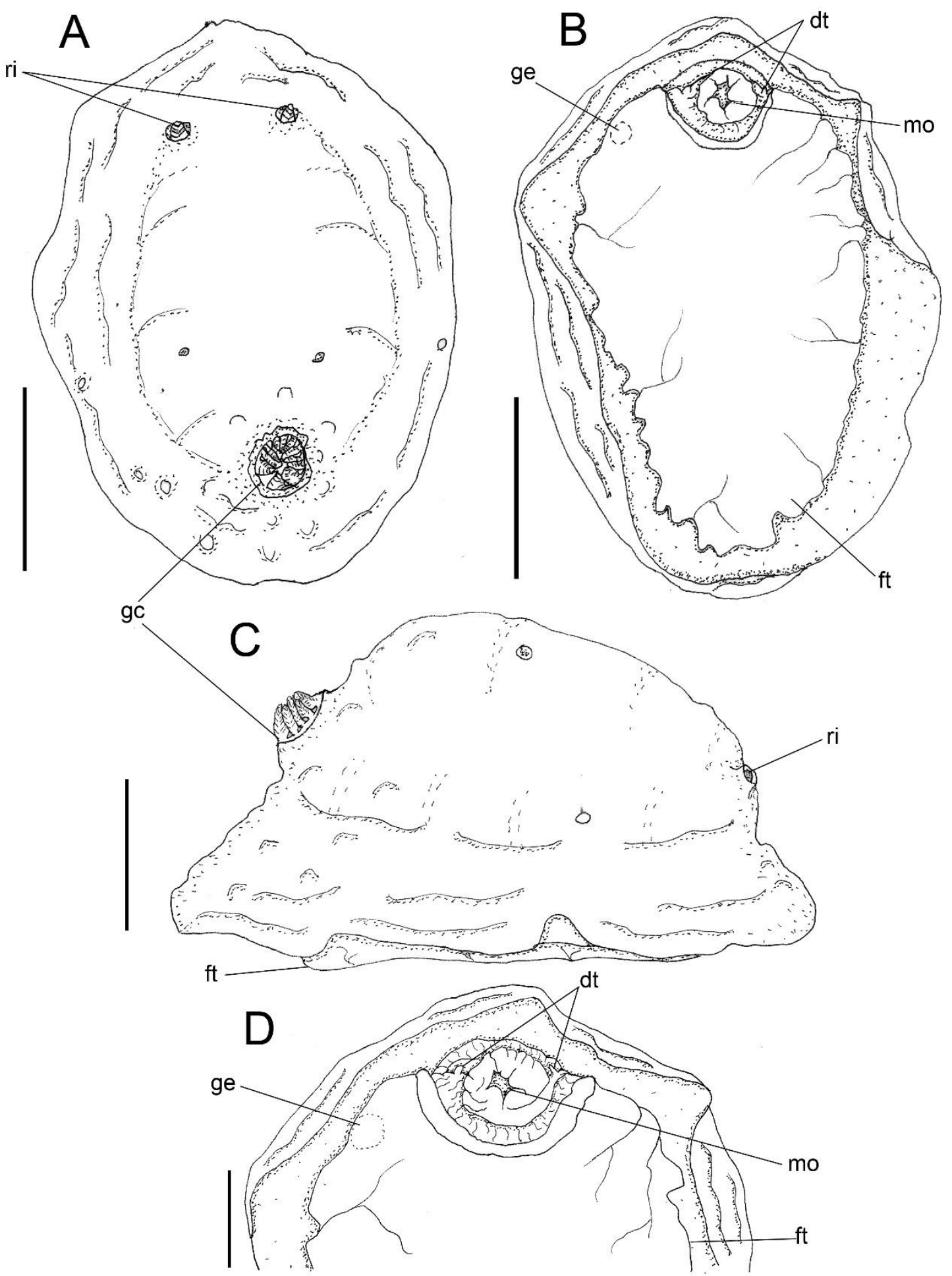

Figure 77: Actinocyclus verrucosus, fixed animal. A. Dorsal view. B. Same, ventral view. C. Same, right lateral view. Scales: $5 \mathrm{~mm}$. D. Anterior border of foot. Scale: $2 \mathrm{~mm}$. 

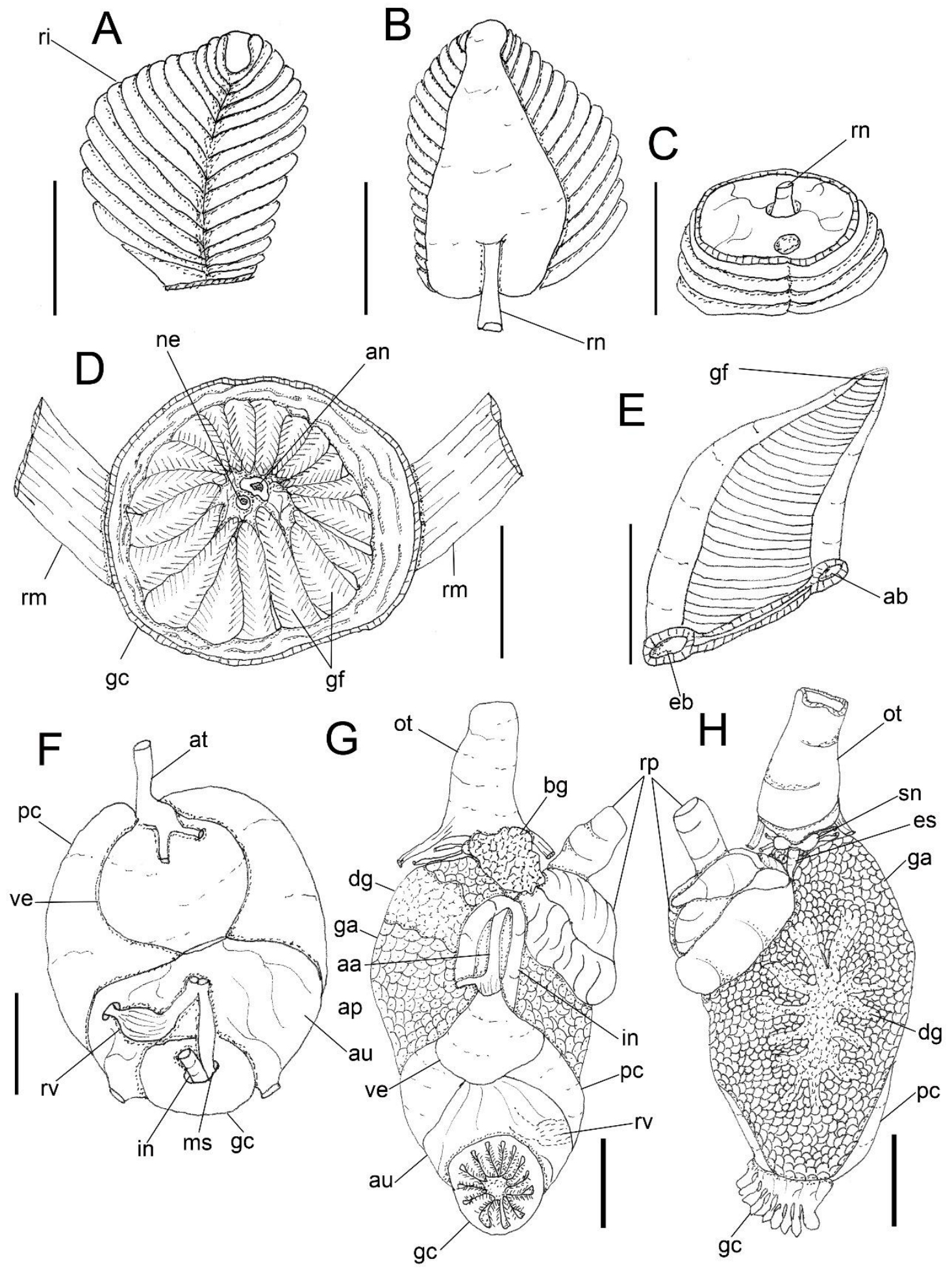

Figure 78: Actinocyclus verrucosus. Detaisl of Rhinophore. A. Anterior view. B. Posterior view. C. Transversal section, detail of rhiniphoral nerve. D. Gill circle. E. Gill filament, afferent and efferent branchial rings. Scales: $1 \mathrm{~mm}$. F. Circulatory and excretory system, ventral view. Visceral mass. G. Dorsal view. H. Same, ventral view. Scales: $2 \mathrm{~mm}$. 


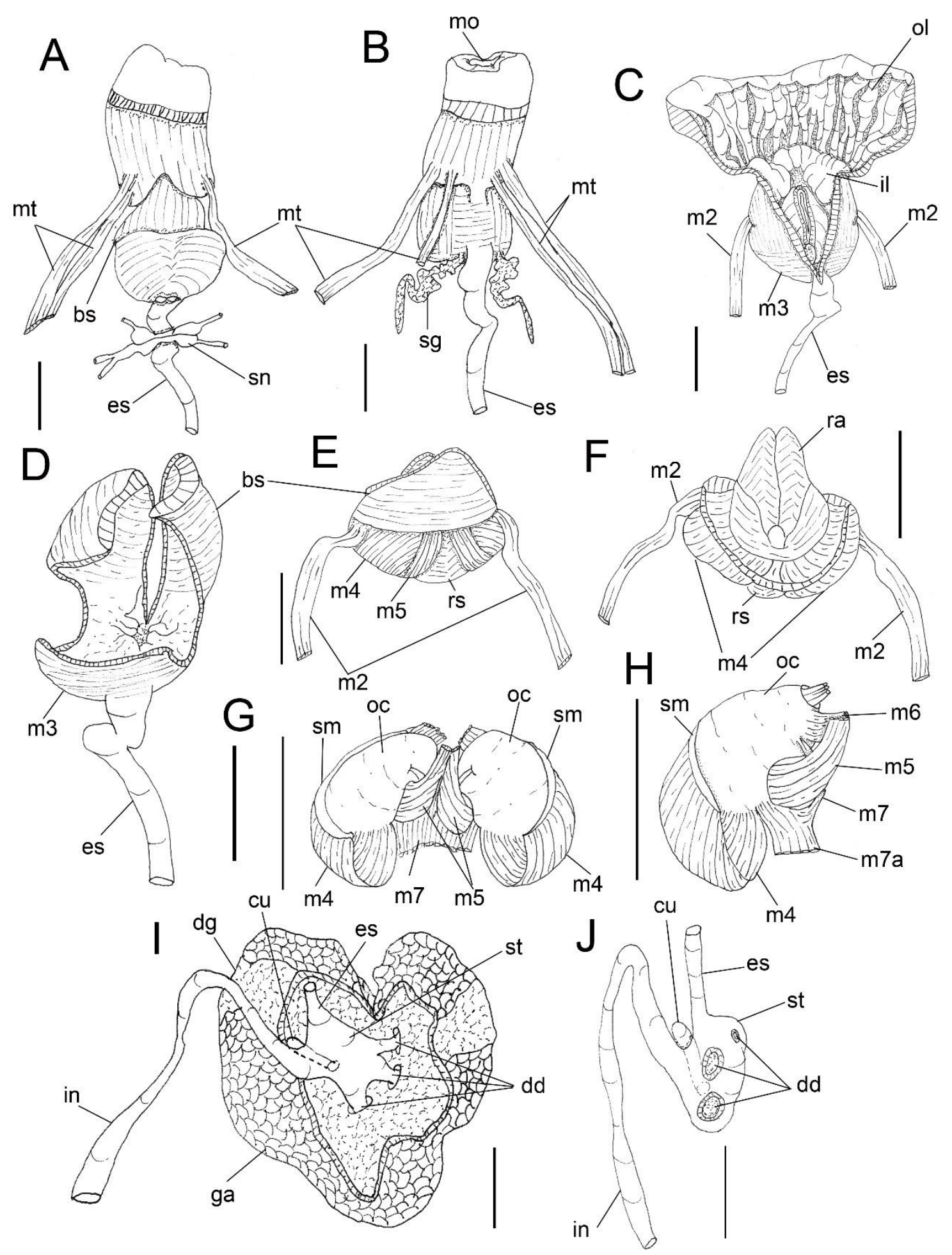

Figure 79: Actinocyclus verrucosus. Anterior digestive system. A. Dorsal view. B. Same, ventral view. C. Logiitudinally sectioned of oral tube. D. Detail of buccal sphincter. Odontophore. E. Ventral view. F. Same, dorsal view with radula. G. Same, dorsal view with radula removed. H. Same, lateral view. Scales: $1 \mathrm{~mm}$. I. Median digestive system, detail of ducts of digestive gland. J. Same, with digestive gland removed. Scales: $2 \mathrm{~mm}$. 


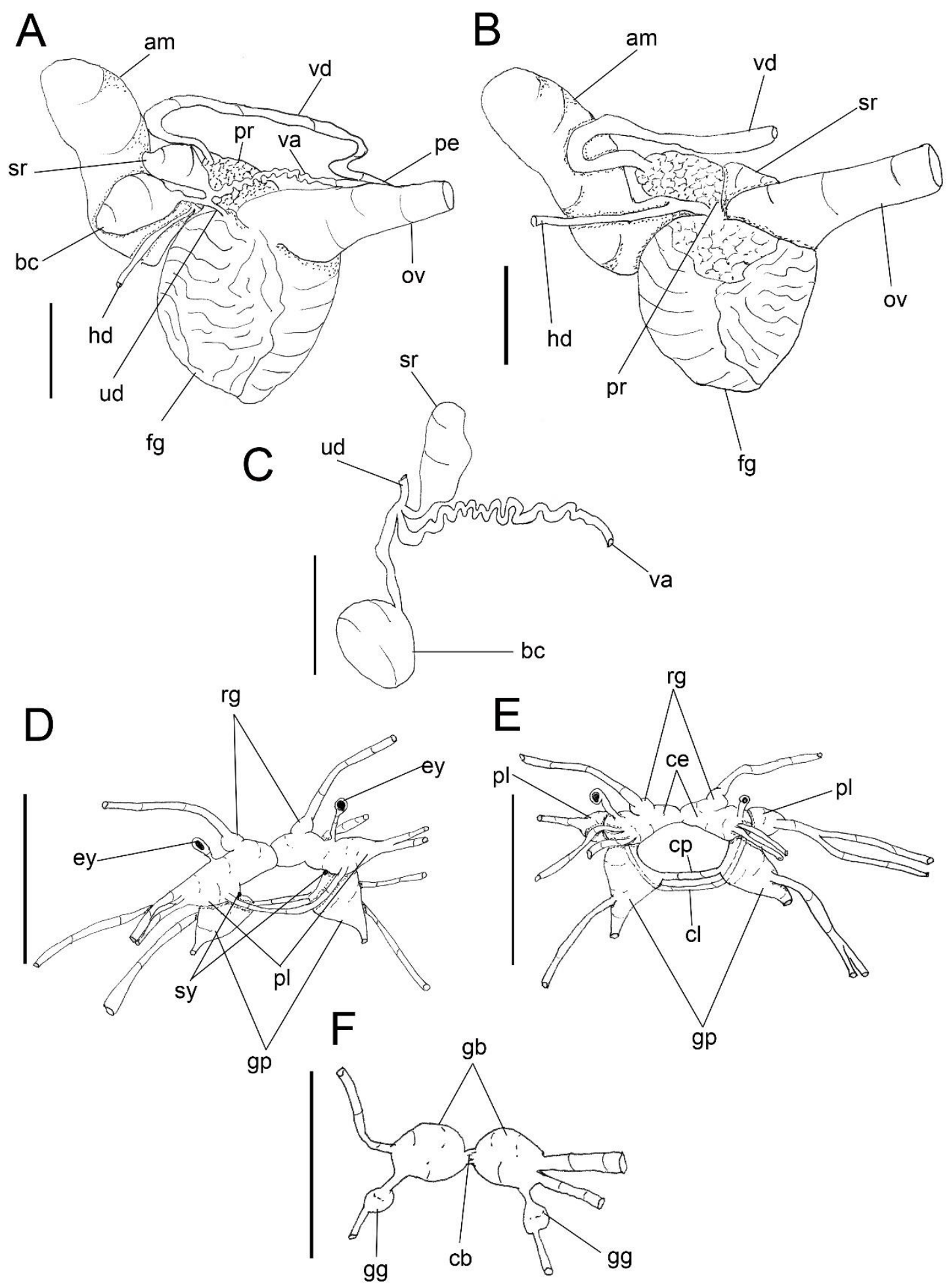

Figure 80: Actinocyclus verrucosus. Reproductive system. A. Dorsal view. B. Same, ventral view. C. Detail of bursa copulatrix, seminal receptacle and vagina. Nervous system. D. Dorsal view. E. Same, ventral view. F. Buccal and gastroesophageal ganglia. Scales: $1 \mathrm{~mm}$. 


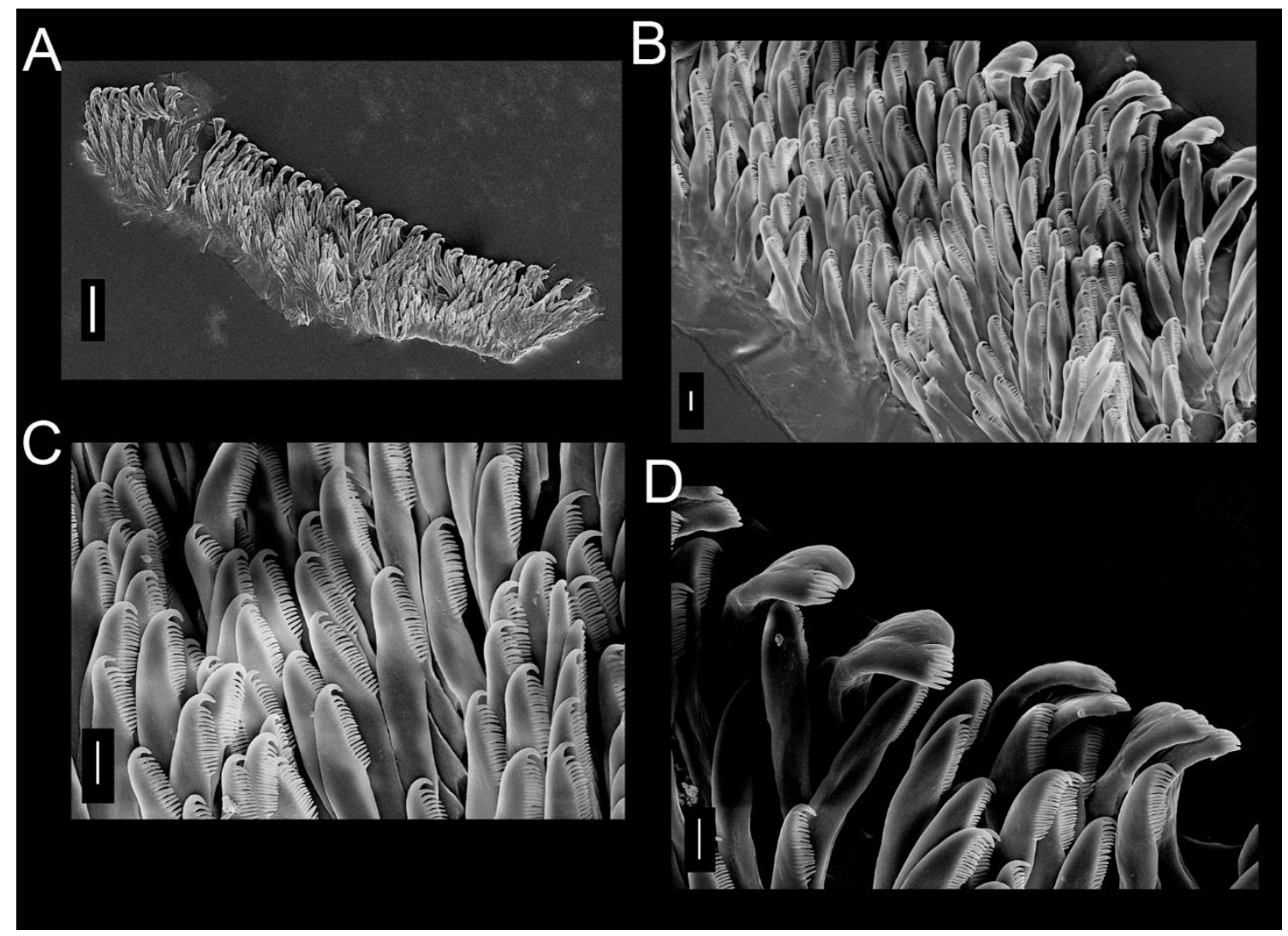

Figure 81: SEM of radula of Actinocyculs verrucosus. A. Panoramic view. Scale: $100 \mu \mathrm{m}$. B. Lateral teeth. C. Detail of lateral teeth. D. Detail of marginal tooth. Scales: $10 \mu \mathrm{m}$.

\section{Family Discodorididae}

\section{Genus Discodoris Bergh, 1877}

Type species: Discodoris boholiensis Bergh, 1877, by subsequent designation by O’Donoghue (1926)

\section{Discodoris boholiensis Bergh, 1877}

(Figures 82-85)

Synonymic list see Dayrat, 2010

Type locality: Philippines

\section{Redescription}

External morphology (Figures 82A-E): Size 7mm length and 5mm width. Color white with brown spots. Body rounded covered by small tubercles (Fig. 82A, B. 
Rhinophores with about 21 transverse lamellae, color brown with white lines; rhinophoral sheaths with small tubercles (Fig. 82D). Gill composed of five bipinnate branchial leaves, color similar to rhinophores, arranged in circular fashion surrounding anus; branchial sheaths with small tubercles, color similar to body (Fig. 82A, E). Mouth opening in anterior ventral region, between anterior region of notum and foot. Digitiform tentacles present. Anterior border of foot bilabiate and with longitudinal groove (Fig. 82C).

Haemocoel organs: pericardium and posterior half of visceral mass volume occupying $15 \%$ of haemocoel volume. Buccal mass located anteriorly, occupying $10 \%$ of haemocoel volume. Nervous system dorsal to buccal mass, covered by blood gland, occupying $5 \%$ of haemocoel volume. Reproductive system on middle/right side of animal, occupying $30 \%$ of haemocoel volume. Stomach, intestine and digestive gland occupying $40 \%$ of haemocoel volume.

Circulatory and excretory systems (Figure 82A; 83A): pericardial cavity dorsal and posterior to digestive gland, anterior to gill circle. Afferent and efferent branches located inside each gill filament, flowing from and to afferent and efferent branchial veins. Gill retractor muscle seems to be divided. Auricle funnel-like (wider anteriorly) with thin walls. Ventricle sligthly taller than wide, with thick muscular walls. Same pattern of Doridoidea vessels. Aortic trunk branched very close to ventricle into posterior artery irrigating stomach, caecum and digestive gland; anterior artery irrigating reproductive system, buccal mass, odontophore and nervous system. Renal vesicle located on right dorsal side of pericardium, near base of auricle, connected to inner surface of pericardium, 1/3 the size of ventricle (Fig. 83A). Renal chamber extending from dorsal to medial sinus, previously connected to renal vesicle, extending posteriorly to center of gill circle and opening in nephrostome, in a pore, next to base of anal papilla (Fig. 82A).

Digestive system (Figures 82A, D; 83B-D; 84A-D; Fig. 85A-D): Oral tube composed of outer lip without pleats and inner lip with transverse fold; mt, three pairs of retractor muscles of buccal mass, originating on oral tube, running dorsally and ventrally to oral tube, inserting on body side, about four times as wide and same as long as m10 (Fig. 83B, C). Odontophore oval, connected to oral tube by pair of ventral protractor muscles (m10); thin longitudinal, ventrolateral protractors of oral sphincter, originating in anterior region of odontophore and inserted in posterior region of integument close to oral tube (Fig. 83C). Oral sphincter surrounding chitinous part of oral tube (Fig. 83B). Odontophore muscles: $\mathbf{m} \mathbf{2}$, pair of strong retractor muscles of buccal mass, as wide as 
long, origin on anterior dorsal odontophore, running laterally to $\mathrm{m} 4$ and inserted ventrally on dorsal portion of foot (Fig.83B, C; 84A-C); $\mathbf{m 4}$, pair of dorsal tensor muscles, strong and broad, 1/2 as long as wide, covering $2 / 3$ of cartilage, inserted on ventral portion of subradular membrane (Fig. 84C, D); m5, pair of dorsal auxiliary tensor muscles, three times as long as wide, originating on most posterior region of odontophore cartilages, covering $\sim 1 / 3$ of posterior cavity of odontophore, as long as, but with $\sim 1 / 3$ of m 4 width, inserting on ventral side of subradular membrane, around radular sac (Fig. 84C, D); m6, unpaired horizontal muscle, with transverse fibers connecting to inner surface of left and right odontophore cartilages, about same length and $1 / 3$ as wide as $\mathrm{m} 4$, anterior and posterior portionsame width (Fig. 84D); m7, pair of thin and narrow muscle, originating on inner surface of odontophore cartilages, running posterior to inserting on radular sac, same length and 1/6 width of m6 (Fig. 84D); m9, unpaired and horizontal muscle, originating on posterior portion of $\mathrm{m} 4$, connecting pair of $\mathrm{m} 4$ (Fig. 84D). Pair of odontophore cartilages elliptical (Fig. 84B, D). Subradular membrane thin, strong, translucent. Radular sac $\sim 1 / 4$ as large as odontophore (Fig. 84A). Radular teeth (Fig. 85AD): rachidian teeth absent; formula $29 \times 53.0 .53$ (in $7 \mathrm{~mm}$ long specimen). Each lateral tooth with narrow base, tapering toward apex, hook-shaped, with single terminal cusp; outermost teeth smaller, inner base width about twice of lateral teeth width, apex also hook-shaped, cusp simple and smooth. Pair of salivary glands not visualized. Esophagus simple, originating dorsally to odontophore, inserting directly in anterior region of stomach, internal longitudinal folds with same diameter along entire length (Fig. 82D). Stomach elongate, with folds at the center of entire inner surface; longitudinal pleats thicker posteriorly, close to anterior region of intestine. Common opening for esophagus, stomach and caecum located on digestive gland. Intestine with longitudinal folds along its entire length, diameter about same esophagus diameter and two times longer than esophagus length. Caecum as an elongated sac, located ventrally to stomach, opening on anterior portion of stomach, close to esophageal insertion, $\sim 1 / 3$ length and $\sim 1 / 3$ of width of stomach (Fig. 82D). Digestive gland dark beige, being largest organ of visceral mass, cone-shaped with anterior portion about twice as wide as posterior portion, inner face of gland sponge-like, bearing a distinct main duct. Anus opening into anal papilla at center of gill circle (Fig. 82A).

Genital system (Figure 82B; 84E): around buccal mass, anterior to digestive gland, mainly on right side dorsally and ventrally. Genital opening on right side, almost in anterior middle of length of animal from head, located between foot and notum (Fig. 
82B). Gonad immersed in digestive gland, dark brown color, easy to distinguish it. Hermaphrodite duct thin, long. Ampulla located on female gland, elongated, slender and tubular. Prostate rounded and glandular, 2/3 of length of ampulla, divided in two portions. Vas deferens same diameter than penis, not distinguishable (Fig. 84E). Penis' muscle absent. Penis short, muscular and cylindrical, about twice length and same width of vagina. Female gland well-developed, rounded, occupying $\sim 40 \%$ of reproductive system volume, divided into mucus gland ( $2 / 3$ of female gland, color beige), and albumen gland ( 1/3 of anteriormost region, dilated, irregularly shaped, color dark brown). Oviduct occupying not visualized. Uterine duct thin, relatively short, length $\sim 1 / 4$ of vagina length, located at base of seminal receptacle, inserted in female gland near oviduct. Seminal receptacle rounded, 1/3 length of bursa copulatrix, connected to vagina by long duct with about same length of vagina. Bursa copulatrix rounded, about same length of vagina length, connected to vagina after seminal receptacle through short stalk. Vagina cylindrical, elongated, approximately five times as long and twice wide as penis, followed ventrally by prostate and located parallel to penis in genital opening (Fig. 84E).

Nervous system (Figure 84F): covered by anterior and posterior blood gland. Pair of cerebral and pleural ganglia fused with each other dorsally and ventrally. Pedal ganglia fused with cerebral and pleural ventrally, but not fused among themselves. Pedal commissure long and simple, four times longer than cerebral ganglia, surrounding esophagus and salivary glands. Buccal ganglia and gastro-esophageal ganglia not analyzed. Rhinophoral (olfactory) ganglia bulb-shaped, connected to anterior portion of cerebral ganglia. Dorsal eyes located on cerebral ganglia with small connective between them.

Distribution: Indo-West Pacific (Rudman, 1999)

Material examined: PHILIPPINES, Bohol Island, Panglao, off Baclayton, C175335, 1 specimen (T. Gosliner, Y. Camacho-Garcia, J. Templado, M. Malaquias, M. Poddubetskaia, coll., 03/vi/2004, 5m depth, soft bottom; Panglao Expedition 2004); Bohol Aibukit, ZMUC-GAS2122, 3 specimen (Semper coll., 1861 (Aibukit), ix/1863 (Bohol - Syntype); Palawan Island, N Hondo Bay, Tanabag Beach, AUS-C158450.001, 1 specimen (I. Loch, coll., under rock on silty coastal reef, TAMS Expedition); AUSTRALIA, Northen Territory, Darwin, Gunn Poit, AUS-C148492.001, 1 specimen (C. Hood, coll.); New Caledonia, Near Ilot Kendek, off Koumac, AUS-C200401.001, 2 specimens (W.B. Rudman \& Mountrouzier Expedition, 08/x/1993, in lagoon, coral blocks, 15-20m depth). 


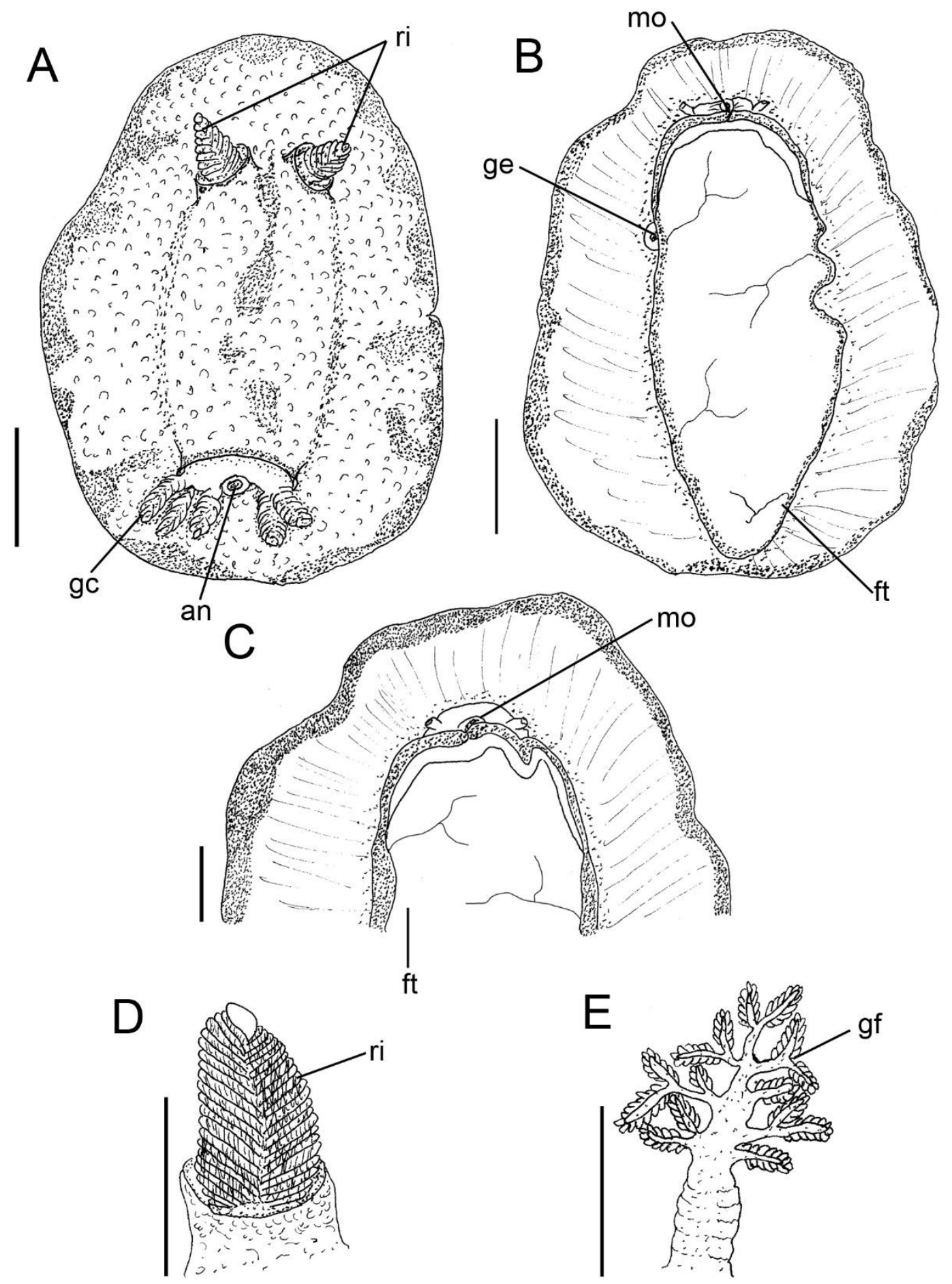

Figure 82: Discodoris boholiensis, fixed animal. A. Dorsal view. B. Same, ventral view. Scales: $2 \mathrm{~mm}$. C. Detail of anterior border of foot. D. Rhinophore. E. Gill filament. Scales: 1mm. 

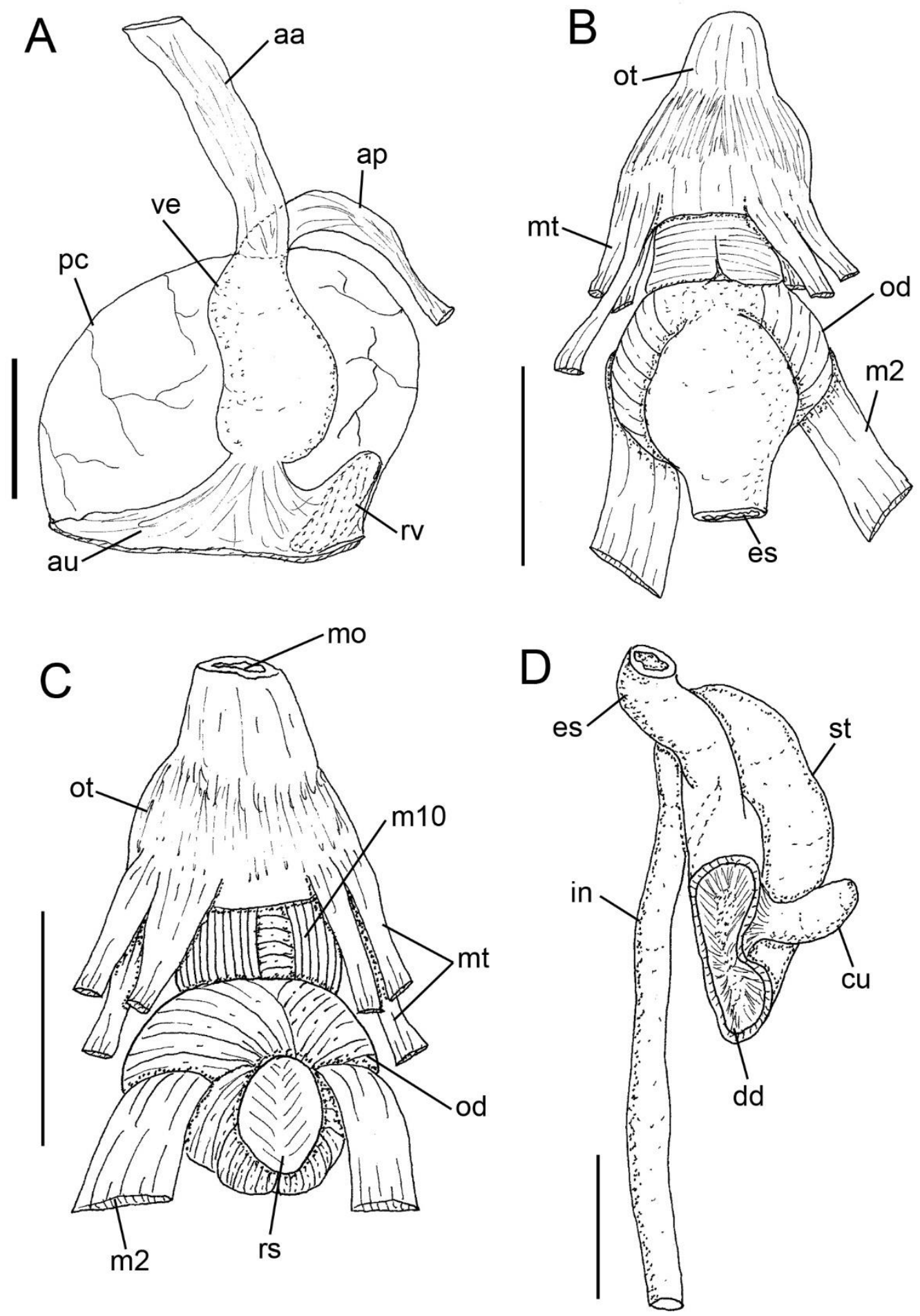

Figure 83: Discodoris boholiensis. A. Circulatory and excretory system. Scale: 5mm. Anterior digestive system. B. Dorsal view. C. Same, ventral view. D. Medium digestive system. Scales: $1 \mathrm{~mm}$. 

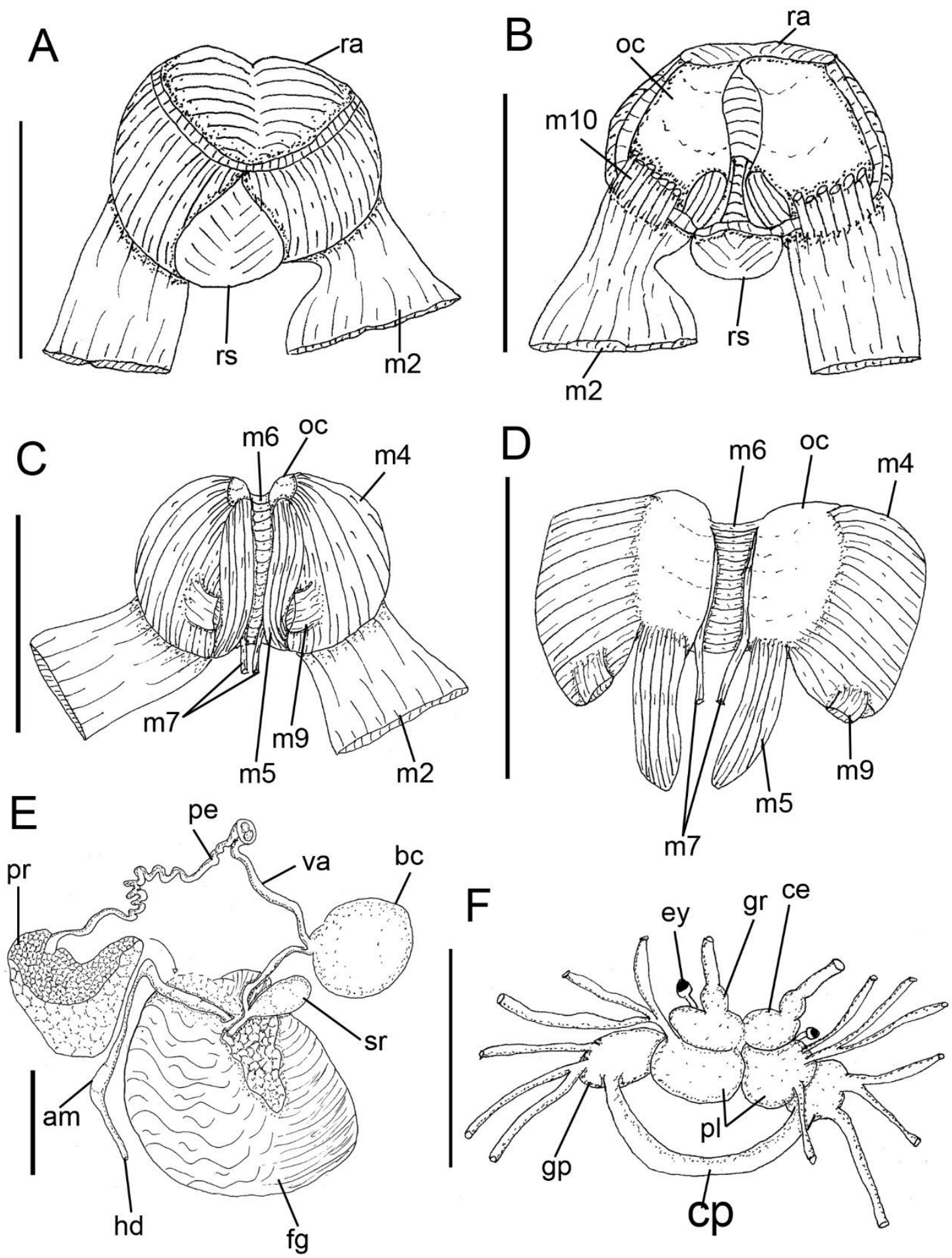

Figure 84: Discodoris boholiensis. Odontophore. A. Dorsal view. B. Same, ventral view. C. Same, dorsal view with removed radula. D. Same, dorsal view with folded down muscles. E. General reproductive system. F. Dorsal view of nervous system. 


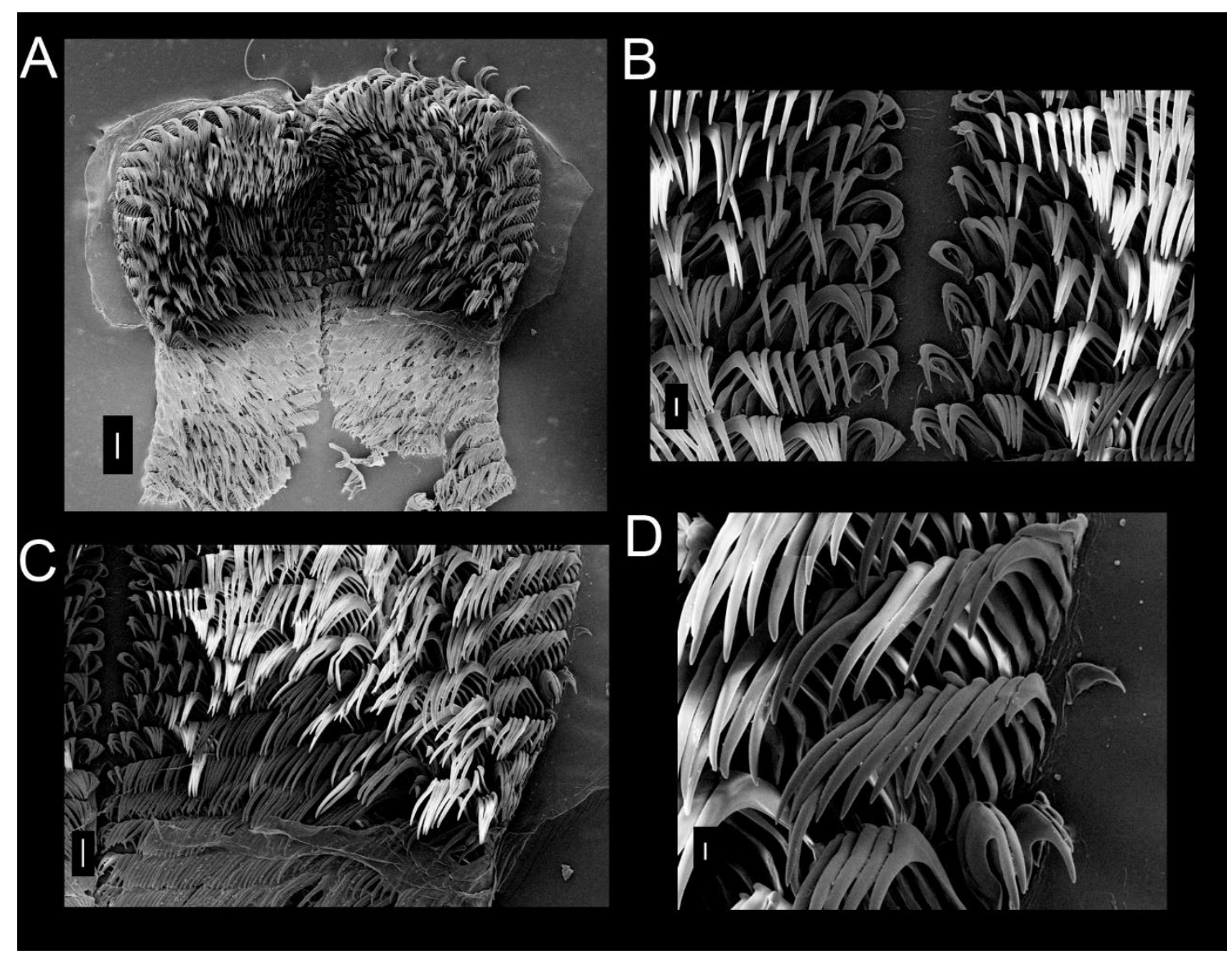

Figure 85: SEM of radula of Discodoris boholiensis. A. Panoramic view. Scale: $200 \mu \mathrm{m}$. B. Median region with rachidian tooth absent. Scale: $30 \mu \mathrm{m}$. C. Lateral teeth. Scale: $100 \mu \mathrm{m}$. D. Outermost lateral teeth. Scale: $20 \mu \mathrm{m}$.

Discodoris pusae Er. Marcus, 1955

(Figures 86-90)

Synonymic list See Alvim \& Pimenta, 2013

Complement: Sales et al., 2013: 698; Camacho-García et al., 2014: 122

Type locality: São Sebastião Island, São Paulo, Brazil

\section{Redescription}

External morphology (Figure 86A-E): Size 14mm lenght, 9mm width. Color orange with small brown dots. Body rounded (Fig. 86A, B). Foot not exceed notum (Fig. 86B). Rhinophores with about 12 transverse lamellae, white color; rhinophoral sheaths with small lobes (Fig. 86D). Gill composed of 8 bipinate branchial leaves, also white color, arranged in circular fashion surrounding anus; branchial sheaths also with small lobes (Fig. 86E). Mouth opening in anterior ventral region, between anterior region of 
notum and foot. Digitiform tentacles present. Anterior border of foot bilabiate with longitudinal groove (Fig. 86C).

Haemocoel organs (Figure 87A, B)): pericardium and posterior half of visceral mass volume occupying $15 \%$ of haemocoel volume. Buccal mass located anteriorly, occupying $15 \%$ of haemocoel volume. Nervous system dorsal to buccal mass, covered by blood gland, occupying 5\% of haemocoel volome. Reproductive system on right side of animal; occupying $25 \%$ of haemocoel volume. Stomach on left side, intestine with median curve at anterior portion and digestive gland, all occupying $40 \%$ of haemocoel volume.

Circulatory and excretory systems (Figure 87A, C, D): pericardial cavity dorsal and posterior to digestive gland, anterior to gill circle (Fig. 87A). Afferent and efferent branches located inside each gill filament, flowing from and to afferent and efferent branchial veins. Gill retractor muscle divided, originating from base of gill circle, running longitudinally up to half of foot level, inserting into dorsal surface of foot (Fig. 87C). Auricle funnel-like (wider anteriorly) with thin walls. Ventricle sligthly taller than wide, with thick muscular walls. Same pattern of Doridoidea vessels. Aortic trunk branched into anterior artery irrigating reproductive system, buccal mass, odontophore and nervous system; posterior artery irrigating stomach and digestive gland. Renal vesicle located on right dorsal side of pericardium, near base of auricle, connected to inner surface of pericardium, about same size and half of ventricle. Renal chamber extending from dorsal to medial sinus, previously connected to renal vesicle, extending posteriorly to center of gill circle and opening in nephrostome, difficult to see (Fig. 87C). Blood gland divided, anterior twice as larger than posterior (Fig. 87D).

Digestive system (Figures 86E; 87A-B, D-E; 88A-D; Fig. 90A-C): Oral tube composed of outer lip, without pleats, glandular; inner lip with broad transverse fold (Fig. $88 \mathrm{~A})$; mt, three pairs of retractor muscles of buccal mass, originating on oral tube, running dorsally and ventrally to oral tube, inserting on body side, about three times as wide and twice as long as m10 (Fig. 88A). Odontophore oval, connected to oral tube by pair of ventral protractor muscles (m10); thin longitudinal, ventrolateral protractors of oral sphincter, originating in anterior region of odontophore and inserted in posterior region of integument close to oral tube. Oral sphincter surrounding chitinous part of oral tube. Odontophore muscles: $\mathbf{m} 2$, pair of strong retractor muscles of buccal mass, twice as long as wide, origin bifurcate on anterior dorsal odontophore, running laterally to $\mathrm{m} 4$ and inserted bifurcate ventrally on dorsal portion of foot (Fig. 88B, C); $\mathbf{m 4}$, pair of dorsal 
tensor muscles, strong and broad, 1/3 as long as wide, covering 2/3 of cartilage, inserted on ventral portion of subradular membrane (Fig. 88D); m5, pair of dorsal auxiliary tensor muscles, as long as wide, originating on most posterior region of odontophore cartilages, covering $\sim 1 / 3$ of posterior cavity of odontophore, as long as, but with $\sim 1 / 2$ of m4 width, inserting on ventral side of subradular membrane, around radular sac (Fig. 88D); m6, unpaired horizontal muscle, seems divided, with transverse fibers connecting to median surface of left and right odontophore cartilages, about same length and half as wide as $\mathrm{m} 4$, posterior portion $\sim$ twice as wide as anterior portion (Fig. 88D); $\mathbf{m} 7$, pair of thin and narrow muscle, originating in middle of $\mathrm{m} 6$, running posterior to inserting on radular sac; m9, unpaired and horizontal muscle, originating on posterior portion of $\mathrm{m} 4$, connecting pair of $\mathrm{m} 4$ (Fig. 88D). Pair of odontophore cartilages elliptical, occupying $\sim 25 \%$ of odontophore volume (Fig. 88C, D). Subradular membrane thin, strong, translucent. Radular sac $\sim 1 / 4$ as large as odontophore (Fig. 88B). Radular teeth (Fig. 90A-C): rachidian teeth absent; formula 14 x 16.0.16 (in $9 \mathrm{~mm}$ long specimen). Each lateral tooth with thin base with twice longer than wide, apex hook-shaped, with single terminal cusp; outermost teeth shovel-shaped, with lamelated base, inner base width about half of lateral teeth width, apex also hook-shaped, cusp simple and smooth. Pair of salivary glands long, tubular; duct inserting in anterior region of esophagus, extending posteriorly to anterior region of digestive gland. Esophagus simple, originating dorsally to odontophore, inserting directly in anterior region of stomach, internal longitudinal folds with same diameter along entire length (Fig. 87D, E). Stomach rounded, small, about same length of ventricle (Fig. 87A, E). Common opening for esophagus and stomach located on digestive gland. Intestine with median curve anteriorly, longitudinal folds along its entire length, about same esophagus diameter. Caecum absent. Digestive gland dark beige, being largest organ of visceral mass and occupying $40 \%$ of its volume, rounded; inner face of gland sponge-like distinct main duct (Fig. 87B). Anus opening into anal papilla at center of gill circle, $\sim 1 / 2$ of gill filament length (Fig. 86E).

Genital system (Figure 87B; 88E-G): occupying 10\% of visceral mass volume, located between buccal mass and digestive gland, mainly on right side and dorsally. Genital opening on right side, anterior third of length of animal from head, located between foot and notum (Fig. 87B). Gonad immersed in digestive gland, difficult to distinguish it. Hermaphrodite duct thin, long. Ampulla located on female gland, elongated and tubular. Prostate rounded, glandular, divided in two parts distinct visible, about half length and twice width of ampulla (Fig. 88G). Vas deferens and penis not distinguished 
about half length as ampulla. Penis' muscle absent. Female gland well-developed, rounded, occupying $\sim 40 \%$ of reproductive system volume, divided into mucus gland ( $2 / 3$ of female gland, color beige), and albumen gland ( 1/3 of anteriormost region, dilated, irregularly shaped, color dark brown) (Fig. 88E). Oviduct occupying $\sim 1 / 8$ of female gland volume. Uterine duct thin, relatively short, length $\sim 1 / 6$ of vagina length, located at base of seminal receptacle, inserted in female gland near oviduct (Fig. 88F). Seminal receptacle pyriform, about same length and half width of bursa copulatrix, length $\sim 1 / 3$ of vagina length, connected to bursa copulatrix by long stalk, same length as vagina. Bursa copulatrix rounded, length $\sim 1 / 2$ of vagina length, connected directly to vagina after seminal receptacle. Vagina cylindrical, thin and elongated, approximately as long and wide as penis, followed ventrally by prostate and located parallel to penis in genital opening (Fig. 88F). One vaginal pouch at opening of vaginal, whithout spine (Fig. 88F).

Nervous system (Figure 87D; 89A-C): located dorsally to odontophoremostly covered by divided blood gland (Fig. 87D). Pair of cerebral and pleural ganglia fused with each other dorsally. Pedal ganglia fused with cerebral and pleural ventrally, but not fused among themselves. Pedal commissure simple and long, about three times of cerebral ganglia length, surrounding esophagus and salivary glands (Fig. 89B). Buccal ganglia short, located ventrally to odontophore, between radular sac and anterior portion of esophagus, connected to cerebral ganglia through long and slender connective tissue, united to gastro-esophageal ganglia by short connective tissue (Fig. 89C). Buccal commissure posterior, easy to visualize. Gastro-esophageal ganglia length about 1/4 of buccal ganglia length, circular (Fig. 89C). Rhinophoral (olfactory) ganglia bulb-shaped, connected to anterior portion of cerebral ganglia. Dorsal eyes located on cerebral ganglia (Fig. 89A). Statocysts small and iridescent, located ventrally to pedal ganglia (Fig. 89B).

Distribution: U.S.A. (Florida) to Argentina.

Habitat: Intertidal zone to $68 \mathrm{~m}$ depth.

Material examined: BRAZIL, Arraial do Cabo, Praia do Forno, Rio de Janeiro, MZSP 96455, 6 specimens (V. Amaral, F. Noel \& P. Oristanio, coll. 28/vi/2010); Cabo Frio, Ilha do Papagaio, enseada 3, MZSP 97506, 2 specimens (V. Padula col., 08/i/2010); Praia das Conchas, MZSP 97520, 3 specimens (V. Padula col., 16/x/2009); Canal de Itajuru, MZSP 109258, 2 specimens (V. Padula, coll., 17/vii/2012); São Sebastião, São Paulo, MZSP 103274, 1 specimen (C.M. Cunha col., 20/1/2012, 4m deep, under rocks). 

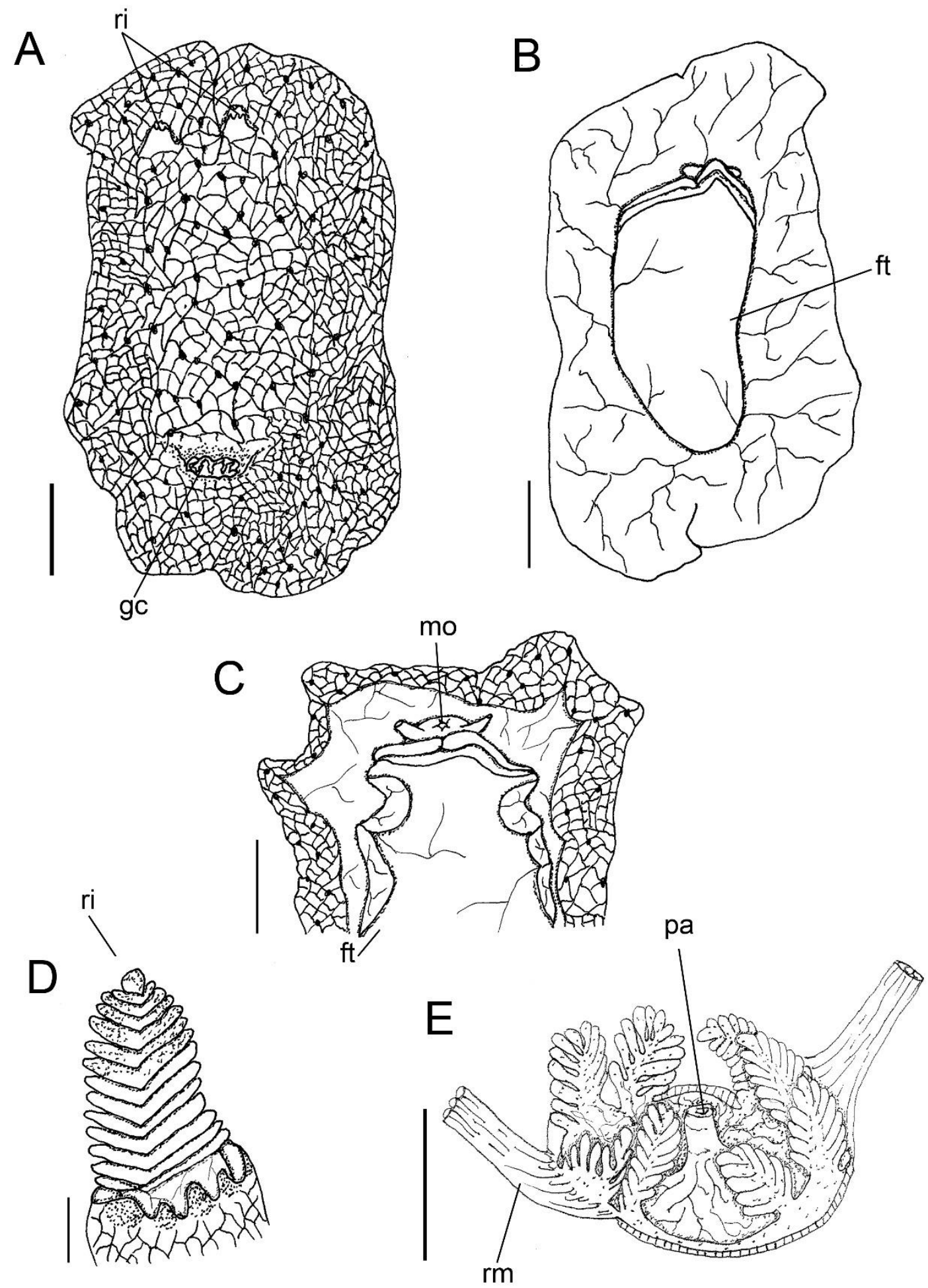

Figure 86: Discodoris pusae, fixed animal. A. Dorsal view. B. Same, ventral view. C. Detail of anterior border of foot. Scales: $2 \mathrm{~mm}$. D. Rhinophore. Scale: 0,5mm E. Gill circle. Scale: $1 \mathrm{~mm}$. 


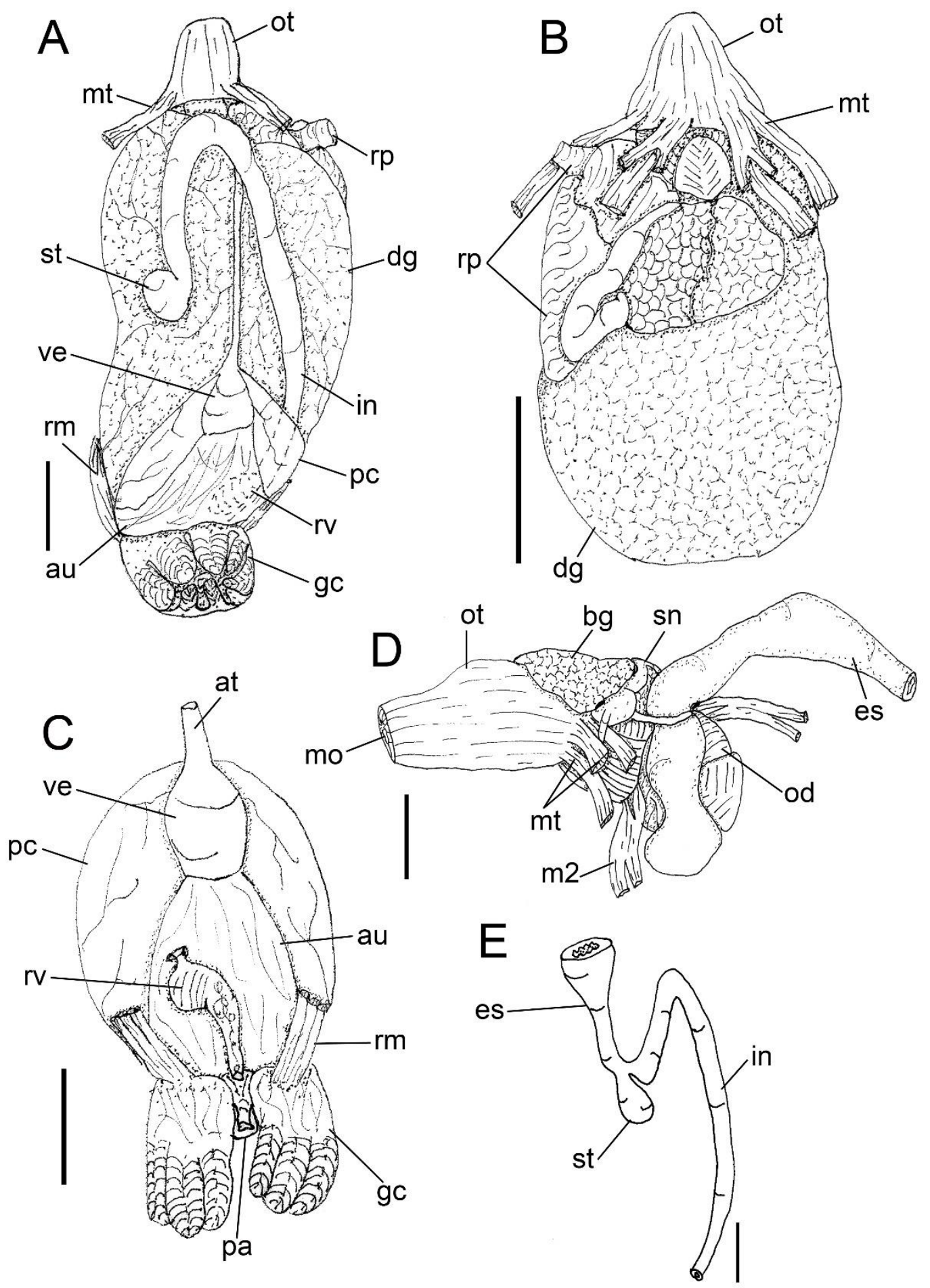

Figure 87: Discodoris pusae. Visceral mass. A. Dorsal view. B. Same, ventral view. C. Circulatory and excretory system, ventral view. Scales: $2 \mathrm{~mm}$. D. Anterior digestive system, left lateral view. Scale: $1 \mathrm{~mm}$. E. Medium digestive system. Scale: $2 \mathrm{~mm}$. 

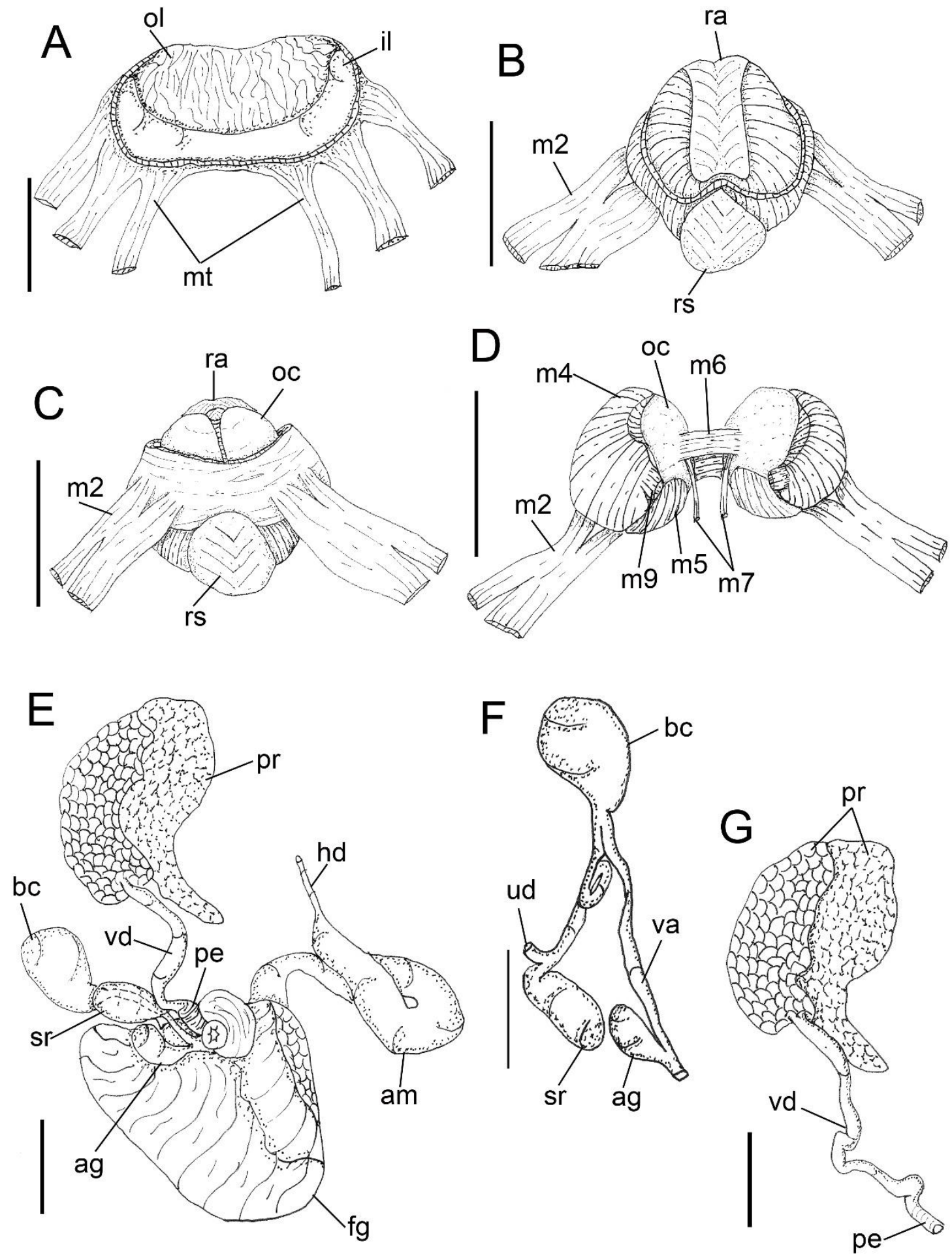

Figure 88: Discodoris pusae. A. Oral tube, longitudinally sectioned. Odontophore: B. Dorsal view. C. Same, ventral view. D. Same, dorsal view with radula removed and folded down muscles. Reproductive system. E. General view. F. Detail of Bursa copulatrix, seminal receptacle and vagina. G. Detail of prostate, vas deferens and pênis. Scales: $1 \mathrm{~mm}$. 

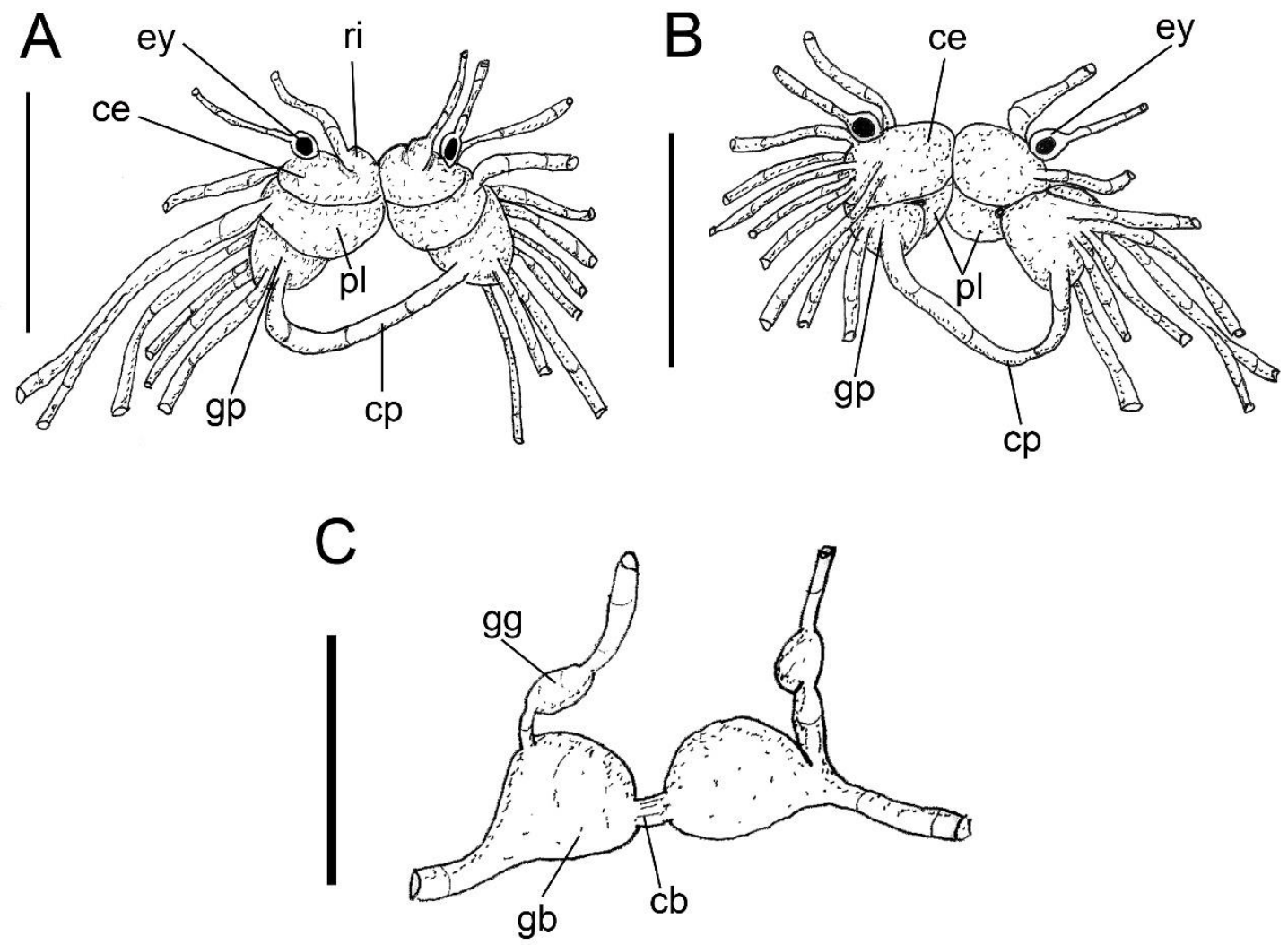

Figure 89: Discodoris pusae. Nervous system. A. Dorsal view. B. Same, ventral view. Scales: $1 \mathrm{~mm}$. C. Detail of buccal and gastroesophageal ganglia. Scale: $0,5 \mathrm{~mm}$ 


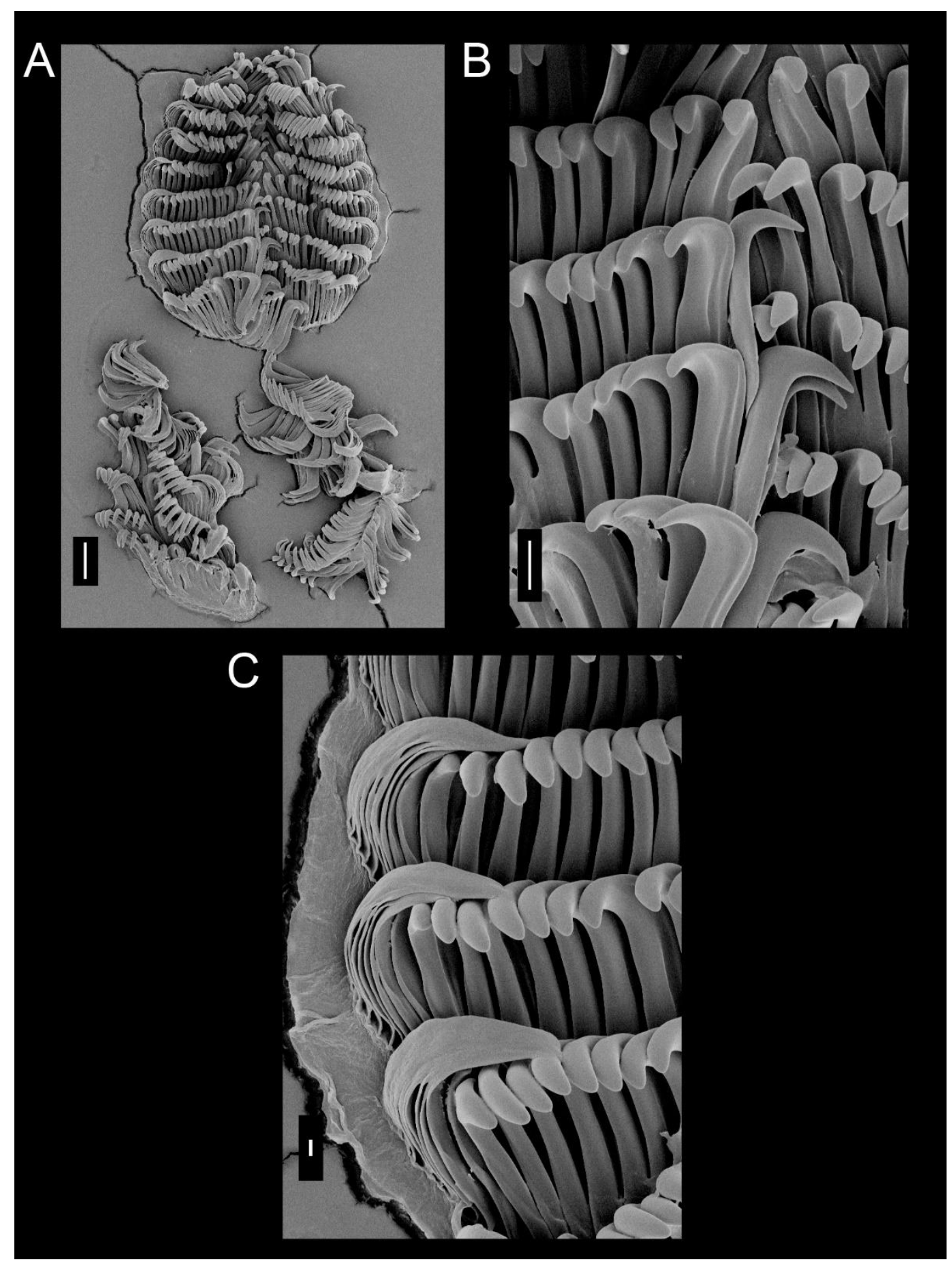

Figure 90: SEM of radula of Discodoris pusae. A. Panoramic view. Scale: $100 \mu \mathrm{m}$. B. Medium region with rachidian tooth absent. Scale: $30 \mu \mathrm{m}$. C. Outermos lateral teeth. Scale: $10 \mu \mathrm{m}$. 


\section{“Discodoris” branneri MacFarland, 1909}

(Figures 91-94)

Synonymic list see Alvim \& Pimenta, 2013.

Complement: Discodoris branneri Camacho-García et al., 2014: 120.

Type locality: Riacho Doce, Alagoas, Brazil

\section{Redescription}

External morphology (Figure 91A-D): Size 30mm length, 15mm width. Color predominantly brownish with several brown and white spots on dorsum of irregular sizes, ventrally white with brown spots. Body rounded covered by small tubercles, slightly depressed (Fig. 91A, B). Rhinophores with about 25 transverse lamellae, color similar to body; rhinophoral sheaths with small tubercles (Fig. 91C). Gill composed of six tripinnate branchial leaves, color similar to body, arranged in circular fashion surrounding anus; branchial sheaths similar to rhinophoral sheaths (Fig. 91D). Mouth opening in anterior ventral region, between anterior region of notum and foot. Digitiform tentacles conical. Anterior border of foot bilabiate with longitudinal groove (Fig. 91B).

Haemocoel organs (Figure 92A, B): pericardium and posterior half of visceral mass volume occupying $20 \%$ of haemocoel volume. Buccal mass located anteriorly, occupying $10 \%$ of haemocoel volume. Nervous system dorsal to buccal mass, covered by blood gland occupying $10 \%$ of haemocoel volume. Reproductive system on right side of animal; occupying $20 \%$ of haemocoel volume. Stomach, intestine and digestive gland occupying $40 \%$ of haemocoel volume.

Circulatory and excretory systems (Figure 92A, C): same as in Discodoris boholiensis. Gill retractor muscle entire, running covering all dorsal face of foot. Renal vesicle with $1 / 2$ of size and width of ventricle (Fig. 92C). Blood gland divided, anterior three times larger than posterior (Fig. 92A).

Digestive system (Figures 90D-F; 91A; 92D-F; 93A-D): Oral tube composed of outer lip, with pleats lengthwise; inner lip also with lengthwise folds, about twice wider than those of outer lip; mt, three pairs of retractor muscles of buccal mass, originating on oral tube, running dorsally and ventrally to oral tube, inserting on body side, about four times as wide and three times as long as m10 (Fig. 92E-F). Odontophore oval, connected to oral tube by pair of ventral protractor muscles (m10); thin longitudinal, dorsolateral protractors of oral sphincter, originating in anterior region of odontophore and inserted in 
posterior region of integument close to oral tube (Figs. 91E; 92A, C). Oral sphincter surrounding chitinous part of oral tube. Odontophore muscles: $\mathbf{m} \mathbf{2}$, pair of strong retractor muscles of buccal mass, twice as long as wide, origin on anterior dorsal odontophore, running laterally to $\mathrm{m} 4$ and inserted ventrally on dorsal portion of foot (Figs. 91E-F; 92AC); m4, pair of dorsal tensor muscles, strong and broad, as long as wide, covering 2/3 of cartilage, inserted on ventral portion of subradular membrane (Fig. 92D); m5, pair of dorsal auxiliary tensor muscles, three times as long as wide, originating on most posterior region of odontophore cartilages, covering $~ 1 / 3$ of posterior cavity of odontophore, as long as, but with $\sim 1 / 4$ of $\mathrm{m} 4$ width, inserting on ventral side of subradular membrane, around radular sac (Fig. 92D); m6, unpaired horizontal muscle, with transverse fibers connecting to median surface of left and right odontophore cartilages, about same length and half as wide as $\mathrm{m} 4$, posterior portion twice as wide as anterior portion (Fig. 92D); $\mathbf{m} 7$, pair of thin and narrow muscle, originating on inner surface of odontophore cartilages, running posterior to inserting on radular sac (Fig. 92D); m9, unpaired and horizontal muscle, originating on posterior portion of $\mathrm{m} 4$, connecting pair of $\mathrm{m} 4$ (Fig. 92D). Pair of odontophore cartilages elliptical. Subradular membrane thin, strong, translucent. Radular sac $\sim 1 / 4$ as large as odontophore. Jaws present (Fig. 92A). Radula and jaw not analized by SEM. Pair of salivary glands long, tubular, with and bulging anteriorlly; duct inserting in anterior region of esophagus, extending posteriorly to anterior region of digestive gland (Fig. 91E). Esophagus simple, originating dorsally to odontophore, inserting directly in anterior region of stomach, internal longitudinal folds with same diameter along entire length (Fig. 91E, F). Stomach oval, large, 30\% of digestive system volume, with folds at the center of entire inner surface; longitudinal pleats thicker posteriorly, close to anterior region of intestine (Fig. 91D). Common opening for esophagus and stomach located on digestive gland (Fig. 91D). Intestine with longitudinal folds along its entire length, diameter about half esophagus diameter (Fig. 91D). Caecum absent. Digestive gland dark beige, being largest organ of visceral mass and occupying $40 \%$ of its volume, cone-shaped; anterior portion about twice as wide as posterior portion, inner face of gland sponge-like, bearing distinct main duct (Fig. 91D). Anus opening into anal papilla at center of gill circle, $\sim 1 / 3$ of gill filament length (Fig. 90D).

Genital system (Figure 92E-G): located between buccal mass and digestive gland, mainly on right side and dorsally. Genital opening on right side, anterior third of length of animal from head, located between foot and notum. Gonad immersed in 
digestive gland, difficult to distinguish it. Hermaphrodite duct thin, short. Ampulla located on female gland, very elongated and tubular. Prostate rounded, glandular, 1/2 of length of ampulla, divided in two parts with different texture. Vas deferens about same length of penis. Penis' muscle absent. Penis muscular, cylindrical and elongated, very broad about same length of prostate; broad penial papillae (Fig. 92G). Female gland welldeveloped, rounded, occupying $\sim 25 \%$ of reproductive system volume, divided into mucus gland ( $2 / 3$ of female gland, color beige), and albumen gland $(\sim 1 / 3$ of anteriormost region, dilated, irregularly shaped, color dark brown) (Fig. 92E). Oviduct occupying 1/3 of female gland volume, with glandular portion and single spine near the aperture (Fig. $92 \mathrm{G})$. Uterine duct thin, relatively short, length $\sim 1 / 4$ of vagina length, located at base of seminal receptacle, inserted in female gland near oviduct (Fig. 92F). Seminal receptacle pyriform, $1 / 4$ length of bursa copulatrix, connected to vagina by long duct with half length of vagina. Bursa copulatrix rounded, about $1 / 2$ of vagina length, connected to vagina after seminal receptacle through medium stalk, $\sim 1 / 4$ of vagina length (Fig. 92F). Vagina cylindrical, elongated, approximately twice as long and wide as penis, followed ventrally by prostate and located parallel to penis in genital opening (Fig. 92G).

Nervous system (Figure 93A-C): mostly covered by blood gland. Pair of cerebral and pleural ganglia fused with each other dorsally and ventrally. Pedal ganglia fused with cerebral and pleural ventrally, but not fused among themselves. Pedal commissure long and simple, $\sim$ three times longe than cerebral ganglia, surrounding esophagus and salivary glands (Fig. 92B). Buccal ganglia short, located ventrally to odontophore, between radular sac and anterior portion of esophagus, connected to cerebral ganglia through long and slender connective tissue, united to gastro-esophageal ganglia by short connective tissue (Fig. 93C). Buccal commissure very short, but visible, in posterior portion between buccal ganglia. Gastro-esophageal ganglia length about 1/4 of buccal ganglia length, circular (Fig. 93C). Rhinophoral (olfactory) ganglia bulb-shaped, connected to anterior portion of cerebral ganglia. Dorsal eyes located on cerebral ganglia (Fig. 93A).

Distribution: U.S.A. (Florida) to Brazil (Sao Paulo).

Habitat: Under intertidal and infralitoral rocks.

Material examined: BRAZIL, Praia de Búzios, Pirangi, Rio Grande do Norte, MZSP 97063, 1 specimen (V. Padula col., 12/iii/2009); Praia da Tartaruga, Búzios, Rio de Janeiro, MZSP 97614, 1 specimen (V. Padula col., 26/vi/2005). 


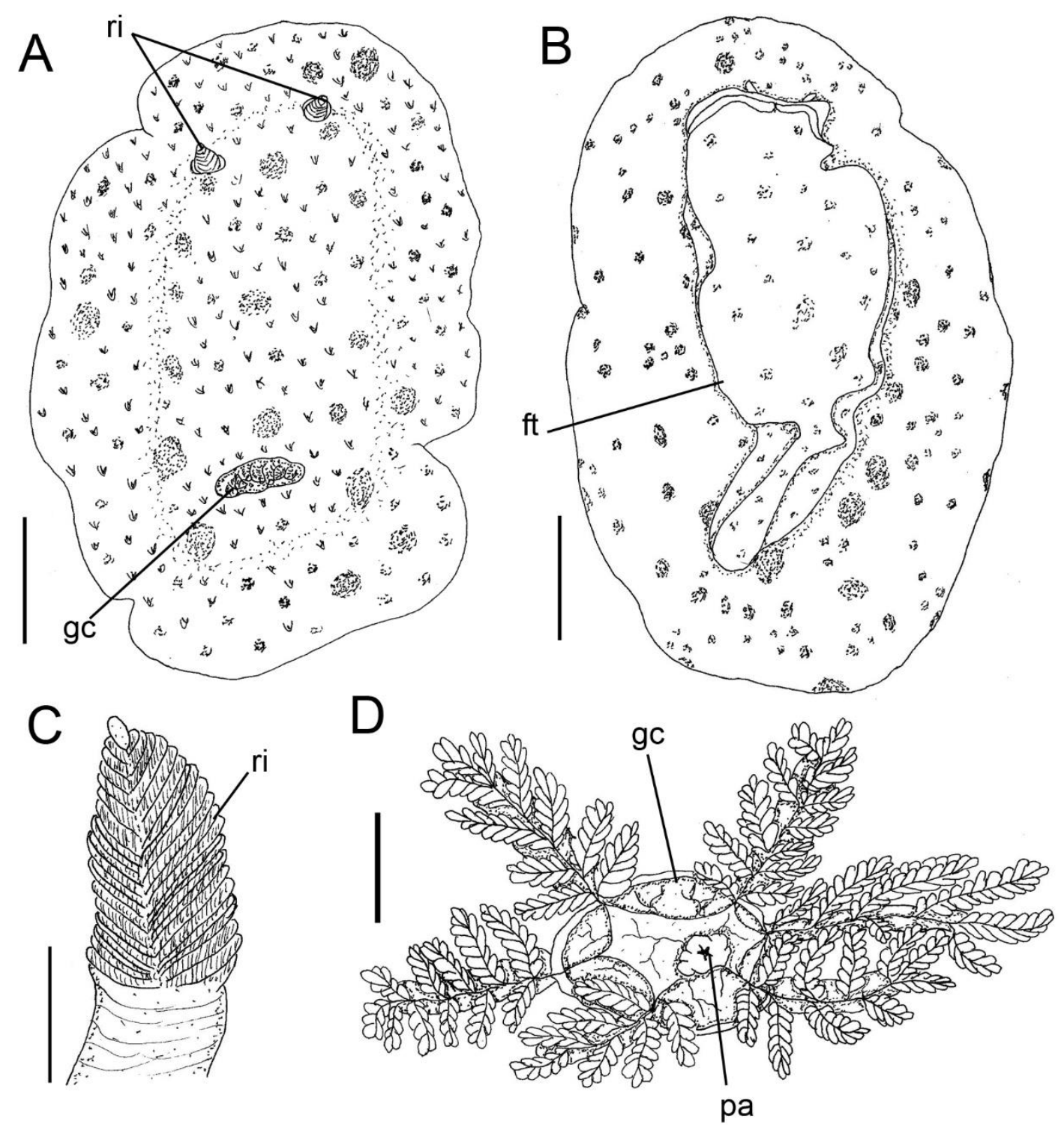

Figure 91: "Discodoris" branneri, fixed animal. A. Dorsal view. B. Same, ventral view. Scales: $5 \mathrm{~mm}$. C. Rhinophore. D. Gill circle, dorsal view. Scales: $1 \mathrm{~mm}$ 

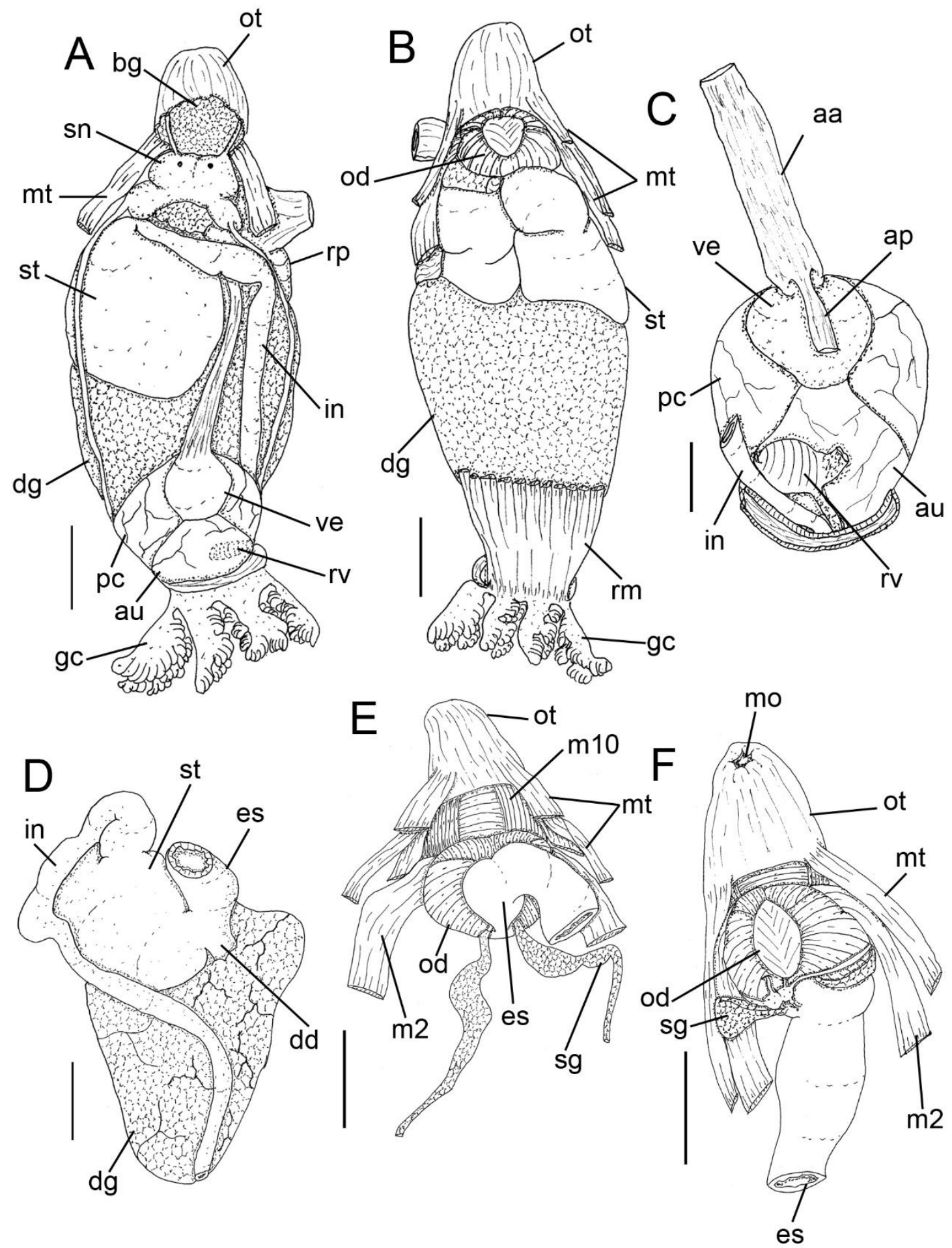

Figure 92: "Discodoris" branneri. Visceral mass. A. Dorsal view. B. Same, ventral view. C. Circulatory and excretory system, ventral view. D. Medium digestive system, dorsal view. Anterior digestive system. E. Dorsal view. F. Same, ventral view. Scales: $2 \mathrm{~mm}$. 

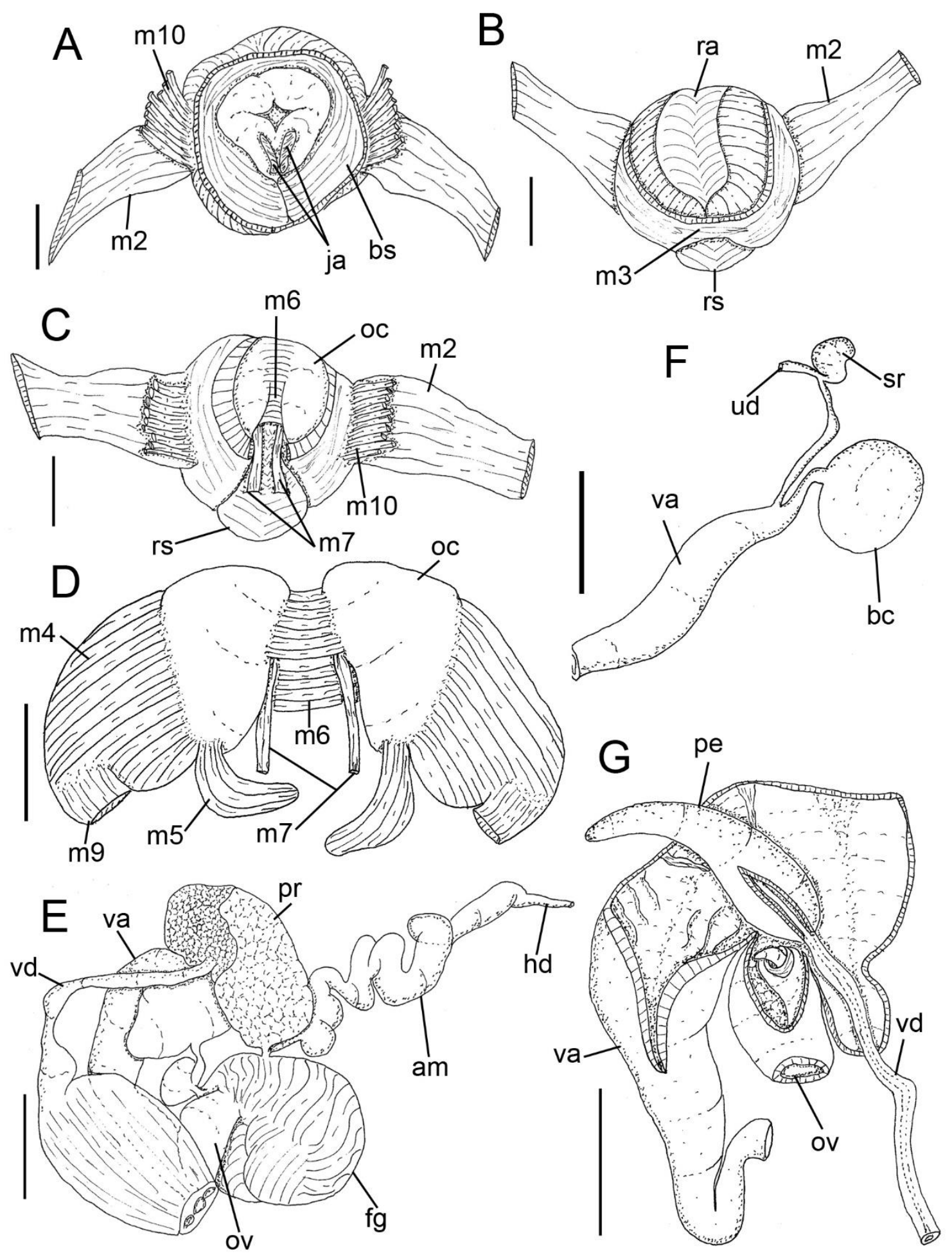

Figure 93: "Discodoris" branneri. Odontophore. A. Dorsal view, with buccal sphincter and jaws. B. Same dorsal view with radula. C. Same, ventral view. D. Same, dorsal view with removed radula and folded down muscles. Reproductive system. E. General view. Scales: $1 \mathrm{~mm}$. F. Detail of bursa copulatrix, seminal receptacle and vagina. G. Detail of aperture, penial papillae and oviduct's spine. Scales: $2 \mathrm{~mm}$ 

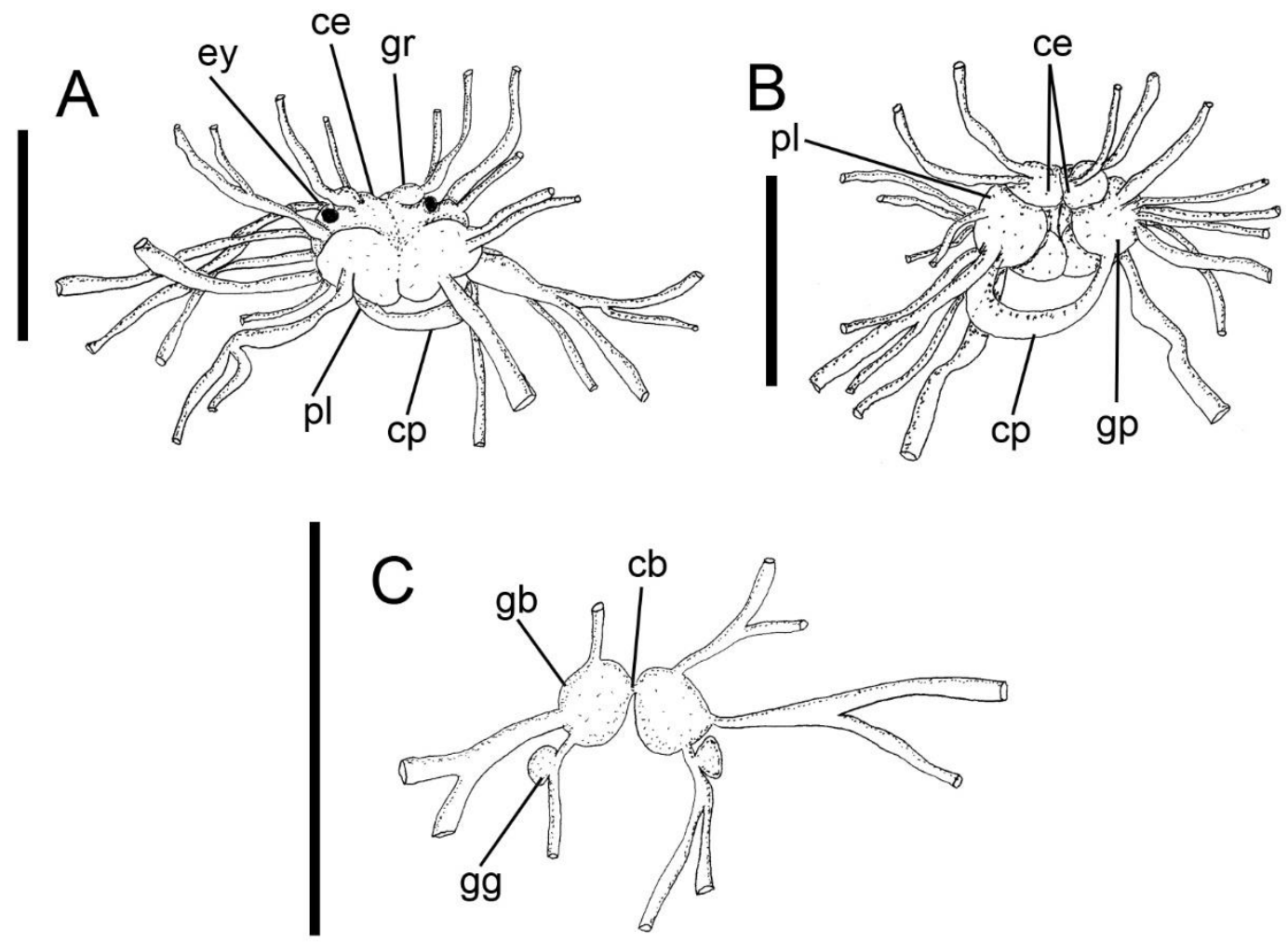

Figure 94: "Discodoris” branneri. Nervous system. A. Dorsal view. B. Same, ventral view. C. Buccal and gastroesophageal ganglia. Scales: $0,5 \mathrm{~mm}$.

Genus Diaulula Bergh, 1878

Type species: Doris sandiegenis Cooper, 1863, by monotypy

Diaulula sandiegensis (J. G. Cooper, 1863)

(Figures 95-98)

Synonymic list see Dayrat, 2010

Type locality: San Diego Bay, California.

\section{Redescription}

External morphology (Figure 95A-D): Size $\sim 30 \mathrm{~mm}$ length, 20mm width. Color beige with some black rings on dorsum from different sizes. Body rounded (Fig. 95A). Foot not exceed from notum (Fig. 95B). Rhinophores with about 20 transverse lamellae, color similar to body; rhinophoral sheaths with small lobes (Fig. 95D). Gill composed of 5 branched branchial leaves, color similar to body, arranged in circular fashion surrounding anus; branchial sheaths also with small lobes. Mouth opening in anterior 
ventral region, between anterior region of notum and foot. Digitiform tentacles present. Anterior border of foot bilabiate (Fig. 95B, C).

Haemocoel organs (Figure 95E-F): pericardium and posterior half of visceral mass volume occupying $10 \%$ of haemocoel. Buccal mass located anteriorly, occupying $10 \%$ of haemocoel volume. Nervous system dorsal to buccal mass, covered by blood gland, occupying $5 \%$ of haemocoel volume. Reproductive system on right side of animal; occupying $25 \%$ of haemocoel volume. Stomach on left side, intestine with small curve at anterior portion and digestive gland occupying $50 \%$ of haemocoel volume.

Circulatory and excretory systems (Figure 95E; 96A): pericardial cavity dorsal and posterior to digestive gland, anterior to gill circle (Fig. 95E). Same pattern of Doridoidea circulatory system. Gill retractor muscle originating divided from base of gill circle, running longitudinally up to half of foot level, inserting into dorsal surface of foot. Auricle funnel-like (wider anteriorly) with thin walls. Ventricle sligthly taller than wide, with thick muscular walls (Fig. 96A) Aortic trunk divided next to ventricle, branched into anterior artery irrigating reproductive system, buccal mass, odontophore and nervous system; posterior artery irrigating stomach and digestive gland. Renal vesicle located on right dorsal side of pericardium, near base of auricle, connected to inner surface of pericardium; renal chamber elliptical, about same size and wide of ventricle (Fig. 96A). Renal chamber extending from dorsal to medial sinus, previously connected to renal vesicle, extending posteriorly to center of gill circle and opening in nephrostome, next to base of anal papilla, but difficult to visualize.

Digestive system (Figures 95E; 96B-F; 98A-C): Oral tube composed of outer lip, with thin pleats lengthwise; inner lip with transverse fold; mt, three pairs of retractor muscles of buccal mass, originating on oral tube, running dorsally and ventrally to oral tube, inserting on body side, about six times as wide and four as long as m10 (Fig. 96C, D). Odontophore oval, connected to oral tube by pair of ventral protractor muscles (m10); thin longitudinal, dorsal and ventrolateral protractors of oral sphincter, originating in anterior region of odontophore and inserted in posterior region of integument close to oral tube (Fig. 96E). Oral sphincter surrounding chitinous part of oral tube. Odontophore muscles: m2, pair of strong retractor muscles of buccal mass, six time longer than wide, origin on anterior dorsal odontophore, running laterally to $\mathrm{m} 4$ and inserted ventrally on dorsal portion of foot (Fig. 96E); m4, pair of dorsal tensor muscles, strong and broad, 1/2 as long as wide, covering $2 / 3$ of cartilage, inserted on ventral portion of subradular membrane (Fig. 96F); m5, pair of dorsal auxiliary tensor muscles, as long as wide, 
originating on most posterior region of odontophore cartilages, covering $\sim 1 / 3$ of posterior cavity of odontophore, as long as, but with $\sim 1 / 3$ of $\mathrm{m} 4$ width, inserting on ventral side of subradular membrane, around radular sac (Fig. 96F); m6, unpaired horizontal muscle, with transverse fibers connecting to median surface of left and right odontophore cartilages, about same length and half as wide as $\mathrm{m} 4$, anterior portion twice as wide as posterior portion; $\mathbf{m} 7$, pair of thin and narrow muscle, originating on middle inner surface of odontophore cartilages, running posterior to inserting on radular sac; $\mathbf{m} \mathbf{9}$, unpaired and horizontal muscle, originating on posterior portion of $\mathrm{m} 4$, connecting pair of $\mathrm{m} 4$ (Fig. 96F). Pair of odontophore cartilages elliptical, occupying $~ 50 \%$ of odontophore volume (Fig. 96F). Subradular membrane thin, strong, translucent. Radular sac $\sim 1 / 3$ as large as odontophore. Radular teeth (Fig. 98A-C): rachidian teeth absent; formula 17 x 27.0.27 (in $20 \mathrm{~mm}$ long specimen). Each lateral tooth with thin base, tapering toward apex, hookshaped, with single terminal cusp; outermost teeth thinner, inner base width about twice of lateral teeth width, apex also hook-shaped, cusp simple and smooth. Pair of salivary glands long, tubular; duct inserting in anterior region of esophagus, with anterior portion external extending posteriorly to anterior region of digestive gland (Fig. 96C). Esophagus simple, originating dorsally to odontophore, inserting directly in anterior region of stomach, internal longitudinal folds with same diameter along entire length (Fig. 96B, C). Stomach oval, $\sim 30 \%$ of visceral mass volume, with folds at the center of entire inner surface (Fig. 95E; 96B). Common opening for esophagus and stomach located on digestive gland. Intestine with longitudinal folds along its entire length, about same diameter and twice as length of esophagus (Fig. 96B). Caecum absent. Digestive gland dark beige, being largest organ of visceral mass, rounded, inner face of gland sponge-like, bearing distinct main duct (Fig. 95E). Anus opening into anal papilla at center of gill circle.

Genital system (Figure 95F; 97A-C): located between buccal mass and digestive gland, mainly on right side and dorsally. Genital opening on right side, anterior third of length of animal from head, located between foot and notum (Fig. 95F). Gonad immersed in digestive gland, difficult to distinguish it. Hermaphrodite duct thin, long. Ampulla located on female gland, very elongated and tubular (Fig. 97A). Prostate glandular, divided in two distinct parts, about half length as ampulla. Vas deferens about twice length as penis, but very thin (Fig. 97B). Penis' muscle absent. Penis muscular, cylindrical, very broad, about half of length of prostate, with internal enlargement of vas deferens with apex papilla shaped (Fig. 97B, C). Female gland well-developed, rounded, 
occupying $\sim 40 \%$ of reproductive system volume, divided into mucus gland ( $2 / 3$ of female gland, color beige), and albumen gland ( $\sim 1 / 3$ of anteriormost region, dilated, irregularly shaped, color dark brown) (Fig. 97A). Oviduct occupying 1/5 of female gland volume. Uterine duct thin, relatively short, length $\sim 1 / 7$ of vagina length, located at base of seminal receptacle, inserted in female gland near oviduct (Fig. 97A). Seminal receptacle pyriform, half length and width as bursa copulatrix, same length of vagina, connected to bursa copulatrix by stalk $\sim 1 / 2$ of vagina length. Bursa copulatrix rounded, same length of vagina, connected directly to vagina. Vagina cylindrical, very broad like penis, approximately as long and wide as penis, followed ventrally by prostate and located parallel to penis in genital opening (Fig. 97A).

Nervous system (Figure 97D, E): located dorsally to odontophore, mostly covered by blood gland. Pair of cerebral and pleural ganglia fused with each other dorsally and ventrally. Pedal ganglia fused with cerebral and pleural ventrally, but not fused among themselves. Pedal commissure simple and very long, five times longer than cerebral ganglia, surrounding esophagus and salivary glands (Fig. 97E). Buccal and gastroesophageal ganglia not visualized. Rhinophoral (olfactory) ganglia inconspicuos. Dorsal eyes located on cerebral ganglia (Fig. 97D).

Distribution: From Alaska to Baja California, Mexico; Japan (Rudman, 2000).

Habitat: Intertidal zone

Material examined: EUA, Washington, Puget Sound, San Juan Country, San Juan Islands, San Juan Island, CAS 68263, 1 specimen (T.S. Oldroyd coll.) 


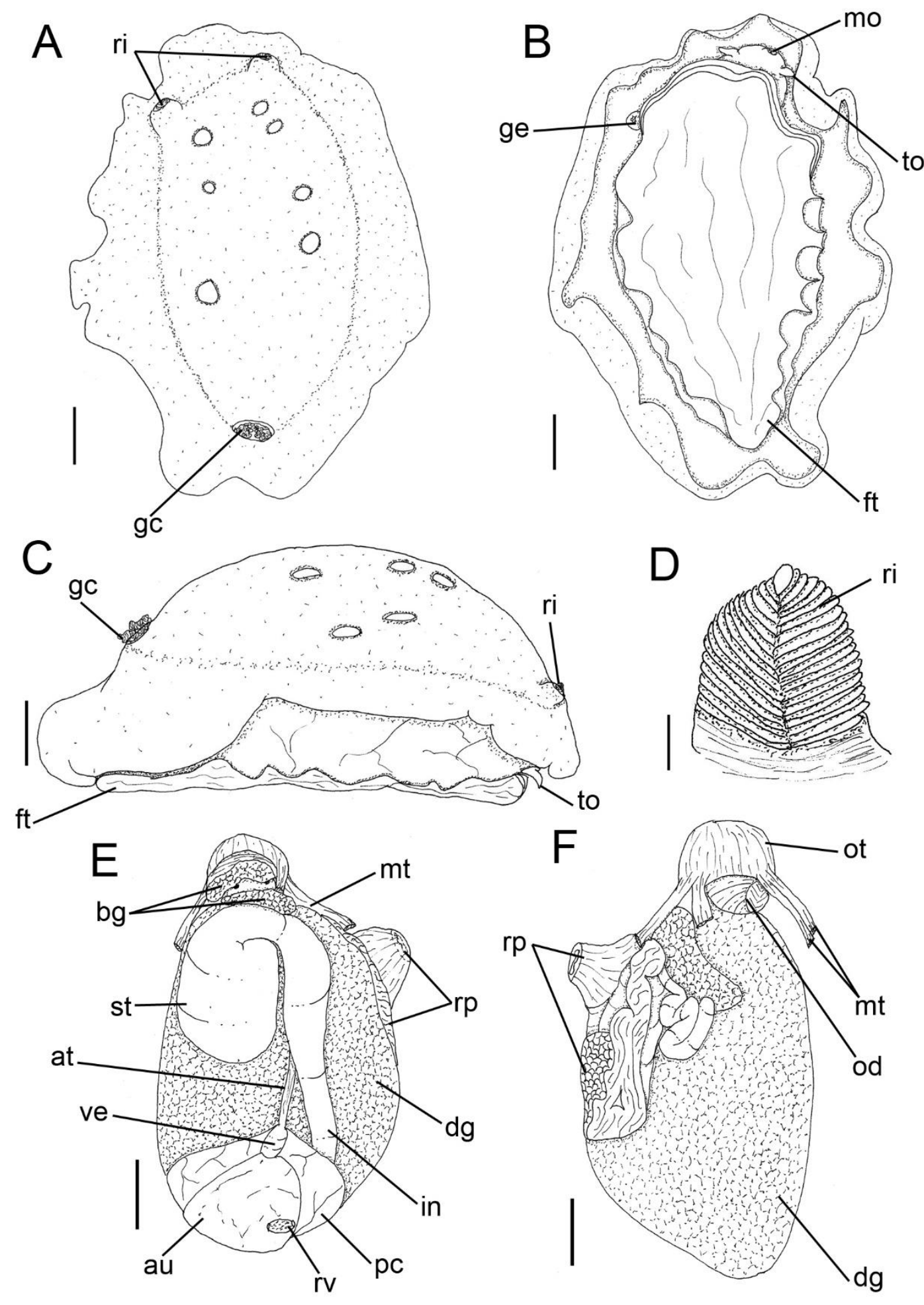

Figure 95: Diaulula sandiegensis, fixed animal. A. Dorsal view. B. Same, ventral view. C. Same, right lateral view. Scales: $5 \mathrm{~mm}$. D. Rhinophore. Scale: $1 \mathrm{~mm}$. Visceral mass. E. Dorsal view. F. Same, ventral view. Scales: $5 \mathrm{~mm}$. 

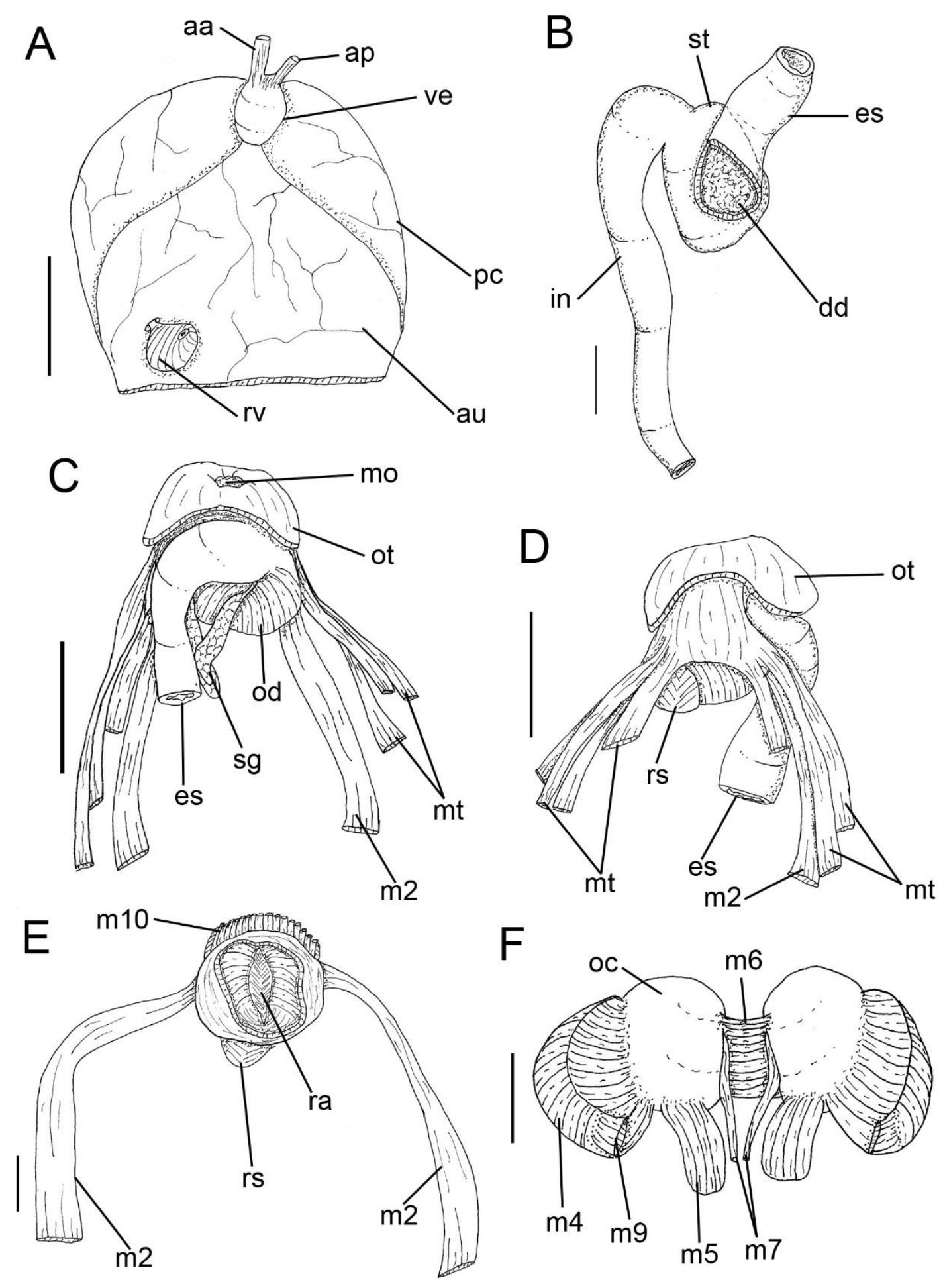

Figure 96: Dialulula sandiegensis. A. Circulatory and excretory system, ventral view. B. Medium digestive system, ventral view. Anterior digestive system. C. Dorsal view. E. Same, ventral view. Scales: $5 \mathrm{~mm}$. Odontophore. E. Dorsal view, with radula. F. Dorsal view, with removed radula and folded down muscles. Scales: $2 \mathrm{~mm}$. 


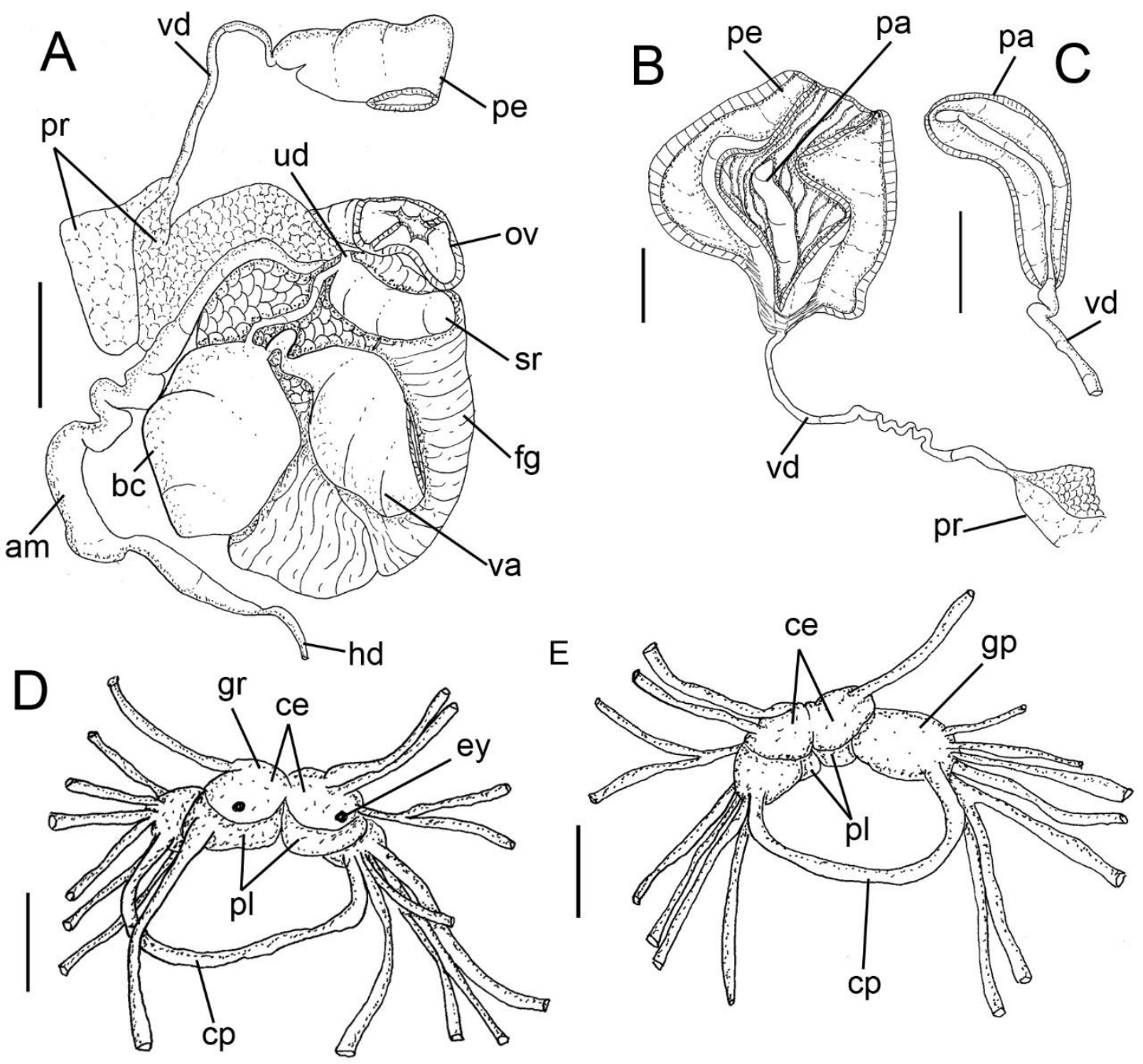

Figure 97: Diaulula sandiegensis. Reproductive system. A. General view. B. Detail of prostate, vas deferens and penis. C. Detail of internal part of vas deferens. Nervous system. D. Dorsal view. E. Same, ventral view. 


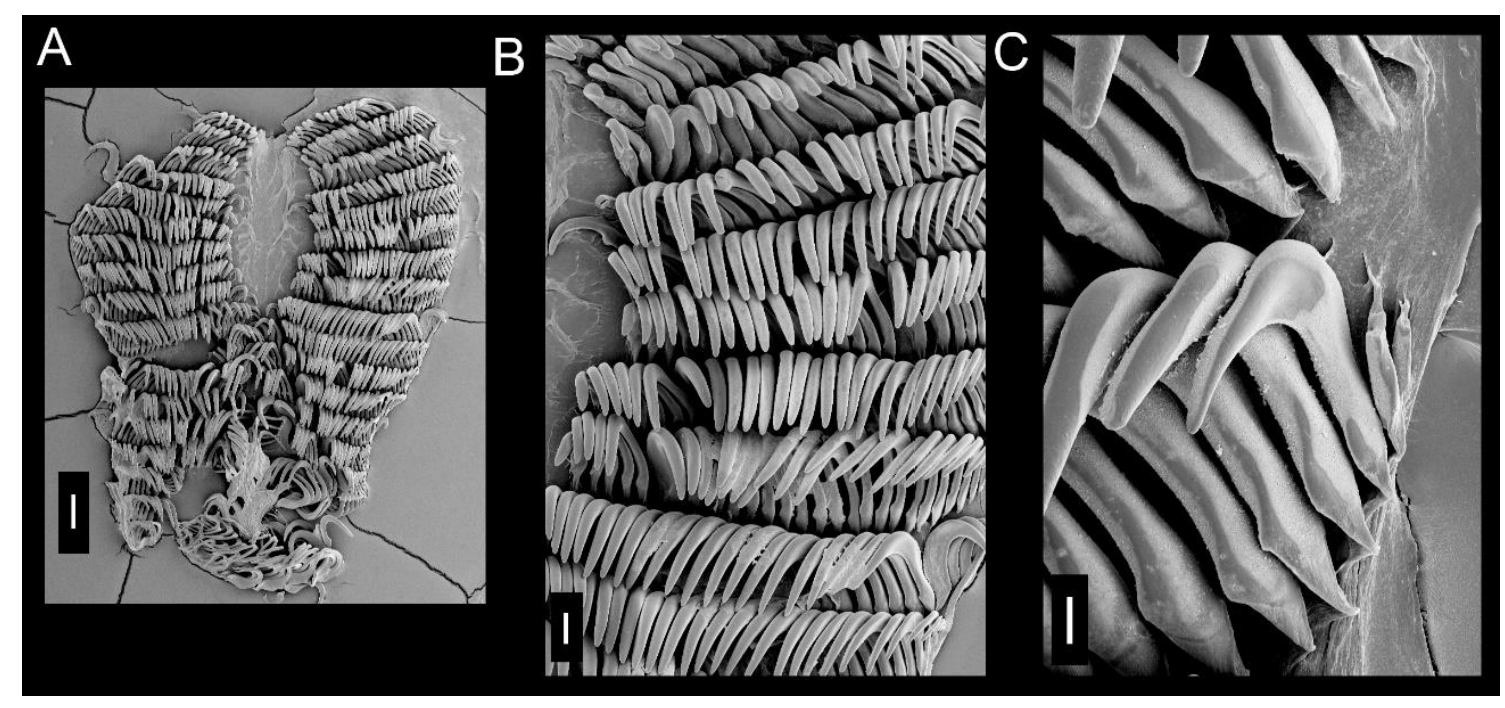

Figure 98: SEM of radula of Diaulula sandiegensis. A. Panoramic view. Scale: $300 \mu \mathrm{m}$. B. Lateral teeth. Scale: $100 \mu \mathrm{m}$. C. Outermost lateral teeth. Scale: $30 \mu \mathrm{m}$.

“Montereina” greeleyi (MacFarland, 1909)

(Figures 99-103)

Synonymic list of Alvim \& Pimenta, 2013

Complement: Camacho-García et al., 2014: 121

Type locality: Riacho Doce, Alagoas, Brazil

\section{Redescription}

External morphology (Figure 99A-E): Size $11 \mathrm{~mm}$ lenth, 8mm width. Color yellow light with some brown spots. Body rounded, foot not exceed from notum (Fig. 99A, B). Rhinophores with about 16 transverse lamellae, color brown; rhinophoral sheaths with small lobes (Fig. 99E). Gill composed of 12 unipinate branchial leaves, color transcluced with brown dots, arranged in circular fashion surrounding anus; branchial sheaths also with small lobes (Fig. 99D). Mouth opening in anterior ventral region, between anterior region of notum and foot. Digitiform tentacles present. Anterior border of foot bilabiate and with longitudinal groove (Fig. 99C).

Haemocoel organs (Figure 100A-B): pericardium and posterior half of visceral mass volume occupying $15 \%$ of haemocoel volume. Buccal mass located anteriorly, occupying $15 \%$ of haemocoel volume. Nervous system dorsal to buccal mass, covered by blood gland, occupying $5 \%$ of haemocoel volume. Reproductive system on right side of 
animal, occupying $25 \%$ of haemocoel volume. Stomach on left side, intestine with small curve at anterior portion and digestive gland, occupying $40 \%$ of haemocoel volume.

Circulatory and excretory systems (Figure 99D; 100A, C): pericardial cavity dorsal and posterior to digestive gland, anterior to gill circle (Fig. 100A). Gill retractor muscle divided, originating from base of gill circle, running longitudinally up to half of foot level, inserting into dorsal surface of foot (Fig. 99D; 100B). Auricle funnel-like (wider anteriorly) with thin walls. Ventricle sligthly taller than wide, with thick muscular walls. Same pattern of vessesl of Doridoidea. Aortic trunk divided near ventricle, branched into anterior artery irrigating reproductive system, buccal mass, odontophore and nervous system; posterior artery irrigating stomach, caecum and digestive gland. Renal vesicle located on right dorsal side of pericardium, near base of auricle, connected to inner surface of pericardium, 1/4 the size of ventricle (Fig. 100C). Renal chamber extending from dorsal to medial sinus, previously connected to renal vesicle, extending posteriorly to center of gill circle and opening in nephrostome, next to base of anal papilla, but difficult to see. Blood gland seem undivided, covering all nervous system (Fig. 100A).

Digestive system (Figures 99D; 100A, B, D; 101A-D; Fig. 103A-D): Oral tube composed of outer lip, with pleats lengthwise; inner lip with transverse fold; mt, three pairs of retractor muscles of buccal mass, originating on oral tube, running dorsally and ventrally to oral tube, inserting on body side, about four times as wide and twice as long as m10 (Fig. 100B, D). Odontophore oval, connected to oral tube by pair of ventral protractor muscles $(\mathbf{m 1 0})$; thin longitudinal, dorsal and ventrolateral protractors of oral sphincter, originating in anterior region of odontophore and inserted in posterior region of integument close to oral tube (Fig. 101B). Oral sphincter surrounding chitinous part of oral tube. Odontophore muscles: $\mathbf{m} \mathbf{2}$, pair of strong retractor muscles of buccal mass, three times longer than wide, origin on anterior dorsal odontophore, running laterally to m4 and inserted ventrally on dorsal portion of foot (Fig. 101B); m2a, pair of retractor muscles, same as m2, but running anteriorly, well distinct from m2 (Fig. 101B); m4, pair of dorsal tensor muscles, strong and broad, 1/3 as long as wide, covering 2/3 of cartilage, inserted on ventral portion of subradular membrane (Fig. 101D, E); m5, pair of dorsal auxiliary tensor muscles, twice as long as wide, originating on most posterior region of odontophore cartilages, covering $~ 1 / 3$ of posterior cavity of odontophore, as long as, but with $\sim 1 / 2$ of $\mathrm{m} 4$ width, inserting on ventral side of subradular membrane, around radular sac (Fig. 101C-E); m6, unpaired horizontal muscle, with transverse fibers connecting to median surface of left and right odontophore cartilages, divided in two parts, about same 
length and wide as $\mathrm{m} 4$, posterior portion $\sim$ twice as wide as anterior portion (Fig. 101E); $\mathbf{m} 7$, pair of thin and narrow muscle, originating on posterior region of $\mathrm{m} 6$, running posterior to inserting on radular sac (Fig. 101E); m9, unpaired and horizontal muscle, originating on posterior portion of $\mathrm{m} 4$, connecting pair of $\mathrm{m} 4$ (Fig. 101E). Pair of odontophore cartilages elliptical, occupying $30 \%$ of odontophore volume (Fig. 101C, E). Subradular membrane thin, strong, translucent. Radular sac $\sim 1 / 4$ as large as odontophore. Radular teeth (Fig. 103A-D): rachidian teeth absent; formula 63 x 41.0 .41 (in $20 \mathrm{~mm}$ long specimen). Each lateral tooth with broad base, tapering toward apex, hook-shaped, with single terminal cusp; outermost teeth winder, apex also hook-shaped, cusp simple and smooth. Pair of salivary glands, tubular, $\sim 1 / 3$ og esophagus length; duct inserting in anterior region of esophagus, extending posteriorly to anterior region of digestive gland (Fig. 100D). Esophagus simple, originating dorsally to odontophore, with S-shaped curve, inserting directly in anterior region of stomach, internal longitudinal folds with same diameter along entire length (Fig. 100D; 101A). Stomach oval, with folds at the center of entire inner surface (Fig. 100D; 101A). Common opening for esophagus, stomach and caecum located on digestive gland (Fig. 101A). Intestine with longitudinal folds along its entire length, diameter about half esophagus diameter, but more uniform. Caecum as an elongated sac, located ventrally to stomach, opening on anterior portion of stomach, close to esophageal insertion, $\sim 1 / 2$ length and $\sim 1 / 4$ of width of stomach (Fig. 101A). Digestive gland dark beige, being largest organ of visceral mass, rounded, inner face of gland sponge-like, bearing a distinct main duct (Fig. 100B). Anus opening into anal papilla at center of gill circle, $\sim 1 / 2$ of gill filament length (Fig. 99D).

Genital system (Figure 99B; 100B; 101F): located between buccal mass and digestive gland, mainly on right side and dorsally (Fig. 100B). Genital opening on right side, anterior third of length of animal from head, located between foot and notum (Fig. 99B). Gonad immersed in digestive gland, difficult to distinguished. Hermaphrodite duct thin, long. Ampulla located on female gland, elongated, tubular and broad. Prostate flattened, glandular, length same as ampulla (Fig. 101F). Vas deferens about same half diameter and twice length of penis. Penis muscular, cylindrical and elongated, about 1/2 of length of prostate. Female gland well-developed, rounded, occupying 25\% of reproductive system volume, divided into mucus gland $(\sim 2 / 3$ of female gland, color beige), and albumen gland ( $\sim 1 / 3$ of anteriormost region, dilated, irregularly shaped, color dark brown) (Fig. 101F). Oviduct occupying 1/7 of female gland volume. Uterine duct thin, relatively short, length $\sim 1 / 6$ of vagina length, located at base of vagina, inserted in 
female gland near oviduct. Seminal receptacle pyriform, as large as bursa copulatrix, length $\sim 1 / 3$ of vagina length, connected to bursa copulatrix through median stalk, $\sim 1 / 2$ of vagina length. Bursa copulatrix rounded, length $\sim 1 / 2$ of vagina length, connected directly to vagina (Fig. 101F). Vagina cylindrical, elongated, approximately as long as and half as wide as penis, followed ventrally by prostate and located parallel to penis in genital opening.

Nervous system (Figure 102A-C): located dorsally to odontophore, mostly covered by blood gland. Pair of cerebral and pleural ganglia fused with each other dorsally and ventrally. Pedal ganglia fused with cerebral and pleural ventrally, but not fused among themselves. Pedal commissure simple, about twice as cerebral ganglia length, surrounding esophagus and salivary glands (Fig. 102B). Buccal ganglia short, located ventrally to odontophore, between radular sac and anterior portion of esophagus, connected to cerebral ganglia through long and slender connective tissue, united to gastroesophageal ganglia by short connective tissue (Fig. 102C). Buccal commissure short. Gastro-esophageal ganglia length about same length of buccal ganglia. Rhinophoral (olfactory) ganglia bulb-shaped, connected to anterior portion of cerebral ganglia. Dorsal eyes located on cerebral ganglia (Fig. 102A). Statocysts small and iridescent, located ventrally to pedal ganglia (Fig. 102C).

Distribution (Alvim \& Pimenta, 2014): U.S.A. (South Carolina) to Brazil (Sao Paulo).

Habitat: Under intertidal rocks.

Material examined: MZSP 37961, 2 specimens (Col. Marcus 14034 - 20’ OT); BRAZIL, Praia do Suape, Cabo de Santo Agostinho, Pernambuco, MZSP 86138, 1 specimen (S. Almeida coll., 19/vii/2005); Praia do Saco da Pedra, Maceió, Alagoas, MZSP 97090, 1 specimen, (J. Bahia coll., 11/i/2008); MZSP 103363, 1 specimen (V. Padula, coll. 26/i/2012, Workshop of Nudibranchia - CEBIMAR); Canal do Itajurú, Cabo Frio, Rio de Janeiro, MZSP 97511, 4 specimens (J. Bahia \& V. Padula, 18/v/2008); Canal de Cabo Frio, MZSP 97604, 2 specimens (V. Padula coll., 10/xii/2007); Praia do Portinho, Ilha Bela, São Paulo, MZSP 92739, 1 specimen (F.N. Santos, V.S. Amaral \& P.O.V. Lima coll., 22/xi/2009); Praia do Segredo, Pedra da Baleia, MZSP 103219, 1 specimen (J. Bahia, coll., 17/i/2012, Workshop of Nudibranchia - CEBIMAR). 

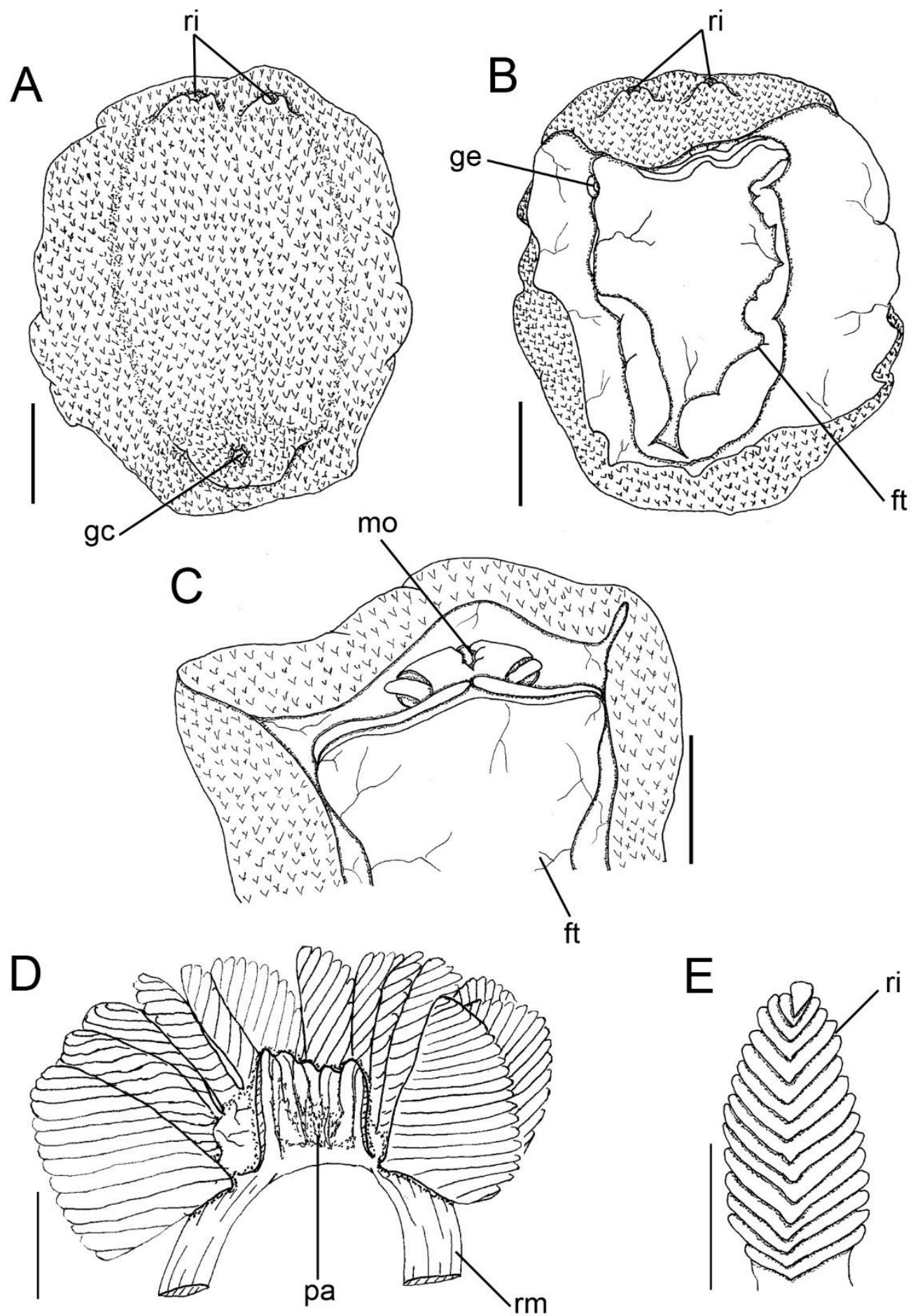

Figure 99: "Montereina" greeleyi, fixed animal. A. Dorsal view. B. Same, ventral view. Scales: $5 \mathrm{~mm}$. C. Detail of anterior border of foot. D. Gill circle. Scales: $1 \mathrm{~mm}$. E. Rhinophore. Scale: 0,5mm. 

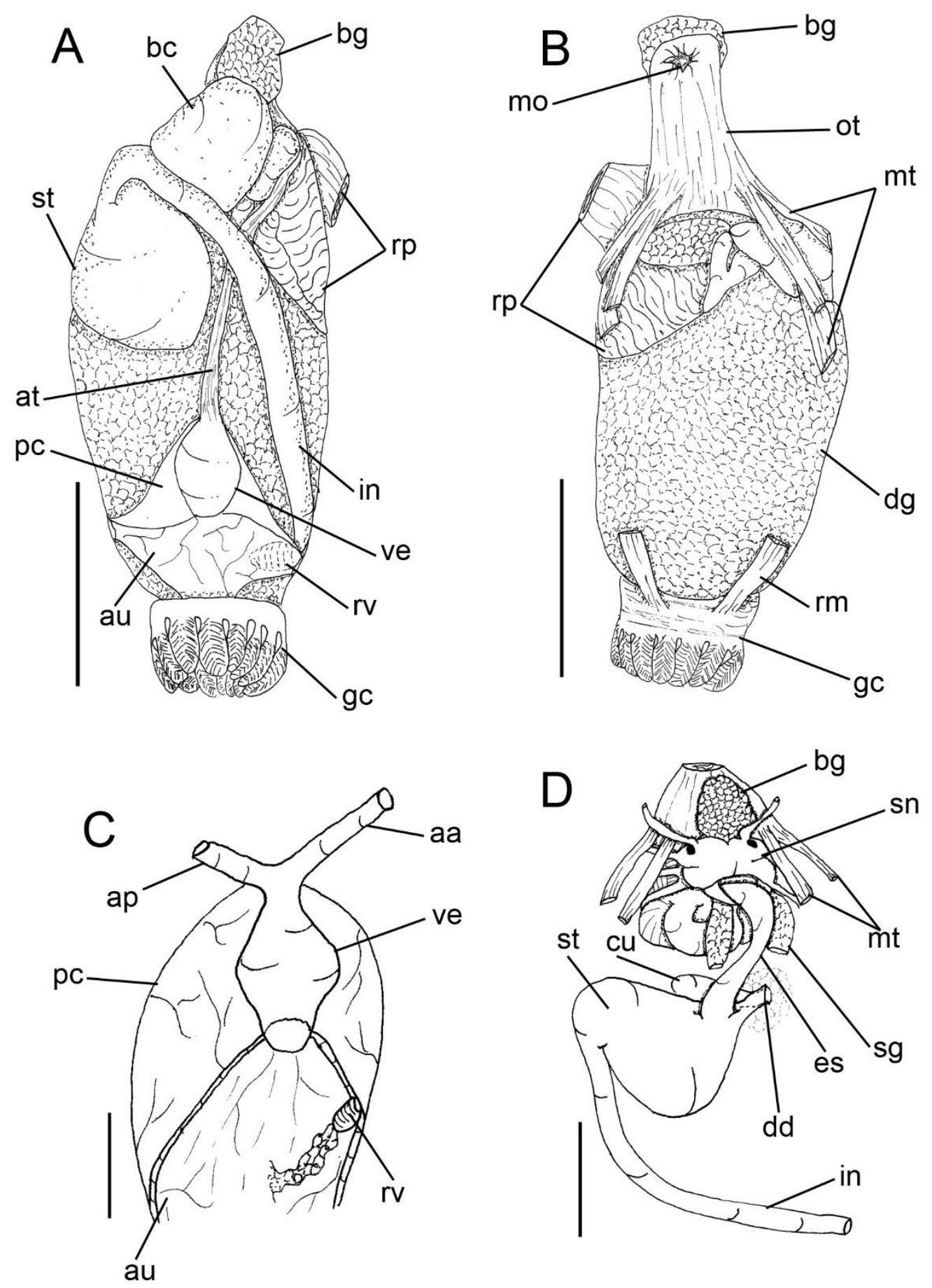

Figure 100: "Montereina" greeleyi. Visceral mass. A. Dorsal view. B. Same, ventral view. Scales: $5 \mathrm{~mm}$. C. Circulatory ande excretory system, vental view. D. Digestive system, dorsal view. Scales: $1 \mathrm{~mm}$. 

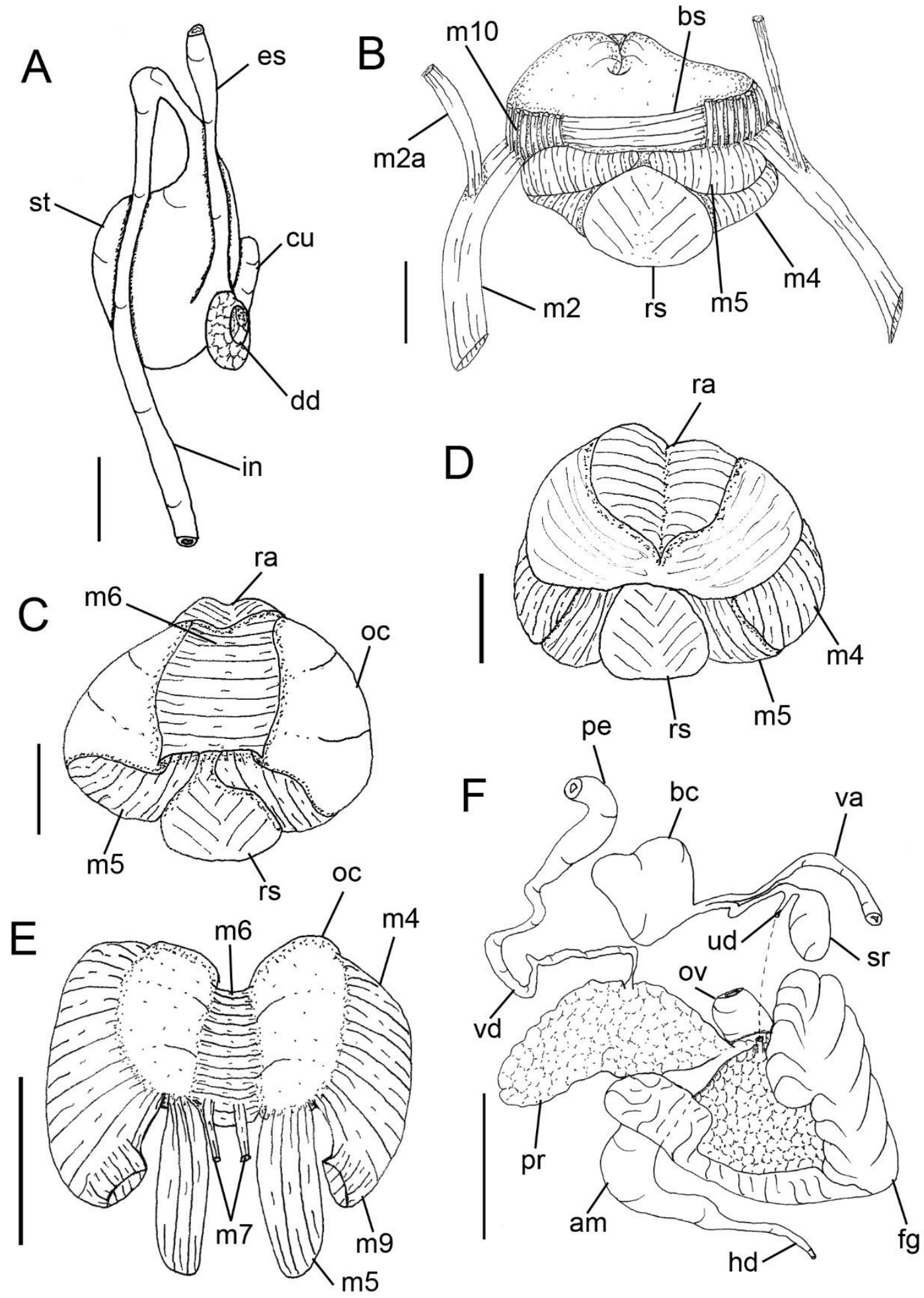

Figure 101: "Montereina”" greeleyi. A. Medium digestive system. B. Anterior digestive with removed oral tube. Odontophore. C. Ventral view. D. Same, dorsal view with radula. E. Same, dorsal view with radula removed and folded down muscles. F. General view of reproductive system. Scales: $1 \mathrm{~mm}$. 

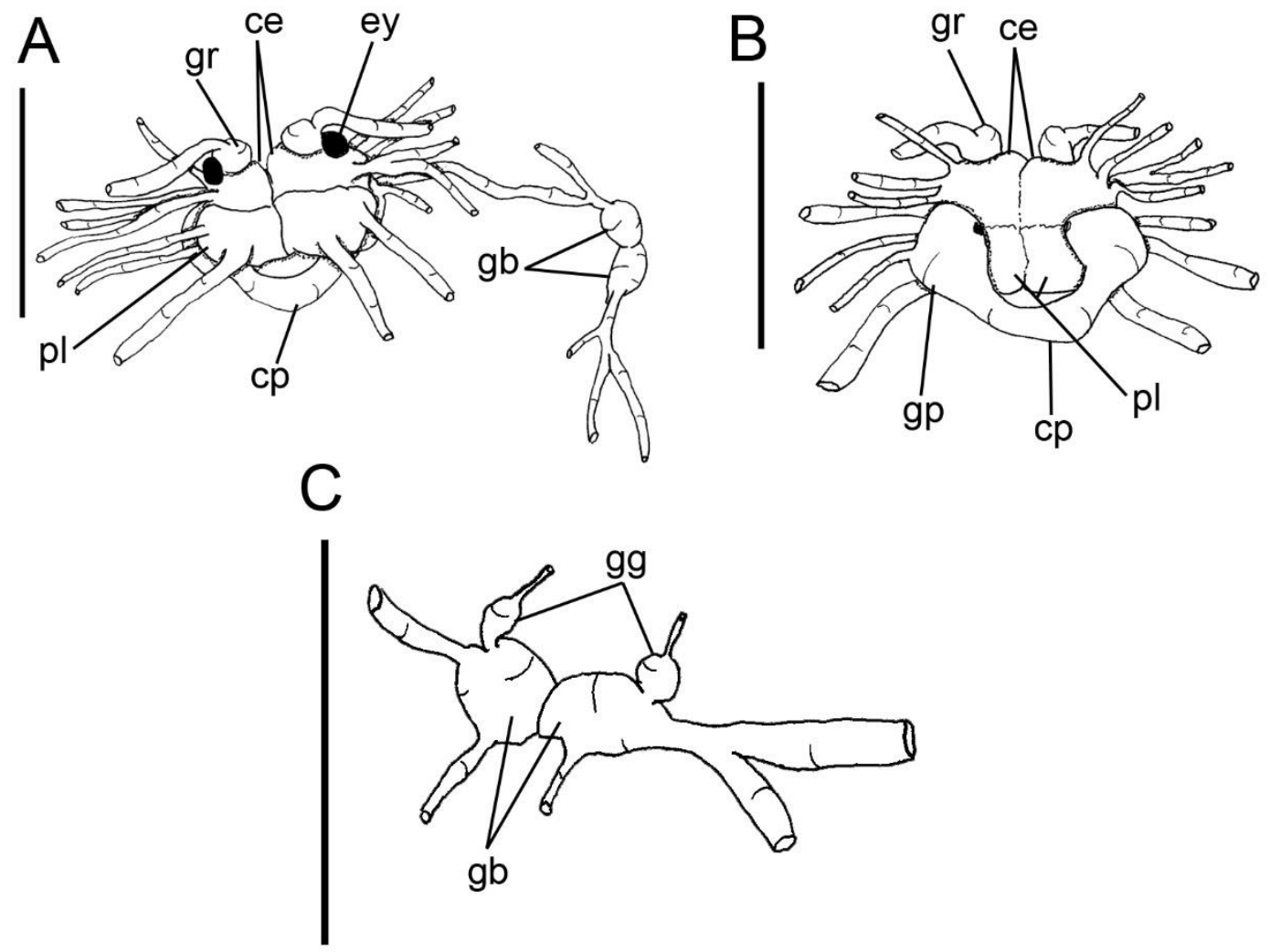

Figure 102: “Montereina” greeleyi. Nervous system. A. Dorsal view. B. Same, ventral view. Scales: $1 \mathrm{~mm}$. C. Buccal and gastroesophageal ganglia. Scale: $0,5 \mathrm{~mm}$. 


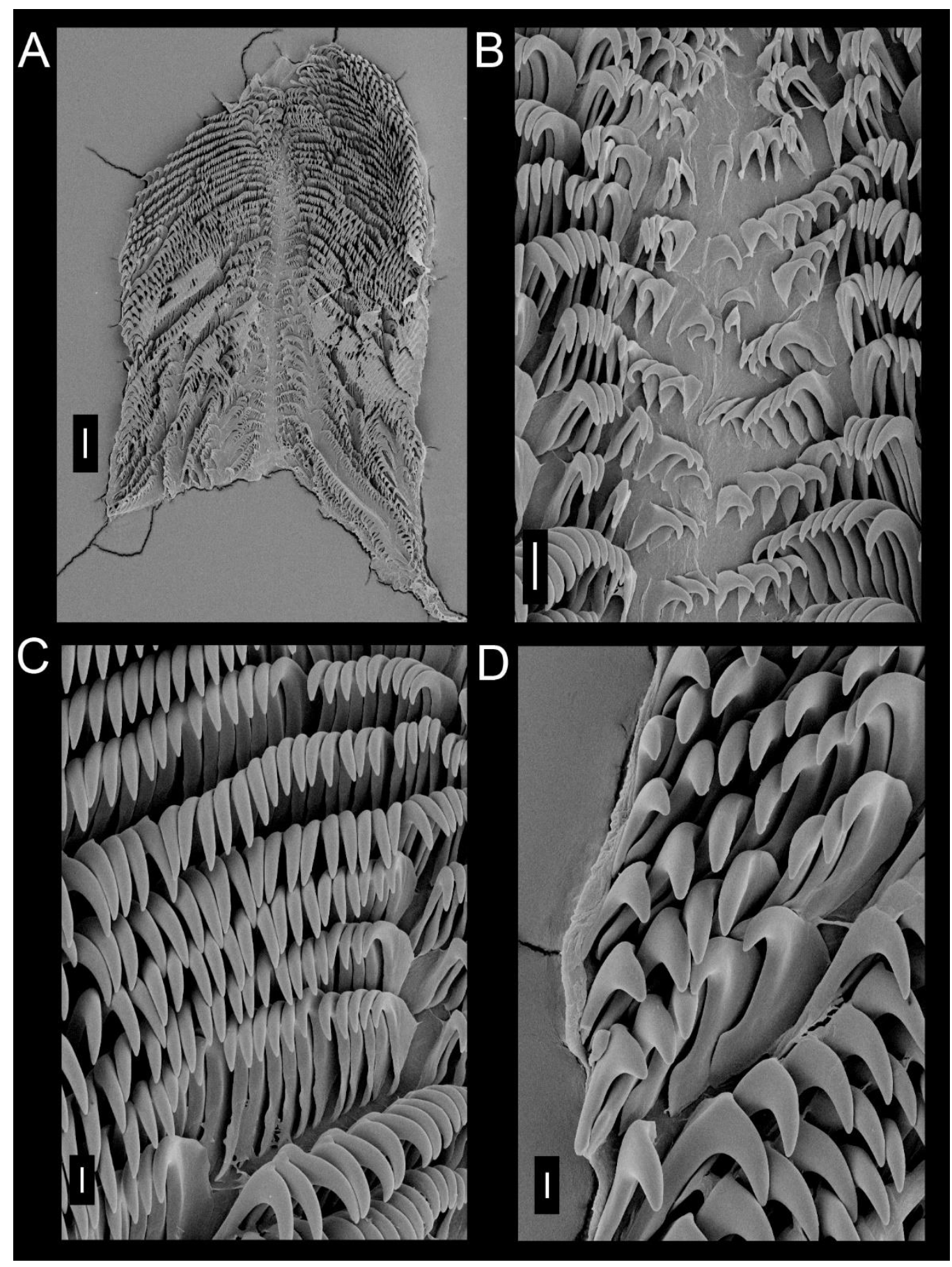

Figure 103: SEM of radula of "Montereina" greeleyi. A. Panoramic view. Scale: $100 \mu \mathrm{m}$. B. Central region with rachidian absent. Scale: $20 \mu \mathrm{m}$. C. Lateral teeth. D. Outermost lateral teeth. Scales: $10 \mu \mathrm{m}$. 


\section{Genus Jorunna Bergh, 1876}

Type species: Doris johnstoni Alder \& Hancock, 1845 [Jorunna tomentosa (Cuvier, 1804)], by monotypy

\section{Jorunna spazzola (Er. Marcus, 1955)}

(Figures 104-108)

Awuka spazzola Er. Marcus, 1955: 156, figs. 180-192; Er. Marcus, 1958b: 57; Ev. Marcus, 1970: 210.

Jorunna spazolla: Ev. Marcus, 1976c: 35; Edmunds \& Just, 1985: 55, figs. 2B, 4B; Valdés et al., 2006: 184; García et al., 2008:154; Rios, 2009: 428; Alvim \& Pimenta, 2013: 179, figs.1H; 17-18; Camacho-García et al., 2014: 121

Type locality: São Sebastião Island, São Paulo, Brazil

\section{Redescription}

External morphology (Figures 104A-F; 105A, B): Size 7mm length, 4mm width. Color grayish white with pale violet blotches. Body rounded covered by caryophillidia (Fig. 104A, C). Foot not exceed from notum (Fig. 104B). Rhinophores with about 8 transverse lamellae, color similar to body; rhinophoral sheaths surrounded by caryophyllidia (Fig. 104E, F). Gill composed of 9 unipinate branchial leaves, color similar to body, arranged in circular fashion surrounding anus; branchial sheaths same as rhinophoral sheaths (Fig. 105A, B). Mouth opening in anterior ventral region, between anterior region of notum and foot. Digitiform tentacles present. Anterior border of foot bilabiate with londitudinal groove (Fig. 104D).

Haemocoel organs (Figure 105C, D): pericardium and posterior half of visceral mass volume occupying $10 \%$ of haemocoel volume. Buccal mass located anteriorly, occupying $20 \%$ of haemocoel volume. Nervous system dorsal to buccal mass, covered by divided blood gland, occupying $5 \%$ of haemocoel volume. Reproductive system on right side of animal, occupying $25 \%$ of haemocoel volume. Stomach internal to digestive gland, intestine with small curve at anterior portion and digestive gland, occupying $40 \%$ of haemocoel volume.

Circulatory and excretory systems (Figure 105A-C, E): pericardial cavity dorsal and posterior to digestive gland, anterior to gill circle (Fig. 105C). Afferent and efferent branches located inside each gill filament, flowing from and to afferent and efferent branchial veins (Fig. 105B). Gill retractor muscle divided, originating from base of gill 
circle, running longitudinally up to half of foot level, inserting into dorsal surface of foot (Fig. 105A). Auricle funnel-like (wider anteriorly) with thin walls. Ventricle sligthly taller than wide, with thick muscular walls. Same pattern of vessels of Discodorididae. Aortic trunk divided close to ventricle, branched into anterior artery irrigating reproductive system, buccal mass, odontophore and nervous system, posterior artery irrigating stomach, caecum and digestive gland (Fig. 105E). Renal vesicle located on right dorsal side of pericardium, near base of auricle, connected to inner surface of pericardium, 1/5 of ventricle size (Fig. 105E). Renal chamber extending from dorsal to medial sinus, previously connected to renal vesicle, extending posteriorly to center of gill circle and opening in nephrostome, difficult to see. Blood gland divided in two parts, anterior $1 / 2$ of length of posterior (Fig. 105C).

Digestive system (Figures 105A, C; 106A-E; 108A-B): Oral tube composed of outer lip, without pleats; inner lip with thin transverse incospicuos folds; mt, three pairs of retractor muscles of buccal mass, originating on oral tube, running dorsally and ventrally to oral tube, inserting on body side, about four times as wide and three times as long as m10 (Fig. 106A, B). Odontophore oval, connected to oral tube by pair of ventral protractor muscles (m10); thin longitudinal, dorsal and ventrolateral protractors of oral sphincter, originating in anterior region of odontophore and inserted in posterior region of integument close to oral tube (Fig. 106D). Oral sphincter surrounding chitinous part of oral tube. Odontophore muscles: $\mathbf{m} \mathbf{2}$, pair of strong retractor muscles of buccal mass, six times long than wide, origin on anterior dorsal odontophore, running laterally to $\mathrm{m} 4$ and inserted ventrally on dorsal portion of foot (Fig. 106A-E); m4, pair of dorsal tensor muscles, strong and broad, $1 / 3$ as long as wide, covering $2 / 3$ of cartilage, inserted on ventral portion of subradular membrane (Fig. 106E); m5, pair of dorsal auxiliary tensor muscles, twice as long as wide, originating on most posterior region of odontophore cartilages, covering $\sim 1 / 3$ of posterior cavity of odontophore, as long as, but with $\sim 1 / 2$ of $\mathrm{m} 4$ width, inserting on ventral side of subradular membrane, around radular sac (Fig. 106E); m6, unpaired horizontal muscle, with transverse fibers connecting to median surface of left and right odontophore cartilages, about same length and half as wide as $\mathrm{m} 4$, posterior portion same as wide as anterior portion (Fig. 106E); m7, pair of thin and narrow muscle, originating in anterior region of $\mathrm{m} 6$, running parallel posteriorly to inserting on radular sac (Fig. 106E); m9, unpaired and horizontal muscle, originating on posterior portion of $\mathrm{m} 4$, connecting pair of $\mathrm{m} 4$ (Fig. 106E). Pair of odontophore cartilages elliptical, occupying $40 \%$ of odontophore volume (Fig. 106D, E). Subradular membrane 
thin, strong, translucent. Radular sac $\sim 1 / 2$ as large as odontophore (Fig. 106C). Radular teeth (Fig. 108A-B): rachidian teeth absent; formula 10 x 11.0.11 (in $6 \mathrm{~mm}$ long specimen). Each lateral tooth with broad base, tapering toward apex, hook-shaped, with single terminal cusp; outermost teeth thinner, inner base width about half of lateral teeth width, apex also hook-shaped, cusp simple and smooth. Esophagus simple, broad, originating dorsally to odontophore, inserting directly in anterior region of stomach (Fig. 106A). Stomach very short, internal to digestive gland, close to anterior region of intestine. Common opening for esophagus, stomach and caecum located on digestive gland. Intestine with longitudinal folds along its entire length, diameter about half esophagus diameter. Caecum as an elongated sac, located ventrally to stomach, opening on anterior portion of stomach, close to esophageal insertion, $\sim 1 / 2$ length and $\sim 1 / 2$ of width of esophagus. Digestive gland dark beige, being largest organ of visceral mass and occupying $40 \%$ of its volume, cone-shaped; anterior portion about twice as wide as posterior portion, inner face of gland sponge-like, bearing distinct main duct (Fig. 105C). Anus opening into anal papilla at center of gill circle, $\sim 1 / 2$ of gill filament length (Fig. 105A).

Genital system (Figure 104B; 105A; 107A-D): located between buccal mass and digestive gland, mainly on right side and dorsally (Fig. 105A). Genital opening on right side, anterior third of length of animal from head, located between foot and notum (Fig. 104B). Gonad immersed in digestive gland, difficult to distinguish it. Hermaphrodite duct thin, long. Ampulla located on female gland, elongated and tubular (Fig. 107A). Prostate tubular, glandular, three times longer than ampulla (Fig. 107A, C). Vas deferens with same diameter of penis, both thin, about $1 / 5$ of prostate length (Fig. 107D). Penis' muscle absent. Penis with internal papilla (Fig. 107D). Female gland well-developed, rounded, occupying $\sim 15 \%$ of reproductive system volume, divided into mucus gland $(\sim 2 / 3$ of female gland, color beige), and albumen gland ( 1/3 of anteriormost region, dilated, irregularly shaped, color dark brown) (Fig. 107A). Oviduct occupying $\sim 1 / 10$ of female gland volume. Uterine duct thin, relatively short, length $\sim 1 / 7$ of vagina length, located at base of seminal receptacle, inserted in female gland near oviduct. Seminal receptacle rounded, $\sim 1 / 2$ of bursa copulatrix length, connected to bursa copulatrix through stalk $\sim 1 / 3$ of vagina length (Fig. 107B). Bursa copulatrix rounded, length $\sim 1 / 2$ of vagina length, connected directly to vagina (Fig. 107B). Vagina cylindrical, elongated, very thin, approximately $1 / 2$ of prostate length and same wide as penis, followed ventrally by prostate and located parallel to penis in genital opening (Fig. 107A). Acessory gland with long 
and tubular duct, about $1 / 2$ of prostate length, and proximal part same bottomless sac (Fig. 107C).

Nervous system (Figure 106A; 107E-G): located dorsally to odontophore, mostly covered by blood gland (Fig. 106A). Pair of cerebral and pleural ganglia fused with each other dorsally and ventrally. Pedal ganglia fused with cerebral and pleural ventrally, but not fused among themselves. Pedal commissure simple, thin, surrounding esophagus and salivary glands (Fig. 107F). Buccal ganglia short, located ventrally to odontophore, between radular sac and anterior portion of esophagus, connected to cerebral ganglia through long and slender connective tissue, united to gastro-esophageal ganglia by short connective tissue (Fig. 107G). Gastro-esophageal ganglia length about 1/4 of buccal ganglia length, circular. Rhinophoral (olfactory) ganglia bulb-shaped, connected to anterior portion of cerebral ganglia (Fig. 107E). Dorsal eyes located on cerebral ganglia, connected by short optical nerve to cerebral ganglia (Fig. 107E). Statocysts small and iridescent, located ventrally to pedal ganglia (Fig. 107F).

Distribution: Barbados to Brazil (Rio de Janeiro, São Paulo) (Edmunds \& Just, 1985; García et al., 2008; Alvim \& Pimenta, 2014).

Habitat: Under intertidal rocks.

Material examined: BRAZIL, Praia do Segredo, Pedra da Baleia, São Sebastião, São Paulo, MZSP103279, 3 specimens (C.M. Cunha col., 20/i/2012, intertidal zone, under rocks); MZSP 103280, 1 specimen (C.M. Cunha, P.O.V. Lima \& L. Saad, 20/i/2012, intertidal zone, under rocks); Ponta da Praia, Santos, MZSP 115222, 1 specimen (C.M. Cunha coll., 07/ix/2013); MZSP 115226, 1 specimen (C.M. Cunha coll., 07/ix/2013). 

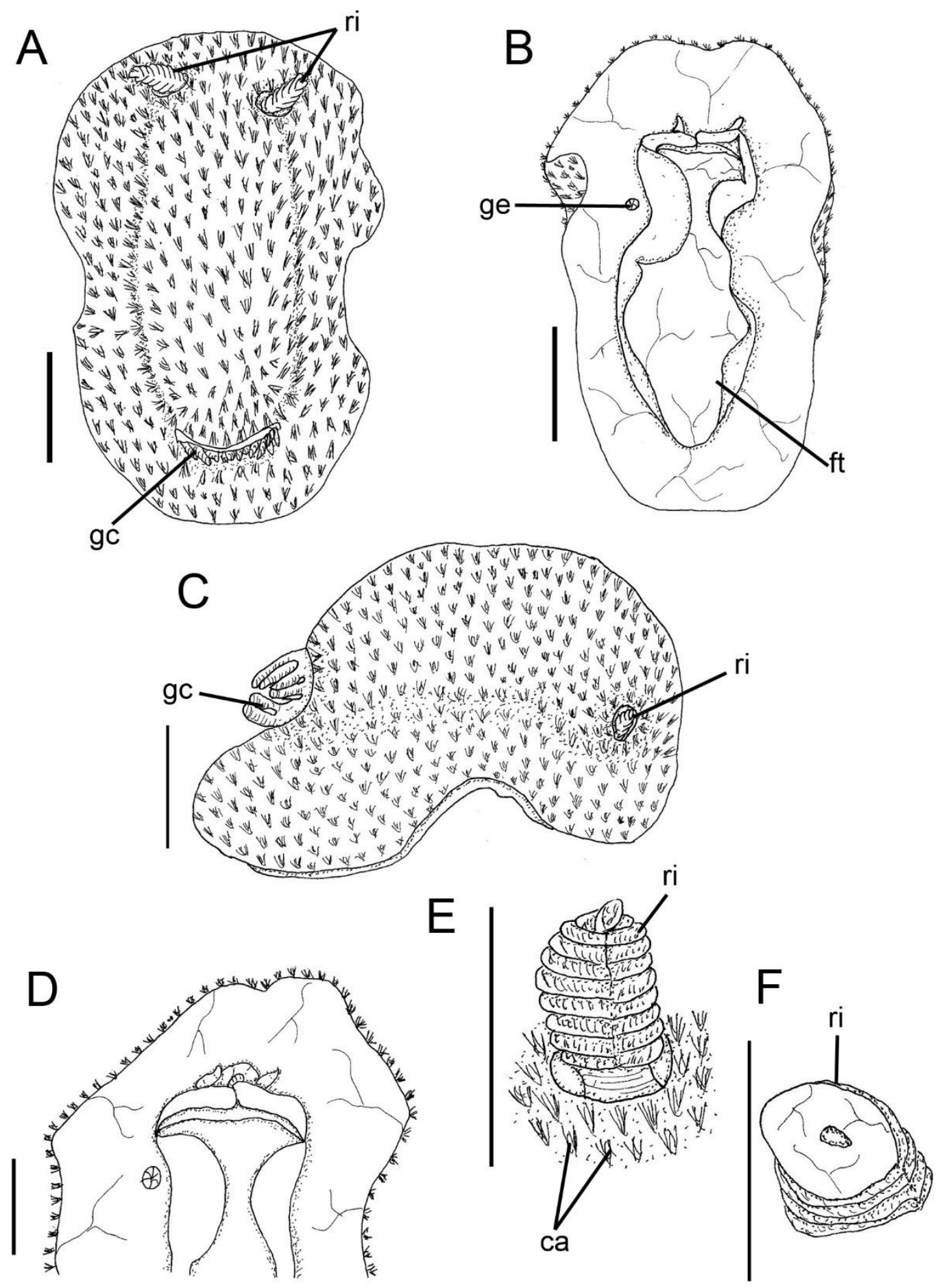

Figure 104: Jorunna spazzola, fixed animal. A. Dorsal view. B. Same, ventral view. C. Same, right lateral view. Scales: $2 \mathrm{~mm}$. D. Detail of anterior border of foot. Rhinophore. E. Rhinophoral sheath. F. Transversally sectioned, dorsal view. Scales: $1 \mathrm{~mm}$. 

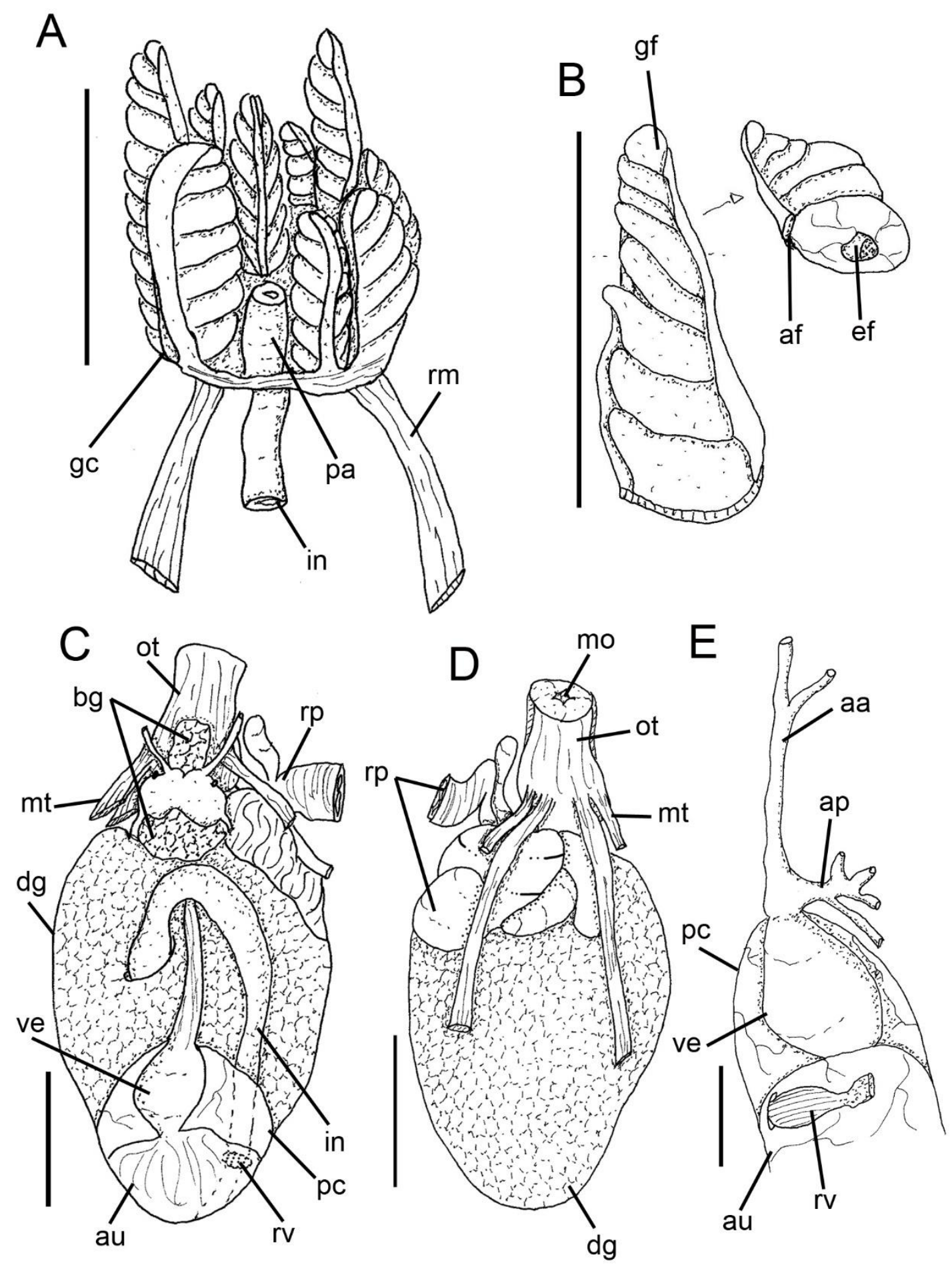

Figure 105: Jorunna spazzola. A. Gill circle. B. Gill filament with transverselly sectioned showing afferent and efferent branchial ring. Vsceral mass. C. Dorsal view. D. Same, ventral view. E. Circulatory and excretory system, ventral view. Scales $1 \mathrm{~mm}$. 


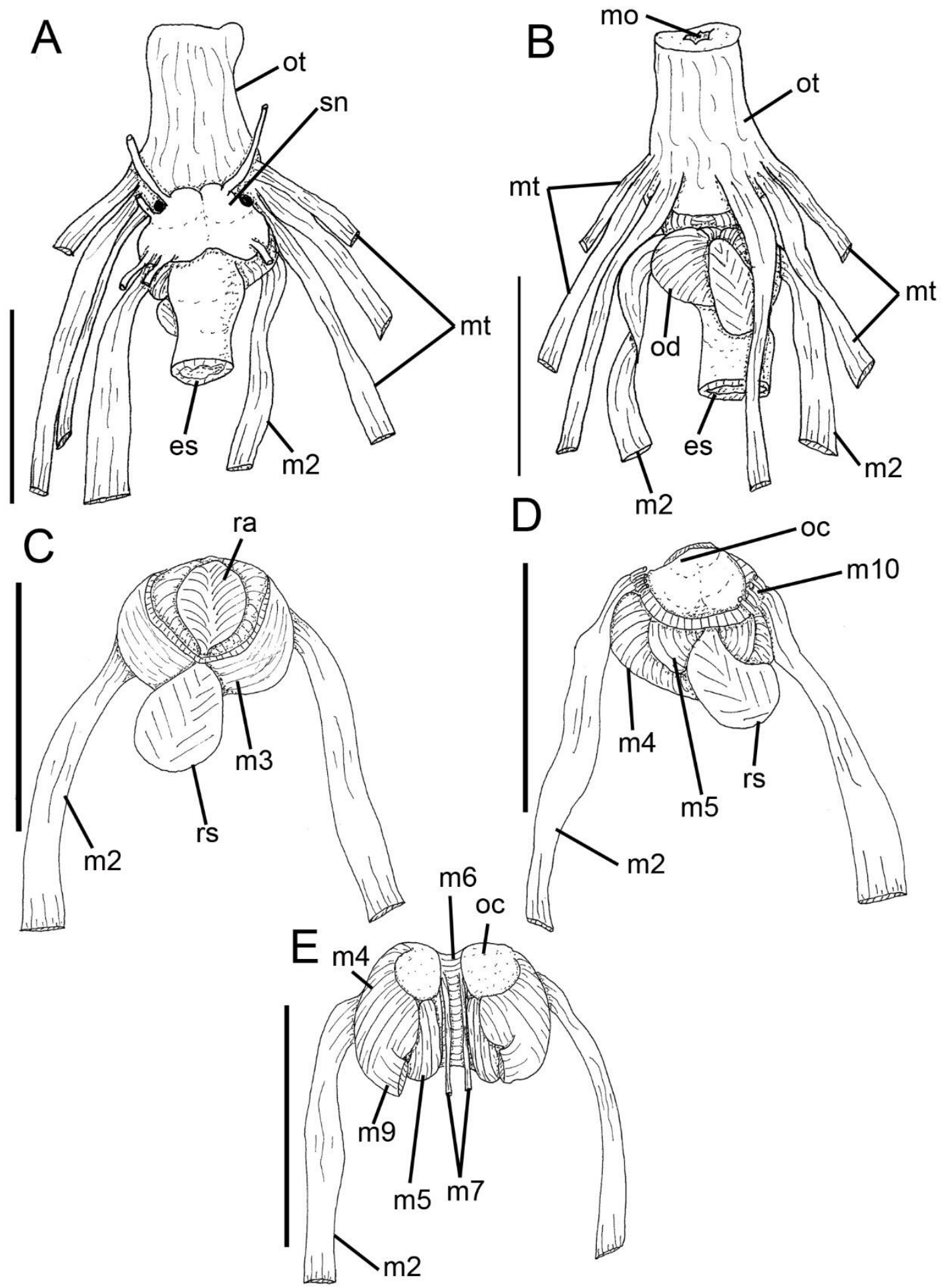

Figure 106: Jorunna spazzola. Anterior digestive system. A. Dorsal view. B. Same, ventral view. Odontophore. C. Dorsal view with radula. D. Same, ventral view. E. Dorsal view wiht radula removed. Scales: $1 \mathrm{~mm}$. 

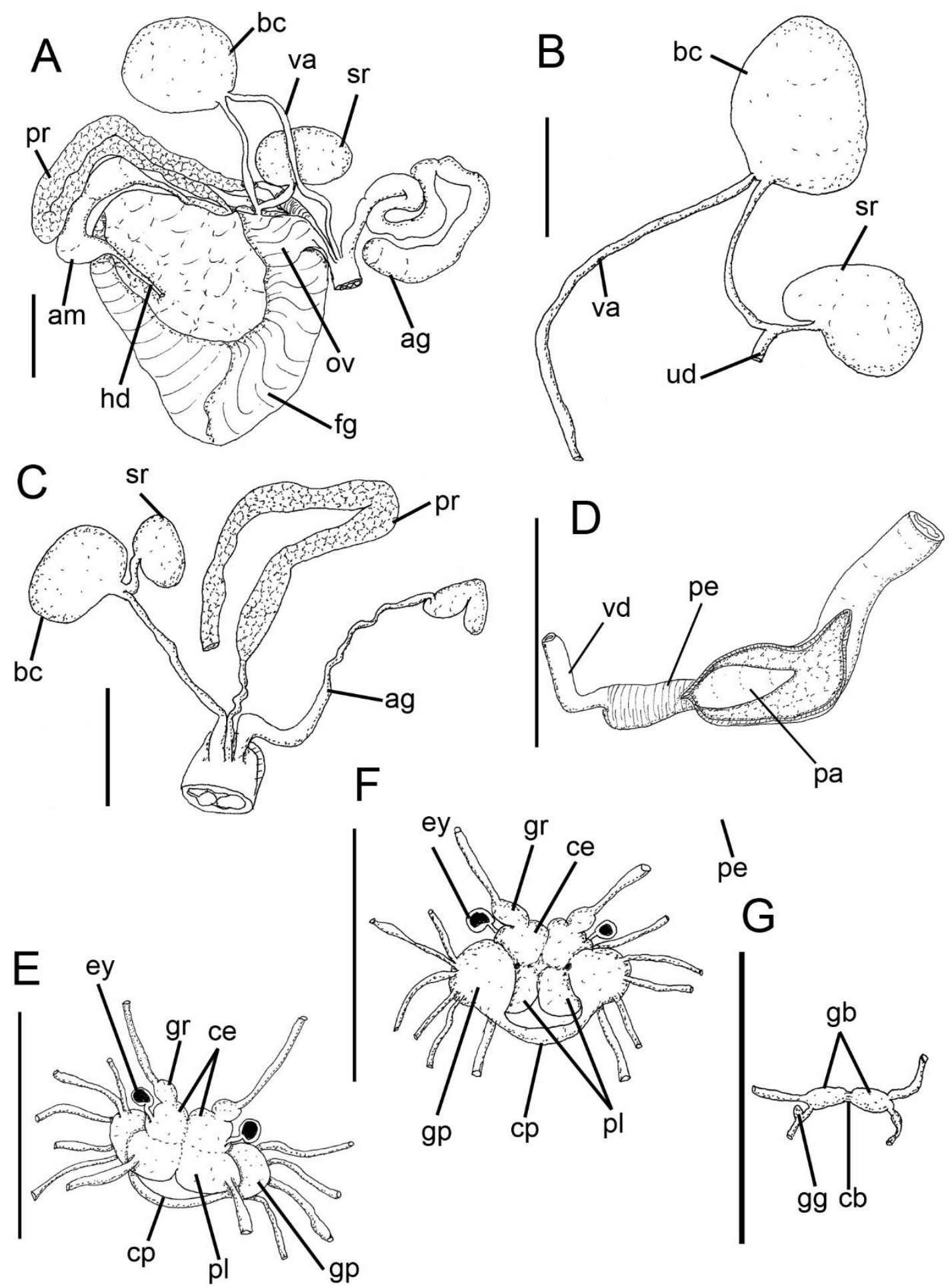

Figure 107: Jorunna spazzola. Reproductive system. A. General view. B. Detail of bursa copulatrix, seminal receptacle and vagina. C. Detail of aperture, with accessory gland. D. Detail of papillae of penis. Nervous system. E. Dorsal view. F. Same, ventral view. 


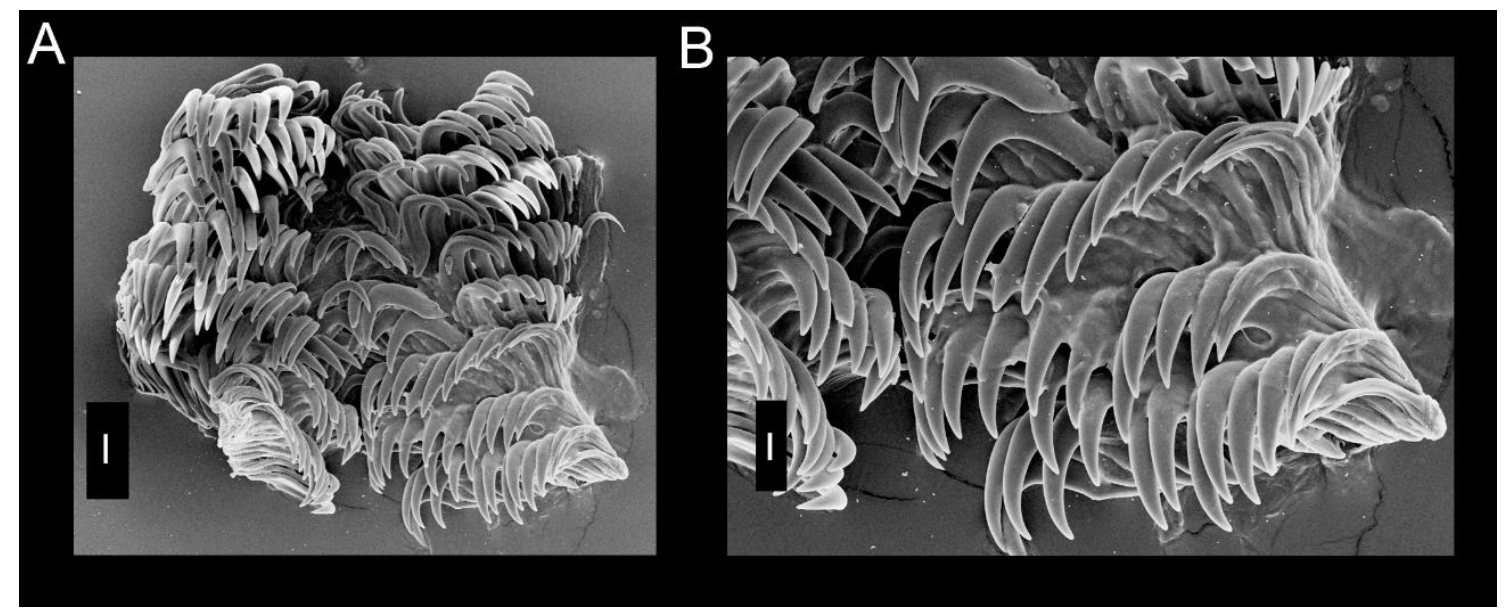

Figure 108: SEM of radula of Jorunna spazzola. A. Panoramic view. Scale: $30 \mu \mathrm{m}$. B. Lateral view. Scale: $10 \mu \mathrm{m}$.

\section{Genus Platydoris Bergh, 1877}

Type species: Doris argo Linnaeus, 1767 by subsequent designation by O’Donoghue (1929)

\section{Platydoris angustipes (Mörch, 1863)}

(Figures 109-114)

Doris (Argus) angustipes Mörch, 1863: 32

Platydoris angustipes var. alaleta Bergh, 1877b: 505, plt. 58, figs. 13-18.

Platydoris rubra White, 1952: 118, fig. 17, plt. 6, fig. 6.

Platydoris angustipes: Er. Marcus, 1957: 422, fig. 81-89; Ev. Marcus \& Er. Marcus, 1967a: 93, fig. 112; Er. Marcus \& Ev. Marcus, 1970: 67, fig. 121; Marcus, Ev., 1972: 79; Meyer, 1977: 301; Humann, 1992: 243; Dorgan et al., 2002: 282, figs. 1B, 2B, 11-13; Valdés et al., 2006: 182; Debelius \& Kuiter, 2007: 245; García et al., 2008: 148; Alvim \& Pimenta, 2013: 186, figs. 2C; 21-22; Padula et al., 2012: 3; Camacho-García et al., 2014: 121.

Type locality: St. Thomas

\section{Redescription}

External morphology (Figure 109A-E): Size 25mm length, 20mm width. Body rounded and dorsoventrally flattened (Fig. 109A, B). Foot not exceeds notum (Fig. 109B) Rhinophores with about 19 transverse lamellae, color similar to body; rhinophoral sheaths with small lobes (Fig. 109C). Gill composed of six tripinnate branchial leaves, color similar to body, arranged in branched fashion with anus in middle of rachis; branchial 
sheaths also with small lobes, color similar to body (Fig. 109E). Mouth opening in anterior ventral region, between anterior region of notum and foot. Digitiform tentacles present. Anterior border of foot bilabiate and with longitudinal groove (Fig. 109B).

Haemocoel organs (Figure 110A-B): pericardium and posterior half of visceral mass volume occupying $15 \%$ of haemocoel volume. Buccal mass located anteriorly, occupying $10 \%$ of haemocoel volume. Nervous system dorsal to buccal mass, covered by blood gland, occupying 5\% of haemocoel volume. Reproductive system on right side of animal; occupying $25 \%$ of haemocoel volume. Stomach on left side, intestine with small curve at anterior portion, and digestive gland occupying $45 \%$ of haemocoel volume.

Circulatory and excretory systems (Figure 109D, E; 110A-C): pericardial cavity dorsal and posterior to digestive gland, anterior to gill circle (Fig. 110A). Afferent and efferent branches located inside each gill filament, flowing from and to afferent and efferent branchial veins (Fig. 109D). Gill retractor muscle divided, originating from base of gill circle, running longitudinally up to half of foot level, inserting into dorsal surface of foot (Fig. 110B). Auricle funnel-like (wider anteriorly) with thin walls. Ventricle sligthly taller than wide, with thick muscular walls (Fig. 110C); Same pattern of vessels of Discodorididae. Aortic trunk divided very close to ventricle, branched into anterior artery irrigating stomach and digestive gland; posterior artery irrigating reproductive system, buccal mass, odontophore and nervous system (Fig. 110C). Renal vesicle located on right dorsal side of pericardium, near base of auricle, connected to inner surface of pericardium, 1/6 of ventricle size (Fig. 110A). Renal chamber extending from dorsal to medial sinus, previously connected to renal vesicle, extending posteriorly to center of gill circle (Fig. 109E). Nephrostome difficult to see. Blood gland divided in anterior and posterior portion (Fig. 110A).

Digestive system (Figures 109E; 110A-B, D-E; 111A-E; Fig. 114A-C): Oral tube composed of outer lip and inner lip, with thick transverse fold; mt, three long pairs of retractor muscles of buccal mass, originating on oral tube, running dorsally and ventrally to oral tube, inserting on body side, about four times as wide and three times as long as m10 (Fig. 110D, E). Odontophore oval, connected to oral tube by pair of ventral protractor muscles $(\mathbf{m 1 0})$; thin longitudinal, dorsal and ventrolateral protractors of oral sphincter, originating in anterior region of odontophore and inserted in posterior region of integument close to oral tube (Fig. 110E; 111C). Oral sphincter surrounding chitinous part of oral tube (Fig. 110D). Odontophore muscles: m2, pair of strong retractor muscles of buccal mass, four times longer than wide, originating on anterior dorsal odontophore, 
running laterally to $\mathrm{m} 4$ and inserted ventrally on dorsal portion of foot, bifurcate on insertion (Fig. 111B-D); m4, pair of dorsal tensor muscles, strong and broad, as long as wide, covering $2 / 3$ of cartilage, inserted on ventral portion of subradular membrane (Fig. 111D, E); m5, pair of dorsal auxiliary tensor muscles, twice as long as wide, originating on most posterior region of odontophore cartilages, covering $\sim 1 / 3$ of posterior cavity of odontophore, as long as, but with $\sim 1 / 3$ of $\mathrm{m} 4$ width, inserting on ventral side of subradular membrane, around radular sac (Fig. 111D, E); m6, unpaired horizontal muscle, with transverse fibers connecting to median surface of left and right odontophore cartilages, about same length and half as wide as $\mathrm{m} 4$, posterior portion as wide as anterior portion (Fig. 111D, E); m7, pair of thin and narrow muscle, originating on inner surface of odontophore cartilages, running together posterior to inserting on radular sac (Fig. 111D, E); m9, unpaired and horizontal muscle, originating on posterior portion of $\mathrm{m} 4$, connecting pair of m4 (Fig. 111D, E). Pair of odontophore cartilages elliptical, occupying $40 \%$ of odontophore volume (Fig. 111D, E). Subradular membrane thin, strong, translucent. Radular sac $\sim 1 / 4$ as large as odontophore. Radular teeth (Fig. 114A-C): rachidian teeth absent; formula $42 \times 62.0 .62$ (in $25 \mathrm{~mm}$ long specimen). Each lateral tooth with broad base, tapering toward apex, hook-shaped, with single terminal cusp; outermost teeth thinner, inner base width about half of lateral teeth width, apex also hook-shaped, cusp simple and smooth. Pair of salivary glands long, tubular; duct inserting in anterior region of esophagus, extending posteriorly to anterior region of digestive gland (Fig. 110B). Esophagus simple, originating dorsally to odontophore, inserting directly in anterior region of stomach, internal longitudinal folds with same diameter along entire length (Fig. 110D, E; 111A). Stomach oval, 30\% of visceral mass volume, with folds at the center of entire inner surface (Fig. 110; 111A). Common opening for esophagus and stomach located on digestive gland. Intestine with longitudinal folds along its entire length, diameter about half esophagus diameter, but more uniform (Fig. 111A). Digestive gland dark beige, being largest organ of visceral mass and occupying $40 \%$ of its volume, cone-shaped; anterior portion about twice as wide as posterior portion, inner face of gland sponge-like, bearing two distinct main duct (Fig. 111A). Anus opening into anal papilla at center of gill circle, $\sim 1 / 4$ of gill filament length (Fig. 109E).

Genital system (Figure 109B; 110B; 112A-E): located between buccal mass and digestive gland, mainly on right side and dorsally (Fig. 110B). Genital opening on right side, anterior third of length of animal from head, located between foot and notum (Fig. 109B). Gonad immersed in digestive gland, difficult to distinguish from digestive gland. 
Hermaphrodite duct thin, long. Ampulla located on female gland, elongated and tubular. Prostate rounded, glandular, connected with female gland duct about $1 / 3$ of ampulla length (Fig. 112A, D). Vas deferens shrot about 1/5 of ampulla (Fig. 112D). Penis' muscle absent. Penis muscular, cylindrical and elongated, about three times longer than prostate, internally with thin folds with cartilage between them and three small tubercles with spine in center (Fig. 112D, E). Female gland well-developed, rounded, occupying $20 \%$ of reproductive system volume, divided into mucus gland $(\sim 2 / 3$ of female gland, color beige), and albumen gland ( $\sim 1 / 3$ of anteriormost region, dilated, irregularly shaped, color dark brown) (Fig. 112B). Oviduct occupying $~ 1 / 2$ of female gland volume (Fig. 112A). Uterine duct thin, relatively short, length $\sim 1 / 7$ of vagina length, located at base of seminal receptacle, inserted in female gland near oviduct (Fig. 112B). Seminal receptacle rounded, as large as bursa copulatrix, length $\sim 1 / 3$ of vagina length, connected to bursa copulatrix through stalk with $\sim 1 / 2$ of vagina length (Fig. 112B). Bursa copulatrix rounded, length $\sim 1 / 3$ of vagina length, connected directly to vagina (Fig. 112B). Vagina cylindrical, elongated, approximately as long as and twice as wide as penis; internally with cartilage between folds and five large tubercles with spines in center; followed ventrally by prostate and located parallel to penis in genital opening (Fig. 112A, C).

Nervous system (Figure 113A-C): located dorsally to odontophore, mostly covered by blood gland. Pair of cerebral and pleural ganglia fused with each other dorsally and ventrally. Pedal ganglia fused with cerebral and pleural ventrally, but not fused among themselves. Pedal commissure simple, broad and short, surrounding esophagus and salivary glands (Fig. 113B). Buccal ganglia short, located ventrally to odontophore, between radular sac and anterior portion of esophagus, connected to cerebral ganglia through long and slender connective tissue, united to gastro-esophageal ganglia by short connective tissue. Gastro-esophageal ganglia length about 1/4 of buccal ganglia length, circular (Fig. 113C). Rhinophoral (olfactory) ganglia inconspicuos. Dorsal eyes located on cerebral ganglia (Fig. 113A).

Distribution: E.U.A. (Florida) to Trinidad \& Tobago.

Habitat: On reefs, tide pools, from 0 to $73 \mathrm{~m}$ depth.

Material examined: CARRIBEAN SEA, West Indies, Lesser Antilles, Martinique, cliffs S of St. Pierre, CAS 76667, 1 specimen (R. William, liltved on “Gloriamaris”, 28/ix/1986, 10-85ft - Liltved - West Indies Cruise 1986); HONDURAS, MZSP 75996, 1 specimen (Col. Marcus, P-938); Saint Thomas, ZMUC-GAS 1505, 1 
specimen (Riise 152 - Holotype od Doris angustipes); Saint Croix, Virgin Island, ZMUCGAS 2020, 1 specimen (Riise 1860 - Holotype of Platydoris angustipes areolata).
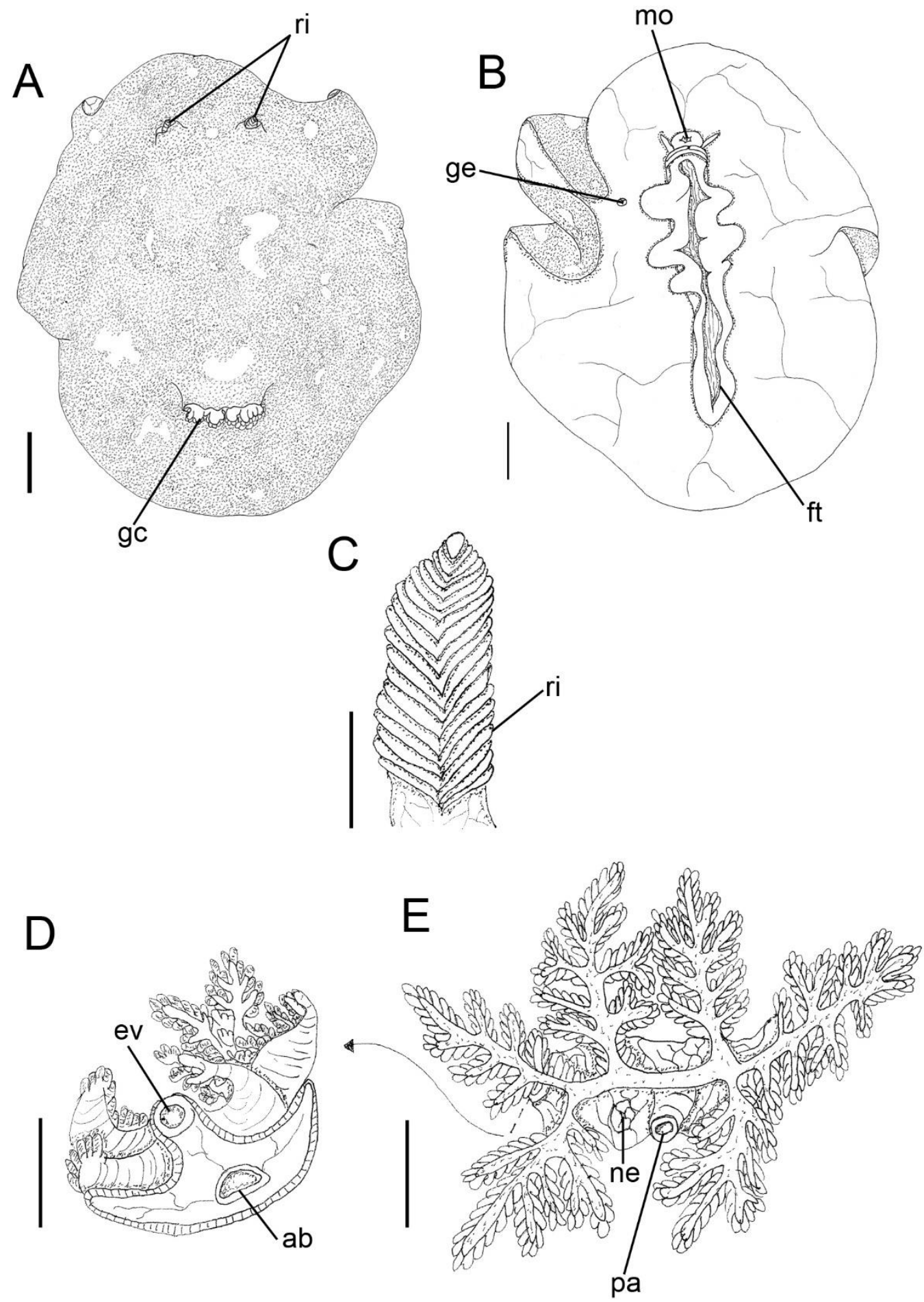

Figure 109: Platydoris angustipes, fixed animal. A. Dorsal view. B. Same, ventral view. Scales: $5 \mathrm{~mm}$. C. Rhinophore. Scale: $1 \mathrm{~mm}$. D. Gill filamento with tranverselly sectioned showing afferent and efferent branchial ring. E. Gill circle. Scales: $2 \mathrm{~mm}$. 

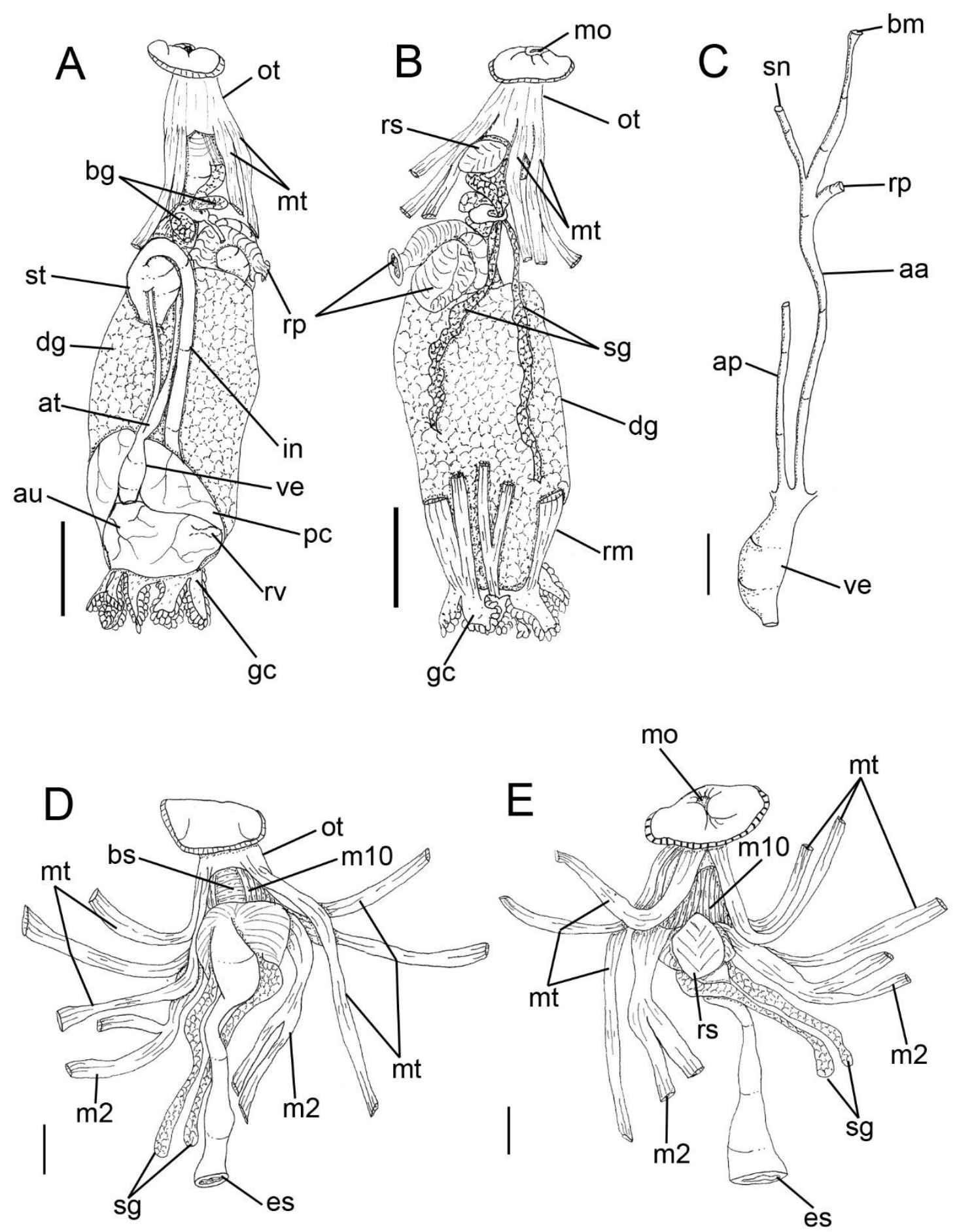

Figure 110: Platydoris angustipes. Visceral mass. A. Dorsal view. B. Same, ventral view. Scales: $5 \mathrm{~mm}$. C. Circulatory system, dorsal view. Anterior digestive system. D. Dorsal view. E. Same, ventral view. Scales: $2 \mathrm{~mm}$. 


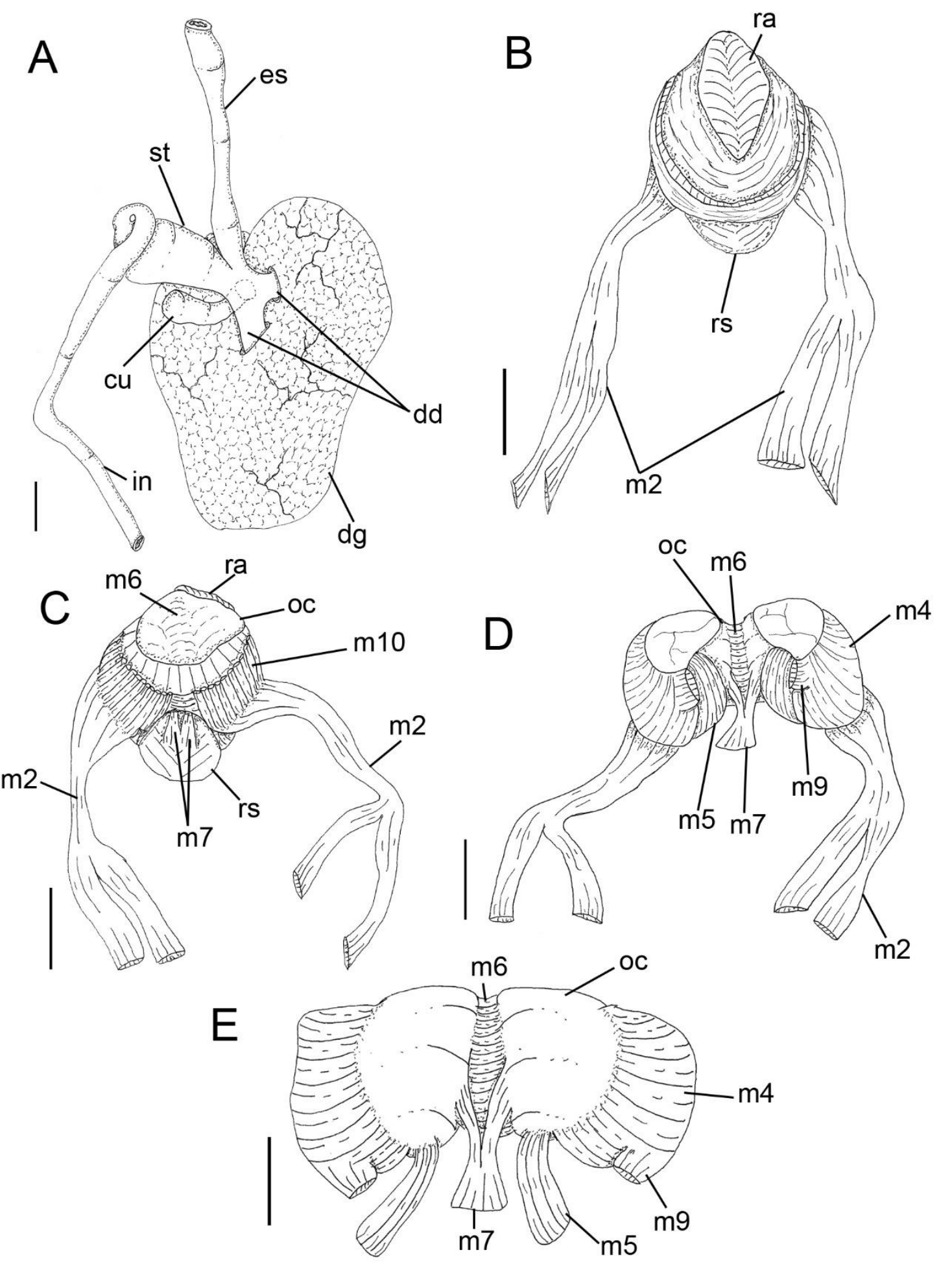

Figure 111: Platydoris angustipes. A. Medium digestive system. Odontophore. B. Dorsal view with radula. C. Same, ventral view. D. Same, dorsal view with removed radula. E. Same, dorsal view with folded down muscles. Scales: $2 \mathrm{~mm}$. 


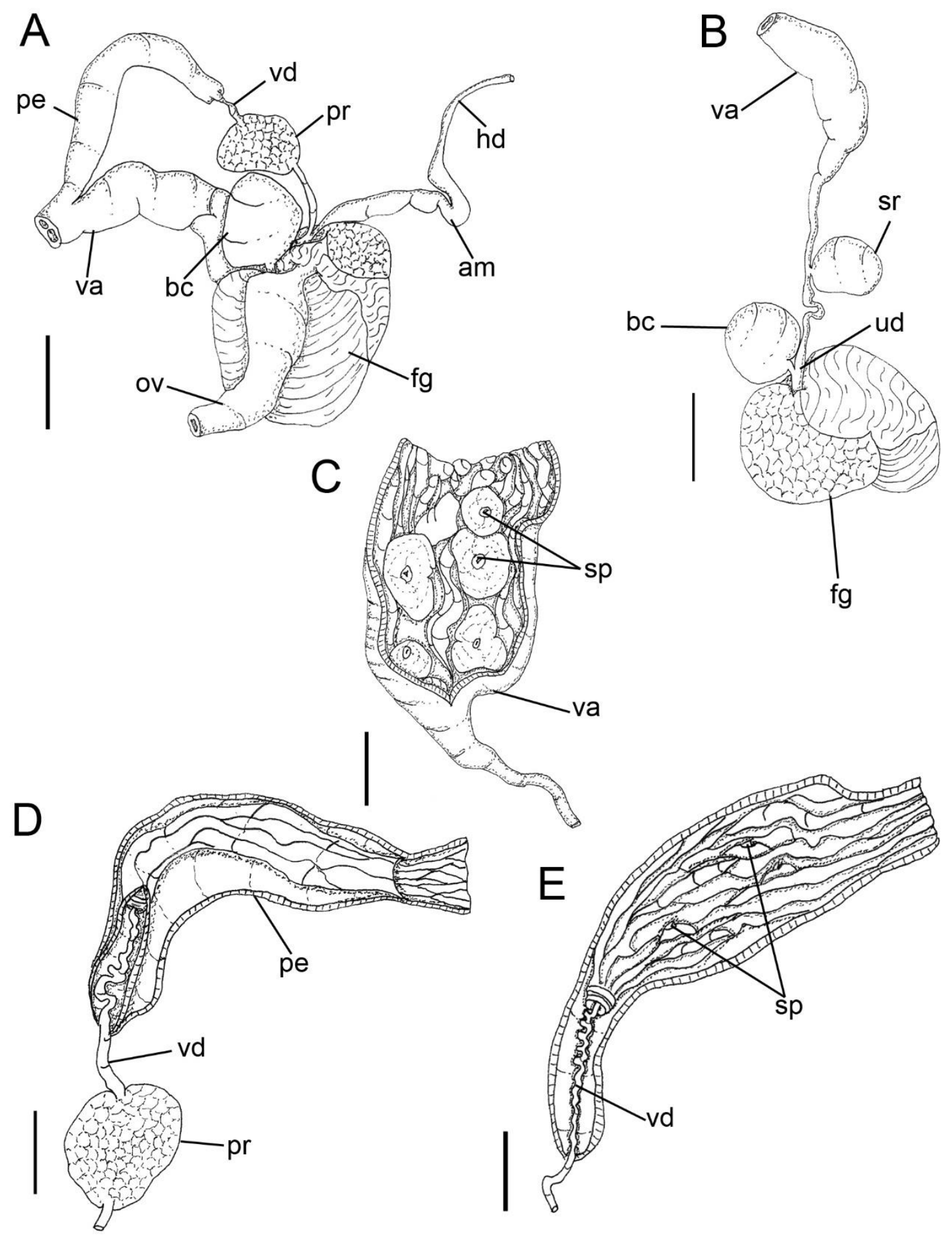

Figure 112: Platydoris angustipes. Reproductive system. A. General view. B. Detail of connection of uterine duct. Scales: $2 \mathrm{~mm}$. C. Detail of vagina's spines. D. Detail of internal part of insertion of vas deferens. E. Detail of penis's spines. Scales: $1 \mathrm{~mm}$. 

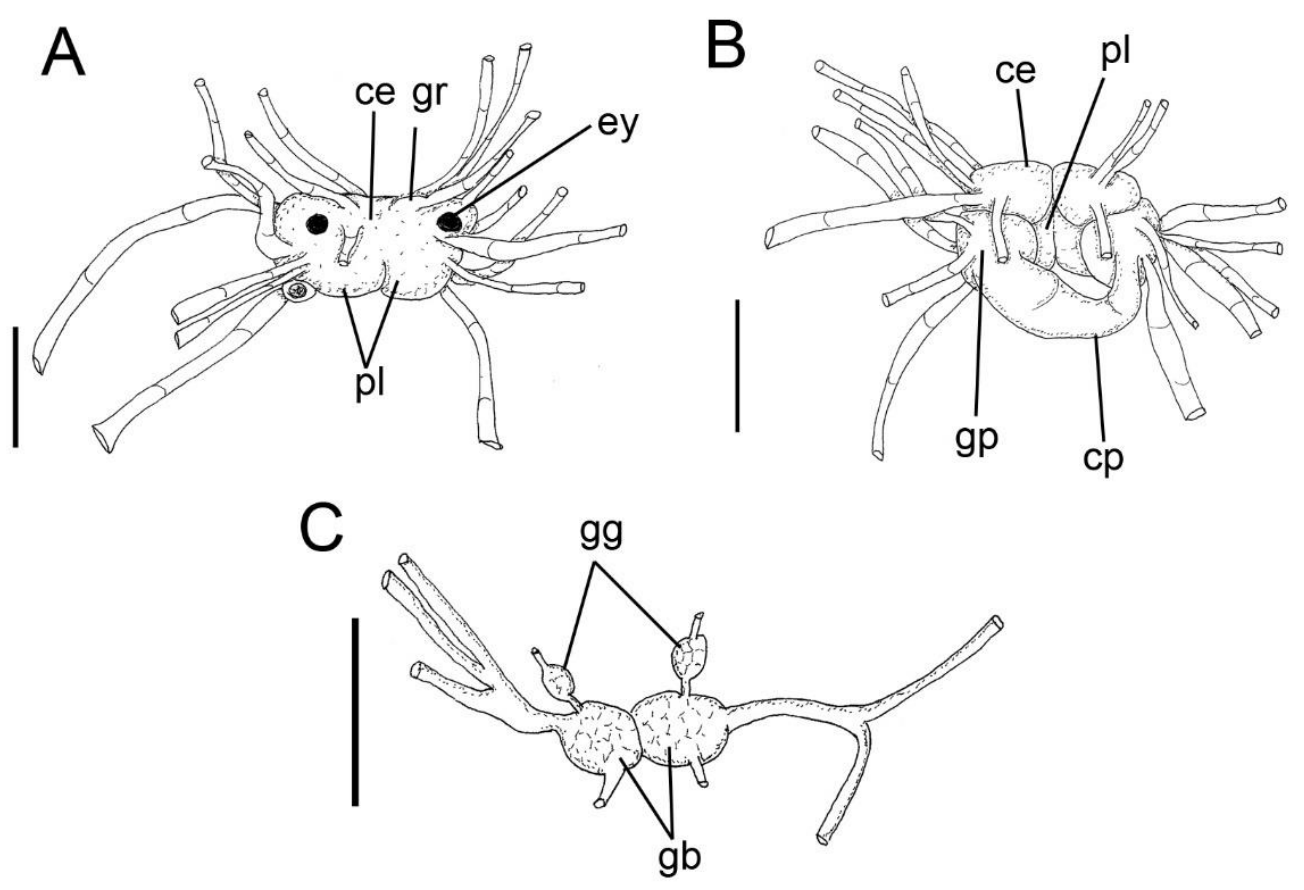

Figure 113: Platydoris angustipes. Nervous system. A. Dorsal view. B. Same, ventral view. C. Buccal and gastroesophageal ganglia. Scales: $1 \mathrm{~mm}$.

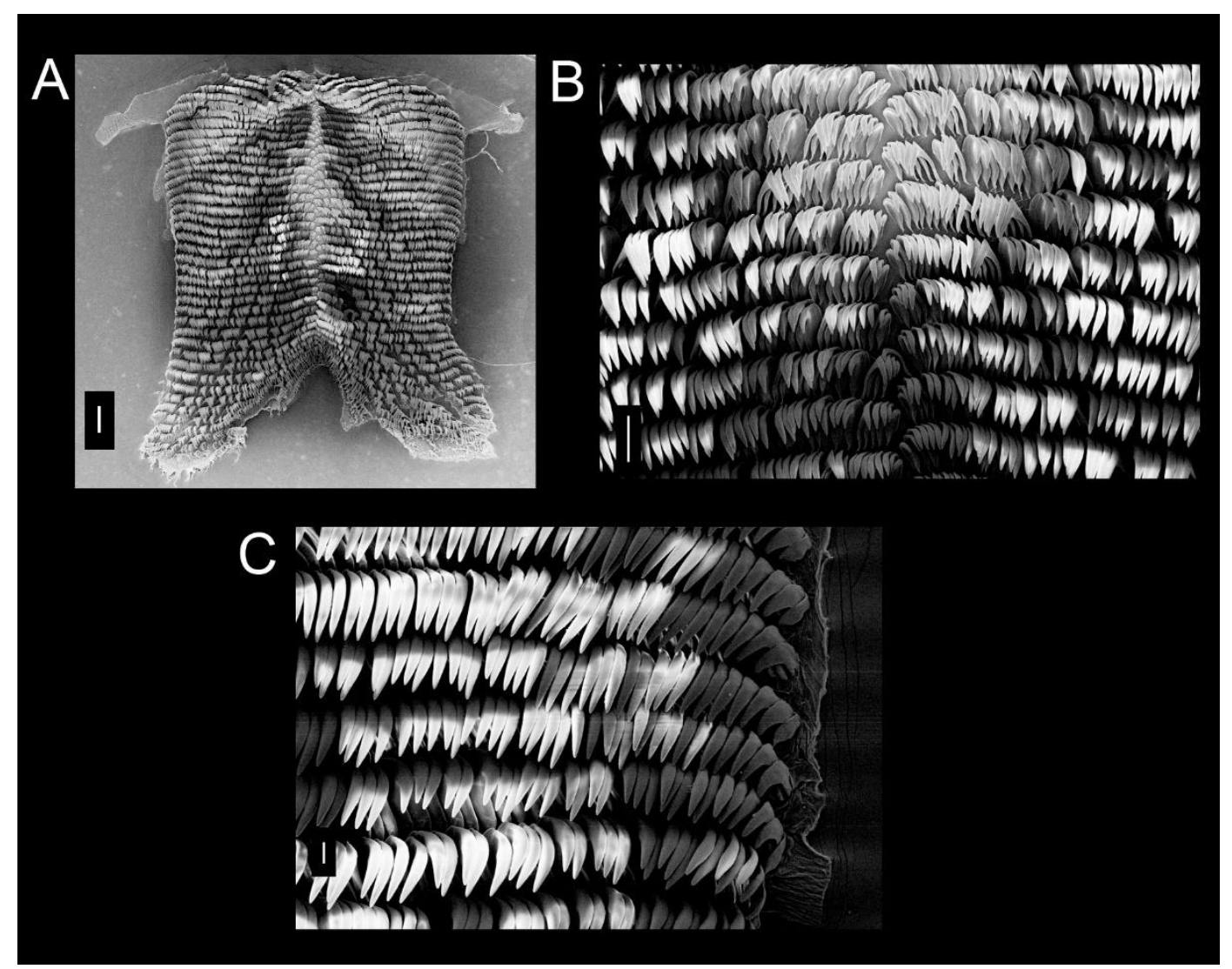

Figure 114: SEM of radula of Platydoris angustipes. A. Panoramic view. Scale: $300 \mu \mathrm{m}$. B. Central region with rachidian tooth absent. Scale: $100 \mu \mathrm{m}$. C. Lateral teeth. Scale: $30 \mu \mathrm{m}$. 


\section{Platydoris sp.}

(Figures 115-118)

Type locality: Brazil, Rio de Janeiro

\section{Redescription}

External morphology: Size 60mm length, 40mm width. Color brownish with some brown spots in ventral view. Body rounded and flattened with small tubercles around dorsum. Rhinophores with about 25 transverse lamellae, very thin; color similar to body; rhinophoral sheaths with very small tubercles. Gill composed of six branched branchial leaves, color similar to body, arranged in circular fashion surrounding anus; branchial sheaths also with very small tubercles, color similar to body. Mouth opening in anterior ventral region, between anterior region of notum and foot. Digitiform tentacles present. Anterior border of foot bilabiate and notched longitudinal.

Haemocoel organs: about same proportions of Platydoris angustipes.

Circulatory and excretory systems (Figure 115A, B): same as P. angustipes, but with renal vesicle very large, well developed, about same length and width as ventricle (Fig. 115B) extending from dorsal to medial sinus, previously connected to renal vesicle, extending posteriorly to center of gill circle and opening in nephrostome (Fig. 115A). Nephrostome pore difficult to see.

Digestive system (Figure 115C, D; 116A-D; Fig. 118A-C): same pattern as $P$. angustipes with some differences: $\mathbf{m} \mathbf{2}$, twice as long as long, not bifurcated on insertion (Fig. 116A, B); m4a, pair of thin muscles originating in posterior region of $\mathrm{m} 4$ and inserting in midle of odontophore cartilagesdorsal and connected with m7b (Fig. 116D); $\mathbf{m} 7 \mathbf{b}$, pair of thin and short muscles originating in posterior region of $\mathrm{m} 6$ and inserting united with posterior part of $\mathrm{m} 7$ (Fig. 116C, D). Radular sac $\sim 1 / 5$ as large as odontophore (Fig. 116A, B). Radular teeth (Fig. 118A-C): rachidian teeth absent; formula 35 x 60.0 .60 (in $60 \mathrm{~mm}$ long specimen). Each lateral tooth with broad base, tapering toward apex, hook-shaped, with single terminal cusp; outermost teeth thinner, inner base width about half of lateral teeth width, apex also hook-shaped, cusp simple and smooth. Pair of salivary glands long, tubular, bulging in anterior portion and tapering posteriorly; duct inserting in anterior region of esophagus, extending posteriorly to anterior region of digestive gland (Fig. 115D). Esophagus simple, originating dorsally to odontophore, inserting directly in anterior region of stomach, internal longitudinal folds with same 
diameter along entire length. Stomach oval, with folds at the center of entire inner surface (Fig. 115C). Common opening for esophagus, stomach and caecum located on digestive gland. Intestine with longitudinal folds along its entire length, diameter about same esophagus diameter; with anterior portion "S-shape", about twice longer than in $P$. angustipes (Fig. 115C). Caecum as short elongated sac, located ventrally to stomach, opening on anterior portion of stomach, close to esophageal insertion, $1 / 12$ length and $\sim 1 / 5$ of width of stomach (Fig. 115C). Digestive gland dark beige, being largest organ of visceral mass; cone-shaped, anterior portion about twice as wide as posterior portion, inner face of gland sponge-like, bearing distinct main duct. Anus opening into anal papilla at center of gill circle, same as $P$. angustipes.

Genital system (Figure 117A-B): located between buccal mass and digestive gland, mainly on right side and dorsally. Genital opening on right side, anterior third of length of animal from head, located between foot and notum. Gonad around all digestive gland, but easy to distinguish it, different from $P$. angustipes. Hermaphrodite duct thin, long. Ampulla located on female gland, elongated and tubular. Prostate rounded, glandular, length same as ampulla (Fig. 117A). Vas deferens about same length as ampulla, connected to penis' muscle. Penis' muscle absent. Penis muscular, cylindrical and very broad, about $1 / 2$ of length and three times wider than ampulla, without spines (Fig. 117A). Female gland well-developed, rounded, occupying $20 \%$ of reproductive system volume, divided into mucus gland ( $2 / 3$ of female gland, color beige), and albumen gland $(\sim 1 / 3$ of anteriormost region, dilated, irregularly shaped, color dark brown). Oviduct occupying $\sim 1 / 5$ of female gland volume (Fig. 117A). Uterine duct thin, relatively short, length $\sim 1 / 10$ of vagina length, located at base of seminal receptacle, inserted in female gland near oviduct (Fig. 117B). Seminal receptacle elongate, as large as bursa copulatrix and $\sim 1 / 3$ width of bursa, connected to vagina through stalk with same length and $1 / 2$ of width of vagina (Fig. 117B). Bursa copulatrix rounded, length $\sim 1 / 2$ of vagina length, connected to vagina after seminal receptacle (Fig. 117B). Vagina cylindrical, very broad, with wide and thick folds, without spines, approximately as long and as wide as penis, followed ventrally by prostate and located parallel to penis in genital opening (Fig. 117B).

Nervous system (Figure): same like $P$. angustipes.

Distribution: Brazil (Valdés et al., 2006): Pernambuco state: Fernando de Noronha; Alagoas state: Saco da Pedra (Padula et al., 2012); Bahia state: Praia de Itapoã 
(García et al.: 2008); Rio de Janeiro state: Cabo Frio: Ilha Comprida; Arraial do Cabo: Prainha (Alvim \& Pimenta, 2014).

Material examined: BRAZIL, Ilha Grande, Angra dos Reis, Rio de Janeiro, MZSP 86082, 3 specimens (E.P. Gonçalves, L.R. Simone \& P. Oristanio, coll., 24/ix/2006, 17m depth, Ponto 3, Pinguino Wreck)
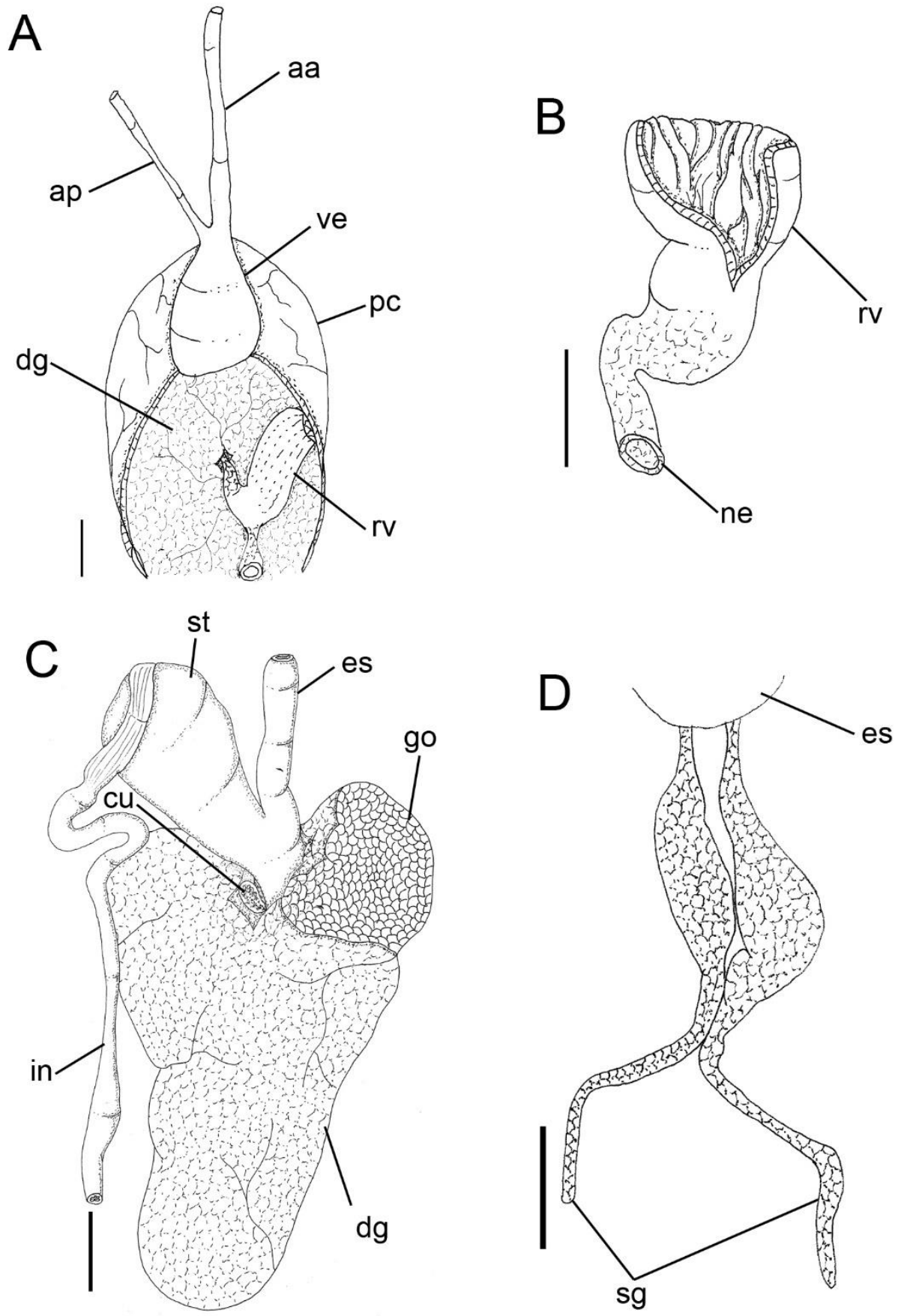

Figure 115: Platydoris sp. A. Circulatory and excretory system, ventral view. B. Renal vesicle. Scales: $2 \mathrm{~mm}$. C. Medium digestive system, dorsal view. Scale: $5 \mathrm{~mm}$. D. Detail of salivar glands. Scale: $2 \mathrm{~mm}$. 

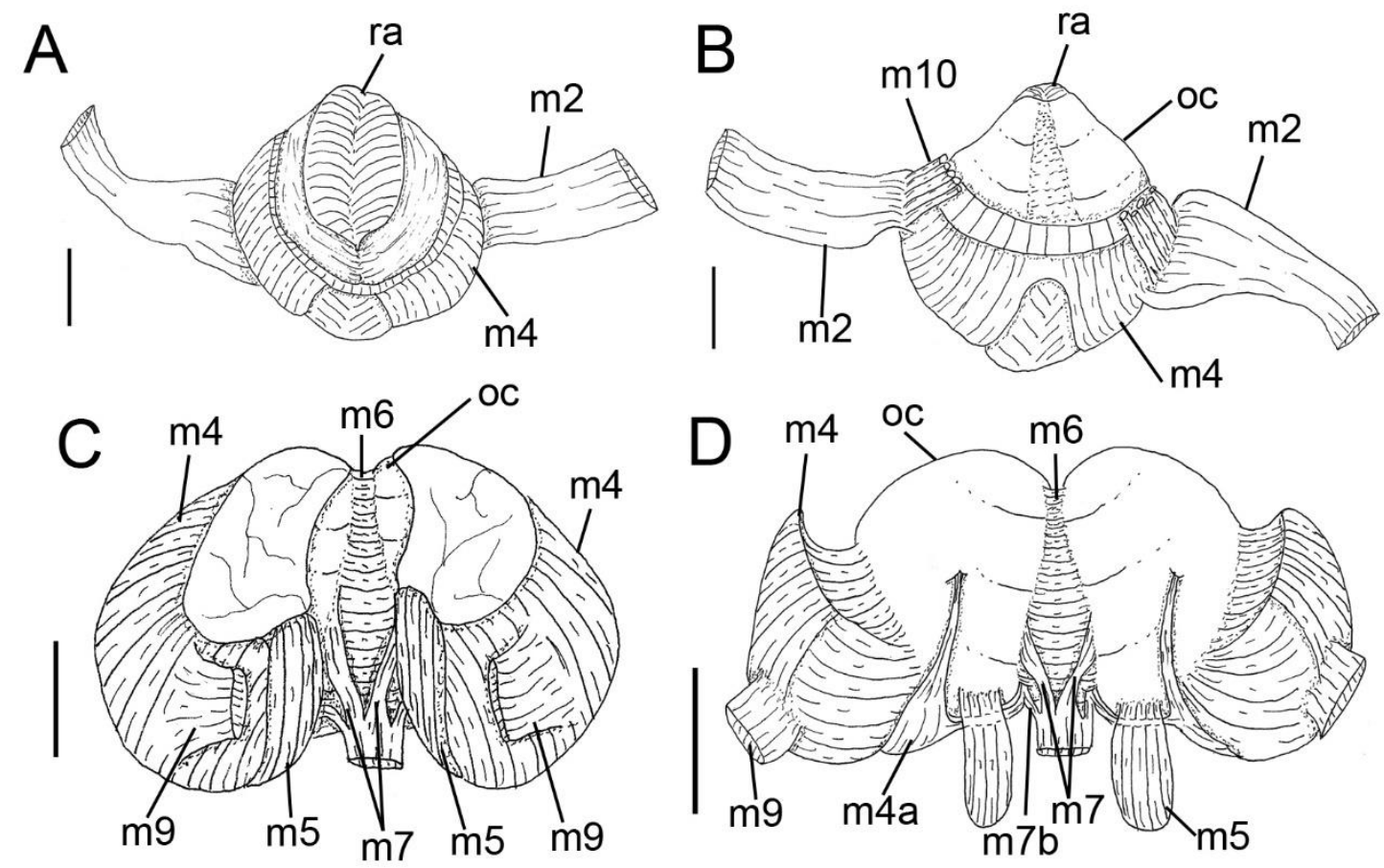

Figure 116: Platydoris sp. Odontophore. A. Dorsal view with radula. B. Same, ventral view. C. Same, dorsal view with removed radula. D. Same, dorsal view, with folded down muscles. Scales: $2 \mathrm{~mm}$.

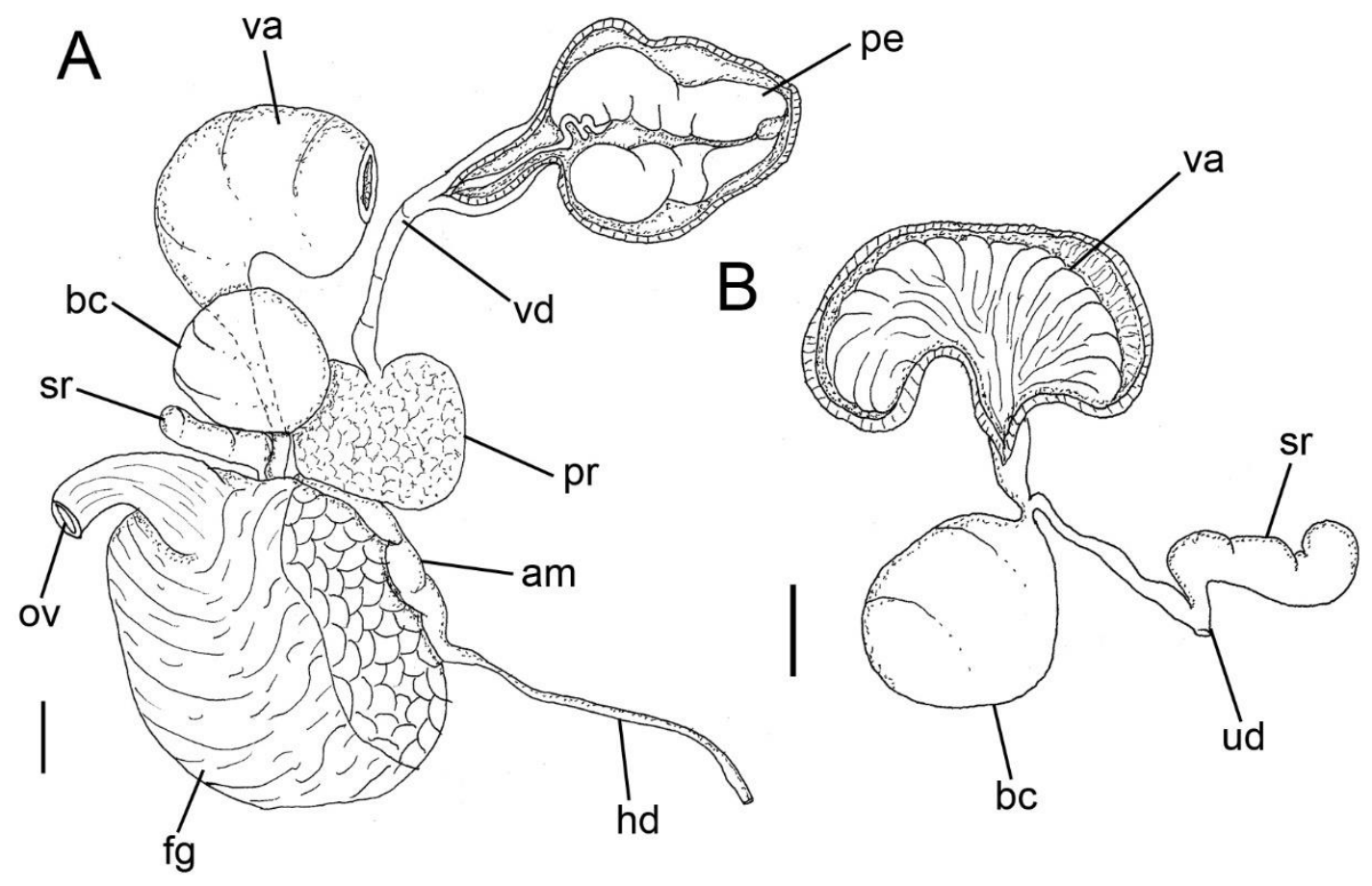

Figure 117: Platydoris sp. Reproductive system. A. General ventral view. B. Detail of Bursa copulatrix, seminal receptacle, uterine duct and vagina. Scales: $2 \mathrm{~mm}$. 


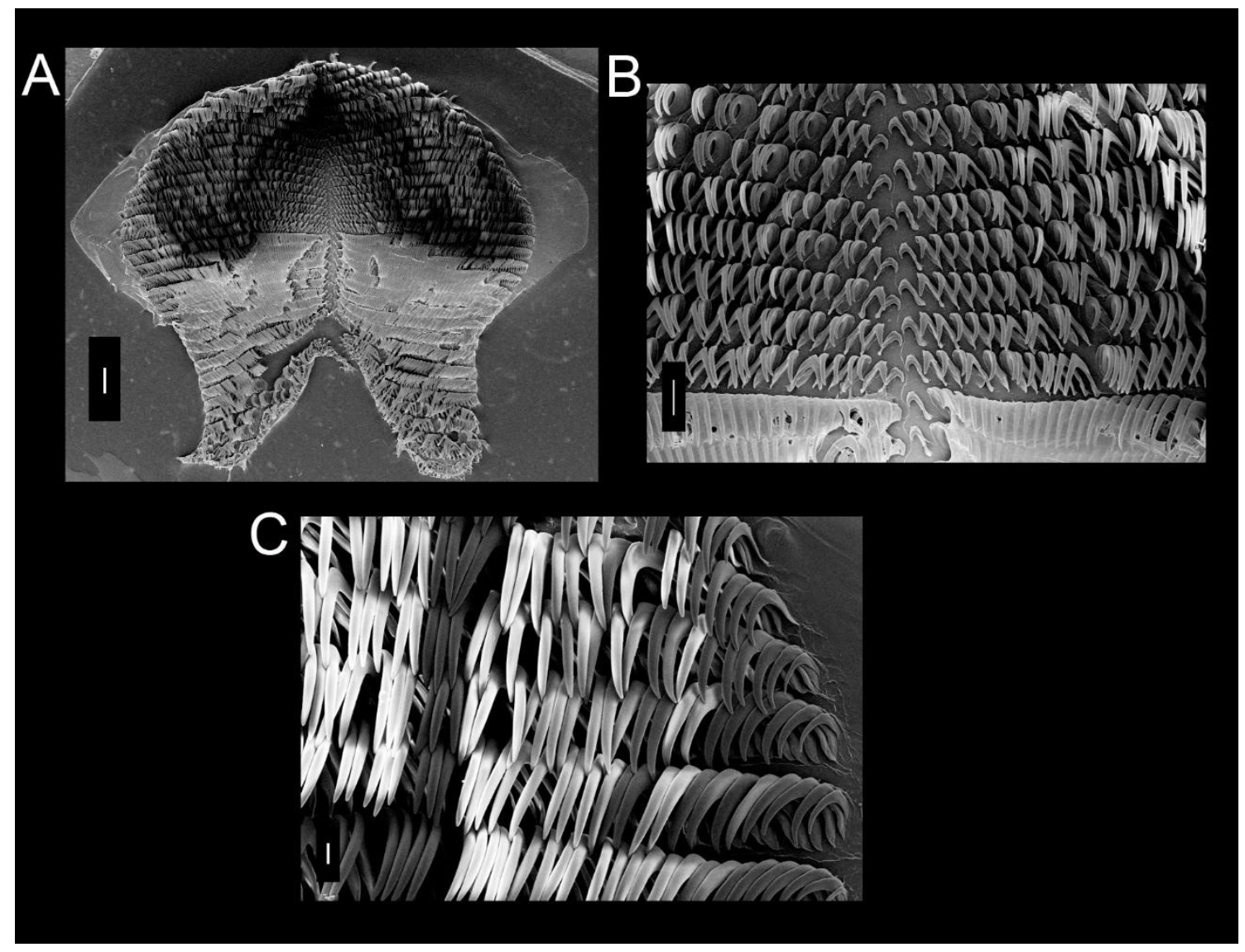

Figure 118: SEM of radula of Platydoris sp. A. Panoramic view. Scale: $300 \mu \mathrm{m}$. B. Central region with rachidian toot absent. Scale: $100 \mu \mathrm{m}$. C. Lateral teeth. Scale: $30 \mu \mathrm{m}$.

\section{Genus Sclerodoris Eliot, 1904}

Type species: Sclerodoris tuberculata Eliot, 1904

\section{Sclerodoris tuberculata Eliot, 1904}

(Figures 119-122)

Sclerodoris tuberculata Eliot, 1903: 381; Rudman, 1978: 70; Orr, 1980: 113; Perrone, 1985a: 25; 1985b: 63; 1990: 24; Valdés \& Gosliner, 2001: 166; Ono, 2004: 152;

Doris castanea Kelaart, 1859: 303; Alder \& Hancock, 1864: 120; Kelaart, 1883: 99; Eliot, 1906: 667

Sclerodoris rubra Eliot, 1903: 382

Type locality: Prison Island, Zanzibar Harbour

\section{Redescription}

External morphology (Figure 119A, E-G): Size 13mm length, 8mm width. Color light gray with small black dots. Body rounded with depressions around tubercles (Fig. 
119A). Rhinophores with about 23 transverse lamellae, color similar to body; rhinophoral sheaths with small lobes. Gill composed of 6-8 bipinnate branchial leaves, color similar to body, arranged in circular fashion surrounding anus; branchial sheaths also with small lobes, color similar to body (Fig. 119E-G). Mouth opening in anterior ventral region, between anterior region of notum and foot. Digitiform tentacles present. Anterior border of foot bilabiate and longitudinal groove (Fig. 119A).

Haemocoel organs (Figure 119C, D): pericardium and posterior half of visceral mass volume occupying $15 \%$ of haemocoel volume. Buccal mass located anteriorly, occupying $10 \%$ of haemocoel volume. Nervous system dorsal to buccal mass, covered by divided blood gland, occupying 5\% of haemocoel volume. Reproductive system on right side of animal, occupying $30 \%$ of haemocoel volume. Stomach on left side, intestine with small curve at anterior portion, and digestive gland, all occupying $40 \%$ of haemocoel volume.

Circulatory and excretory systems (Figure 119B-H): pericardial cavity dorsal and posterior to digestive gland, same as anteriorly species (Fig. 119C). Afferent and efferent branches located inside each gill filament, flowing from and to afferent and efferent branchial veins (Fig. 119H). Gill retractor muscle originating from base of gill circle, running longitudinally up to half of foot level, inserting into dorsal surface of foot (Fig. 119D). Aortic trunk divided close to ventricle, branched into anterior artery irrigating stomach, caecum and digestive gland; posterior artery irrigating reproductive system, buccal mass, odontophore and nervous system (Fig. 119B). Renal vesicle located on right dorsal side of pericardium, near base of auricle, connected to inner surface of pericardium; renal chamber elliptical, about $1 / 2$ length and same width of ventricle (Fig. 119B). Renal chamber extending from dorsal to medial sinus, previously connected to renal vesicle, extending posteriorly to center of gill circle and opening in nephrostome, in a papilla, next to base of anal papilla, about $1 / 3$ of length of anal papilla. Blood gland divided in anterior and posterior portion (Fig. 119C).

Digestive system (Figures 119C, E; 120A-F; 122A-B): Oral tube composed of outer lip, with two thick lateral pleats lengthwise; inner lip with two transverse fold; mt, three pairs of retractor muscles of buccal mass, originating on oral tube, running dorsally and ventrally to oral tube, inserting on body side, about three times as wide and twice as long as m10 (Fig. 120A, B). Odontophore oval, connected to oral tube by pair of ventral protractor muscles $(\mathbf{m 1 0})$; thin longitudinal, dorsal and ventrolateral protractors of oral sphincter, originating in anterior region of odontophore and inserted in posterior region 
of integument close to oral tube (Fig. 120B). Oral sphincter surrounding chitinous part of oral tube. Odontophore muscles: $\mathbf{m} \mathbf{2}$, pair of strong retractor muscles of buccal mass, two time long than wide, origin bifurcate on anterior dorsal odontophore, running laterally to m4 and inserted ventrally on dorsal portion of foot (Fig. 120C, D); m4, pair of dorsal tensor muscles, strong and broad, as long as wide, covering 2/3 of cartilage, inserted on ventral portion of subradular membrane (Fig. 120E, F); m5, pair of dorsal auxiliary tensor muscles, twice as long as wide, originating on most posterior region of odontophore cartilages, covering $\sim 1 / 3$ of posterior cavity of odontophore, as long as, but with $\sim 1 / 2$ of m4 width, inserting on ventral side of subradular membrane, around radular sac (Fig. 120E, F); m6, unpaired horizontal muscle, divided in two parts, with transverse fibers connecting to median surface of left and right odontophore cartilages, about same length and half as wide as $\mathrm{m} 4$, posterior portion same as wide as anterior portion (Fig. 120E, F); $\mathbf{m 7}$, pair of thin and narrow muscle, originating united in middle of m6 and running divided posterior to inserting on radular sac (Fig. 120F); m9, unpaired and horizontal muscle, originating on posterior portion of $\mathrm{m} 4$, connecting pair of $\mathrm{m} 4$ (Fig. 120F). Pair of odontophore cartilages elliptical, occupying 13 of odontophore volume (Fig. 120F). Subradular membrane thin, strong, translucent. Radular sac $\sim 1 / 3$ as large as odontophore (Fig. 120C, D). Radular teeth (Fig. 122A-B): rachidian teeth absent; formula 32 x 40.0 .40 (in $13 \mathrm{~mm}$ long specimen). Each lateral tooth with broad base, tapering toward apex, hook-shaped, with single terminal cusp; outermost teeth thinner, inner base width about half of lateral teeth width, apex also hook-shaped, cusp simple and smooth. Pair of salivary glands long, tubular and thin; duct inserting in anterior region of esophagus, extending posteriorly to anterior region of digestive gland. Esophagus simple, originating dorsally to odontophore, inserting directly in anterior region of stomach, internal longitudinal folds with same diameter along entire length (Fig. 120A, B). Stomach oval, with folds at the center of entire inner surface. Common opening for esophagus, stomach and caecum located on digestive gland. Intestine with longitudinal folds along its entire length, diameter about half esophagus diameter, but more uniform (Fig. 119C). Caecum as an elongated sac, located ventrally to stomach, opening on anterior portion of stomach, close to esophageal insertion, $\sim 1 / 3$ length and $\sim 1 / 4$ of width of stomach. Digestive gland dark beige, being largest organ of visceral mass and occupying $\sim 30 \%$ of its volume, rounded, anterior portion same as wide as posterior portion, inner face of gland spongelike, bearing a distinct main duct (Fig. 119C). Anus opening into anal papilla at center of gill circle, $\sim 1 / 2$ of gill filament length (Fig. 119E). 
Genital system (Figure 119B; 121A-B): located between buccal mass and digestive gland, mainly on right side and dorsally (Fig. 119B). Genital opening on right side, anterior third of length of animal from head, located between foot and notum. Gonad immersed in digestive gland, difficult to distinguish it. Hermaphrodite duct thin, long. Ampulla located on female gland, elongated and tubular (Fig. 121A). Prostate rounded, glandular, about $1 / 4$ of ampulla length. Vas deferens and penis same diameter, about same length of vagina (Fig. 121A). Penis' muscle absent. Female gland well-developed, rounded, occupying $\sim 50 \%$ of reproductive system volume, divided into mucus gland ( $2 / 3$ of female gland, color beige), and albumen gland ( $\sim 1 / 3$ of anteriormost region, dilated, irregularly shaped, color dark brown) (Fig. 121A). Oviduct occupying $\sim 1 / 8$ of female gland volume. Uterine duct thin, relatively short, length $\sim 1 / 8$ of vagina length, located at base of seminal receptacle, inserted in female gland near oviduct (Fig. 121B). Seminal receptacle pyriform, as large and wide as bursa copulatrix, length $\sim 1 / 2$ of vagina length, connected to bursa copulatrix through stalk, about 1/3 of vagina length (Fig. 121B). Bursa copulatrix rounded, length $\sim 1 / 2$ of vagina length, connected directly to vagina (Fig. 121B). Vagina cylindrical, elongated, thin, approximately as long and wide as penis, followed ventrally by prostate and located parallel to penis in genital opening (Fig. 121A-B).

Nervous system (Figure 119C; 121C-E): located dorsally to odontophore, mostly covered by blood gland (Fig. 119C). Pair of cerebral and pleural ganglia fused with each other dorsally. Pedal ganglia fused with cerebral and pleural ventrally, but not fused among themselves. Pedal commissure double, surrounding esophagus and salivary glands (Fig. 121D). Buccal ganglia short, located ventrally to odontophore, between radular sac and anterior portion of esophagus, connected to cerebral ganglia through long and slender connective tissue, united to gastro-esophageal ganglia by short connective tissue (Fig. 121E). Buccal commissure short but easy to see. Gastro-esophageal ganglia length about 1/3 of buccal ganglia length, circular (Fig. 121E). Rhinophoral ganglia bulb-shaped, connected to anterior portion of cerebral ganglia (Fig. 121C). Dorsal eyes located on cerebral ganglia (Fig. 121C). Statocysts small and iridescent, located ventrally between to pedal, pleural and cerebral ganglia, easy to see it (Fig. 121D).

Distribution: Caribbean Sea to Brazil (Pola et al., 2009)

Material examined: PHILIPPINES, Bohol Island, Panglao, Alona Reef, CAS 175843, 1 specimen (T. Gosliner, Y. Camacho-Garcia, J. Templado, M. Malaquias, M. Poddubetskaia, coll., 30/v/2004, 10-15m depth, slope between reef patches; Panglao 
Expedition 2004); AUSTRALIA, Queensland, GBR Capricorn Group, AUSC315459.001, 2 specimens (I. Loch, coll., 09/viii/1990, under rock on reef plataforma).

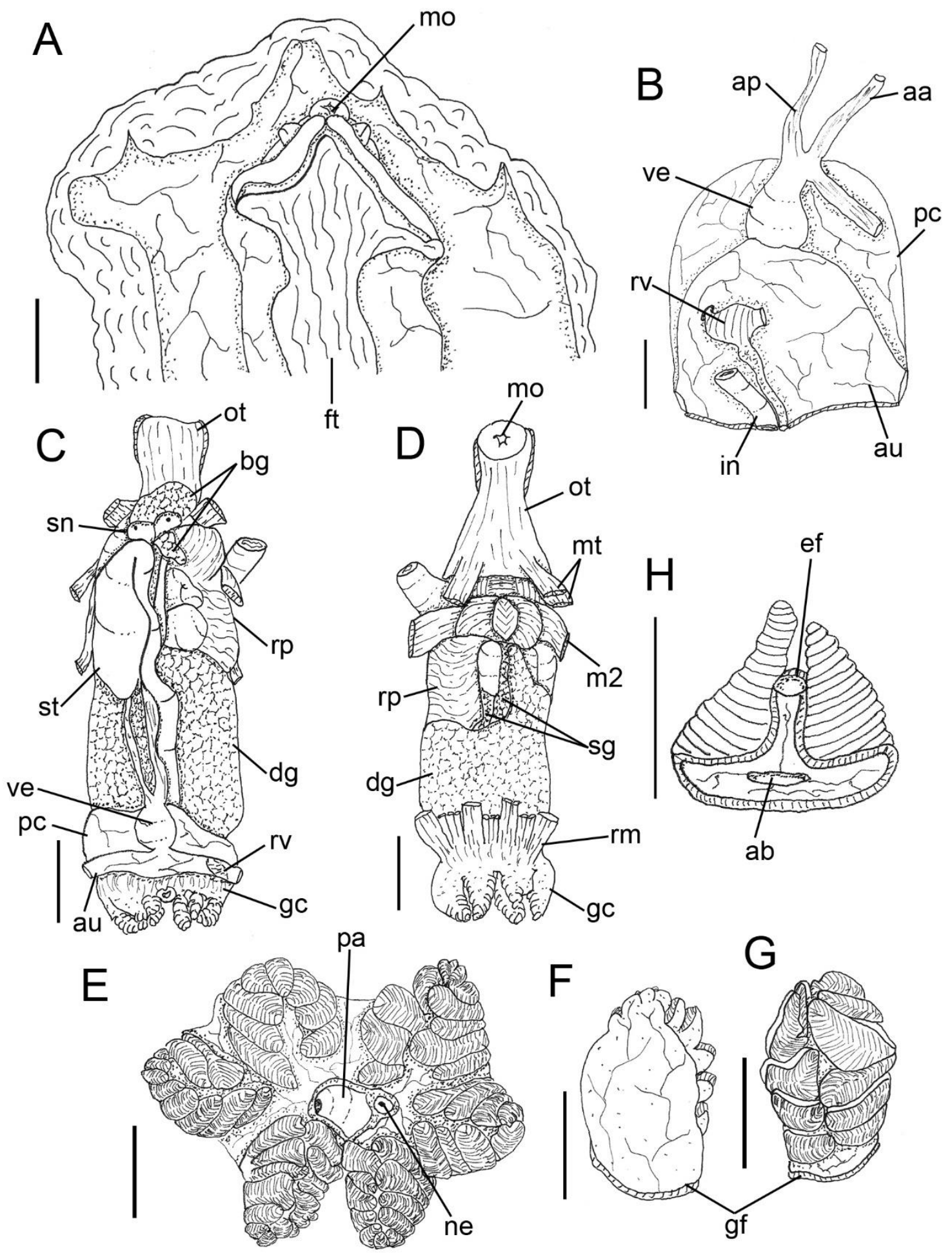

Figure 119: Sclerodoris tuberculata, fixed animal. A. Detail of anterior border of foot. Scale: $2 \mathrm{~mm}$. B. Circulatory and excretory system, ventral view. Scale: $1 \mathrm{~mm}$. Visceral mass. C. Dorsal view. D. Same, ventral view. Scales: 2mm. E. Gill circle, dorsal view. Gill filament. F. Posterior view. G. Same, anterior view. H. Same, tranversally sectioned with afferent and efferent branchia ring. Scales: $1 \mathrm{~mm}$. 

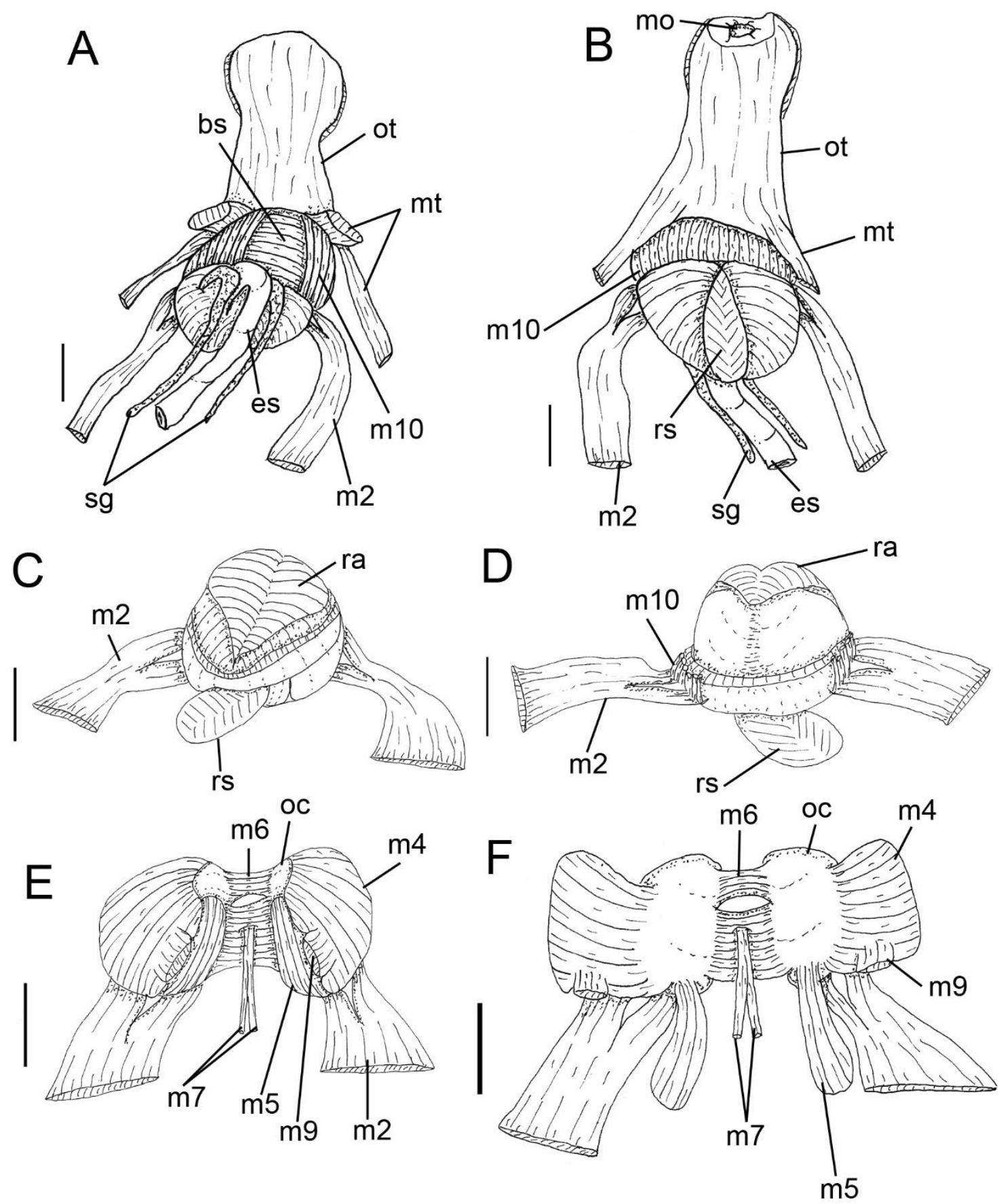

Figure 120: Sclerodoris tuberculate. Anterior digestive system. A. Dorsal view. B. Same, ventral view. Odontophore. C. Dorsal view with radula. D. Same, ventral view. E. Same, dorsal view with removed radula. F. Same, with folded down muscles. Scales: $1 \mathrm{~mm}$. 


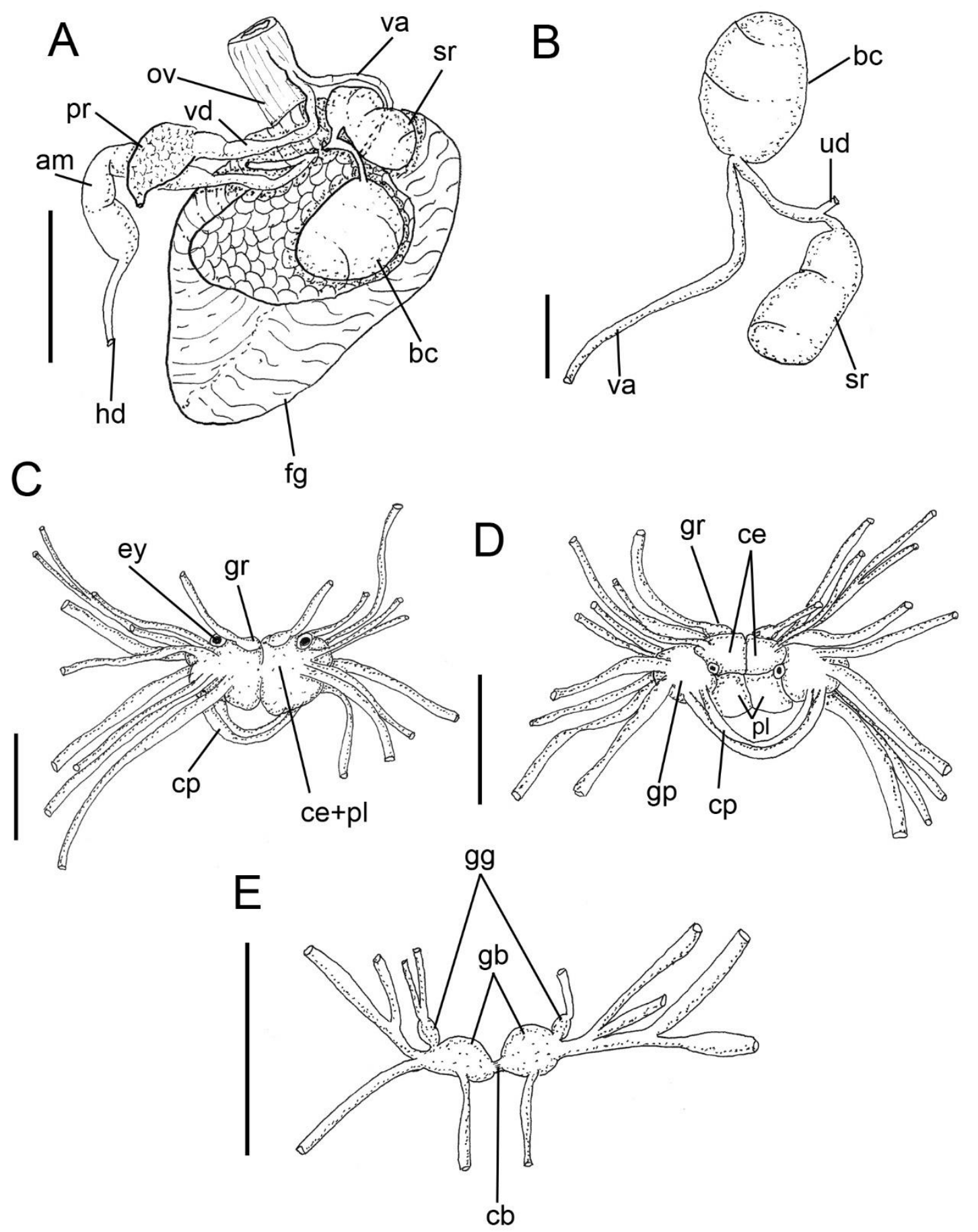

Figure 121: Sclerodoris tuberculate. Reproductive system. A. General view. Scale: $2 \mathrm{~mm}$; B. Detail of bursa copulatrix, seminal receptacle and vagina. Nervous system. C. Dorsal view. D. Same, ventral view. E. Buccal and gastroesophageal ganglia. Scales: $1 \mathrm{~mm}$. 


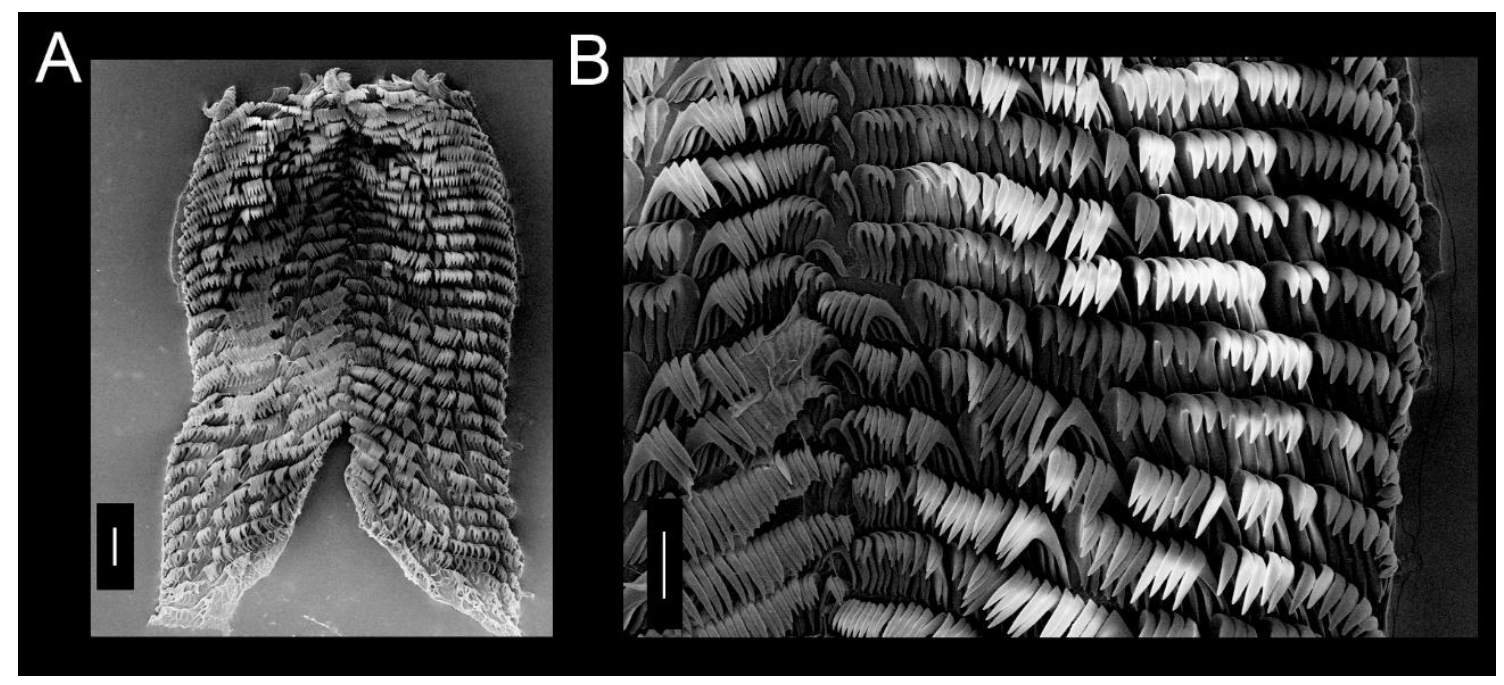

Figure 122: SEM of radula of Sclerodoris tuberculata. A. Panoramic view. Scale: $200 \mu \mathrm{m}$. B. Lateral view. Scale: $100 \mu \mathrm{m}$.

\section{Sclerodoris sp.}

(Figures 123-124)

Type locality: Alagoas, Maceió, Brazil

\section{Description}

External morphology: Size 50mm length, 25mm width. Color brown with light gray tubercles. Body Rounded with small tubercles covering all dorsum and small depression, different from S. tuberculata. Rhinophores with about 30 transverse lamellae, color brown with white apex; rhinophoral sheaths surrounded by small tubercles. Gill composed of six bipinnate branchial leaves, color similar to body, arranged in circular fashion surrounding anus; branchial sheaths also surrounded by small tubercles, color beige. Mouth opening in anterior ventral region, between anterior region of notum and foot. Digitiform tentacles present. Anterior border of foot bilabiate with longitudinal groove.

Haemocoel organs (Figure 123A): pericardium and posterior half of visceral mass volume occupying $15 \%$ of haemocoel volume. Buccal mass located anteriorly, occupying $20 \%$ of haemocoel volume. Nervous system dorsal to buccal mass, with divided blood gland, occupying $5 \%$ of haemocoel volume. Reproductive system on right side of animal, occupying $20 \%$ of haemocoel volume. Stomach on left side, intestine with small curve at anterior portion, and digestive gland occupying $40 \%$ of haemocoel volume. 
Circulatory and excretory systems (Figure 123A): Same as in S. tuberculate, with renal vesicle about $1 / 2$ of ventricle length. Blood gland divided in two parts, anterior portion twice as posterior.

Digestive system (Figure 123A-E; 124A): Same as in $S$. tuberculate with some differences: mt, three pairs of retractor muscles of buccal mass, originating on oral tube, running dorsally and ventrally to oral tube, inserting on body side, about six times as wide and twice as long as m10; about three time longer than in S. tuberculata (Fig. 123B, C). Odontophore muscles: $\mathbf{m} 2$, three times longer than wide; about $1 / 2$ of width of $S$. tuberculate and bifurcated origen absent (Fig. 123D, E); m6, unpaired horizontal muscle, with transverse fibers connecting to median surface of left and right odontophore cartilages, about same length and half as wide as $\mathrm{m} 4$, posterior portion three time as wide as anterior portion (Fig. 124A); m7, originating on odontophore cartilages and united in posterior region inserting on radular sac (Fig. 124A); m7a, thin and same length as $\mathrm{m} 7$, originating in middle of odontophore cartilage running between $\mathrm{m} 4$ and $\mathrm{m} 5$ inserting on radular sac (Fig. 124A). Radular sac $~ 1 / 4$ as large as odontophore (Fig. 123D, E). Radula not analyzed. Pair of salivary glands long, thin and tubular; duct inserting in anterior region of esophagus, extending posteriorly to anterior region of digestive gland (Fig. 123B, C). Esophagus simple, originating dorsally to odontophore, inserting directly in anterior region of stomach, internal longitudinal folds with same diameter along entire length. Stomach oval, $\sim 30 \%$ of visceral mass volume, with folds at the center of entire inner surface (Fig. 123A). Common opening for esophagus, stomach and caecum located on digestive gland. Intestine with longitudinal folds along its entire length, diameter about half esophagus diameter, but more uniform (Fig. 123A). Caecum as an elongated sac, located ventrally to stomach, opening on anterior portion of stomach, close to esophageal insertion, $\sim 1 / 2$ length and $\sim 1 / 3$ of width of stomach. Digestive gland dark beige, being largest organ of visceral mass, cone-shaped; anterior portion about twice as wide as posterior portion, inner face of gland sponge-like, bearing distinct main duct (Fig. 123A). Anus opening into anal papilla at center of gill circle, 1/6 of gill filament length.

Genital system (Figure 123A; 124B-F): located between buccal mass and digestive gland, mainly on right side and dorsally (Fig. 123A). Genital opening on right side, anterior third of length of animal from head, located between foot and notum. Gonad immersed in digestive gland, but difficult to distinguish it. Hermaphrodite duct thin, long. Ampulla located on female gland, elongated and tubular. Prostate rounded and divided in two different parts, length half as ampulla (Fig. 124B). Vas deferens about twice length 
of penis. Penis' muscle absent. Penis muscular, cylindrical and elongated, about same length and half width of prostate; posterior end papillae-shaped, with aperture in midlle of muscular part of penis (Fig. 124E, F). Female gland well-developed, rounded, occupying $\sim 30 \%$ of reproductive system volume, divided into mucus gland ( $2 / 3$ of female gland, color beige), and albumen gland ( $\sim 1 / 3$ of anteriormost region, dilated, irregularly shaped, color dark brown) (Fig. 124B). Oviduct occupying $\sim 1 / 6$ of female gland volume. Uterine duct thin, relatively short, length $\sim 1 / 10$ of vagina length, located at base of seminal receptacle, inserted in female gland near oviduct (Fig. 124C). Seminal receptacle pyriform, as large as bursa copulatrix, length $\sim 1 / 2$ of vagina length, connected to bursa copulatrix through long stalk (Fig. 124C). Bursa copulatrix rounded, length $\sim 1 / 2$ of vagina length, connected to vagina after seminal receptacle through short stalk (Fig. 124C, D). Vagina cylindrical, elongated, approximately as long as and half as wide as penis, followed ventrally by prostate and located parallel to penis in genital opening. Acessory gland glandular connected to posterior region of vagina by short duct, inserting in bulged region of vagina, this region with one spine (Fig. 124C, D).

Nervous system (Figure): Same as S. tuberclata. Gastro-esophageal ganglia length about $1 / 2$ of buccal ganglia length, circular.

Distribution: Northeast of Brazil

Material examined: BRAZIL, Praia do Pacheco, Caucaia, Ceará, CMPHRM B4112, 1 specimen (H. Galvão Filho, coll.); Recife do Saco da Pedra, Maceió, Alagoas, MZSP 103366, 1 specimen (L.S. Tocino col., 26/i/2012, 1,5m deep, under rocks) 

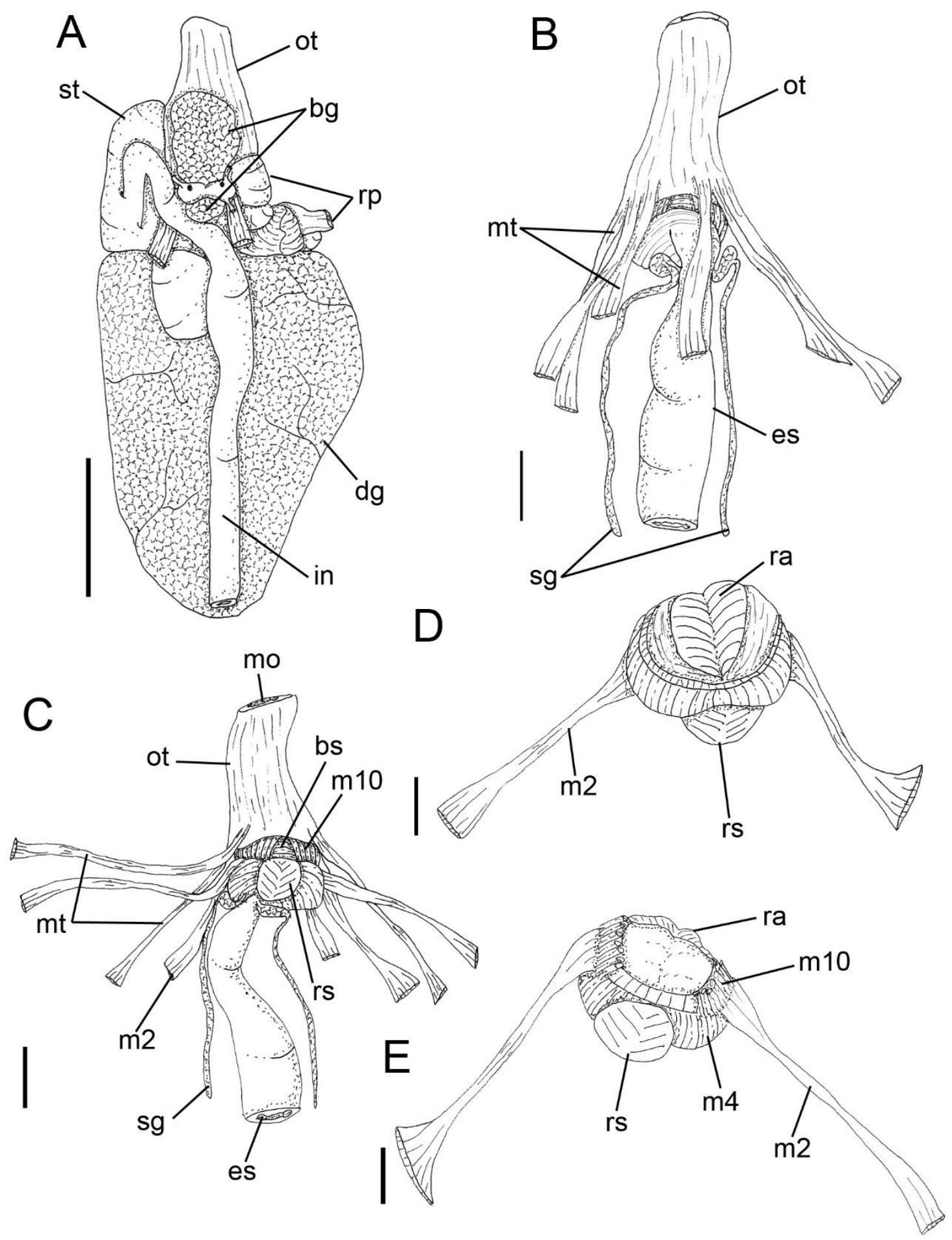

Figure 123: Sclerodoris sp. A. Visceral mass, dorsal view. Scale: $5 \mathrm{~mm}$. Anterior digestive system. B. Dorsal view. C. Same, ventral view. Scales: $2 \mathrm{~mm}$. Odontophore. D. Dorsal view with radula. E. Same, ventral view. Scales: $1 \mathrm{~mm}$. 


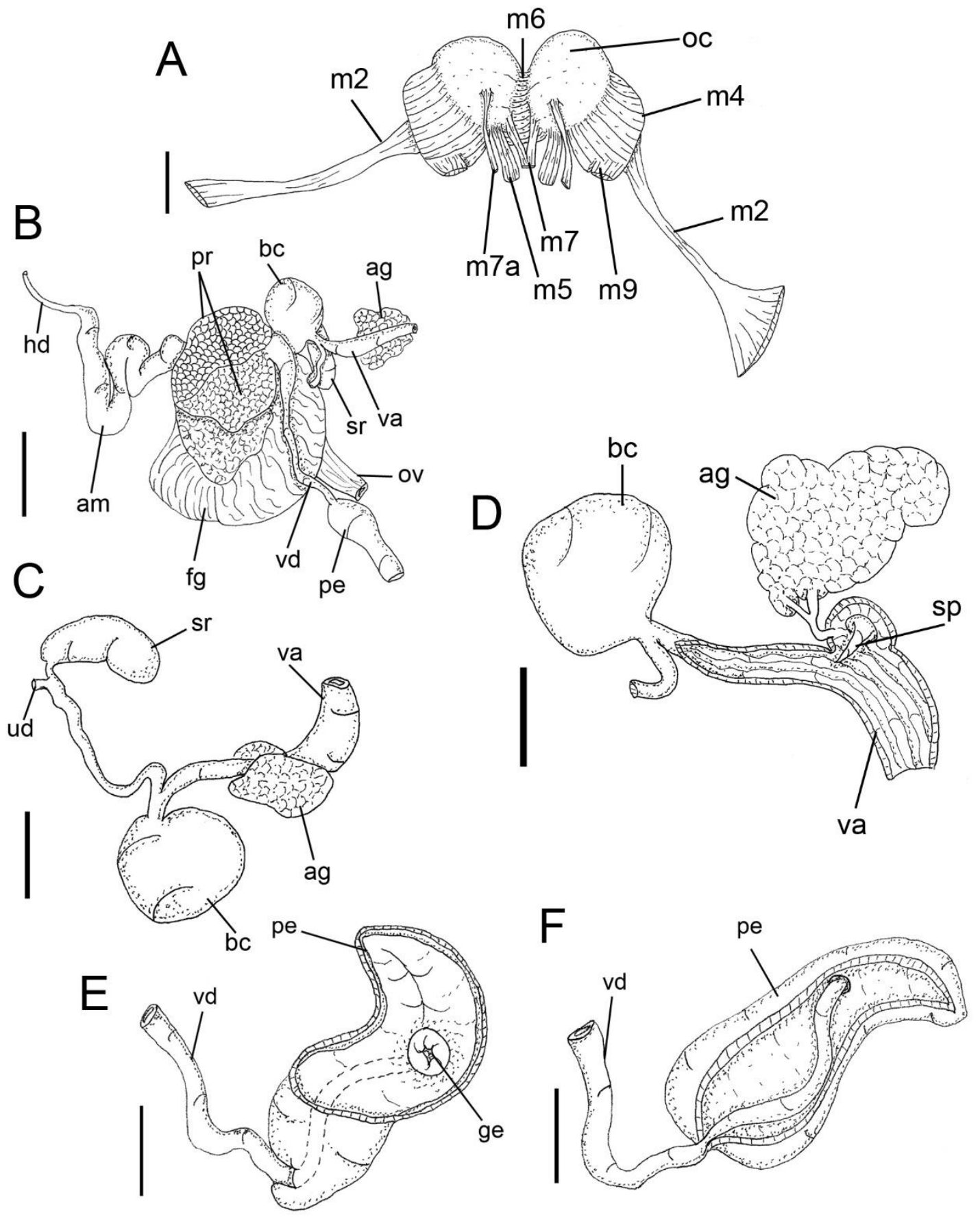

Figure 125: Sclerodoris sp. A. Dorsal view of odontophore with folded down muscles. Reproductive system. B. General view. C. Detail of bursa copulatrix, seminal receptacle, vagina and accessory gland. D. Detail of internal part of vagina, with spine near accessory gland. E. Dorsal view of penis. F. Internal view of penis, detail of vas deferens. 


\section{Genus Thordisa Bergh, 1877}

Type species: Thordisa maculigera Bergh, 1877, by subsequent designation by Bergh (1905).

\section{Thordisa ladislavii (Ihering, 1886)}

(Figures 125-127)

Etidoris ladislavii Ihering, 1886: 234, pl. 9, fig. 2; Rios, 2009: 426, fig. 1200.

Thordisa ladislavii (Ihering, 1886) MacFarland, 1909: 10; Morretes, 1949: 116

Type locality: Armação, Desterro, Província de Santa Catarina, Brazil

\section{Redescription}

External morphology (Figure 125A-F; 126A-B): Size 10mm length, 5mm width. Body rounded, foot not extend notum (Fig. 125A-C). Rhinophores with about 9 transverse lamellae; rhinophoral sheaths surrounded by small but well difined tubercles (Fig. 125E, F). Gill composed of five bipinnate branchial leaves, arranged in circular fashion surrounding anus; branchial sheaths also surrounded by small tubercles (Fig. $125 \mathrm{C} ; 126 \mathrm{~A}, \mathrm{~B})$. Mouth opening in anterior ventral region, between anterior region of notum and foot. Digitiform tentacles absent. Lateral extensions of integument barrelshaped, each one with small lateral furrow up to half of their extensions. Anterior border of foot bilabiate (Fig. 125D).

Haemocoel organs: specimen dissected, it was not possible to confirm the proportion of each system in haemocoel volume.

Circulatory and excretory systems (Figure 126A, C, D): same as other genera of Discodorididae. Pericardial cavity dorsal and posterior to digestive gland, anterior to gill circle. Gill retractor muscle originating from base of gill circle, running longitudinally up to half of foot level, inserting into dorsal surface of foot. Afferent and efferent branches located inside each gill filament, flowing from and to afferent and efferent branchial veins (Fig. 126C). Auricle funnel-like (wider anteriorly) with thin walls. Ventricle sligthly taller than wide, with thick muscular walls. Renal vesicle located on right dorsal side of pericardium, near base of auricle, connected to inner surface of pericardium; renal chamber elliptical, 1/2 the size and same width of ventricle (Fig. 126D). Renal chamber extending from dorsal to medial sinus, previously connected to renal vesicle, extending posteriorly to center of gill circle and opening in nephrostome, next to base of anal papilla (Fig. 126A). 
Digestive system (Figures 126A, E-H; 127A-D): Oral tube composed of outer lip, with pleats lengthwise; inner lip with transverse fold (Fig. 126G); mt, three pairs, about three times as wide and twice as long as m10 (Fig. 126H). Odontophore oval, connected to oral tube by pair of ventral protractor muscles (m10); thin longitudinal, dorsal and ventrolateral protractors of oral sphincter, originating in anterior region of odontophore and inserted in posterior region of integument close to oral tube (Fig. 126E). Oral sphincter surrounding chitinous part of oral tube. Odontophore muscles: $\mathbf{m} 2$, three times longer than wide, origin on anterior dorsal odontophore, running laterally to $\mathrm{m} 4$ and inserted ventrally on dorsal portion of foot (Fig. 127A-C); m4, 1/3 as long as wide, covering 2/3 of cartilage, inserted on ventral portion of subradular membrane (Fig. 127C, D); $\mathbf{m 5}$, twice as long as wide, originating on most posterior region of odontophore cartilages, covering $\sim 1 / 3$ of posterior cavity of odontophore, as long as, but with $\sim 1 / 2$ of m4 width, inserting on ventral side of subradular membrane, around radular sac (Fig. 127C, D); m6, unpaired horizontal muscle, with transverse fibers connecting to median surface of left and right odontophore cartilages, about same length and half as wide as $\mathrm{m} 4$, posterior portion $\sim$ twice as wide as anterior portion (Fig. 127D); m7, pair of thin and narrow muscle, originating in posterior region of $\mathrm{m} 6$ and running posterior to inserting on radular sac (Fig. 127D); m9, unpaired and horizontal muscle, originating on posterior portion of $\mathrm{m} 4$, connecting pair of $\mathrm{m} 4$ (Fig. 127D). Pair of odontophore cartilages elliptical, occupying $\sim 40 \%$ of odontophore volume (Fig. 127D). Radular sac 1/5 of odontophore volume (Fig 126F; 127A, B). Radular not analized. Some structures like: salivary glands, stomach, intestine and digestive gland not analyzed because of poor preservation. Anus opening into anal papilla at center of gill circle, $\sim 1 / 3$ of gill filament length (Fig. 126A).

Genital system: not analyzed

Nervous system: not analyzed.

Distribution: Brazil: Sao Paulo to Santa Catarina

Habitat: Under intertidal rocks.

Material examined: MZSP 75220, 1 specimen (Col. Marcus). 

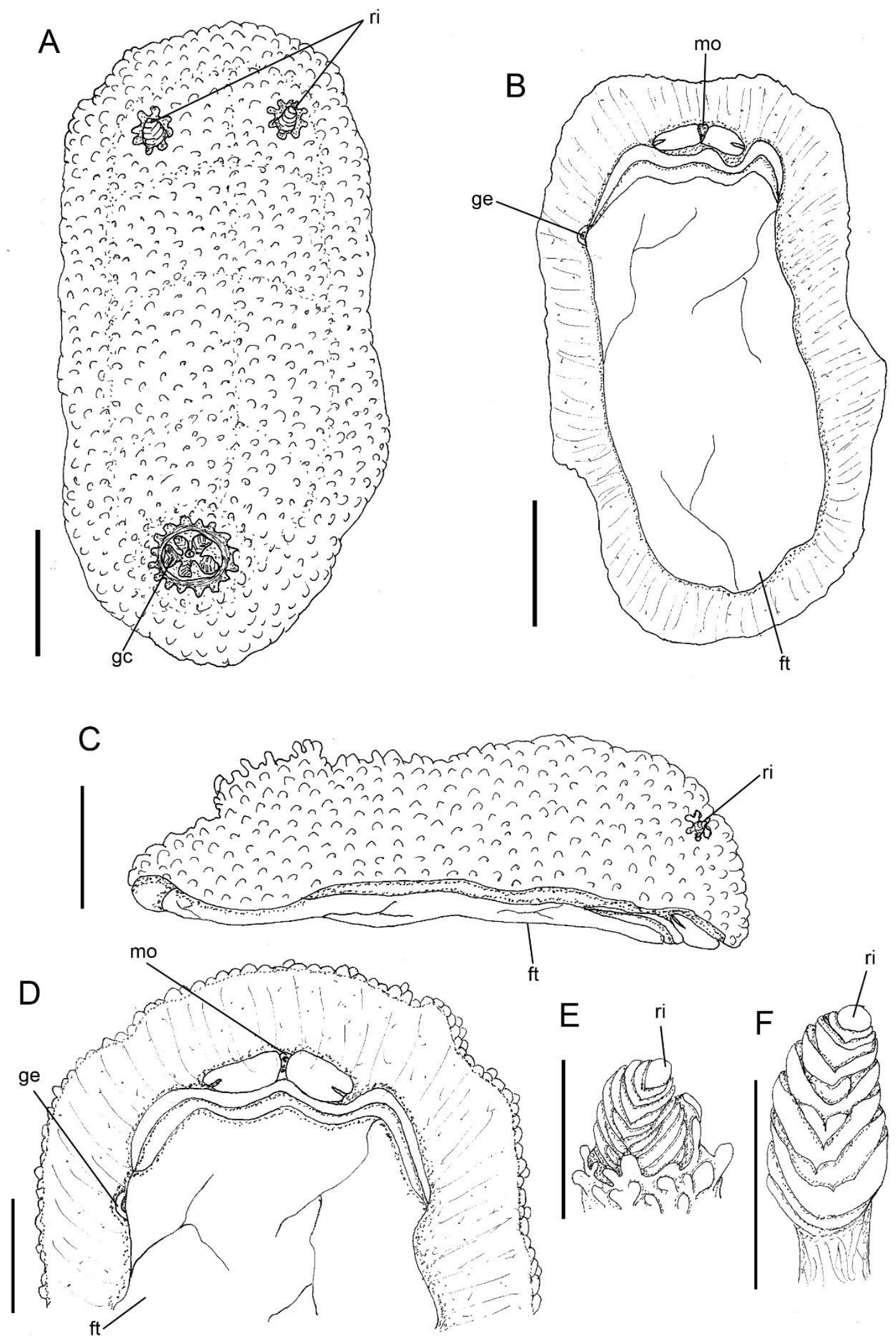

Figure 125: Thordisa ladislavii, fixed animal. A. Dorsal view. B. Same, ventral view. C. Same, right lateral view. D. Detail of anterior border of foot. Scales: $2 \mathrm{~mm}$. Rhinophore. E. Rhinophoral shealth. F. Rhinophore. Scales: $1 \mathrm{~mm}$. 

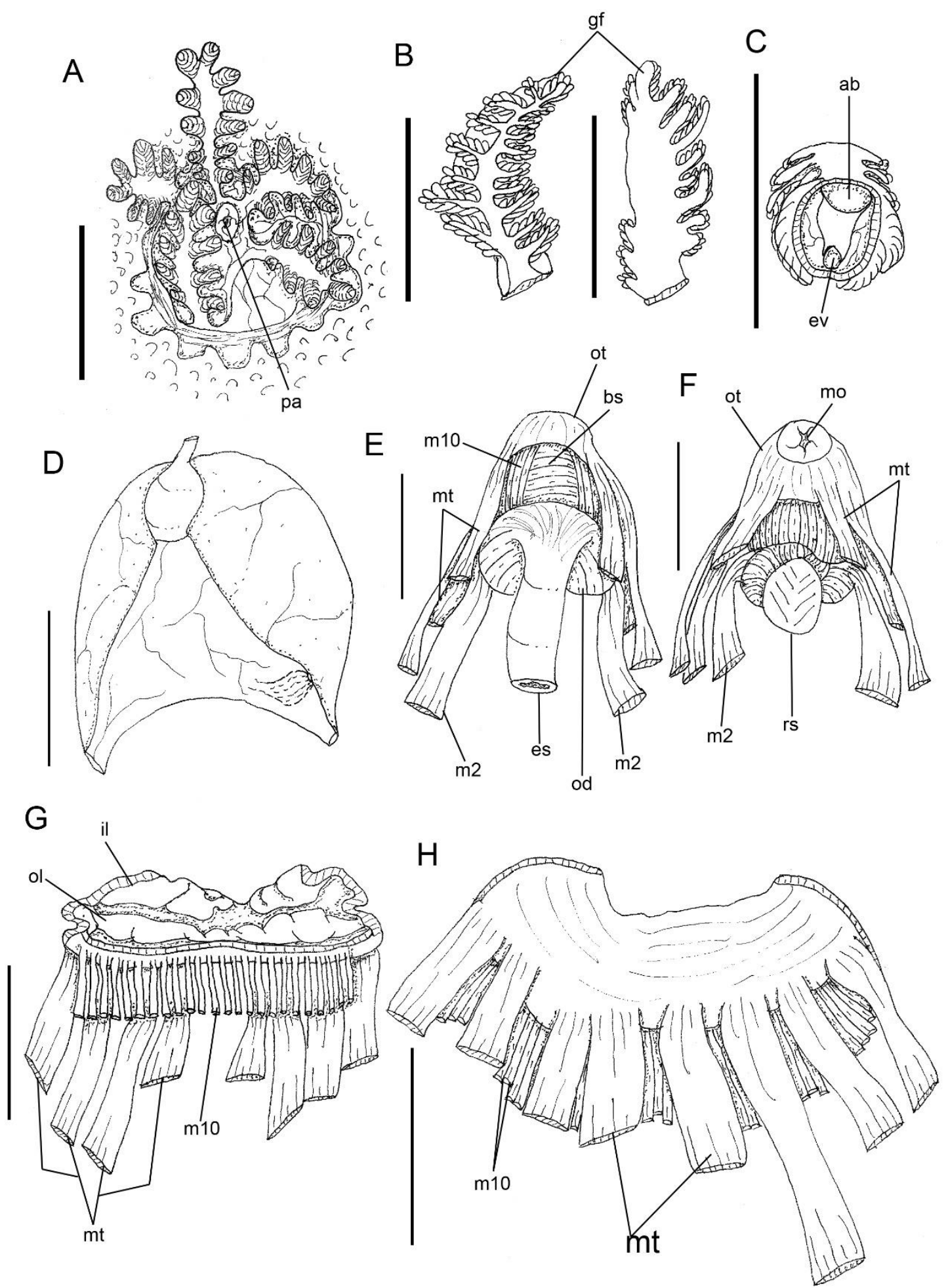

Figure 126: Thordisa ladislavii, A. Gill circle, dorsal view. Gill filament. B. Anterior and posterior view. C. Same, tranversally sectioned with afferente and efferent branchial ring. D. Circulatory and excretory system. Anterior digestive system. E. Dorsal view. E. Same, ventral view. Oral tube. G. Internal, ventral view. H. Same, dorsal view. Scales: $1 \mathrm{~mm}$. 

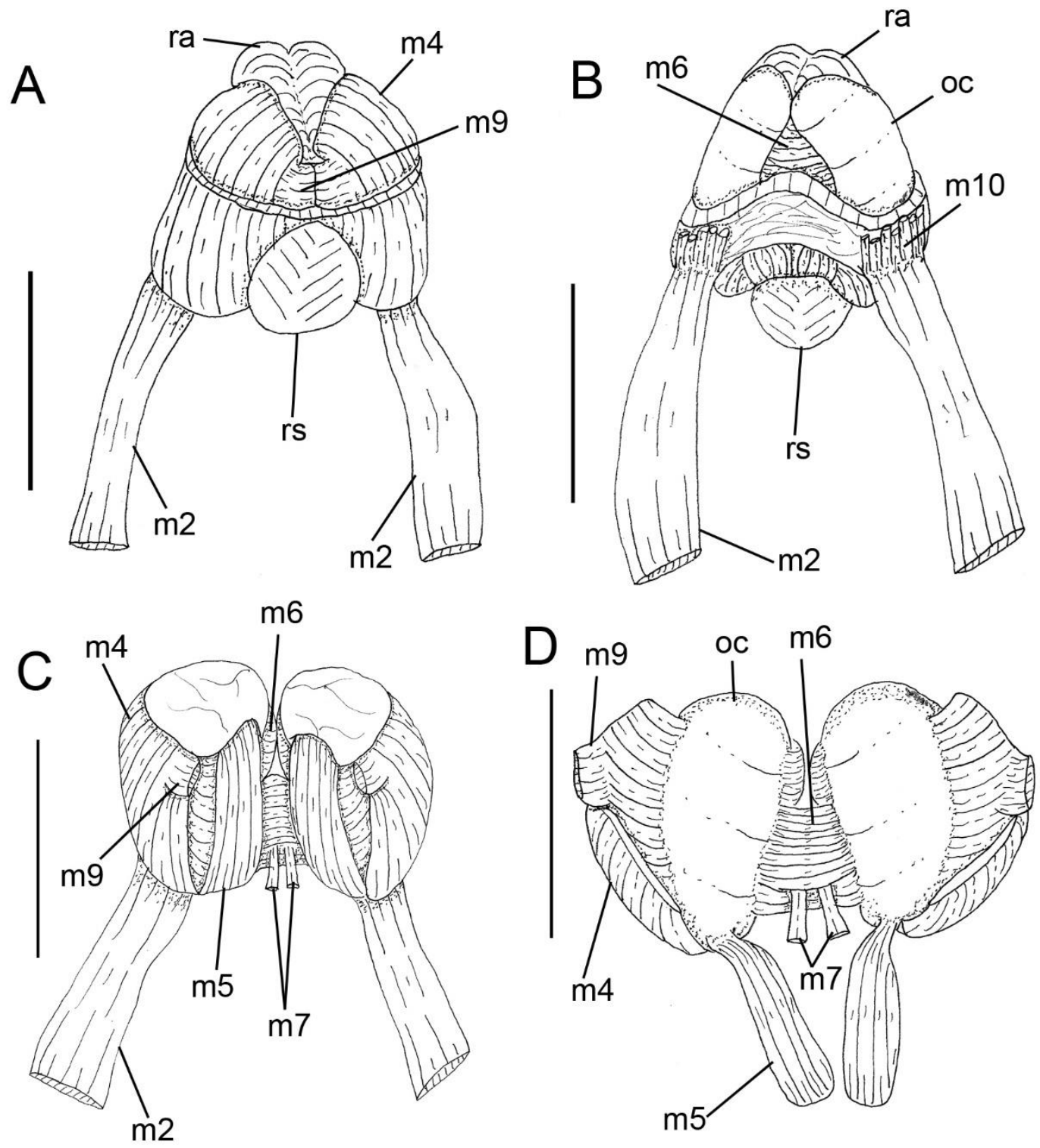

Figure 127: Thordisa ladislavii. Odontophore. A. Dorsal view with radula. B. Same, ventral view. C. Same, dorsal view with removed radula. D. Same, dorsal view with folded down muscles. Scales: $1 \mathrm{~mm}$. 


\title{
Family Dendrodorididae O'Donoghue, 1924 (1864)
}

\author{
Genus Dendrodoris Ehrenberg, 1831
}

Type species: Dendrodoris limbata (Cuvier, 1804) original combination

\section{Dendrodoris limbata (Cuvier, 1804)}

(Figures 128-132)

Synonymic list see Valdés et al., 1996.

Type locality: Marsielle, France

\section{Redescription}

External morphology (Figure 128A-G): Size $\sim 28 \mathrm{~mm}$ length, $\sim 22 \mathrm{~mm}$ width. Body rounded and smooth (Fig. 128A-C). Rhinophores with about 20 transverse lamellae, color similar to body; rhinophoral sheaths smooth (Fig. 128E). Gill composed of six trippinate branchial leaves, color similar to body, arranged in circular fashion surrounding anus; branchial sheaths smooth, color similar to body (Fig. 128F, G). Mouth opening in a pore, ventral region, between anterior region of notum and foot (Fig. 128D). Digitiform tentacles absent. Anterior border of foot not bilabiate (Fig. 128D).

Haemocoel organs (Figure 129A, B): pericardium posterior dorsal half of dorsal visceral mass volume, with gill circle occupying $15 \%$ of haemocoel volume. Buccal mass located anteriorly, occupying $10 \%$ of haemocoel volume. Nervous system dorsal to buccal mass, covered by blood gland, occupying $5 \%$ of haemocoel volume. Reproductive system located between buccal mass and digestive gland, mainly on right side and dorsally, occupying $30 \%$ of haemocoel volume. Stomach internal to digestive gland, intestine with small curve at anterior portion, both with digestive gland/gonad occupying $40 \%$ of haemocoel volume.

Circulatory and excretory systems (Figure 128F, G; 129A, C, D): pericardial cavity dorsal and posterior to digestive gland, anterior to gill circle. Afferent (two branches) and efferent branches located inside each gill filament, flowing from and to afferent and efferent branchial veins (Fig. 128G). Gill retractor muscle in middle of gill circle (Fig. 129D). Auricle funnel-like (wider anteriorly) with thin walls. Ventricle as wide as long, with thick muscular walls (Fig. 129A, C). Aortic trunk divided very close to ventricle, branched into anterior artery irrigating stomach and digestive gland; posterior artery irrigating reproductive system, buccal mass and nervous system (Fig. 129C). Renal 
vesicle located on right dorsal side of pericardium, near base of auricle, connected to inner surface of pericardium; renal chamber elliptical with longitudinal folds, same size and half width of ventricle (Fig. 129C). Renal chamber extending from dorsal to medial sinus, previously connected to renal vesicle, extending posteriorly to center of gill circle and opening in nephrostome (difficult to see), next to base of anal papilla.

Digestive system (Figures Fig. 128F; 130A-E): Oral tube very short (Fig. 130A); mt, five pairs of retractor muscles of buccal mass, originating on oral tube, running dorsally and ventrally to oral tube, inserting on body side (Fig. 130D, E). Odontophore absent. Salivary glands rounded; just one broad duct inserting in anterior region of oral tube parallel to oesophagus, extending posteriorly in same direction of oesophagus (Fig. 130E). Esophagus divided into three parts, originating internal to oral tube, inserting directly in anterior region of stomach, first anterior region with three longitudinal folds, like in Phyllidiella pustulosa; second region determinated by a strangulation and very glandular portion; third region maintains tradicional narrow longitudinal folds with same diameter along entire length (Fig. 130B, C). Stomach widespread in digestive gland. Intestine with longitudinal folds along its entire length, diameter same diameter of first region of esophagus (Fig. 130A, B). Caecum absent. Digestive gland being largest organ of visceral mass, rounded; inner face of gland sponge-like, bearing various ducts and a distinct main duct (Fig. 130A, B). Anus opening into anal papilla near the edge of gill circle, $\sim 1 / 3$ of gill filament length (Fig. 128F).

Genital system (Figure 129A, B; 131A-D): Genital opening on right side, anterior third of length of animal from head, located between foot and notum (Fig. 129A). Gonad anterior and distinguished to digestive gland (Fig. 129B). Hermaphrodite duct thin, long. Ampulla located on female gland, elongated and tubular (Fig. 131A). Prostate tubular, glandular, nine times longer than ampulla (Fig. 131A). Vas deferens about same width as penis. Penis' muscle absent. Penis muscular, cylindrical and elongated, about six times long than prostate (Fig. 131A, B, D). Female gland well-developed, rounded, occupying $1 / 3$ of reproductive system volume, divided into mucus gland ( $2 / 3$ of female gland, color beige), and albumen gland ( 1/3 of anteriormost region, dilated, irregularly shaped, color dark brown) (Fig. 131A). Oviduct occupying 1/4 of female gland volume (Fig. 131A). Uterine duct thin, relatively short, length $1 / 6$ of vagina length, located at base of seminal receptacle, inserted in female gland near oviduct (Fig. 131B). Seminal receptacle pyriform, as large as bursa copulatrix, same length of vagina, connected to bursa copulatrix by duct as same legth of vagina (Fig. 131B). Bursa copulatrix rounded, length 
$\sim 1 / 3$ of vagina length, connected to vagina after seminal receptacle (Fig. 131B). Vagina cylindrical, elongated, approximately as long as and twice as wide as penis, followed ventrally by prostate and located parallel to penis in genital opening (Fig. 131C).

Nervous system (Figure 132A-C): located dorsally to odontophore, mostly covered by blood gland. Pair of cerebral and pleural ganglia fused with each other dorsally and ventrally. Pedal ganglia fused with cerebral and pleural ventrally and almost fused among themselves. Pedal commissure inconspicuous, surrounding esophagus and salivary glands (Fig. 132B). Buccal ganglia and gastro-esophageal ganglia not visualized. Rhinophoral (olfactory) ganglia bulb-shaped, connected to anterior portion of cerebral ganglia. Dorsal eyes located on cerebral ganglia (Fig. 132A). Statocysts small and iridescent, located ventrally to pedal ganglia (Fig. 132C).

Distribution: Mediterranean Sea (From Israel to Strait of Gilbratar), South of Portugal and Atlantic North of Africa (Valdés et al., 1996).

Habitat: Found in rock bottoms.

Material examined: PORTUGAL, Algarve, Sagres, Sagres Harbor, CAS 181882, 1 specimen (B. Dayrat coll., 09/vii/2002, intertidal). 

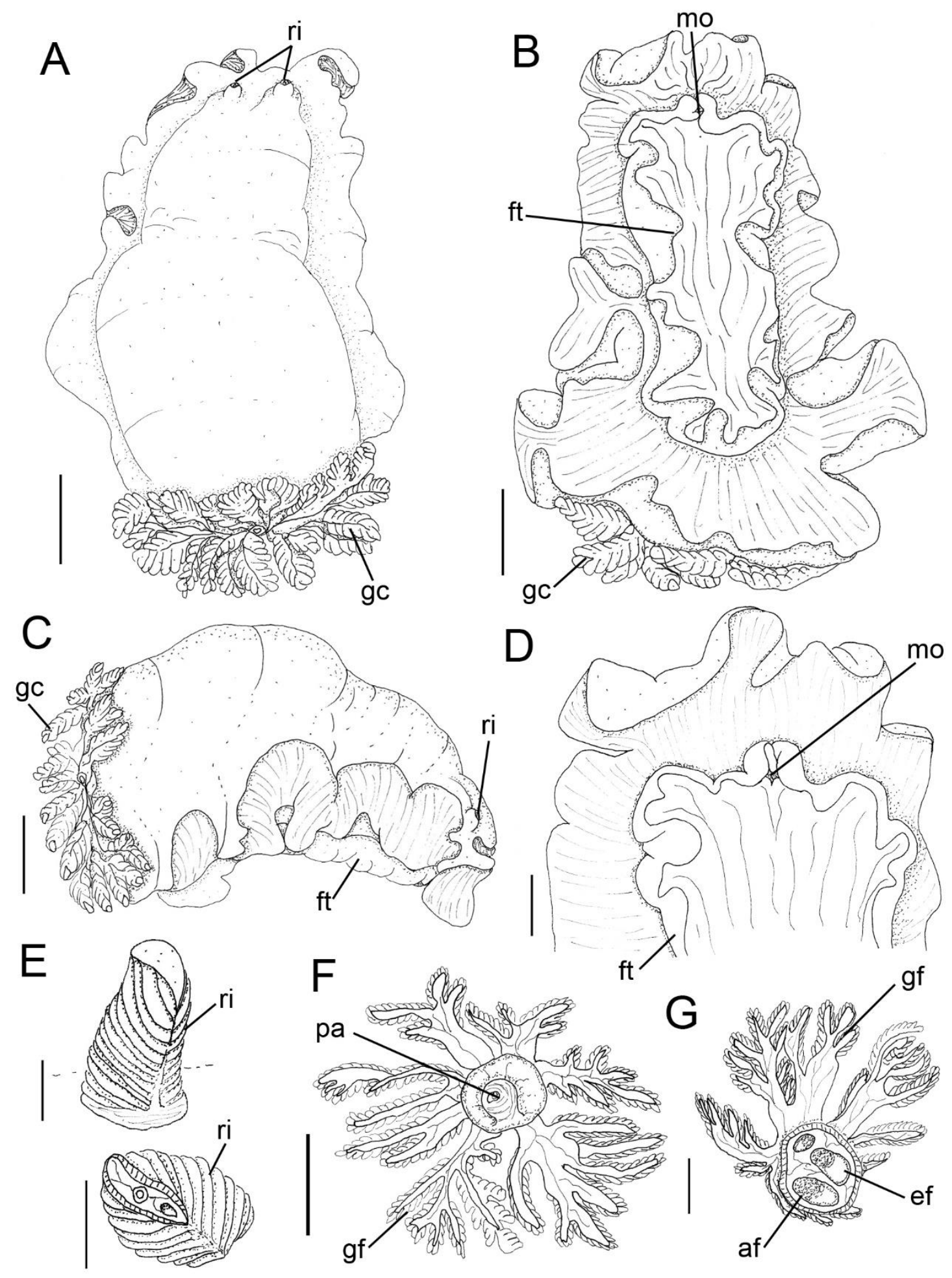

Figure 128: Dendrodoris limbata, fixed animal. A. Dorsal view. B. Same, ventral view. C. Same, right lateral view. Scales: $5 \mathrm{~mm}$. D. Anterior border of foot. Scale: $2 \mathrm{~mm}$. E. Rhinophore with transversally sectioned. Scale: $1 \mathrm{~mm}$. F. Gill circle, dorsal view. Scale: $5 \mathrm{~mm}$. G. Gill filament, with afferent and efferent branchial rings. Scale: $2 \mathrm{~mm}$. 

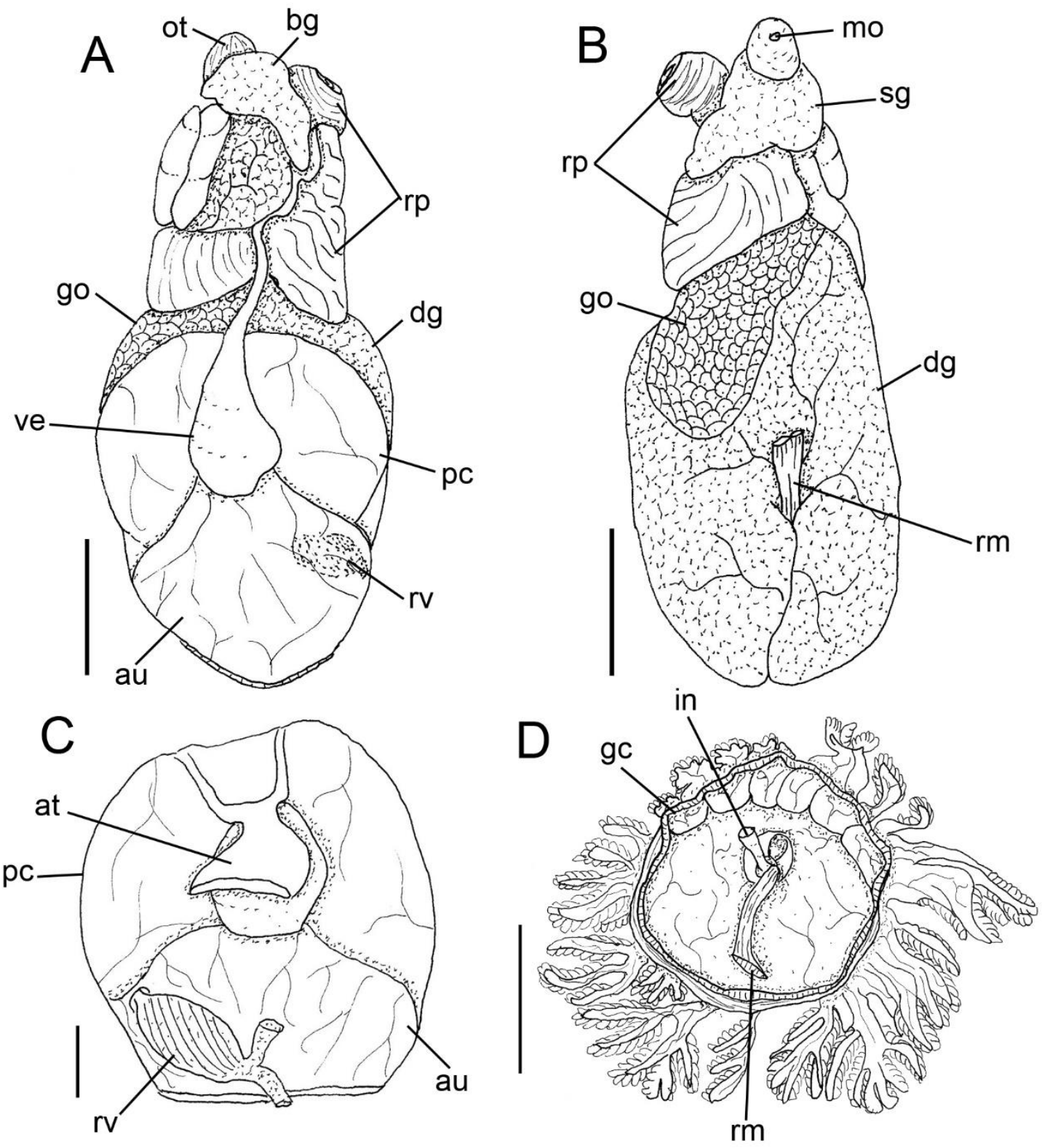

Figure 129: Dendrodoris limbata. Visceral mass. A. Dorsal view. B. Same, ventral view. Scales: $5 \mathrm{~mm}$. C. Circulatory and excretory system, ventral view. Scale: $2 \mathrm{~mm}$. D. Detail of anterior view of gill circle. Scale: $5 \mathrm{~mm}$. 

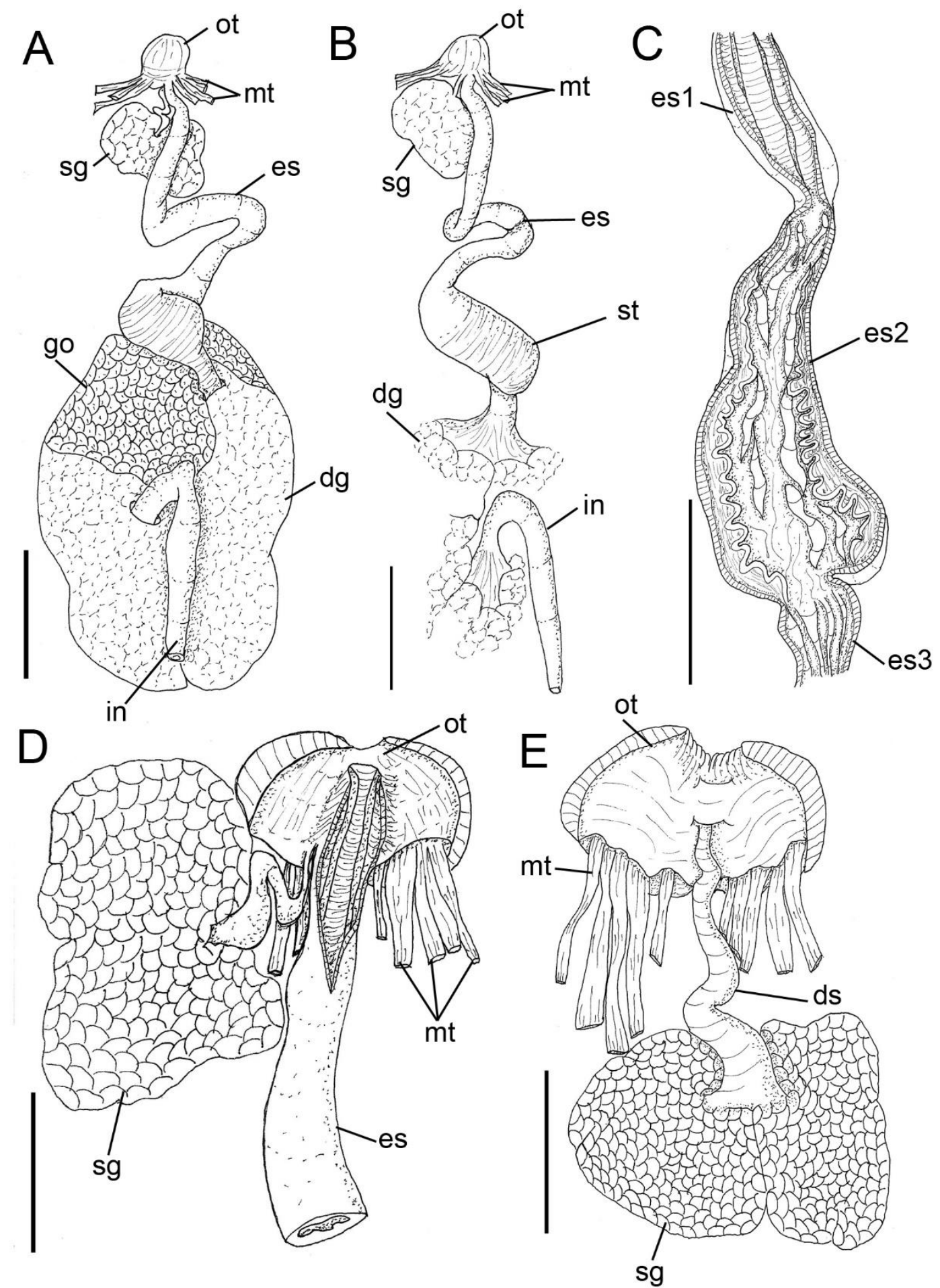

Figure 130: Dendrodoris limbata. Digestive system. A. Dorsal view. B. Same, with removed digestive gland. C. Longitudinally sectioned esophagus. Scales: $5 \mathrm{~mm}$. D. Longitudinally sectioned oral tube. E. Detail of connection of salivary gland. Scales: $2 \mathrm{~mm}$. 

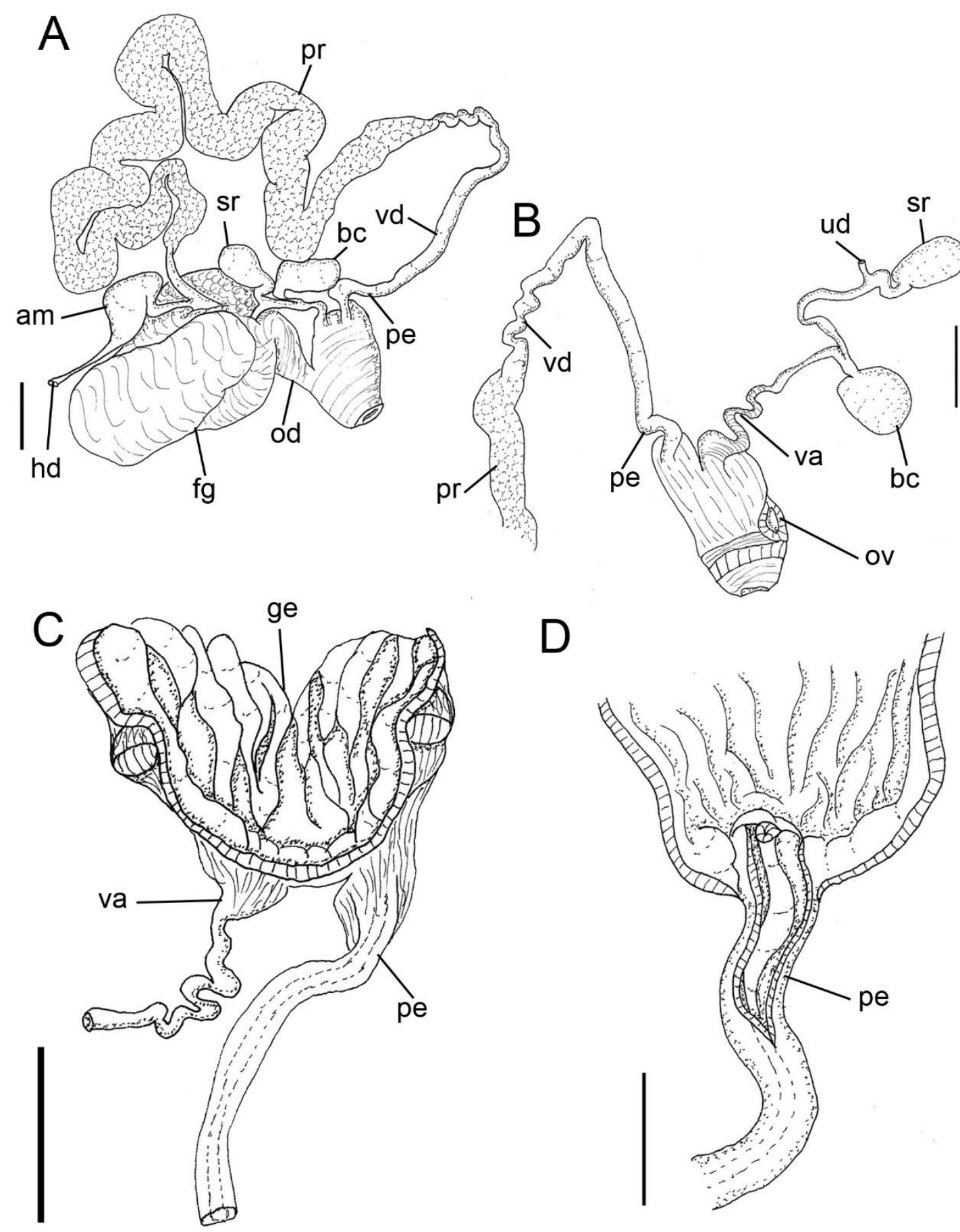

Figure 131: Dendrodoris limbata. Reproductive system. A. General view. B. Detail of male and female parts. C. Detail of aperture. Scales: $2 \mathrm{~mm}$. D. Detail of penis. Scale: $1 \mathrm{~mm}$. 


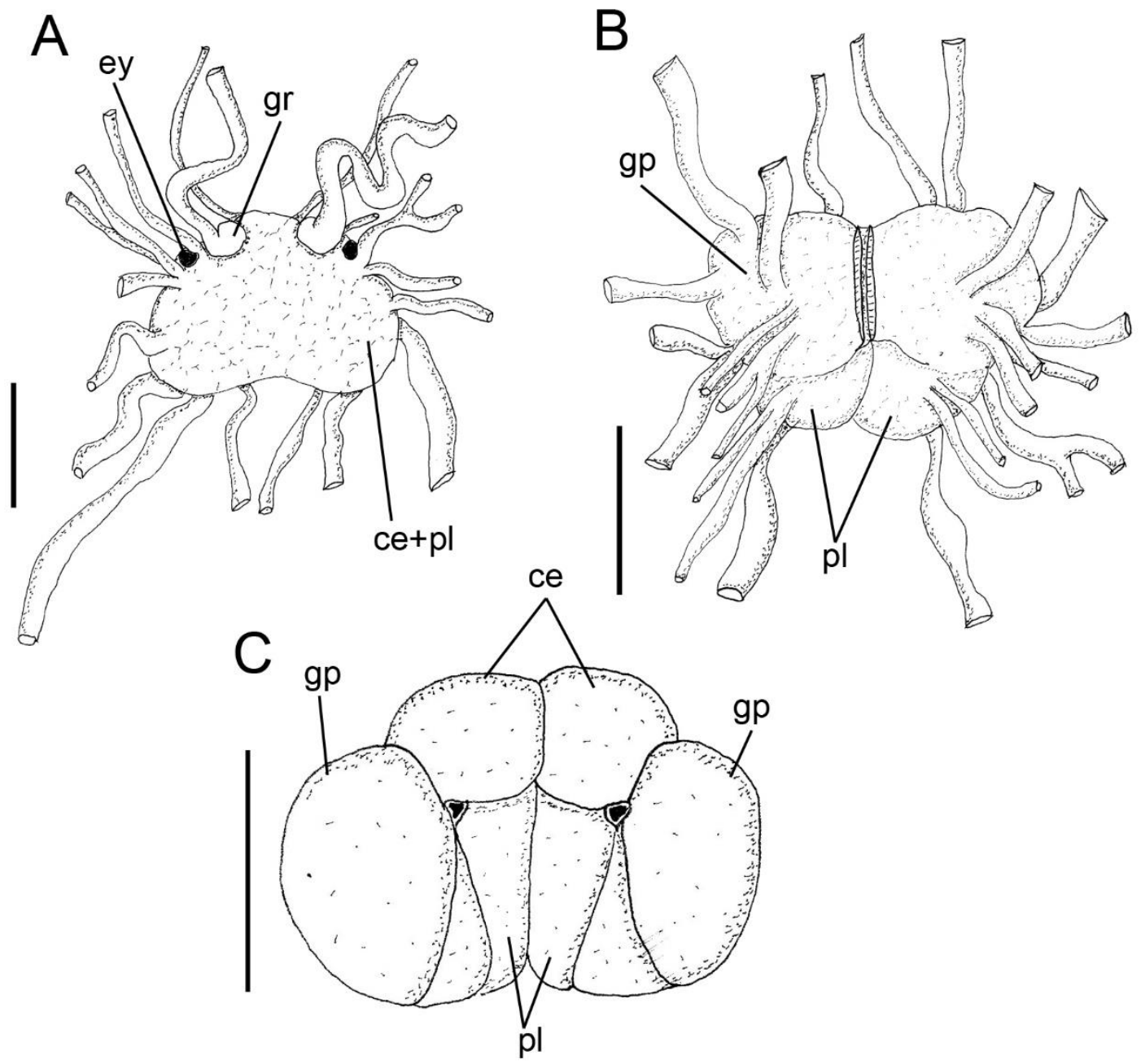

Figure 132: Dendrodoris limbata. Nervous system. A. Dorsal view. B. Same, ventral view. C. Same ventral view with detail of fused ganglia. Scales: $1 \mathrm{~mm}$. 


\section{Genus Doriospilla Bergh, 1880}

Type species: Doriopsilla areolata Bergh, 1880

\section{Doriopsilla areolata Bergh, 1880}

(Figures 133-137)

Doriopsilla areolata Bergh, 1880: 318, pl. 11, figs. 3-11; Abbott, 1974: 566, figs. 4349; Valdés et al., 2006: 202; Rios, 2009: 429; Calado \& Silva, 2012: F35.

Doriopsilla areolata areolata Valdés \& Ortea, 1997: 243, figs.1A-D.

Doriopsilla ciminoi Avila et al., 1992: 24, figs. 1-3.

Doriopsilla evanae Ballesteros \& Ortea, 1980: 26, figs. 1-2.

Doriopsilla fedalae Pruvot-Fol, 1953: 92, fig. 34, pl. 2, 32.

Doriopsilla pusilla Pruvot-Fol, 1951: 41, pl. 2, 1-2.

Doriopsilla rarispinosa Pruvot-Fol, 1951: 41, 22.

Doris reticulata Schultz in Philippi, 1836: 105

Type locality: Mediterranean Sea (Valdés \& Ortea, 1997)

\section{Redescription}

External morphology (Figure 133A-F; 134D): Size 23mm length, 16mm width. Color light yellow. Body rounded, foot not exceed notum (Fig. 133A-C). Rhinophores with about 16 transverse lamellae, color similar to body (Fig. 133F); rhinophoral sheaths smooth (Fig. 133E). Gill composed of five branched branchial leaves, color similar to body, arranged in circular fashion surrounding anus; branchial sheaths smooth, color similar to body (Fig. 134D). Mouth opening in anterior ventral region, between anterior region of notum and foot. Digitiform tentacles or lateral extensions of integument absent. Anterior border of foot not bilabiate (Fig. 133D).

Haemocoel organs (Figure 134A, B): pericardium and posterior half of visceral mass volume occupying $10 \%$ of haemocoel. Buccal mass located anteriorly, occupying $15 \%$ of haemocoel volume. Nervous system more posteriorly to buccal mass, occupying $5 \%$ of haemocoel volume followed posteriorly by blood gland. Reproductive system located between buccal mass and digestive gland, mainly on right side and dorsally, occupying $30 \%$ of haemocoel volume. Stomach, intestine and digestive gland occupying $40 \%$ of haemocoel volume. 
Circulatory and excretory systems (Figure 134A, C): same as Dendrodoris limbata. Renal vesicle with longitudinal folds, half the size and width of ventricle (Fig. 134C). Nephrostome difficult to see.

Digestive system (Figures 134D; 135A-G): Oral tube composed by three sections of pleats, first with longitudinal pleats at opening of rhinchostoma, second with horizontal pleats and third glandular portion. mt, a pair of retractor muscles of buccal mass, originating on oral tube, running dorsally to oral tube, inserting on body side, about four times longer than wide (Fig. 135B, C). Odontophore absent. Pair of salivary glands as long as mt (Fig. 135C, D); duct inserting in anterior region of mouth, extending parallel to anterior region of esophagus. Esophagus same as in anterior portion of Dendrodoris, inserting in circular muscular posterior portion that preceding stomach; circular muscular portion glandular, with a pair of thin and narrow muscle that pass ventral to pericardium and inserts in gill circle $(\mathbf{m x})$ (Fig. 135B, E, F). Stomach rectangular with entire inner surface pleated and glandular. Intestine with longitudinal folds along its entire length, diameter about same esophagus diameter (Fig. 135B, G). Caecum absent. Digestive gland dark beige, being largest organ of visceral mass, elongated, inner face of gland spongelike, with a distinct main duct (Fig. 135A). Anus opening into anal papilla at edge of gill circle, $\sim 1 / 3$ of gill filament length (Fig. 134D).

Genital system (Figure 134B; 136A-E): Genital opening on right side, anterior third of length of animal from head, located between foot and notum (Fig. 134B). Gonad immersed in digestive gland but easy to distinguish it (Fig. 134B). Hermaphrodite duct thin, long. Ampulla located on female gland, elongated and tubular (Fig. 136A). Prostate glandular immersed in female gland (Fig. 136B). Vas deferens not distinguished from penis (Fig. 136B). Penis' muscle absent. Penis muscular, cylindrical and elongated, about same of length and width of vagina (Fig. 136C, D). Female gland well-developed, rounded, occupying $50 \%$ of reproductive system volume, divided into mucus gland ( 2/3 of female gland, color beige), and albumen gland ( 1/3 of anteriormost region, dilated, irregularly shaped, color dark brown) (Fig. 136A). Oviduct occupying 1/7 of female gland volume (Fig. 136B, C). Uterine duct thin, length $\sim 1 / 2$ of length and 1/3 of width of vagina, located at commun base of vagina, seminal receptacle and bursa copulatrix, inserted in female gland near oviduct (Fig. 136E). Seminal receptacle pyriform, 1/2 of length and width of copulatrix (Fig. 136E). Bursa copulatrix rounded, length $\sim 1 / 2$ of vagina length (Fig. 136E). Vagina cylindrical, elongated, approximately as long and as 
wide as penis, followed ventrally by prostate and located parallel to penis in genital opening (Fig.136C, E).

Nervous system (Figure 134A; 137A-D): located dorsally to odontophore, mostly covered by blood gland (Fig. 134A). Pair of cerebral and pleural ganglia fused with each other dorsally and ventrally. Pedal ganglia fused with cerebral and pleural ventrally, but not fused among themselves. Pedal commissure simple and short, surrounding anterior esophagus and salivary glands (Fig. 137B). Buccal ganglia short and almost fused (Fig. 127D). Gastro-esophageal not visualized. Rhinophoral (olfactory) ganglia bulb-shaped, connected to anterior portion of cerebral ganglia (Fig. 137A). Dorsal eyes located on cerebral ganglia (Fig. 137A). Statocysts small and iridescent, located ventrally between cerebral and pleural ganglia (Fig. 137C).

Distribution: Mediterranean, Atlantic Coast of Europe to France (Rudman, 2000).

Habitat: Shallow water to $150 \mathrm{~m}$ depth.

Material examined: FRANCE, VilleFrance, ZMUC-GAS 234, 1 specimen (Barrois, coll. Neotype select by Valdés, A. 7 Ortea, J., 1997); PORTUGAL, Algarve, Ponta da Baleeira, CAS 181838, 1 specimen (Y. Camacho-Garcia et al. Coll., 08/vii/2002, 10-22m depth); SENEGAL, Dakar, ZMUC-GAS 739, 1 specimen (Githorson coll., 12/iv/1952). 

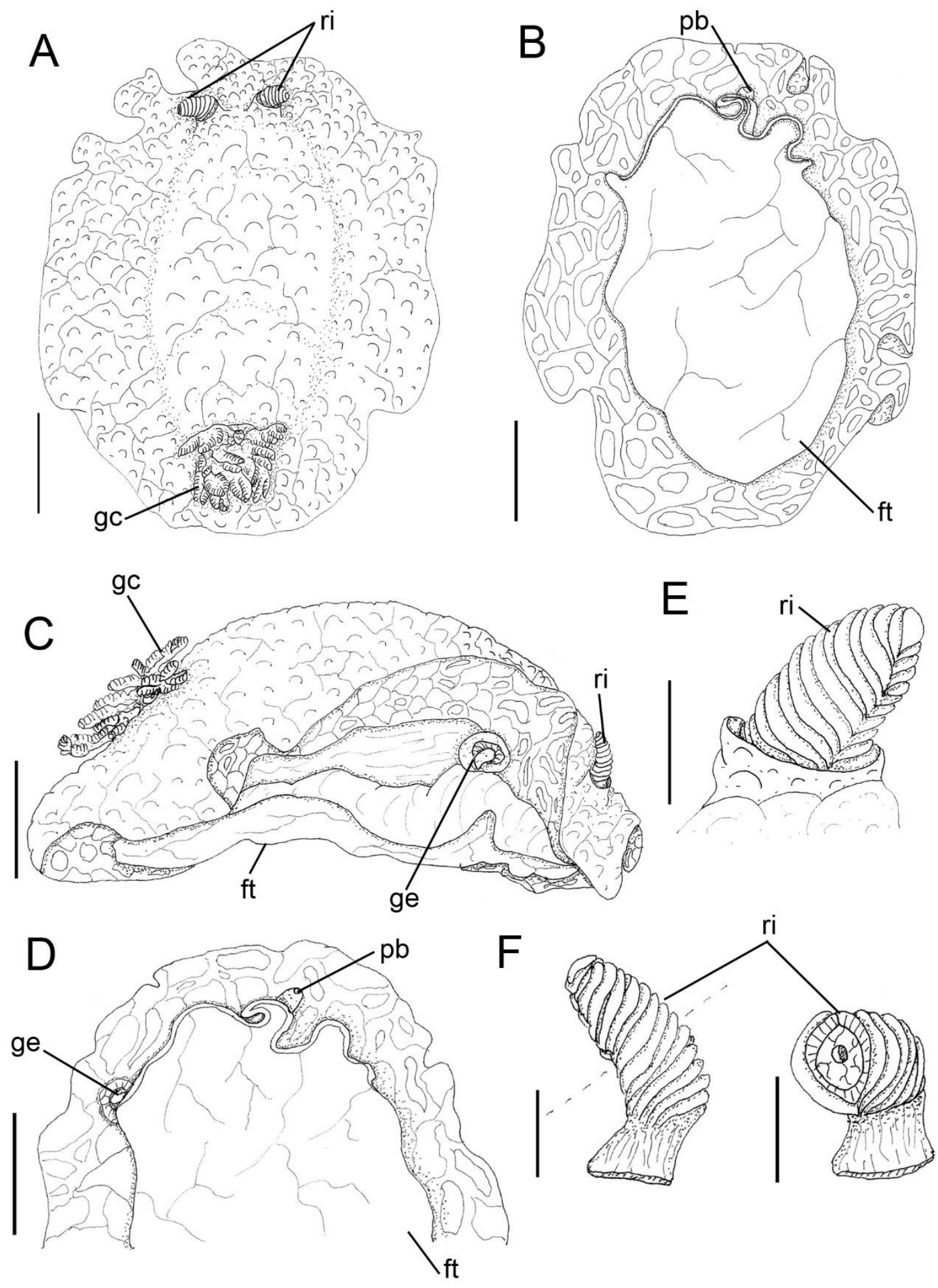

Figure 133: Doriopsilla areolata, fixed animal. A. Dorsal view. B. Same, ventral view. C. Same, right lateral view. D. Anterior border of foot. Scales: $5 \mathrm{~mm}$. E. Rhinophoral sheath. F. Rhinophore with transversally sectioned. Scales: $1 \mathrm{~mm}$. 

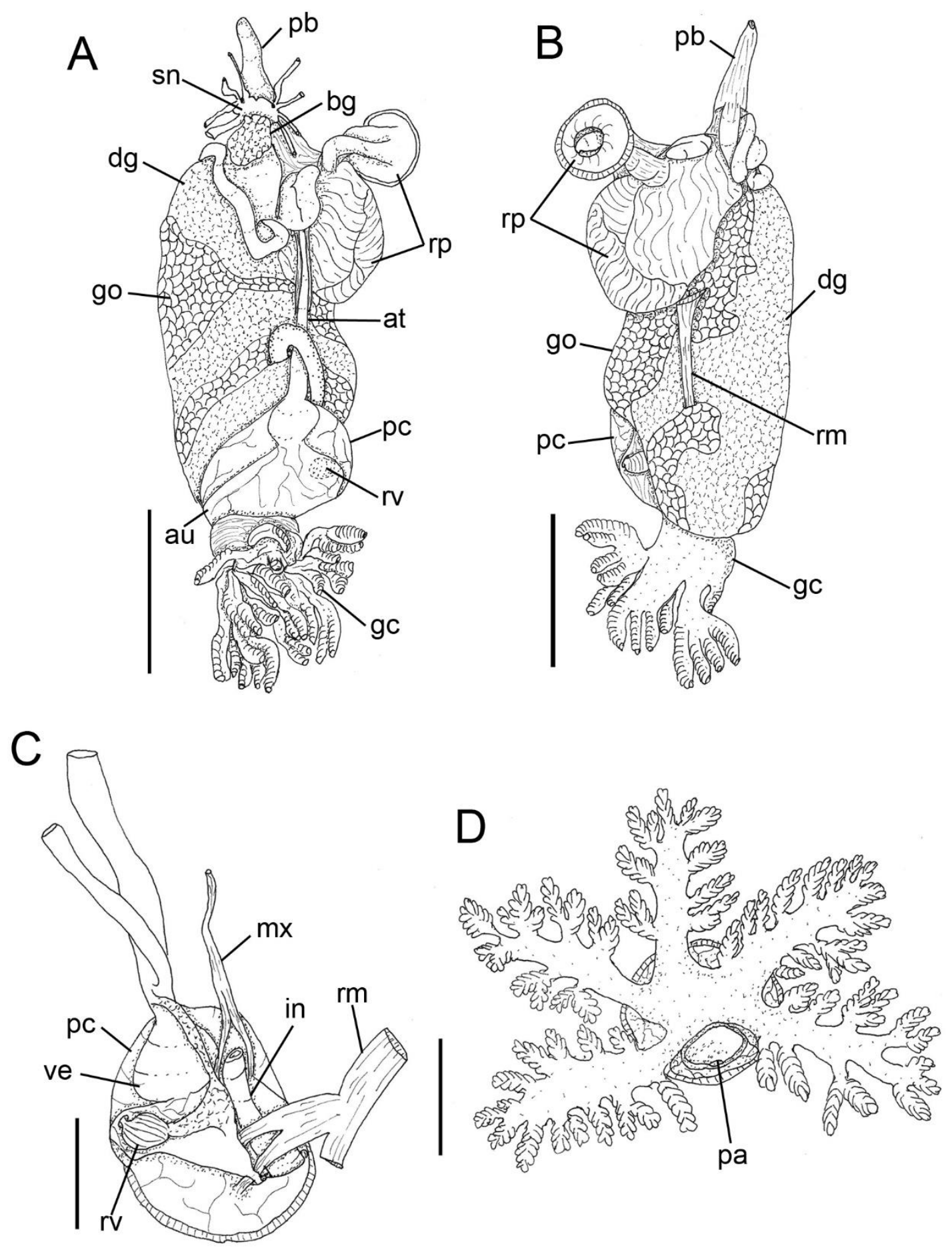

Figure 134: Doriopsilla areolata. Visceral mass. A. Dorsal view. B. Same, ventral view. Scale: $5 \mathrm{~mm}$. C. Circylatory and excretory system, ventral view. Scale: $1 \mathrm{~mm}$. D. Gill circle, dorsal view. Scale: $2 \mathrm{~mm}$. 


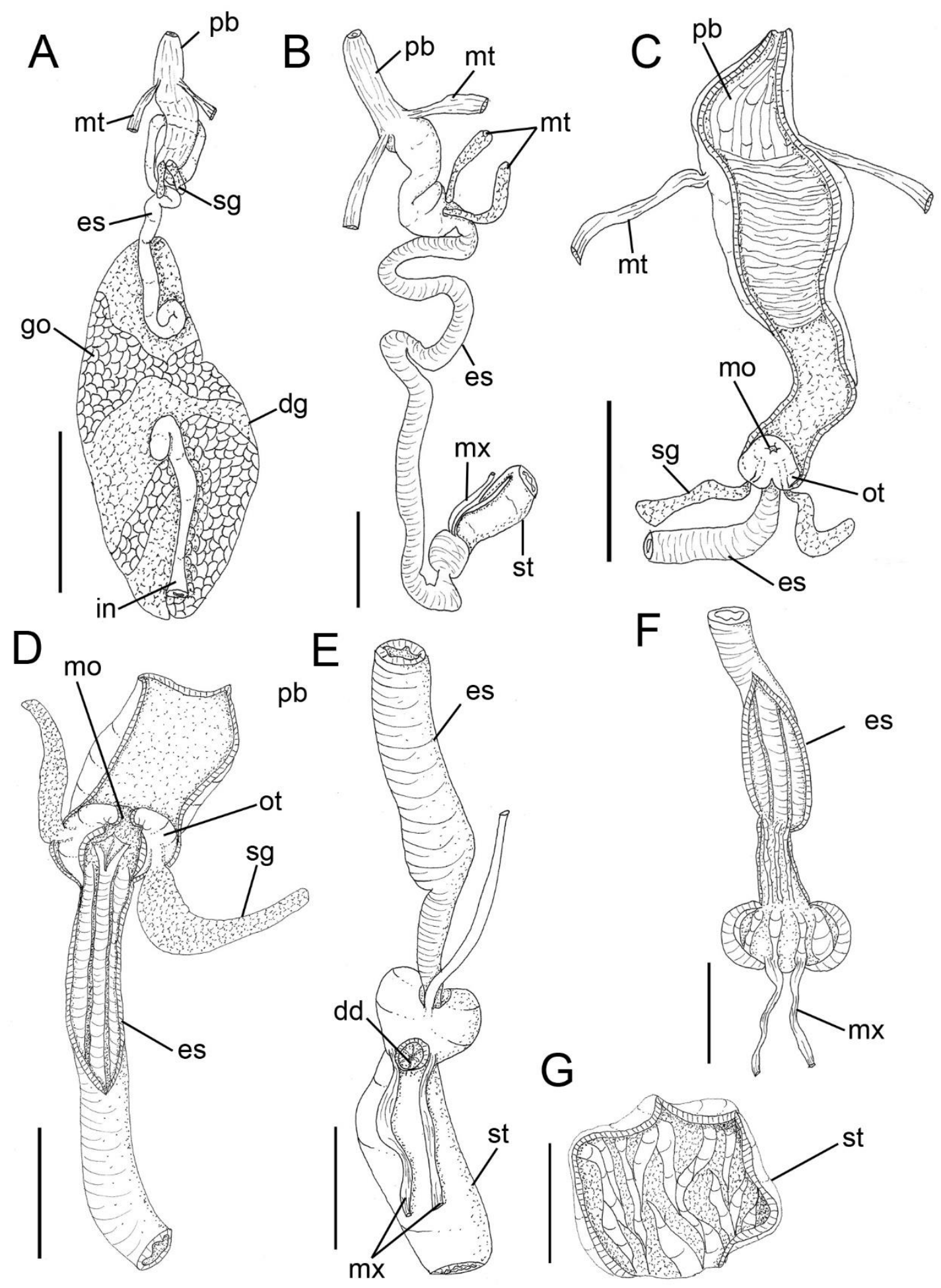

Figure 135: Doriopsilla areolata. Digestive system. A. Dorsal view. B. Same, dorsal view with removed digestive gland. Scales: $2 \mathrm{~mm}$. C. Longitudinally sectioned proboscid. D. Detail of mouth, doral view. E. Detail of esophagus and duct of digestive gland. F. Internal view of esophagus. G. Internal view of stomach. Scales: $1 \mathrm{~mm}$ 


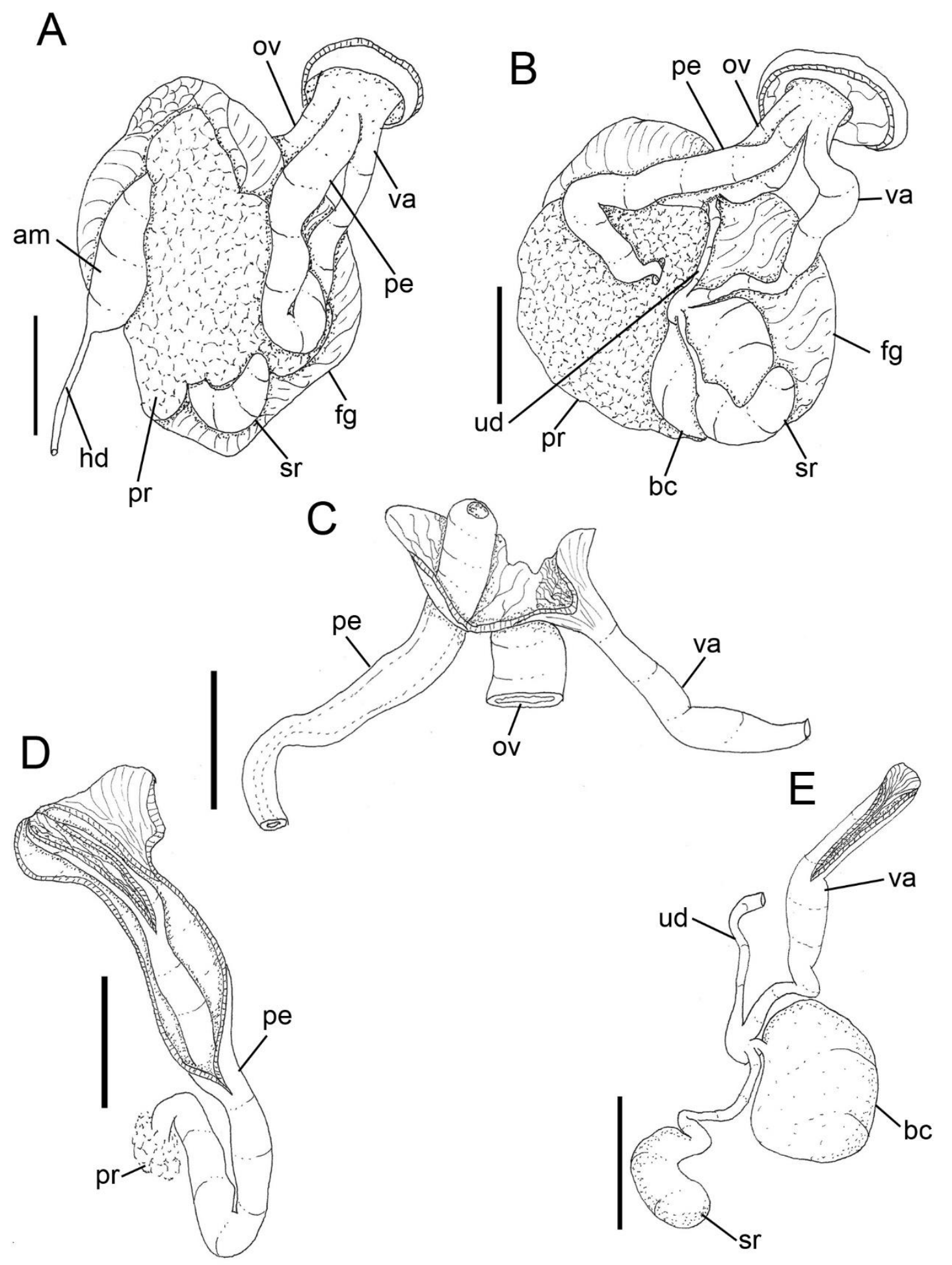

Figure 136: Doriopsilla areolata. Reproductive system. A. Dorsal view. B. Same, ventral view. C. Detail of aperture. D. Detail of penis, internal vas deferens. E. Detail of bursa copulatrix, seminal receptacle and vaginal. Scales: $1 \mathrm{~mm}$. 

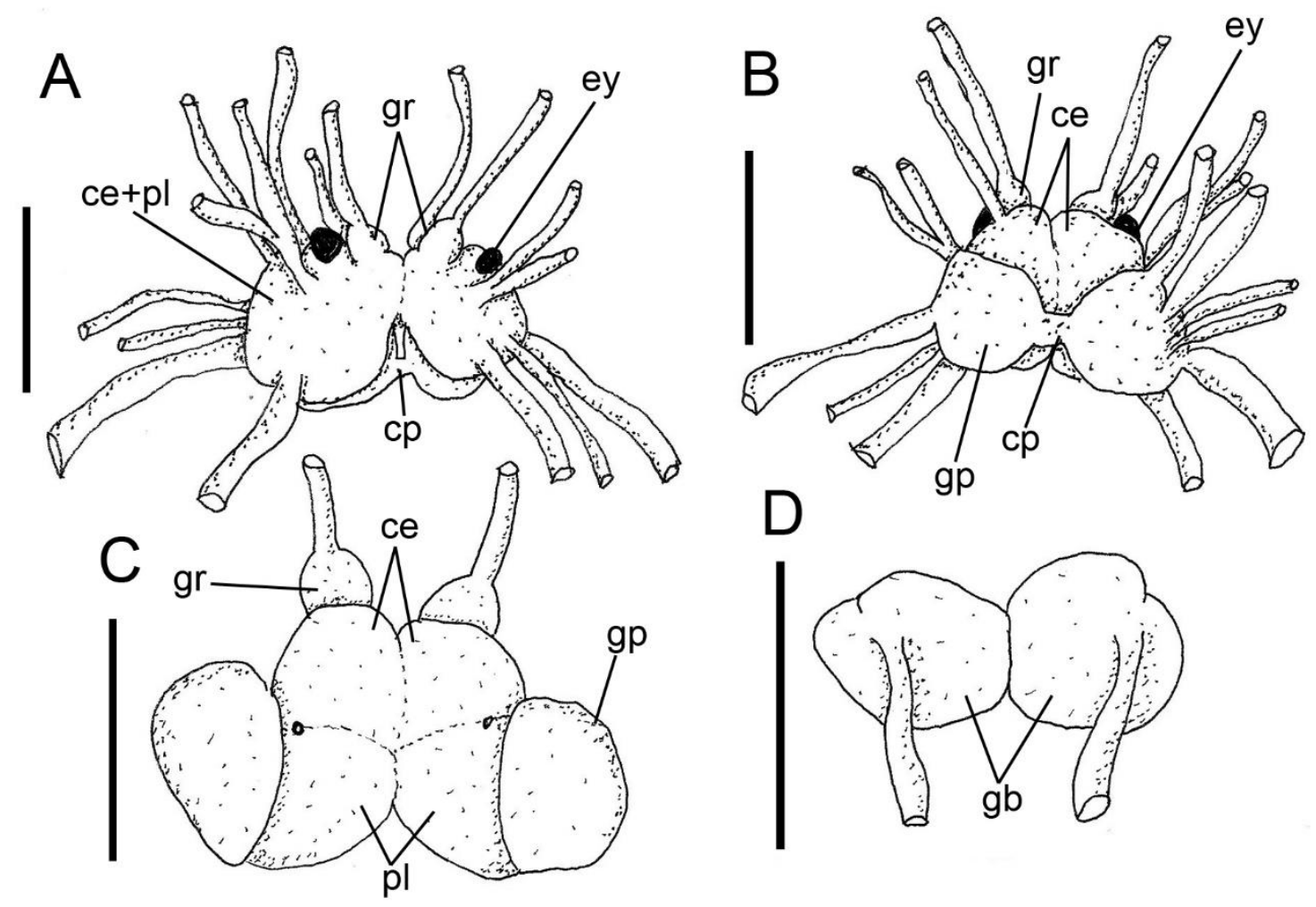

Figure 137: Doriopsilla areolata. Nervous system. A. Dorsal view. B. Same, ventral view. C. Detail of fused ganglia. D. Buccal ganglia. Scales: $1 \mathrm{~mm}$.

\section{Genus Mandelia Valdés \& Gosliner, 1999}

Type species: Mandelia mirocornata Valdés \& Gosliner, 1999

\section{Mandelia mirocornata Valdés \& Gosliner, 1999}

(Figures 138-141)

Mandelia mirocornata Valdés \& Gosliner, 1999: 341, fig. 4 J, 5C, 6F, 7B, 9A, 10D, 11C-D, 16G-H, 17C-D, 19, 20F, 21D.

Type locality: Bakoven, Cape Peninsula, Atlantic Coast, Cape Province, South Africa

\section{Redescription}

External morphology (Figure 138A-G): Size 26mm length, 12mm width. Color white to brown with large black dots arranged all over dorsum. Body rounded, entire dorsum covered by small tubercles (Fig. 138A-C). Rhinophores with about 17 transverse lamellae (Fig. 138F, G), color similar to body; rhinophoral sheaths with small tubercles. 
Gill composed of 7 bipinnate branchial leaves, color similar to body, arranged in circular fashion surrounding anus; branchial sheaths also with small tubercles, color similar to body (Fig. 138D, E). Mouth opening in anterior ventral region of foot (Fig. 138B). Digitiform tentacles and lateral extensions of integument absent. Anterior border of foot not bilabiate (Fig. 138B).

Haemocoel organs (Figure 139A-B): pericardium and posterior half of visceral mass volume occupying $15 \%$ of haemocoel. Buccal mass located anteriorly, occupying $10 \%$ of haemocoel volume. Nervous system posteriorly to buccal mass, covered by blood gland, occupying $10 \%$ of haemocoel volume. Reproductive system on right side of animal; occupying $30 \%$ of haemocoel volume. Stomach, intestine and digestive gland occupying $40 \%$ of haemocoel volume.

Circulatory and excretory systems (Figure 139A-D): same as in Dendrodoris and Doriopsilla. Pericardial cavity dorsal and posterior to digestive gland, anterior to gill circle (Fig. 139A). Renal vesicle 1/3 the size and width of ventricle (Fig. 139C). Gill retractor muscle originating in midlle of gill circle (Fig. B, D). Renal chamber extending from dorsal to medial sinus, previously connected to renal vesicle, extending posteriorly to center of gill circle. Nephrostome difficult to see.

Digestive system (Figures 138D, 139A, E-H): Oral tube composed of proboscid (Fig. 139B, E-H); mt, a pairs of retractor muscles of buccal mass, originating on oral tube, running dorsally to oral tube, inserting on body side, about five times longer than wide (Fig. 139F, G). Odontophore absent. Pair of salivary glands long, tubular, internal to proboscis with 1/5 posterior external, lateral to anterior esophagus (Fig. 139G). Circular muscular portion glandular, with a pair of thin and narrow muscle that pass ventral to pericardium and inserts in gill circle $(\mathbf{m x})$, same as in Doriopsilla areolata (Fig. $139 \mathrm{G}, \mathrm{H})$. Esophagus simple, originating dorsally to odontophore, inserting directly in anterior region of stomach, internal longitudinal folds with same diameter along entire length (Fig. 139E, H). Stomach widespread in digestive gland. Caecum absent. Intestine with longitudinal folds along its entire length, about twice diameter of esophagus (Fig. 139E). Digestive gland dark beige, being largest organ of visceral mass, rounded, inner face of gland sponge-like, bearing various ducts and a distinct main duct (Fig. 139B). Anus opening into anal papilla at center of gill circle, $\sim 1 / 2$ of gill filament length (Fig. 138D).

Genital system (Figure 139A, B; 140A-E): Genital opening on right side, anterior third of length of animal from head, located between foot and notum (Fig. 139B). Gonad 
immersed in digestive gland but easy to distinguished it (Fig. 139A). Hermaphrodite duct thin, long (Fig. 140C). Ampulla located on female gland, elongated and tubular (Fig. 140C). Prostate rounded, glandular, length same and three times width as ampulla (Fig. 140A, C). Vas deferens $1 / 3$ of length and $1 / 2$ of width of penis (Fig. 140A, D). Penis' muscle absent. Penis muscular, cylindrical and elongated, about same length of vagina (Fig. 140C). Female gland well-developed, rounded, occupying $~ 50 \%$ of reproductive system volume, divided into mucus gland ( 2/3 of female gland, color beige), and albumen gland ( 1/3 of anteriormost region, dilated, irregularly shaped, color dark brown) (Fig. 140C). Oviduct occupying $~ 1 / 3$ of female gland volume. Uterine duct thin, length $\sim 1 / 2$ of vagina length, located at base of seminal receptacle in female gland near oviduct (Fig. 140B). Seminal receptacle pyriform, same length and half of bursa copulatrix (Fig. 140B). Bursa copulatrix rounded, length $\sim 1 / 3$ of vagina length, connected to vagina after seminal receptacle, also through short stalk (Fig. 140B). Vagina cylindrical, elongated, approximately as long and same wide as penis, followed ventrally by prostate and located parallel to penis in genital opening (Fig. 140B, C, E).

Nervous system (Figures 139A; 141A-C): Pair of cerebral and pleural ganglia fused with each other dorsally and ventrally. Pair of cerebral ganglia with short and narrow commissure (Fig. 141C). Pedal ganglia fused with cerebral and pleural ventrally and almost fused among themselves. Pedal commissure inconspicuous, surrounding esophagus and salivary glands (Fig. 141B). Buccal and gastro-esophageal ganglia not visualized. Rhinophoral (olfactory) ganglia bulb-shaped, connected to anterior portion of cerebral ganglia (Fig. 141A). Dorsal eyes located on cerebral ganglia (Fig. 141A).

Distribution: South Africa

Material examined: SOUTH AFRICA, Western Cape Province, Atlantic Coast, Gelderland Wreck CAS 176401, 1 specimen, (T.M. Gosliner, A. Valdés, M. Pola, B. Moore, L. Withey \& C. Stout coll., 12/i/2008; $34.00^{\circ} 2.07$ ' ' S $18.00^{\circ} 18.18$ ' ' E; 30$35 \mathrm{~m}$ depth). 


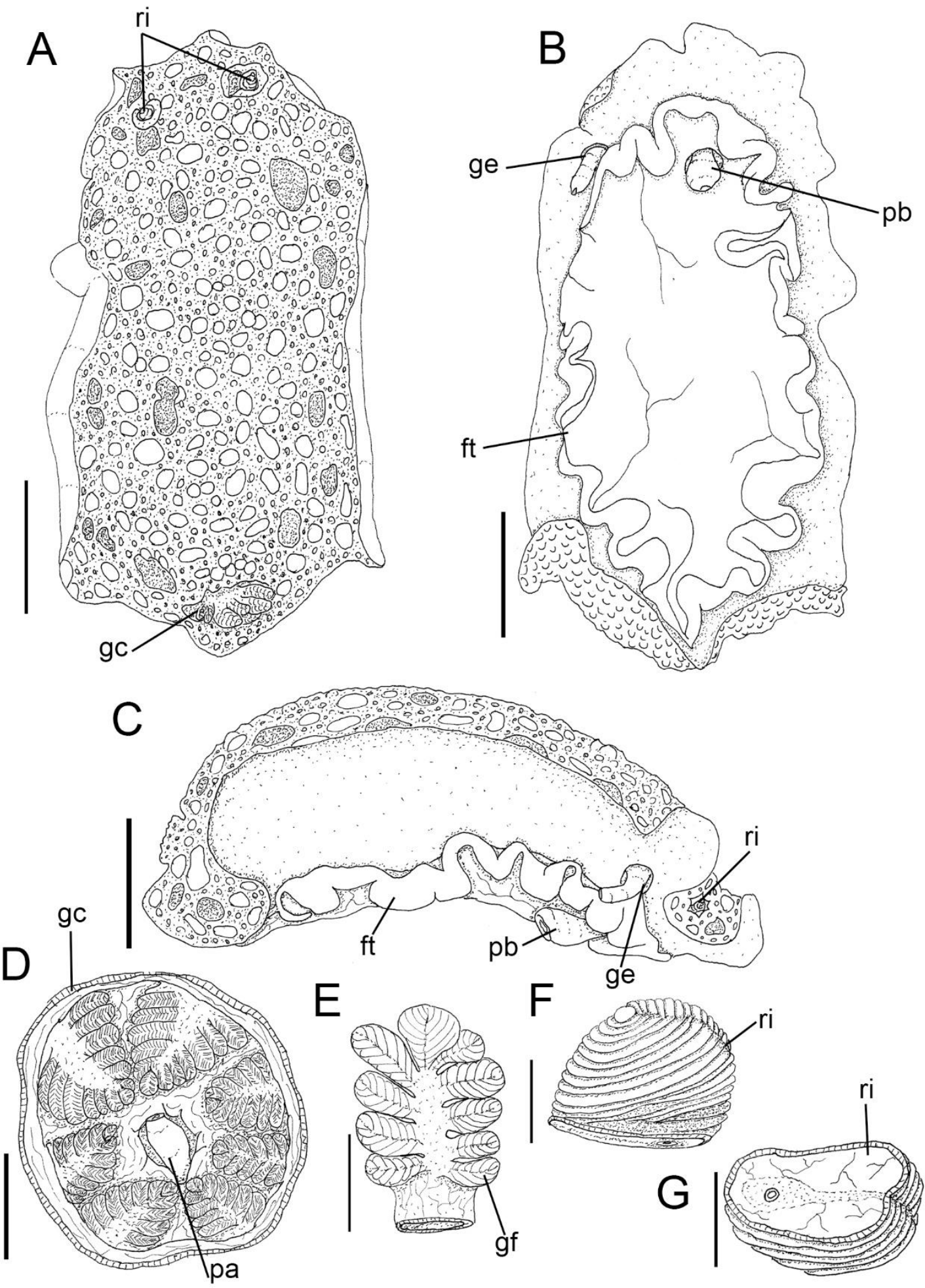

Figure 138: Mandelia mirocornata, fixed animal. A. Dorsal view. B. Same, ventral view. C. Same, right lateral view. Scales: $5 \mathrm{~mm}$. D. Gill circle, dorsal view. Scale: $2 \mathrm{~mm}$. E. Gill filamento. F. Rhinophore. G. Transversal section of rhinophore. Scales: $1 \mathrm{~mm}$. 


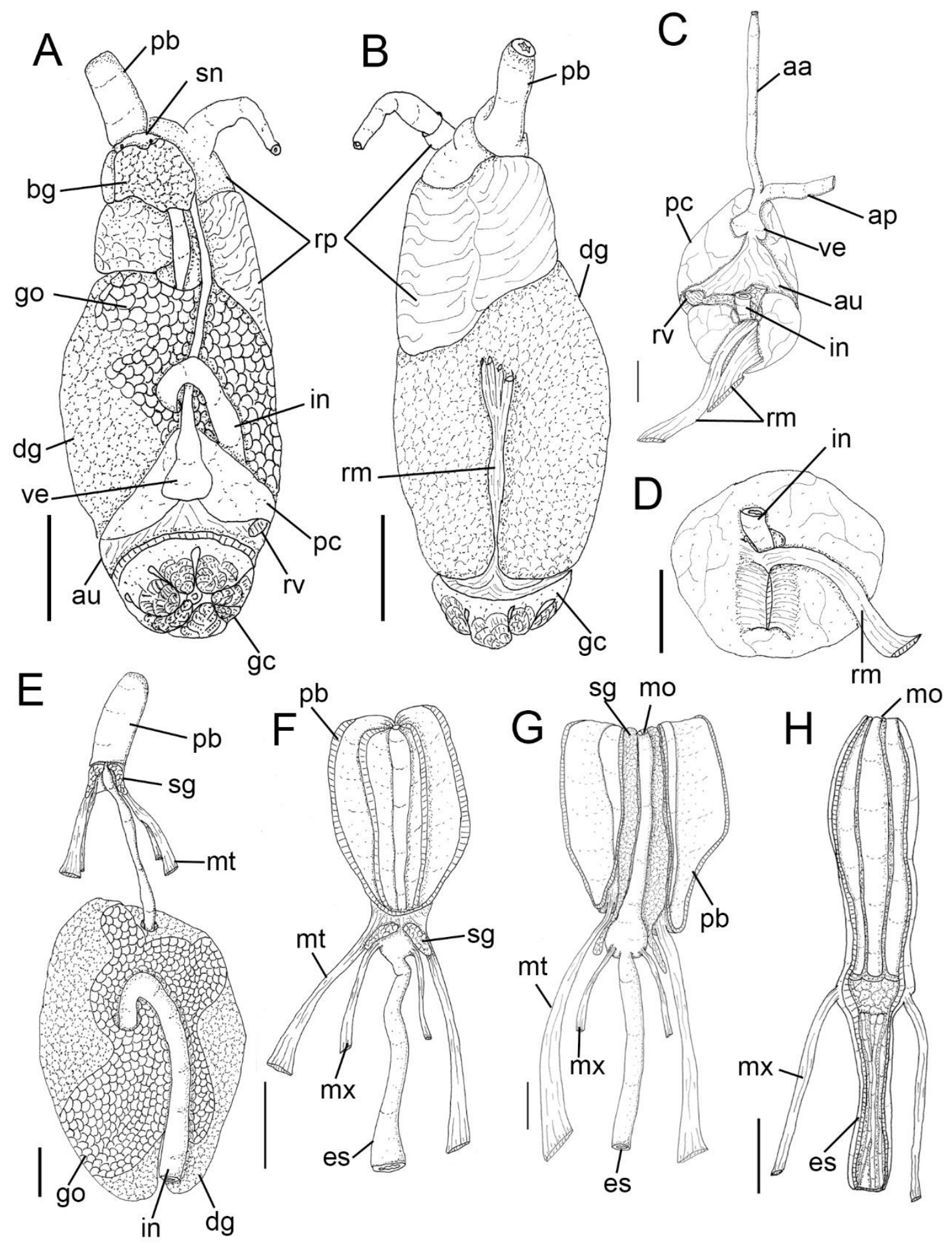

Figure 139: Mandelia mirocornata. Visceral mass. A. Dorsal view. B. Same, ventral view. Scales: $5 \mathrm{~mm}$. C. Circulatory and excretory system, ventral view. D. Detail of gill retractor muscle, ventral view. E. Digestive system, dorsal view. Detail of proboscid. F. Dorsal view. Scales:2mm. G. Same, longitudinally sectioned, with expoded of salivar glang. H. Same, internal of proposcid. Scales: $1 \mathrm{~mm}$. 


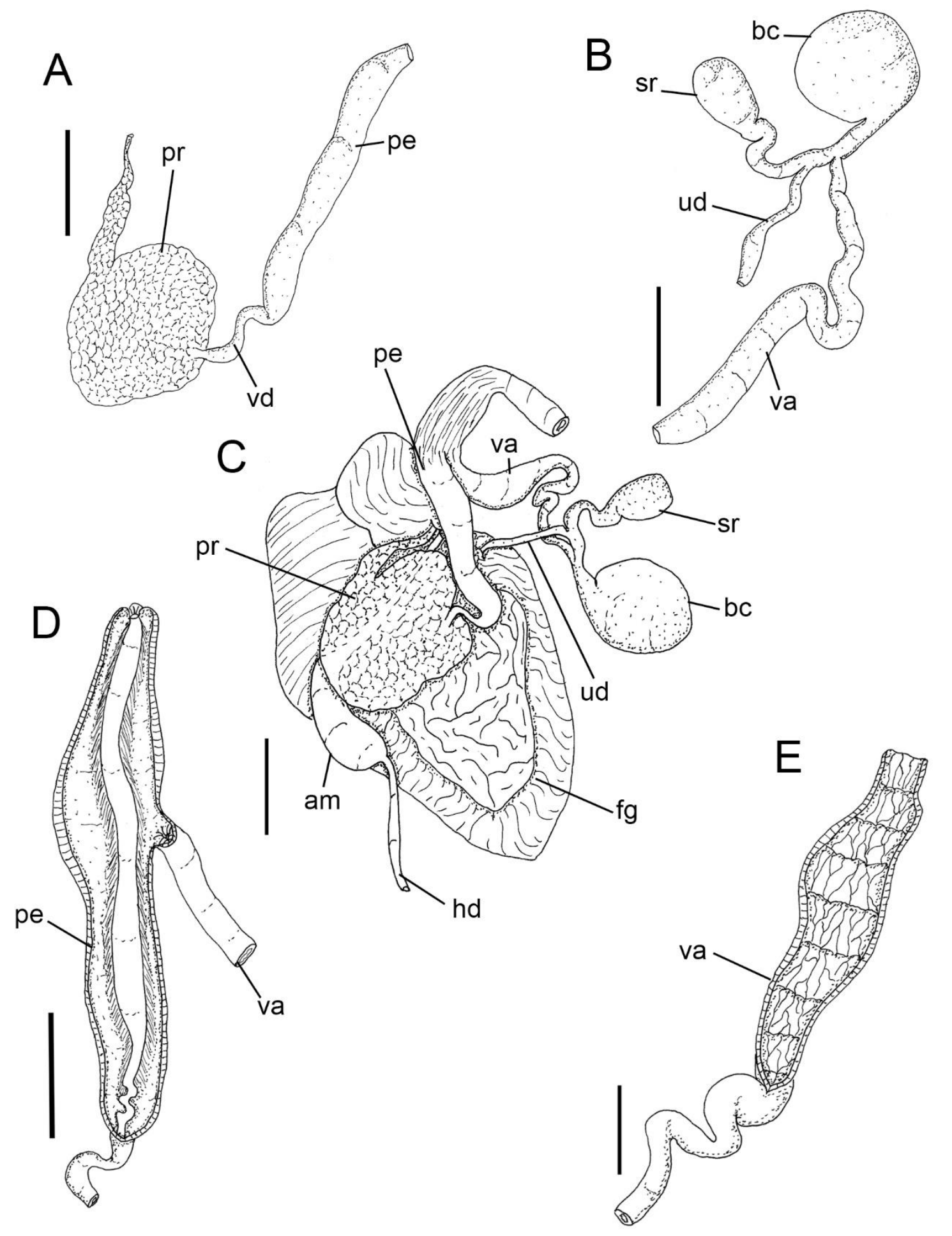

Figure 140: Mandelia mirocornata. Reproductive system, A. Detail of male parts: prontate, vas deferens and penis. B. Detail of Bursa copulatrix, seminal receptacle and vaginal. C. General view. D. Internal view of penis. E. Internal view of vagina. 

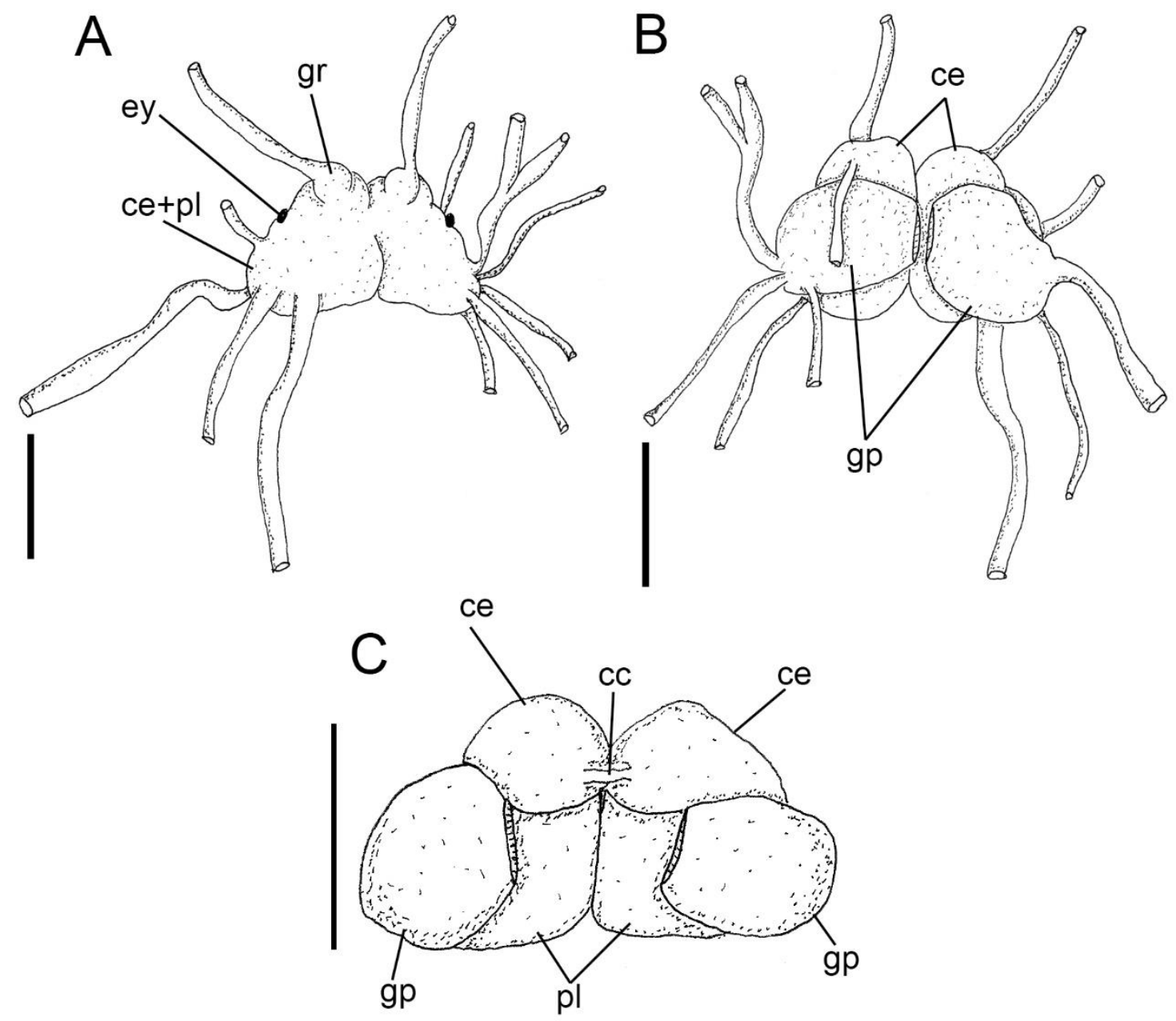

Figure 141: Mandelia mirocornata. Nervous system. A. Dorsal view. B. Same, ventral view. C. Detail of fused ganglia, ventral view. 


\subsection{Apresentação e discussão dos caracteres}

Os caracteres utilizados nesta análise filogenética de Cryptobranchia levaram em conta uma ampla variedade de características morfológicas e anatômicas dos táxons envolvidos na análise. Dos caracteres, 50 são binários e 25 são multiestados. Como de praxe, os estados de carácter são indicados com números: 0, para a condição plesiomórfica; 1-5, para a condição apomórfica.

A lista de caracteres utilizados na análise está dividida em: Estruturas externas, estruturas do noto, sistema circulatório, massa bucal, sistema digestivo, sistema reprodutor e sistema nervoso.

\section{Estruturas externas}

1 - Concha: 0 - presente (H. elegans e B. agassizii); 1- ausente (demais táxons) (Ci: 100; Cr: 100; L: 1)

A presença de concha é inquestionavelmente um estado plesiomórfico (Gosliner, 1994; Mikkelsen, 1996; Wägele \& Willan, 2000) enquanto que a ausência dela através da perda ocorreu várias vezes dentro dos "Opisthobranchia" (Wägele \&Willan, 2000). O estado 1 resultou como sinapomorfia do nó 2 (Nudibranchia).

2 - Forma do corpo: 0 - arredondada; 1 alongada (N. kristenseni, B. calcarata, $P$. pustulosa, G. mimula, T. brasiliensis e Chromodorididae) (Ci: 33; Cr: 83; L: 3)

O estado 1 resultou em sinapomorfia do nó 3 . O estado 0 resultou em duas convergências independentes, uma de $K$. brasiliensis e uma como sinapomorfia do

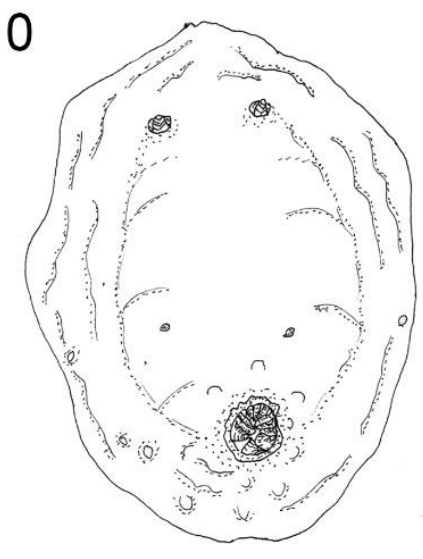
nó 17. 
3 - Projeção do pé, em relação ao noto: 0

- presente; 1- ausente (B. agassizii, A. muelleri, B. calcarata, P. pustulosa, K. brasiliensis, Dendrodorididae, C. rumia, A. verrucosus, Dorididae, Discodorididae) (Ci: 20; Cr: 63; L: 5)
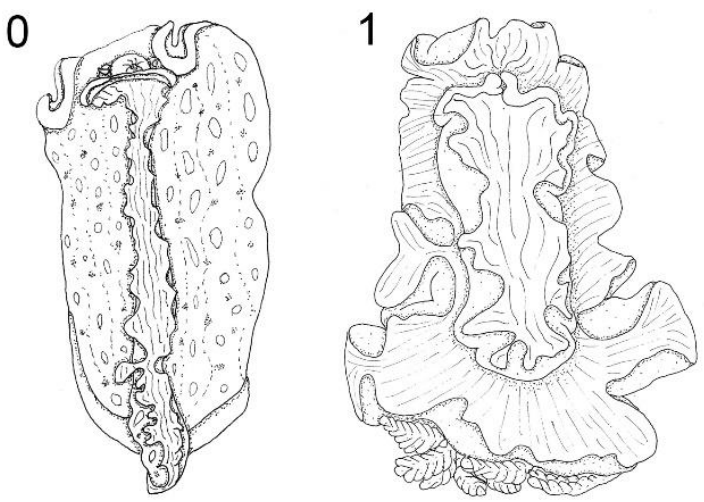

No caso da polarização (H. elegans), em relação a concha, se considerarmos uma relação de homologia entre a concha somada com a cavidade do manto e o noto. Com a otimização DELTRAN o estado 1 resultou em sinapomorfia do nó 1 (Nudipleura) e estado 0 resultou independentemente como autapomorfia de $N$. kristenseni, G. mimula, $T$. brasiliensis e sinapomorfia do nó 10 (Chromodorididae). Com a otimização ACCTRAN o estado 1 mantêm-se como sinapomorfia do nó 1 , convergência de $K$. brasiliensis e sinapomorfia do nó 17.

4 - Noto em relação ao pé: 0 - noto menor que o pé; 1 - noto do mesmo tamanho ou um pouco menor que o pé (A. muelleri, N. kristenseni e $B$. calcarata); 2 - noto consideravelmente maior do que o pé (B. agassizi, $P$. pustulosa, $\quad$ K. brasiliensis $\quad \mathrm{e}$ Cryptobranchia) (Ci: 40; Cr: 25; L: 5)
0

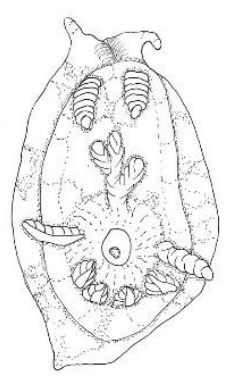

1

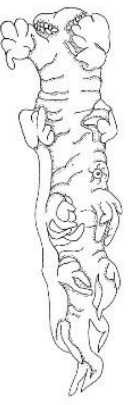

2

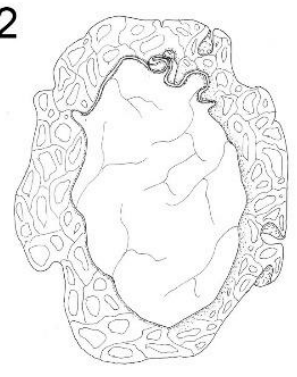

Mantendo o mesmo padrão de homologia do caráter anterior (3), com a otimização ACCTRAN o estado 1 resultou como sinapomorfia do nó 1 (Nudipleura), o estado 2 convergentemente como autapomorfia de B. agassizii e sinapomorfia do nó 5; e duas reversões para o estado 0 de $G$. mimula e $T$. brasiliensis. Com a otimização DELTRAN o estado 1 resultou como sinapomorfia do nó 2 e as outras mudanças se mantiveram iguais. 
5 - Órgão quimiorreceptor: 0 - órgão de Hancock; 1 - rinóforos (Nudipleura) (Ci: 100; Cr: 100; L: 1)
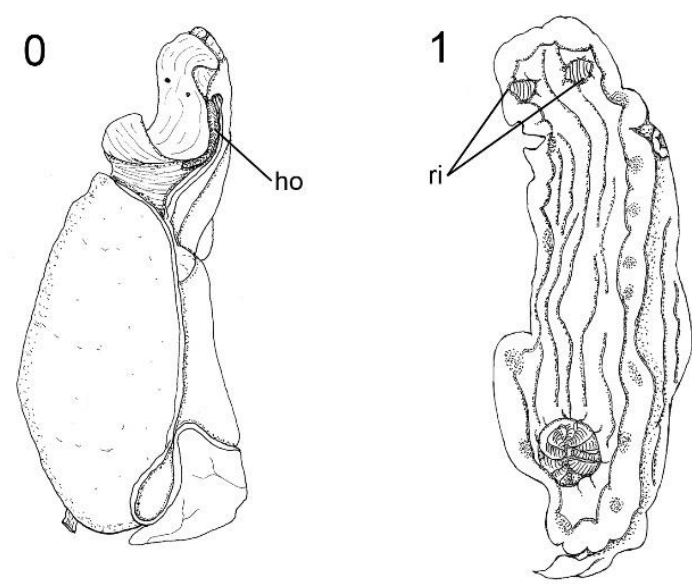

Caráter utilizado na análise para falar sobre a hipótese de homologia entre o órgão de Hancock e os rinóforos, sendo as duas estruturas participantes na função olfativa, de captura de presa e encontro com parceiro potenciais (Klussmann-Kolb et al., 2013).

Alguns estudos sustentam a hipótese de homologia dessas estruturas baseados nos padrões de rastreamento dos nervos cerebrais entre os Opisthobranchia, considerando a inervação do órgão de Hancock e dos rinóforos homólogas (Schmekel, 1985; Staubach \& Klussmann-Kolb, 2007; Staubach et al., 2008; Klussmann-Kolb et al., 2013).

Entre os gastrópodes podemos distinguir três estruturas que normalmente são conhecidas pela função olfativa/quimiorreceptora, atuando na localização de presas e possíveis parceiros. Na maioria dos gastrópodes encontramos o osfrádio, normalmente associado à brânquia (Ponder \& Lindberg, 1995). Os "Opistobranchia” mais basais, os Cephaladpidea, apresentam o órgão de Hancock, como esturura quimiorreceptora, localizado no tegumento, em ambos os lados da região cefálica. As demais ordens de “Opisthobranchia" apresentam os rinóforos, sempre pareados, como o órgão de Hancock, e dependendo da ordem ainda mantidos na região anterior, por exemplo em Pleurobranchomorpha. Já nos Nudibranchia estão localizados na região anterior, mas passam a serem dorsais. (Wägele \& Willan, 2000). 
6 - Posição das estruturas quimiorreceptoras: 0 - anterior, lateral ao escudo cefálico; 1 - anterior $(B$. agassizii e A. muelleri); 2 - dorsal (demais táxons) (Ci: 100; Cr: 100; L:2)
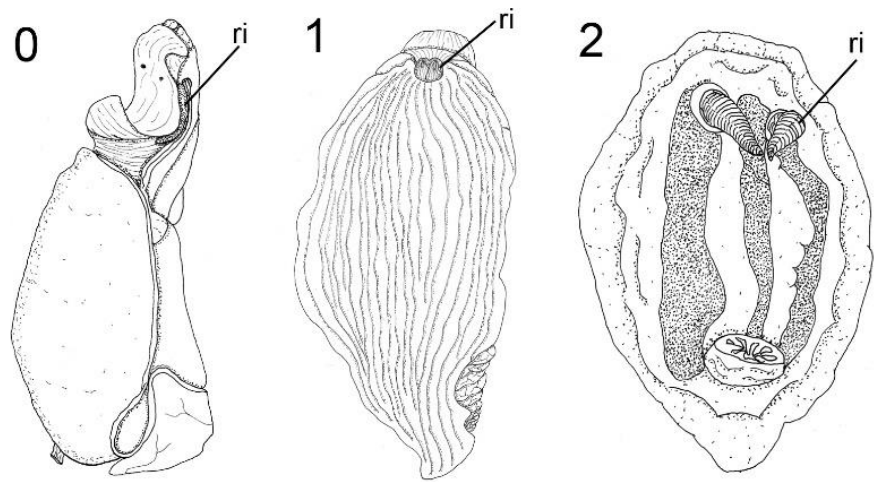

Os rinóforos e a cabeça são claramente separados da borda anterior do noto em Armina e Berthela (Wägele \& Willan, 2000). De acordo com a evolução do caráter na filogenia é possível sugerir uma certa ordenação, considerando que a estrutura passou da posição ventral para a região anterior e posteriormente para a posição ventral. E dessa maneira, a transformação passa a ser considerada uma sinapomorfia do nó 3 .

7 - Tipo do rinóforo: 0 - enrolado; 1 sólido (Nudibranchia) (Ci: 100; Cr: 100; L: 1)
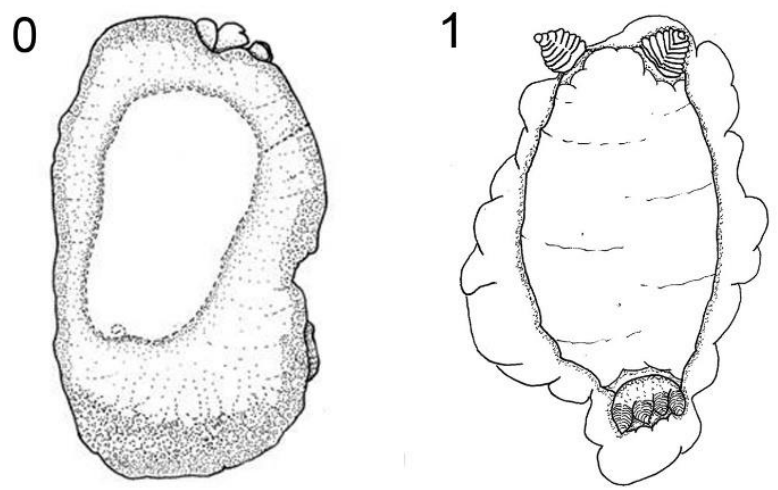

O estado 1 resultou como sinapomorfia do nó 2 (Nudibranchia), caráter este já considerado anteriormente como sinapomorfia (Wägele \& Willan, 2000). 
8 - Base do rinóforo: 0 - base próxima; 1

- base separada (B. calcarata, P. pustulosa, K. brasiliensis, G. mimula, T. brasiliensis e Cryptobranchia) (Ci: 100; Cr: 100; L: 1)
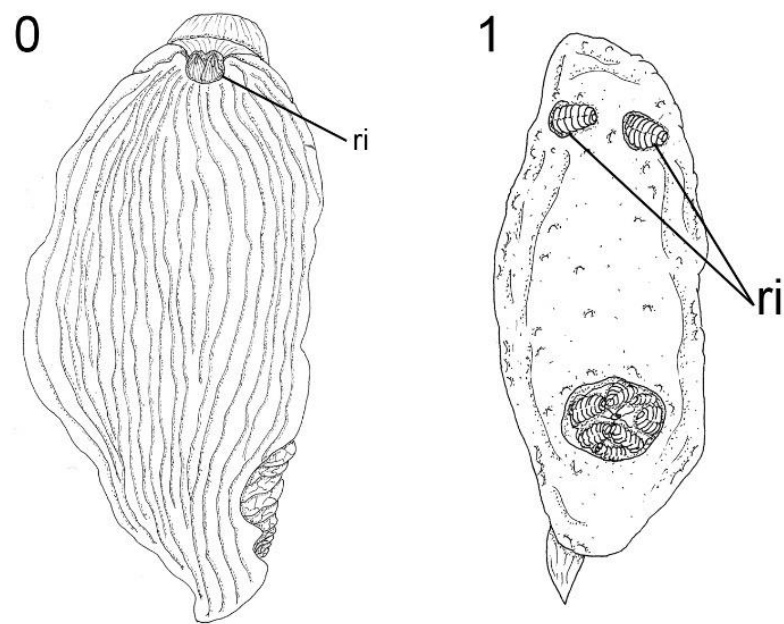

$\mathrm{Na}$ maioria dos táxons analisados a base do rinóforo se mantém separada. Nas espécies mais basais, $B$. agassizii, A. muelleri e $N$. kristenseni a base se mantem junta. $\mathrm{O}$ estado 1 resultou como sinapomorfia para o nó 3.

9 - Lamelas dos rinóforos: 0 - lisa; 1 lamelas diagonais (Nudibranchia); 2 lamelas verticais (A. muelleri); 3 lamelas aneladas $(K$. brasiliensis e $G$. mimula); 4 - lamelas em forma de papilas (N. kristenseni) (Ci: 100; Cr: 100; L: 4)

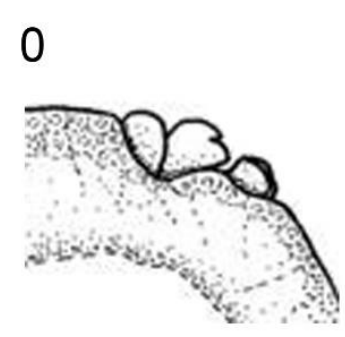

1

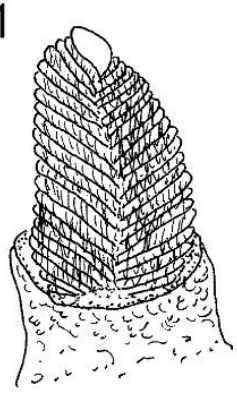

2

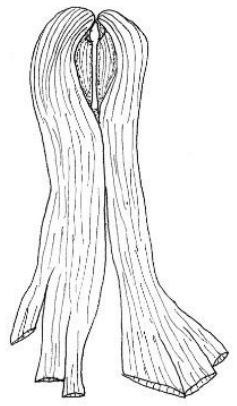

3

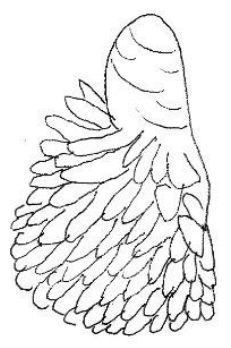

Diversos tipos de lamelas dos rinóforos são reconhecidos entre os nudibrânquios. Nesta análise a maioria dos estados resultou em autapomorfia. Com a otimização ACCTRAN o estado 1 resultou em sinapomorfia do nó 2 (Nudibranchia) e o estado 2 como sinapomorfia do nó 7. Com a otimização DELTRAN a mudança para o estado 1 resultou como sinapomorfia do nó 3 e todas as outras transformações se mantiveram. 
10 - Cavidade do rinóforo: 0 - ausente; 1 - formada pela borda frontal do noto $(B$. calcarata); 2 - formada pela elevação do bolso notal (P. pustulosa, K. brasiliensis, T. brasiliensis e Cryptobranchia) (Ci: 66; Cr: 66; L: 3)
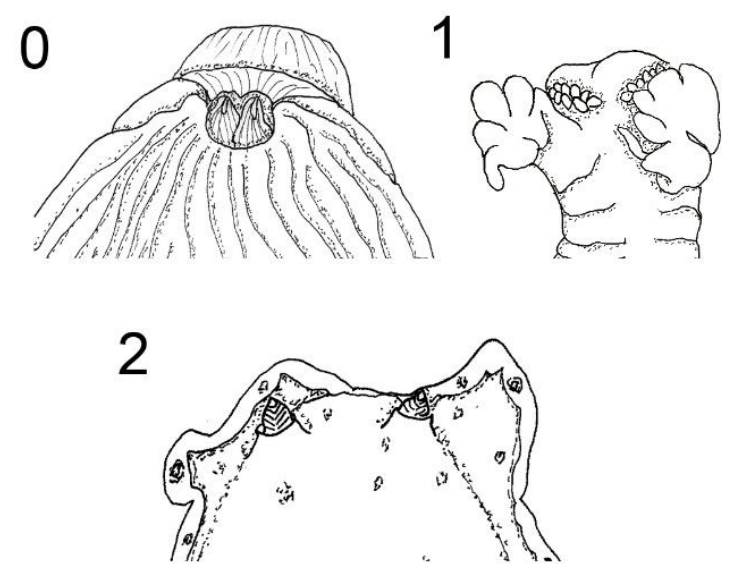

Normalmente, a cavidade do rinóforo está ausente na maioria dos táxons de Nudibranchia (em muitos Phanerobranchia, Arminoidea e Aeolidoidea) e na maioria dos outros táxons de "Opisthobranchia" (Wägele \& Willan, 2000). O estado 1 resultou em uma autapomorfia de $B$. calcarata. O estado 2 do caráter resultou como sinapomorfia do nó 5; O estado 0 resultou em uma reversão autapomórfica de G. mimula.

11 - Ornamento na cavidade do rinóforo:

0 - lisa; 1 - papilas alongadas (Bornella calcarata $) ; 2-$ tubérculos $(M$. mirocornata, D. ananas, D. januarii, D. verrucosa e T. ladislavii); 3 - pequenos lobos (D. ilo, D. bovena, D. kyolis, D. boholiensis, D. pusae, D. branneri, D. sansiegensis, S. tuberculata e Sclerodoris sp.); 4 - caryophyllidia ( $J$. spazzola, $M$. greeleyi, $P$. angustipes e $P$. sp. BR) (Ci: 66; Cr: 66; L: 6)

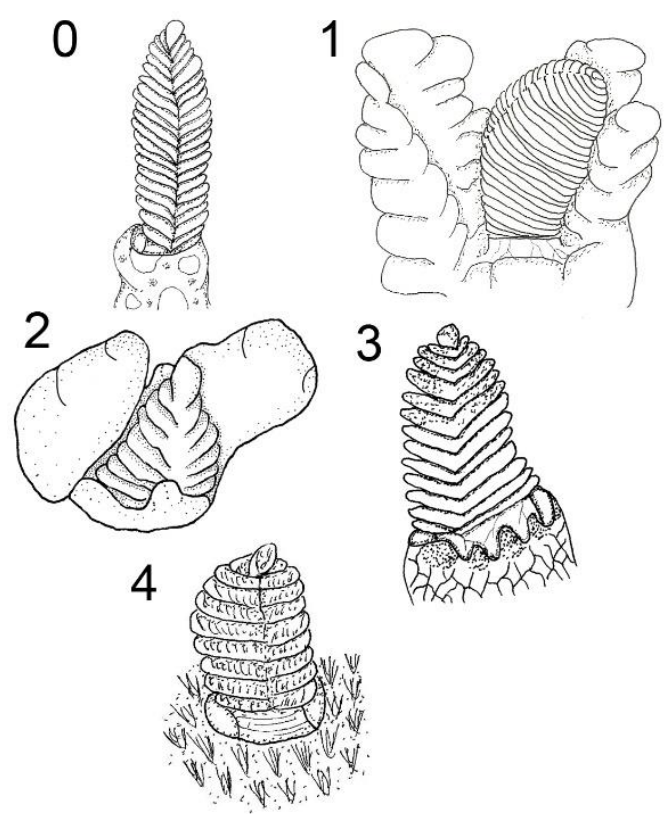

O tipo de ornamento da cavidade do rinóforo normalmente está associado ao tipo de ornamento presente em todo o noto. Com a otimização ACCTRAN o estado 1 resultou como sinapomorfia do nó 4.0 estado 2 resultou três vezes independentes, mas em uma delas é sinapomorfia do nó 25 . O estado 3 resultou em sinapomorfia do nó 21 . O estado 4 resultou em sinapomorfia do nó 28. Com a otimização DELTRAN o estado 1 resultou apenas como autapomorfia de B. calcarata e as outras transformações se mantiveram iguais a otimização ACCTRAN. 
12 - Cavidade para retração da brânquia: 0 - ausente; 1 - presente (Cryptobranchia) (Ci: 100; Cr: 100; L: 1)

A capacidade de uma completa retração das brânquias em uma cavidade já é considerada como uma característica sinapomorfia para os Cryptobranchia (Wägele \& Willan, 2000; Valdés, 2002a), nesta filogenia se confirma como sinapomorfia do nó 9.

13 - Ornamento na cavidade branquial: 0 - lisa; 1-tubérculos (M. mirocornata, D. ananas, D. januarii, D. verrucosa e T. ladislavii); 2 - pequenos lobos (D. ilo, D. bovena, D. kyolis, D. boholiensis, D. pusae, D. branneri, D. sansiegensis, S. tuberculata e Sclerodoris sp.); 3 - caryophyllidia (J. spazzola, M. greeleyi, P. angustipes e Platydoris sp. BR) (Ci: 60; Cr: 86; L: 5)

Assim como as cavidades dos rinóforos, a cavidade branquial também apresenta ornamentos, sempre relacionados aos do noto e normalmente mantendo o mesmo padrão entre elas. Essas estruturas se mostraram informativas. O estado 1 resultou em convergência autapomorfica de M. mirocornata e T. ladislavii, sinapomorfia e do nó 25. O estado 2 resultou em sinapomorfia do nó 22 . O estado 3 resultou em sinapomorfia do nó 28.

14 - Borda anterior do pé bilabiada (fenda transversal): 0 - ausente; 1 presente (B. agassizii, N. kristenseni, T. brasiliensis, H. obscura, M. kempfi, D. atromarginata, H. lajensis, $\quad$. magnifica, $F$. neona, $T$. evelinae, $C$. rumia, Dorididae e Discodorididae) (Ci: 16; Cr: 50; L: 6)
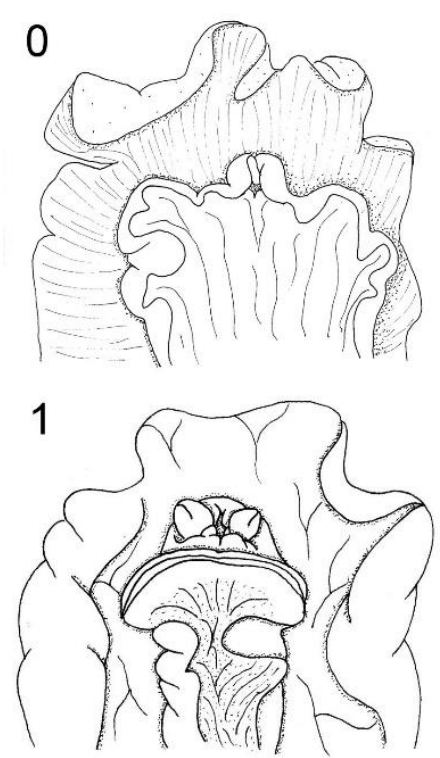

A borda anterior do pé de muitos opistobrânquios é mais ou menos dividida horizontalmente em duas bordas e geralmente apresenta uma camada espessa de glândulas subdérmicas (Wägele \& Willan, 2000). Nesta análise a presença dessa divisão transversal através da otimização ACCTRAN resultou como autapomorfia de B. agassizii e $N$. kristenseni, e como sinapomorfia do nó 8 . O estado 0 resultou em três reversões: 
autapomorfia de $H$. apefae e $A$. verrucosus e sinapomorfia do nó 18. Com a otimização DELTRAN o estado 1 resultou como autapomorfia de B. agassizii, N. kristenseni, $T$. brasiliensis e C. rumia e como sinapomorfia dos nós 11 e 22.

15 - Fenda longitudinal borda anterior bilabiada: 0 - ausente; 1 - presente (Discodorididae) (Ci: 100; Cr: 100; L: 1)
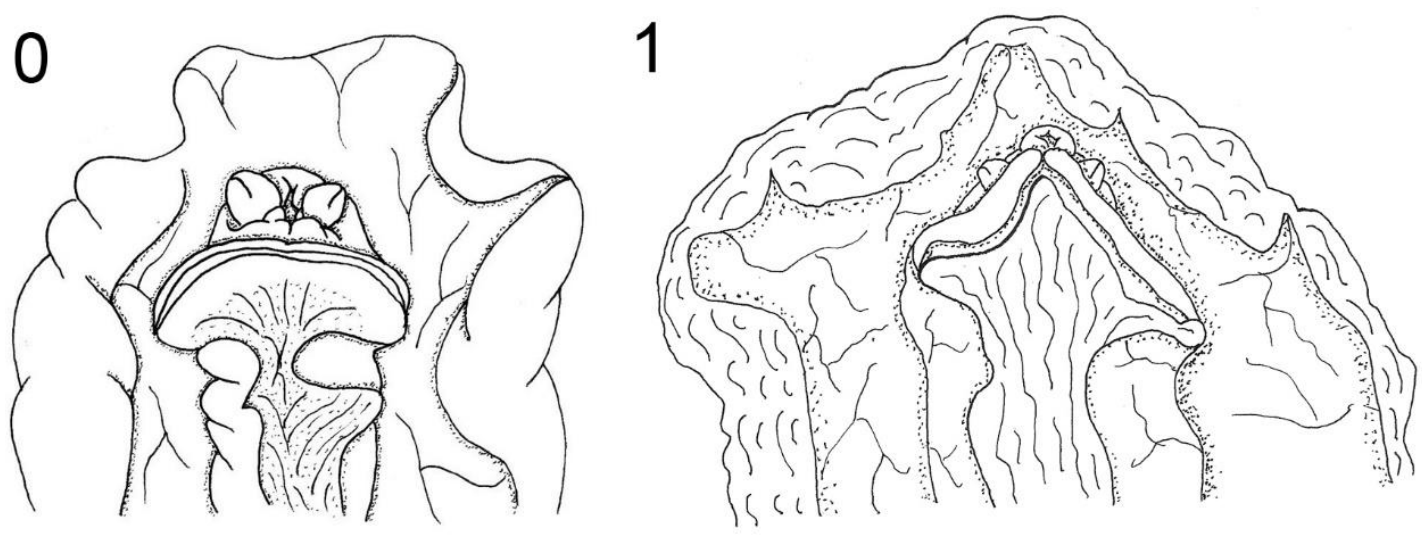

A borda anterior do pé, como dito no caráter anterior (14) pode ser dividida em determinados táxons e ainda pode apresentar uma divisão longitudinal mediana no lábio superior (Dayrat, 2010). Esta fenda provavelmente é uma especialização relacionada a um tipo particular de alimentação ou à ingestão desses, e sua presença faz com que a boca e o tubo oral tenham mais espaço para se projetarem para agarrar o alimento (Wägele \& Willan, 2000). Nesta análise a presença da fenda longitudinal no lábio superior se confirma como sinapomorfia do nó 28 , a família Discodorididae.

16 - Estruturas ao redor da boca: 0- presente; 1 - ausente (D. atromarginata e Dendrodorididae) (Ci: 50; Cr: 66; L: 2)

Diversos tipos de estruturas podem ser encontrados ao redor da boca, como por exemplo: tentáculos orais (distintos do tegumento), véu oral, véu oral transformado em tentáculo oral, prolongamentos do tegumento e poros. O estado 1 resultou em autapomorfia de D. atromarginata e como sinapomorfia do nó 18. 
17 - Tentáculos orais: 0 - presente achatado; 1 - presente digitiforme $(H$. obscura, M. kempfi, F. lajensis, C. magnifica, $F$. neona, $T$ evelinae e Discodorididae); $2-$ ausente $(B$. agassizii, A. muelleri, N. kristenseni, B. calcarata, Onchidorididae, D. atromarginata, Dendrodorididae e $D$. ananas). (Ci: 22; Cr: 66; L: 9)
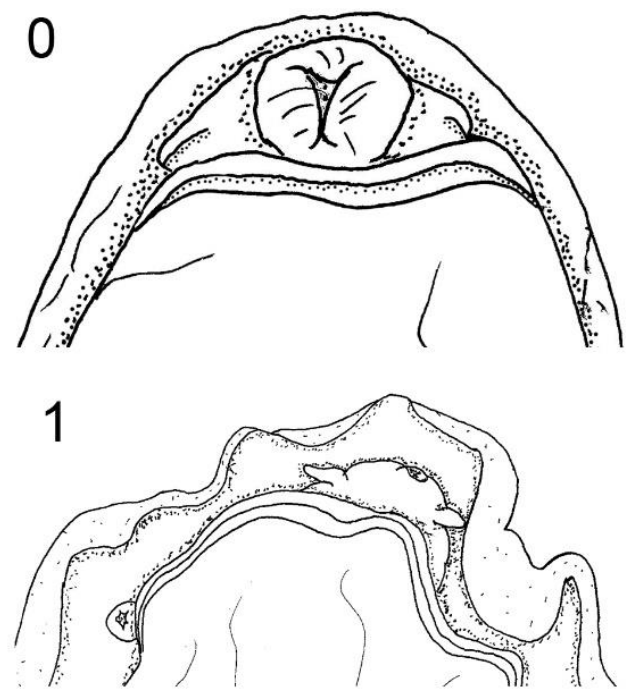

São estruturas claramente distintas do tegumento da boca, separadas da borda anterior do pé. Com a otimização ACCTRAN o estado 1 resultou como sinapomorfia dos nós, 11 e 28 (Discodorididae), o estado 2 como sinapomorfia dos nós 1 (Nudipleura), 7 (Onchidorididae) e 18 (Dendrodorididae) e como autapomorfia dos terminais $D$. atromarginata e $D$. ananas, e o estado 0 resultou em sinapomorfia do nó 5 e uma autapomorfia de T. ladislavii. Já com a otimização DELTRAN o estado 0 resultou como autapomorfia de $P$. pustulosa e T. ladislavii e sinapomorfia do nó 8.

\section{Estruturas no noto}

18 - Tubérculos dorsais: 0 - ausente; 1 presente (P. pustulosa, Onchidorididae, T. brasiliensis, $H$. apefae, $M$. mirocornata, C. rumia, A. verrucosus, Dorididae e Discodoridae) (Ci: 25; Cr: 76; L: 4)
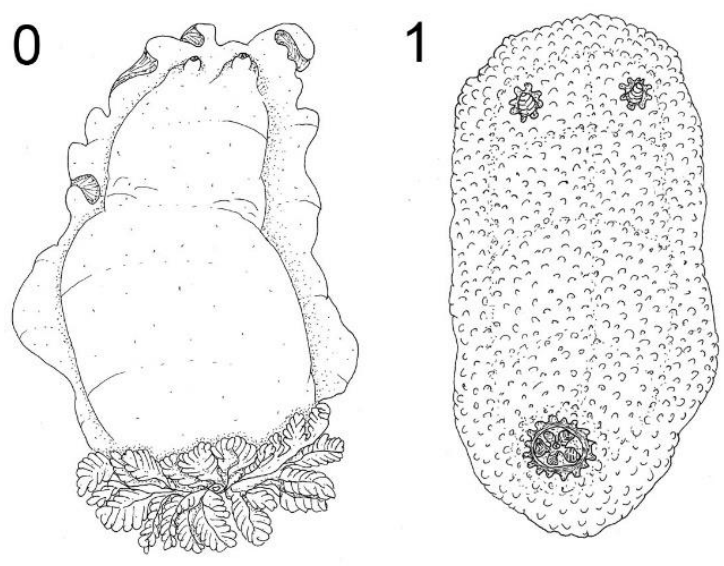

Os tubérculos dorsais são extensões do noto, geralmente no formato arredondado, podendo ser um pouco achatado ou alongado. São claramente visíveis, mesmo nos exemplares fixados. Com a otimização ACCTRAN o estado 1 resultou como sinapomorfia do nó 5 e uma convergência autapomórfica de $M$. mirocornata e o estado 0 resultou em sinapomorfia dos nós 11 e 18. Com a otimização DELTRAN o estado 1 
mantem-se como sinapomorfia do nó 5 e o estado 0 como sinapomorfia do nó 11 e autapomorfia de D. limbata e M. mirocornata.

19 - Caryophyllidia: 0 - ausente; 1 - presente (J. spazzola, M. greeleyi, P. angustipes, Platydoris sp., D. sandiegensis, S. tuberculata e Sclerodoris sp.) (Ci: 50; Cr: 83; L: 2)

São estruturas altamente especializadas presentes no dorso de vários nudibrânquios doridídeos. São tubérculos que apresentam órgãos sensoriais apicais, reodeado por um anel de espículas calcareas protuberantes. A função do "caryophyllidia" ainda é desconhecida e aberta a especulações (Valdés \& Gosliner, 2001). Restrito a algumas espécies da família Discodorididae e conhecidos como "caryphyllidia-bearing”. O estado 1 resultou como sinapomorfia dos nós 29 e 36.

20 - MDF (Mantle dermal formation): 0 - ausente; 1 - presente (Ci: 100; Cr: 100; L: 1)

MDF (Mantle dermal formation) é uma terminologia designada para formações dermais na borda do noto que armazenam glândulas defensivas (García-Gomez et al., 1990, 1991; Avila \& Durfort, 1996). Investigações recentes e mais extensivas sobre as glândulas defensivas sugerem o armazenamento de bioquímicos de poríferos, alimento dos cromodoridídeos. Eles são discutidos como caráter-chave na evolução, em particular da família Chromodorididae, entretanto outros grupos de opisthobrânquios que não se alimentam de poríferos também possuem MDFs (Wägele et al., 2006). Nesta análise apenas os representantes de Chromodorididae apresentaram a estrutura, e dessa maneira foi considerado como sinapomorfia do nó 11.

21 - Espículas tegumentares: 0 - ausente; 1 - presente (P. pustulosa, K. brasiliensis, $T$. brasiliensis, Dendrodorididae, C. rumia, A. verrucosus, Dorididae, J. spazzola, D. boholiensis, T. ladislavii, D. branneri) (Ci: 16; Cr: 70; L: 6)

Os nudibrânquios são carnívoros e muitas espécies apresentam dietas especializadas, predando uma única espécie ou algumas espécies de invertebrados marinhos. Os nudibrânquios doridídeos são o grupo mais diverso de predadores de poríferos (Belmonte et al., 2015). As espículas tegumentares são claramente visíveis no tegumento em forma de uma rede amplamente arranjada, se assemelham com as espículas presentes em poríferas, dos quais se alimentam. Essas espículas não são consideradas homólogas à concha dos demais moluscas, uma vez que elas não aparecem apenas no noto, mas também estão presentes no pé, nos rinóforos e nos filamentos branquiais (Cattaneo-Vietti 
et al., 1993). O estado 1 resultou como sinapomorfia para o nó 5. O estado 0 resultou como autapomorfia de G. mimula e D. pusae, e como sinapomorfia dos nós 10 e 30 . As espécies que facilmente de vê as espículas, mesmo depois de fixadas foram: $K$. brasiliensis, J. spazzola, D. branneri e D. boholiensis.

\section{Sistema circulatório}

22 - Posição das estruturas respiratórias:

0 - interna, na cavidade do manto; 1 dorsal/posterior $(K$. brasiliensis, $G$. mimula, $\quad$ T. brasiliensis $\mathrm{e}$ Cryptobranchia); 2 - ventral, entre o pé e o noto (B. agassizii, A. muelleri e $P$. pustulosa); 3 - dispostas ao longo do noto simetricamente (N. kristensini e $B$. calcarata) (Ci: 100; Cr: 100; L: 3)

Sugere-se neste que a evolução das estruturas respiratórias tenha se iniciado no interior da cavidade do manto, posteriormente migrado para a região ventral no caso das espécies com concha reduzida ou sem concha. Posteriormente, a estrutura migrou para a região dorsal, na forma de cerata, tufos branquiais e círculo branquial. O estado 1 resultou como sinapomorfia do nó 6 . $\mathrm{O}$ estado 2 resultou como sinapomorfia do nó 1
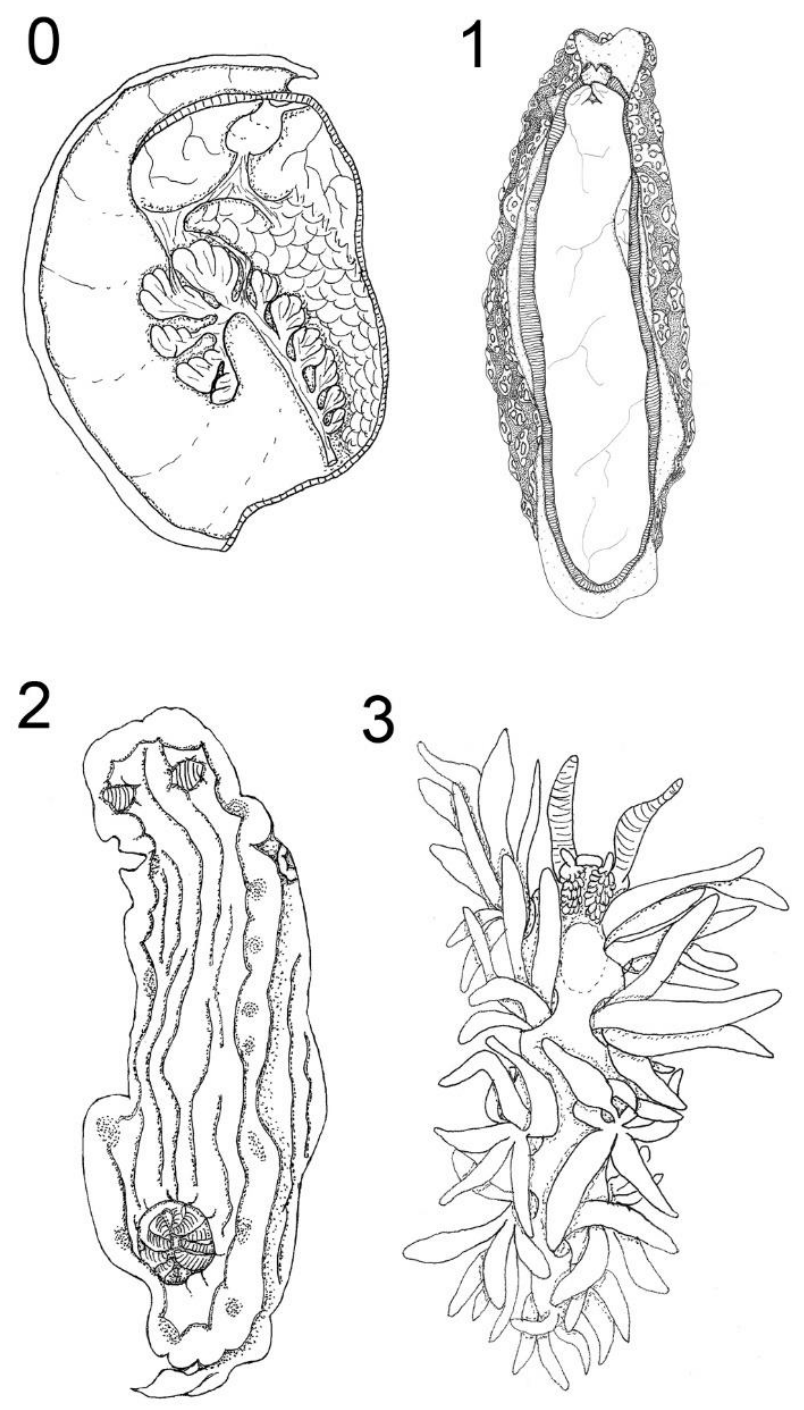

(Nudipleura) e 0 estado 3 como sinapomorfia do nó 4. 
23 - Brânquia anal: 0 - ausente; 1 presente (K. brasiliensis, G. mimula, $T$. brasiliensis e Cryptobranchia) (Ci: 100; Cr: 100; L: 1)

A brânquia anal é um círculo de filamentos branquiais circundando $\mathrm{o}$ ânus. O termo adotado, brânquia anal, foi o mesmo adotado por Wägele \& Willan (2000), que foi considerado neutro para definir as brânquias dos Anthobranchia.

0

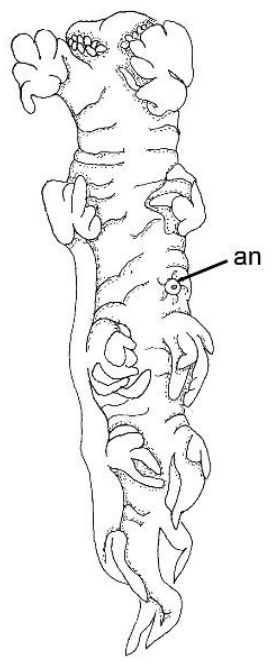

1

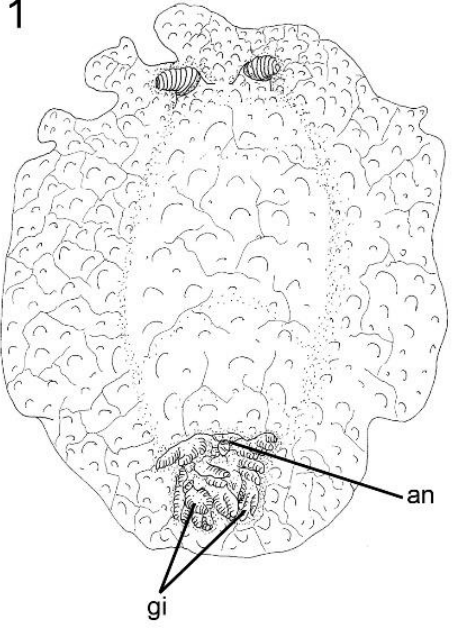

O estado 1 resultou como sinapomorfia do nó 6.

24 - Brânquia pinada: 0 - ausente; 1 - presente (B. calcarata, K. brasiliensis, G. mimula, T. brasiliensis e Cryptobranchia) (Ci: 50; Cr: 75; L: 2)

O estado 1 surge convergentemente como uma autapomorfia de B. calcarata, que apresenta a "ceratal-gills" com o filamento, provavelmente, homólogo ao filamento branquial dos Doridoidea, exceto P. pustulosa; e como uma sinapomorfia do nó 6 (Onchidoridoidea, Polyceroidea e Cryptobranchia).

25 - Tipo de brânquia pinada: 0 simples, unipinada; 1 - ramificada $(T$. brasiliensis, H. apefae, T. evelinae, Dendrodorididae, D. ananas, J. spazzola, P. angustipes, Platydoris sp., T. ladislavii, D. branneri, D. sandiegensis, S. tuberculata e Sclerodoris sp.) (Ci: 12; Cr: 53; L: 8)
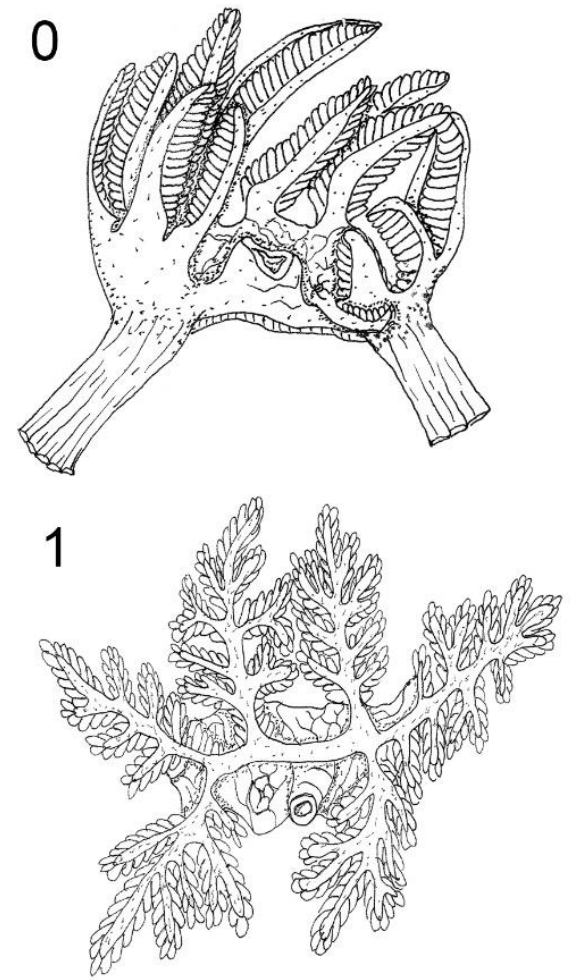
Os filamentos branquiais podem ser unipinados ou ramificados, sendo que os filamentos ramificados podem ser reconhecidos como bipinados ou tripinados. Com a otimização ACCTRAN o estado 1 resultou como sinapomorfia dos nós 8 e 28 e como autapomorfia para T. evelinae e D. ananas. Duas reversões sinapomórficas foram detectadas nos nós 11 e 20, e duas autapomorfias de $M$. greeleyi e D. pusae. Com a otimização DELTRAN o estado 1 resultou como sinapomorfia dos nós 18 e 28 e como autapomorfia de $T$. brasiliensis, $H$. apefae, $T$. evelinae e $D$. ananas e o estado 0 resultou somente como autapomorfia de $M$. greeleyi e D. pusae.

26 - Tipo de estrutura respiratória: 0 interna; 1 - lateral (B. agassizii, A. muelleri, P. pustulosa); 2 - cerata ( $N$. kristenseni $) ; 3$ - “ceratal-gills" $(B$. calcarata); 4 - perianal (K. brasiliensis, G. mimula, T. brasiliensis e Cryptobranchia) (Ci: 100; Cr: 100; L: 4)
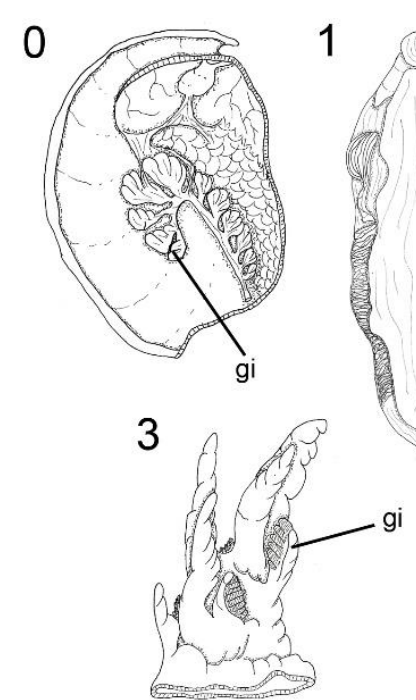
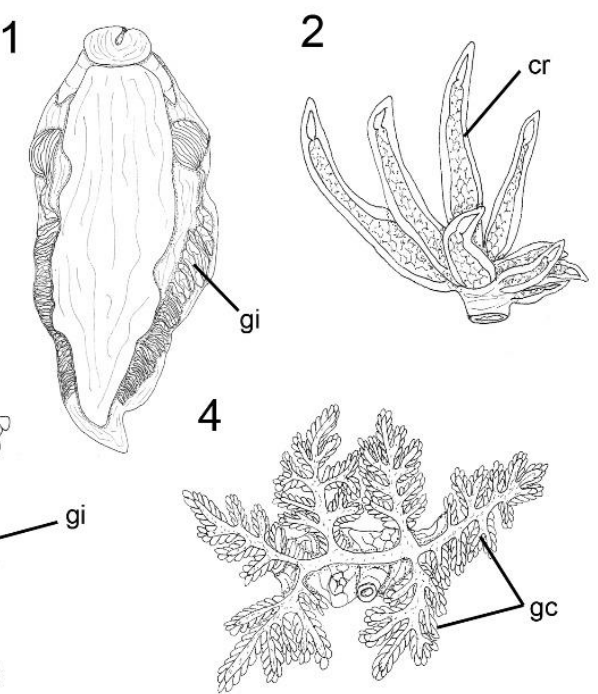

Apesar dos diferentes tipos de brânquias encontrados entre os "opistobrânquios", como: "plicate gill” [Architectibranchia, Bullomorpha, Aplysiomorpha e Peracle (um gênero de Thecosomata)], "lamellate gill” (Sacoglossa com concha), "bipectinate gill" (Notaspidea) e "circunal gill" (Anthobranchia) existe um consenso com relação à homologia das brânquias dos "opistobrânquios" e do ctenídio dos Prosobranchia, se comparados quanto ao tipo de inervação e função (Haszprunar, 1988).

Nesta análise, optando-se pela otimização ACCTRAN, o estado 1 resultou como sinapomorfia do nó 1 , o estado 2 como sinapomorfia do nó 4, o estado 3 como autapomorfia de $B$. calcarata e o estado 4 como sinapomorfia do nó 6 . Já com a otimização DELTRAN o estado 2 resultou apenas como autapomorfia de N. kristenseni, as outras transformações se mantiveram iguais.

27 - Círculo branquial peri-anal: 0 - ausente; 1 - fechado completamente (K. brasiliensis, G. mimula, H. apefae, H. obscura, D. atromarginata, F. lajensis, Dendrodorididae, A. verrucosus, D. bovena, D. kyolis, D. januarii, D. verrucosa, M. greeleyi, D. boholiensis, 
T. ladislavii, D. branneri, D. sandiegensis, S. tuberculata e Sclerodoris sp.); 2 - fechado parcialmente (T. brasiliensis, M. kempfi, C. magnifica, F. neona, T. evelinae, C. rumia, D. ilo, D. ananas, J. spazzola, P. angustipes, Platydoris sp. e D. pusae) (Ci: 20; Cr: 50; L: 10)

Em algumas espécies o círculo branquial não é fechado completamente, tendo alguns filamentos branquiais que adentram o círculo. Com a otimização ACCTRAN o estado 1 resultou como sinapomorfia do nó 6 e 14 e o estado 2 resultou como sinapomorfia dos nós 12 e 29. Com a otimização DELTRAN o estado 1 resultou como sinapomorfia apenas do nó 6, já o estado 2 resultou como autapomorfia de T. brasiliensis, M. kempfi, C. rumia, D. ilo, D. ananas, J. spazzola, D. pusae e sinapomorfia dos nós 15 e 31.

28 - Posição do círculo branquial: 0 1/4 mais anterior à glândula digestiva; 1 - totalmente posterior à glândula digestiva (C. magnifica, F. neona, T. evelinae, Dendrodorididae, C. rumia, $A$. verrucosus, Dorididae e Discodorididae) (Ci: 50; Cr: 85; L: 2)

O caráter tem relação com a evolução da posição da brânquia, que passou de interna ( $H$. elegans) para lateral (B. agassizii, A. muelleri e P. pustulosa) e possivelmente dorsal. O
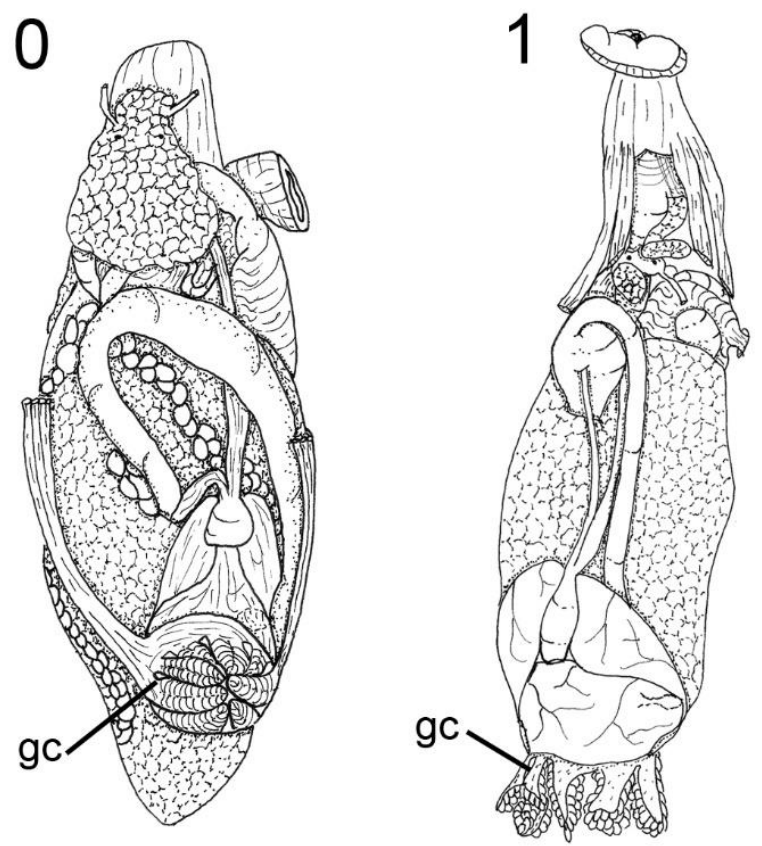
estado 1 convergentemente resultou como sinapomorfia para os nós 15 e 17. 
29 - Posição do pericárdio: 0 mediana/lateral; $1-$ posterior $(P$. pustulosa e Cryptobranchia) (Ci: 50; Cr: $85 ; \mathrm{L}: 2)$

O pericárdio normalmente está localizado na região mediana anterior do corpo em Berthella, Dendronotoidea, Arminoidea e Aeolidoidea (Wägele \& Willan, 2000). Nesta análise foi possível confirmar esse estado 1 resultou como autapomorfia de $P$. pustulosa e sinapomorfia do nó 9.

30 - Divisão da aorta: 0 - bem próxima do ventrículo; 1 - mais distante do ventrículo (H. apefae, M. kempfi, D. atromarginata, $F$. neona, Dorididae, $D$. pusae) Ci: 16; Cr: 50; L: 6)
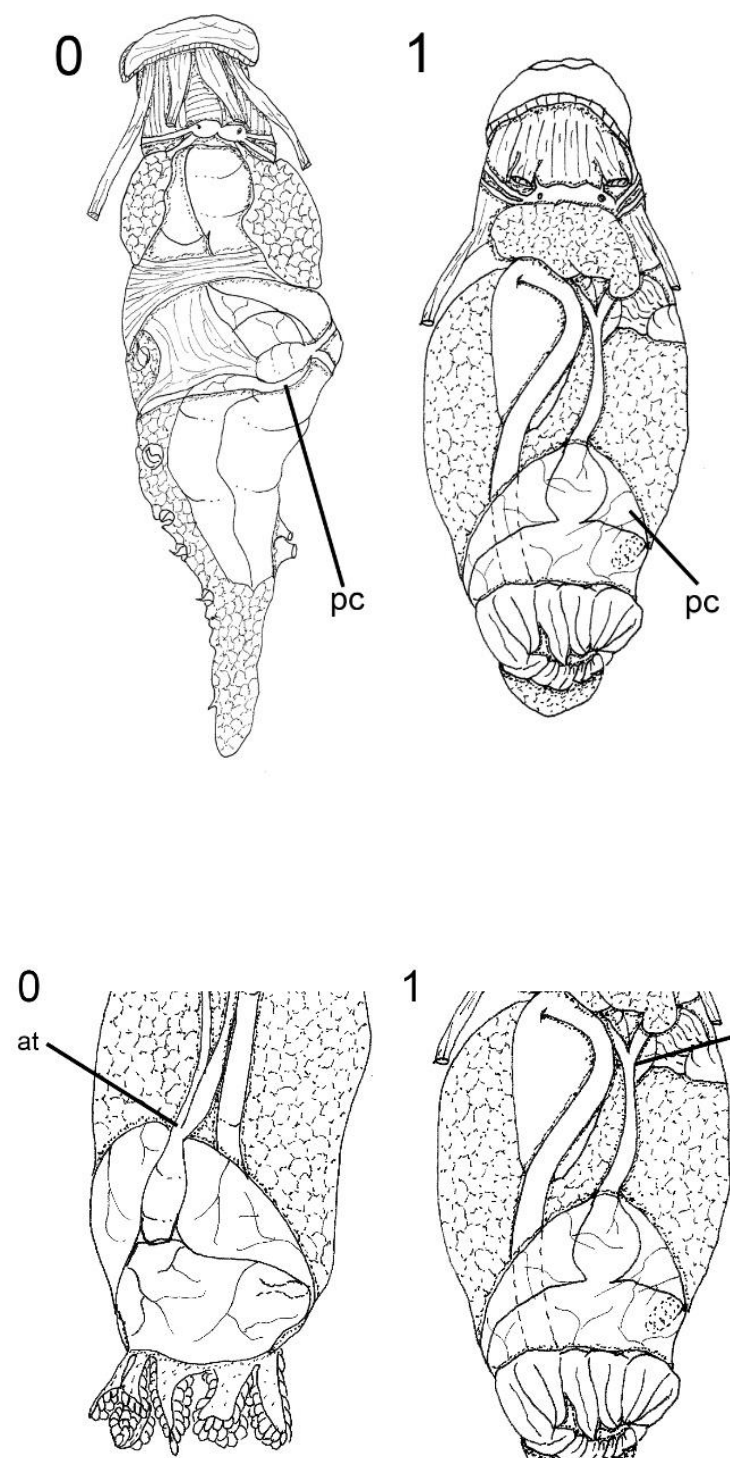

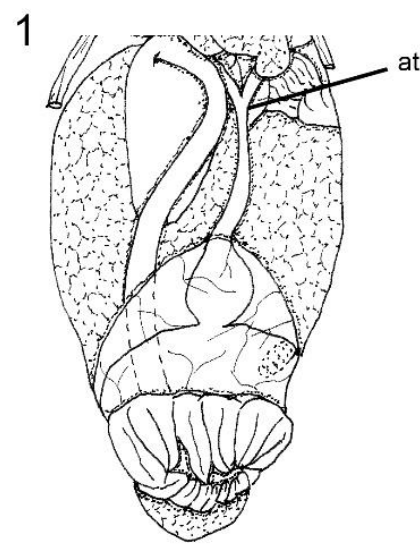

Normalmente a divisão do tronco aórtico em aorta posterior e aorta anterior acontece bem na conexão com o ventrículo, o que caracteriza o estado plesiomórfico, no entanto foi possível observar uma divisão um pouco mais distante, seguindo mais anteriormente. Com a otimização ACCTRAN o estado 1 resultou como autapomorfia de $H$. apefae, $F$. neona e $D$. pusae e como sinapomorfia dos nós 13 e 23, e uma reversão (estado 0 ) de $H$. lajensis foi detectada. Com a otimização DELTRAN o estado 1 resultou em autapomorfia de $H$. apefae, $M$. kempfi, D. atromarginata, $F$. neona e $D$. pusae e sinapomorfia apenas do nó 23. 
31 - Glândula de sangue: 0 - ausente; 1 - presente, associada ao pericárdio (B. agassizii); 2 - presente associada ao sistema nervoso (P. pustulosa, K. brasiliensis, G. mimula, $T$. brasiliensis e Cryptobranchia) (Ci: 100; Cr: 100; L: 2)
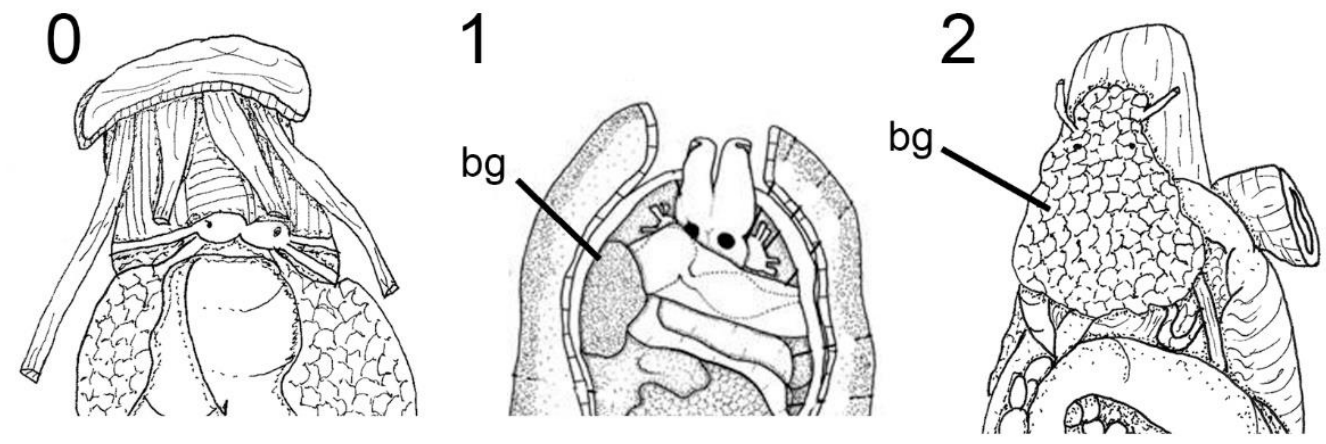

A glândula de sangue é um órgão de função desconhecida e está presente na região dorsal da massa visceral em Pleurobranchoidea, Bathydoridoidea e Doridoidea. Normalmente está associada ao sistema nervoso central nos Nudibranchia (exceto os Cladobranchia), ou no caso dos Pleurobranchomorpha ela é associada ao pericárdio, e foi considerada uma sinapomorfia de Nudipleura (Pleurobrancomorpha + Nudibranchia) (Wägele \& Willan, 2000). Nesta análise, o estado 1 resultou como uma autapomorfia de B. agassizii, uma vez que essa espécie foi a única representante dos Pleurobranchomorpha incluída na análise. Já o estado 2 resultou como sinapomorfia do nó 5, corroborando com a hipótese anterior.

32 - Glândula de sangue presente: 0 única; 1 - dividida (C. magnifica, $F$. neona, D. ilo, D. bovena, D. kyolis, D. ananas e Discodorididae) (Ci: 25; Cr: 80; L: 4)
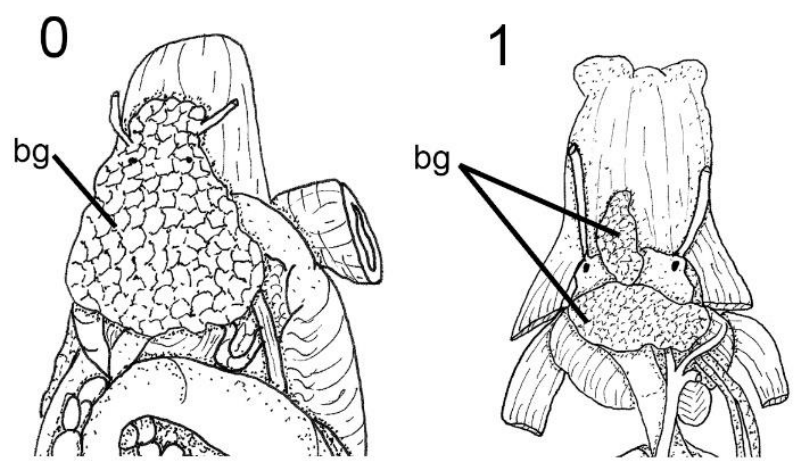

Nas espécies que apresentam a glândula de sangue foi possível verificar que a glândula normalmente aparece como um único órgão, mas que em alguns casos também pode estar dividida em duas partes. Com a otimização ACCTRAN o padrão da glândula dividida (1) resultou independentemente como sinapomorfia dos nós 15 e 22; o estado 0 resultou em autapomorfia de $T$. evelinae e sinapomorfia do nó 27. Já com a otimização 
DELTRAN o estado 1 resultou como autapomorfia de $C$. magnifica e $F$. neona e mantevese como sinapomorfia do nó 22 e o estado 0 manteve-se apenas como sinapomorfia do nó 27.

33 - Músculo retrator do círculo branquial: 0 - ausente; 1 - inteiro ( $F$. neona, Dorididae, T. ladislavii, D. branneri, S. tuberculata e Sclerodoris sp.); 2 -dividido (H. apefae, $H$. obscura, M. kempfi, D. atromarginata, F. lajensis, C. magnifica, T. evelinae, C. rumia, A. verrucosus, J. spazzola, M. greeleyi, P. angustipes, Platydoris sp. e D. sandiegensis); 3 - central (Dendrodorididae) (Ci: 50; Cr: 85; L: 6)

Apesar de ser um músculo importante, uma vez que está ligado à retração do círculo branquial, nunca foi analisado individualmente. Tem sua origem no círculo branquial e normalmente se insere na região dorsal do pé. Neste estudo foi possível verificar uma variação da musculatura, sendo que todas as possíveis variações resultaram em sinapomorfias, o estado 1 resultou como sinapomorfia dos nós 22 e 33. Já o estado 2 resultou como sinapomorfia do nó 9 e o estado 3 com sinapomorfia do nó 18.

34 - Papila do nefróstoma: 0 - ausente; 1 - presente (D. atromarginata, $F$. lajensis, D. ananas, S. tuberculata e Sclerodoris sp.) (Ci: 33; Cr: 50; L: 3)

Algumas espécies apresentam também uma papila do nefróstoma, normalmente de fácil visualização, quando presente está associada a mais comum papila anal. $\mathrm{O}$ estado 1 resultou convergente como sinapomorfia dos nós 14 e 37 , e como autapomorfia de $D$. ananas.
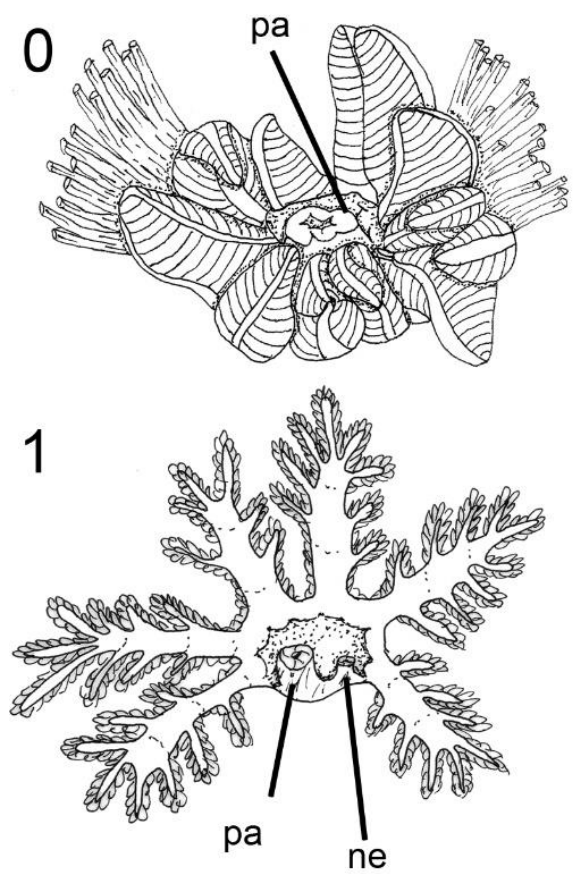
35 - Poro do nefróstoma: 0 - difícil visualização; 1 - fácil visualização $(G$. mimula, T. brasiliensis, M. kempfi, D. atromarginata, F. lajensis, C. magnifica, A. verrucosus, $D$. ananas, $S$. tuberculata e Sclerodoris sp.) (Ci: 12; Cr: 30; L: 8)

Geralmente o nefróstoma está situado próximo do ânus e quando este se desloca posteriormente ou dorsal se mantem essa justaposição entre ambas estruturas (Wägele \& Willan, 2000). Com a otimização ACCTRAN o estado 1 resultou em duas sinapomorfias convergentes dos nós 12 e 37 e autapomorfias de G. mimula, $T$. brasiliensis, A. verrucosus e D. ananas. Apenas uma reversão para o estado 0 resultou em sinapomorfia do nó 16 . Com a otimização DELTRAN o estado 1 resultou em autapomorfia de G. mimula,
T. brasiliensis, C. magnifica, $A$. verrucosus e D. ananas e como sinapomorfia dos nós 13 e 37 .
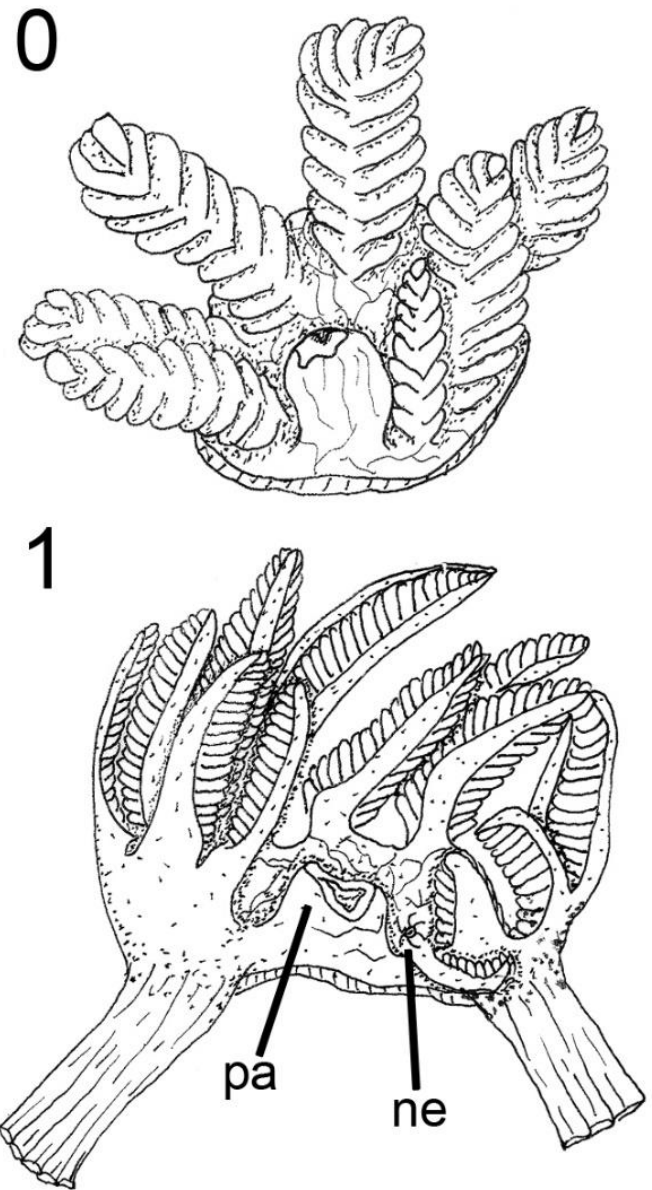

36 - Vesícula renal: 0 - ausente; 1 - presente (P. pustulosa, K. brasiliensis, G. mimula, T. brasiliensis e Cryptobranchia) (Ci: 100; Cr: 100; L: 1)

Estrutura relacionada ao sistema excretor, provavelmente homóloga ao rim, que se abre ventralmente no pericárdio, do lado direito e normalmente apresenta forma tubular ou piriforme, ciliada (Wägele \& Willan, 2000). Não apresentou uma variação de forma, mas uma distinção no sentido dos cílios, que podem ser longitudinais ou transversais, no entanto não é sempre que podemos confirmar a direção dos cílios por conta da fixação e por isso não foi utilizado com um caráter informativo. Entretando a presença dessa estrutura mostrou-se importante, uma vez que surgiu como sinapomorfia do nó 5 (Anthobranchia). 


\section{Massa bucal}

37 - Probóscide: 0 - ausente; 1 - presente (M. mirocornata e D. areolata) (Ci: 100; Cr: $100 ; \mathrm{L}: 1)$

A probóscide é um alongamento da região anterior do sistema digestivo com a capacidade de mover-se independentemente do restante do corpo e capaz de se recolher na cavidade hemocélica (Simone, 2011). Embora seja uma estrutura bem conhecida entre os gastrópodes não está presente na maioria dos nudibrânquios. O estado 1 resultou como sinapomorfia do nó 18 , exceto $D$. limbata.

38 - Mt (músculos do tubo oral): 0 - ausente; 1 - presente (Nudibranchia) (Ci: 33; Cr: 33; L: 3)

São músculos associados com o tubo oral e são inseridos na parede interna/lateral do noto. São pareados e normalmente apresentam três pares, mas podem variar de 01 até 05 pares. O estado 1 resultou como sinapomorfia do nó 2 . O estado 0 resultou em duas reversões convergentes nas espécies $N$. kristenseni e G. mimula.

39 - Odontóforo: 0 - presente; 1 - ausente (P. pustulosa e Dendrodorididae) (Ci: 50; Cr: 66; L: 1)

$\mathrm{O}$ odontóforo inclui um conjunto de músculos que movimentam a rádula. $\mathrm{O}$ odontóforo é uma estrutura já bem conhecida para os gastrópodes (Simone, 2011), no entanto normalmente negligenciada nos estudos anatômicos sobre nudibrânquios. Apesar da redução no número de músculos que compõe a estrutura (Valdés, 2002a), nesta análise se mostrou uma estrutura potencialmente informativa e com variação principalmente intraespecífica. O estado 1 resulta em uma autapomórfica de $P$. pustulosa e sinapomorfia do nó 18, Dendrodorididae, esse considerado um táxon com algumas modificações no sistema digestório, como ausência de rádula.

40 - Posição do odontóforo: 0 - interno (se está completamente dentro do tubo oral); 1 externo (está fora do tubo oral, normalmente antecedido pelo esfíncter muscular) ( $B$. agassizii, A. muelleri, T. brasiliensis e Cryptobranchia) (Ci: 33; Cr: 50; L: 3) 
Foi possível observar que o odontóforo pode ser interno ou externo ao tubo oral. Quando externo está conectado ao esfíncter muscular (que conecta o odontóforo com o tubo oral). Com a otimização ACCTRAN o estado 1 resultou como sinapomorfia dos nós 1 e 8 , e o estado 0 resultou como uma reversão do nó 3 . Para as espécies $P$. pustulosa, D. limbata, D. areolata e $M$. mirocornata o caráter não foi aplicável, já que essas espécies apresentam modificações no sistema digestivo, não apresentando o odontóforo. Com a otimização DELTRAN o estado 1 resultou como autapomorfia de $B$. agassizii e A. muelleri e manteve-se como sinapomorfia do nó 8.
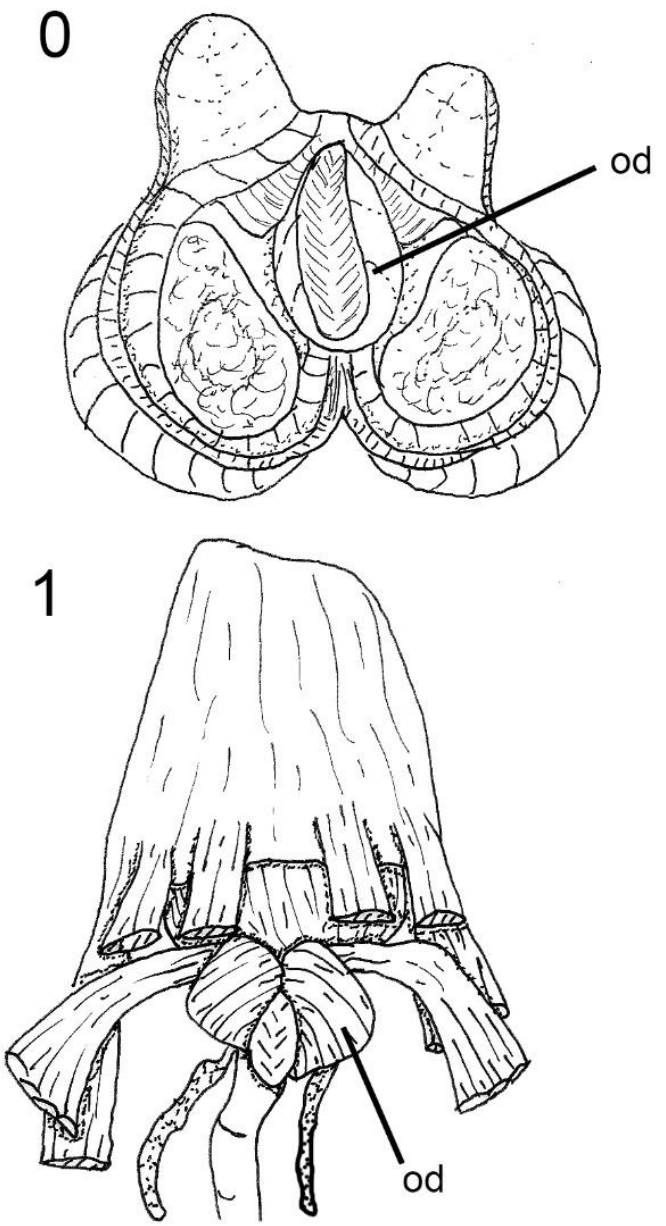

41 - Músculo dorsal septado: 0 - ausente; 1 - presente (K. brasiliensis e G. mimula) (Ci: 100; Cr: 100; L: 1)

É um músculo característico na maioria dos representantes de Sacoglossa, visto dorsalmente o tubo oral é geralmente listrado, com o formato de barril e abriga a rádula uniseriada, característica deste táxon (Jensen, 1991). O estado 1 resultou como sinapomorfia para o nó 7.

42 - m2: 0 - ausente; 1 - longo (quando o m2 é de 3 a 6 vezes mais longo que largo) ( $H$. apefae, M. kempfi, C. magnifica, C. rumia, A. verrucosus, D. ilo, D. kyolis, D. ananas, D. januarii, J. spazzola, M. greeleyi, P. angustipes, T. ladislavii, D. branneri, D. sandiegensis, $S$. tuberculata e Sclerodoris sp.); 2 - curto (quando o m2 é tão longo quanto largo) (H. obscura, D. atromarginata, F. neona, T. evelinae, D. bovena, D. verrucosa, Platydoris sp. BR, D. boholiensis e D. pusae) (Ci: 25; Cr: 60; L: 8) 
O m2 é um dos músculos retratores do odontóforo, normalmente é pareado e segue lateral ao odontóforo se inserindo na parede do tegumento, na região dorsal/mediana do pé, parece ser homólogo ao descrito para Epiathoidea (Simone, 2011). Nesta análise apresentou uma variação de comprimento, de forma que o estado 1 resultou como sinapomorfia do nó 8 , e pode estar associado com o fato do odontóforo ser externo ao tubo oral. O estado 2 resultou em algumas autapomorfias, mas também como sinapomorfia dos nós 16 e 33, além disso foi importante para frisar a distinção das duas espécies de Platydoris.
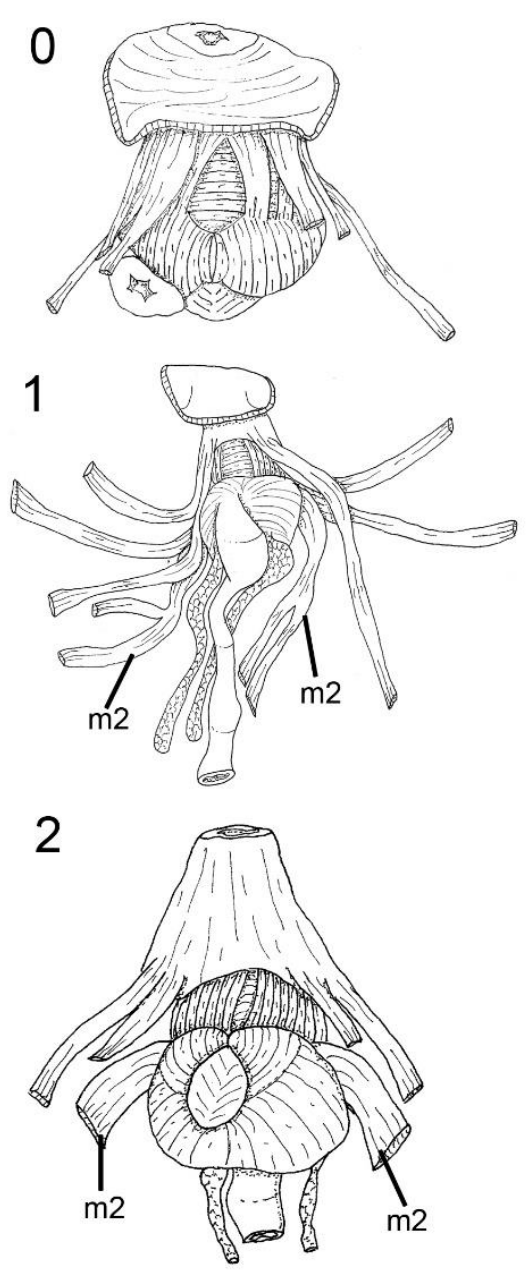

43 - $\mathrm{m} 4$ em relação ao $\mathrm{m} 5: 0$ - 1/3 maior que o $\mathrm{m} 5 ; 1-\mathrm{m} 4$ reduzido, metade do $\mathrm{m} 5$ ( $B$. agassizii); 2 - m4 robusto, o dobro do m5 (B. calcarata, T. brasiliensis, Cryptobranchia, exceto Dendrodorididae); 3 - m4 circundando toda a cartilagem do odontóforo, m5 provavelmente fundido com m4 (A. muelleri, N. kristenseni, K. brasiliensis, G. mimula) (Ci: 75; Cr: 66; L: 4)

O m4 é o maior par de músculos do odontóforo e caracteristicamente circunda ambas as cartilagens do odontóforo, originando em sua região anterior e externa, posteriormente à origem do mj. Além disso, insere na membrana subradular, bem como no tecido sobre a rádula que precede a região exposta no tubo oral (Simone, 2011). No caso dos Nudibranchia, a proporção que o m4 ocupa no odontóforo, é normalmente o dobro do m5, no entanto foi possível verificar diferentes proporções entre esses dois músculos. Optando-se pela otimização ACCTRAN o estado 1 resultou como sinapomorfia do nó 1 , o estado 2 resultou como autapomorfia de B. calcarata e sinapomorfia do nó 8 , e o estado 3 como sinapomorfia do nó 2 (Nudibranchia). Já utilizando a otimização DELTRAN, o 
estado 1 resultou apenas como autapomorfia de $B$. agassizii, enquanto as outras transformações se mantiveram iguais.

44 - m4a: 0 - ausente; 1 - presente (Platydoris sp.) (Ci: 100; Cr: 100; L: 1)

Músculo pareado com origem no m4, provavelmente um múculo auxiliar, que segue dividido para a região mediana da cartilagem do odontóforo e para a $\mathrm{o} \mathrm{m} 7$, passando dorsal ao m5. Caráter autapomórfico, apenas apresentado como diferença entre as duas espécies de Platydoris utilizadas na análise, Platydoris angustipes e Platydoris sp. do Brasil.

45 - m6: 0 - único; 1 - dividido $(D$. pusae, S. tuberculata, M. greeleyi); 2 ausente (Cladobranchia) (Ci: 40; Cr: 25; L: 5)

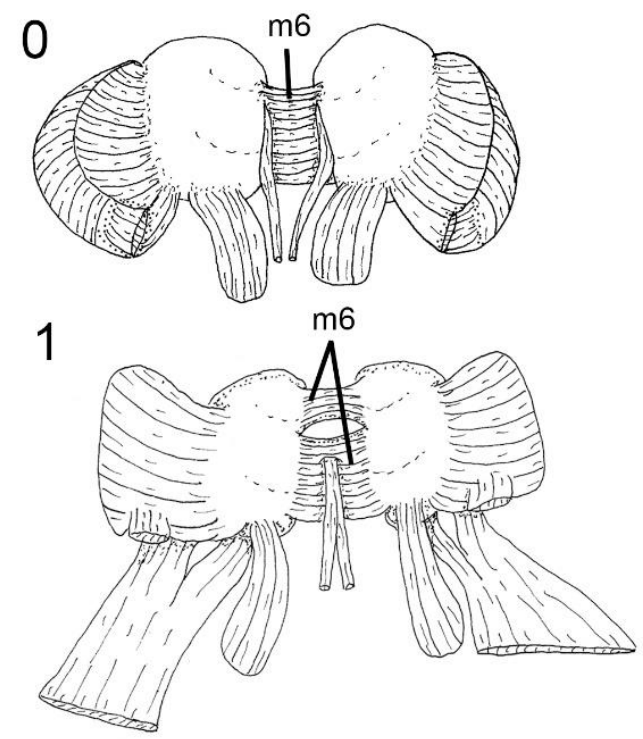

Músculo ímpar, horizontal, com fibras transversais que ligam as duas cartilagens do odontóforo. O músculo mais fácil de ser comparado entre os táxons, devido a sua situação peculias (Simone, 2011). Nesta análise foi possível verificar três estados, sendo o músculo na maioria das vezes único. Com a otimização ACCTRAN a forma dividida do músculo (1) se mostrou apenas como autapomorfia de $M$. greeleyi, D. pusae e $S$. tuberculata; a ausência do m6 (2) resultou como sinapomorfia do nó 1, e uma reversão para o estado 0 resultou como sinapomorfia do nó 5. Com a otimização DELTRAN o estado 1 mantem-se autapomórfico para as espécies já citadas, enquanto que o estado 2 resultou como autapomorfia de $A$. muelleri e sinapomorfia do nó 4 . $\mathrm{O}$ estado 0 deixa de ser sinapomorfia dó nó 5. 
46 - m7: 0 - ímpar; 1 - ausente $(B$. agassizii, A. muelleri, N. kristenseni, B. calcarata, K. brasiliensis e G. mimula); 2 - par (T. brasiliensis e Cryptobranchia) (Ci: 50; Cr: 80; L: 2)

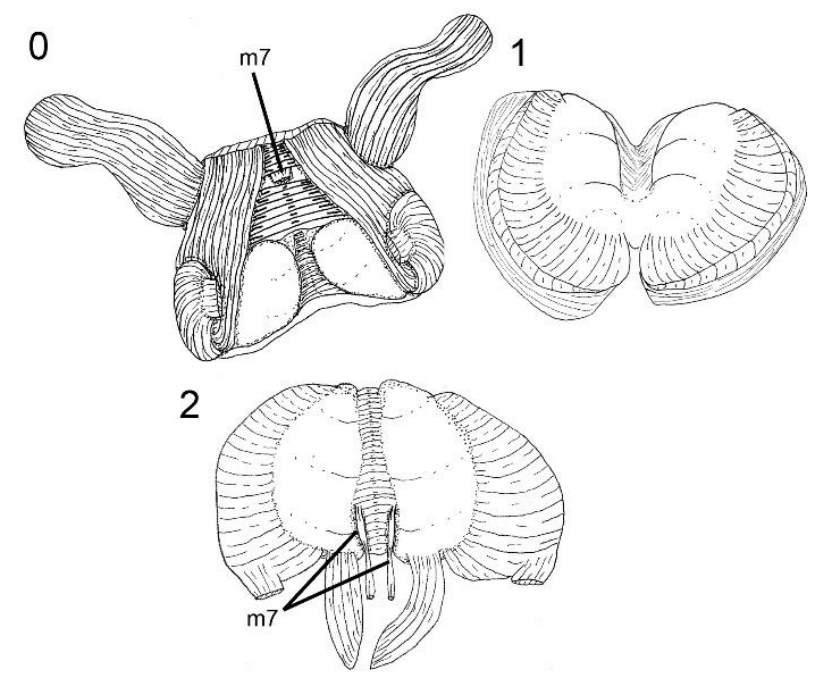

Como visto em outras superordens de Gatropoda (Simone, 2001, 2011), as espécies de Opisthobranchia analisadas neste estudo, principalmente as de Nudibranchia, apresentam esse músculo $(\mathrm{m} 7)$ ligados ao saco da radula. No entanto não se sabe muito sobre essa musculatura, assim como a musculatura do odontóforo como um todo, pois como já dito é uma estrutura neglicenciada nas análises tradicionais, não apresenta estudos funcionais e de fisiologia, e a função de cada músculo é apenas inferida através da análise da posição de cada músculo como nas referências aqui citadas. Tanto o estado 1 quando o 2 resultaram em sinapomorfias dos nós 1 e 8 , respectivamente.

47 - Origem do m7: 0 - origina-se no m6; 1 - origina-se na cartilagem do odontóforo ( $T$. brasiliensis, A. verrucosus, $P$. angustipes, Platydoris sp., D. boholiensis, D. sandiegensis e Sclerodoris sp.) (Ci:16; Cr: 16; L: 6)
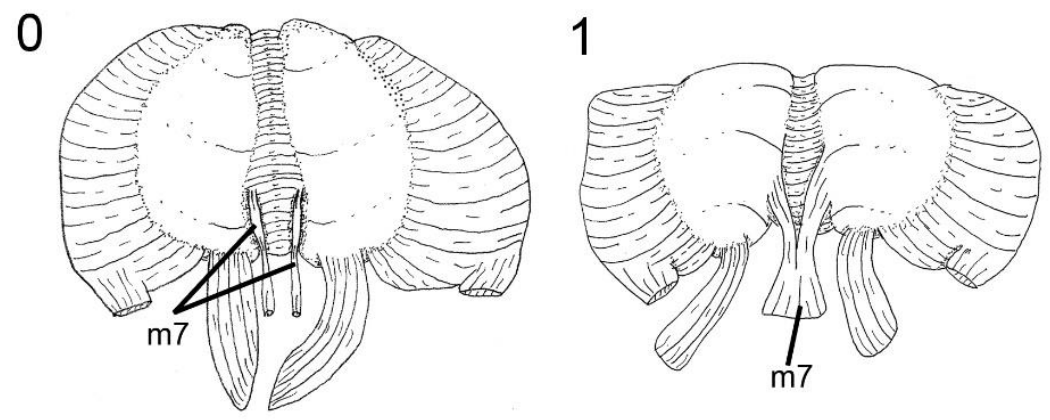

Essa musculatura é conhecida por apresentar origem em diferentes musculaturas, como m4 e m11 (Simone, 2001, 2011). Neste estudo foi possível observar dois tipos de origem do músculo $\mathrm{m} 7$, sendo elas: origem no $\mathrm{m} 6$ ou origem na cartilagem do odontóforo, claramente distintas e de fácil visualização quando é possível identificar o músculo. 
Através da otimização ACCTRAN o estado 1 resultou como autapomorfia de $T$. brasiliensis, A. verrucosus e D. boholiensis e como sinapomorfia dos nós 31 e 36. Com a otimização DELTRAN o estado 1 deixou de ser sinapomorfia do nó 36 e passou a ser autapomorfia de $D$. sandiegensis e Sclerodoris sp., além das espécies já citadas.

48 - m10: 0 - ausente; 1 - circundando todo esfíncter muscular (A. muelleri, B. calcarata, D. atromarginata, F. lajensis e Dorididae); 2 - circundando latero/ventral o esfíncter muscular; 3 - apenas ventral (B. agassizii e N. kristenseni) (Ci: 42; Cr: 66; L: 7)

Músculos longitudinais que ligam o odontóforo ao tubo oral, passando dorsal e ventral ao esfíncter muscular. Parece ser homólogo ao m10 encontrado nos Caenogastropoda, no entanto se origina na região posterior do tubo oral, segue posteriormente dorsal, lateral ou ventro-lateral e insere na região anterior do odontóforo. Nesta análise, utlilizando a otimização ACCTRAN, o estado 1 resultou convergentemente como sinapomorfia dos nós 1 (Nudipleura), 14 e 23 (Dorididae). O estado 2 resultou como sinapomorfia do nó 8 . O estado 3 como autapomorfia de B. agassizii e N. kristenseni. O estado 0 resultou em reversão sinapomórfica do nó 5. Com a otimização DELTRAN o estado 1 resultou como autapomorfia de A. muelleri, B. calcarata e manteve-se como sinapomorfia dos nós 14 e 23 . As outras transformações se mantiveram iguais.

49 - Esfíncter muscular: 0 - ausente; 1 presente (A. muelleri, T. brasiliensis, Chromodorididae, Dorididae e Discodorididae). (Ci: 33; Cr: 77; L: 3)

Possivelmente o esfíncter muscular presente nos Nudibranchia, pode ser uma especialização do tradicional mj (conjunto de pares musculares que forma a região peribucal) (Simone, 2011).

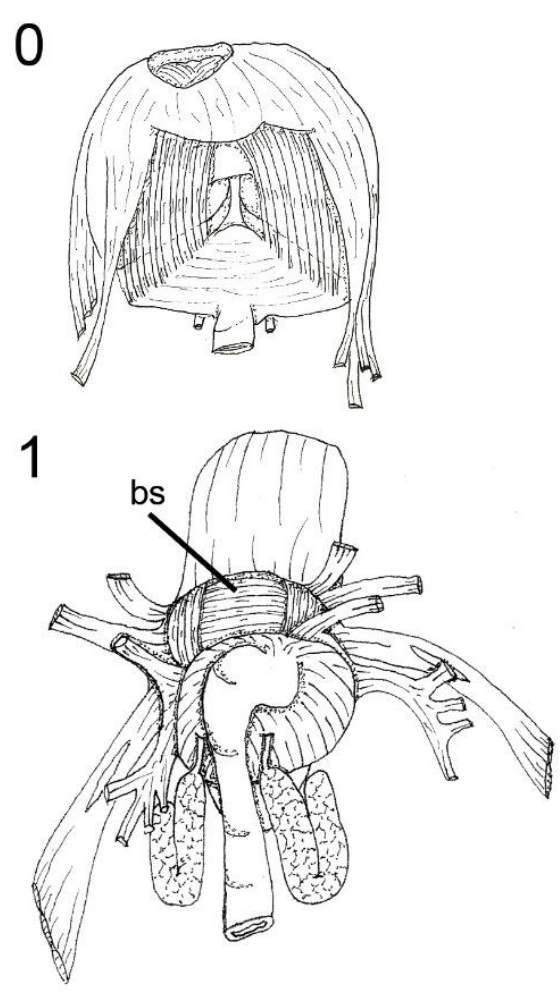


É um músculo circular, bem robusto, que antecede o odontóforo. Parece ser uma característica dos Doridacea, uma vez que sua presença resultou como sinapomorfia do nó 8, englobando $T$. brasiliensis e todos os Cryptobranchia analisados, exceto os representantes de Dendrodoridoidea, que possuem um tubo oral especializado e perderam algumas estruturas do sistema digestivo anterior.

50 - Rádula: 0 - presente; 1 - ausente (P. pustulosa e Dendrodorididae) (Ci: 50; Cr: 66; L: 2)

Estrutura plesiomórfica na presente análise, característica geral dos moluscos, que está ausente em alguns grupos de opistobrânquios (Ponder \& Lindberg, 1997), por conta de modificações na região anterior do sistema digestivo. $\mathrm{O}$ estado 1 resultou convergente como autapomorfia de P. pustulosa e sinapomorfia do nó 18.

51 - Número de dentes laterais: 0 - muitos dentes; 1 - de um a três dentes laterais $(K$. brasiliensis, G. mimula, T. brasiliensis, H. apefae, H. obscura, C. magnifica, F. neona, T. evelinae e C. rumia); 2 - sem nenhum dente lateral (N. kristenseni) (Ci: 50; Cr: 75; L: 4)

Dentes adjacentes ao raquidiano. A maioria das espécies analisadas apresentou o caráter plesiomórfico que apresenta uma rádula larga e com muitos dentes laterais, concordando com Hoffmann (1939), Gosliner (1994) e Wägele \& Willan (2000). Com a otimização ACCTRAN o estado 1 resultou como sinapomorfia do nó 5, enquanto o estado 0 resultou como sinapomorfia dos nós 13 e 21. Com a otimização DELTRAN O estado 1 resultou como sinapomorfia do nó 6 . O estado 0 se mantem com reversão sinapomórfica dos nós 13 e 21. 
52 - Dente raquidiano: 0 - presente; 1 ausente (B. agassizii, K. brasiliensis, G. mimula, $H$. apefae, $H$. obscura, $M$. kempfi, F. lajensis, C. magnifica, A. verrucosus, Dorididae e Discodorididae) (Ci: 16; Cr: 37; L: 6)

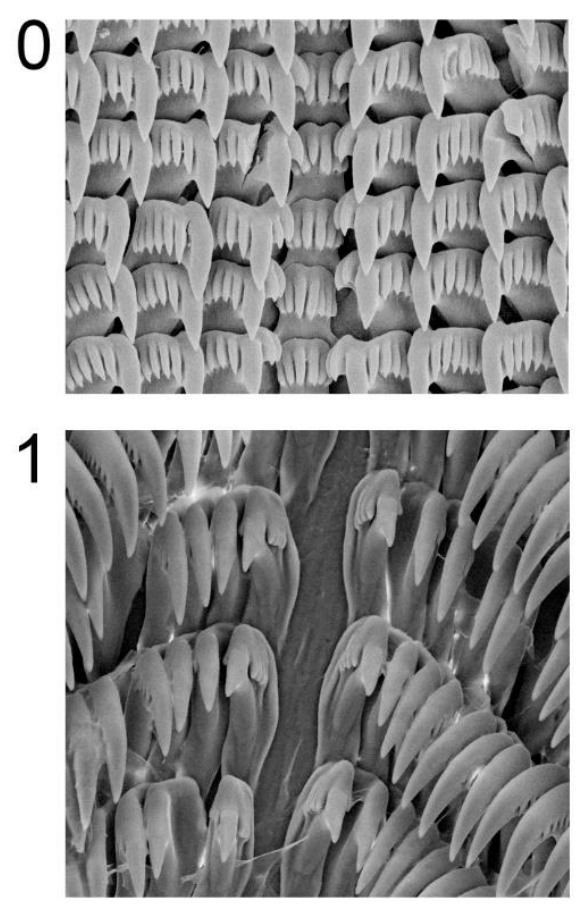

Dente central da rádula. A presença do dente raquidiano é considerada plesiomórfica. Utilizando a otimização ACCTRAN o estado 1 resultou como autapomorfia de $B$. agassizii e como sinapomorfia do nó 5 . O estado 0 resultou em autapomorfia de $T$. brasiliensis, C. rumia e T. ladislavii e como sinapomorfia do nó 16. Com a otimização DELTRAN o estado 1 resultou em autapomorfia de B. agassizii e sinapomorfia dos nós 7, 10 e 21 e o estado 0 como sinapomorfia do nó 16 e autapomorfia de T. ladislavii.

53 - Mandíbula: 0 - presente; 1 - ausente (T. brasiliensis, H. apefae, H. obscura, A. verrucosus, Dorididae, M. greeleyi, P. angustipes, Platydoris sp., T. ladislavii, D. sandiegensis, S. tuberculata, Sclerodoris sp.) (Ci: 16; Cr: 68; L: 6)

Tradicionalmente, a sistemática tem assumido que a região da cutícula labial de indivíduos de uma dada espécie pode ser armada (com a presença da mandíbula) ou lisa, mas não ambas (Dayrat, 2010). Nesta análise a presença da mandíbula é plesiomórfica. O estado 1 resultou como sinapomorfia do nó 8 . O estado 0 resultou como sinapomorfia dos nós 12 e 33.

\section{Sistema digestivo médio}

54 - Posição do estômago: 0 - lado esquerdo da massa visceral; 1 - interno à glândula digestiva (demais táxons); 2 - lado direito, torcido, da massa visceral (A. muelleri e $B$. 
calcarata $) ; 3$ - central à glândula digestiva $(H$. apefae, D. atromarginata e $C$. rumia $)(\mathrm{Ci}$ : 30; Cr: 63; L: 10)
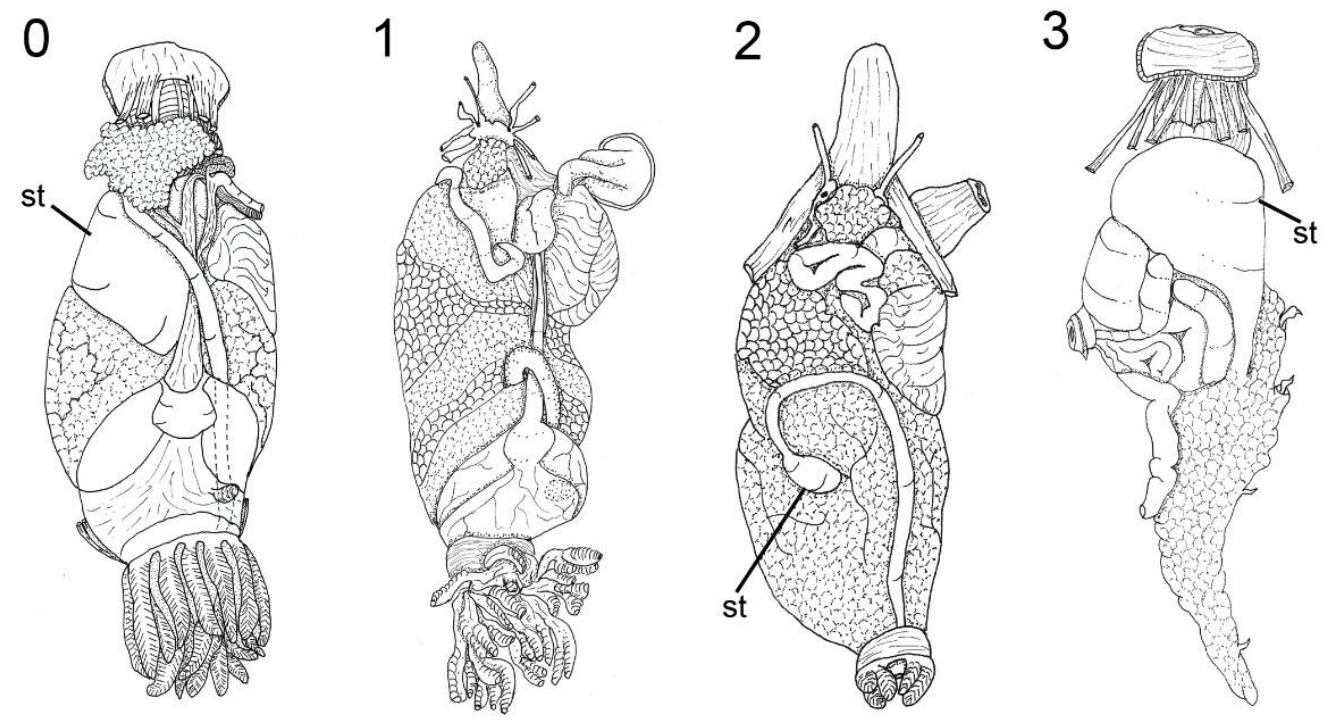

O estômago é uma estrutura dilatada entre a região posterior do esôfago e anterior do intestino, normalmente onde estão localizadas as aberturas para a glândula digestiva. $\mathrm{O}$ estado 1 resultou em sinapomorfia do nó 1 (Nudipleura). Já o estado 0 como sinapomorfia do nó 22.

55 - Ceco: 0 - ausente; 1 - presente $(D$. atromarginata, F. lajensis, T. evelinae, C. rumia, A. verrucosus, Dorididae, J. spazzola, M. greeleyi, $P$. angustipes, Platydoris sp., D. boholiensis, $T$. ladislavii e Sclerodoris sp.) (Ci: 16; Cr: 70; L: 6)
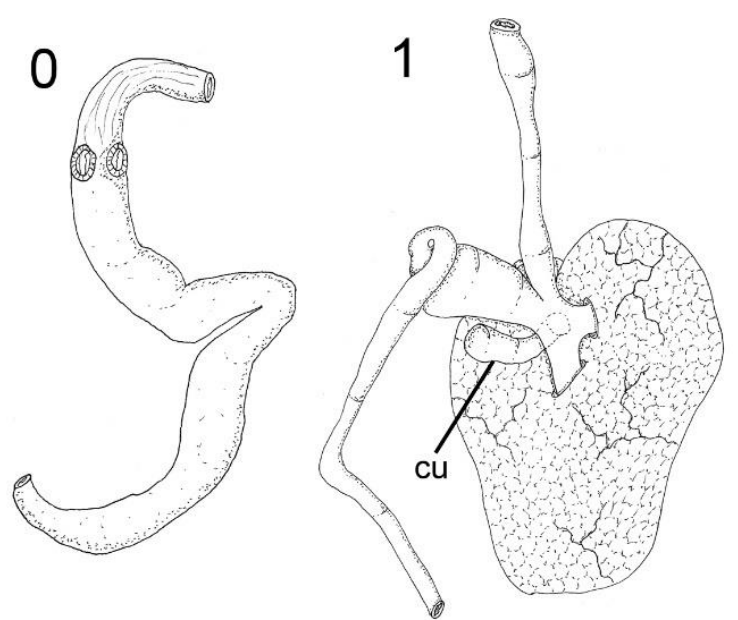

Estrutura sacular do sistema digestivo médio, associada ao estômago, normalmente apresenta uma massa glandular marrom. O estado 1 resultou como autapomorfia de $T$. evelinae e Sclerodoris sp. e como sinapomorfia dos nós 14 e 20. O estado 0 resultou como reversão autapomórfica de $D$. pusae e sinapomorfia do nó 35. 
56 - Posição do ânus: 0 - interno à cavidade do manto, lado direito; 1 - lateral, perto do meio do corpo (B. agassizii, A. muelleri e N. kristenseni); 2 - dorsal, na posição mediana e lateral direito (B. calcarata); 3 - médio-dorsal no sentido posterior do corpo ( $P$. pustulosa, K. brasiliensis, G. mimula, T. brasiliensis e Cryptobranchia) (Ci: 100; Cr: 100; L: 3)

A posição do ânus sofreu várias modificações nos opistobrânquios, correlacionadas com a perda da cavidade palial (Ponder \& Lindberg, 1997), em muitos táxons, como alguns nudibrânquios, o ânus se abre na região anterior do lado direito do corpo (Wägele \& Willan, 2000). Neste estudo foi possível observar três posições do ânus dentre os Nudibranchia, sendo elas lateral, nos táxons mais basais; dorsal e mediana, na lateral direita do noto e na maioria dos táxons analisados na região médio-dorsal posterior. $\mathrm{O}$ estado 1 resultou em sinapomorfia do nó 1 (Nudipleura), o estado 2 apenas como autapomorfia de B. calcarata e o estado 3 como sinapomorfia do nó 5 .
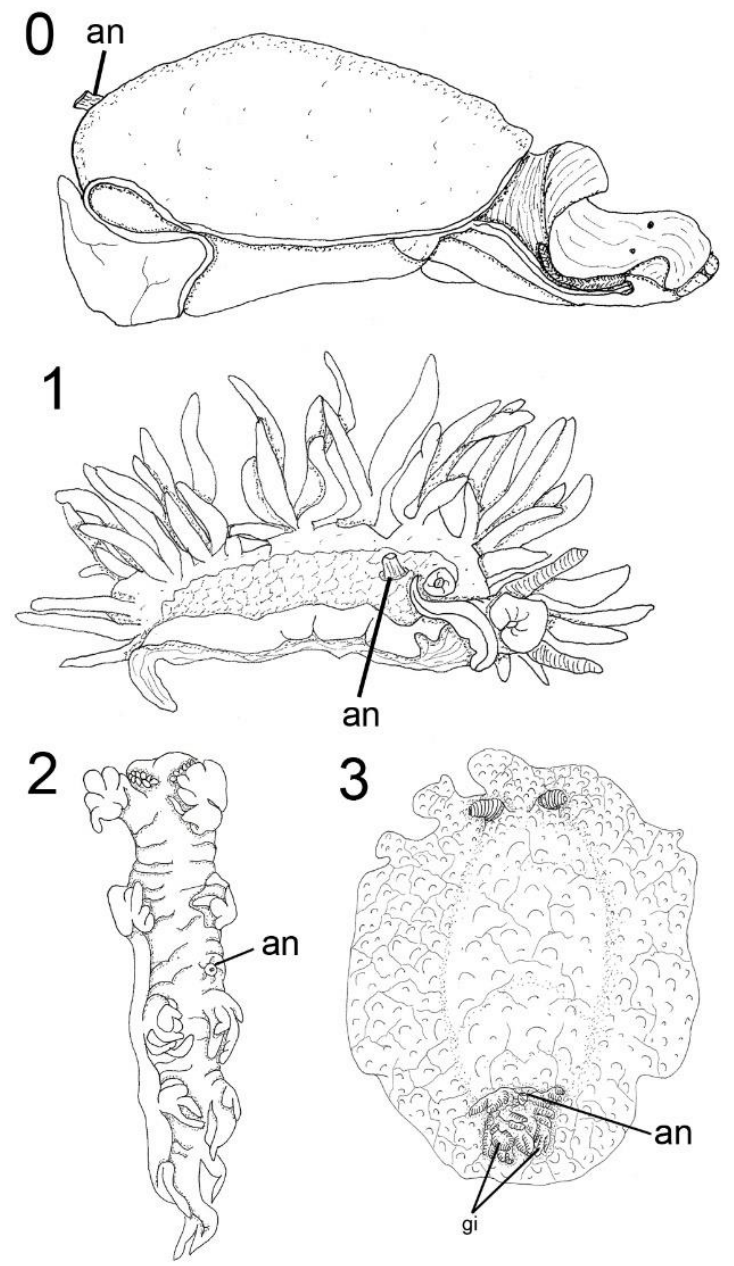

57 - Papila anal: 0 - ausente; 1 - presente (N. kristenseni, B. calcarata, T. brasiliensis, $H$. obscura, M. kempfi, D. atromarginata, F. lajensis, C. magnifica, F. neona, T. evelinae, Dendrodorididae, C. rumia, Dorididae e Discodorididae) (Ci: 25; Cr: 57; L: 4)

Elevação externa do tegumento com o poro anal apical, quando presente a papila é bem visível. O estado 1 resulta em sinapomorfia dos nós 4 e 8.

58 - Posição da papila anal: 0 - central ao círculo branquial; 1 - mais posterior, quase na borda do círculo branquial (M. kempfi, F. lajensis, C. magnifica e T. evelinae, D. areolata, 
C. rumia, D. ananas e P. angustipes); 2 - lateral/mediana ( $N$. kristenseni); 3 dorsal/lateral (B. calcarata) (Ci: 33; Cr: 14; L: 9)

A posição da papila certamente está ligada à posição do ânus, no entanto entre aqueles que apresentam a papila rodeada pelo círculo branquial foi possível observar que a papila pode estar complemente centralizada no círculo branquial ou estar mais próxima da borda do círculo. Com a otimização ACCTRAN o estado 1 resultou como sinapomorfia do nó 12 e como autapomorfia de D. areolata, C. rumia, D. ananas e $P$. angustipes. $\mathrm{O}$ estado 2 resultou como sinapomorfia do nó 4 e o estado 3 como autapomorfia de $B$. calcarata. Já as reversões para o estado 0 ocorreram em D. prismática e $F$. neona. Com a otimização DELTRAN os estados 2 e 3 resultaram como autapomorfias de $N$. kristenseni e $B$. calcarata, respectivamente.

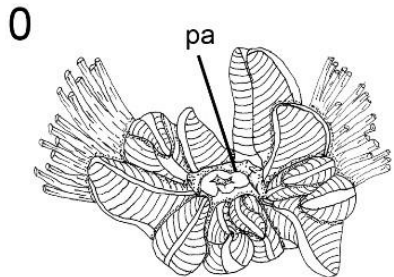

2

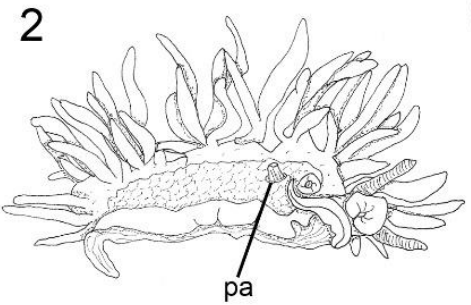

1

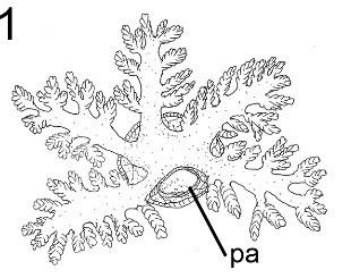

3

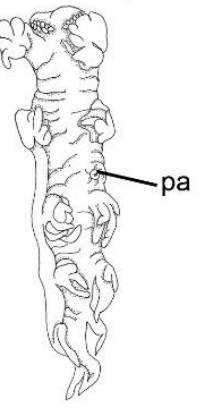

\section{Sistema reprodutor}

59 - Distinção entre gônada e glândula digestiva: 0 - fácil distinção; 1 - difícil distinção (D. atromarginata, T. evelinae, Dorididae (exceto D. kyolis), Discodorididae (exceto Platydoris sp. e T. ladislavii) (Ci: 16; Cr: 66; L: 6)
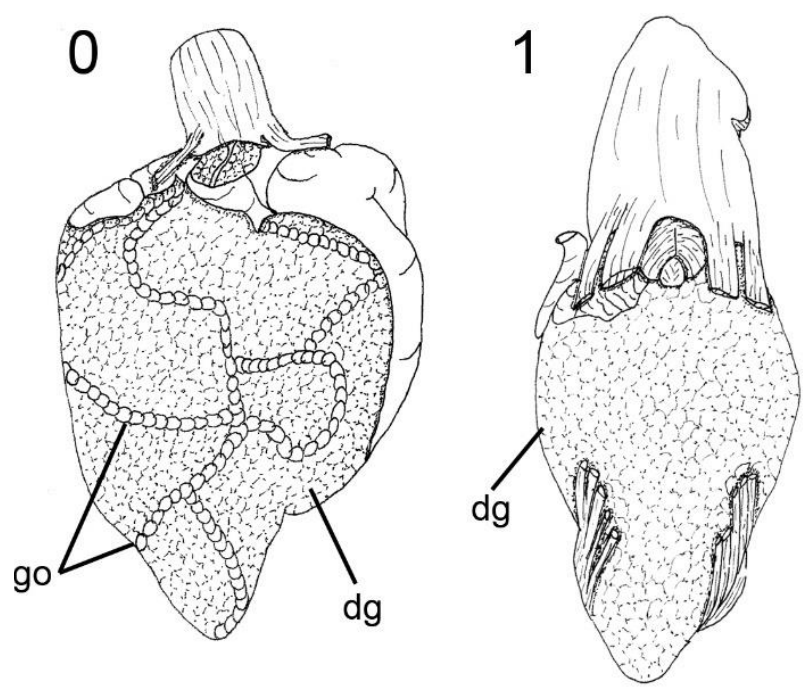
Em muitos nudibrânquios a gônada se espalha dorsalmente sobre a glândula digestiva e está intimamente ligada a ela (Medina et al., 1986). A fácil distinção entre as estruturas é a condição plesiomórfica. O estado 1 resultou como sinapomorfia do nó 22.

60 - Próstata: 0 - dividida; 1 - única $(B$. agassizii, A. muelleri, N. kristenseni, B. calcarata, P. pustulosa, K. brasiliensis, G. mimula, T. brasiliensis, Chromodorididae, Dendrodorididae, $C$. rumia, A. verrucosus, Dorididae, J. spazzola, M. greeleyi, P. angustipes, Platydoris sp.) (Ci: 50; Cr: 85; L: 2)

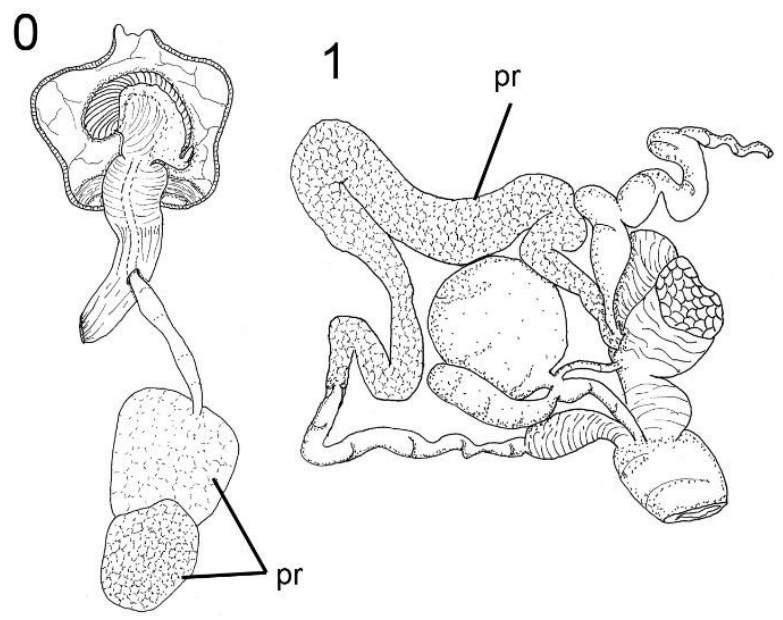

A próstata glandular e um pênis muscular geralmente estão associados com o vaso deferente (Klussmann-Kolb, 2000). Na maioria dos Cryptobranchia a próstata tem apenas uma única parte, no entanto em algumas espécies a próstata está dividida em duas partes claramente distintas (Valdés, 2002a). Nesta análise a próstata dividida é a condição plesiomórfica e o estado 1 resultou como sinapomorfia do nó 1 (Nudipleura), como uma estrutura glandular sem divisão. $\mathrm{O}$ estado 0 resultou em uma reversão sinapomórfica do nó 32, espécies que apresenta uma próstata claramente dividida em duas partes glandulares, mas com texturas distintas.

61 - Músculo do pênis: 0 - presente, com origem no tegumento (H. elegans); 1 - ausente (demais táxons); 2 - presente, com origem na região ventral do pericárdio (D. januarii e D. verrucosa) (Ci: 100; Cr: 100; L: 2)

Em H. elegans o pênis está claramente conectado ao tegumento lateral através de uma musculatura bem proeminente. Já em $D$. verrucosa e $D$. januari é possível identificar uma musculatura, mas esta está ligada a região ventral do pericárdio e é bem mais delgada do que a presente em $H$. elegans. O estado 1 resultou como sinapomorfia do nó 1 (Nudipleura), o estado 2 como sinapomorfia do nó 27.

62 - Papila no pênis: 0 - presente; 1 - ausente (A. muelleri, N. kristenseni, B. calcarata, P. pustulosa, K. brasiliensis, G. mimula, T. basiliensis, Chromodorididae, 
Dendrodorididae, C. rumia, A. verrucosus, Dorididae, J. spazzola, M. greeleyi, $P$. angustipes, Platydoris sp., D. boholiensis, D. pusae, S. tuberculata) (Ci: 33; Cr: 60; L: 3)

O estado 1 resultou como sinapomorfia do nó 2 (Nudibranchia) e como autapomorfia de $S$. tuberculata. O estado 0 resultou em uma sinapomorfia do nó 34.

63 - Espinhos no pênis: 0 - ausente; 1 - presente (B. calcarata, G. mimula, T. brasiliensis, D. limbata, D. areolata, P. angustipes e D. branneri) (Ci: 14; Cr: 0; L: 7)

Apesar de diversas espécies de Cryptobranchia e Phanerobranchia apresentarem várias fileiras de espinhos no pênis (Valdés \& Gosliner, 1999), a maioria das espécies escolhidas para esta análise apresentou o estado plesiomórfico (estado 0), de forma que a presença de espinhos no pênis (estado 1), utilizando a otimização ACCTRAN, resultou como autapomorfia de $B$. calcarata, G. mimula, T. brasiliensis e D. branneri; e como sinapomorfia dos nós 18 e 31 . Já o estado 0 surge como uma reversão autapomórfica de $M$. mirocornata. Com a otimização DELTRAN o estado 1 resultou apenas como autapomorfias das espécies $B$. calcarata, G. mimula, T. brasiliensis, D. limbata, D. areolata, P. angustipes e D. branneri.

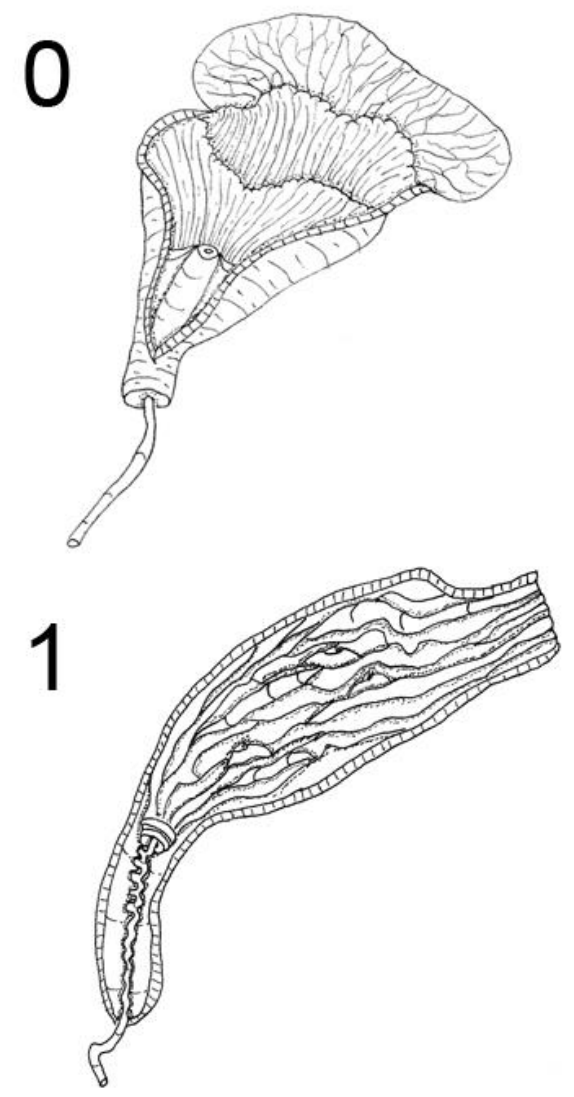


64 - Espinhos na vagina: 0 - ausente; 1 presente (K. brasiliensis, $P$. angustipes e Sclerodoris sp.) (Ci: 33; Cr: 0; L: 3)
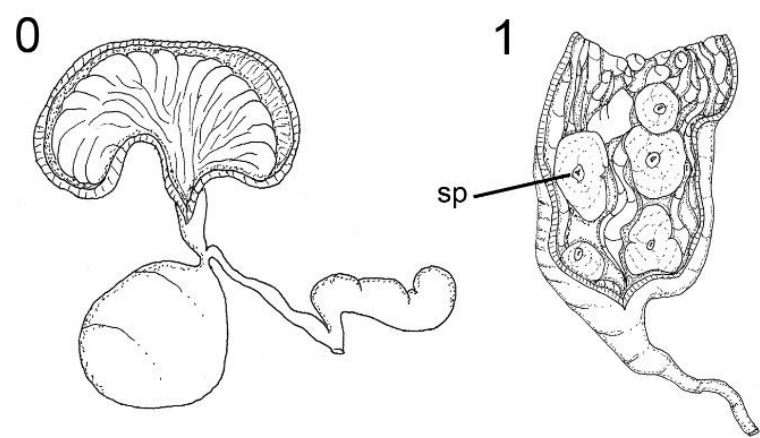

Em alguns gêneros de Cryptobranchia é comum a presença de espinhos grandes na região interna da vagina (Valdés, 2002). Esses espinhos estão localizados no ducto da vagina e não em alguma estrutura associada a ela. Com a otimização ACCTRAN o estado 1 resultou como autapomorfia de K. brasilienssi e Sclerodoris sp. e como sinapomorfia do nó 31. Já com a otimização DELTRAN o estado 1 resultou apenas em autapomorfia de K. brasiliensis, Platydoris angustipes e Sclerodoris sp. O caráter foi incluído na análise para diferenciar as duas espécies de Sclerodoris que foram separadas através da comparação anatômica.

65 - Bolsas vaginais: 0 - ausente; 1 - presente, sem espinhos (N. kristenseni, $T$. brasiliensis e D. pusae); 2 - presente, com espinhos (D. ananas) (Ci: 50; Cr: 0; L: 4)

Estruturas em forma de saco, como uma bursa ou receptáculo, associadas à região terminal da vagina (Lima et al., 2016). Caráter do sistema reprodutor que resultou apenas como autapomorfia.

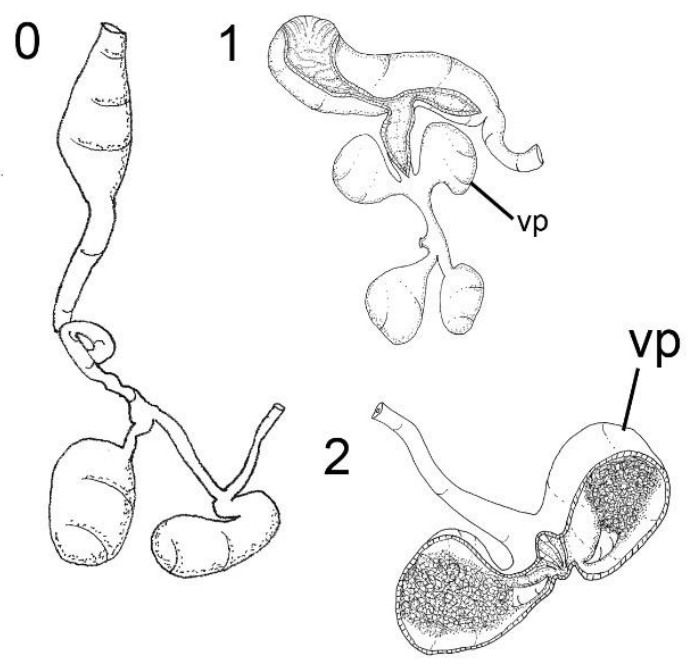


66 - Bursa copulatrix e receptáculo seminal: 0 - ausentes (H. elegans, A. muelleri e $B$. calcarata); 1 - ambos presentes (Ci: 33; Cr: 0; L: 3)

Ambas vesículas, como definidas histologicamente por Schmekel (1971), estão presentes em todas as espécies da análise, exceto em $H$. elegans, A. muelleri e $B$. calcarata que não apresentam a bursa copulatrix (Wägele \& Willan, 2000; Pola et al., 2008), de forma que o estado 1 resultou como sinapomorfia do nó 1 e o estado 0 como reversão de A. muelleri e B. calcarata.

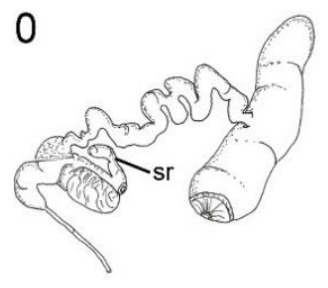
67 - Inserção do receptáculo seminal: 0 - próximo da ampula; 1 - na base da bursa copulatrix (N. kristenseni, K. brasiliensis, G. mimula, T. brasiliensis, Chromodorididae, D. areolata, D. bovena, D. kyolis, $D$. ananas, $D$. januarii e $D$. verrucosa); 2 - próximo do ducto uterino (B. agassizii); 3 - no meio da vagina (A. muelleri); 4 - na abertura da vagina (B. calarata); 5 - junto do ducto uterino ( $P$. pustulosa, D. limbata, M. mirocornata, C. rumia, A. verrucosus, D. ilo e Discodorididae) (Ci: 62; Cr: 81; L: 8)

Caráter já utilizado em outra filogenia (Valdés, 2002a), no entanto neste estudo foi possível verificar outros estados nas espécies analisadas. Com a otimização ACCTRAN o estado 1 resultou como sinapomorfia do nó 1 (Nudipleura) e nó 24, e como autapomorfia de $D$. areolata. Os estados 2, 3 e 4 resultaram como autapomorfias de $B$. agassizii, A. muelleri e $B$. calcarata, respectivamente. $\mathrm{O}$ estado 5 resultou como autapomorfia de P. pustulosa e sinapomorfia do nó 17. Com a otimização DELTRAN o estado 1 resultou como sinapomorfia do nó 3, mas manteve-se como autapomorfia de $D$. areolata e sinapomorfia do nó 24 . Os outros estados mantiveram-se iguais.

68 - Ducto uterino: 0 - ausente; 1 - 0 presente (Anthobranchia) (Ci: 50; Cr: 80; L: 2)
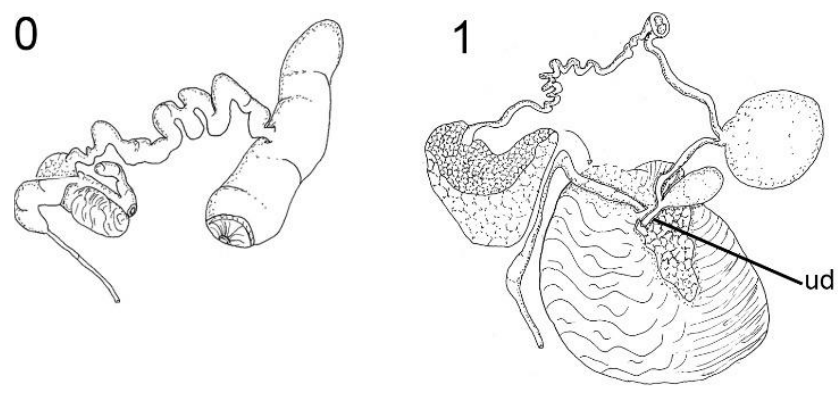
É o ducto que conecta o complexo "bursa copulatrix - receptáculo seminal - vagina" com a glândula feminina. Normalmente não é utilizado em estudos filogenéticos, no entanto mostrou-se um caráter importante, resultando como sinapomorfia do nó 5.

69 - Glândula acessória: 0 - ausente; 1 - presente (T. evelinae, J. spazzola e Sclerodoris sp.) (Ci: 33; Cr: 0; L: 3)
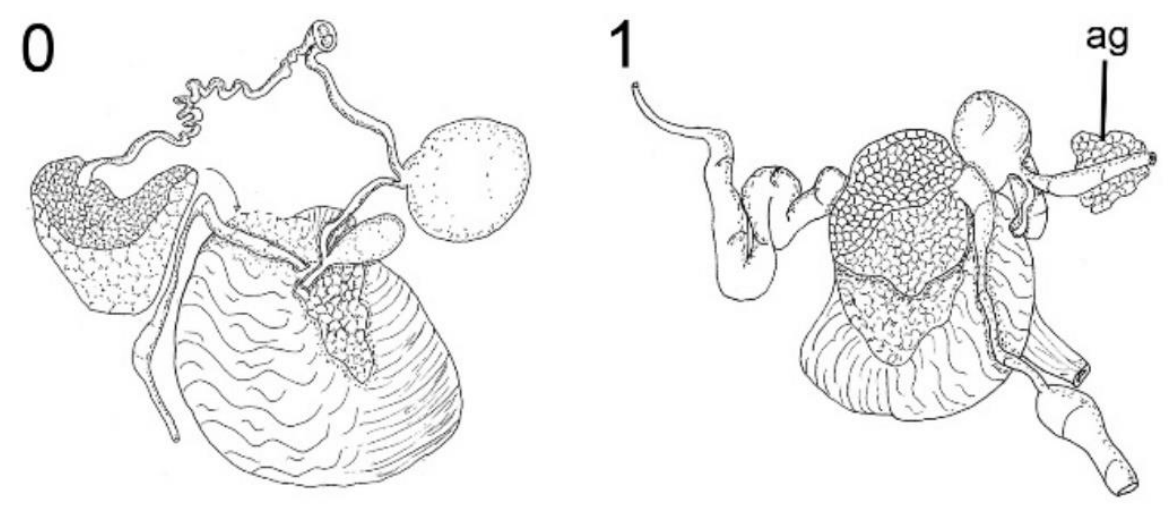

As glândulas acessórias muitas vezes abrem no átrio genital comum, e assim são atribuídas à vagina, ao oviduto e ás vezes ao vaso deferente, no entanto ainda não se estabeleceu uma relação específica, pois é necessário um melhor conhecimento da fisiologia do sistema reprodutor (Wägele \& Willan, 2000). Nesta análise consideramos a glândula acessória uma estrutura maciça (não em forma de bolsa) que pode estar associada à vagina ou ao pênis. Apesar de se mostar um caráter autapomórfico, foi incluído na análise para separar as duas espécies de Sclerodoris.

\section{Sistema nervoso}

O sistema nervoso dos nudibrânquios, inclusive intraespecificamente, não se mantem invariavelmente constante, apesar de alguns caracteres se manterem mais ou menos fixos para cada espécie. Isso acontece, fundamentalmente, com o maior ou menor grau de fusão dos gânglios entre si ou a tendência de conectivos e comissuras com um certo comprimento (García et al., 1988).

Nesta análise, foi possível comparar os caracteres ligados às comissuras e alguns conectivos, já que a maioria das espécies apresenta um grau de fusão bem avançado dos gânglios principais. 
70 - Gânglio gastroesofágico: 0 ausente; 1 - presente (A. muelleri, B. calcarata, Chromodorididae, C. rumia, A. verrucosus, Dorididae e Discodoridae) (Ci: 25; Cr: 62; L: 4)

Os gânglios gastroesofágicos estão associados aos gânglios bucais (García et al., 1988). Neste estudo foi possível verificar a presença ou ausência da estrutura. Utilizando a otimização ACCTRAN o estado 1 resultou como autapomorfia de $A$. muelleri e $B$. calcarata e como sinapomorfia do nó 9. $\mathrm{O}$ estado 0 resultou como sinapomorfia do nó 18. Optando-se pela otimização DELTRAN o estado 1 manteve-se como autapomorfia de A. muelleri e $B$. calcarata, no entanto passou a ser sinapomorfia dos nós 10 e 20.

71 - Comissura cerebral: 0 - comissura aparente; 1 - gânglios fundidos (B. agassizii, A. muelleri, N. kristenseni, $P$. pustulosa, $\quad$ T. brasiliensis, Chromodorididae, D. limbata, D. areolata, C. rumia, A. verrucosus, Dorididae e Discodorididae) (Ci: 25; Cr: $25 ; \mathrm{L}: 4)$
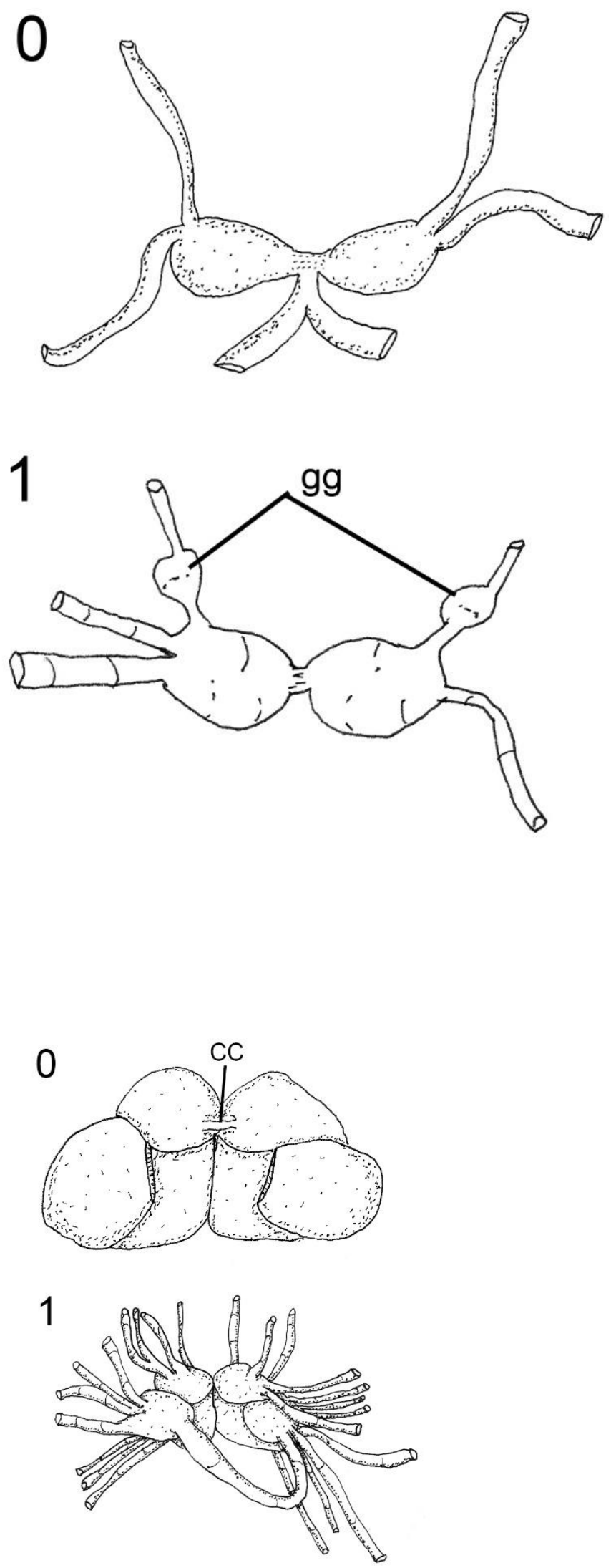

O estado 1 resultou como sinapomorfia do nó 1 (Nudipleura). O estado 0 resultou em autapomorfia de B. calcarata e M. mirocornata e sinapomorfia do nó 7. 
72 - Comissura pediosa: 0 - estreita simples; 1 - estreita dupla $(T$. brasiliensis, C. magnifica, D. bovena, D. januarii e $S$. tuberculata); 2 - estreita tripla (C. rumia); 3 - gânglios praticamente fundidos (D. limbata e $M$. mirocornata) (Ci: 37; Cr: 0; L: 8)

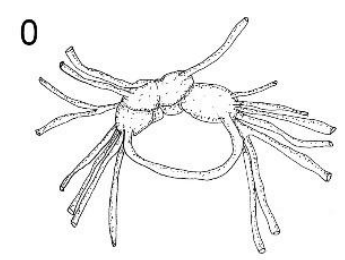

2

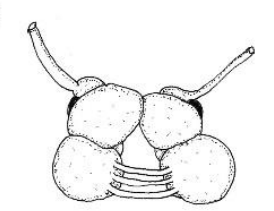

1

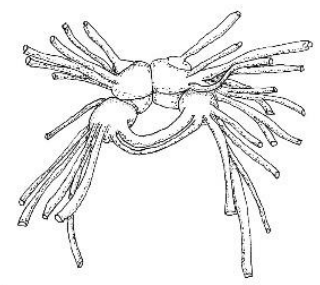

3

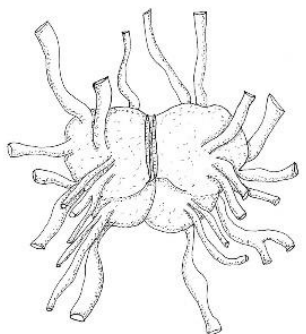

Comissura que interliga os dois gânglios pediosos, por ela passam esôfago e glândulas salivares. Com a otimização ACCTRAN os estados 1 resultou em autapomorfias de C. magnifica, D. bovena, D. januarii e sinapomorfia do nó 37 . O estado 2 resultou em autapomorfia de $C$. rumia e o estado 3 resultou como sinapomorfia do nó 18. Já com a otimização DELTRAN os estados 1 e 2 se mantiveram iguais, no entanto o estado 3 passou a ser autapomorfia de D. limbata e M. mirocornata.

73 - Comissura pediosa II: 0 - curta (menor que o gânglio cerebral); 1 - longa (maior que o gânglio cerebral) $(A$. muelleri, T. brasiliensis, $H$. obscura, $F$. lajensis, C. magnifica T. evelinae, D. ilo, D. ananas, D. januarii, D. verrucosa e Discodorididae) (Ci: 20; Cr: 50; L: 10)
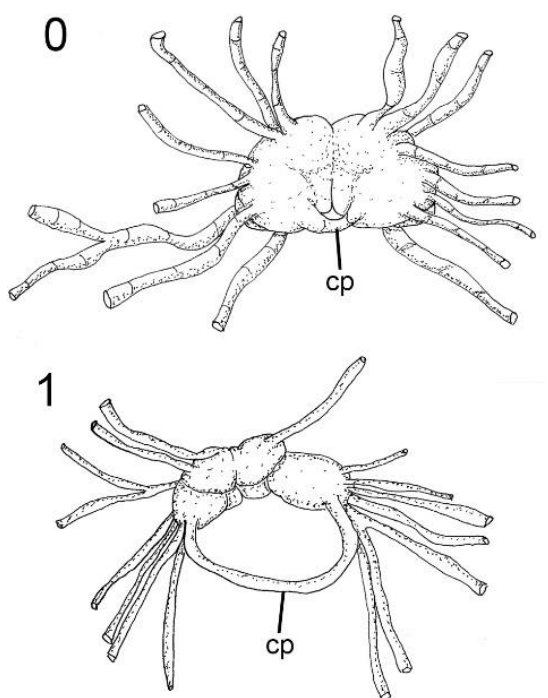

Comprimento da comissura em relação ao gânglio cerebral. Adorando a otimização ACCTRAN o estado 1 resultou em autapomorfia de A. muelleri, T. brasiliensis e $F$. lajensis e sinapomorfia dos nós 11 e o nó 22 . O estado 2 resultou como sinapomorfia do nó 18 . O estado 0 resultou como reversão autapomórfica de $F$. neona e $D$. areolata, e como sinapomorfia dos nós 13e 25. Com a otimização DELTRAN o estado 1 resultou como autapomorfia de T. brasiliensis, H. obscura, F. lajensis, C. magnifica e T. evelinae 
e manteve-se como sinapomorfia do nó 22, o estado 2 resultou como autapomorfia de $D$. limbata e M. mirocornata e o estado 0 como sinapomorfia do nó 25.

74 - Comissura bucal: 0 - comissura aparente; 1 - gânglios fundidos $(B$. agassizii, N. kristenseni, G. mimula, $H$. apefae, H. obscura, M. kempfi, D. areolata, C. rumia, D. ilo, D. ananas, $M$. greeleyi, $P$. angustipes e Platydoris sp.). (Ci: 10; Cr: 25; L: 10)

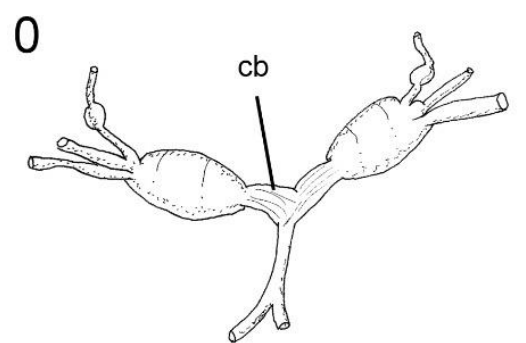

1

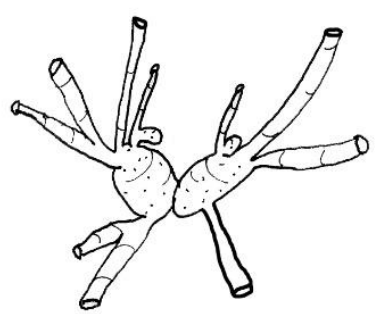

Conexão entre os gânglios bucais. Com a otimização ACCTRAN o estado 1 resultou como autapomorfia de F. kempfi, D. ilo e D. ananas e como sinapomorfia dos nós 1 e 30. O estado 0 resultou em autapomorfia de A. muelleri, B. calcarata e $T$. brasiliensis e como sinapomorfia dos nós 12 e 21. Utilizando a otimização DELTRAN o estado 1 resultou em autapomorfia de B. agassizii, N. kristenseni, G. mimula, D. ilo e D. ananas e como sinapomorfia dos nós 9 e 30, enquanto o estado 0 resultou em sinapomorfia dos nós 14 , 15 e 21.

75 - Nervo óptico: 0 - facilmente visível; 1 - fundido com os gânglios cerebrais $(B$. agassizii, A. muelleri, N. kristenseni, $K$. brasiliensis, G. mimula, T. brasiliensis, H. apefae, H. obscura, F. kempfi, D. atromarginata, F. neona, T. evelinae, Dendrodorididae, $\quad$. rumia, $A$. verrucosus, Dorididae, M. greeleyi, $P$. angustipes, Platydoris sp., D. boholiensis, D. pusae, D. sandiegensis, S. tuberculata, Sclerodoris sp.). (Ci: 16; Cr: 0; L: 6)
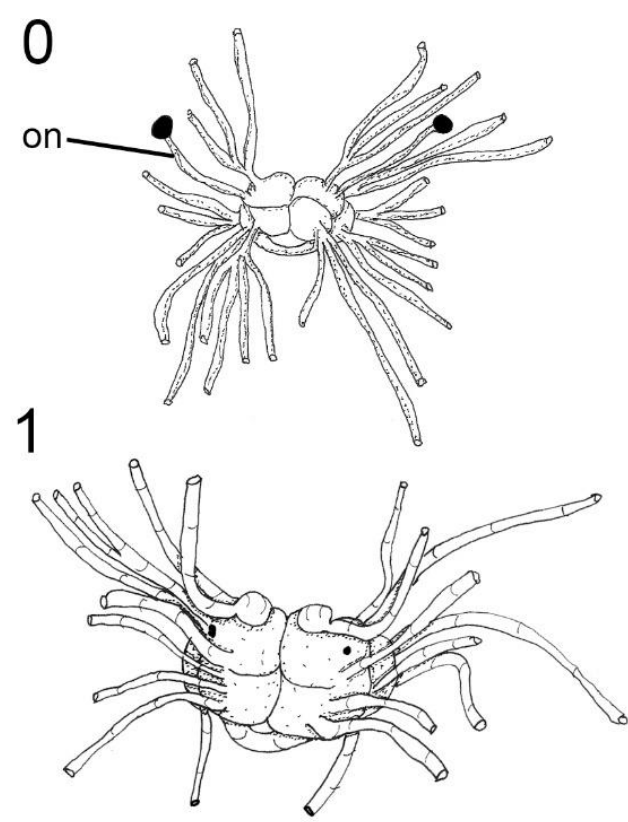
Conectivo entre os gânglios ópticos e cerebral. O estado 1 resultou em autapomorfia de B. calcarata, P. pustulosa, C. magnifica, J. spazzola e D. branneri e como sinapomorfia do nó 1 .

\subsubsection{Caracteres excluídos da análise}

Os caracteres autapomórficos foram excluídos da análise para diminuir o número de passos da árvore, evitando o aumento dos índices de consistência e retenção da mesma. No entanto, por serem consideradas informações anatômicas com bom potencial em um outro universo comparativo, parece interessante listá-las a seguir:

\#1. Cerata (stritu sensu - Aeolidoidea): (0) ausente; (1) presente (Noumeaella kristenseni).

\#2. m2a (músculos retratores auxiliares com mesma origem do m2, mas que seguem anteriormente, no sentido do tubo oral): (0) ausente; (1) presente (Chromodoris magnifica; Felimare lajensis; Montereina greeleyi).

\#3. $\mathrm{m} 4 \mathrm{a}$ (par de finos músculos originados na região posterior do $\mathrm{m} 4$, inserindo na região dorsal mediana de cada cartilagem do odontóforo e conectado com m7b): (0) ausente; (1) presente (Platydoris sp. BR).

\#4. m5a (músculo que liga a região posterior do m4 e m5): (0) ausente; (1) presente (Felimare lajensis).

\#5. m7a (músculo originado na região posterior da cartilagem do odontóforo que insere no saco radular, provavelmente um axiliar do tradicional m7): (0) ausente; (1) presente (Actinocyclus verrucosus).

\#6. m7b (par de pequenos e finos músculos originados na região posterior do m6 inserindo unidos na região posterior do tradicional m7): (0) ausente; (1) presente (Platydoris sp.).

\#7. m7c (par de finos músculos originado no $\mathrm{m} 3$ e inseridos no saco radular, dorsalmente): (0) ausente; (1) presenta (Doris januarii).

\#8. Rádula mineralizada: (0) ausente; (1) presente (T. brasiliensis).

\#9. Espinho no oviduto: (0) ausente; (1) presente ("Discodoris" branneri).

\#10. Pleural commissure (0) ausente; (1) presente (Actinocyclus verrucosus). 


\subsection{Matriz}

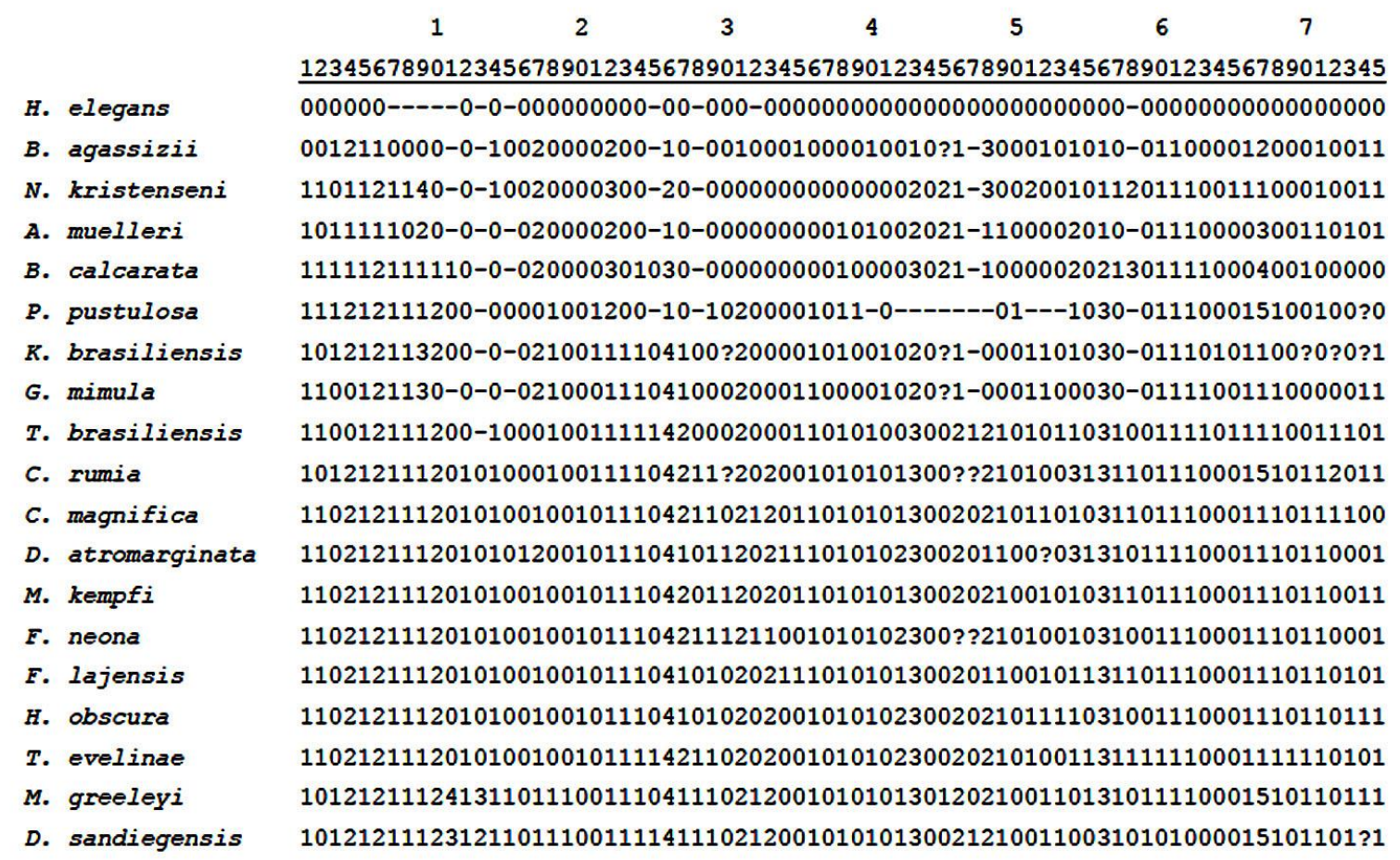
D. boholiensis
D. branneri
D. pusae
J. spazzola
T. ladislavii
$P$. angustipes Platydoris_BR
S. tuberculata Sclerodoris_BR
D. ananas
D. bovena
D. $i 10$
D. kyolis
D. januarii
D. verrucosa
A. verrucosus
H. apefae
M. mirocornata
D. limbata
D. areolata 


\subsection{Análise dos Cladogramas}

Como dito no M\&M, as análises foram realizadas com 39 táxons e 75 caracteres morfológicos, sendo todos os caracteres pesados igualmente. Alguns caracteres foram baseados a partir de trabalhos de filogenias englobando táxons de Nudibranchia (Wägele \& Willan, 2000; Valdés, 2002a, Dayrat, 2010, Báez et al., 2011).

A análise realizada sem pesagem, resultou em 20 árvores igualmente mais parcimoniosas, com 308 passos (IC: 38; IR: 65), as quais apresentaram uma árvore de consenso estrito de comprimento igual a 326 passos (IC: 36; IR: 62) apresentada na Fig. 149.

Para melhor resolução das relações entre os criptobrânquios, estabeleceu-se a busca através de uma pesagem implícita, com valor de concavidade $(\mathrm{k}=6.484375)$ resultou em uma única árvore com comprimento de 311 passos (IC: 38; IR 64), apresentada nas Figs. 142, 143, 144, 145, 146, 147 e 148). Para as otimizações e discussão dos caracteres foi utilizada a topologia da ávore de pesagem (Fig. 148).

Abaixo estão apresentados os cladogramas de pesagem implícita, sendo o primeiro uma visão geral da árvore completa (Fig. 142), e posteriormente o mesmo cladograma dividido em cinco partes (Figs. 143, 144, 145, 146, 147) e apresenta todos os caracteres utilizados (na região superior) e os estados para cada caráter (abaixo) em cada nó e terminais. Cada sinapomorfia está apresentada com o círculo preenchido (•), para as homoplasias (reversões ou convergências) a representação como um círculo vazio (०). O cladograma com os nós numerados e com os nomes dos principais nós (Fig. 148) e por último a árvore de consenso estrito (Fig. 149).

Os caracteres e nós discutidos serão os resultantes da árvore de pesagem implícita (Fig. 142). 


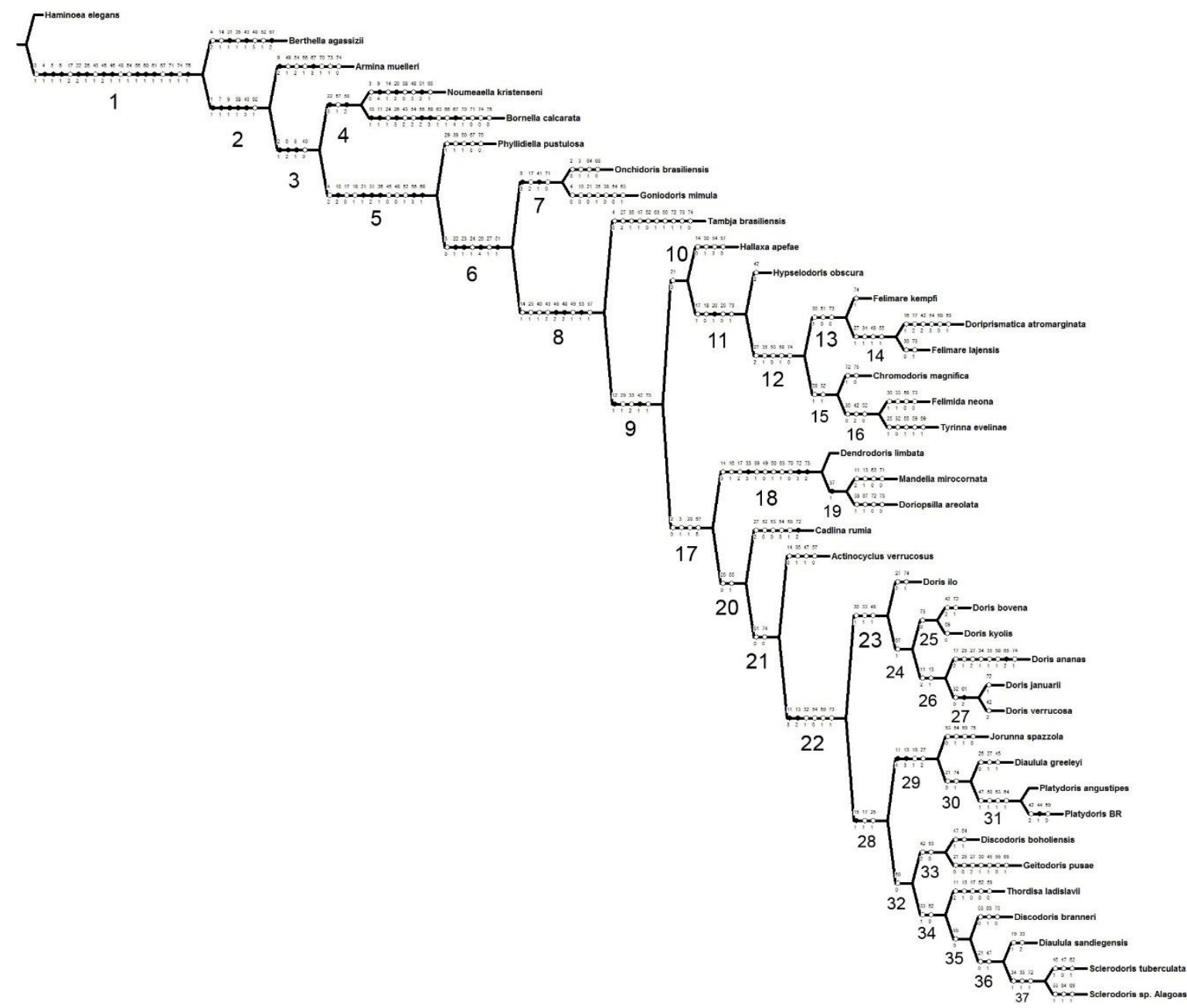

Figura 142: Árvore obtida através da pesagem implícita, com nós maiores nomeados numerados.

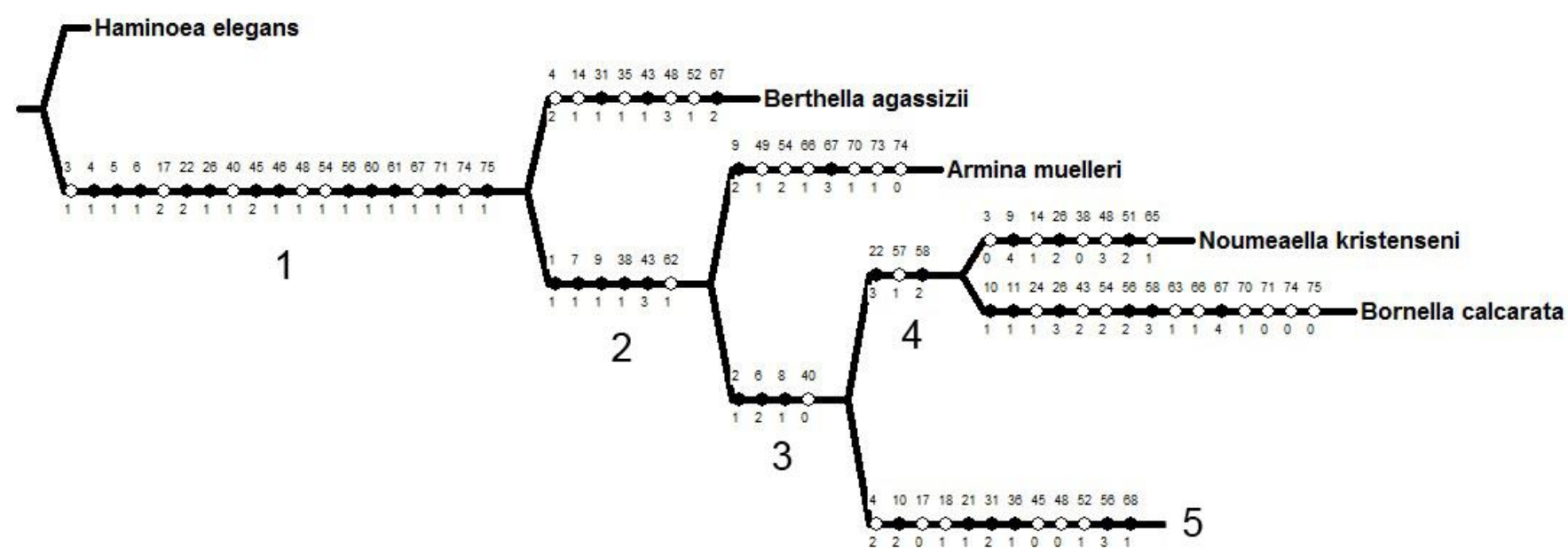

Figura 143: Parte da (1 de 5) árvore obtida através da pesagem implícita. Sinapomorfias de cada nó indicadas pelos círculos pretos e as homoplasias com círculos brancos. O número acima de cada símbolo indica o caráter, e o abaixo, o estado. 


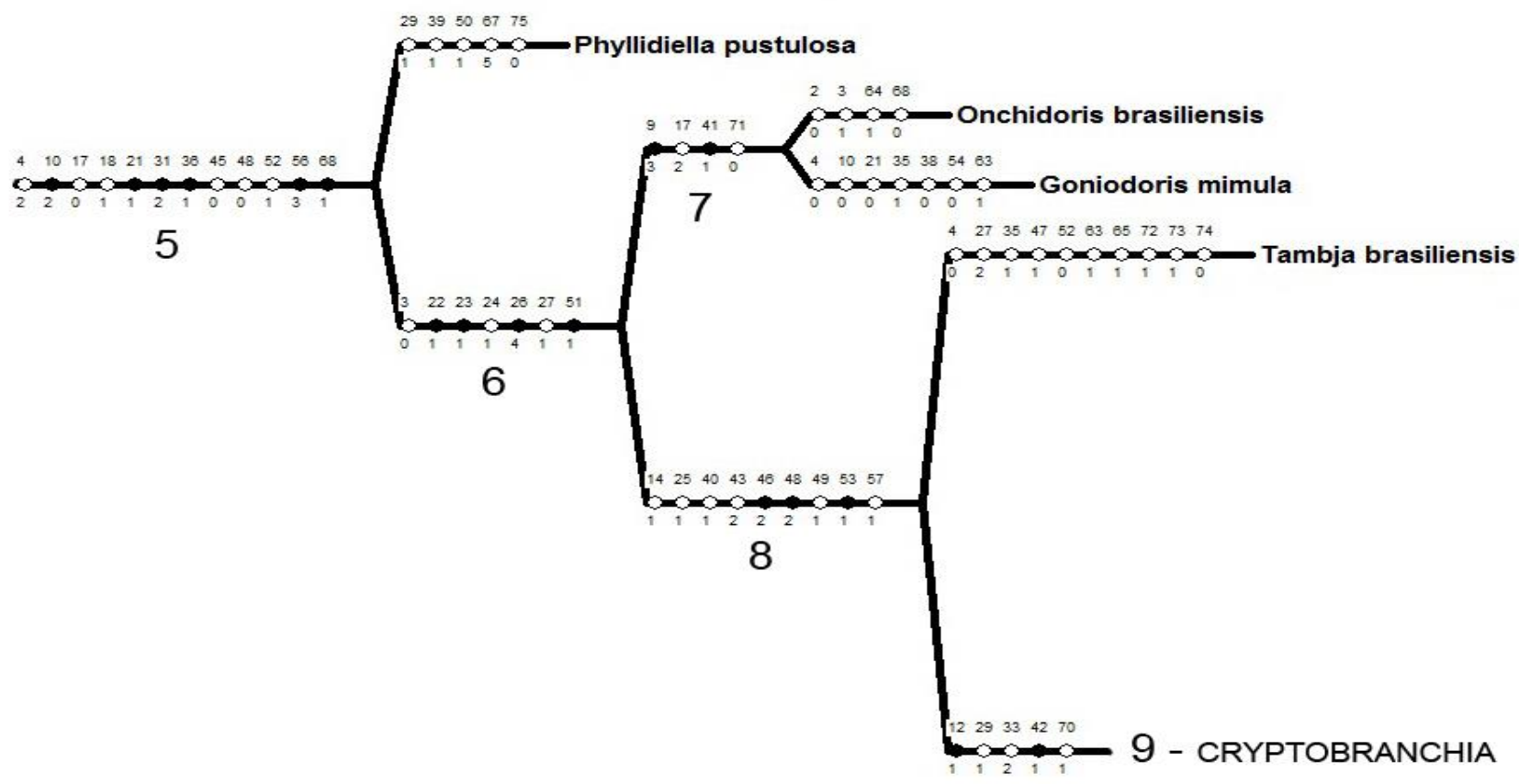

Figura 144: Parte da ( 2 de 5) árvore obtida através da pesagem implícita. Sinapomorfias de cada nó indicadas pelos círculos pretos e as homoplasias com círculos brancos. O número acima de cada símbolo indica o caráter, e o abaixo, o estado.

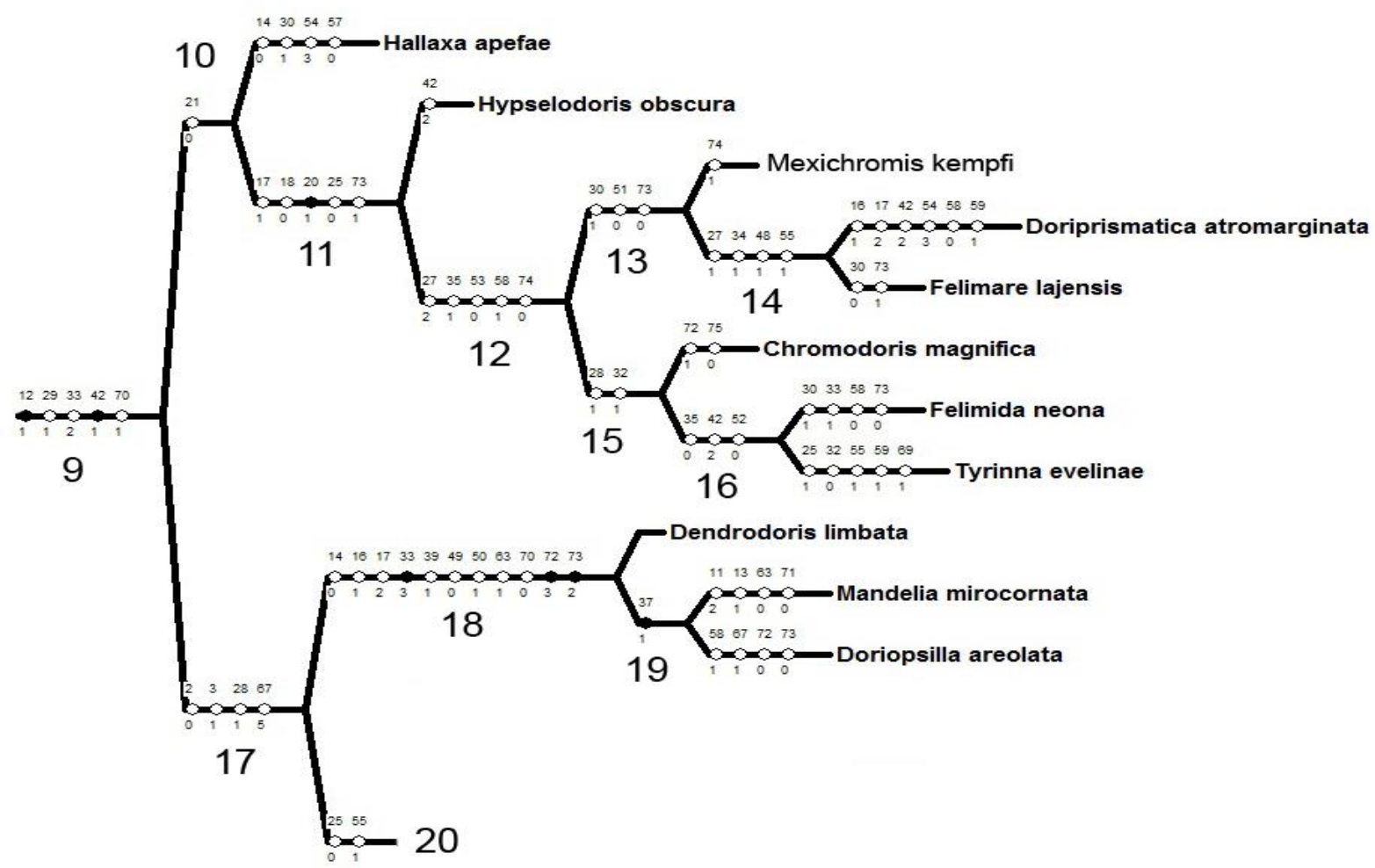

Figura 145: Parte da (3 de 5) árvore obtida através da pesagem implícita. Sinapomorfias de cada nó indicadas pelos círculos pretos e as homoplasias com círculos brancos. O número acima de cada símbolo indica o caráter, e o abaixo, o estado. 


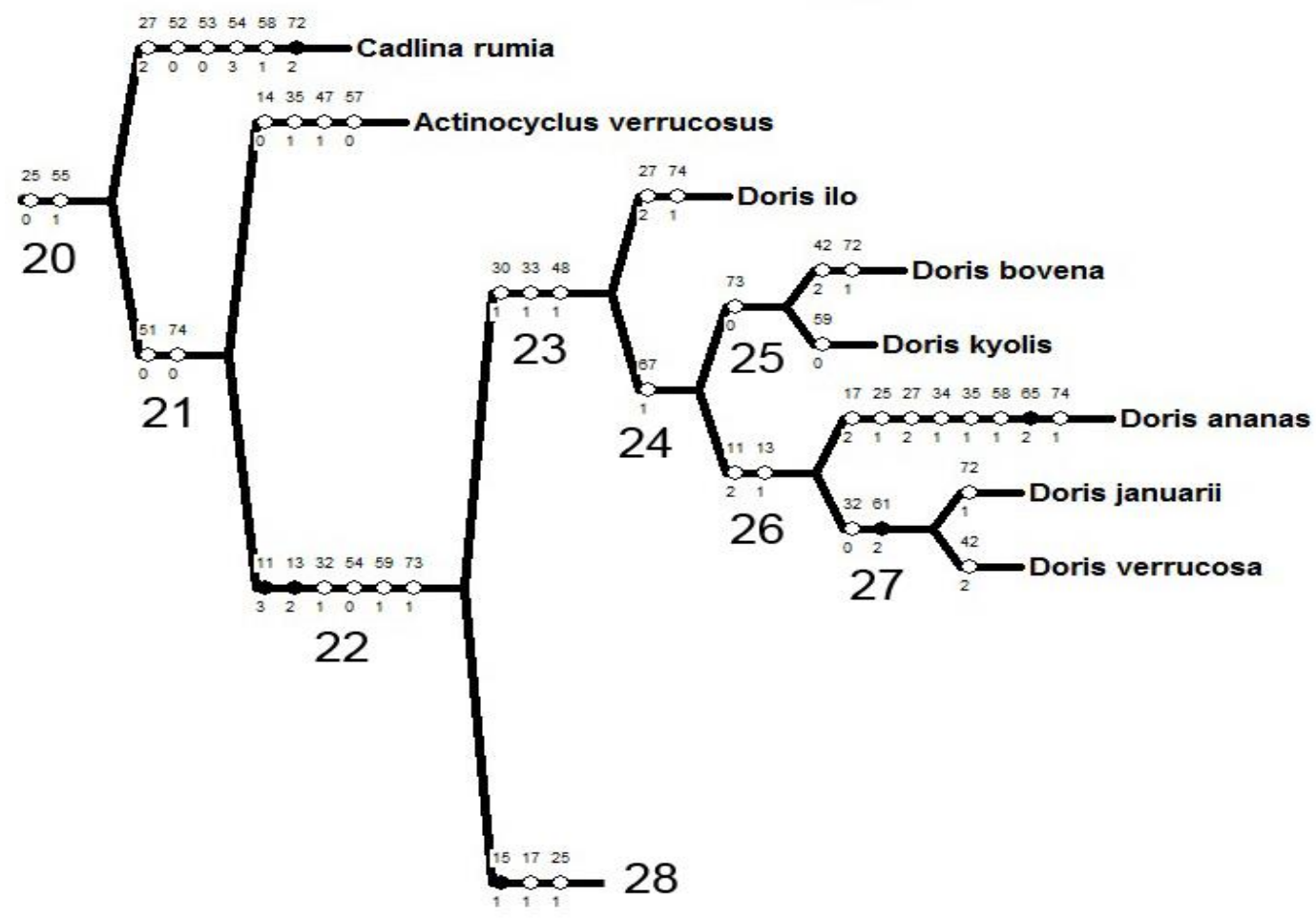

Figura 146: Parte da (4 de 5) árvore obtida através da pesagem implícita. Sinapomorfias de cada nó indicadas pelos círculos pretos e as homoplasias com círculos brancos. O número acima de cada símbolo indica o caráter, e o abaixo, o estado.

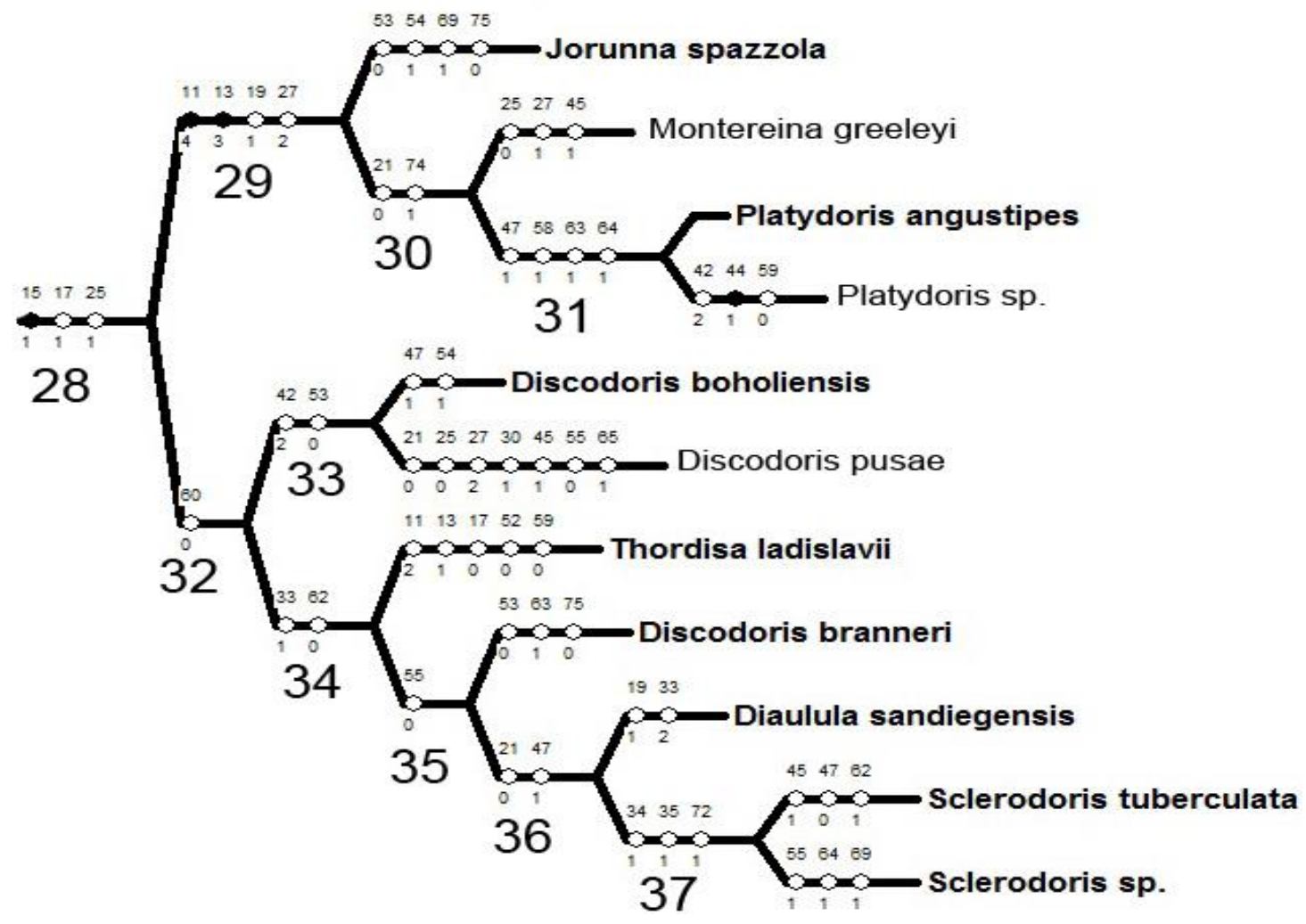

Figura 147: Parte da (5 de 5) árvore obtida através da pesagem implícita. Sinapomorfias de cada nó indicadas pelos círculos pretos e as homoplasias com círculos brancos. O número acima de cada símbolo indica o caráter, e o abaixo, o estado. 


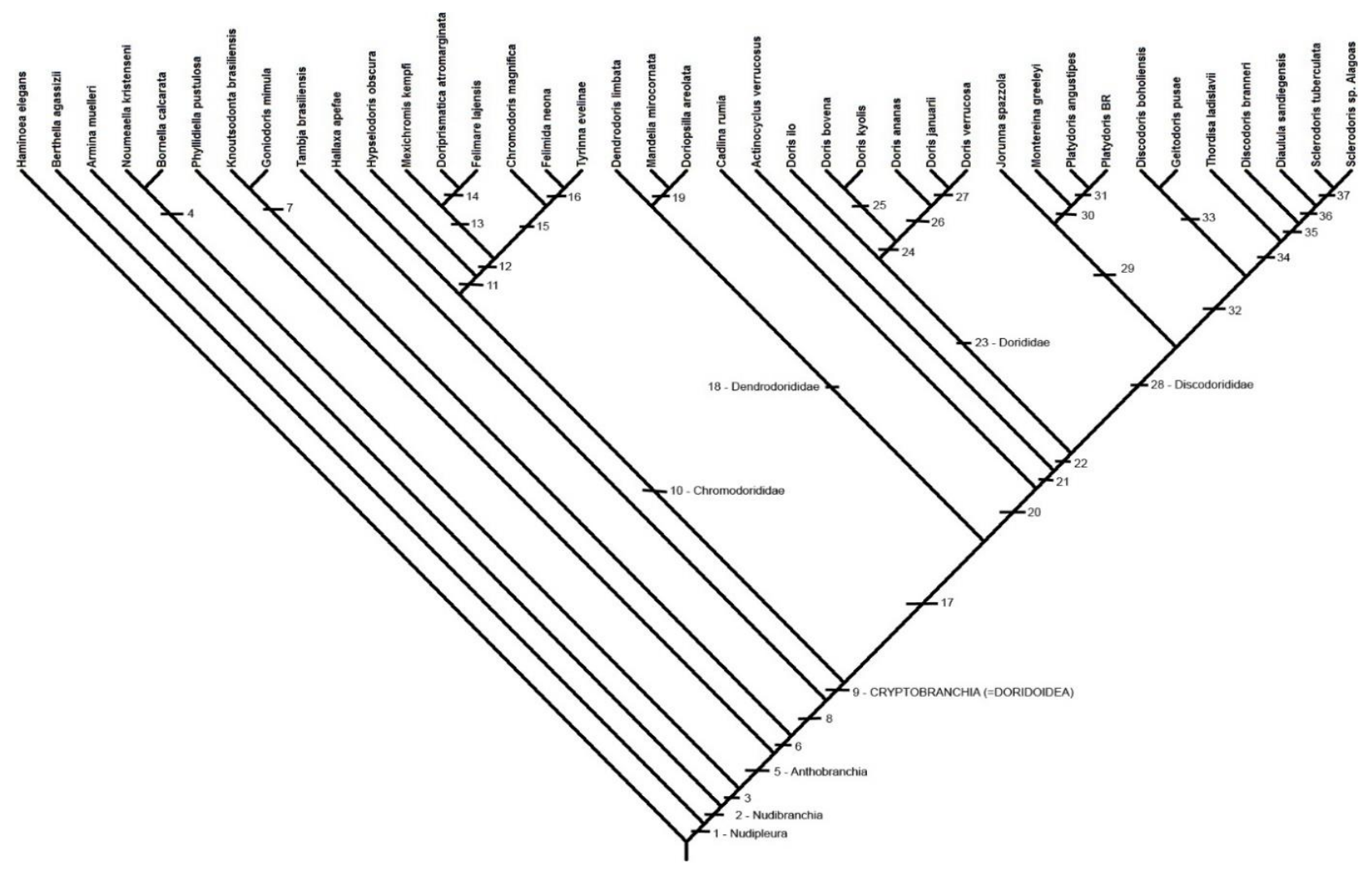

Figura 148: Árvore obtida através da pesagem implícita, com nós maiores nomeados: Nudipleura (1); Nudibranchia (2); Cryptobranchia (=Doridoidea) (9); Chromodorididae (10); Dendrodorididae, com inclusão de Mandelia mirocornata (18); Dorididae (23); Discodorididae (28). 


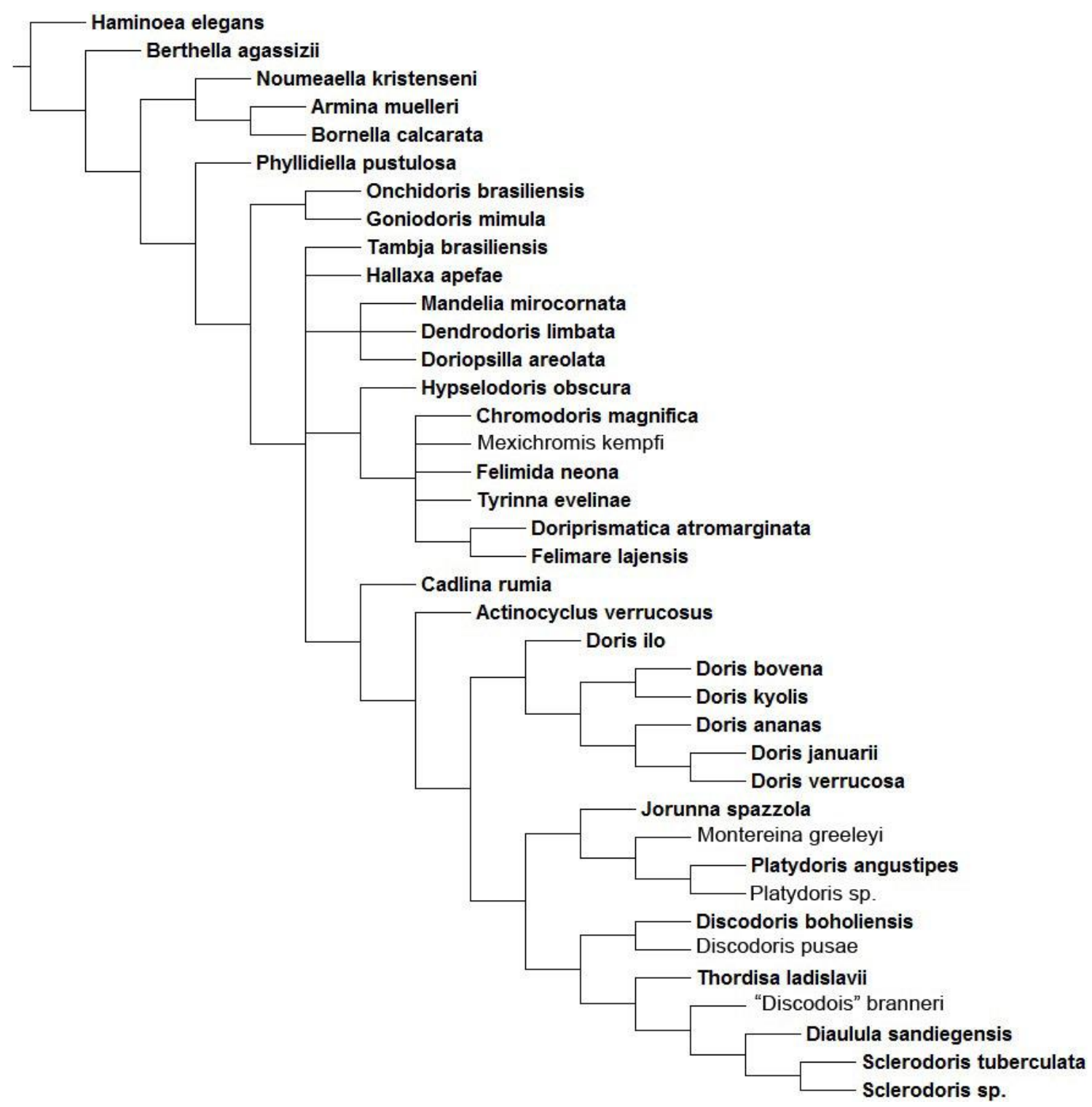

Figura 149: Árvore de consenso estrito obtida a partir de 20 árvores mais parcimoniosas encontradas na análise com pesagens iguais (L: 326; IC: 36; IR: 62).

É bom frisar que cada caráter foi analisado através da anatomia comparada de todo o elenco de espécies, com algumas informações comparadas da literatura. O grupo externo está representado entre os nós 1-8, a partir do nó 9 está o grupo interno (Cryptobranchia/Doridoidea).

O nó 1 (Fig. 143) apresenta o táxon já conhecido na literatura por Nudipleura, com um representante de Pleurobranchomorpha, B. agassizii, e os demais Nudibranchia utilizados na análise. O nó está sustentado por 19 sinapomorfias, sendo 13 delas exclusivas $\left(^{*}\right)$ deste táxon e as outras 6 são homoplásticas. São elas: projeção do pé ausente ( 3 estado $1^{*}$ ), noto do mesmo tamanho ou um pouco menor que o pé (4 estado $1^{*}$ ), rinóforo presente (5 estado $\left.1^{*}\right)$, posição da estrutura quimiorreceptora anterior (6 
estado $1^{*}$ ), tentáculos orais ausentes (17 estado 2), posição das estruturas respiratórias ventral entre o pé e o noto (22 estado $2 *$ ), tipo de estrutura respiratória lateral (26 estado $1^{*}$ ), posição do odontóforo externa (40 estado 1), m6 ausente (45 estado $2 *$ ), m7 ausente (46 estado $1^{*}$ ), m10 circundando todo o esfíncter muscular (48 estado 1), estômago interno à glândula digestiva (54 estado 1), posição do ânus lateral (56 estado 1*), próstata única (60 estado $\left.1^{*}\right)$, músculo do pênis ausente (61 estado $\left.1^{*}\right)$, inserção do receptáculo seminal na base da Bursa copulatrix (67 estado 1), gânglios cerebrais fundidos (71 estado 1*), gânglios bucais fundidos (74 estado 1) e ocelos fundidos com os gânglios cerebrais (75 estado $1 *$ ). A maioria dos caracteres que sustentam este nó (Nudipleura) paraceram bem plesiomórficos, sendo normalmente encontrados nos primeiros táxons, mais basais, eg. B. agassizii e A. muelleri.

O nó 2 (Fig. 143) inclui os Nudibranchia, aqui representados por Armina muelleri, Noumeaella kristenseni, Bornella calcarata, e os Doridacea. O nó está suportado por seis caracteres, sendo cinco deles exclusivos $(*)$ : concha ausente ( 1 estado $1 *)$, rinóforo sólido (7 estado $\left.1^{*}\right)$, lamelas diagonais dos rinóforos (9 estado $\left.1^{*}\right)$, músculos do tubo oral (mt) presentes (38 estado $1 *$ ), m4 em relação ao m5 circundando toda a cartilagem do odontóforo (m5 ausente) (43 estado $3 *$ ) e papila do pênis ausente (62 estado 1).

O nó 3 (Fig. 143), não representado por um táxon definido nomenclaturalmente, está suportado por quatro sinapomorfias, três delas exclusivas $(*)$ : forma do corpo alongada ( 2 estado $1^{*}$ ), estrutura quimiorreceptora na posição dorsal ( 6 estado $2^{*}$ ), base do rinóforo separada ( 8 estado $1^{*}$ ) e odontóforo interno ao tubo oral (40 estado 0$)$, este último como um caráter homoplástico.

No nó 4 (Fig. 143) está suportado pelos seguintes caracteres, dois deles exclusivos (*): estruturas respiratórias dispostas ao longo do noto simetricamente (22 estado $3 *$ ), papila anal presente (57 estado 1) e papila anal lateral/mediana (58 estado $2 *$ ). As duas espécies incluídas neste nó são representantes de Aeolidoidea (Noumeaella kristenseni) e Tritonoidea (Bornella calcarata), ambas normalmente consideradas como "Cladobranchia", junto com os Arminoidea (A. muelleri), que nesta análise se manteve como um táxon parafilético.

No nó 5 (Fig. 144) - Doridacea (Phyllidiella pustulosa, Knoutsodonta brasiliensis, Goniodoris mimula, Tambja brasiliensis e Cryptobranchia) (Fig. 143) está suportado por 12 caracteres, entre eles seis são exclusivos (*). São eles: noto consideravelmente maior 
que o pé (4 estado 2), cavidade do rinóforo formada pela elevação do bolso notal (10 estado $\left.2^{*}\right)$, tentáculos orais achatados (17 estado 0$)$, presença de tubérculos dorsais (18 estado 1), espículas tegumentares presentes (21 estado $1^{*}$ ), glândula de sangue presente associada ao Sistema Nervoso (31 estado $2^{*}$ ), vesícula renal presente (36 estado $1 *$ ), m6 único (45 estado 0), m10 ausente (48 estado 0), dente raquidiano ausente (52 estado 1), posição do ânus médio/dorsal, no sentido posterior do corpo (56 estado $3^{*}$ ) e ducto uterino presente (68 estado $1 *)$.

O nó 6 (Fig. 144), sem definição taxonômica, está suportado seis caracteres, sendo quatro exclusivos $(*)$ : estruturas respiratórias localizadas na região dorsal/posterior (22 estado $1 *$ ), brânquia anal presente ( 23 estado $1 *$ ), brânquia pinada presente ( 24 estado 1 ), estrutura respiratória perianal (26 estado $4 *$ ), círculo braquial fechado parcialmente (27 estado 2) e radula com um a três dentes laterais (51 estado $1 *$ ).

O nó 7 (Fig. 144) está representando a superfamília Onchidoridoidea, com as espécies $K$. brasiliensis e G. mimula e está sustentado por quatro caracteres, sendo dois exclisivos (*): lamelas dos rinóforos aneladas (9 estado $\left.3^{*}\right)$, tentáculos orais ausentes (17 estado 2), músculo dorsal septado presente (41 estado $1^{*}$ ) e comissura cerebral aparente (71 estado 0).

Para o nó 8 (Fig. 144), sem táxon definido, que agrupa Tambja brasiliensis e os Cryptobranchia, nove caracteres suportam o nó, entre eles apenas três são exclusivos*: borda anterior do pé bilabiada presente (14 estado 1), brânquia pinada ramificada (25 estado 1), odontóforo externo (40 estado 1), m4 em relação ao m5 robusto, o dobro do m5 (43 estado 2), m7 par (46 estado 2*), m10 circundando latero/ventral o esfíncter muscular (48 estado $2 *$ ), esfíncter muscular presente (49 estado 1), mandíbula ausente (53 estado $1 *$ ) e papila anal presente (57 estado 1 - papila anal presente.

A partir do nó 9 (Cryptobranchia) (Fig. 144) consideramos o grupo interno a ser testado nessa análise. Assim como considerado por diversos autores (Valdés \& Gosliner, 1999; Valdés, 2002a; Valdés, 2004; Fahey \& Gosliner, 2004; Pola et al., 2007; Pola \& Gosliner, 2010). O táxon Cryptobranchia se mantem monofilético e está suportado por cinco caracteres, sendo dois deles exclusivos (*): presença de uma cavidade para retração das brânquias (12 estado 1*), pericárdio localizado posteriormente (29 estado 1), músculo retrator da brânquia dividido (33 estado 2), m2 longo (42 estado $1^{*}$ ) e presença de gânglio 
gastroesofágico (70 estado 1). Destes cinco caracteres, quatro deles (29, 33, 42 e 70) são novos caracteres que suportam o táxon.

Apesar da monofilia de Cryptobranchia ser suportada nesta análise de pesagem, não pudemos confirmar a monofilia de Labiostomata, atribuída como tal na literatura (Valdés, 2002). Nesta análise Labiostomata resultou parafilético, dividido em dois clados distintos. Já o táxon Porostomata se manteve monofilético, representado pela família Dendrodorididae.

O nó 10 (Fig. 145) agrupou H. apefae com a família Chromodorididae, pela presença da projeção do pé (3 estado 0) e ausência de espículas tegumentares (21 estado 0). Neste caso, $H$. apefae deixa de pertencer à família Actinocyclidae e passa a pertencer à família Chromodorididae.

O nó 11 (Fig. 145) está suportado por cinco caracteres, apenas 1 exclusivo (*): tentáculos orais digitiformes (17 estado 1), tubérculos dorsais ausentes (18 estado 0), MDF presente (20 estado $1 *$ ), brânquia pinada simples (25 estado 0 ) e comissura pediosa longa (73 estaco 1$)$.

O nó 12 (Fig. 145) apresenta cinco caracteres homoplásticos, sendo eles: círculo branquial fechado parcialmente (27 estado 2), poro do nefróstoma de fácil visualização (35 estado 1), mandíbula presente (53 estado 0), posição da papila anal mais posterior, quase na borda do círculo branquial (58 estado 1) e comissura bucal aparente (74 estado $0)$.

O nó 13 (Fig. 145) está suportado por três caracteres homoplásticos: divisão da aorta mais distante do ventrículo (30 estado 1), muitos dentes laterais (51 estado 0) e comissura pediosa curta (73 estado 0). O nó 14 (Fig. 145) está suportado por quatro caracteres: círculo branquial fechado completamente (27 estado 1), papila do nefróstoma presente (34 estado 1), m10 circundando todo o esfíncter muscular (48 estado 1) e ceco presente (55 estado 1). O nó 15 (Fig. 145) está sustentado por dois caracteres homoplásticos: posição do círculo branquial totalmente posterior à glândula digestiva (28 estado 1) e glândula de sangue dividida (32 estado 1). O último nó interno da família Chromodorididae é o nó 16 (Fig. 145) que está suportado por três caracteres: poro do nefróstoma de difícil visualização (35 estado 0), m2 curto (42 estado 2) e dente raquidiano presente (52 estado 0). 
O nó 17 (Fig. 145) está suportado por três caracteres homoplásticos e engloba os representantes da família Dendrodorididae, Cadlina rumia, Actinocyclus verrucosus e as famílias Dorididae e Discodorididae. Os caracteres são: forma do corpo arredondada (2 estado 0), círculo branquial totalmente posterior à glândula digestiva (28 estado 1) e receptáculo seminal com inserção junto do ducto uterino (67 estado 5). Esta análise corrobora com a hipótese de rejeição do agrupamento "Porostomata" para Phyllidiidae e Dendrodorididae como uma homoplasia, uma vez que detalhes do sistema digestivo anterior são distintos em ambos os táxons, de maneira que os Dendrodorididae compartilham mais sinapomorfias com outros doridídeos (Brunckhorst, 1993).

O nó 18 (Fig. 145), aqui considerado a família Dendrodorididae, com inclusão de $M$. mirocornata, é sustentado por doze caracteres, sendo três deles exclusivos (*): borda anterior do pé bilabiada ausente (14 estado 0), estrutura ao redor da boca ausente (16 estado 1 , convergência com $D$. atromarginata, único Chromodorididae que não apresenta tentáculo oral), tentáculos orais ausentes (17 estado 2), tubérculos dorsais ausentes (18 estado 0), músculo retrator da brânquia central (33 estado 3*), odontóforo ausente (39 estado 1, convergente com P. pustulosa), esfíncter muscular ausente (49 estado 0), radula ausente (50 estado 1, convergência também com P. pustulosa), presença de espinhos no pênis (63 estado 1), gânglio gastroesofágico ausente (70 estado 0), comissura pediosa inconspícua (72 estado $3 *$ ) e gânglios pediosos praticamente fundidos (73 estado $2^{*}$ ).

O nó 19 (Fig. 145) aproxima M. mirocornata e D. areolata e está suportado pela presença de probóscide (37, estado 1), caráter exclusivo deste nó.

O nó 20 (Fig. 146) está sustentado por um caráter, a presença de um ceco digestivo associado ao estômago (caráter 55, estado 1), e agrupa $C$. rumia, A. verrucosus e as famílias Dorididae e Discodorididae.

O nó 21 (Fig. 146) aproxima A. verrucosus das famílias Dorididae e Discodorididae e está suportado por dois caracteres homoplásticos: muitos dentes laterais na rádula (51 estado 0 ) e comissura bucal aparente (74 estado 0).

O nó 22 (Fig. 146), agrupa as famílias Dorididae e Discodorididae, está sustentado por seis caracteres, sendo dois exclusivos $(*)$ : pequenos lobos como ornamento da cavidade do rinóforo (11 estado $3^{*}$ ), pequenos lobos como ornamento da cavidade branquial (13 estado $2 *$ ), glândula de sangue dividida (32 estado 1), estômago do lado 
esquerdo (54 estado 0), difícil distinção de gônada e glândula digestiva (59 estado 1) e comissura pediosa longa (73 estado 1).

A família Dorididae está representada pelo nó 23 (Fig. 146) e suportada por três caracteres homoplásticos e convergentes: divisão da aorta bem próximo ao ventrículo (30 estado 1), músculo retrator da brânquia único (33 estado 1) e m10 circundando todo o esfíncter muscular (48 estado 1). Quanto aos nós internos à família Dorididae: o nó 24 (Fig. 145) está suportado pela inserção do receptáculo seminal na base da Bursa copulatrix (67 estado 1), o nó 25 (Fig. 146) pela comissura pediosa curta (73 estado 0), no nó 26 (Fig. 146) por dois caracteres convergentes: cavidade do rinóforo com tubérculos como ornamentos (11 estado 2) e cavidade branquial com tubérculos como ornamentos (13 estado 1). O nó 27 (Fig. 146) está sustentado por dois caracteres, sendo um deles exclusivo (*): presença da glândula de sangue inteira (32 estado 0) e músculo do pênis presente, vental ao pericárdio (61 estado 2).

O nó 28 (Fig. 146) representa a família Discodorididae, suportado por três caracteres, sendo um deles exclusivo (*): fenda longitudinal na borda anterior do pé bilabiada (15 estado 1), tentáculos orais presentes digitiformes (17 estado 1) e brânquia pinada ramificada (25 estado 1$)$.

Interno à família Discodorididae há uma divisão em dois táxons. O primeiro no nó 29 (Fig. 147) é sustentado por quatro caracteres, sendo dois exclusivos: caryophyllidia como ornamento da cavidade do rinóforo (11 estado $4 *$ ), caryophyllidia como ornamento da cavidade branquial (13 estado $3^{*}$ ), caryophyllidia presente (19 estado 1) e círculo branquial fechado parcialmente (27 estado 2). O nó 30 (Fig. 147) está suportado por dois carátes homoplásticos convergentes: espículas tegumentares ausentes (21 estado 0) e comissura bucal inconspícua (74 (estado 1). O nó 31 (Fig. 147) que une as duas espécies de Platydoris analisadas está suportado pela presença do $\mathrm{m} 7$ com origem na cartilagem do odontóforo (47 estado 1), papila anal mais posterior, quase na borda do círculo branquial (58 estado 1) e a presença de espinhos na vagina (64 estado 1).

O segundo nó da família Discodorididae é o nó 32 (Fig. 147) suportado pela presença da próstata dividida (60 estado 0). O nó 33 (Fig. 147) está suportado por dois caracteres homoplásticos: $\mathrm{m} 2$ curto (42 estado 2) e mandíbula presente (53 estado 0 ), que aproximou a espécie até então considerada como Geitodoris pusae da espécie-tipo do gênero Discodoris, D. boholieneis. 
O nó 34 (Fig. 147) está suportado por dois caracteres homoplásticos: músculo retrator da brânquia inteiro (33 estado 1) e papila do pênis presente (62 estado 0).

O nó 35 (Fig. 147) é suportado pela ausência do ceco (55 estado 0). O nó 36 (Fig. 147) pela ausência de espículas tegumentares (21 estado 0) e finalmente o nó 37 (Fig. 147), que une as duas espécies de Sclerodoris analisadas, está suportado por três caracteres homoplásticos: papila do nefróstoma presente (34 estado 1), poro do nefróstoma de fácil visualização (35 estado 1) e comissura pediosa estreita e dupla (72 estado 1).

De acordo com a árvore de consenso estrito (Fig. 149), resultante de 20 árvores igualmente parcimoniosas, existem três nós onde há politomias. A primeira politomia agrupa Tambja brasiliensis aos Cryptobranchia, nesse caso não confirmando a monofilia do táxon. No entanto, através da pesagem foi possível confirma a monofilia deste táxon suportada por cinco sinapomorfias, sendo duas exclusivas (Fig. 144).

A segunda politomia é referente a um subgrupo de Cryptobranchia, formado por Mandelia, Dendrodoris e Doriopsila, que com a hipótese proposta na pesagem resultou como um táxon monofilético suportado por 11 sinapomorfias, sendo 3 delas exclusivas e dessa maneira sugerindo a inclusão de Mandelia na família Dendrodorididae.

Por fim, há uma politomia interna aos representantes de Chromodorididae, englobando as espécies Chromodoris magnifica, Mexichromis kempfi, Felimida neona e Tyrinna evelinae.

Hallaxa apefae não está agrupada à família Chromodorididae e tampouco esta relacionada à Actinocyclus verrucosus. Através da pesagem ela resultou na base dos cromodoridídeos compartilhando com as outras espécies da família ausência de espículas tegumentares (21 estado 0$)$.

O nó que engloba C. rumia, A. verrucosus, Dorididae e Discodorididae resultou monofilético em ambas as árvores, consenso estrito e pesagem, com as mesmas relações entre as espécies. 


\subsection{Análise taxonômica resultante da filogenia obtida}

Cryptobranchia é confirmado como um táxon monofilético, e é sinônimo de Dorididea. No entanto, de acordo com o Código Internacional de Nomenclatura (ICZN, 1999), Art. 29.1, um nome do "Family-group" deve ser formado pelo gênero-tipo, e o Art. 29. 2, diz que toda superfamília deve apresenta o sufixo "oidea", e dessa maneira mantém-se o nome Doridoidea para a superfamília.

A proposta sugerida nesta análise é a divisão de Doridoidea (=Cryptobranchia) em seis famílias: Chromodorididae (nó 10), com a inclusão de Hallaxa apefae; Dendrodorididae (nó 18) com inclusão de Mandelia mirocornata, representando os tradicionalmente conhecidos Porostomata; Cadlinidae (Cadlina rumia), Actinocyclidae (Actinocyclus verrucosus), Dorididae (nó 23) e Discodorididae (nó 28), contrariando a última classificação proposta por Valdés (2002a), que considera Cryptobranchia dividido em dois táxons, Porostomata e Labiostomata, nome introduzido pelo próprio autor.

O primeiro ramo monofilético engloba família Chromodorididae (Fig. 144), com a inclusão de Hallaxa apefae, antes reconchecida para a família Actinocyclidae. Nesta análise $H$. apefae não está relacionada a $A$. verrucosus, diferente das hipóteses propostas por Valdés (2002a) e Johnson (2001).

Todas as espécies representantes da família Chromodorididae mantiveram-se nos respectivos gêneros, exceto $M$. kempfi, que atualmente está alocada no gênero Felimare, de acordo com a última proposta filogenética baseada em dados moleculares (Johnson \& Gosliner, 2012). A espécie foi mantida no gênero Mexichromis, tendo em vista a distância entre Felimare lajensis, a espécie representante do gênero.

Felimare lajensis confirma-se como um representante deste gênero (Johnson \& Gosliner, 2012) já que não resultou próxima de Hypselodoris obscura, espécie-tipo de Hypselodoris.

A inclusão de Porostomata em Cryptobranchoidea seria aceita somente com a exclusão de Phyllidiella pustulosa, que nesta análise não foi considerada um Cryptobranchia, concordando com a hipótese de Bergh (1892) que considerou a família Phyllidiidae mais relacionada com Corambidae por não apresentarem brânquias retráteis. Neste estudo foram incluídos dois representantes da superfamília Onchidoridoidea, e que também não apresentam brânquias retráteis, os quais saíram próximos de P. pustulosa. 
Desta maneira poderíamos considerar Porostomata como sinônimo da família Dendrodorididae, considerando aqui os representantes que não possuem rádula, mas possuem a brânquia dorsal retrátil, uma vez assim considerados como Doridopsidae (Fischer, 1883).

Em ambas as hipóteses apresentadas, tanto na árvore de consenso estrito, quanto na árvore de pesagem, Actinocyclus verrucosus é grupo-irmão do táxon que une Dorididae e Discodorididae e está próximo de Cadlina rumia, que por hora corrobora com a hipótese de Johnson (2001) e deve ser alocada na família Cadlinidae, por não ser um membro da família Chromodorididae (Figs. 148, 149).

É possível concordar que as famílias Dorididae e Discodorididae são claramente distintas (Valdés, 2002a), como confirmado tanto na árvore de consenso estrito quanto na de pesagem.

Apesar da família Dorididae (Fig. 145) estar representada apenas por espécies atualmente considedaras pertencentes ao gênero Doris, é possível traçar algumas possíveis relações internas taxonômicas, seguindo o princípio dos ramos com as espéciestipo é possível sugerir que $D$. ilo possa ser realocada no gênero original para o qual ela foi descrita, Siraius, do qual é espécie-tipo, e que atualmente (Valdés, 2002a) está na sinonímia de Doris. Já para D. kyolis e D. bovena também é possível considerar uma realocação, no entanto ainda não existe um gênero provável para essas duas espécies.

Já na família Discodorididae (Fig. 146), Diaulula greeleyi não resultou próxima da espécie-tipo do gênero, D. sandiegensis, e dessa maneira foi considerada como Montereina greeleyi (Dayrat, 2010).

Os conhecidos "caryophyllidia-bearing" (Valdés \& Gosliner, 2001) saíram divididos em dois nós: 29 (Fig. 146) - com as espécies Jorunna spazzola, Montereina greeleyi, Platydoris angustipes e Platydoris sp., e o nó 36, com as espécies Diaulula sangiegensis, Sclerodoris tuberculata e Sclerodoris sp.

Na presente análise, “Geitodoris” pusae retornou para o gênero Discodoris, como na descrição original, pois resultou como espécie-irmã de Discodoris boholiensis, ficando assim com a combinação original Discodoris pusae (Er. Marcus, 1955). 
Para "Discodoris" branneri não foi possível especificar um gênero, pois da mesma maneira que $M$. greeleyi, também saiu distante da espécie-tipo Discodoris boholiensis. No entanto, julgou-se prematura a descrição de um novo gênero. 


\section{CONCLUSÕES}

1. Através da presente análise cladistica a monofilia do clado Cryptobranchia foi confirmada, baseada em caracteres morfológicos.

2. De acordo com o ICZN (1999) mantém-se o nome Doridoidea para a superfamília, sendo Cryptobranchia um sinônimo.

3. Tambja brasiliensis, representando a superfamília Polyceroidea, resultou como grupo-irmão de Cryptobranchia.

4. O táxon Labiostomata, como definido por Valdés (2002) é parafilético.

5. Phyllidiella pustulosa, está mais relacionada com a superfamília Onchidoridoidea, que também não apresentam brânquias dorsais retráteis, do que com a família Dendrodorididae, o que concorda com Bergh (1892).

6. Crytobranchia resultou dividida em seis famílias monofiléticas: Chromodorididae, Dendrodorididae, Cadlinidae, Actinocyclidae, Dorididae e Discodorididae.

7. A monofilia da família Dendrodorididae só é possível com a inclusão de Mandelia mirocornata (previamente em Mandelidae).

8. O gênero Mexichromis é mantido para M. kempfi, apesar de uma filogenia molecular ter alocado a espécie no gênero Felimare.

9. Diaulula greeleyi é realocada no gênero Montereina.

10. Geitodoris pusae retornou para o gênero original, Discodris pusae.

11. Embora necessário, não foi definido um gênero para alocar "Discodoris" branneri, mantendo-se uma postura conservativa.

12. Uma série de caracteres morfológicos, normalmente não utilizados, como, e.g., os músculos do odontóforo, mostraram-se potencialmente informativos, especialmente interespecífica. 


\section{REFERÊNCIAS BIBLIOGRÁFICAS}

ABBOTT, R. T. 1974. American Seashells: the marine Mollusca of the Atlantic and Pacific coasts of North America. Van Nostrand: Melbourne; 662p.

AJELANDRINO, A. \& VALDÉS, Á. 2005. Phylogeny and Biogeography of the Atlantic and Eastern Pacific Hypselodoris Stimpson, 1855 (Nudibranchia, Chromodorididae) with the description of a new species from the Caribbean Sea. Journal of Molluscan Studies 72: 189-198.

ALDER, J. \& HANCOCK, A. 1845-1855. A monograph of the British nudibranchiate Mollusca. Parts 1-7. London: Ray Society.

ALDER, J. \& HANCOCK, A. 1864. Notice of a collection of nudibranchiate Mollusca made in India by Walter Elliot Esq. with descriptions of several new genera and species. Transactions of the Zoological Society London 5: 113-147.

ALVIM, J., PADULA, V. \& PIMENTA, A. D. 2011. First record of the genus Onchidoris (Gastropoda: Nudibranchia: Onchidorididae) from the South Atlantic Ocean, with the description of a new species from Brazil. Journal of the Marine Biologial Association of the United Kingdom 91 (2): 505-511.

ALVIM, J. \& PIMENTA, A. D. 2013. Taxonomic review of the family Discodorididae (Mollusca: Gastropoda: Nudibranchia) from Brazil, with description of two new species. Zootaxa 3745 (2): 152-198.

ALVIM, J. \& PIMENTA, A. D. 2015. Taxonomic review of Berthella and Berthellina (Gastropoda: Pleurobranchoidea) from Brazil, with description of two new species. Zoologia 32(6): 497-531.

ARDILA, N. E. \& DIAZ, J. M. 2002. Armina Juliana (Gastropoda: Nudibranchia: Arminidae), a new species from the Southern Caribbean. Boletin de Investigaciones Marinas y Costeras-INVEMAR 31(1): 25-31.

ARDILA, N. E. \& VALDÉS, A. 2004. The genus Armina (Gastropoda: Nudibranchia: Arminidae) in the Southern Caribbean, with the description of a new species. Nautilus $118,131-138$.

ARDILA, N. E., BÁEZ, D. P. \& VALDÉS, Á. 2007. Babosas y Liebres de mar (Mollusca: Gastropoda: Opisthobranchia) de Colombia. Biota Colombiana 8 (2): 185-197.

AVILA, C., BAlleSteros, M. \& ORTEA, J. A. 1992. Una nueva especie de Doriopsilla, Bergh, 1880 (Mollusca: Nudibranchia) del Archipiélago de Cabo Verde. Historia Animalium 1:23-31.

AVILA, C. \& DURFORT, M. 1996. Histology of epithelia and mantle glands of selected species of doridacean mollusks with chemical defensive strategies. The Veliger 39(2): $148-163$.

BÁEZ, D. P., ARDILA, N., VALDÉS, A. \& ACERO, A. P. 2011. Taxonomy and phylogeny of Armina (Gastropoda: Nudibranchia: Arminidae) from the Atlantic and 
eastern Pacific. Journal of the Marine Biological Association of United Kingdom 91 (5), $1107-1121$.

BALLESTEROS, M. \& ORTEA, J. 1980. Contribución al conocimiento de los Dendrodorididae (Moluscos, Opistobranquios, Doridáceos) del litoral Ibérico. 1. Publicaciones de Departamento de Zoologia, Universidad de Barcelona 5: 25-37.

BARANETZ, O. N. \& MINICHEV, Y. S. 1993. The evolution of the mantle complex in nudibranchiate molluscs (Gastropoda, Nudibranchia). Zoologichesky Zhurn 73: 29-35 [In Russian].

BELMONTE, T., ALVIM, J. PADULA, V. \& MURICY, G. 2015. Spongivory by nudibranchs on the coast of Rio de Janeiro state, southeastern Brazil. Spixiana 38(2): 187195.

BERGH, L. S. R. 1877a. Kritische Untersuchung der Ehrenberg'schen Doriden. Deutsche Malakozoologische Gesellschaft Jahrbücher 4:45-76.

BERGH, L. S. R. 1877b. Malacologische Untersuchungen. In: Reisen im Archipel der Philippinen von Dr. Carl Gottfried Semper. Zweiter Theil. Wissenschaftliche Resultate. Band 2, Theil 2, Heft 12, pp. 495-546, pls. 58-61.

BERGH, L. S. R. 1878. Malacologische Untersuchungen. In: Reisen im Archipel der Philippinen von Dr. Carl Gottfried Semper. Zweiter Theil. Wissenschaftliche Resultate. Band 2, Theil 2, Heft 13, pp. 547-601, pls. 62-65.

BERGH, R. 1880. Malacologische Untersuchungen. In: Semper C, ed. Reisen im Archipel der Philippinen, theil 4, heft 2. Wiesbaden: Kreidel, 1-78, plates A-F.

BERGH, R. 1890. Malacologische Untersuchungen. In: Semper C, ed. Reisen im Archipel der Philippinen, theil 3, heft 16. Wiesbaden: Kreidel, 815-872, plates 82-84.

BERGH, R. 1891. Die cryptobranchiaten Dorididen. Zoologische Jahrbücher, Abteilung für Systematik, Geographie und Biologie der Tiere 6: 103-144.

BERGH, R. 1905. Die Opisthobranchiata der Siboga-Expedition. In: Weber M, ed. Uitkomsten op Zoologisch, Botanisch, Oceanographisch en Geologisch Gebied verzameld in Nederlandsch Oost-Indie 1899-1900 aan boord H.M. Siboga onder commando van Luitenant ter zee Ie kl. G. F. Tydeman, Vol. 50. Leiden: Brill, 1-248, plates $1-20$.

BOUCHET, P. \& ROCROI, J. P. 2005. Classification and Nomenclator of Gastropod Families. Malacologia 47 (1-2): 1-397.

BRUNCKHORST, D. J. 1993. The Systematycs and Phylogeny of Phyllidiid Nudibranchs (Doridoidea). Records of the Australian Museum, Supplement, 16: 1-107.

BURN, R. F.1965 A centennial commentary and zoogeographical remarks on Angas' Sydney nudibranchs (molluscs, Gastropoda). Journal de Conchyliologie 104:85-93. 
CALADO, G. \& J. P. SILVA. 2012. Lesmas do Mar de Algarve - Guia de Moluscos Opistobrânquios da Costa Sul de Portugal. Edição Subnauta, 164pp.

CAMACHO-GARCÍA, Y. E., POLA, M., CARMONA, L., PADULA, V., VILLANI, G. \& CERVERA, J. L. Diversity and distribution of the heterobranchs sea slug fauna on the Caribbean of Costa Rica. Cah. Biol. Mar. 55: 109-127.

CARMONA, L., POLA, M., GOSLINER, T. M. \& CERVERA, J. L. 2013. A tale that morphology fails to tell: a molecular phylogeny of Aeolidiidae (Aeolidida, Nudibranchia, Gastropoda). PLoS ONE 8(5): e63000. doi: 10.1371/journal.pone.0063000.

CAS - California Academy of Science. 2015. Phylogeny of Nudibranchia. Disponível em: http://researcharchive.calacademy.org/research/izg/nudibranchs/.

CATTANEO-VIETTI, R., ANGELINI, S. \& BAVASTRELLO, G. 1993. Skin and gut spicules in Discodoris atromaculata (Bergh, 1880) (Mollusca: Nudibranchia). Bolletino Malacologico 29, 173-180.

CIMINO, G. \& GHISELIN, M. T. 1999. Chemical defence and evolutionary trends in biosynthetic capacity among dorid nudibranchs (Mollusca: Gastropoda: Opisthobranchia). Chemoecology 9: 187-207.

COLEMAN, N. 2008. Nudibranchs Encyclopedia. Australasian Marine Photographic Index, Caringbah, Sydney.

COLLIER, C. L. \& FARMER, W. M. 1964. Additions to the nudibranch fauna of the East Pacific and the Gulf of California. Transactions of the San Diego Society of Natural History 13: 377-396.

CUVIER, G. L. 1804. Mémoire sur le genre doris. Annales Du Museum National

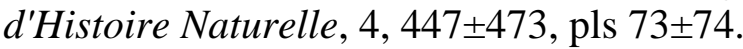

CUVIER, G. L. 1817. Le Re'gne Animale distribue' d'apre's son Organisation, pour servir de base a l'Histoire Naturelle des Animaux et de l'Introduction a l'Anatomie Compare'e volume 2. Deterville, Paris.

DACOSTA, S., PADULA, V. \& SCHRÖDL, M. 2010. A new species of Hypselodoris and a redescription of Hypselodoris picta lajensis (Nudibranchia: Chromodorididae) from Brazil. The Veliger 51 (1): 15-25.

DAYRAT, B. 2010. A monography revision of basal Discodorid sea slugs (Mollusca: Gastropoda: Nudibranchia: Doridina). Proceedings of the California Academy of Science 61: 1-403.

DEBELIUS, H. \& KUITER, R. H. 2007. Nudibranchs of the world. Germany. ConchBooks. 362 pp.

de PINNA, M. G. G. 1991. Concepts and tests of homology in the cladistics paradigm. Cladistics 7: 367-394. 
DOMinguÉZ, M., GARCiÁ, F. J. \& TRONCOSO, J. S. 2006. Some aspects of the family Chromodorididae (Opisthobranchia: Nudibranchia) from Brazil, with description of a new species. Scientia Marina 70 (4): 621-634.

DOMINGUÉZ, M., QUINTAS, P. \& TRONCOSO, J. S. 2007. Phyllidiidae (Opisthobranchia: Nudibranchia) from Papua New Guinea with the description of a new species of Phyllidiella. American Malacological Bulletin 22(1): 89-117.

DORGAN, K. M., VALDÉS, À. \& GOSLINER, T. M. 2002. Phylogenetic systematics of the genus Platydoris (Mollusca, Nudibranchia, Doridoidea) with descriptions of six new species. Zoologica Scripta 31(3): 271-319.

EDMUNDS, M. 1981. Opisthobranchiate Mollusca from Ghana: Chromodorididae. Zoological Journal of the Linnean Society 72(2):175-201.

EDMUNDS, M. \& JUST, H, 1983. Eolid nudibranchiate Mollusca from Barbados. Journal of Molluscan Studies 49: 185-203.

EHRENBERGH, C. G. 1831. Symbolae physicae seu icons et descriptions animalium evertebratorum sepositis insectis quae ex itinere per Africam borealem et Asiam Occidentalem-novae aut illustratae redierunt. Decas1 Mollusca. Ex Officina Academica, Berolini [no pagination].

ELIOT, C. N. E. 1903. On some nudibranchs from east Africa and Zanzibar. Part. III. Dorididae Cryptobranchiatae, I. Proceedings of the Zoological Society of London 2: 354385.

ELIOT, C. N. E. 1906. On the nudibranchs of Southern India and Ceylon, with special reference to the drawings by Kelaart and the collection belonging to Alder and Hancock preserved in the Hancock Museum at Newcastle-on-Tyne. Proceedings of the Zoological Society, London for 1906: 636-691, 999-1008.

FAHEY, S., \& GOSLINER, T.M., 2004. A phylogenetic analysis of the Aegiridae Fischer, 1883 (Mollusca, Nudibranchia, Anadoridoidea) with descriptions of eight new species and a re-assessment of phanerobranch relationships. Procceedings of the California Academy of Sciences 55: 613-689.

FARRIS, J. S. 1983. The logical basis of phylogenetic analysis. In: Platnick, N.I., Funk, V.A. (Eds.), Advances in Cladistics 2: Proceedings of the Second Meeting of The Willi Henning Society. Columbia University Press, New York, pp. 7-36.

FARRIS, J. S. 1989. The retention index and the rescaled consistency index. Cladistics $5,417-419$.

FARMER, W. M. 1980. Sea Slug Gastropods. W. M. Farmer Enterprises. Inc., Tempe, Arizona. 177p. [157 taxa illustrated]

FISCHER, P. - 1887. Manuel de Conchyliologie. XXIV + 1369 p., 23 t. Paris (Librairie F. Savy). 
FRANC, A. 1968. Mollusques, gasterópodes et scaphopodes. In: Grassé P, ed. Traité de Zoologie Anatomie, Systématique, Biologie, Vol. 5. Paris: Masson, 608-893.

GARCÍA, F. J., GARCÍA-GÓMEZ, J. C. \& CERVERA, J. L. 1988. Estudio anatômico del sistema nervioso de Platydoris argo (Linneo, 1767) (Gastropoda, Opisthobranchia, Doridacea). Malacologia 29(2): 383-404.

GARCIÁ, F. J. \& GARCIÁ-GÓMEZ, J. C. 1990. Anatomy of the circulatory system of the nudibranch Platydoris argo (Linné, 1767) with comparisons among Doridacea (Gastropoda: Opisthobranchia). The Veliger 33 (2): 166-173.

GARCÍA-GÓMEZ J. C., CIMINO G. \& MEDINA A. 1990. Studies on the defensive behaviour of Hypselodoris species (Gastropoda: Nudibranchia): ultrastructure and chemical analysis of mantle dermal formations (MDFs). Marine Biology 106: 245-250.

GARCÍA-GÓMEZ J. C., MEDINA A. \& COVENAS R. 1991. Study of the anatomy and histology of the mantle dermal formations (MDFs) of Chromodoris and Hypselodoris (Opisthobranchia: Chromodorididae). Malacologia 32: 233-240.

GARCÍA, F. J., DOMINGUEZ, M. \& TRONCOSO, J. S. 2008. Opistobranquios de Brasil: Descripción y distribución de opistobranquios del litoral de Brasil y del Archipiélago Fernando de Noronha. Vigo: Feito, S.L. 215 p.

GOFAS, S. 2004. Doriopsilla areolate Bergh, 1880. In: MolluscaBase (2016). Accessed through: World Register of Marine Species at http://www.marinespecies.org/aphia.php?p=taxdetails\&id=139520 on 2016-09-13

GOLOBOFF, P. A., CARPENTER, J. M., ARIAS, J. S. \& ESQUIVEL, D. R. M. 2008. Weigthing against homoplasy improves phylogenetic analysis of morphological data sets. Cladistics 24: 1-16.

GOSLINER, T. M. 1994. Gastropoda: Opisthobranchia. In: Harrison FW, Gardiner SL, eds. Microscopic anatomy of invertebrates Vol 5: Mollusca I. New York: Wiley-Liss Inc, 253-355.

GOSLINER, T. M. \& JOHNSON, S. 1994. Review of genus Hallaxa (Nudibranchia: Actinocyclidae) with descriptions of nine new species. The Veliger 37(2): 155-191.

GOSLINER, T. M. \& JOHNSON, S. 1999. Phylogeny and biogeography of the Atlantic and Eastern Pacific Hypselodoris Stimpson, 1855 (Nudibranchia, Chromodorididae) with the description of a new species from the Caribbean Sea. Journal of Molluscan Studies 72(2): 189-198.

GOULD, A. A. 1852. Mollusca \& Shells United States Exploring Expedition 12 xv + 510pp. Gould \& Lincoln: Boston.

GRAY, J. E. 1825. A list and description of some species of shells not taken notice of by Lamarck (continued) Annals of Philosophy (2)9: 407-415. 
HALLAS, J. M. \& GOSLINER, T. M. 2015. Family matters: The first molecular phylogeny of the Onchidorididae Gray, 1827 (Mollusca, Gastropoda, Nudibranchia). Molecular Phylogenetics and Evolution. 88: 16-27.

HANCOCK, A., \& D. EMBLETON. 1852. On the anatomy of Doris. Philosophical Transactions of the Royal Society of London 142:207-252, pls. 11-18.

HANCOCK, A. 1864. On the structure and homologies of the renal organ in the nudibranchiate Mollusca. Transactions of the Linnean Society of London 24:511-530, pls. 54-59.

HASZPRUNAR, G. 1988. On the origin and evolution of major gastropods group, with special reference to the streptoneura. Journal of Molluscan Studies 54: 367-441.

HENNIG, W. 1966. Phylogenetic systematics. Urbana, Chicago: University of Illinois Press.

HOFFMANN, H. 1939. I: Opisthobranchia. In: Bronn HG, ed. Klassen und ordnungen des tierreiches, Bd. II, Abt.II, Buch 3. Leipzig: Akademische Verlagsgesellschaft.

HUMMANN, J. C. 1992. A warm water Atlantic synonymy, Aphelodoris antillensis equals Chromodoris bistellata (Opisthobranchia: Gastropoda). The Veliger 35: 215-221.

ICZN. 1999. International Code of Zoological Nomenclature. London: International Trust for Zoological Nomenclature.

IHERING, von H. 1886. Zur Kenntniss der Nudibranchien der brasilianischen Kuste. Jahrbücher der Deutschen Malakozoologischen Gesellschaft 13: 223-240, pl. 9.

JENSEN, K. R. 1991. Comparison od alimentary system in shelled and non-shelled Sacoglossa (Mollusca, Opisthobranchia). Acta Zoologica 72(3): 143-150.

JENSEN, K. R. 1996. Phylogenetic systematics and classification of the Sacoglossa (Mollusca, Gastropoda, Opisthobranchia). Phylosophical Transactions: Biological Sciences 91-122.

JOHNSON, R. F. \& VALDÉS, A. 2001. The Hypselodoris infucata, H. obscura and H. saintvincentius species complex (Mollusca, Nudibranchia, Chromodorididae), with remarks on the genus Brachyclanis Ehrenberg, 1831. Journal of Natural History 35: 1371-1398.

JOHNSON, R. F. \& GOSLINER, T. M. 2012. Traditional taxonomic grouping mask evolutionary history: a molecular phylogeny and new classification of the chromodorid nudibranchs. PLoS ONE 7(4): e33479. Doi: 10.1371/journal.pone.0033479.

KAMALAKANNAN, K., KUMARAM, S., BALAKRISHNAN, S., THENMOZHI, C., SAMPATHKUMAR, P. \& BALASUBRAMANIAN, T. 2010. Occurrence of Glaucus atlanticus and Glaucus marginata (Blue Ocean Slug) from Nagapattinam Coastal Waters, Southeast Coast of India. International Journal of Current Research 5: 071-073. 
KELAART, E. F. 1859. Descriptions of new and little-known species of Ceylonese nudibranchiate mollusks. Annals \& Magazine of Natural History, series 3, 3:291-304.

KELAART, E. F. 1883. New and little known species of Ceylon nudibranchiate molluscs, and zoophytes. Journal of the Ceylon Branch of the Royal Asiatic Society 1856-61 3(9):76-125.

KLUGE, A. G. \& FARRIS, J. S. 1969. Quantitative phyletics and the evolution of anurans. Systematic Zoology 18: 1-32.

KLUSSMANN-KOLB, A. 2000. Comparative investigation of the genital systems in the Opisthobranchia (Mollusca, Gastropoda) with special emphasis on the nidamental glandular system. Zoomorphology 120: 215-235.

KLUSSMANN-KOLB, A., CROLL, R. P. \& STOUBACK, S. 2013. Use of axonal projection patterns for the homologisation of cerebral nerves in Opisthobranchia, (Mollusca, Gastropoda). Frontiers in Zoology 10:20.

LIMA, P. O. V., TIBIRIÇÁ, Y. \& SIMONE, L. R. L. 2016. A new large and common species of Doris (Gastropoda, Nudibranchia) from the Western Indian Ocean. Journal of Conchology 42(4): 205-212.

MacFARLAND, F. M. 1909. The Opisthobranchiate Mollusca of the Branner-Agassiz Expedition to Brazil. Leland Stanfor Junior University Publications 2: 1-104, pls. 1-19.

McDONALD, G. R. 2006. Nudibranch Systematic Index. Institute of Marine Science Univerity of California, Santa Cruz. p. 418.

MARCUS, E. 1955. Opisthobranchia from Brazil. Boletim da Faculdade de Filosofia, Ciências e Letras. Universidade de São Paulo, Zoologia 20: 98-261. Pls. 1-30.

MARCUS, E. 1957. On Opisthobranchia from Brazil (2). Journal of the Linnean Society, London 34: 390-486.

MARCUS, Er. 1958. Notes on Opisthobranchia. Boletim do Instituto Oceanográfico 7: 31-18, plates 1-8.

MARCUS, Er. 1958b.On Western Atlantic opisthobranchiate gastropods. American Museum Novitates 1906: 1-82.

MARCUS, E. 1961. Opisthobranchia from North Carolina. Journal Elisha Mitchell Scient. Soc., 77: 141-151.

MARCUS, Er. 1970. Opisthobranchs from northern Brazil. Bulletin of Marine Science 20: 922-951.

MARCUS, Ev. 1971. One some ethyneuran gastropods from the Indian and Pacific Oceans. Proceedings of the Malacological Society of London 39: 355-369. 
MARCUS, Ev. 1972. Lista de Opisthobranchia (Mollusca, Gastropoda) coletados pelo Labóratorio de Ciências do Mar, Recife, Brasil. Trabalhos Oceanograficos Universidade Federal de Pernambuco 13:71-82.

MARCUS, Ev. 1976. On Kentrodoris and Jorunna (Gastropoda Opisthobranchia). Boletim de Zoologia, Universidade de São Paulo 1:11-68.

MARCUS, Er. \& MARCUS, Ev. 1960. Opisthobranchs from American Atlantic warm waters. Bulletin of Marine Sciences of the Gulf of Caribbean 10: 129-207.

MARCUS, Ev. \& MARCUS, Er. 1963. Opisthobranchs from the Lesser Antilles. Studies on the fauna of Curaçao and other Carribbean Islands 19: 1-76.

MARCUS, Ev. \& MARCUS, Er. 1966. The R/V Pillsbry deep-sea biological expedition to the Gulf of Guinea, 1964-65 (9), Opisthobranchs from tropical west Africa. Studies in Tropical Oceanography 4(1): 152-208.

MARCUS, Ev. \& MARCUS, Er. 1967. Opisthobranchs from the southwestern Caribbean Sea. Biological Investigations of the Deep Sea, 33. Bulletin of Marine Science 17: 597628.

MARCUS, Ev. \& MARCUS, Er. 1970. Opisthobranchs from Curação and faunistically related regions. Studies on the Fauna of Curaçao and other Caribbean Islands 33: 1-129.

MEDINA, A., GARCIA, J. C. \& MORENO, F. J. 1986. Comparative studies on the histology of the ovotestis in Hypselodoris tricolor and Godiva banyulensis (Gastropoda, Opisthobranchia), with special reference to yolk formation. Journal of Morphology 188: 105-118.

MEYER, K. B. 1977. Dorid nudibranchs of the Caribbean coast of the Panama Canal Zone. Bulletin of Marine Science 27(2): 299-307.

MIKKELSEN, P. M. 1996. The evolutionary relationships of Cephalaspidea s.l. (Gastropoda, Opisthobranchia): a phylogenetic analysis. Malacologia 37: 375-442.

MÖRCH, O. A. L. 1863. Contributions à la Faune malacologique des Antilles Danoises. Journal de Conchyliologie 11: 21-43.

MORRETES, F. L. 1949. Ensaio de Catálogo dos Moluscos do Brasil. Arquivos do Museu Paraense vol. VII, 216p.

MUNIAÍN, C. VALDÉS, À. \& ORTEA, J. 1996. Redescription of Tyrinna nobilis Bergh, 1898 (Opisthobranchia: Chromodorididae) from Patagonia, Argentina. Journal of Molluscan Studies 62: 265-273.

NIXON, K. C. 1999. Computer program: Winclada (Beta) version 0.9.9. Distributed by author. Ithaca, New York.

NIXON, K. C. \& CARPENTER, J. M. 1993. On outgroups. Cladistics, 9: 413-426. 
ODHNER, N. H. 1934. The Nudibranchiata. British Antarctic ('Terra Nova') Expedition, 1910. Natural History Report Zoology 7: 229-310, plates 1-3.

ODHNER, N. H. 1939. Opisthobranchiate Mollusca from the western and northern coasts of Norway. Det Kongelige Norske Videnskabernes Selskabs Skrifter 1: 1-93.

ONO, A. 2004. Opisthobranchs of Ryukyu Islands. Rutles, Tokyo, Japan. 304 pp.

ORR, J. 1980. Annotated checklist of Hong Kong nudibranchs. Pages 109-117 in B. Morton, ed., The Malacofauna of Hong Kong and Southern China. Proceedings of the First International Workshop 23 March-8 April 1977. Hong Kong University Press, Hong Kong, China. vi +345 pp.

ORTEA, J. 1988. Moluscos Opistobranquios del Arquipiélago de Cabo Verde: Chromodorididae. Publicações Ocasionais da Sociedade Portuguesa de Malacologia 11: $1-16$.

ORTEA, J. VALDÉS, Á. \& TEMPLADO, J. 1997. Hallaxa apefae Marcus, 1957 (Nudibranchia: Actinocyclidae) from Ghana (West Africa), newly recognized as an amphiatlantic species. The Veliger 40: 86-88.

PADULA, V., BAHIA, J., CORREIA, M. D. \& SOVIERZOSKI, H. H. 2012. New records of opisthobranchs (Mollusca: Gastropoda) from Alagoas, Northeastern Brazil. Marine Biodiversity Records 5: 1-11.

PELSENEER, P. 1906. Mollusca. In: Lankester ER, ed. A Treatise on Zoology, Part 5. London: Black.

PERRONE, A. S. 1985a. The tropical genus Sclerodoris Eliot, 1904 from the Mediterranean (Opisthobranchia: Nudibranchia). Bollettino Malacologico (Pubblicazione Mensile Edita dalla Societa Italiana di Malacologia) 21(1-4):25-32.

PERRONE, A. S. 1985b. Una forma di nudibranchi doridi del genere tropicale Sclerodoris Eliot, 1904 rinvenuta in Mediterraneo (Opisthobranchia: Nudibranchia). Thalassia Salentina (15):63-70.

PETUCH, E. L. 1987. New Caribbean molluscan faunas [v] + 154 + A1-A4. 29pls. Costal Education \& Research Foundation: Charlottesville. Virginia.

PHILIPPI, R. A. 1836. Enumeratio molluscorum Siciliae cum viventium tum in tellure tertiaria fosssilium quae in itinere suo observavit, pars 1. Schroppii, Berolini, [Germany]. $\mathrm{xiv}+267 \mathrm{p}$.

PILSBRY, H. A. - 1893. George W. Tryon, Jr., Manual of Conchology; structural and systematic, v. 15, Order Opisthobranchiata, p. 134-436, t. 18-61. Philadelphia, Pa.

POLA, M., CERVERA, J. L., \& GOSLINER, T. M., 2007. Phylogenetic relationships of Nembrothinae (Mollusca: Doridacea: Polyceridae) inferred from morphology and mitochondrial DNA. Molecular Phylogenetics Evolution 43: 726-742. 
POLA, M., RUDMAN, W. B., \& GOSLINER, T. M., 2008. Systematics and preliminary phylogeny of Bornellidae (Mollusca: Nudibranchia: Dendronotina) based on morphological characters with description of four new species. Zootaxa 1-57.

POLA, M., RUDMAN, W. B. \& GOSLINER, T. M. 2009. Systematics and preliminary phylogeny of Bornellidae (Mollusca: Nudibranchia: Dendronotina) based on morphological characters with description of four new species. Zootaxa 1975: 1-57.

POLA, M. \& GOSLINER, T. M. 2010. The first molecular phylogeny of cladobranchian opisthobranchs (Mollusca, Gastropoda, Nudibranchia). Molecular Phylogenetics and Evolution 56: 931-941.

POLA, M., PADULA, V., GOSLINER, T. M. \& CERVERA, J. L. 2014. Going further on an intricate challenging group of nudibranchs: description of five novel species and a more complete molecular phylogeny of the subfamily Nembrothinae (Polyceridae). Cladistics 30: 607-634.

PONDER, W.F. \& LINDBERG, D. R. 1995. Gastropod phylogeny - challenges for the 90's. In: Taylor J. D., ed. Origin and evolutionary radiation of the Mollusca. Oxford: Oxford University Press.

PRUVOT-FOL, A. 1934. Les opisthobranches de Quoy \& Gimard. Archives du Muséum National d'Histoire Naturalle, Paris, série 6 11: 13-89.

PRUVOT-FOL, A. 1951. Études des nudibranches de la Méditerranée (2éme partie). Archives de Zoologie Expérimentale et Génerale 88: 1-80.

PRUVOT-FOL, A. 1953. Études de quelques opisthobranches de la côte Atantique du Maroc et du Sénegal. Travaux de l'Institut Scientifique Chérifien, Zoologie 5: 1-105.

QUOY, J. R. C. \& GAIMARD, J. P. 1832. Voyage de découvertes de l'Astrolabe execute par ordre du Roi, pendant les annees 1826-1827-1828-1829, sous le commandement de M. J. Drumont d'Urville. Zoologie Mollusca, volume 2. Ministère de la Marine, Paris, France. 686 pp [1832-1833].

REDFERN, C. 2001. Bahamian Seashells - A Thousand Species from Abaco, Bahamas, 280 pp. Bahamianseashells.com, Boca Ratón.

RIOS, E. 2009. Compendium of Brazilian Sea Shells. Rio Grande: Ed. Evangraf. 668p.

RISBEC, J. 1956. Nudibranches du Viet-Nam. Archives du Museum National d'Historie Naturalle Paris, série 7 4: 1-34.

ROSENBERG, G. 2009. Malacolog 4.1.1: A Database of Western Atlantic Marine Mollusca. [In] $W W W$ database (version 4.1.1). URL http://www.malacolog.org/search.php?nameid=8530.

RUDMAN, W. B. 1971. On the Opisthobranch genus Haminoea Turton \& Kingston. Pacific Science 25: 545-559. 
RUDMAN, W. B. 1977. Chromodorid opisthobranch Mollusca from east Africa and the tropical West Pacific. Zoological Journal of the Linnean Society 61(4):351-397.

RUDMAN, W. B. 1978. The dorid opisthobranch genera Halgerda Bergh and Sclerodoris Eliot from the Indo-West Pacific. Zoological Journal of the Linnean Society 62(1):59-88, pl. 1.

RUDMAN, W. B. 1984. The Chromodorididae (Ophistobranchia: Mollusca) of the IndoWest Pacific: a review of the genera. Zoological Journal of the Linnean Society 81: 115273.

RUDMAN, W. B. 1986. The Chromodorididae (Opisthobranchia: Mollusca) of the IndoWest Pacific: the genus Glossodoris Ehrenbergh (=Casella, H. \& A. Adams). Zoological Journal of the Linnean Society 86(2):101-184.

RUDMAN, W. B. 1998. Suborder Doridina. Pp. 990-1007 in BEESLEY, P. L. ROSS (ed.). Mollusca the Southern Synthesis. Fauna of Australia. vol. 5. CSIRO Publishing: Melbourne, Part. B viii 565-1234.

RUDMAN, W. B. 1999. Cerata (ceras) in aeolids. [In] Sea Slug Forum. Australian Museum, Sydney. Disponível em: http://www.seaslugforum.net/factsheet/ceras.

RUDMAN, W. B. 1999. Discodoris boholiensis Bergh, 1877. [In] Sea Slug Forum. Australian Museum Sydney: Disponível em: http://www.seaslugforum.net/factsheet/discboho.

SALES, L., QUEIROZ, V., PADULA, V., NEVES, E. G. \& JOHNSSON, R., 2013. New records of nudibranchs (Mollusca: Gastropoda) from Bahia State, northeastern Brazil. Checklist 9(3): 689-691.

SCHMEKEL, L. 1971. Histologie und Feinstruktur der Genitalorgane von Nudibranchiern (Gastropoda, Euthyneura). Zeitschrift Morphologie der Tiere 69: 115183.

SCHEMEKEL, L. 1985. Aspects of evolution within the opisthobranchs. The Mollusca. Volume 10 Evolution. Edited by: Trueman ER, Clarke MR. London: Academic Press, 221-267.

SCHEMEKEL, L. \& PORTMAN, A. 1982. Opisthobranchia des Mittelmeeres. Nudibranchia und Sacoglossa. Berlin: Springer-Verlag.

SERENO, P. C. 2007. Logical basis for morphological characters in phylogenetics. Cladistics 23: 565-587.

SCHRÖDL, M., JÖRGER, K. M., KLUSSMANN-KOLB, A. \& WILSON, N. G. 2010. Bye Bye "Opisthobranchia"! A review on the contribution of mesopsammic sea slugs to euthyneurean systematics. Thalassas. 27 (2): 101-112. 
SCHRÖDL, M. \& MILLEN, S. V. 2001. Revision of the nudibranch gastropod genus Tyrinna Bergh, 1898 (Doridoidea: Chromodorididae). Journal of Natural History 35: 1143-1171.

SIMONE, L. R. L. 2001. Phylogenetic analysis of Cerihioidea (Mollusca, Caenogastropoda) based on comparative morphology. Arquivos de Zoologia. São Paulo 36(2): 147-263.

SIMONE, L. R. L. 2004. Morphology and phylogeny of the Cypraeoidea (Mollusca: Caenogastropoda). Papel Virtual, Rio de Janeiro. 185p.

SIMONE, L. R. L. 2011. Phylogeny of the Caenogastropoda (Mollusca), based on comparative morphology. Arquivos de Zoologia 42(4): 161-323.

STAUBACH, S., KLUSSMANN-KOLB, A. 2007. The cephalic sensory organs of Acteon tornatilis (Linnaeus, 1758) (Gastropoda Opisthobranchia) - cellular innervation patterns as a tool for homologisation. Bonner Zool Beitr 55: 311-318.

STAUBACH, S., SCHÜTZNER, P., CROLL, R. P., KLUSSMANN-KOLB, A. 2008. Innervation patterns of the cerebral nerves in Haminoea hydatis (Linnaeus, 1758) (Gastropoda: Opisthobranchia) - A test for intraspecific variability. Zoomorph 127: 203212.

SWAINSON, W. 1840. A treatise on Malacology viii + 419pp., frontispiece. Longman, Orme, Brown, Green \& Longmans and John Taylor: London.

TARDY, J. 1970. Contribution a' l'etude des me'tamorphoses chez les nudibranches. Annales des Sciences Naturelles (Zoologie) 12: 299-370.

THIELE, J. 1929-1935. Handbuch der Systematischen Weichtierkunde. Jena: Gustav Fischer. Dates publication: Teil 1, pp. 1-376 [1929]; Teil 2, pp.377-778 [1931]; Teil 3, pp.779-1022 [1934]; Teil4, pp. 1023-1154 [1935].

THOMPSON, T. E. \& BENNETT, I. 1970. Observation on Australian Glaucidae (Mollusca: Opisthobranchia). Zoological Journal of Linnean Society 49: 187-197.

THOMPSON, T. E. 1976. Biology of opisthobranch molluscs. Vol. I. London The Ray Society.

THOMPSON, T. E. 1980. Jamaican Opisthobranch Molluscs II. Journal of Molluscan Studies 46: 74-99.

THOMPSON, T. E. \& BROWN, G.H. 1981. Biology and relationship of the nudibranch mollusk Notobryon wardii in South Africa, with a review of the Scyllaeidae. Journal of Zoology 194: 437-444.

THOLLESSON, M. 1999. Phylogenetic analysis of dorid nudibranchs (Gastropoda: Doridacea) using the mitocondrial 16S rRNA gene. Journal of Molluscan Studies 65: 335-353. 
TRONCOSO, J. S., GARCIA, F. J. \& URGORRI, V. 1998. Anatomical data on a rare Hypselodoris picta (Schultz, 1836) (Gastropoda, Doridacea) from the Coast of Brazil with description of a new subspecies. Bulletin of Marine Science 63(9): 133-141.

VALDÉS, Á. 2002a. A phylogenetic analysis and systematic revision of the cryptobranch dorids (Mollusca, Nudibranchia, Anthobranchia). Zoological Journal of the Linnean Society 136: 535-636.

VALDÉS, Á. 2002b. Phylogetic systematics of “Bathydoris” s.1. Bergh, 1884 (Mollusca, Nudibranchia), with the description of a new species from New Caledonian deep waters. Canadian Journal of Zoology 80(6): 1084 -1099.

VALDÉS, Á. 2003. Preliminary molecular phylogeny of the radula-less dorids (Gastropoda: Opisthobranchia) based on 16S mtDNA sequence data. Journal of Mollusc Studies 69: 75-80.

VALDÉS, Á. 2004. Phylogeography and phyloecology of dorid nudibranchs (Mollusca, Gastropoda). Biological Journal of the Linnean Society 83: 551-559.

VALDÉS, Á., ORTEA, J. ÁVILLA, C. \& BALLESTEROS, M. 1996. Review of the genus Dendrodoris (Gatropoda, Nudibranchia) in the Atlantic Ocean. Journal of Molluscan Studies 62: 1-31.

VALDÉS, Á. \& GOSLINER, T. M. 1999. Phylogeny of the radula-less dorids (Mollusca, Nudibranchia), with the description of a new genus and a new family. Zoologica Scripta 28: $315-360$.

VALDÉS, Á. \& GOSLINER T. M. 2001. Systematics and phylogeny of the caryophyllidia-bearing dorids (Mollusca, Nudibranchia), with descriptions of a new genus and four new species from Indo-Pacific deep waters. Zoological Journal of the Linnean Society 133(2): 103-198.

VALDÉS, Á., HAMMANN, J., BEHRENS, D. \& DUPONT, A. 2006. Caribbean Seas Slugs. A Field Guide to the Opisthobranch Mollusks from the Tropical Northwestern Atlantic. Sea Challengers, Gig Harbor, WA, 289pp.

VALDÉS, Á. \& ORTEA, J. 1997. Review of the genus Doriopsila Bergh, 1880 (Gastropoda: Nudibranchia) in the Atlantic Ocean. The Veliger 40(3): 240-254.

VALLÈS, Y., VALDÉS, A. \& ORTEA, J. 2000. On the phanerobranch dorids of Angola (Mollusca, Nudibranchia): a crossroads of temperate and tropical species. Zoosystema 22(1): 15-31.

W ÄGELE, H. 1989. A revision of the Antarctic species of Bathydoris Bergh, 1884 and comparison with other known bathydorids (Opisthobranchia, Nudibranchia). Journal of Molluscan Studies 55:343-364.

WÄGELE, H. 1989. Die Gattung Bathydoris Bergh, 1884 (Gnathodoridacea) im phylogenetischen System der Nudibranchia (Opisthobranchia, Gastropoda). Journal of Zoologial Systematics and Evolutionary Research 27(4): 273-281. 
WÄGELE, H. \& WILLAN, R. C. 2000. Phylogeny of the Nudibranchia. Zoological Journal of the Linnean Society 130: 83-181.

WÄGELE, H. BALLESTEROS, M. \& AVILA, C. 2006. Defensive glandular structures in Opisthobrach Molluscs - from histology to ecology. Oceanography and Marine Biology: An Annual Review 44: 197-276.

WÄGELE, H., KLUSSMANN-KOLB, A., VERBEEK, E. \& SCHRÖDL, M. 2013. Flashback and foreshadowing - a review of the taxon Opisthobranchia. Organisms Diversity \& Evolution 14 (1): 133-149.

WARMKE, G. \& ABBOTT, R. T. 1961. Caribbean Seashells. Livingstone Publ. Comp., Narbeth, Pennsylvania, $x+346 p ., 44$ pls.

WHITE, K. M. 1952. On a collection of molluscs from the Dry Tortuga, Florida. Proceedings of the Malacological Society of London 29: 106-120.

WILLIAN, R. C. 1998. Order Nudibranchia. Pp. 990 in BEELEY, P.L. ROSS (ed.). Mollusca the Southern Synthesis. Fauna of Australia. vol. 5. CSIRO Publishing: Melbourne, Part. B viii 565-1234.

WILLAN, R.C. \& COLEMAN, N. 1984. Nudibranchs of Australasia. Australasian Marine Photographic Index, Caringbah, Sydney.

WILLAN, R. C. \& MORTON, J. 1984. Marine Molluscs II. Opisthobranchia. Auckland: University of Auckland and Leigh Marine Laboratory.

WOLLOSCHEID-LENGELING, E., BOORE, J., BROWN, W. \& WÄGELE, H. 2001. The Phylogeny of Nudibranchia (Opisthobranchia, Gastropoda, Mollusca) reconstructed by three molecular markers. Organism Diversity and Evolution 1: 241-256.

YONOW, N. 1989. Red Sea Opisthobranchia 2: the family Chromodorididae (Mollusca, Nudibranchia). Fauna of Saudi Arabia 10:290-309.

YONOW, N. 2001. Results of the Rumphius Biohistorical Expedition to Ambon (1990). Part 11. Doridacea of the families Chromodorididae and Hexabranchidae (Mollusca, Gastropoda, Opisthobranchia, Nudibranchia), including additional Molukkan material. Zoologische Mededelingen, Leiden 75(1-15): 1-50.

YONOW, N. \& HAYWARD, P. J. 1991. Opisthobranches de l'Ile Maurice, avec la description de deux espèces nouvelles (Mollusca: Opisthobranchia). Revue Française d'Aquariologie Herpétologie 18(1): 1-30.

YOUNG, D. K. 1969. The functional morphology of the feeding apparatus of some IndoWest-Pacific dorid nudibranchs. Malacologia 9: 421-446. 


\section{ANEXOS}

Artigos publicados contendo as descrições das seguintes espécies: Doris verrucosa, Doris januarii e Doris ananas.

Anexo I: Anatomical review of Doris verrucosa and redescription of Doris januarii (Gastropoda, Nudibranchia) based on comparative morphology

Anexo II: A large and common species of Doris (Gastropoda, Nudibranchia) from the Western Indian Ocean. 